\title{
Consensos y conflictos en la política tributaria de América Latina
}

JUAN CARLOS GÓMEZ SABAINI JUAN PABLO JIMÉNEZ RICARDO MARTNER Editores

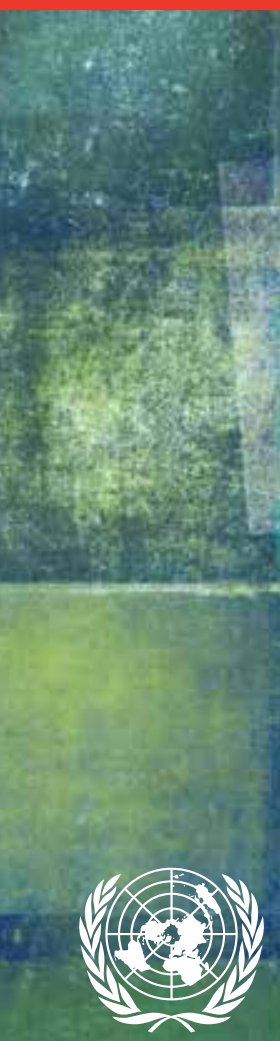




\section{Gracias por su interés en esta}

\section{publicación de la CEPAL}

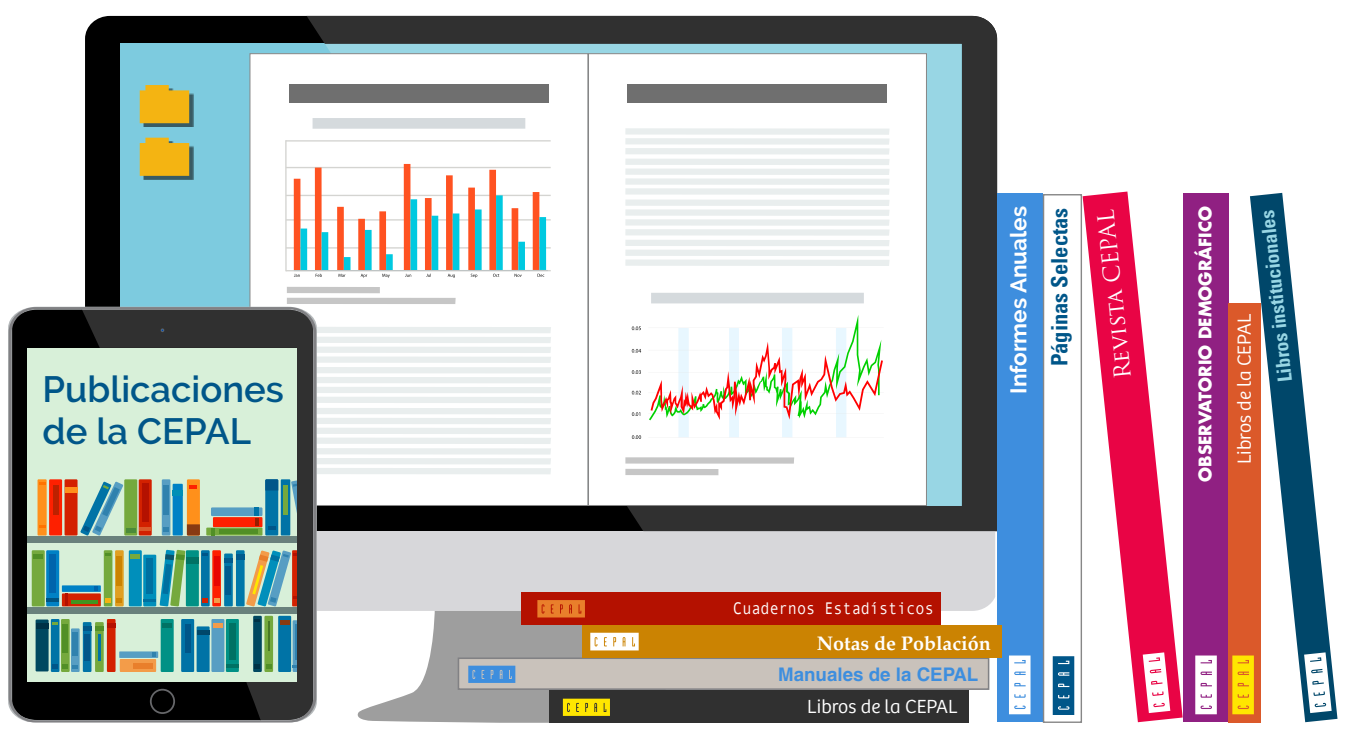

Si desea recibir información oportuna sobre nuestros productos editoriales y actividades, le invitamos a registrarse. Podrá definir sus áreas de interés y acceder a nuestros productos en otros formatos.

\section{Deseo registrarme}

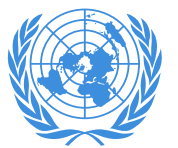

NACIONES UNIDAS

C E P \& L

\section{www.cepal.org/es/suscripciones}




\title{
Consensos y conflictos en la política tributaria de América Latina
}

\author{
Juan Carlos Gómez Sabaini \\ Juan Pablo Jiménez \\ Ricardo Martner
}

Editores

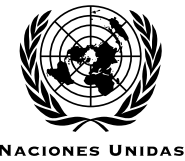

C E P A L

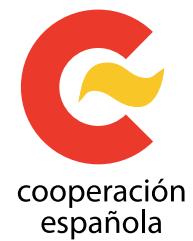

Comisión Económica para América Latina y el Caribe (CEPAL) Santiago, marzo de 2017 


\section{Libros de la CEPAL}

\section{2}

Alicia Bárcena

Secretaria Ejecutiva

Antonio Prado

Secretario Ejecutivo Adjunto

Daniel Titelman

Director de la División de Desarrollo Económico

\section{Ricardo Pérez}

Director de la División de Publicaciones y Servicios Web

Los autores agradecen las contribuciones de Claudio Agostini, Maynor Cabrera, Oscar Cetrángolo, José María Fanelli, Ivonne González, Michael Hanni, Michel Jorrat, Isabel López Azcúnaga, Dalmiro Morán, Andrea Podestá, Darío Rossignolo y los valiosos comentarios de Alberto Arenas a una versión del borrador de este libro. Agradecen asimismo a Nancy Rivas su sustancial apoyo.

Las opiniones expresadas en este documento son de exclusiva responsabilidad de los autores y pueden no coincidir con las de la Organización.

Diseño de portada: Marcela Veas

Publicación de las Naciones Unidas

ISBN: 978-92-1-121947-0 (versión impresa)

ISBN: 978-92-1-058584-2 (versión pdf)

ISBN: 978-92-1-358054-7 (versión ePub)

Número de venta: S.17.II.G.11

LC/PUB.2017/5-P

Distr.: General

Copyright (C) Naciones Unidas, 2017

Todos los derechos reservados

Impreso en Naciones Unidas, Santiago

S.17-00003

Esta publicación debe citarse como: Juan Carlos Gómez Sabaini, Juan Pablo Jiménez, Ricardo Martner (eds.), Consensos y conflictos en la política tributaria de América Latina, Libros de la CEPAL, N 142 (LC/PUB.2017/5-P), Santiago, Comisión Económica para América Latina y el Caribe (CEPAL), 2017.

La autorización para reproducir total o parcialmente esta obra debe solicitarse a la Comisión Económica para América Latina y el Caribe (CEPAL), División de Publicaciones y Servicios Web, publicaciones@cepal.org. Los Estados Miembros de las Naciones Unidas y sus instituciones gubernamentales pueden reproducir esta obra sin autorización previa. Solo se les solicita que mencionen la fuente e informen a la CEPAL de tal reproducción. 


\section{Índice}

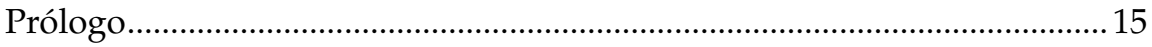

Introducción

Juan C. Gómez Sabaini, Juan Pablo Jiménez, Ricardo Martner............................ 19

Parte 1

Los ingresos tributarios en América Latina ...................................................... 33

Capítulo I

El nivel y la estructura de la carga tributaria en los países de la región

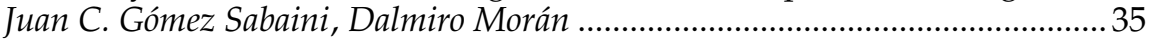

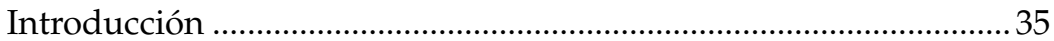

A. Los ingresos tributarios en América Latina: raíces históricas y evolución reciente …………………………....36

B. Cambios en la estructura tributaria de los países de la región....................................................................................... 44

C. Tendencias de reforma tributaria en las últimas décadas .........55

D. Conclusiones y desafíos de la tributación a nivel regional .......62

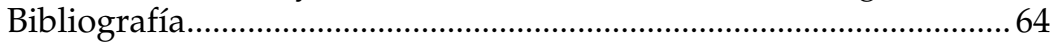

Capítulo II

La tributación sobre la renta en América Latina: desafíos y perspectivas

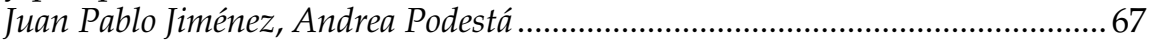

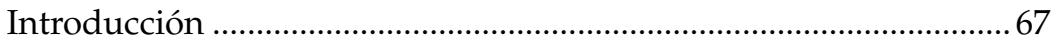

A. Características de la imposición sobre la renta en América Latina: empresas y personas físicas...........................6 68

B. Factores que limitan la recaudación del impuesto sobre la renta personal en la región 
1. La evolución de las tasas legales del impuesto .......................74

2. La estrechez de las bases imponibles: ingresos gravables y gastos tributarios

3. Los niveles de incumplimiento: evasión y morosidad en el pago del impuesto sobre la renta

C. Análisis de los principales aspectos normativos del impuesto sobre la renta de personas físicas en los países de la región.

1. Naturaleza del tributo y principio de imposición jurisdiccional

2. Rentas objeto de gravamen y principales rentas exentas ...85

3. Sujetos pasivos, tratamiento de las rentas obtenidas por un no residente y regímenes especiales

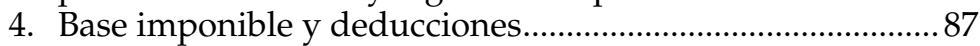

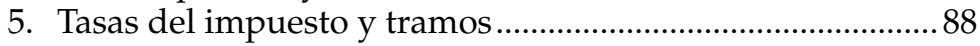

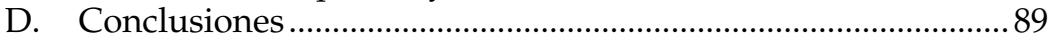

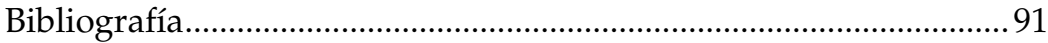

Capítulo III

La tributación en los gobiernos subnacionales

Juan C. Gómez Sabaini, Juan Pablo Jiménez ………….......................................93

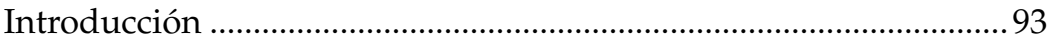

A. El camino hacia el fortalecimiento fiscal

de los gobiernos subnacionales .................................................94

B. Los ingresos tributarios de los gobiernos subnacionales: estructura y evolución

1. Imposición sobre la propiedad inmueble ..............................100

2. Imposición sobre la actividad económica .............................104

3. Imposición sobre los automotores ....................................... 107

4. Otros impuestos subnacionales relevantes en los países de la región

C. Las fuentes no tributarias de financiamiento:

la relevancia de los recursos no renovables.

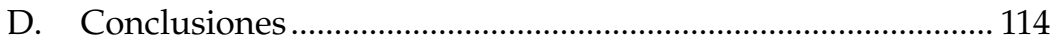

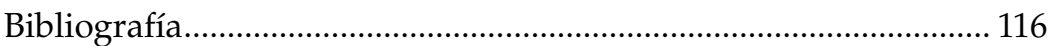

Parte 2

La tributación y sus efectos sobre la desigualdad

Capítulo IV

La incidencia distributiva de la fiscalidad en América Latina

Michael Hanni, Ricardo Martner, Andrea Podestá

Introducción

A. Métodos de estimación de la incidencia de la acción fiscal ...122

B. Resultados de 17 países de América Latina

C. Progresividad y potencial redistributivo del impuesto sobre la renta personal 
D. Conclusiones y reflexiones finales ............................................ 140

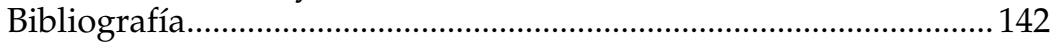

\section{Capítulo V}

La equidad vertical y horizontal de los impuestos

Michel Jorratt.

Introducción

A. Aspectos metodológicos............................................................... 146

1. Definiciones y convenciones básicas .................................. 147

2. Estimación del ingreso antes de la política fiscal.................149

3. Estimación de los impuestos pagados...................................149

4. Índice de equidad ...................................................................... 151

5. Simulaciones de reformas tributarias ................................... 155

B. Consideraciones específicas de los casos de estudio................. 158

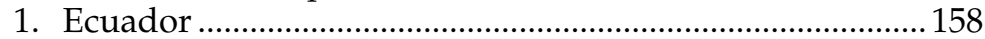

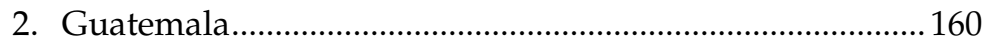

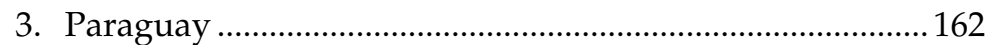

C. Resultados de las estimaciones ……………............................... 163

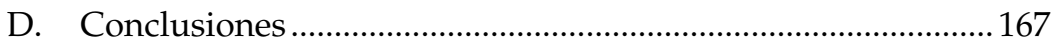

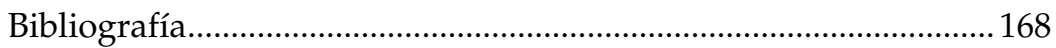

Capítulo VI

La tributación sobre las altas rentas en los países de la región Juan C. Gómez Sabaini, Darío Rossignolo .......................................................... 169

Introducción

A. Aspectos metodológicos para definir e identificar a los individuos de altas rentas

B. Principales resultados de los estudios realizados en los países desarrollados.............................................................173

C. Estudios sobre las altas rentas en América Latina..................... 179

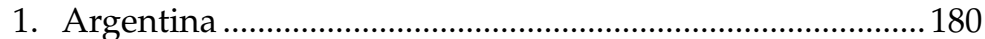

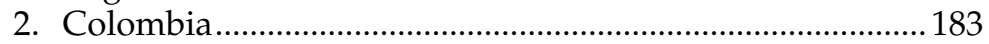

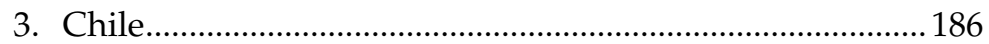

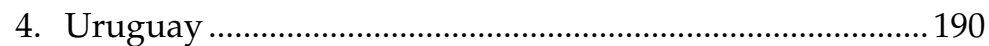

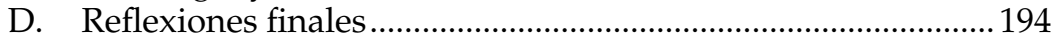

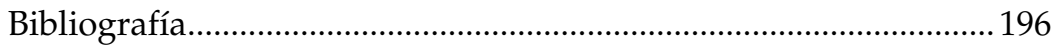

Parte 3

Tributación, crecimiento e inversión

Capítulo VII

Políticas fiscales y crecimiento económico

Ricardo Martner, Andrea Podestá, Ivonne González ........................................ 201

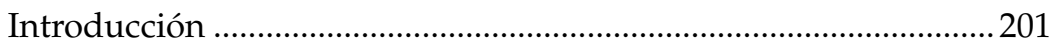

A. Evidencia empírica del vínculo entre política fiscal

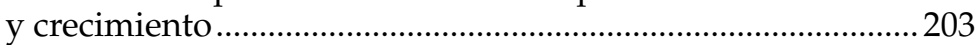

B. La incidencia del gasto público sobre el crecimiento................214 
1. La clasificación económica: prioridad a la inversión...........214

2. La clasificación funcional: preponderancia para el gasto social.

C. Los límites al financiamiento: el papel de los sistemas tributarios.

D. Síntesis y conclusiones 224

Bibliografía. 225

Capítulo VIII

Política tributaria para mejorar la inversión y el crecimiento en América Latina

Claudio Agostini, Michel Jorratt

Introducción

A. Revisión de la literatura sobre incentivos tributarios a la inversión 230

1. Efectividad de los incentivos a la inversión ...........................230

2. Costos de los incentivos tributarios ......................................236

3. Efectividad relativa de los incentivos tributarios ...............2237

4. Evaluación integral de los incentivos tributarios ................239

B. Incentivos tributarios a la inversión en América Latina ......... 241

1. Marco de análisis

2. Panorama de los incentivos a la inversión en América Latina

3. Costo fiscal de los incentivos tributarios a la inversión....248

C. Resumen y conclusiones 249

Bibliografía. 251

Capítulo IX

Reformas fiscales, crecimiento e inversión: el caso de la Argentina

Oscar Cetrángolo, Juan C. Gómez Sabaini, Dalmiro Morán

Introducción

A. Crecimiento, formación bruta de capital e impactos en las finanzas públicas, 2000-2014.

B. Política fiscal e inversión en la Argentina.....

C. Reforma previsional, espacio fiscal e inversión en proyectos productivos: el caso del Fondo de Garantía de Sustentabilidad

D. Las políticas públicas directas para la promoción de la inversión privada.

1. Incentivos a la innovación y el desarrollo tecnológico ......265

2. Incentivos al empleo .............................................................2. 266

3. Financiamiento de la inversión ...........................................266

E. Políticas tributarias para favorecer la inversión ........................267

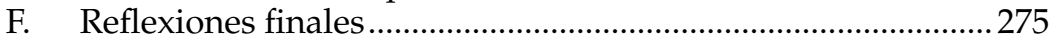

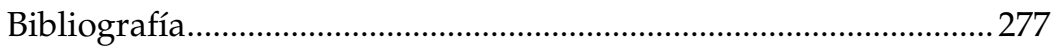




\section{Capítulo X}

Reformas fiscales, crecimiento e inversión: los casos de Guatemala, Nicaragua y Panamá Maynor Cabrera, Juan Alberto Fuentes Knight

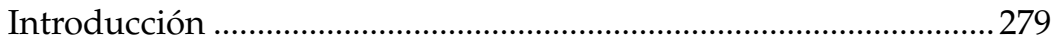

A. Evolución de la inversión y de su composición...........................280

B. Incidencia de factores sistémicos sobre los niveles

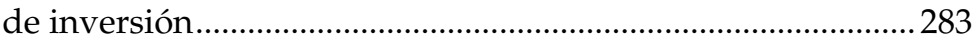

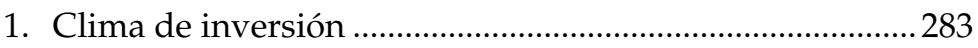

2. La menor volatilidad macroeconómica reciente .................284

3. El espacio fiscal como factor relevante …….........................225

C. Políticas fiscales para la inversión .............................................290

1. Primeros pasos hacia las alianzas público-privadas ..........291

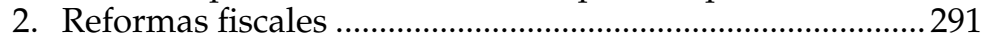

3. Incentivos fiscales ...................................................................293

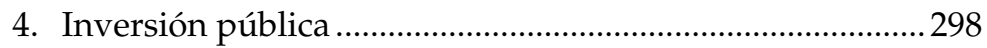

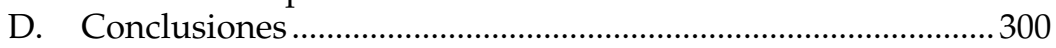

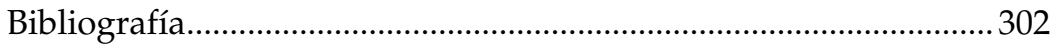

Parte 4

Evasión tributaria e informalidad: los obstáculos principales 303

Capítulo XI

Economía informal y tributación: una exploración de los nexos

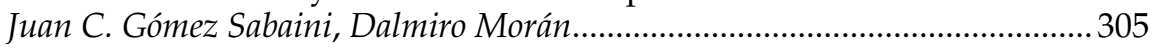

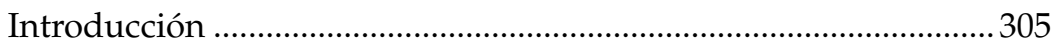

A. El complejo círculo de interacciones entre

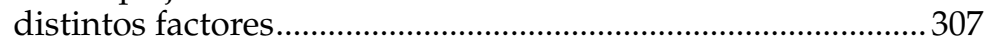

B. El tamaño de la economía informal en América Latina: evidencias y tendencias ..................................................................310

C. Interacciones entre la tributación y el tamaño de la economía informal.

D. Las respuestas tributarias para atender los niveles de informalidad

E. Conclusiones y alternativas de política tributaria para reducir la informalidad

Bibliografía.

Capítulo XII

La evasión tributaria en los países de la región

Oscar Cetrángolo, Juan C. Gómez Sabain, Dalmiro Morán ...............................337

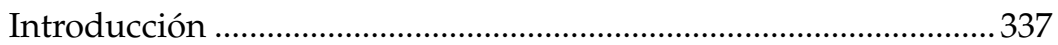

A. Importancia del problema y cuestiones metodológicas ............339

B. La evasión del pago del IVA en los países de la región ............343

C. El caso del impuesto sobre la renta.................................................349

D. La evasión contributiva (o el incumplimiento en los sistemas de seguridad social). 
E. Reflexiones finales: obstáculos y desafíos en la materia..........360

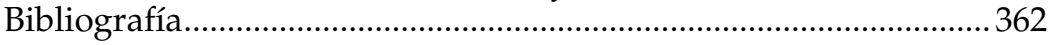

Capítulo XIII

La evasión internacional y la erosión de las bases tributarias

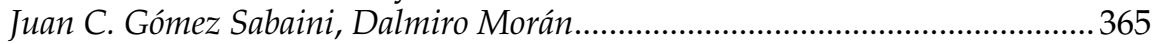

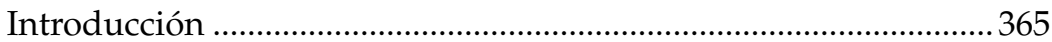

A. La planificación fiscal agresiva y las regulaciones

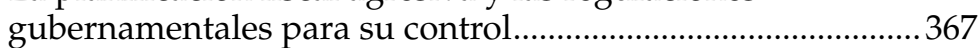

B. Estudios y metodologías aplicadas para la cuantificación de la evasión internacional .........................................................373

C. Conclusiones y perspectivas futuras .............................................. 387

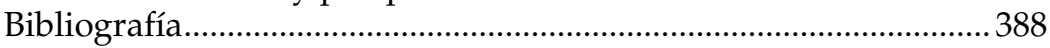

Parte 5

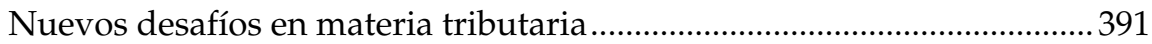

Capítulo XIV

El impacto fiscal de los recursos naturales no renovables

Juan C. Gómez Sabaini, Juan Pablo Jiménez, Dalmiro Morán .............................. 393

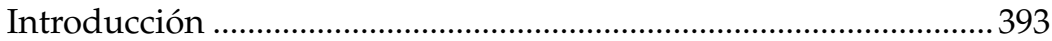

A. Instrumentos fiscales en las industrias extractivas:

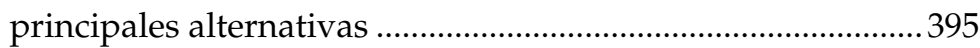

B. Experiencias y reformas recientes en la región ..........................400

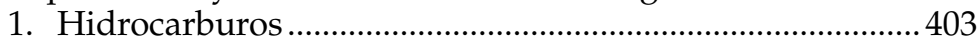

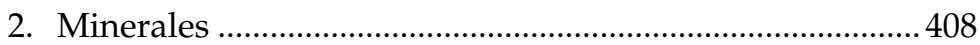

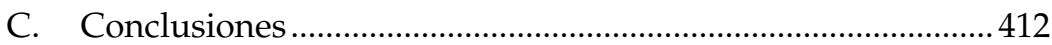

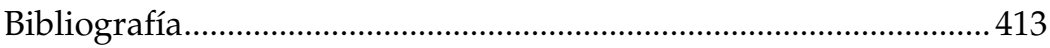

Capítulo XV

Reformas fiscales ambientales: el rol de los tributos

José María Fanelli, Juan Pablo Jiménez, Isabel López Azcúnaga ......................... 415

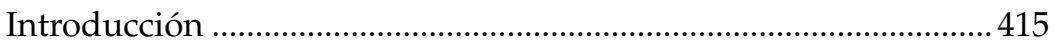

A. Reformas fiscales ambientales: enfoque conceptual .................416

1. El concepto de reforma fiscal ambiental y su evolución... 416

2. La reforma fiscal y sus instrumentos: incentivos, mercados y regulación

B. La experiencia internacional y regional ..................................... 422

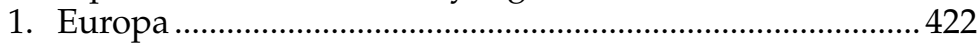

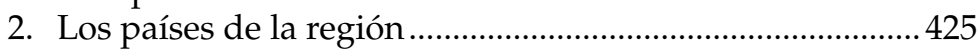

C. Lecciones para el diseño de la reforma fiscal

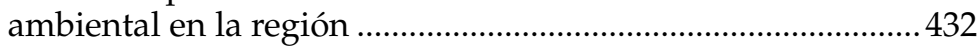

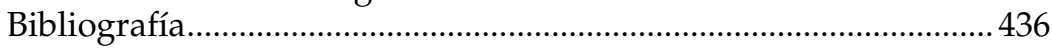

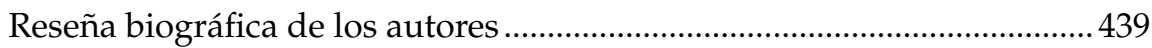

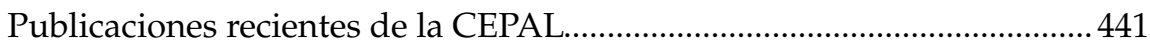




\section{Cuadros}

I.1 América Latina (18 países) y Organización de Cooperación y Desarrollo Económicos (OCDE): nivel de la carga tributaria, incluidas las contribuciones de la seguridad social, 1990-2014

I.2 América Latina (18 países): evolución de la alícuota general del IVA, 1975-2015

I.3 América Latina y Organización de Cooperación y Desarrollo Económicos (OCDE): estructura tributaria media, 1990,2000 y 2014.

I.4 América Latina (18 países) y Organización de Cooperación y Desarrollo Económicos (OCDE): ingresos tributarios por contribuciones de la seguridad social, 1990, 2000 y 2014

I.5 América Latina y Organización de Cooperación

y Desarrollo Económicos (OCDE): estructura tributaria media, 1990, 2000 y 2014

I.6 América Latina (6 países): alícuotas, recaudación y productividad de los impuestos sobre las transacciones financieras (ITF) vigentes en América Latina, 2014

II.1 América Latina (6 países): impuestos sobre los ingresos, utilidades y ganancias de capital, 1940-2014

II.2 América Latina, Organización de Cooperación y Desarrollo Económicos (OCDE) y Unión Europea (15 países): recaudación del impuesto sobre la renta de empresas y personas naturales, 2010 .

II.3 América Latina (18 países): tasas marginales máximas y mínimas del impuesto sobre la renta de las personas físicas por países, 1985-2016

II.4 América Latina y otras regiones: ingreso gravable y alícuotas del impuesto sobre la renta personal, alrededor de 2012-2013 ........77

II.5 América Latina: niveles de renta para la aplicación de tasas mínimas y máximas del impuesto sobre la renta, 2007 y 2016 .........79

II.6 América Latina (países seleccionados): gastos tributarios por tipo de impuesto, 2012

II.7 América Latina (13 países): naturaleza del impuesto sobre la renta y principio de imposición jurisdiccional, 2015

II.8 América Latina (13 países): rentas objeto de gravamen, 2015........... 85

II.9 América Latina (13 países): sujetos pasivos, tratamiento de las rentas obtenidas por los no residentes y regímenes especiales, 2015.

II.10 América Latina (13 países): principales deducciones de la base imponible, 2015

II.11 América Latina (13 países): tasas y tramos del impuesto sobre la renta, 2015

III.1 América Latina (8 países): estructura de los ingresos totales de los gobiernos subnacionales, 2013 
III.2 América Latina (8 países): estructura de los ingresos tributarios de los gobiernos subnacionales, 2014

III.3 América Latina y el Caribe (10 países): marcos legales que rigen la distribución y asignación de ingresos fiscales derivados de los sectores de hidrocarburos y minerales

IV.1 América Latina (17 países): coeficientes de Gini antes y después de impuestos y transferencias públicas, alrededor de 2011.............127

IV.2 América Latina (17 países): relación del ingreso medio per cápita entre los deciles X y I, alrededor de 2011

IV.3 América Latina (16 países): progresividad y redistribución del impuesto sobre la renta de las personas físicas, alrededor de 2011

V.1 Equidad vertical en el IVA con base de ingreso ...................................163

V.2 Equidad vertical en el IVA con base de consumo ................................. 163

V.3 Equidad horizontal en el IVA con base de ingreso ...............................164

V.4 Equidad horizontal en el IVA con base de consumo ..........................164

V.5 Equidad vertical en el impuesto sobre la renta ...................................165

V.6 Equidad vertical en el impuesto sobre la renta con exenciones y transferencias.

V.7 Equidad horizontal en el impuesto sobre la renta ............................. 166

VI.1 Evolución de la participación de los tramos de ingresos elevados, alrededor de 1949 y 2005

VI.2 Estados Unidos: concentración de ingresos en el 1\% superior y crecimiento medio del ingreso, 1976-2007

VI.3 Estados Unidos: evolución del coeficiente de Gini según la Encuesta Continua de Población, 1976 y 2006.

VI.4 Uruguay: participación en el ingreso total de grupos de ingresos altos y variación del ingreso medio, según fuente de información, 2009-2011

VI.5 Uruguay: composición del ingreso de los sectores altos, 2009-2011

VI.6 Uruguay: evolución del coeficiente de Gini según encuestas de hogares y ajustado con datos de declaraciones juradas de la Dirección General Impositiva (DGI), 2009-2011

VII.1 Efectos de corto plazo de la política fiscal sobre el crecimiento: modelos alternativos

VII.2 Literatura empírica sobre la relación entre impuestos y crecimiento económico: principales resultados

VII.3 Aumentos de impuestos, gastos y déficit y su efecto en el crecimiento

VII.4 América Latina (20 países): efectos del gasto público sobre el producto, $1990-2010$

VII.5 Ejemplos de impactos económicos de las funciones sociales

VIII.1 América Latina (10 países): número de incentivos a la inversión, por país y por objetivo

VIII.2 América Latina (10 países): número de incentivos sectoriales a la inversión, por país y por sector favorecido 
VIII.3 América Latina (10 países): número de incentivos a la inversión, por país y por técnica tributaria.

VIII.4 América Latina (10 países): número de incentivos a la inversión, por país y por impuesto

VIII.5 América Latina (10 países): número de incentivos a la inversión, por impuesto y por técnica tributaria

VIII.6 América Latina (5 países): distribución del gasto tributario, por objetivo, 2010 (en porcentajes del total).

VIII.7 América Latina (5 países): distribución del gasto tributario, por objetivo, 2010 (en porcentajes del PIB)

X.1 Obstáculos principales para las empresas, 2010.................................284

X.2 Evolución de los ingresos fiscales del sector público no financiero por períodos

X.3 Principales medidas tributarias aprobadas en Guatemala, Nicaragua y Panamá

X.4 Fuentes de financiamiento de la inversión pública, 2010-2014 .......300

XI.1 América Latina: tamaño de la economía informal.............................313

XI.2 América Latina: regímenes especiales para pequeños contribuyentes.

XI.3 Comparación de los umbrales máximos para la inclusión en el régimen simplificado

XI.4 América Latina (12 países): recaudación tributaria de regímenes simplificados, 2010.

XII.1 América Latina (11 países): tasa de evasión del IVA, 2000-2014 ....345

XII.2 América Latina (6 países): estimaciones del nivel de incumplimiento en contribuciones de la seguridad social

XII.3 Argentina, Colombia y Perú: estimaciones sobre incumplimiento contributivo de los trabajadores asalariados, 2007 y 2010

XIII.1 Metodologías utilizadas para identificar y cuantificar la traslación internacional de ingresos.

XIII.2 América Latina (países seleccionados): pérdidas estimadas de ingresos tributarios por manipulación de precios en operaciones comerciales con empresas de los Estados Unidos y la Unión Europea (27 países).

XIII.3 América Latina (países seleccionados): pérdidas estimadas de ingresos tributarios por manipulación de precios en operaciones comerciales, datos anuales, valores medios, 2002-2006

XIII.4 América Latina (países seleccionados): flujos financieros ilícitos como producto de la manipulación de precios en operaciones comerciales, datos anuales, valores medios, 2003-2012

XIV.1 Instrumentos usualmente aplicados en regímenes fiscales de industrias extractivas

XIV.2 América Latina y el Caribe (10 países): indicadores relativos de los ingresos fiscales generados por la producción de hidrocarburos, 2000-2014.

XIV.3 América Latina y el Caribe (10 países): estructura de los ingresos fiscales provenientes del sector de hidrocarburos, 2000-2014 
XIV.4 América Latina y el Caribe (8 países): indicadores relativos de los ingresos fiscales generados por la producción de minerales, 2000-2014

XIV.5 América Latina y el Caribe (8 países): estructura de los ingresos fiscales provenientes del sector de minerales, 2000-2014.

XV.1 América Latina: elementos ambientales de las reformas

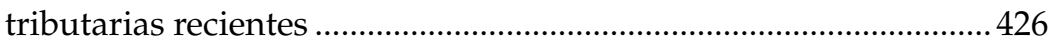

XV.2 América Latina: impuestos ambientales, 1990-2012 …................... 428

\section{Gráficos}

I.1 América Latina (18 países): ingresos tributarios, 2014

II.1 América Latina (países seleccionados): evolución y estructura del impuesto sobre la renta, 1990-2014

II.2 América Latina, Organización de Cooperación y Desarrollo Económicos (OCDE) y 15 economías de la Unión Europea (15 países): estructura del impuesto sobre la renta, 2010

II.3 América Latina (países seleccionados): evolución de las tasas marginales máximas y mínimas del impuesto sobre la renta de personas físicas, 1985-2016.

III.1 América Latina (8 países): evolución de la estructura de los ingresos totales de los gobiernos subnacionales, promedio simple, 1997-2013.

III.2 América Latina (8 países): ingresos tributarios, según nivel de gobierno, 2013

III.3 América Latina (8 países): estructura de los recursos propios corrientes de los gobiernos subnacionales, 2013

IV.1 América Latina (18 países): participación en el ingreso por grupos de deciles, alrededor de 2012.

IV.2 América Latina (16 países): reducción de la desigualdad, según instrumento de la política fiscal, alrededor de 2011

IV.3 América Latina (17 países), OCDE y Unión Europea (15 países): desigualdad de los ingresos de mercado, de los ingresos brutos y de los ingresos disponibles, alrededor de 2011.

IV.4 América Latina (17 países), OCDE y Unión Europea (15 países): desigualdad de los ingresos de mercado y de los ingresos disponibles, alrededor de 2010 y 2011

IV.5 América Latina: tasa media efectiva del decil $\mathrm{X}$, redistribución y efecto de reordenamiento del impuesto sobre la renta de personas físicas bajo distintos escenarios

IV.6 América Latina: reducción media del coeficiente de Gini debido al impuesto sobre la renta de las personas físicas bajo distintos escenarios

IV.7 América Latina: relación media del ingreso medio per cápita entre el decil $\mathrm{X}$ y el decil I bajo distintos escenarios

VI.1 Argentina: participación en el ingreso total de los tramos de ingreso más elevados, 1997-2004 
VI.2 Argentina: evolución del coeficiente de Gini según la Encuesta Permanente de Hogares (EPH) y ajustado con datos de declaraciones juradas del impuesto sobre la renta, 1997-2004 ....... 182

VI.3 Argentina: composición del 1\% de ingresos más elevados, 2001-2004.

VI.4 Colombia: participación en el ingreso total de los tramos de ingresos más elevados, 2006-2010

VI.5 Colombia: evolución del coeficiente de Gini según encuestas de hogares y ajustado con datos de declaraciones juradas del impuesto sobre la renta, 2007-2010.

VI.6 Colombia: composición del 1\% de ingresos más elevados, 2006-2010.

VI.7 Chile: participación en el ingreso total de los tramos de ingresos más elevados, 2005-2010

VI.8 Chile: evolución del coeficiente de Gini según encuestas de hogares y ajustado con datos de declaraciones juradas del impuesto sobre la renta, 2005-2010.

VII.1 América Latina (20 países) y el Caribe (13 países): composición del gasto público.

VII.2 América Latina (19 países) y el Caribe (13 países): gastos públicos de capital.

VII.3 América Latina y el Caribe (21 países): gasto público social...........219

VII.4 América Latina y el Caribe (21 países): composición del gasto público social, 2011

VII.5 América Latina (19 países) y el Caribe (13 países): estructura tributaria (sin seguridad social).

IX.1 Argentina: evolución de los agregados macroeconómicos, 1993-2013.

IX.2 Argentina: resultado del sector público consolidado (nación y provincias), 1961-2013.

IX.3 Argentina: evolución de la inversión real directa del sector público, 1965-2013

IX.4 Argentina: composición de la cartera del Fondo de Garantía de Sustentabilidad, 2002-2014

IX.5 Argentina: estructura de proyectos productivos o de infraestructura en la cartera del Fondo de Garantía de Sustentabilidad, 2009-2014

IX.6 Argentina: gastos tributarios del gobierno central (impuestos nacionales), 2001-2013

IX.7 Argentina: composición de gastos tributarios por tipo de impuesto, 2013

X.1 Evolución de la formación bruta de capital fijo, 2004-2014 ............. 281

X.2 Comportamiento de la inversión pública y privada, 2004-2014 ....282

X.3 Evolución del déficit fiscal y sus principales determinantes, 2004-2008 y 2010-2013

X.4 Gasto total del sector público no financiero por períodos 
X.5 Evolución del gasto público del gobierno central, 2010-2014

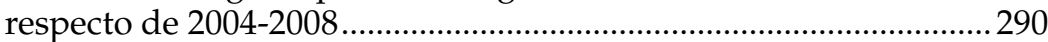

X.6 Estructura impositiva, 2004-2008 y 2010-2013 …..............................293

X.7 Inversión extranjera directa vinculada a incentivos fiscales ...........296

X.8 Gasto tributario medio, 2008-2012 ………….................................. 297

X.9 Inversión pública según etapas del ciclo económico, 1990-2013 ...299

XI.1 Regiones o grupos de países: tamaño de la economía informal, promedio 1999-2007

XI.2 América Latina (18 países): tamaño de la economía informal y recaudación del impuesto sobre el valor agregado (IVA), 1999-2000 y 2006-2007

XI.3 América Latina (17 países): tamaño de la economía informal y recaudación del impuesto sobre la renta (ISR), 1999-2000 y 2006-2007

XI.4 América Latina (14 países): tamaño de la economía informal y evasión tributaria del impuesto sobre el valor agregado (IVA), 2006-2007.

XII.1 América Latina (países y años seleccionados): evolución de las tasas de evasión del IVA, 2003-2012

XII.2 América Latina (último año disponible) y Unión Europea (año 2013) (países seleccionados): tasas de evasión del IVA

XII.3 América Latina (7 países): tasas estimadas de evasión impositiva del impuesto sobre la renta

XIV.1 Índice de precios de productos primarios no renovables, 2000 a mayo de 2016

XIV.2 América Latina y el Caribe (10 países): ingresos provenientes de recursos naturales no renovables, 2000-2015.................................403

XV.1 Unión Europea (27 países): total de impuestos ambientales........... 424

XV.2 Unión Europea: composición de los impuestos ambientales por tipo de impuesto, 2012 ................................................................ 424

XV.3 América Latina: composición de la tributación ambiental, 2012..... 429

XV.4 América Latina (19 países): subsidios a la energía antes de impuestos, 2011-2013

\section{Recuadros}

I.1 Modelos alternativos en materia de imposición sobre la renta ........56

IV.1 Progresividad y redistribución de los impuestos: principales indicadores

VI.1 El ajuste de los altos ingresos en las mediciones de desigualdad

XI.1 El monotributo en la Argentina, el Brasil y el Uruguay.......................327

XII.1 Evasión de los impuestos selectivos sobre el consumo 


\section{Prólogo}

La comunidad internacional, en respuesta a los desequilibrios económicos, distributivos y ambientales del estilo de desarrollo dominante, ha aprobado recientemente la Agenda 2030 para el Desarrollo Sostenible y sus 17 Objetivos. La Comisión Económica para América Latina y el Caribe (CEPAL), en su XXXVI período de sesiones, presentó a los Estados miembros el documento Horizontes 2030: la igualdad en el centro del desarrollo sostenible, que complementa analíticamente esa Agenda sobre la base de la perspectiva estructuralista del desarrollo y desde el punto de vista de los países de América Latina y el Caribe.

Sus propuestas se centran en la necesidad de impulsar un cambio estructural progresivo que aumente la incorporación de conocimiento en la producción, garantice la inclusión social y combata los efectos negativos del cambio climático. El foco de las reflexiones y propuestas para avanzar hacia un nuevo estilo de desarrollo radica en el impulso a la igualdad y la sostenibilidad ambiental. La creación de bienes públicos globales y de sus correlatos a nivel regional y la formulación de políticas nacionales en la materia es el núcleo desde el que se expande la visión estructuralista hacia un keynesianismo global y una estrategia de desarrollo centrada en un gran impulso ambiental.

Ante el imperativo de movilizar recursos nacionales para el financiamiento del desarrollo sostenible y procurar el cumplimiento de la Agenda 2030, la CEPAL ha reafirmado la necesidad de reformar las estructuras tributarias de los países, de manera de ampliar el espacio fiscal, mejorar su impacto distributivo y fortalecer el crecimiento económico. Para recuperar el espacio fiscal serán necesarias reformas integradas y sostenidas en el ámbito de las finanzas públicas, que apunten a asegurar la solvencia 
del sector público, proteger la inversión y los logros sociales y ampliar los recursos tributarios.

Si bien en los últimos años se han comprobado avances en materia de reformas tributarias, todavía queda mucho por hacer. La alta concentración de la riqueza y el ingreso en nuestros países, que hacen de América Latina y el Caribe la región más desigual del planeta, requiere de un tratamiento cuidadoso del sistema tributario y de las reformas por implementar, a fin de promover un aprovechamiento integral de su acción redistributiva.

En el ámbito de la fiscalidad, la CEPAL ha venido impulsando la elaboración de numerosos documentos y estudios que reflejan dicha visión y la expanden de acuerdo con las circunstancias cambiantes del contexto macroeconómico. En ese sentido, la presente publicación reúne las contribuciones específicas de numerosos especialistas en materia tributaria. Los capítulos aquí recopilados constituyen versiones resumidas y actualizadas de documentos de trabajo publicados por la CEPAL con la asistencia financiera de diversos organismos de cooperación, como la Agencia Española de Cooperación Internacional para el Desarrollo (AECID) y la Agencia Alemana de Cooperación Internacional (GIZ), los que ubicaron la fiscalidad como un tema prioritario en sus programas de cooperación con la CEPAL. Vale remarcar que el impacto de todos estos documentos y de las actividades de difusión y de capacitación asociadas ha sido creciente en la región y, en ocasiones, las recomendaciones entregadas se han transformado en los ejes rectores de las reformas tributarias recientes.

Como señalan los editores del libro, en la región la política tributaria transita entre consensos y conflictos. Podrá haber consensos en cuanto a la necesidad de corregir la baja capacidad recaudatoria, en lo referido a reducir la evasión fiscal, en lo que hace a iniciar acciones globales para reducir la elusión proveniente de las multinacionales y de los individuos de elevado patrimonio, en evitar distorsiones en la aplicación de los impuestos, pero perduran disensos significativos en cuanto a los objetivos últimos de los sistemas tributarios. El objetivo de favorecer la redistribución del ingreso y la riqueza mediante estos instrumentos aún enfrenta objeciones; de hecho, la idea de fortalecer el impuesto sobre la renta de las personas físicas (y las acciones destinadas a ello) ha suscitado amplios conflictos de interés.

De esa convivencia de consensos y conflictos, surge el título de este libro. En cada capítulo se recogen estos dilemas y se exponen las distintas consideraciones que intervienen en la política tributaria a nivel regional. Para la CEPAL, el camino hacia el desarrollo inclusivo pasa por la construcción de acuerdos nacionales bajo un solo principio ético normativo y objetivo fundamental: la igualdad de derechos de las personas. América Latina debe transitar de sociedades de privilegios a la igualdad de derechos, y ello solo se logra reforzando el pilar distributivo de los sistemas tributarios. 
En definitiva, esta publicación contribuye al estudio de un tema central en la región, por lo que se espera que los estudios realizados sirvan de apoyo a las autoridades regionales en el diseño de reformas orientadas a sistemas tributarios que, además de ser sostenibles, resguarden la equidad distributiva, de manera de forjar un futuro más inclusivo para los países de nuestra región.

\author{
Alicia Bárcena \\ Secretaria Ejecutiva \\ Comisión Económica para \\ América Latina y el Caribe (CEPAL)
}





\section{Introducción}

Juan C. Gómez Sabaini ${ }^{1}$

Juan Pablo Jiménez ${ }^{2}$

Ricardo Martner ${ }^{3}$

Durante los primeros días de septiembre de 1972, en el entonces denominado Distrito Federal de México, se celebró la Tercera Conferencia Interamericana sobre Tributación, organizada conjuntamente por la Organización de los Estados Americanos (OEA), el Banco Interamericano de Desarrollo (BID) y la Comisión Económica para América Latina y el Caribe (CEPAL). Aunque ha pasado mucho tiempo, dicho evento sigue siendo reivindicado por los especialistas más memoriosos como un hito transcendental en lo que respecta a la política tributaria en América Latina.

Vale recordar que a inicios de los años sesenta se había iniciado un período novedoso para la región: la puesta en marcha del programa de ayuda exterior conocido como "Alianza para el Progreso", que (en agosto de 1961) propició en la mayoría de los países la puesta en marcha de ambiciosos planes de desarrollo económico y social. Entre otras medidas, dichos planes incluían la realización de reformas tributarias para fortalecer los ingresos y satisfacer las necesidades financieras de los Estados.

1 Consultor de la Comisión Económica para América Latina y el Caribe (CEPAL), el Banco Interamericano de Desarrollo (BID), el Fondo Monetario Internacional (FMI) y el Centro Interamericano de Administraciones Tributarias (CIAT) especializado en temas de política tributaria en países de América Latina. Profesor de posgrado en la Universidad Nacional de Buenos Aires. Correo electrónico: gomezsabaini@gmail.com.

2 Oficial de Asuntos Económicos de la División de Desarrollo Económico de la Comisión Económica para América Latina y el Caribe (CEPAL). Correo electrónico: juanpablo.jimenez@cepal.org.

3 Jefe de la Unidad de Asuntos Fiscales de la División de Desarrollo Económico de la Comisión Económica para América Latina y el Caribe (CEPAL). Correo electrónico: ricardo.martner@cepal.org. 
En ese contexto surgió el Programa Conjunto de Tributación OEA/ $\mathrm{BID} / \mathrm{CEPAL}$, siendo esta la instancia rectora para consensuar las orientaciones generales en materia tributaria para los países de la región. En particular, se alentaron la reforma, la simplificación y la actualización del sistema de tributación indirecta y, sobre todo, el fortalecimiento de la imposición directa mediante la generalización del impuesto personal progresivo sobre la renta y el aumento de las alícuotas aplicadas a individuos y empresas, a fin de mejorar la equidad vertical de los sistemas tributarios vigentes. Esas iniciativas se sustentaban en las recomendaciones que provenían del ámbito académico a través de especialistas como Nicholas Kaldor, Richard Musgrave y Federico Herschel. Esos expertos comenzaban a proponer una reformulación de la tributación como instrumento de política económica que no solo sirviera para el financiamiento de bienes públicos provistos por el Estado, sino que también contribuyera a corregir la desigual distribución del ingreso y de la riqueza que se observaba en países en desarrollo como los de América Latina.

La Conferencia de 1972 encontró su fundamentación en el hecho de que las reformas consensuadas para la región no habían tenido los resultados esperados por no haberse tomado debidamente en cuenta las características, restricciones y limitaciones específicas de América Latina (informalidad, evasión tributaria, bajo nivel de institucionalidad, insuficiente estructura productiva, entre otras). Como señaló Gerson da Silva, en ese entonces Director de la Oficina de Finanzas Públicas de la OEA, "[...] infortunadamente, los avances registrados en la formulación de la política económica [durante los años sesenta] no se extendieron, en igual medida, al proceso de su implementación [...]. Limitados dentro del marco conceptual de los enfoques elaborados en función de la problemática de las economías centrales, los países latinoamericanos se encontraron carentes de instrumentos de acción capaces de disciplinar eficazmente las fuerzas del mercado al servicio de los objetivos generales de la sociedad" ${ }^{\prime \prime}$.

Vale destacar que, con ese enfoque, lejos de refutar los objetivos "ampliados" que guiaban a la política fiscal en su conjunto, se reconocía explícitamente por primera vez la imposibilidad de establecer una "receta convencional única" para América Latina por tratarse de una región con características específicas y, a la vez, con una gran heterogeneidad entre los países que la componían. El rol preponderante que había adquirido la política tributaria como instrumento de política debía, a partir de entonces,

\footnotetext{
Véase Organización de los Estados Americanos (OEA) / Banco Interamericano de Desarrollo (BID)/ Comisión Económica para América Latina y el Caribe (CEPAL), "La política tributaria como instrumento de desarrollo", Documentos y conclusiones de la Tercera Conferencia Interamericana sobre Tributación (México, 3-8 septiembre 1972), Programa Conjunto de Tributación, Serie Reforma Tributaria para América Latina, tomo IV, Washington, D.C., Secretaría General de la Organización de los Estados Americanos, 1973.
} 
tomar en cuenta esas particularidades al momento de diseñar e implementar reformas estructurales en cada país.

Los significativos desequilibrios, la volatilidad macroeconómica regional y los intrincados contextos políticos propiciaron la difusión y aceptación por parte de los Gobiernos latinoamericanos de lo que se conoce como Consenso de Washington y, con ello, hubo nuevas reformulaciones de criterios, objetivos e instrumentos. La tributación directa quedó desplazada del centro de la escena tributaria. El impuesto sobre el valor agregado (IVA) se introdujo aceleradamente en varios países de la región y fue ganando espacio como principal generador de recursos tributarios, a partir del incremento de la alícuota general y la ampliación de su base imponible.

Los sistemas tributarios se simplificaron, los impuestos al comercio internacional se redujeron a una mínima expresión y, en general, los países pusieron mucho énfasis en mejorar los procedimientos de administración tributaria para incrementar el monto efectivo de los ingresos recaudados. Incluso se llegó a sugerir que la política tributaria estaba supeditada a las posibilidades técnicas de los organismos de recaudación de los países. Si bien se reconoce una gran complementariedad entre ambas dimensiones, ese enfoque atentaba claramente contra la potencialidad de la tributación como instrumento de política y no solo situaba el objetivo recaudatorio otra vez por encima del resto, sino que desalentaba cualquier esfuerzo por reformar y mejorar los sistemas tributarios sobre la base de criterios de equidad.

El mantenimiento de problemas estructurales, más allá de algunos resultados satisfactorios en el ámbito tributario, puso de manifiesto las limitaciones de las reformas introducidas en los años ochenta y noventa. América Latina ha sufrido, y sigue haciéndolo, una serie de choques externos y frecuentes cambios de política económica que, al menoscabar las estrategias de desarrollo y generar crisis fiscales recurrentes, han agudizado el eterno dilema entre el crecimiento y la distribución del ingreso.

Afortunadamente, desde los primeros años del nuevo siglo se percibió una revalorización de algunas ideas centrales que, lejos de ser nuevas, habían sido más bien menospreciadas en la región. Cabe destacar muy especialmente el resurgimiento del énfasis en las cuestiones distributivas y en la posibilidad de moldear la política tributaria en función de ese objetivo. De hecho, tal como muestra la edición más reciente del Panorama Fiscal de América Latina y el Caribe, las reformas tributarias más importantes a nivel regional han apuntado principalmente a fortalecer la participación de la tributación sobre la renta en los respectivos países ${ }^{5}$.

Véase Comisión Económica para América Latina y el Caribe (CEPAL); Panorama Fiscal de América Latina y el Caribe 2016: Las finanzas públicas ante el desafío de conciliar austeridad con crecimiento e igualdad (LC/L.4140), Santiago, 2016. 
En la actualidad se ha afianzado la idea de la relevancia de la tributación como un elemento esencial para el desarrollo. Los impuestos constituyen una herramienta fundamental para un Estado que busque aumentar ingresos medianamente predecibles (a diferencia de otros más volátiles, como los provenientes de la explotación de recursos naturales), mejorar su relación con el ciclo macroeconómico, favorecer la redistribución del ingreso en la sociedad y proveer a sus ciudadanos de infraestructura y servicios básicos, como los de salud y educación. La tributación también fortalece la democracia y la rendición de cuentas por parte de los gobiernos, al mismo tiempo que promueve una mayor participación ciudadana en el proceso político al exigirse que los ingresos tributarios se inviertan de una manera inteligente y en pos del bien común.

Sin embargo, aunque las ideas anteriores puedan gozar de una aceptación bastante generalizada entre los expertos, la política tributaria en sí misma es un campo en el que conviven, o tratan de convivir, diversos consensos y conflictos. Por ejemplo, a lo largo de los años, los aportes académicos han demostrado que la eficiencia económica, es decir la asignación de recursos que permite maximizar el nivel de producción e ingreso nacional, puede verse diezmada por la presencia de impuestos distorsivos. En consecuencia, sería deseable minimizar ese efecto sobre los agentes económicos al momento de diseñar e implementar determinado tributo. En ese sentido, al parecer existe consenso acerca de ese objetivo en los niveles tanto de decisión política como del ciudadano común en los países de América Latina. Asimismo, parece haber un acuerdo generalizado acerca de la importancia de alcanzar y mantener un determinado nivel de recursos tributarios que haga viable el financiamiento de la provisión de bienes y servicios públicos de calidad y de otros gastos públicos relevantes (como los vinculados a los sistemas de protección social) ante las exigencias cada vez mayores de la ciudadanía. En relación con ello, generalmente se destaca la relativa mayor estabilidad de los impuestos tradicionales para cumplir con dicho objetivo y generar un flujo predecible de ingresos fiscales. Esto es especialmente válido en comparación con otros tipos de impuestos (por ejemplo, los vinculados a la variación de los precios internacionales de los productos básicos) que quedan más expuestos a la volatilidad macroeconómica tan característica de las economías de la región.

En cambio, la posibilidad de favorecer la redistribución del ingreso y la riqueza mediante los instrumentos tributarios aún enfrenta objeciones de variada índole y a distintos niveles. De hecho, las resistencias y los obstáculos con que ha tropezado a lo largo de los años la idea de fortalecer el impuesto sobre la renta de las personas físicas responden al conflicto de intereses en torno al mismo. Podría hacerse una observación similar acerca del escaso grado de descentralización fiscal alcanzado (al menos en lo que respecta a la asignación de potestades tributarias a los niveles subnacionales 
de gobierno), de la utilización de determinados tributos en los particulares regímenes fiscales que se aplican en las industrias extractivas, de la eficacia de los incentivos tributarios para favorecer el crecimiento y la inversión, de la necesidad de cuantificar y combatir la evasión tanto a nivel nacional como internacional, de la posibilidad concreta de facilitar una reducción del tamaño de la economía informal y también del rol de la tributación en las recientes reformas fiscales orientadas a la protección del medio ambiente. Sin entrar en demasiados detalles, se podrían dar ejemplos de consensos y conflictos en todas estas dimensiones de la tributación. Esos consensos y conflictos tienen la particularidad de ir cambiando (reduciéndose o acentuándose) a lo largo del tiempo y de acuerdo a las características específicas de cada sociedad.

De esa convivencia de consensos y conflictos surge el título de este libro. Así, en cada capítulo se recoge este dilema y se exponen, explícita o implícitamente, las distintas consideraciones que intervienen en la política tributaria a nivel regional. Lejos de recaer demasiado en los conflictos, se ha puesto énfasis en los consensos logrados hasta el momento y en los que podrían resultar indispensables de cara al futuro.

Dada la magnitud de la obra emprendida, los editores consideran necesario reconocer el esfuerzo realizado por los profesionales que contribuyeron significativamente al proceso de elaboración. En ese sentido, se agradece la valiosa colaboración de Dalmiro Morán, quien estuvo a cargo de resumir, actualizar, revisar y compilar los documentos originales de los autores de cada capítulo, además de contribuir a la discusión sobre el enfoque adoptado a lo largo del libro. Por su parte, Ignacio Ruelas Ávila aportó una eficiente asistencia estadística en algunos capítulos. Ariela Goldschmit realizó una segunda lectura de todo el material recopilado y efectuó revisiones y correcciones adicionales con el fin de perfeccionar el estilo de redacción utilizado. Por último, los autores de los documentos originales convalidaron el contenido de los capítulos finales y aportaron sugerencias y comentarios pertinentes.

La presente publicación, que recoge la visión de la CEPAL, se ha estructurado sobre la base de cinco partes temáticas que responden a los principales desafíos que enfrenta la política tributaria entendida como instrumento de desarrollo en los países de América Latina. En particular, se ha puesto el énfasis en los aspectos relacionados con la equidad, siendo la desigualdad (junto con el esquivo crecimiento económico) uno de los principales obstáculos que enfrenta la región. Llama la atención que los objetivos rectores de políticas públicas de hace más de 40 años (de ahí la reseña histórica de los primeros párrafos) sean bastante similares a los que se plantean en la actualidad, lo que denota la persistencia de problemas estructurales, sumada a cierta ineficacia, o el insuficiente impacto de antiguas oleadas de reformas tributarias. 
La primera parte se centra en las cuestiones referentes al nivel de ingresos tributarios y a su estructura, es decir, al peso relativo de los principales tipos de impuestos en la recaudación total. En los últimos años, la comunidad internacional ha enfatizado repetidamente la necesidad de movilizar recursos internos en los países en desarrollo como la manera más sostenible de financiar el desarrollo y reducir la dependencia externa. La cantidad de recursos disponibles es un aspecto importante, pero también importa conocer cómo o a través de cuáles instrumentos se recaudan. Además, en los países más descentralizados es necesario considerar la tributación en los niveles subnacionales de gobierno.

En el capítulo I, Gómez Sabaini y Morán analizan la evolución de la carga tributaria en los países de América Latina desde una perspectiva histórica. Aparte del gran incremento de dicha variable durante la última década, también se destacan los hechos estilizados referidos a la estructura tributaria latinoamericana, aún con marcadas diferencias entre países. Asimismo, se describen las tendencias más recientes de reforma tributaria a nivel regional, en especial las que tienen que ver con la imposición directa y con algunos gravámenes poco convencionales, como los que recaen sobre las transacciones financieras. A partir del estudio de casos, tanto exitosos como frustrados, los autores identifican una serie de lecciones y desafíos de la política tributaria (en la que los aspectos de economía política juegan un papel relevante) que pueden servir de guía hacia el futuro.

En el capítulo II, Jiménez y Podestá abordan un aspecto que sigue siendo la principal debilidad de los sistemas tributarios vigentes en América Latina. Más allá de que, con el paso de los años, se haya transformado en un pilar tributario (junto con el impuesto sobre el valor agregado (IVA) y las contribuciones a la seguridad social), el impuesto sobre la renta (ISR) constituye actualmente el centro de los esfuerzos en materia de análisis y reformas tributarias, ante el escaso peso relativo del impuesto sobre los ingresos de las personas físicas. Además de definir los factores que limitan la recaudación de ese impuesto, los autores proveen un extenso análisis de sus principales aspectos normativos, señalando las importantes diferencias entre los países de la región y las áreas críticas de reforma.

En el capítulo III, Gómez Sabaini y Jiménez realizan una descripción de la tributación en América Latina, pero a nivel de los gobiernos subnacionales. Enfatizan los distintos procesos de reasignación de responsabilidades entre niveles de gobierno que han derivado en el actual sistema de relaciones fiscales intergubernamentales. En particular se analiza el reparto de bases imponibles entre niveles de gobierno, la estructura de ingresos tributarios subnacionales y su evolución en términos generales, sin dejar de destacar algunos aspectos específicos de cada país. Se reconoce, además, el gran peso que adquieren otras fuentes no tributarias en el financiamiento subnacional, 
sobre todo las asociadas a la explotación económica de recursos naturales no renovables.

Sobre la base de lo anterior, en la segunda parte se profundiza en una de las temáticas centrales de este libro, a saber, la vinculación entre tributación y desigualdad. Como ya se mencionó, la función redistributiva del sistema tributario recuperó protagonismo desde los primeros años de la década de 2000 , lo que se ha reflejado cada vez más en las reformas tributarias recientes a nivel regional. En ese sentido, son igualmente importantes las mediciones cuantitativas sobre la magnitud y el alcance de esa redistribución y las simulaciones tendientes a evaluar los potenciales efectos de cada reforma tributaria. Las experiencias de cada país brindan valiosos aprendizajes para el resto.

En el capítulo IV, Hanni, Martner y Podestá aportan un análisis de la incidencia distributiva de la fiscalidad en América Latina. Sobre la base de una metodología estándar (similar a la aplicada en los estudios sobre países desarrollados), se exponen resultados actualizados y comparables respecto de los países de América Latina y se comprueba que hay un impacto redistributivo muy inferior al calculado respecto de los países desarrollados. Más allá de esas diferencias, la reducción de la desigualdad en la región (medida por el coeficiente de Gini) proviene principalmente de las transferencias públicas en efectivo (incluidas las pensiones) y del impuesto a la renta personal y las contribuciones a la seguridad social. Además, los autores realizan una serie de simulaciones para evaluar la progresividad y el potencial redistributivo del impuesto a la renta personal y encuentran bastante margen para la introducción de reformas concretas en ese sentido, ya sea a partir de la ampliación de la base imponible del tributo, como de un aumento de la tasa efectiva aplicable a los deciles superiores en la escala de ingresos.

En el capítulo V, Jorrat provee un marco conceptual para evaluar la equidad vertical y horizontal de los impuestos. Además, diseña una metodología básica que permite evaluar el impacto distributivo de distintas reformas legales en el impuesto sobre la renta (ISR), como la aplicación de un impuesto plano, un impuesto dual y un impuesto familiar. Luego de explicar distintos aspectos metodológicos generales y un conjunto de consideraciones específicas según el caso de estudio, el autor aplica esa metodología a tres países de la región: Ecuador, Guatemala y Paraguay. Como resultado de las estimaciones se comprueba que la incidencia (progresiva o regresiva) del IVA depende crucialmente del indicador de bienestar utilizado (consumo o ingreso), mientras que el impuesto a la renta es progresivo en los tres casos, pero con una escasa contribución a la equidad.

En el capítulo VI, Gómez Sabaini y Rossignolo se adentran en un área poco explorada, pero que, a nivel regional e internacional, ha suscitado un creciente interés durante los últimos años, a saber, la tributación sobre las 
personas de ingresos muy elevados. Los autores comienzan con una revisión de los aspectos metodológicos vinculados a la definición y la identificación de los contribuyentes de altas rentas y repasan brevemente las evidencias encontradas en países desarrollados para luego centrar la atención en los resultados de una serie de estudios recientes sobre cuatro países de la región. Más allá de los obstáculos estadísticos que deben sortear, dichos análisis encienden una luz de alerta al proveer información concreta acerca de la importancia económica de ese reducido conjunto de individuos y de los efectos que su consideración tendría para la política tributaria.

La tercera parte de este libro trata sobre la relación entre la política fiscal y el crecimiento económico. Actualmente continúan los debates teóricos y empíricos acerca de los efectos de la política fiscal sobre el crecimiento y la inversión, diferenciados según se trate del corto, del mediano o del largo plazo. No obstante, parece existir cierto consenso en cuanto a la necesidad de generar avances en la productividad mediante mejoras en la provisión de bienes públicos, e incrementar por esa vía el potencial de crecimiento de las economías en desarrollo. Desde el punto de vista del gasto público, se ha destacado la importancia de la inversión pública (vista como complemento y no como competencia para la inversión privada) y de facilitar el financiamiento de inversiones privadas con fines productivos. Desde el punto de vista tributario, la modalidad más conocida es la concesión de incentivos o gastos tributarios (o el diseño de impuestos ad hoc para favorecer a un determinado sector). A ese respecto, los países de América Latina tienen amplias experiencias que brindan siempre aprendizajes sobre las mejores prácticas en la materia. Aunque se han observado varios procesos de racionalización de los incentivos, históricamente han significado un importante sacrificio de recursos tributarios sin una clara justificación vinculada con su incidencia sobre el crecimiento y la inversión agregada.

En el capítulo VII, Martner, Podestá y González examinan aspectos conceptuales y la evidencia empírica más reciente acerca del vínculo entre política fiscal y crecimiento, diferenciando los efectos a corto, mediano y largo plazo. Luego centran su análisis en el gasto público y encuentran un creciente y alentador énfasis en la inversión pública y en los programas de gasto social. Además, ponen de relieve el papel de los sistemas tributarios como límite al financiamiento y las implicancias derivadas de la estructura tributaria de un país. Como conclusión principal, se argumenta que solo un gasto público de mayor calidad, debidamente respaldado por un sistema tributario eficiente y equitativo, podría permitir el tránsito hacia modalidades de desarrollo sostenible y con grados crecientes de igualdad e inclusión social. A su vez, se destaca la importancia de contar con instituciones orientadas a construir políticas fiscales transparentes y con objetivos claros para superar los dilemas de corto plazo (crecimiento) y de largo plazo (desarrollo económico). 
En el capítulo VIII, Agostini y Jorratt examinan los puntos de contacto entre la política tributaria y la inversión en los países de América Latina. Con ese fin, centran su análisis en un conjunto de instrumentos de política utilizados ampliamente en los países de la región, como los incentivos a la inversión. En primer lugar, hacen un extenso análisis de la evidencia empírica acerca de la eficacia y la eficiencia de los gastos tributarios destinados a la inversión que figura en estudios disponibles sobre países desarrollados y en desarrollo. En ese sentido, los resultados son diversos y no concluyentes. Si bien ello reforzaría la necesidad de realizar evaluaciones integrales para el establecimiento y mantenimiento de incentivos tributarios, tales evaluaciones no son frecuentes en los países de la región. Luego se presenta la información acerca de los distintos tipos de incentivos tributarios para promover la inversión que se utilizan en los países latinoamericanos. Se detecta una serie de regularidades en cuanto a su propósito específico, las técnicas tributarias escogidas y los impuestos usados para otorgar incentivos.

En el capítulo IX, Cetrángolo, Gómez Sabaini y Morán analizan lo sucedido con las políticas de gasto e ingresos fiscales en la Argentina durante la última década y después de la última crisis económica, quizás la más profunda de la historia de ese país. Primero se repasa la evolución reciente de la situación macroeconómica, para luego concentrarse en el análisis de la política fiscal predominante y la trayectoria de la inversión pública de los diferentes niveles de gobierno y su estructura sectorial. Los autores destacan las nuevas condiciones que plantean la existencia de un gran excedente financiero, denominado Fondo de Garantía de Sustentabilidad, producto de la reforma previsional que nacionalizó el, hasta entonces sistema privado de capitalización individual y ha permitido el financiamiento de varios proyectos productivos o de infraestructura. En relación con los capítulos mencionados, resulta ineludible un análisis crítico de los gastos tributarios en la Argentina, sobre todo de los regímenes de promoción económica que no muestran haber aportado soluciones coherentes a problemas estructurales.

En el capítulo X, Cabrera provee un análisis de tres casos de países centroamericanos en cuanto a las reformas fiscales recientes orientadas a estimular el crecimiento económico y la inversión. Según el autor, algunos factores sistémicos son importantes para explicar el comportamiento diferenciado entre un país con un bajo coeficiente de inversión como Guatemala, respecto de Panamá y Nicaragua, donde la inversión privada ha crecido y la inversión pública se ha mantenido en niveles elevados. En particular se destacan las debilidades en el campo de la seguridad, en la relación entre el sector público y el sector privado y en la sostenibilidad fiscal de los países. Por otra parte, los incentivos fiscales aumentaron, lo que erosionó la base fiscal de Guatemala y Nicaragua. La ausencia de una relación clara entre incentivos y el desempeño de la inversión no permite concluir que los primeros hayan tenido un impacto decisivo sobre la segunda, aun 
cuando su incidencia haya podido ser diferente en cada país. Las alianzas público-privadas tampoco han jugado un papel importante en la promoción de la inversión.

En la cuarta parte se indaga acerca de lo que los editores consideran los dos principales obstáculos con que debe lidiar la política tributaria, especialmente en América Latina, para lograr objetivos como la suficiencia y la estabilidad recaudatorias, la eficiencia en la asignación de recursos y la equidad distributiva entre los contribuyentes. Por un lado, en todos los países de la región una parte importante de las actividades económicas se desarrolla fuera de los marcos legales, jurídicos e institucionales, lo que da lugar a la existencia de un sector informal o economía informal de magnitud variable, pero significativa en todos los casos. La consideración de este fenómeno resulta crucial al momento de diseñar las políticas macroeconómicas, dadas las connotaciones negativas asociadas a él (malas condiciones de trabajo, empresas de baja productividad, falta de cumplimiento de las leyes, normas y obligaciones tributarias, entre otras). Por otro lado, el mayor desafío para los sistemas tributarios de la región (que también limita la capacidad de recaudar impuestos) continúa siendo la evasión impositiva. Ese fenómeno puede abordarse desde dos dimensiones distintas, pero complementarias. En el ámbito interno, las deficiencias asociadas a la administración tributaria, ya sea en el diagnóstico o en el control y la fiscalización de los contribuyentes, se ven reforzadas por una baja moral tributaria, es decir, por una débil condena social hacia las conductas evasivas y una escasa transparencia acerca de la utilización de los recursos públicos a través del gasto público. En el ámbito internacional, la erosión de las bases imponibles y el traslado de beneficios hacia países de baja o nula tributación imponen un desafío relativamente novedoso para los países latinoamericanos. Por supuesto, ello no impide una aproximación integral a estos problemas, en tanto comparten raíces e implicancias económicas.

En el capítulo XI, Gómez Sabaini y Morán exploran los vínculos entre la economía informal y el sistema tributario. Partiendo de la relación entre ambos conceptos, donde el nivel y la estructura de los ingresos tributarios pueden ser tanto causa como consecuencia de la informalidad en un país, los autores muestran las evidencias recientes acerca del tamaño de la economía informal en los países de la región y establecen una serie de relaciones recíprocas respecto de su situación tributaria en la última década. Con importantes sectores de la economía fuera del sector formal, los regímenes simplificados para pequeños contribuyentes aparecen como una respuesta lógica de política tributaria para combatir dicho fenómeno y sus múltiples causas. Si bien se reconoce su incapacidad para generar una suma significativa de recursos, se destaca la utilidad de esos instrumentos para favorecer una transición de los trabajadores informales al régimen general de tributación. Por último, después de una revisión pormenorizada de los 
sistemas vigentes en América Latina, se plantean algunos lineamientos de política tributaria tendientes a reducir el tamaño de la economía informal en los países de la región.

En el capítulo XII, Cetrángolo, Gómez Sabaini y Morán analizan las principales cuestiones relacionadas con el problema de la evasión tributaria desde la perspectiva interna. En países en desarrollo como los de América Latina, donde los recursos públicos no abundan y generalmente no son suficientes para financiar las necesidades de gasto público, suele existir una brecha entre la recaudación teórica (determinada por la legislación) y la recaudación efectivamente ingresada. Sin embargo, y aun cuando se han venido perfeccionando las metodologías de estimación, se advierte un gran desconocimiento de la magnitud del fenómeno. Los estudios oficiales realizados por las administraciones tributarias se han centrado en el IVA, en cuyo caso se comprobó una reducción de las tasas de evasión a lo largo de la pasada década. No ha ocurrido así en relación con el impuesto sobre la renta (IRS), en cuyo caso las estimaciones son escasas a pesar de algunos indicios que alertan sobre niveles inaceptables de incumplimiento tributario. A su vez, los autores destacan la importancia de ampliar el análisis para abarcar la evasión en los sistemas contributivos de seguridad social, dado el gran peso relativo de esta fuente de recursos tributarios, y en otros tributos relevantes.

En el capítulo XIII, Gómez Sabaini y Morán abordan la temática de la evasión con un enfoque internacional. Específicamente, ahondan en las implicancias de un importante pero poco conocido caudal de flujos financieros y comerciales por parte de las empresas multinacionales que provocan la erosión de las bases tributarias nacionales y el traslado de beneficios entre países. Ante este fenómeno, como describen los autores, los países de la región han incorporado regulaciones específicas para controlar maniobras evasivas como la manipulación de precios de transferencia o la transferencia de deudas ("capitalización débil") entre filiales para reducir la carga tributaria global de las multinacionales. Especialmente en esta dimensión internacional de la evasión fiscal se ha percibido un gran desconocimiento cuantitativo, con algunas metodologías de estimación sujetas a numerosas objeciones y grandes limitaciones en términos de información estadística. Sin embargo, los autores presentan las evidencias más recientes que dan una idea aproximada de la magnitud del fenómeno de erosión de las bases tributarias y sus implicancias para los países de América Latina, además de resumir los avances más relevantes en materia de cooperación internacional relacionados con el intercambio automático de información tributaria entre los países.

Por último, en la quinta parte se expande la discusión y el ámbito de la política tributaria hacia dos dimensiones que han cobrado una relevancia significativa en años recientes en los países de América Latina. Como 
se destaca ampliamente en este libro, la heterogeneidad regional es una característica distintiva de América Latina. Al respecto, uno de los elementos que provocan grandes disparidades se refiere a la desigual disponibilidad de recursos naturales no renovables, cuya explotación económica permite a los países productores de la región obtener un cuantioso caudal de ingresos fiscales. El auge de precios internacionales de los productos básicos entre 2003 y 2008, así como la posterior y drástica caída a los niveles actuales, han planteado una serie de circunstancias y cambios en los regímenes fiscales aplicados a los sectores de los minerales e hidrocarburos. Por otra parte, además del impacto económico, las industrias extractivas (y otras también) generan externalidades e impactos negativos sobre el medio ambiente, ya sea a nivel de las industrias productoras de materias primas (upstream) o de los consumidores en fases ulteriores del proceso productivo (downstream), por la contaminación derivada del uso de combustibles y vehículos automotores. Si bien el uso de la tributación como instrumento ambiental no es una idea novedosa ni está exenta de objeciones, en la última década pudieron observarse los primeros experimentos latinoamericanos en esta materia. Sobre la base de la experiencia de los países desarrollados, se crearon impuestos nuevos, al tiempo que se procedió con la adaptación y la reforma de tributos existentes a fin de incorporar en su diseño las cuestiones ambientales.

En el capítulo XIV, Gómez Sabaini, Jiménez y Morán proveen un análisis detallado del manejo fiscal de los recursos naturales no renovables en los países de la región. Para ello, en primer lugar, realizan una breve pero completa descripción de los distintos instrumentos fiscales utilizados en las industrias extractivas para garantizar una adecuada apropiación de las rentas generadas en estas actividades por parte del Estado, tanto desde una perspectiva teórica como a partir de las experiencias recientes a nivel internacional. Luego repasan las distintas políticas seguidas por los Gobiernos de la región, tanto en relación con la imposición en los sectores de hidrocarburos como de minerales, especialmente durante el ciclo alcista de los precios internacionales que se experimentó entre 2003 y 2008. En particular, se avanzó en asegurar el control estatal de los recursos disponibles, se introdujeron nuevos tributos, se fortalecieron los esquemas de regalías y se establecieron impuestos sobre los ingresos extraordinarios. El análisis estadístico incluido en este capítulo permite observar la evolución reciente y constatar el gran peso relativo de estos recursos en varios países de la región, además de la ostensible dependencia fiscal de algunos de ellos respecto de esa fuente de financiamiento estatal.

En el capítulo XV, Fanelli, Jiménez y López Azcúnaga se centran en los aspectos destacados vinculados a las reformas fiscales ambientales y al rol de la tributación en ese sentido. Primeramente, los autores sintetizan el enfoque conceptual de qué se entiende por reforma fiscal ambiental y cómo este concepto, así como los instrumentos que suelen componerla, han ido 
evolucionando a lo largo del tiempo, tanto desde el punto de vista analítico como aplicado. Luego se analiza la experiencia en esta materia tanto en los países desarrollados como en los países de América Latina y el Caribe, donde priman los impuestos con fines recaudatorios, destacándose los impuestos ambientales sobre la energía (combustibles). Las experiencias recientes de México y Chile pueden ser un primer paso hacia una imposición ambiental dirigida puntualmente a la emisión, pero son incipientes. También se destaca la reformulación de los impuestos sobre vehículos automotores (tendiente a incorporar variables ambientales al momento de su determinación) como se ha observado en Chile, el Ecuador y la República Dominicana. Por último, entre las lecciones sugeridas por los autores para implementar una reforma fiscal ambiental en los países de la región, sobresale la necesidad de incluir una racionalización de los subsidios a la energía, que absorben una buena parte del espacio fiscal de los países y pueden tener distintos impactos sobre la pobreza y la distribución del ingreso. 

Parte 1

Los ingresos tributarios en América Latina 



\title{
El nivel y la estructura de la carga tributaria en los países de la región ${ }^{1}$
}

\author{
Juan C. Gómez Sabaini² \\ Dalmiro Morán ${ }^{3}$
}

\section{Introducción}

En América Latina se han observado profundas transformaciones en materia tributaria en los últimos 25 años. En la gran mayoría de los países, el nivel de la carga tributaria experimentó un fuerte crecimiento en relación con el PIB, sobre todo a partir de 2003, aunque con marcadas diferencias entre los distintos casos. También se produjeron cambios estructurales significativos, como la consolidación del impuesto sobre el valor agregado (IVA) y la reciente mejora de la participación de los impuestos directos, más allá de las características específicas de cada sistema tributario en particular.

Este capítulo constituye una versión resumida y actualizada de Gómez Sabaini y Morán (2014).

Consultor de la Comisión Económica para América Latina y el Caribe (CEPAL), el Banco Interamericano de Desarrollo (BID), el Fondo Monetario Internacional (FMI) y el Centro Interamericano de Administraciones Tributarias (CIAT) especializado en temas de política tributaria en países de América Latina. Profesor de posgrado en la Universidad Nacional de Buenos Aires. Correo electrónico: gomezsabaini@gmail.com.

3 Consultor de la Comisión Económica para América Latina y el Caribe (CEPAL) y del Centro Interamericano de Administraciones Tributarias (CIAT) especializado en temas de política tributaria en países de América Latina. Correo electrónico: dalomoran@gmail.com. 
Sin embargo, muchos de los sistemas tributarios latinoamericanos se han mostrado incapaces de resolver importantes debilidades en relación con el nivel de los recursos que efectivamente se recaudan, los efectos en la eficiencia económica y, en especial, la incidencia sobre la equidad distributiva. Por ejemplo, según análisis recientes, en la mayoría de los países de la región la recaudación tributaria se ubica por debajo del nivel potencial que correspondería de acuerdo con el grado de desarrollo económico, es decir que exhiben bajos niveles de esfuerzo tributario (Fenochietto y Pessino, 2010). A su vez, las estructuras tributarias vigentes en estos países presentan un típico y marcado sesgo hacia la imposición indirecta, lo que determina, en muchos casos, la regresividad del sistema en su conjunto. Esto suele contrastar con la situación observada en los países miembros de la Organización de Cooperación y Desarrollo Económicos (OCDE), donde se registra un nivel de recursos más elevado, que les permite financiar amplios programas de gasto público, y una combinación más equilibrada de los tributos directos e indirectos y de las contribuciones de la seguridad social, lo que redunda en una mayor progresividad en la distribución de los ingresos (Goñi, López y Servén, 2008).

En este capítulo se propone, en un principio, describir la evolución y la situación actual de los países de América Latina en cuanto al nivel de recursos tributarios, e identificar los factores fundamentales que explican la elevada heterogeneidad existente en la región. Luego, se analiza la estructura tributaria media de la región y se exploran las raíces y los ejes de las reformas llevadas a cabo en décadas pasadas, y se efectúa una comparación a grandes rasgos con el sistema vigente en los países miembros de la OCDE. En la sección siguiente se presenta un breve análisis de las dos principales tendencias en materia de reforma tributaria observadas en la última década en la región. Por último, se abordan, con una mirada regional, los mayores desafíos - a juicio de los autores- que deberán afrontarse en el ámbito tributario en los años venideros.

\section{A. Los ingresos tributarios en América Latina: raíces históricas y evolución reciente}

Para entender los cambios relativamente recientes en la política tributaria regional es necesario remontarse varias décadas y adoptar una visión de largo plazo.

A principios del siglo $\mathrm{XX}$, los sistemas tributarios, tanto de los países desarrollados como subdesarrollados, estaban dominados casi exclusivamente por impuestos sobre el comercio internacional. No obstante, la caída de la demanda internacional de productos primarios durante la Gran Depresión de los años treinta, los altos niveles de concentración de la riqueza y los 
sistemas proteccionistas basados en la industrialización por sustitución de importaciones puestos en marcha en la región obligaron a los países a adoptar reformas a fin de incrementar el nivel de los recursos fiscales (Cornia, Gómez Sabaini y Martorano, 2011).

Tras la Segunda Guerra Mundial, en un contexto macroeconómico completamente diferente, este cambio de paradigma se vio reforzado al adjudicarse a la política tributaria, además del clásico papel de financiamiento de bienes públicos, el objetivo fundamental de corregir la desigual distribución del ingreso que determinaba el mercado (Kaldor, 1962). En los países de la región esto propició el fortalecimiento de la tributación sobre los ingresos a través del aumento de las alícuotas aplicadas a los individuos y las empresas, lo que mejoró la equidad vertical de los sistemas tributarios - pero no la equidad horizontal - por la presencia de una larga serie de exenciones, incentivos y regímenes especiales de tributación.

Sin embargo, este enfoque redistributivo, originado en los países desarrollados durante la posguerra, debió enfrentar una serie de obstáculos en los países latinoamericanos, debido principalmente a la estructura rural e informal de sus economías, el elevado nivel de desigualdad, la débil gobernanza y calidad institucional, la limitada capacidad de las administraciones tributarias y la resistencia de las élites. Además, la crisis del petróleo de 1973 marcó el inicio de un subperíodo en el que los ingresos tributarios, si bien continuaron su curso alcista en la mayoría de los países, mostraron una fuerte volatilidad. El contexto macroeconómico internacional - caracterizado por una larga recesión, un profundo proceso inflacionario y el crecimiento del déficit fiscal en varios países desarrollados- perjudicó a las economías de América Latina, consecuencia que se vio reflejada en el nivel de recaudación tributaria ${ }^{4}$.

Estos problemas propiciaron el advenimiento de la denominada "revolución neoliberal de la política fiscal" a comienzos de la década de 1980 (Jenkins, 1995), que implicó un cambio en los objetivos principales que guiaron a la política tributaria en los años subsiguientes con el foco puesto en la eficiencia, la equidad horizontal y la captación de mayores ingresos tributarios. Siguiendo fielmente las recomendaciones en la materia de organismos internacionales como el Banco Mundial y el Fondo Monetario Internacional (Consenso de Washington), los encargados de formular la política tributaria en América Latina promovieron una fuerte reducción de las alícuotas de los impuestos sobre el comercio internacional — considerados fuentes de ineficiencias en la producción local y en la asignación internacional

En un trabajo reciente de Morán y Pecho (2016) se confirman estas tendencias, gracias a la detallada información presentada acerca de la evolución de la carga tributaria y su estructura relativa desde 1960 hasta la actualidad. 
de recursos-, la introducción del impuesto sobre el valor agregado, la reducción de los niveles y la cantidad de alícuotas del impuesto sobre la renta tanto de personas naturales como de sociedades, la disminución sustancial del número de tributos vigentes (por lo que se eliminó la mayoría cuya contribución a la recaudación era insignificante) y los continuados esfuerzos —no siempre exitosos - por mejorar las administraciones tributarias y el control de la evasión ${ }^{5}$.

Por ende y pese a la visión crítica de muchos analistas respecto del Consenso de Washington y sus consecuencias para las economías de América Latina, no puede dejar de reconocerse su influencia en algunos de los puntos fuertes de los sistemas tributarios actuales, así como también en muchas de las debilidades que hoy muestran. De hecho, entre las principales objeciones que se plantean, el énfasis en el perfeccionamiento de la administración tributaria (aun con avances relativos), el fortalecimiento del IVA y la simplificación de las estructuras tributarias encuentran su origen en ese contexto y suelen destacarse entre los logros alcanzados, mientras que entre las críticas resaltan los escasos efectos distributivos de los impuestos, la falta de equidad y la debilitada imposición sobre la renta personal que se observa actualmente en los países de la región.

No menos cierto es que, más allá de los profundos cambios que provocaron en las economías de la región, las políticas tributarias pregonadas por el Consenso de Washington y sustentadas en el enfoque de la economía de la oferta no llevaron a un proceso estable y sostenido de crecimiento económico que se tradujera, a su vez, en una mejora del bienestar general de la población. A nivel regional, se redujo la carga tributaria, se incrementó el endeudamiento externo (lo que limitó aún más el crecimiento) y se intensificaron la desigualdad y la volatilidad fiscal.

Ante este panorama, puede distinguirse una nueva etapa de la tributación latinoamericana a partir de mediados de los años noventa y, en especial, a lo largo de la última década, en la que el nivel de recaudación tributaria siguió una tendencia creciente en términos porcentuales del producto interno bruto (PIB) y no solo como promedio regional sino también en la gran mayoría de los países de América Latina. Entre 1990 y 2014, la carga tributaria media de la región aumentó casi el $60 \%$ : pasó del 13,2\% al 21,0\% del PIB (véase el cuadro I.1).

Según Lora (2007), el arancel medio sobre las importaciones aplicado en los países de América del Sur cayó del 55\% en 1985 a aproximadamente el 10\% en 2000, mientras que en los países de Centroamérica y México la merma fue aún mayor: del $66 \%$ al $6 \%$ en promedio. 


\section{Cuadro I.1}

América Latina (18 países) y Organización de Cooperación y Desarrollo Económicos (OCDE): nivel de la carga tributaria, incluidas las contribuciones de la seguridad social, 1990-2014

(En porcentajes del PIB)

\begin{tabular}{lrrrrrr}
\hline País & 1990 & 1995 & 2000 & 2005 & 2010 & 2014 \\
\hline Argentina & 12,4 & 16,9 & 18,0 & 22,1 & 26,7 & 32,2 \\
\hline Bolivia (Estado Plurinacional de) & 8,1 & 12,3 & 16,4 & 21,6 & 23,3 & 28,7 \\
\hline Brasil & 25,4 & 26,5 & 29,5 & 32,7 & 32,4 & 33,4 \\
\hline Chile & 17,0 & 18,4 & 18,8 & 20,7 & 19,5 & 19,8 \\
\hline Colombia & 9,0 & 13,8 & 14,6 & 18,1 & 18,0 & 20,3 \\
\hline Costa Rica & 16,1 & 16,3 & 18,2 & 20,1 & 20,8 & 22,5 \\
\hline Ecuador & 7,1 & 7,9 & 10,1 & 11,7 & 16,3 & 19,0 \\
\hline El Salvador & 10,5 & 13,0 & 12,1 & 13,9 & 15,1 & 16,5 \\
\hline Guatemala & 9,0 & 10,4 & 12,4 & 13,1 & 12,4 & 12,6 \\
\hline Honduras & 16,2 & 18,1 & 15,3 & 16,9 & 17,3 & 19,8 \\
\hline México & 15,5 & 14,9 & 16,5 & 17,7 & 18,5 & 19,5 \\
\hline Nicaragua & $\ldots$ & 10,9 & 13,0 & 16,1 & 18,0 & 20,3 \\
\hline Panamá & 14,7 & 17,1 & 17,4 & 15,2 & 18,9 & 18,1 \\
\hline Paraguay & 5,4 & 13,6 & 14,5 & 13,8 & 16,5 & 17,1 \\
\hline Perú & 12,1 & 15,9 & 14,6 & 16,5 & 17,8 & 18,8 \\
\hline República Dominicana & 7,8 & 10,0 & 11,7 & 13,8 & 12,3 & 14,1 \\
\hline Uruguay & 19,6 & 21,0 & 21,6 & 23,8 & 26,0 & 27,0 \\
\hline Venezuela (República Bolivariana de) & 18,1 & 12,8 & 13,6 & 15,9 & 11,8 & 18,2 \\
\hline América Latina & 13,2 & 15,0 & 16,0 & 18,0 & 19,0 & 21,0 \\
\hline OcDE & 32,1 & 33,6 & 34,2 & 33,9 & 32,8 & 34,2 \\
\hline
\end{tabular}

Fuente: Elaboración propia sobre la base de Organización de Cooperación y Desarrollo Económicos (OCDE)/Comisión Económica para América Latina y el Caribe (CEPAL)/Centro Interamericano de Administraciones Tributarias (CIAT)/Banco Interamericano de Desarrollo (BID) y OECD.Stat.

No obstante, como señalan Cornia, Gómez Sabaini y Martorano (2011), a este alentador resultado contribuyeron diversos factores que exceden lo estrictamente tributario. Por un lado, los gobiernos latinoamericanos han venido mejorando el diseño de los respectivos sistemas tributarios a partir, por ejemplo, de un sostenido esfuerzo por reducir y eliminar una extensa lista de exenciones, deducciones y beneficios tributarios concedidos en décadas pasadas con el fin de atraer inversiones extranjeras, que no siempre dieron los frutos esperados. En ese sentido, se observa una mayor responsabilidad en el uso de los recursos públicos. Sumado a esto, también se lograron considerables avances en la administración del IVA y del impuesto sobre la renta (ISR), que condujeron a un rápido incremento de la recaudación tributaria vinculada a ellos. Asimismo, se adoptaron nuevos tributos sobre las transacciones financieras e impuestos mínimos que ayudaron a acrecentar los recursos, elevaron el nivel de cumplimiento y ampliaron la gama de instrumentos de política tributaria. 
También cabe señalar que el cambio de tendencia en la tributación de América Latina aconteció en un contexto macroeconómico favorable marcado por una reducción sustancial del déficit de las cuentas públicas y el nivel de endeudamiento de los países, donde se revitalizó la importancia de la acción del Estado en el aspecto distributivo a través de tributos o transferencias. Precisamente, la reducción de los niveles de desigualdad propició un aumento del consumo privado, que se vio reflejado en la evolución de los impuestos que gravan los bienes y servicios. A su vez, esta situación vino de la mano de nuevas políticas nacionales de reformalización de la economía que contribuyeron a ampliar las bases tributarias.

Además, en algunos países de la región, la intensificación de la carga tributaria se debió a factores contingentes, como el sostenido aumento del precio internacional de los productos básicos y los minerales a partir de 2002 y 2003, que incrementó los ingresos fiscales tributarios y no tributarios de los países de la región especializados en la explotación y comercialización de los recursos naturales. Asimismo, el contexto internacional, caracterizado por la aceleración de las tasas de crecimiento económico mundial (sobre todo de las economías emergentes), fue aprovechado por los países de la región: llevaron adelante estrategias de apertura comercial y financiera, junto con procesos exitosos de estabilización monetaria, lo que otorgó mayor elasticidad tributaria (ex post) a los países de América Latina (Cornia, Gómez Sabaini y Martorano, 2011).

Un elemento adicional que permitió una mayor presión tributaria en muchos países fue el mayor énfasis puesto en los últimos años en el criterio de intercambio fiscal, en virtud del cual los gobiernos pueden aumentar los impuestos si, respetando un pacto fiscal con los ciudadanos (CEPAL, 2010), procuran al mismo tiempo aumentar la cantidad y calidad de los servicios que brindan a la sociedad (Fjeldstad, Katera y Ngalewa, 2009). Como bien ha señalado Bird (2003), en un marco democrático (wickselliano) en el que las decisiones relativas a los gastos y los impuestos se toman en forma conjunta, deberá suponerse que la estructura tributaria existente, cualquiera que sea, fue adoptada con pleno conocimiento de sus consecuencias, lo que refleja el consentimiento de la sociedad en cuanto a que los beneficios de las acciones financiadas por el Estado compensan con creces todos los costos de la tributación.

Así, en el largo plazo, la legitimidad y la capacidad de aumentar los impuestos se ven afectadas por la mayor eficiencia del gasto público. En este sentido, las reformas de la era neoliberal acotaron el papel del Estado en la prestación de los servicios públicos, llevando a la clase media a menudo a optar por las alternativas privadas, y causando, de esta manera, una reducción de la calidad de los servicios públicos y del grado de satisfacción de los usuarios. Por el contrario, desde los inicios del siglo XXI aumentaron 
las transferencias sociales y se amplió el acceso a la atención primaria de la salud y la educación secundaria (Huber, 2009).

La crisis financiera internacional de 2008 tuvo un claro efecto negativo en las economías de la región. Salvo algunas excepciones, como el Ecuador, Panamá y el Paraguay, en la mayoría de los casos se experimentó una merma - con cierto rezago- de los ingresos tributarios. Sin embargo, superadas las repercusiones más directas de dicha crisis, los niveles de recaudación impositiva de estos países retomaron la tendencia creciente y pronto alcanzaron los máximos históricos de los últimos años.

En ese sentido, la fortaleza que han mostrado las finanzas públicas para soportar y dejar atrás la última gran crisis financiera es un hecho a destacar en la historia económica de los países latinoamericanos. Dicho fenómeno está vinculado, en parte, con una maduración de los sistemas tributarios actuales, alcanzada mediante una serie de reformas que en años recientes apuntaron a consolidar los logros de décadas pasadas (como la generalización del IVA y los avances en la administración del tributo) y a profundizar los cambios en la imposición directa (sobre todo del ISR) a fin de aumentar los ingresos y mejorar el efecto distributivo de la tributación (CEPAL, 2015).

No obstante, la favorable evolución general de la carga tributaria media de América Latina esconde una marcada heterogeneidad impositiva, más allá de las diversas realidades políticas, sociales y económicas.

En principio, puede observarse que el Brasil y la Argentina son en la actualidad los países con la mayor carga tributaria (en 2014 alcanzaron el 33,4\% y el 32,2\%, respectivamente), pero en décadas pasadas solo en el primero se registraron estos elevados niveles recaudatorios. La Argentina recién comenzó a destacarse en este aspecto a partir de la segunda mitad de los años noventa y, sobre todo, a partir de 2002, tras reincorporar los derechos de exportación sobre los productos primarios y ver consolidarse el IVA y el ISR con la reactivación económica. Vale remarcar que desde hace ya unos años ambos países se ubican en un nivel cercado al promedio de la OCDE - 34,2\% en 2014- y similar al registrado en 2014 en varios de sus miembros más representativos, como el Reino Unido (32,6\%), España (33,2\%) y el Canadá (30,8\%).

Por debajo de estos dos países, pero aún muy por encima del promedio regional (21\%), destacan el Uruguay, con un incremento importante, aunque moderado, de la carga tributaria, que llegó al 27,0\% del PIB en el último año analizado, y el Estado Plurinacional de Bolivia, que casi cuadruplicó la recaudación tributaria entre 1990 y 2014, año en que llegó al 28,7\% del PIB, con una proporción significativa de recursos tributarios provenientes de la explotación de hidrocarburos. 
Luego se distingue un amplio grupo de países con niveles de carga tributaria que en 2014 fueron del $17 \%$ al $23 \%$ del PIB. Liderados por Costa Rica (22,5\%), Colombia y Nicaragua (20,3\%), y el Paraguay (17,1\%), todos estos países han logrado, en mayor o menor medida, aumentar la presión tributaria a lo largo de las dos últimas décadas. Sin embargo, entre ellos se destacan algunos casos, como el del Ecuador, que alcanzó el 19,0\% en 2014, que muestran notables incrementos en los últimos 20 años.

Como se ha expresado, el aumento de los niveles recaudatorios entre 1990 y 2014 fue generalizado en toda la región y también tuvo lugar en aquellos países que aún se muestran rezagados en cuanto a esta variable, como El Salvador (16,5\%), la República Dominicana (14,1\%) y Guatemala (12,6\%).

Debe tenerse en cuenta que la heterogeneidad tributaria regional no solo se vincula con el nivel de ingresos obtenidos o las reformas aplicadas en cada caso durante el período analizado. De hecho, las diferencias entre países - también comprobables en términos de la estructura de estos recursosguardan un nexo estrecho con tres factores fundamentales que constituyen determinantes primordiales de los distintos sistemas de financiamiento público de los Estados latinoamericanos.

En primer lugar, es posible identificar un grupo acotado de países con grandes dotaciones de recursos naturales no renovables, principalmente hidrocarburos y minerales, que obtienen gran parte de sus ingresos fiscales tributarios y no tributarios mediante la aplicación de regímenes específicos de apropiación estatal de las rentas derivadas de su explotación económica ${ }^{6}$. En efecto, son varios los países que muestran una considerable dependencia fiscal de estas fuentes de recursos, lo que puede influir en el grado de esfuerzo tributario de un país y, por consiguiente, en el nivel de su carga tributaria y el diseño de potenciales reformas del sistema tributario. Además, como se pudo comprobar a lo largo de la década pasada, la elevada volatilidad de los precios internacionales de los productos primarios puede trasladar una inestabilidad considerable al caudal de recursos fiscales disponibles en los países productores de la región, incluidos los tributarios.

Otro elemento de heterogeneidad en América Latina se relaciona con la organización política de los países y el grado de descentralización fiscal de los distintos niveles de gobierno. En la mayoría de los países, la atribución de los ingresos tributarios parece estar sesgada marcadamente hacia los gobiernos centrales, con entidades subnacionales que muestran una gran dependencia respecto de las transferencias que reciben de los primeros ${ }^{7}$. Sin embargo, de acuerdo con los datos más actualizados (OCDE/CEPAL/

6 En el capítulo XIV de este libro, Gómez Sabaini, Jiménez y Morán brindan una descripción actualizada de los regímenes fiscales aplicados a las industrias extractivas de los países de la región y analizan las recientes reformas tributarias llevadas a cabo en estos sectores.

7 En el capítulo III de este libro, Gómez Sabaini y Jiménez abordan el tema de la tributación en los gobiernos subnacionales de varios países de América Latina. 
CIAT/BID, 2016), la Argentina - con un 16,8\% de los ingresos tributarios totales de 2013 proveniente de las provincias-y el Brasil — con el 31,7\% proveniente de estados y municipios - registran considerables grados de descentralización fiscal hacia los gobiernos subnacionales. Por su parte, Colombia $(15,0 \%)$, Chile $(7,3 \%)$, México $(4,3 \%$, a pesar de estar organizado como una federación) y el Uruguay $(3,9 \%)$ exhiben una menor capacidad recaudatoria en los niveles inferiores de gobierno, y este aporte resulta casi insignificante en el resto de los países de la región.

Por último, existen numerosos y diversos sistemas públicos de seguridad social basados en el pago de contribuciones obligatorias que constituyen claramente un elemento diferenciador a nivel regional ${ }^{8}$. Así, es posible encontrar países con sistemas de pensiones y jubilaciones muy desarrollados que movilizan una cuantiosa masa de recursos monetarios provenientes de los trabajadores formales, al tiempo que se observan estructuras previsionales rudimentarias en otros países donde, por distintas razones, no se han logrado avances concretos en este sentido.

Esta diversidad de situaciones, tal como se profundiza en la próxima sección y en otros capítulos del libro, da cuenta en gran parte de las marcadas diferencias regionales en lo concerniente al nivel total de ingresos tributarios. De hecho, cabe destacar que el ordenamiento de los países de la región según el nivel de ingresos tributarios puede experimentar cambios significativos si, por ejemplo, se excluyen los recursos tributarios destinados a financiar la seguridad social, aun cuando esto vaya en contra de la metodología estadística generalmente aceptada en la actualidad. Así, en el gráfico I.1 puede comprobarse que el Estado Plurinacional de Bolivia pasaría a ser el país con la mayor carga tributaria a nivel regional (27,3\% del PIB), por encima de la Argentina y el Brasil, que rondarían el 25\%, independientemente de los ingentes ingresos procedentes de las contribuciones de la seguridad social. El Uruguay mostraría un descenso pronunciado, pero se mantendría entre los países de mayor carga tributaria. En cambio, muy distinto es lo que se observaría en el caso de Costa Rica y Panamá y, en menor medida, en el Ecuador y Nicaragua, que retrocederían varias posiciones en el escalafón regional, con valores cercanos o inferiores al 15\% del PIB.

En este análisis se adopta el criterio sugerido por la CEPAL (2006) en virtud del cual los ingresos públicos por contribuciones a los sistemas de seguridad social deben contabilizarse como parte integrante de la presión tributaria si: i) los aportes son de carácter obligatorio; ii) el sistema está a cargo de instituciones públicas, y iii) las prestaciones cumplen una función redistributiva. Ejemplos de estos casos son los sistemas de pensiones de la Argentina (hasta 1994 y a partir de 2008), el Brasil, Costa Rica, Panamá y el Paraguay. En cambio, cuando las prestaciones no cumplen una función redistributiva, sino que se organizan según el principio del beneficio - por ejemplo, en los sistemas de cuentas nacionales, como el Régimen General de la Seguridad Social del sector privado del Brasil- o bien cuando la recaudación queda a cargo de instituciones privadas, independientemente de su obligatoriedad y del criterio redistributivo de las prestaciones - como sucede con las administradoras de fondos de pensión en Chile-, los recursos obtenidos no deberían formar parte de lo que se conoce como carga tributaria. 


\section{Gráfico l.1}

América Latina (18 países): ingresos tributarios, 2014

(En porcentajes del PIB)

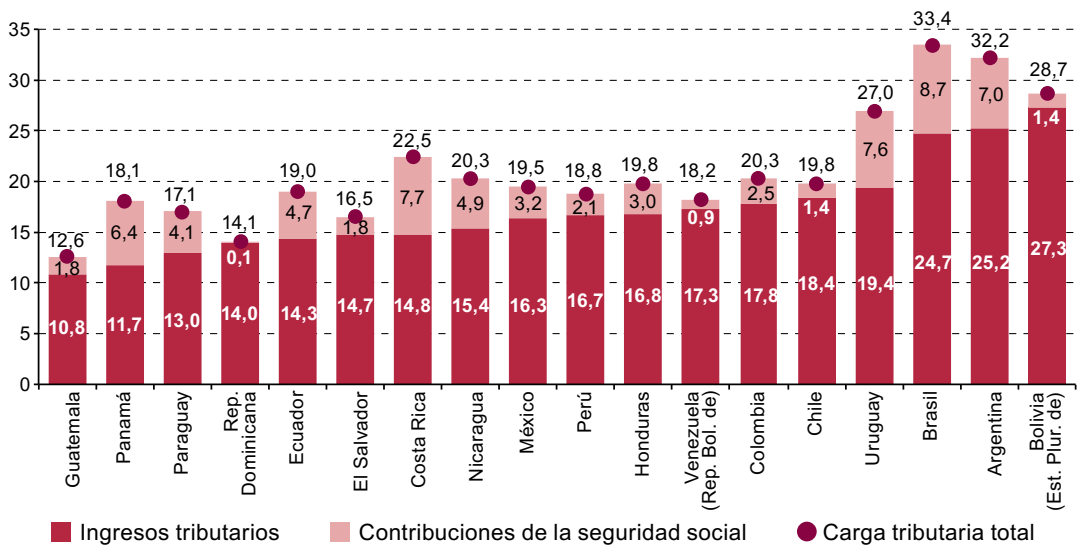

Fuente: Elaboración propia, sobre la base de Organización de Cooperación y Desarrollo Económicos (OCDE)/Comisión Económica para América Latina y el Caribe (CEPAL)/Centro Interamericano de Administraciones Tributarias (CIAT)/Banco Interamericano de Desarrollo (BID), Estadísticas tributarias en América Latina y el Caribe 1990-2014, París, OECD Publishing, 2016.

\section{B. Cambios en la estructura tributaria de los países de la región}

Si bien la elevada heterogeneidad entre los países de América Latina obliga a proceder con cautela al momento de realizar cualquier análisis tributario de carácter general, en lo referente a la estructura de los sistemas tributarios es posible encontrar ciertas características básicas que se repiten en la mayoría de los casos. Esto permite detectar las tendencias tributarias regionales, que se resumen a continuación.

Como se mencionó, el denominado Consenso de Washington ejerció una influencia muy fuerte en la política tributaria latinoamericana. Con el énfasis puesto en la eficiencia, desde los albores de la década de 1980 se observó una reducción de los niveles y la dispersión de los aranceles de importación, orientada al logro de una protección arancelaria más uniforme, tanto en términos nominales como efectivos. De igual manera, en un contexto de globalización financiera y comercial creciente, se avanzó en la supresión de los derechos de exportación vigentes en muchos de los países de la región, que gravaban fundamentalmente la producción primaria (Barreix, Bès y Roca, 2010). Como resultado, los ingresos tributarios obtenidos mediante impuestos aduaneros sufrieron una caída marcada y progresiva en valores absolutos y relativos, tendencia que se prolongó también durante la década de 1990. 
Con el objeto de compensar la pérdida recaudatoria que acarreaba dicho fenómeno, se alentó a los países de la región a fortalecer el IVA, impuesto que varios ya habían adoptado, pero que aún no producía una recaudación significativa. Para ello, se avanzó en la generalización de la base imponible y se la extendió también a los servicios intermedios y finales, pues al inicio el gravamen se aplicaba casi exclusivamente a bienes físicos. De hecho, el proceso de simplificación de los sistemas tributarios - recomendado por el Consenso de Washington-mediante la eliminación de muchos impuestos específicos de escaso aporte recaudatorio, lejos de significar una renuncia tributaria, implicó una transferencia de pequeñas bases gravables hacia el ámbito del IVA.

A su vez, comenzó a observarse un aumento progresivo de la tasa general del IVA en casi todos los países de la región, que pasó de un promedio inicial de un 11,7\% (cuando solo la mitad de los países aplicaba el tributo) a un 10,6\% en 1985 (no por un descenso del nivel sino por el agregado de países al promedio), y luego subió a un 13,7\% en 1995 y a un $15,0 \%$ en 2005 . A partir de entonces, se mantuvo cerca de este valor y trepó al 15,2\% en 2015 (véase el cuadro I.2). Gracias a estos cambios y a las mejoras en la administración del tributo, el IVA se transformó - ya en los inicios de la década pasada- en el principal instrumento generador de recursos tributarios en la mayoría de los países de América Latina.

El sostenido ascenso del IVA condujo a un aumento considerable de la importancia de los impuestos generales sobre los bienes y servicios en los ingresos tributarios de la región. Como puede verse en el cuadro I.3, el peso relativo de dicho impuesto en la estructura tributaria media de América Latina pasó de un 23,6\% en 1990 a un 32,1\% en 2000 y registra un valor de participación similar en la recaudación total en 2014, muy por encima de los promedios registrados en los países de la OCDE (20,4\% en ese último año). Vale remarcar que casi todo el aumento de la ponderación porcentual de este impuesto se materializó durante los años noventa a raíz de las reformas tanto de la base imponible como de la alícuota general.

En contraposición con esta tendencia, como también se muestra en el cuadro I.3, el resto de los impuestos sobre bienes y servicios específicos han perdido gran parte de su peso relativo en la estructura recaudatoria en las últimas dos décadas: menguaron del 27,2\% al 15,6\% entre 1990 y 2014, tendencia también observada en los países desarrollados. En este grupo, la participación relativa de los impuestos selectivos experimentó una merma moderada: el promedio regional se contrajo del 10,6\% (1990) al 8,6\% (2014). Asimismo, estos gravámenes quedaron limitados a la producción de un conjunto acotado de bienes (bebidas alcohólicas, tabaco y combustibles) y servicios (energía eléctrica), sobre todo en los países de mayor carga 
tributaria de la región. A su vez, como ya se comentó, se registró una fuerte y progresiva caída de la participación porcentual de los gravámenes sobre el comercio internacional — del 15,9\% en 1990 al 5,2\% en 2014-, sobre todo en los países de menor carga tributaria a nivel regional.

\section{Cuadro I.2}

América Latina (18 países): evolución de la alícuota general del IVA, 1975-2015 (En porcentajes)

\begin{tabular}{|c|c|c|c|c|c|c|c|}
\hline País & $\begin{array}{c}\text { Año de } \\
\text { introducción }\end{array}$ & $\begin{array}{l}\text { Tasa } \\
\text { inicial }\end{array}$ & 1975 & 1985 & 1995 & 2005 & 2015 \\
\hline Argentina & 1975 & 13,0 & 13,0 & 18,0 & 21,0 & 21,0 & 21,0 \\
\hline $\begin{array}{l}\text { Bolivia (Estado } \\
\text { Plurinacional de) }\end{array}$ & 1973 & 5,0 & 5,0 & 5,0 & 14,9 & 14,9 & 14,9 \\
\hline Brasil $^{b}$ & 1967 & 15,0 & n.d. & n.d. & 20,5 & 20,5 & 20,5 \\
\hline Chile & 1975 & 20,0 & 20,0 & 20,0 & 18,0 & 19,0 & 19,0 \\
\hline Colombia & 1975 & 10,0 & 10,0 & 10,0 & 14,0 & 16,0 & 16,0 \\
\hline Costa Rica & 1975 & 10,0 & 10,0 & 10,0 & 15,0 & 13,0 & 13,0 \\
\hline Ecuador & 1970 & 4,0 & 4,0 & 6,0 & 10,0 & 12,0 & 12,0 \\
\hline El Salvador & 1992 & 10,0 & - & - & 13,0 & 13,0 & 13,0 \\
\hline Guatemala & 1983 & 10,0 & - & 7,0 & 7,0 & 12,0 & 12,0 \\
\hline Honduras & 1976 & 3,0 & - & 5,0 & 7,0 & 12,0 & 15,0 \\
\hline México & 1980 & 10,0 & - & 15,0 & 15,0 & 15,0 & 16,0 \\
\hline Nicaragua & 1975 & 6,0 & 6,0 & 10,0 & 15,0 & 15,0 & 15,0 \\
\hline Panamá & 1977 & 5,0 & - & 5,0 & 5,0 & 5,0 & 7,0 \\
\hline Paraguay & 1993 & 10,0 & - & - & 10,0 & 10,0 & 10,0 \\
\hline Perú & 1973 & 15,0 & 17,0 & 11,0 & 18,0 & 19,0 & 18,0 \\
\hline República Dominicana & 1983 & 6,0 & - & 6,0 & 8,0 & 16,0 & 18,0 \\
\hline Uruguay & 1973 & 14,0 & 20,0 & 20,0 & 23,0 & 23,0 & 22,0 \\
\hline $\begin{array}{l}\text { Venezuela (República } \\
\text { Bolivariana de) }\end{array}$ & 1993 & 10,0 & - & - & 12,5 & 14,0 & 12,0 \\
\hline América Latina & & 9,8 & 11,7 & 10,6 & 13,7 & 15,0 & 15,2 \\
\hline
\end{tabular}

Fuente: Elaboración propia, sobre la base de la Comisión Económica para América Latina y el Caribe (CEPAL) y el Centro Interamericano de Administraciones Tributarias (CIAT) .

Nota: n.d.: no disponible.

a Aprobado en 1973, vigente desde 1974. Si bien la ley establece el pago de retenciones a partir del establecimiento del monto bruto del precio de venta del servicio o del bien, la práctica habitual en el país ha hecho que se negocie el monto neto, es decir el importe que el vendedor o proveedor del servicio va a obtener después del descuento de los impuestos. Por tal razón, se presenta el valor de la tasa efectiva del IVA (calculado "por fuera" sin considerar el impuesto aplicado). La tasa nominal ha sido del $13 \%$ desde hace más de 20 años. Así, para un valor neto de 100 se debe considerar un valor bruto de $100^{*}(1+0,149)=114,9$ sobre el cual se aplicará la tasa nominal del $13 \%$.

b Tasa promedio del impuesto sobre la circulación de mercaderías y servicios (ICMS), cuyo valor varía según la legislación propia de cada Estado. Además existen diferentes tasas según se apliquen a operaciones internas o interestaduales. Se puede asumir una tasa media nacional aproximada de un $17 \%$, pero como el impuesto conforma la base gravable del mismo, se llega a una tasa efectiva promedio del $20,5 \%$ $\left(17 /(1-17)^{\star} 100\right)$. 


\section{Cuadro I.3}

\section{América Latina y Organización de Cooperación y Desarrollo Económicos (OCDE): estructura tributaria media, 1990, 2000 y 2014}

(En porcentajes de la recaudación total

\begin{tabular}{|c|c|c|c|c|c|c|}
\hline \multirow{2}{*}{ Categoría de impuestos } & \multicolumn{3}{|c|}{ América Latina } & \multicolumn{3}{|c|}{ OCDE } \\
\hline & 1990 & 2000 & 2014 & 1990 & 2000 & 2014 \\
\hline Renta y ganancias de capital & 22,3 & 19,8 & 25,5 & 37,9 & 35,7 & 33,7 \\
\hline Personas físicas & 6,3 & 6,7 & 9,3 & 31,0 & 26,9 & 24,9 \\
\hline Sociedades & 15,9 & 13,1 & 16,2 & 6,9 & 8,8 & 8,8 \\
\hline Seguridad social & 16,3 & 17,8 & 18,3 & 22,9 & 25,0 & 26,6 \\
\hline Nómina salarial & 1,6 & 1,7 & 0,9 & 1,1 & 1,1 & 1,2 \\
\hline Propiedad & 4,7 & 3,5 & 3,6 & 5,5 & 5,2 & 5,6 \\
\hline Impuestos directos (A) & 44,9 & 42,8 & 48,3 & 67,4 & 67,0 & 67,1 \\
\hline Generales sobre bienes y servicios & 23,6 & 32,1 & 32,1 & 17,7 & 19,5 & 20,4 \\
\hline Específicos sobre bienes y servicios & 27,2 & 22,2 & 15,6 & 11,9 & 10,6 & 9,5 \\
\hline Selectivos & 10,6 & 11,9 & 8,6 & 8,0 & 8,4 & 7,5 \\
\hline Comercio internacional & 15,9 & 10,0 & 5,2 & 2,0 & 1,0 & 0,4 \\
\hline Otros impuestos específicos ${ }^{a}$ & 0,6 & 0,3 & 1,8 & 2,0 & 1,3 & 1,6 \\
\hline Otros impuestos ${ }^{b}$ & 4,3 & 2,9 & 4,0 & 3,0 & 2,9 & 3,0 \\
\hline Impuestos indirectos (B) & 55,1 & 57,2 & 51,7 & 32,6 & 33,0 & 32,9 \\
\hline Ingresos tributarios totales & 100,0 & 100,0 & 100,0 & 100,0 & 100,0 & 100,0 \\
\hline $\begin{array}{l}\text { Relación entre los impuestos directos } \\
\text { e indirectos }(A / B)\end{array}$ & 0,8 & 0,7 & 0,9 & 2,1 & 2,0 & 2,0 \\
\hline
\end{tabular}

Fuente: Elaboración propia, sobre la base de Organización de Cooperación y Desarrollo Económicos (OCDE)/Comisión Económica para América Latina y el Caribe (CEPAL)/Centro Interamericano de Administraciones Tributarias (CIAT)/Banco Interamericano de Desarrollo (BID), Estadísticas tributarias en América Latina y el Caribe 1990-2014, París, OECD Publishing, 2016 y OECD.Stat.

- Incluye otros ítems de la categoría 5120 de la clasificación de impuestos elaborada por la OCDE (utilidades de los monopolios fiscales, impuestos sobre los bienes de inversión, impuestos sobre servicios específicos y otros tributos menores).

b Incluye los impuestos sobre el uso de bienes y sobre el permiso para usar bienes y realizar actividades económicas (por ejemplo, sobre vehículos automotores) de la categoría 5200 y otros tributos agrupados en la categoría 6000 (clasificación de impuestos de la OCDE).

La estructura típica de los sistemas tributarios de la región se completa con otros dos pilares fundamentales: las contribuciones de la seguridad social y los impuestos que recaen sobre los ingresos y las ganancias de capital (principalmente el ISR).

En el primer caso, este tipo de recursos ha mantenido una participación estable en la estructura tributaria latinoamericana media entre el $16 \%$ y el $18 \%$ del total recaudado (véase el cuadro I.3). Sin embargo, en este segmento las diferencias entre los países de la región son muy amplias, ya que en aquellos con una mayor carga tributaria y regímenes previsionales más consolidados, estos impuestos permiten obtener una recaudación que, como porcentaje del PIB, es hasta tres o cuatro veces más alta y llega al doble en términos del total recaudado respecto de los demás países (véase el cuadro I.4). En cuanto al promedio regional, resalta claramente la diferencia con lo observado en los países de la OCDE, especialmente entre los miembros de 
Europa Occidental, donde los ingresos tributarios por contribuciones de la seguridad social no solo tienen mayor cuantía económica — casi 2,5 veces superior en función del PIB—, sino que también representan una parte más significativa de la carga tributaria total.

\section{Cuadro I.4}

\section{América Latina (18 países) y Organización de Cooperación y Desarrollo Económicos (OCDE): ingresos tributarios por contribuciones de la seguridad social, 1990, 2000 y 2014}

(En porcentajes del PIB y de la recaudación total)

\begin{tabular}{|c|c|c|c|c|c|c|}
\hline \multirow[b]{2}{*}{ País } & 1990 & 2000 & 2014 & 1990 & 2000 & 2014 \\
\hline & \multicolumn{3}{|c|}{ (en porcentajes del PIB) } & \multicolumn{3}{|c|}{$\begin{array}{l}\text { (en porcentajes de la } \\
\text { recaudación total) }\end{array}$} \\
\hline Argentina & 3,1 & 2,8 & 7,0 & 25,3 & 15,8 & 21,6 \\
\hline Bolivia (Estado Plurinacional de) & 0,0 & 1,3 & 1,4 & 0,0 & 7,8 & 4,7 \\
\hline Brasil & 6,1 & 6,9 & 8,7 & 24,0 & 23,5 & 26,2 \\
\hline Chile & 1,5 & 1,4 & 1,4 & 9,0 & 7,3 & 7,2 \\
\hline Colombia & 0,7 & 2,4 & 2,5 & 7,9 & 16,3 & 12,6 \\
\hline Costa Rica & 4,4 & 5,1 & 7,7 & 27,2 & 28,0 & 34,0 \\
\hline Ecuador & 1,6 & 1,2 & 4,7 & 22,5 & 12,3 & 24,6 \\
\hline El Salvador & 1,4 & 2,0 & 1,8 & 13,3 & 16,6 & 10,7 \\
\hline Guatemala & 1,4 & 1,9 & 1,8 & 15,6 & 15,5 & 14,2 \\
\hline Honduras & 1,4 & 1,6 & 3,0 & 8,8 & 10,6 & 15,4 \\
\hline México & 2,1 & 2,7 & 3,2 & 13,4 & 16,5 & 16,2 \\
\hline Nicaragua & $\ldots$ & 2,6 & 4,9 & $\ldots$ & 19,9 & 24,3 \\
\hline Panamá & 4,5 & 6,4 & 6,4 & 30,4 & 36,8 & 35,2 \\
\hline Paraguay & 0,4 & 3,7 & 4,1 & 8,3 & 25,6 & 23,9 \\
\hline Perú & 0,9 & 1,8 & 2,1 & 7,7 & 12,3 & 11,0 \\
\hline República Dominicana & 0,1 & 0,1 & 0,1 & 0,8 & 1,0 & 0,4 \\
\hline Uruguay & 6,0 & 6,4 & 7,6 & 30,5 & 29,6 & 28,0 \\
\hline Venezuela (República Bolivariana de) & 0,9 & 0,7 & 0,9 & 4,9 & 5,4 & 5,0 \\
\hline América Latina & 2,1 & 2,8 & 3,8 & 16,3 & 17,8 & 18,3 \\
\hline OCDE & 7,4 & 8,6 & 9,1 & 22,9 & 25,0 & 26,6 \\
\hline
\end{tabular}

Fuente: Elaboración propia, sobre la base de Organización de Cooperación y Desarrollo Económicos (OCDE)/Comisión Económica para América Latina y el Caribe (CEPAL)/Centro Interamericano de Administraciones Tributarias (CIAT)/Banco Interamericano de Desarrollo (BID), Estadísticas tributarias en América Latina y el Caribe 1990-2014, París, OECD Publishing, 2016.

Nota: Para elaborar los promedios regionales, se calculó la participación relativa de estos recursos en la estructura media de América Latina y la OCDE, que no equivale necesariamente al promedio simple de los porcentajes de cada uno de los países analizados.

Vale remarcar que esta es un área donde se han observado profundos procesos de reforma que modificaron la participación del Estado y su financiamiento en los últimos años: en algunos países se han implementado reformas estructurales, donde el sistema público fue sustituido en forma total o parcial por uno privado, mientras que en otros casos las reformas 
fueron paramétricas y apuntaron a fortalecer financieramente el sistema público a largo plazo, ya sea aumentando la edad de retiro o las cotizaciones, haciendo más rigurosa la fórmula para el cálculo o tomando otras medidas (Mesa-Lago, 2004).

Los recursos provenientes de contribuciones de la seguridad social revisten una importancia crucial en la estructura de la carga tributaria de algunos países. Destacándose ampliamente los casos de Panamá y Costa Rica -donde representan más de un tercio del total-, así como los de la Argentina, el Brasil, el Ecuador, Nicaragua, el Paraguay y el Uruguay, donde estos recursos exhiben una participación relativa superior al promedio regional (18,3\% en 2014) y a veces resulta equivalente o, incluso, mayor al valor medio calculado para los países de la OCDE (26,6\% en 2014).

En cambio, en otros países de la región el peso de estas contribuciones representa en la actualidad menos del $15 \%$ de las respectivas estructuras tributarias (véase el cuadro I.4). Las causas de estos magros resultados recaudatorios son diversas y varían de un país a otro, ya que, más allá de las diferencias en el grado de desarrollo de cada sistema previsional, en algunos casos estas cifras se explican como consecuencia de los procesos de reforma estructural de los sistemas previsionales, especialmente en el caso de Chile, Colombia y México, donde los sistemas públicos de reparto tradicionales han sido transformados, desplazados o complementados con regímenes privados de capitalización entre los años ochenta y noventa, en el marco de las recomendaciones del Consenso de Washington.

Por otra parte, las reformas tributarias de ese período apartaron al ISR - y a la imposición directa en general- del centro de la escena tributaria y fiscal. Durante esos años tomó fuerza, entre la mayoría de los analistas y autoridades de los países, la creencia de que las tasas impositivas elevadas no solo resultaban impopulares, sino que además desalentaban la actividad económica y no lograban mejorar la distribución del ingreso y la riqueza (Bird y Zolt, 2005).

Por ende, en los distintos países se disminuyó la cantidad y los niveles de las alícuotas legales del ISR pagados por las personas naturales y las sociedades. Según datos de la CEPAL y el Centro Interamericano de Administraciones Tributarias (CIAT), a diferencia de lo ocurrido con la tasa general del IVA, la alícuota marginal máxima aplicada a las personas físicas cayó en promedio del 55,1\% al 28,5\% entre 1975 y 2005, tras lo cual experimentó un leve descenso y llegó al 27,4\% en 2015. En algunos casos extremos, se eliminó el ISR personal, por ejemplo en el Uruguay (1974) y el Paraguay (1992), mientras que otros países adoptaron una tasa uniforme, como el Estado Plurinacional de Bolivia, donde se fijó en un 10\% y luego subió al $13 \%$. Las tasas generales aplicadas a las personas jurídicas también 
descendieron de un promedio regional del 45,2\% en 1975 al 28,3\% en 2005, y en los últimos años sufrieron un leve declive: en 2015 se ubicaron en el 26,8\%.

Cabe resaltar que el descenso de las alícuotas del ISR de las personas jurídicas en América Latina estuvo en línea con la tendencia internacional $\mathrm{y}$, en los últimos años, las tasas generales se han equiparado a las vigentes en los países desarrollados. Sin embargo, las alícuotas marginales máximas del impuesto sobre la renta de las personas físicas (IRPF) vigentes en los países latinoamericanos se ubican dentro de un rango del $25 \%$ al $35 \%$, muy por debajo de las aplicadas en los países de la OCDE, especialmente en los europeos, donde alcanzan cifras elevadas, por ejemplo, el 45\% (Reino Unido), el 46\% (España), el 47,5\% (Alemania) e, incluso, el 54\% (Francia). Vale remarcar que esta tendencia no se ha visto compensada en sus efectos recaudatorios por una expansión de las bases gravadas, sino que las alícuotas impositivas han continuado aplicándose básicamente y con mayor peso en la imposición sobre las rentas del trabajo, sin incorporar a los ingresos del capital en las bases del impuesto.

Como se expuso en la sección anterior, a partir de 2003 comienza a evidenciarse una nueva etapa tributaria en América Latina, que se plasma no solo en el nivel de los recursos disponibles sino también en un renovado énfasis en las cuestiones distributivas asociadas a la política fiscal y, en consonancia con ello, la revalorización del potencial del ISR en esa dimensión y como fuente de ingresos públicos. Tanto es así que un incremento marcado de la recaudación procedente de este gravamen, sobre todo vinculado a las sociedades, y ante el mayor dinamismo económico y el auge del precio internacional de los productos básicos hasta 2008, facilitó la recuperación del peso relativo de la imposición directa en las estructuras tributarias de los países de la región.

En la actualidad, los ingresos aportados por el ISR (y otros tributos complementarios sobre los ingresos) representan el 25,5\% de la carga tributaria media de América Latina (véase el cuadro I.3). Entre las causas del aumento reciente de la participación relativa de estos impuestos, deben incluirse la aplicación de gravámenes mínimos y las mejoras en la administración tributaria en un contexto de mayor formalización laboral, estabilidad de precios y crecimiento económico sostenido, lo que derivó en un mayor caudal de rentas del sector privado y una mayor obtención de recursos fiscales a partir de ellas.

Por último, además de los impuestos sobre la nómina (vigentes en solo cuatro países de la región y con una limitada recaudación) y algunos gravámenes menores, las estructuras tributarias de América Latina también reciben un discreto aporte de los impuestos que recaen sobre la propiedad, que sufrieron cierto estancamiento y un lento retroceso durante el período analizado: en 2014 representaron menos del 4\% de la recaudación total (véase 
el cuadro I.3). También en este caso, los países de mayor carga tributaria, como la Argentina, el Brasil y el Uruguay, dan cuenta de casi la totalidad de esta evolución, ya que son los únicos donde estos impuestos experimentaron un leve aumento en función del PIB, mientras que los valores alcanzan una significancia ínfima en el resto de la región.

Este tipo de tributación suele abarcar un amplio conjunto de impuestos que incluyen, entre otros, los gravámenes recurrentes aplicados sobre los bienes inmuebles y sobre la tenencia de vehículos automotores, los gravámenes sobre la riqueza o el patrimonio neto e, incluso, impuestos sobre las transacciones financieras (ITF), si bien en el caso de estos últimos no existe consenso acerca de su clasificación como un impuesto directo (véase la próxima sección) ${ }^{9}$. En lo que atañe en particular a los impuestos sobre los bienes inmuebles, el rendimiento recaudatorio de estos tributos ha sido y aún es exiguo en todos los países latinoamericanos donde están vigentes, lo que se explica por una combinación de factores - relativos tanto a la política como a la administración tributaria- que limitan su capacidad como fuente de recursos subnacionales propios.

En suma, las disímiles tendencias mencionadas contribuyeron a mantener la predominancia de la imposición indirecta en la estructura tributaria típica de América Latina (y en la mayoría de los países de la región). En promedio, la relación entre los impuestos directos e indirectos se ubicó por debajo de uno durante el período 1990-2014 y tuvo un repunte leve pero insuficiente en años más recientes, lo que demuestra el desequilibrio estructural. En claro contraste, las estructuras tributarias de los países de la OCDE se caracterizan por un mayor peso relativo de la imposición directa (67,1\% en 2014), donde sobresalen tanto los impuestos sobre los ingresos -que aportan un tercio de la recaudación media e igualan la recaudación media del conjunto de impuestos indirectos-como las contribuciones de la seguridad social. Así, esta relación entre los impuestos directos e indirectos fue de dos en 2014 (véase el cuadro I.3).

Sin embargo, estas diferencias relativas no deben ocultar las brechas en términos de magnitudes cuantitativas. Por ello, en el cuadro I.5 se presentan las cifras de recaudación tributaria por categoría de impuesto y en porcentajes del PIB, de América Latina (promedio regional) y de los 34 países miembros de la OCDE. En resumidas cuentas puede señalarse que:

- El contraste más evidente se da en la imposición sobre los ingresos y las ganancias de capital, ya que en promedio el ISR genera en los 34 países de la OCDE más de dos veces la recaudación que, en términos del PIB, promediaron los 18 países de América Latina en

De hecho, Cetrángolo y Gómez Sabaini (2007) lo han clasificado como un impuesto especial selectivo aplicado a una actividad determinada, que consiste en el uso del cheque bancario. 
2014: 11,5\% y 5,4\%, respectivamente. Si bien esta brecha en parte se redujo respecto de lo observado 20 años atrás, en la actualidad es la más amplia entre ambos grupos de países ${ }^{10}$.

- Un análisis más profundo de la estructura interna del impuesto permite distinguir que la principal diferencia entre las estructuras tributarias de América Latina y la OCDE radica en el ISR que recae sobre las personas naturales, lo que da cuenta de una de las más claras debilidades de los sistemas tributarios de la región. Así, mientras el ISR que pagan las sociedades aporta un monto medio similar entre ambos grupos de países, el ISR personal genera recursos tributarios en la OCDE que, en promedio, alcanzaron el 8,5\% del PIB en 2014. En América Latina, este tributo representa, en promedio, apenas el 2,0\% del PIB (véase el cuadro I.5). Visto de otra manera, la relación entre ambos componentes del ISR en la OCDE, en promedio, favorece al impuesto que grava a las personas físicas ya que es 2,8 veces mayor, mientras que en América Latina ese indicador solo llega a 0,6, es decir que los ingresos tributarios en concepto de ISR personal equivalen, en promedio, a un $60 \%$ de lo recaudado por la aplicación del tributo sobre las sociedades.

- En cuanto a los ingresos procedentes de las contribuciones de la seguridad social, también existen marcadas diferencias entre ambos grupos de países. A raíz de una cobertura limitada y varias reformas orientadas a implementar regímenes de capitalización — que no conforman la carga tributaria-, al día de hoy solo algunos de los países latinoamericanos poseen sistemas previsionales afianzados. En 2014, encabezaban el escalafón regional de recaudación de este tipo de recursos el Brasil (8,7\% del PIB), Costa Rica $(7,7 \%)$, el Uruguay $(7,6 \%)$ y la Argentina $(7,0 \%)$, cuyas cifras superaban las de países desarrollados, por ejemplo, Suiza (6,7\%), los Estados Unidos $(6,2 \%)$ y el Reino Unido (6,0\%). Sin embargo, existe una brecha considerable con otros miembros de la OCDE, como Francia $(17,0 \%)$, Alemania (13,9\%), Italia $(13,0 \%)$ e, incluso, España $(11,6 \%)$, que se agiganta al compararla con el resto de los países latinoamericanos, en muchos de los cuales esta recaudación no llega al $2 \%$ del PIB.

Esto no se debe solo a una mayor recaudación del tributo en los países de la región, sino también a que en 1990 aún no se tomaban en cuenta los miembros más recientes de la OCDE (los países de Europa Oriental, México y Chile), que claramente incidieron negativamente en el valor medio obtenido, dadas las características de sus respectivas estructuras tributarias. 


\section{Cuadro I.5}

\section{América Latina y Organización de Cooperación y Desarrollo Económicos (OCDE): estructura tributaria media, 1990, 2000 y 2014}

(En porcentajes del PIB)

\begin{tabular}{lrrrrrrrr}
\hline \multirow{2}{*}{ Categoría de impuestos } & \multicolumn{3}{c}{ América Latina } & & \multicolumn{3}{c}{ OCDE } \\
\cline { 2 - 5 } \cline { 9 - 10 } & 1990 & 2000 & 2014 & & 1990 & 2000 & 2014 \\
\hline Renta y ganancias de capital & 2,9 & 3,2 & 5,4 & & 12,2 & 12,2 & 11,5 \\
\hline Personas físicas (A) & 0,8 & 1,1 & 2,0 & & 10,0 & 9,2 & 8,5 \\
\hline Sociedades (B) & 2,1 & 2,1 & 3,4 & & 2,2 & 3,0 & 3,0 \\
\hline Seguridad social & 2,1 & 2,8 & 3,8 & & 7,4 & 8,6 & 9,1 \\
\hline Nómina salarial & 0,2 & 0,3 & 0,2 & & 0,3 & 0,4 & 0,4 \\
\hline Propiedad & 0,6 & 0,6 & 0,7 & & 1,8 & 1,8 & 1,9 \\
\hline Impuestos directos & 5,9 & 6,9 & 10,1 & & 21,6 & 22,9 & 22,9 \\
\hline Generales sobre bienes y servicios & 3,1 & 5,1 & 6,7 & & 5,7 & 6,7 & 7,0 \\
\hline Específicos sobre bienes y servicios & 3,6 & 3,6 & 3,3 & & 3,8 & 3,6 & 3,3 \\
\hline Selectivos & 1,4 & 1,9 & 1,8 & & 2,6 & 2,9 & 2,6 \\
\hline Comercio internacional & 2,1 & 1,6 & 1,1 & & 0,6 & 0,3 & 0,1 \\
\hline Otros impuestos específicos & 0,1 & 0,1 & 0,4 & & 0,6 & 0,4 & 0,5 \\
\hline Otros impuestos & 0,6 & 0,5 & 0,8 & & 1,0 & 1,0 & 1,0 \\
\hline Impuestos indirectos & 7,3 & 9,2 & 10,9 & & 10,5 & 11,3 & 11,3 \\
\hline Ingresos tributarios totales & 13,2 & 16,0 & 21,0 & & 32,1 & 34,2 & 34,2 \\
\hline Relación entre el ISR de personas físicas & 0,4 & 0,5 & 0,6 & & 4,5 & 3,1 & 2,8 \\
\hline y sociedades (A/B) & & & & &
\end{tabular}

Fuente: Elaboración propia, sobre la base de Organización de Cooperación y Desarrollo Económicos (OCDE)/Comisión Económica para América Latina y el Caribe (CEPAL)/Centro Interamericano de Administraciones Tributarias (CIAT)/Banco Interamericano de Desarrollo (BID), Estadísticas tributarias en América Latina y el Caribe 1990-2014, París, OECD Publishing, 2016 y OECD.Stat.

Nota: La estructura del ISR surge de estimaciones propias sobre la base de Gómez Sabaini, Jiménez y Rossignolo (2012). Se aplican las mismas aclaraciones presentadas al pie del cuadro I.3.

- En cuanto a los impuestos generales sobre los bienes y servicios, el fuerte crecimiento de la recaudación del IVA en casi todos los países de la región provocó un notable acercamiento entre los promedios regionales, levemente por debajo del 7\% del PIB. En este resultado, repercuten, sobre todo, los aportes de la Argentina y el Brasil, países que, además de obtener cuantiosos ingresos a partir del impuesto sobre el valor agregado $(7,2 \%$ y $7,6 \%$ del PIB, respectivamente) ${ }^{11}$, aplican impuestos sobre las ventas (generalmente en el ámbito subnacional) que también

11 En la Argentina se refiere exclusivamente al IVA, pero en el Brasil comprende el impuesto sobre la circulación de mercaderías y servicios (ICMS) —aplicado por los estados-y el impuesto sobre los productos industrializados (IPI), administrado por el gobierno central. 
reportan un monto considerable de ingresos tributarios $(4,2 \%$ y $5,3 \%$, respectivamente) ${ }^{12}$.

- Entre los tributos específicos sobre los bienes y servicios, se observa una llamativa similitud en cuanto a los niveles de recaudación media, aunque con distintas composiciones: los impuestos selectivos representan una parte mayoritaria en los países de la OCDE y algo más de la mitad en América Latina, donde aún retienen cierto peso relativo los gravámenes sobre el comercio internacional, lo que no ocurre en los países desarrollados, donde casi desaparecieron como instrumento recaudatorio.

- Por último, los impuestos sobre la nómina salarial representan un porcentaje casi insignificante en ambos grupos de países, mientras que en el caso de la tributación sobre la propiedad —si bien no aporta ingresos muy significativos-, el promedio de los países de la OCDE equivale al doble del promedio latinoamericano, lo que demuestra, como ya se planteó, cierta relevancia solo en los países de mayor carga tributaria de la región.

Cabe agregar que, tal como se señaló al analizar el nivel de carga tributaria, en la región existe una amplia diversidad de casos en cuanto a la evolución y la situación actual de la estructura tributaria. Aunque esto no invalida las tendencias generales mencionadas, sí obliga a proceder con cautela al momento de evaluar las fortalezas y debilidades de cada sistema tributario en particular.

Por ejemplo, pese a su drástica reducción generalizada a nivel regional, puede comprobarse que los impuestos sobre el comercio internacional mantienen relevancia en países como la Argentina (desde la reintroducción de los derechos de exportación sobre los productos primarios en 2002), el Ecuador, el Paraguay y la República Bolivariana de Venezuela.

En lo que respecta a los tributos internos sobre bienes y servicios (IVA e impuestos selectivos), su peso relativo es superior al de la imposición directa en la mayoría de los países. Este desequilibrio determina gran parte del efecto redistributivo global regresivo o poco progresivo de los sistemas tributarios de América Latina ${ }^{13}$. Solo en Panamá — cuya tasa de IVA equivale al 7\%, cifra

12 En la Argentina se refiere al impuesto sobre los ingresos brutos — potestad de las provinciasmientras que en el Brasil esto comprende tanto la contribución para el financiamiento de la seguridad social (COFINS) como la contribución para el Programa de Integración Social (PIS), ambas administradas por el gobierno central.

13 En los estudios acerca de la incidencia de la política fiscal sobre la región, se ha demostrado que el IVA ejerce un efecto regresivo moderado y que el ISR personal presenta una progresividad muy alta, pero un efecto redistributivo muy limitado dado su escaso aporte recaudatorio (Gómez Sabaini y Morán, 2014). 
muy inferior al promedio regional-y en México, donde la base gravable del tributo se encuentra históricamente acotada por la presencia de exenciones sobre los alimentos y las medicinas, no se observa tal predominancia de la imposición indirecta.

\section{Tendencias de reforma tributaria en las últimas décadas}

Así como la generalización y el fortalecimiento del IVA en las estructuras tributarias de América Latina supo concentrar la mayor parte de los esfuerzos en términos de política tributaria durante los años ochenta y noventa, desde los inicios de la década de 2000 pueden distinguirse otras dos tendencias de reforma tributaria a nivel regional, que responden a diferentes necesidades e involucran la utilización de distintos instrumentos fiscales: por un lado, el fortalecimiento del impuesto sobre la renta (ISR) y, por el otro, la introducción de tributos heterodoxos o no convencionales.

Históricamente, el ISR típico de América Latina se consideraba, en la práctica, un impuesto cedular que gravaba por separado los distintos tipos o "cédulas" de renta que percibe un mismo contribuyente, por ejemplo, los ingresos procedentes del trabajo asalariado, los intereses recibidos por depósitos o los dividendos obtenidos por la tenencia de acciones. Además, en varios países se podía encontrar una larga serie de exenciones y exoneraciones según la fuente generadora, sobre todo en el ámbito de las rentas del capital (Cetrángolo y Gómez Sabaini, 2007).

Sin embargo, en años recientes se han registrado tenues progresos en cuanto a la ampliación de la base tributaria del ISR con la incorporación de sistemas duales. Tras tomar como referencia y adaptar el modelo aplicado originalmente en los países nórdicos (véase el recuadro I.1), el Uruguay fue el primero en la región en embarcarse en esta tendencia, ya que a partir de julio de 2007 volvió a aplicar el impuesto sobre la renta -derogado varias décadas atrás - y comenzó a gravar por separado las rentas del trabajo (con tasas progresivas del 10\% al 25\%) y las rentas del capital (con una tasa uniforme del $12 \%$, excepto los dividendos, que tributan al $7 \%$ ). La sola reintroducción del ISR personal en el sistema tributario uruguayo significó una considerable mejora en términos de recaudación y de poder distributivo (Amarante, Arim y Salas, 2007), lo que muestra la importancia de este gravamen en materia distributiva. 
Recuadro I.1

\section{Modelos alternativos en materia de imposición sobre la renta}

Varios países desarrollados se embarcaron en los últimos 30 años en procesos destinados a reformar la imposición sobre la renta personal, apartándose de los principios ortodoxos del impuesto global o sintético, formulación tradicional sustentada en el principio de Schanz-Haig-Simons, en virtud del cual se grava la totalidad de los ingresos - menos las deducciones - del trabajo y del capital de manera global y a la misma tasa progresiva. Ello implica que el valor de las deducciones admitidas es creciente en función del nivel de ingreso, ya que los contribuyentes se benefician de acuerdo con su tasa marginal. De ahí en más, cabe analizar distintas alternativas seguidas en las últimas décadas en lo atinente a la orientación de las reformas adoptadas, que son básicamente las siguientes.

Por una parte, el sistema de impuestos de tasa uniforme utiliza una tasa proporcional - de ahí su nombre - para gravar tanto el ingreso del trabajo como del capital, donde las deducciones admitidas son independientes del nivel de ingreso. En este modelo de imposición, la tasa a la que tributan las rentas societarias es igual a la utilizada para el conjunto de las otras rentas, y se la aplica sobre un concepto de beneficio societario tipo flujo de caja, determinado como el total de los ingresos por ventas menos la totalidad de los gastos e inversiones efectuados en el período, que pueden deducirse por completo al momento de su realización. Varios países de Europa Central y Oriental adoptaron variantes del impuesto de tasa uniforme al menos para gravar los salarios, con una alícuota uniforme. Estonia fue el pionero: en 1994 impuso una tasa del $26 \%$ tanto sobre el ingreso personal como sobre los beneficios de las sociedades. Le siguieron Lituania, Letonia, la Federación de Rusia, Serbia, Ucrania, Eslovaquia y Rumania.

Por otra parte, el sistema de imposición dual aplica tasas distintas según se trate de ingresos netos del trabajo o del capital (dividendos, intereses o ganancias de capital realizadas). Este sistema prevé la aplicación de tasas proporcionales para gravar los ingresos del capital y tasas progresivas para los ingresos del trabajo y de las pensiones. A su vez, en su concepción más pura, el nivel de la tasa sobre los ingresos del capital es igual a la aplicada sobre las rentas corporativas o empresariales a fin de que los distintos tipos de rentas pasivas del capital (dividendos, intereses y ganancias de capital) tributen de manera homogénea. Suele mencionarse a los países nórdicos como pioneros de la imposición dual, pues fueron los primeros en adoptar esta metodología: Dinamarca (1987), Suecia (1991), Noruega (1992) y Finlandia (1999). Estos países aún tienen un alto nivel de imposición a la renta, pero las tasas efectivas previas a las reformas perjudicaban su competitividad nacional e internacional. En 2006, España se sumó a esta ola de reformas.

La evidencia disponible en la materia permite concluir que casi en ninguna circunstancia se adoptaron sistemas puros, ya sea de impuesto dual o de tasa uniforme, sino que los países han optado por combinaciones o sistemas híbridos que, en buena medida, los acercan a los sistemas híbridos que parten del mismo sistema global o sintético. Es por esta razón que se suele hablar de impuestos semiglobales o semiduales, o de combinaciones de impuestos duales y de tasa uniforme. Esta diversidad se relaciona con el hecho de que 
Recuadro I.1 (conclusión)

todos estos sistemas tienen ventajas y desventajas, fortalezas y debilidades, defensores y detractores, así como impulsos y remansos a lo largo del tiempo en cuanto a su análisis. Por ello, resulta difícil brindar una opinión ecléctica al respecto sin tomar en cuenta la situación económica y social, y, sobre todo, el contexto tributario preexistente al momento de la reforma.

Así, las reformas emprendidas por los países desarrollados, en especial de Europa septentrional, se vieron motivadas por la creciente brecha resultante de la evolución de las tasas en los Estados Unidos tras la reforma de 1986 y del propio nivel de imposición. En ese sentido, la necesidad de mejorar la competitividad internacional, evitar la salida de capitales y atenuar el efecto de las estrategias fiscales destinadas a eludir o bajar el nivel de imposición en los países nórdicos constituye una de las principales causas de estas reformas. Por su parte, la alternativa escogida por los países bálticos se relaciona directamente con la búsqueda de una mayor simplicidad para los sistemas tributarios en el contexto de sus respectivos procesos de transformación económica. Sin embargo, ninguno de los dos sistemas se ha logrado imponer - al menos a nivel mundial y generalizado - como una alternativa superior al modelo global o sintético en el marco de las reformas tributarias recientes.

Fuente: Elaboración propia, sobre la base de O. Cetrángolo y J.C. Gómez Sabaini, "La tributación directa en América Latina y los desafíos a la imposición sobre la renta", Serie Macroeconomía del Desarrollo, N 60 (LC/L.2838-P), Santiago, Comisión Económica para América Latina y el Caribe (CEPAL), 2007.

En una misma línea, el Perú también incorporó algunos elementos de imposición dual, ya que desde 2009 aplica una escala progresiva de tasas (del $15 \%$ al $30 \%$ ) sobre los ingresos provenientes de rentas del trabajo, mientras que las rentas del capital son gravadas con una tasa proporcional del 6,25\% (sobre el $80 \%$ de la renta gravable), salvo los dividendos, que tributan al 4,1\%, y los intereses devengados por ahorros y depósitos bancarios de personas naturales, que se encuentran exentos desde 2010.

Tras la crisis internacional de 2008, varios países de Centroamérica también aprobaron reformas tributarias similares y establecieron alícuotas uniformes para gravar las rentas del capital — que se encontraban exentas-, que se sitúan entre un $10 \%$ y un $15 \%$ (salvo las rentas percibidas por los no residentes). Estas alícuotas se conjugan con tasas mayores en el caso de las utilidades empresariales y tasas progresivas para las rentas del trabajo, situación semejante a la versión uruguaya del ISR dual (ICEFI, 2011).

En años más recientes, otros países de la región ampliaron la base imponible del ISR personal. En el Uruguay, además, se derogó la exoneración del impuesto a las rentas de los no residentes (IRNR), por lo que la venta de acciones al portador pasó a estar gravada en las mismas condiciones que las acciones nominativas. En la Argentina, se eliminó la exención a la compraventa de acciones y títulos que no cotizan en la bolsa de valores (Bolsa de Comercio de Buenos Aires), por lo que estas operaciones quedaron gravadas al 15\%, y 
se aplicó una alícuota del 10\% a la distribución de dividendos ${ }^{14}$. En México se creó un impuesto del 10\% sobre las ganancias de capital en la bolsa y la distribución de dividendos.

En el caso del ISR que recae sobre las personas jurídicas, también se obtuvieron algunos resultados satisfactorios en varios países gracias a la limitación de los incentivos tributarios otorgados en el marco de regímenes de promoción económica (zonas francas) y a la introducción de impuestos mínimos sobre los ingresos societarios.

La reforma tributaria aprobada en Chile en 2014 ha sido el caso más resonante en virtud de dos medidas principales: i) se dispuso un aumento gradual de la tasa general del ISR para las empresas (del 20\% al 25\%) y ii) se introdujo una norma general antielusión en el Código Tributario ${ }^{15}$. En virtud de la misma, se reemplazó el sistema del Fondo de Utilidades Tributables $(\mathrm{FUT})^{16}$ (que permitía diferir el ISR persona $1{ }^{17}$ para las utilidades no distribuidas como forma de incentivar la inversión), por dos nuevos regímenes tributarios alternativos entre los que los contribuyentes tienen el derecho de optar y que entrarán en vigor a partir de 2017. Por un lado, el Sistema de Renta Atribuida prevé que los accionistas tributen en el mismo ejercicio por la totalidad de las rentas que genera una firma y no solo por las utilidades que retiren (renta devengada), considerando tanto las rentas propias como las que se le atribuyan provenientes de terceras empresas. Además, los contribuyentes tienen el derecho a utilizar el 100\% del monto de impuesto pagado por las sociedades en que participen como crédito contra los impuestos finales y a una tasa del $25 \%$. En cambio, en el sistema parcialmente integrado, los contribuyentes quedarán gravados sobre la base de los ingresos que efectivamente obtengan de las sociedades en las que participen y no sobre las rentas que se les atribuyan; es decir que si no se retiran utilidades, no se genera tributación para los accionistas a nivel individual (renta percibida). En este sistema, la tasa del ISR societario (impuesto de primera categoría) aumenta en forma gradual y llegará al 27\% a partir de 2018. A diferencia del primer régimen, quienes hayan imputado el impuesto pagado a nivel societario contra los impuestos finales deberán restituir una cantidad equivalente al $35 \%$ del monto de dicho crédito, lo que

14 Mientras los autores redactaban este trabajo, en julio de 2016 se aprobaron medidas legislativas que dejan sin efecto la aplicación del impuesto a este tipo particular de rentas del capital (adoptado en setiembre de 2013 mediante la Ley núm. 26.893).

15 Véase un análisis minucioso de la reforma tributaria chilena y de las principales reformas recientes en América Latina en Arenas (2016).

16 Cabe aclarar que el FUT no se elimina, sino que se mantiene el registro histórico, que solo se aplica en los casos de retiros superiores a los registros establecidos en el nuevo texto jurídico. De esta manera, en ambos regímenes se establece un orden de prelación a los que el contribuyente debe imputar los retiros efectuados y, una vez agotados, los retiros deben ser imputados al FUT histórico.

17 Se lo denominó impuesto global complementario y la alícuota máxima fue reducida del $40 \%$ al $35 \%$ mediante la misma reforma tributaria. 
significa que solo se otorgará como crédito el $65 \%$ del impuesto de primera categoría pagado por los contribuyentes ${ }^{18}$.

Asimismo, en varios países se han adoptado y perfeccionado normas de tributación internacional, por ejemplo, sobre precios de transferencia, paraísos fiscales y rentas de los no residentes, y se impulsaron convenios para el intercambio de información entre los países como una forma de combatir la evasión.

Ciertamente, todas estas reformas han contribuido a aumentar la recaudación del ISR, gravamen que ocupa el segundo lugar en importancia en las estructuras tributarias latinoamericanas, y a mejorar su capacidad redistributiva. No obstante, esto no parece aún ser suficiente para modificar la estructura de recaudación del ISR, que exhibe desde hace varios años un sesgo marcado hacia las personas jurídicas por sobre las personas naturales. De hecho, salvo contadas excepciones, como las de México, El Salvador y el Uruguay, en la mayoría de los países de América Latina más de dos tercios de los ingresos tributarios obtenidos por el ISR son aportados por las sociedades, mientras que la imposición a la renta personal tiene una participación minoritaria (Gómez Sabaini y Morán, 2016).

Por otro lado, en las últimas dos décadas varios países intentaron suplir las deficiencias en el nivel de la carga tributaria mediante la creación de gravámenes poco convencionales que permiten obtener ingresos tributarios adicionales para financiar las crecientes necesidades de gasto público. Al anteponer el objetivo recaudatorio y administrativo por sobre la eficiencia y la equidad del sistema tributario, las reformas llevadas a cabo apuntaron a lograr "salidas fáciles" inducidas por administraciones tributarias débiles, y se adoptaron sin sopesar suficientemente sus costos económicos.

En general, se observa que los gravámenes de emergencia comparten una característica común: permiten un manejo administrativo más simple que los tributos tradicionales, pues ofrecen menores posibilidades de evasión o elusión. Además, algunos de estos tributos han demostrado ser instrumentos aptos para lograr montos significativos de recaudación en el corto plazo. Sin embargo, también es cierto que todas estas modalidades de imposición no convencional suelen estar sujetas a varias objeciones relacionadas con su efecto negativo en la asignación de recursos (eficiencia) y las implicancias distributivas derivadas de su aplicación (equidad).

18 La obligación de restituir el 35\% también se aplicará a los contribuyentes no residentes, que en Chile quedan alcanzados por el impuesto adicional sobre las rentas cuya fuente esté dentro del país, excepto en el caso de quienes residan en países con los que Chile haya suscrito y mantenga vigente un convenio de doble tributación, los que tributarán por las rentas efectivamente distribuidas o retiradas de las empresas chilenas y podrán utilizar el $100 \%$ del crédito recibido por el pago del impuesto de primera categoría, con una carga final del $35 \%$. 
Como ejemplo del primer caso, se pueden mencionar los regímenes simplificados de tributación para pequeños contribuyentes, que en la actualidad tienen amplia difusión en los países de América Latina ${ }^{19}$. En contextos de elevada informalidad y altos niveles de evasión, estos instrumentos constituyen un claro ejemplo de comportamientos adaptativos de las administraciones tributarias y responden a la necesidad de garantizar el cumplimiento voluntario de las obligaciones fiscales de un numeroso grupo de contribuyentes, cuya fiscalización y control resultan muy complejos y costosos. Asimismo, su implementación apunta a minimizar el costo implícito para las empresas más pequeñas $\mathrm{y}$, sobre todo, a descomprimir el volumen de trabajo que estas representan para las administraciones tributarias, que se acrecienta en los países menos desarrollados.

Si bien se reconoce que estos regímenes generan una recaudación exigua, inferior al 1\% del total en la mayoría de los países donde se los aplica (con excepción del Brasil y la Argentina), cabe destacar la posibilidad que brindan de liberar recursos que pueden encauzarse hacia la fiscalización de otros impuestos de mayor rendimiento, como el IVA o el ISR que pesa sobre los contribuyentes de mayor importancia. Es por ello que, como han señalado Gómez Sabaini y Morán (2012), su eficacia debe medirse en función de la capacidad para incorporar al sector formal de la economía a los contribuyentes que operan en la informalidad, atendiendo a que no se convierta en un refugio artificial para la evasión, sino en un mecanismo de transición hacia el régimen general de tributación.

Por otra parte, muchos países de la región han recurrido a gravámenes que actúan como un piso mínimo del ISR, sobre la base del valor de los activos o en función del monto total de ventas brutas o ingresos brutos de las empresas. Por ejemplo, en la Argentina se aplica sobre el valor de los activos brutos, lo que, en el supuesto de movilidad del capital, constituye un sustituto de la renta de las empresas, mientras que en Costa Rica se ha optado por gravar los activos fijos de las empresas. El patrimonio o los activos netos se utilizan ampliamente como base imponible de estos tributos en Colombia, el Ecuador, Panamá y el Uruguay, aunque con diferentes niveles de alícuotas. En Guatemala se aplica el impuesto de solidaridad, que grava con una tasa del 1\% el 25\% del activo neto o los ingresos brutos, de ellos, el que sea mayor. Vale señalar que en México estuvo vigente desde 2008 hasta su derogación en octubre de 2013 un gravamen denominado impuesto empresarial a tasa única (IETU), que constaba de una alícuota uniforme (17,5\%) sobre el flujo de efectivo neto de la retribución a los factores de producción.

Por último, un grupo no menor de países ha introducido -o reintroducido - alguna variante del impuesto sobre las transacciones

19 En el capítulo XI de este libro, Gómez Sabaini y Morán abordan los principales aspectos técnicos relativos a los regímenes vigentes en la región y proporcionan datos estadísticos al respecto. 
financieras (ITF), que, si bien se puso en marcha en momentos de crisis de manera transitoria y ante la urgencia de acrecentar los ingresos fiscales, ha perdurado hasta la actualidad entre los elementos permanentes de algunos sistemas tributarios de la región. En general, los argumentos para usar este tipo de gravámenes como fuente de recursos se relacionan con el hecho de que pueden introducirse en un período relativamente breve, puesto que se basan en una retención por parte de los intermediarios financieros, requieren pocas tareas preparatorias y no exigen cooperación alguna del contribuyente. Pero además, incluso con una pequeña tasa impositiva, permiten recaudar un monto significativo, sobre todo en países con un alto grado de bancarización, dado que los débitos de los bancos son un múltiplo del PIB.

En el cuadro I.6 puede comprobarse que en la Argentina, el impuesto sobre los débitos y créditos en cuenta corriente ha alcanzado un rendimiento aceptable: dio origen a una recaudación de entre el 1,5\% y el $2 \%$ del PIB en los últimos años y en 2014 representó el 5,39\% de la carga tributaria total del país. En Colombia, el gravamen a los movimientos financieros posee cierta relevancia dentro de la estructura tributaria vigente, puesto que en 2014 aportó recursos equivalentes al 0,85\% del PIB y al 4,20\% del total recaudado. Vale señalar que en dicho país la Ley núm.1.739 de 2014 estableció un proceso de reducción progresiva a partir de 2019 de la alícuota de este impuesto, que en la actualidad es del 0,40\% sobre los débitos, con la finalidad de lograr su eliminación completa en 2022.

Cuadro I.6

América Latina (6 países): alícuotas, recaudación y productividad de los impuestos sobre las transacciones financieras (ITF) vigentes en América Latina, 2014

\begin{tabular}{lllcc}
\hline Países & \multicolumn{1}{c}{$\begin{array}{c}\text { Alícuota } \\
\text { (en porcentajes) } \\
\text { y base del tributo }\end{array}$} & $\begin{array}{c}c \\
\text { (en porcentajes } \\
\text { del PIB) }\end{array}$ & $\begin{array}{c}\text { Ren porcentajes } \\
\text { del total) }\end{array}$ & $\begin{array}{c}\text { Productividad } \\
\text { sobre tasa } \\
\text { general } \\
\text { en porcentajes } \\
\text { del PIB) }\end{array}$ \\
\hline Argentina & $\begin{array}{l}0,60 \% \text { / débitos } \\
\text { y créditos }\end{array}$ & 1,73 & 5,39 & 1,44 \\
\hline $\begin{array}{l}\text { Bolivia (Estado } \\
\text { Plurinacional de) }\end{array}$ & $\begin{array}{l}0,15 \% / \text { débitos } \\
\text { y créditos }\end{array}$ & 0,18 & 0,61 & 0,59 \\
\hline Colombia & $0,40 \% /$ débitos & 0,85 & 4,20 & 2,13 \\
\hline Honduras & $0,20 \% /$ débitos & 0,45 & 2,28 & 2,25 \\
\hline Perú & $\begin{array}{l}0,005 \% / \text { débitos } \\
\text { y créditos }\end{array}$ & 0,03 & 0,14 & 2,65 \\
\hline $\begin{array}{l}\text { República } \\
\text { Dominicana }\end{array}$ & $0,15 \%$ / débitos & 0,20 & 1,43 & 1,34 \\
\hline
\end{tabular}

Fuente: Elaboración propia, sobre la base de Organización de Cooperación y Desarrollo Económicos (OCDE)/Comisión Económica para América Latina y el Caribe (CEPAL)/Centro Interamericano de Administraciones Tributarias (CIAT)/Banco Interamericano de Desarrollo (BID), Estadísticas tributarias en América Latina y el Caribe 1990-2014, París, OECD Publishing, 2016.

Nota: En los países donde se aplica sobre los créditos y los débitos, la productividad (ingresos tributarios por punto porcentual de la alícuota) se calcula sobre la tasa conjunta. 
En los demás países donde se hallan vigentes estos tributos, los resultados no han sido tan satisfactorios, al menos en términos recaudatorios. Por ejemplo, en el Estado Plurinacional de Bolivia y la República Dominicana produjeron ingresos que apenas se ubicaron cerca del $0,2 \%$ del PIB y por debajo del $2 \%$ de la recaudación total, mientras que en el Perú la recaudación derivada de su aplicación es poco significativa (véase el cuadro I.6) ${ }^{20}$. En Honduras, el rendimiento es bastante mayor: un impuesto con alícuotas muy reducidas que permite alcanzar una productividad elevada.

Cabe señalar que, al menos hasta su derogación, el ITF también se destacó en el Brasil y la República Bolivariana de Venezuela por su elevada productividad. En el primer caso, la contribución provisoria sobre los movimientos financieros (CPMF) llegó a generar recursos tributarios equivalentes al 1,4\% del PIB en 2007 (momento en que se aplicaba a una tasa del 0,38\%), mientras que en la República Bolivariana de Venezuela el ITF permitió acumular una recaudación equivalente al 0,9\% del PIB en 2008 a una tasa del 1,5\% sobre los débitos y créditos bancarios de las empresas (Coelho, 2009).

\section{Conclusiones y desafíos de la tributación a nivel regional}

Tras sucesivas oleadas de reformas tributarias durante la segunda parte del siglo XX, en América Latina puede identificarse una serie casi equivalente de alentadores avances y claros fracasos. El nivel de recursos tributarios disponibles creció significativamente en varios países, aunque el promedio regional aún diste bastante del que exhiben hoy los países desarrollados y, en la mayoría de los casos, no resulte suficiente para financiar las crecientes necesidades de gasto público. Lejos de relacionarse con el diferente grado de desarrollo de los países, este fenómeno se explica más por las limitaciones y debilidades propias de la tributación a nivel regional.

Por otra parte, las estructuras tributarias se han simplificado y consolidado en un número bastante acotado de instrumentos - cuyos pilares fundamentales son el IVA y el ISR-, pero aún muestran, también en contraste con lo observado en la OCDE, un fuerte sesgo relativo hacia la imposición indirecta, lo que en la gran mayoría de los casos se traduce en un efecto distributivo regresivo o poco progresivo de los sistemas tributarios vigentes en la región.

Hasta el inicio del siglo XXI, las medidas de reforma estuvieron enfocadas en la expansión y el fortalecimiento del IVA. Así, el principal

20 El ITF que grava los créditos y débitos se introdujo en 2004 con una alícuota inicial del 0,15\%, que sufrió una merma progresiva y hoy equivale al 0,005\%. 
instrumento generador de recursos tributarios a nivel regional parece haber alcanzado un aceptable grado de maduración en la mayoría de los casos. De todos modos, la mirada hacia el futuro debería centrarse en la adopción de alternativas destinadas a morigerar el efecto regresivo del IVA, por ejemplo, mediante la compensación con programas de transferencias condicionadas destinadas a los hogares de menores ingresos ${ }^{21}$.

Por lo tanto, sin desalentar la introducción de mejoras en el cumplimiento del IVA, el peso de una nueva generación de reformas tributarias en América Latina debería concentrarse en el ISR, tanto el que grava a las sociedades como a las personas naturales, al tiempo que se fortalece la imposición de gravámenes sobre la propiedad. Es indispensable profundizar y tornar efectiva una aplicación amplia y general del principio de equidad horizontal en lo atinente a las bases imponibles. Asimismo, la estructura y el nivel de las tasas deben apuntar a salvaguardar la equidad vertical. No obstante, la heterogeneidad regional obliga a proceder con cautela al momento de definir reformas con cierto grado de generalidad, ya que, como suele suceder con todas las políticas públicas, no existe una receta única para todos los países de la región.

Por último, es posible afirmar que las reformas tributarias que se erigen como necesarias en los países de América Latina no solo exigen focalizar los esfuerzos en el diseño específico de los tributos vigentes: igual de importante es la percepción de los contribuyentes acerca de la justicia del sistema tributario y del uso eficiente de los recursos que el Estado obtiene a partir de su aplicación. Es por ello que las futuras reformas deben ser concebidas en el marco de un pacto fiscal entre los gobiernos y los ciudadanos, sobre la base de la reciprocidad y la consolidación de las instituciones del Estado.

21 Barreix, Bès y Roca (2010) analizan distintas alternativas para lograr este objetivo. 


\section{Bibliografía}

Amarante, V., R. Arim y G. Salas (2007), “Impacto distributivo de la reforma impositiva en Uruguay", documento preparado para el Análisis de Impacto Social y Pobreza (AISP), Uruguay - Segundo Préstamo Programático para Políticas de Desarrollo (DPL) II, junio.

Arenas, A. (2016), Sostenibilidad fiscal y reformas tributarias en América Latina (LC/G.2688-P), Santiago, Comisión Económica para América Latina y el Caribe (CEPAL).

Barreix, A., M. Bès y J. Roca (2010), “El IVA personalizado. Aumentando la recaudación y compensando a los más pobres", Washington, D.C., Banco Interamericano de Desarrollo.

Bird, R. (2003), "Taxation in Latin America: reflections on sustainability and the balance between equity and efficiency", International Tax Program Papers, $\mathrm{N}^{\circ} 306$, Toronto, Universidad de Toronto.

Bird, R. y E. Zolt (2005), "Rethinking redistribution: tax policy in an era of rising inequality", UCLA Law Review, vol. 52, N 6, Universidad de California.

CEPAL (Comisión Económica para América Latina y el Caribe) (2015), Panorama Fiscal de América Latina y el Caribe 2015. Dilemas y espacios de políticas (LC/L.3961), Santiago. (2010), La hora de la igualdad: brechas por cerrar, caminos por abrir (LC/G.2432 (SES.33/3)), Santiago.

(2006), La protección social de cara al futuro: acceso, financiamiento y solidaridad (LC/G.2294(SES.31/3)), Santiago.

Cetrángolo, O. y J.C. Gómez Sabaini (2007), “La tributación directa en América Latina y los desafíos a la imposición sobre la renta", Serie Macroeconomía del Desarrollo, No 60 (LC/L.2838-P), Santiago, Comisión Económica para América Latina y el Caribe (CEPAL).

Coelho, I. (2009), "Taxing bank transactions. The experience in Latin America and elsewhere", documento presentado en la Tercera Conferencia Mundial del Diálogo Internacional sobre Fiscalidad, Beijing.

Cornia, G.A, J.C. Gómez Sabaini y B. Martorano (2011), “A new fiscal pact, tax policy changes and income inequality: Latin America during the last decade", Working Paper, $N^{\circ} 70 / 2011$, Instituto Mundial de Investigaciones de Economía del Desarrollo (UNU-WIDER).

Fenochietto, R. y C. Pessino (2010), "Determining countries' tax effort", Hacienda Pública Española/Revista de Economía Pública, N 195-4(2010), Madrid, Instituto de Estudios Fiscales.

Fjeldstad, O., L. Katera y E. Ngalewa (2009), "Maybe we should pay tax after all? Citizens' views on taxation in Tanzania", REPOA Special Paper, $\mathrm{N}^{\circ} 29$.

Gómez Sabaini, J.C. y D. Morán (2016), “La situación tributaria en América Latina: raíces y hechos estilizados", Cuadernos de Economía, vol. 35, N 67, Bogotá, Universidad Nacional de Colombia.

(2014), "Tax policy in Latin America: Diagnosis and guidelines for a second generation of reforms", Macroeconomics of Development series, N No 133 (LC/L.3632), Santiago, Comisión Económica para América Latina y el Caribe (CEPAL) [en línea] http://repositorio.cepal.org/bitstream/handle/11362/36806/ S1420166_en.pdf?sequence $=1$.

(2012), "Informalidad y tributación en América Latina: explorando los nexos para mejorar la equidad", serie Macroeconomía del Desarrollo, No 124 (LC/L.3534), Santiago, Comisión Económica para América Latina y el Caribe (CEPAL). 
Gómez Sabaini, J.C., J.P. Jiménez y D. Rossignolo (2012), “Imposición a la renta personal y equidad en América Latina: nuevos desafíos", serie Macroeconomía del Desarrollo, No 119 (LC/L.3477-P), Santiago, Comisión Económica para América Latina y el Caribe (CEPAL).

Goñi, E., H. López y L. Servén (2008), “Fiscal redistribution and income inequality in Latin America", Policy Research Working Paper, N 4487, Washington, D.C., Banco Mundial.

Huber, E. (2009), "Including the middle classes? Latin American social policies after the Washington Consensus", Doing Good or Doing Better: Development Policies in a Globalizing World, M. Kremer, P. van Lieshout y R. Went (eds.), Amsterdam, Amsterdam University Press.

ICEFI (Instituto Centroamericano de Estudios Fiscales) (2011), “Evolución de las reformas tributarias recientes en América Central", Boletín de Estudios Fiscales, $\mathrm{N}^{\circ} 14$, Ciudad de Guatemala.

Jenkins, G.P. (1995), "Tax reform: lesson learned", Development Discussion Paper, $\mathrm{N}^{\circ}$ 281, Cambridge, Massachusetts, Universidad de Harvard.

Kaldor, N. (1962), "The role of taxation in economic development" (UNESCO/SS/ PED/11), Organización de las Naciones Unidas para la Educación, la Ciencia y la Cultura (UNESCO).

Lora, E. (ed.) (2007), El estado de las reformas del Estado en América Latina, Washington, D.C., Banco Mundial / Banco Interamericano de Desarrollo (BID)/Mayol Ediciones.

Mesa-Lago, C. (2004), “Las reformas de pensiones en América Latina y su impacto en los principios de la seguridad social" (LC/L.2090), serie Financiamiento del Desarrollo, N 144 (LC/L.2090-P), Santiago.

Morán, D. y M. Pecho (2016), "La tributación en América Latina en los últimos cincuenta años", CIAT: Cincuenta años en el quehacer tributario de América Latina, Ciudad de Panamá, Centro Interamericano de Administraciones Tributarias (CIAT), en prensa.

OCDE/CEPAL/CIAT/BID (Organización de Cooperación y Desarrollo Económicos / Comisión Económica para América Latina y el Caribe/Centro Interamericano de Administraciones Tributarias/Banco Interamericano de Desarrollo) (2016), Estadísticas tributarias en América Latina y el Caribe 1990-2014, París, OECD Publishing. 

Capítulo II

\section{La tributación sobre la renta en América Latina: desafíos y perspectivas ${ }^{1}$}

Juan Pablo Jiménez²

Andrea Podestá ${ }^{3}$

\section{Introducción}

En el capítulo I se presentó evidencia de un aumento de los ingresos fiscales y, en particular, de la carga tributaria en los países de América Latina durante las últimas décadas. Ello concuerda con el comportamiento indicado en la literatura respecto de la existencia de una relación positiva entre el desarrollo económico y los niveles de imposición. Es decir, a medida que los países van creciendo y alcanzando un mayor grado de desarrollo, los niveles de tributación se incrementan, en especial la recaudación proveniente de impuestos directos.

A continuación, se analizan la evolución y las principales características de la tributación sobre la renta, uno de los factores importantes que explican,

Este capítulo constituye una versión resumida de un capítulo que forma parte del libro "Sistemas fiscales en América Latina", que será publicado próximamente por el Instituto de Estudios Fiscales (IEF) de España.

2 Oficial de Asuntos Económicos de la División de Desarrollo Económico de la Comisión Económica para América Latina y el Caribe (CEPAL). Correo electrónico: juanpablo.jimenez@cepal.org.

3 Consultora de la Comisión Económica para América Latina y el Caribe (CEPAL). Correo electrónico: andrea.podesta@cepal.org. 
al menos parcialmente, el incremento de la carga tributaria en la región. Además, se estudia con mayor detalle el impuesto sobre la renta de las personas físicas con el fin de identificar los cambios producidos en los últimos decenios y los desafíos que enfrentan los países latinoamericanos a la hora de fortalecer este impuesto, que tiene un rol clave en la mejora de la desigual distribución del ingreso.

\section{A. Características de la imposición sobre la renta en América Latina: empresas y personas físicas}

Al considerar una mirada de largo plazo en la evolución del impuesto sobre la renta, se obtiene evidencia de que, en general, la recaudación proveniente de ese tipo de impuesto creció entre 1940 y 1980 en los países de América Latina sobre los que se dispone de información histórica (véase el cuadro II.1). Luego, con la crisis de la deuda en los años ochenta, los ingresos fiscales originados en los impuestos sobre los ingresos, las utilidades y las ganancias de capital, medidos en porcentajes del PIB, disminuyeron en la mayoría de los países, al tiempo que en los años noventa, la proporción de estos impuestos en relación con el PIB se mantuvo estable en el promedio de seis países de la región.

\section{Cuadro Il.1}

América Latina (6 países): impuestos sobre los ingresos, utilidades y ganancias de capital, 1940-2014

(En porcentajes del PIB)

\begin{tabular}{lcccccccc}
\hline Países & $1940-$ & $1950-$ & $1960-$ & $1970-$ & $1980-$ & $1990-$ & $2000-$ & $2010-$ \\
& 1949 & 1959 & 1969 & 1979 & 1989 & 1999 & 2009 & 2014 \\
\hline Argentina & 2,3 & 2,8 & 1,8 & 1,4 & 0,8 & 1,9 & 3,9 & 5,2 \\
\hline Brasil & 1,9 & 2,4 & 2,0 & 2,7 & 4,6 & 4,9 & 6,6 & 6,9 \\
\hline Chile & 3,1 & 4,6 & 6,7 & 6,0 & 4,5 & 3,5 & 5,3 & 6,8 \\
\hline Colombia & 2,2 & 3,6 & 4,1 & 4,0 & 2,9 & 3,4 & 4,8 & 6,0 \\
\hline México & 1,7 & 2,4 & 2,9 & 4,4 & 4,7 & 4,3 & 4,6 & 5,7 \\
\hline Perú & 1,9 & 4,3 & 4,3 & 4,4 & 2,9 & 2,6 & 5,2 & 7,5 \\
\hline Promedio & 2,2 & 3,4 & 3,6 & 3,8 & 3,4 & 3,4 & 5,1 & 6,3 \\
\hline
\end{tabular}

Fuente: Gómez Sabaini, J.C., J.P. Jiménez y D. Rossignolo, "Imposición a la renta personal y equidad en América Latina: nuevos desafíos", serie Macroeconomía del Desarrollo, № 119 (LC/L.3477-P), Santiago, Comisión Económica para América Latina y el Caribe (CEPAL), 2012.

De acuerdo con Gómez Sabaini, Jiménez y Rossignolo (2012), durante los años ochenta y noventa, las políticas económicas en América Latina estuvieron decididamente orientadas por los criterios resumidos en el Consenso de Washington y se centraron en la eficiencia económica y la búsqueda de solvencia fiscal. Por ese motivo, las reformas tributarias impulsadas en esos períodos enfatizaron la aplicación de un gravamen general sobre bienes y 
servicios (el impuesto sobre el valor agregado (IVA)) como sustituto de la imposición arancelaria, la derogación de impuestos de bajo rendimiento, la simplificación de las normas, la reducción de los niveles y tramos del impuesto sobre la renta y la generalización de las bases imponibles, aunque este último aspecto se refería más bien al IVA que a la imposición sobre los ingresos. En líneas generales, el diseño de la política tributaria estuvo influenciado por la creencia de que era más apropiado reducir el tamaño del Estado que aumentar significativamente el nivel de imposición por encima de los valores históricos observados.

En el siglo XXI tiene lugar un importante crecimiento de la recaudación del impuesto sobre la renta en todos los países considerados. El promedio del último quinquenio casi triplica los valores (en porcentajes del PIB) de hace siete décadas.

La tendencia positiva registrada durante este siglo puede separarse en dos determinantes principales. En primer lugar, entre 2003 y 2008 ocurrió un mayor crecimiento del impuesto sobre la renta de las personas jurídicas (véase el gráfico II.1). En esencia, ello estuvo asociado al significativo aumento de la recaudación proveniente de empresas mineras y petroleras, como resultado del auge de los precios de exportación de los productos primarios y de ciertas reformas implementadas para lograr una mayor apropiación fiscal de ese tipo de rentas. En segundo término, y en especial a partir de 2011, se destaca el incremento de la recaudación del impuesto sobre la renta de las personas físicas. En ese sentido, un factor importante han sido las reformas implementadas por los países de la región que buscaban ampliar las bases imponibles de ese tributo, sobre todo para fortalecer la tributación sobre las rentas de capital. También se incluyeron cambios en las alícuotas y en los tramos de ingresos imponibles y se mejoraron las reglas de tributación internacional ${ }^{4}$.

A pesar de que la recaudación de los impuestos sobre la renta personal se ha ido incrementando, el crecimiento de los impuestos que recaen sobre la renta de las empresas corresponde a casi dos tercios del aumento total de este tipo de tributo en el período 1990-2014. En América Latina, las personas jurídicas aportan alrededor del $71 \%$ del total recaudado en concepto del impuesto sobre la renta, mientras que las personas naturales apenas aportan el 29\% restante. En los países de la Organización de Cooperación y Desarrollo Económicos (OCDE) esas participaciones son inversas: el 74\% es aportado por las personas físicas y el $26 \%$ por las empresas, mientras que en el promedio de 15 economías de la Unión Europea, el impuesto sobre la renta personal alcanza una participación del 79\% del total (véase el gráfico II.2).

Véanse más detalles sobre las reformas tributarias aprobadas en la última década en CEPAL (2015) y Arenas (2016). 


\section{Gráfico II.1}

América Latina (países seleccionados): evolución y estructura del impuesto sobre la renta, 1990-2014

(En porcentajes del PIB)

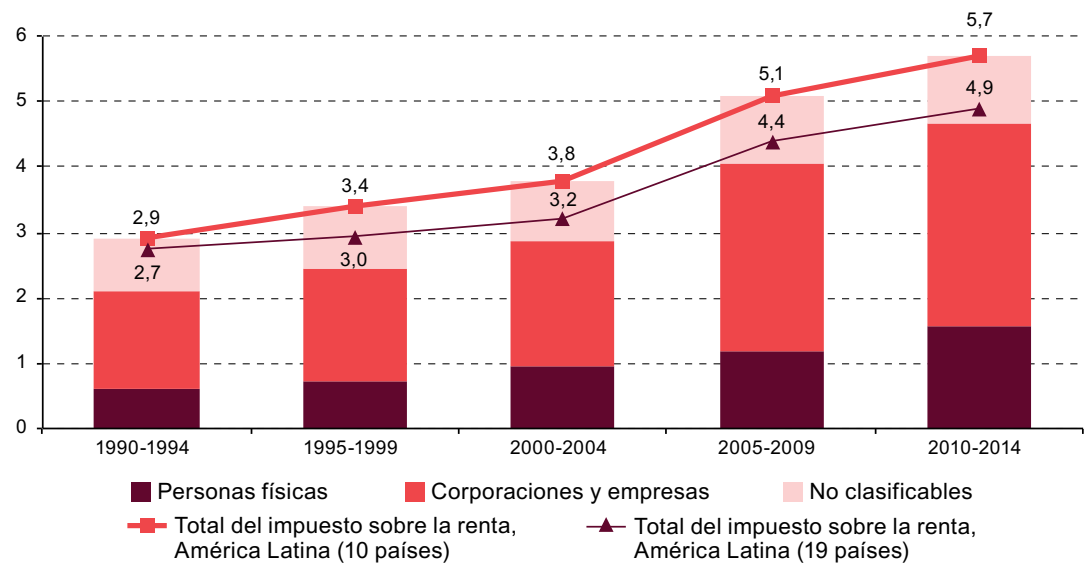

Fuente: Elaboración propia, sobre la base de información de la Comisión Económica para América Latina y el Caribe (CEPAL).

a La desagregación entre personas físicas y empresas corresponde al promedio simple de diez países sobre los que se dispone de información correspondiente al período 1990-2014 (Argentina, Brasil, Chile, Colombia, Guatemala, Honduras, México, Panamá, Perú y Uruguay).

\section{Gráfico II.2}

América Latina, Organización de Cooperación y Desarrollo Económicos (OCDE) y 15 economías de la Unión Europea (15 países): estructura del impuesto sobre la renta, 2010

(En porcentajes del PIB y del total recaudado)

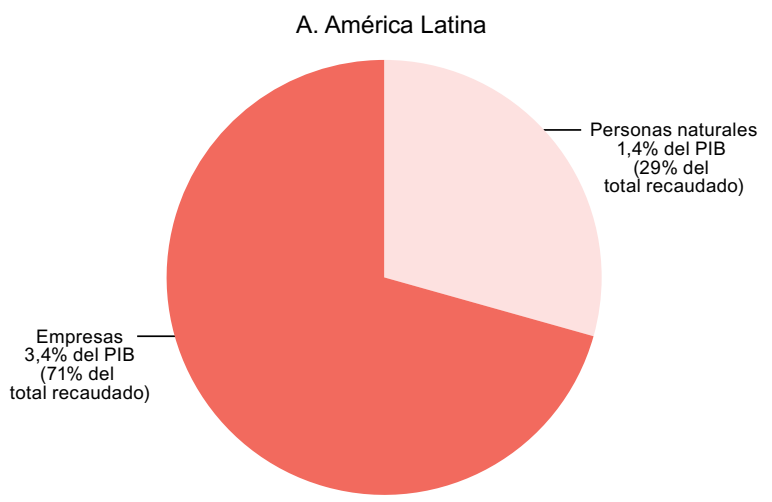


Gráfico II.2 (conclusión)

B. OCDE

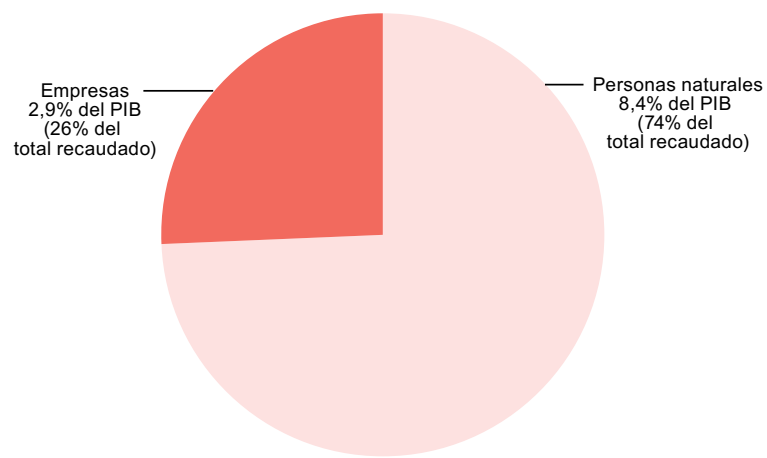

C. Unión Europea (15 países)

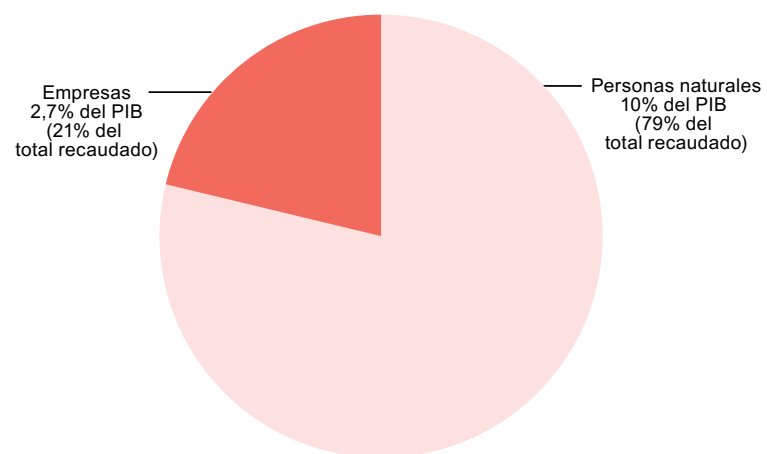

Fuente: Elaboración propia, sobre la base de información de CEPALSTAT, Banco Interamericano de Desarrollo (BID), Centro Interamericano de Administraciones Tributarias (CIAT) y Organización de Cooperación y Desarrollo Económicos (OCDE) .

En términos del nivel de recaudación media del impuesto sobre la renta aportado por las empresas, la región está algo por encima de la media de los países desarrollados (un 3,4\% del PIB en América Latina frente al 2,9\% del PIB en la OCDE y el 2,7\% en los 15 países de la Unión Europea). En cambio, en lo que se refiere al impuesto sobre la renta personal, América Latina está muy lejos de la OCDE y, aún más, del promedio de los 15 países de la Unión Europea, ya que los países latinoamericanos obtienen en promedio solo un $1,4 \%$ del PIB en comparación con las economías de la OCDE, donde el valor medio supera el 8\% del PIB y con los 15 países de la Unión Europea, que registran un 10\% del PIB. De esta forma, en América Latina el impuesto sobre la renta recauda en total menos de la mitad que en los países de la OCDE (4,7\% frente al 11,3\% del PIB) o que en las 15 economías de la Unión Europea (12,7\% del PIB). 
Este desequilibrio intrínseco en el impuesto sobre la renta de los países de la región y el reducido nivel de recaudación plantean un doble desafío para América Latina. Por un lado, es necesario aumentar, en la medida de lo posible, la recaudación global de los tributos sobre los ingresos, con el fin de afectar positivamente la estructura impositiva vigente $y$, a su vez, procurar que ese incremento se dirija en mayor proporción hacia el impuesto que recae sobre las personas naturales, a fin de alcanzar un mejor equilibrio en la composición del tributo.

En cuanto a la situación particular de los países de la región, se observa que, a excepción de El Salvador, México y el Uruguay, donde la proporción que recae sobre las personas físicas y las empresas es bastante similar, los demás países presentan una estructura desequilibrada ${ }^{5}$. En otras palabras, tanto en los países donde la carga tributaria es más elevada (Argentina y Brasil) como en los que tienen una presión tributaria mucho más baja (Guatemala, Paraguay o República Dominicana), las personas jurídicas suelen ser las que aportan la mayor parte del tributo (véase el cuadro II.2). Además, dentro de la región, los niveles de recaudación son bastante heterogéneos. Los países que más recaudan en concepto de impuesto sobre la renta personal apenas llegan al 2,6\% del PIB (México y Uruguay) y existen varios casos con un nivel inferior al 1\% del PIB (Bolivia (Estado Plurinacional de), Colombia, Ecuador, Guatemala, Paraguay, República Dominicana y Venezuela (República Bolivariana de)).

Dado que en varios países latinoamericanos la evolución positiva del impuesto sobre la renta se explica por las altas utilidades percibidas por empresas vinculadas a los productos básicos, esa evolución podría ser transitoria o revertirse con el paso del tiempo. Los progresos en materia de impuesto sobre la renta de las personas físicas han sido más lentos en términos de recaudación, como se documenta en el informe sobre estadísticas tributarias en América Latina (OCDE/CEPAL/CIAT/BID, 2016).

Debe observarse que una limitación importante del impuesto sobre la renta personal en América Latina es que se recauda fundamentalmente de los asalariados, es decir, recae sobre los trabajadores formales en relación de dependencia, a quienes se les realiza la retención en su fuente de ingreso. De acuerdo con los estudios recopilados en Gómez Sabaini, Jiménez y Podestá (2010), el 60\% (o más) del impuesto sobre la renta personal proviene de

\footnotetext{
Sin embargo, de acuerdo con Cabrera y Guzmán (2010), la menor recaudación relativa de las personas jurídicas en El Salvador puede deberse a dos factores. En primer lugar, debe tomarse en cuenta que la tributación de personas naturales corresponde a trabajadores asalariados y no asalariados, y estos contribuyentes comprenden algunas actividades empresariales, servicios profesionales y pequeñas empresas que tributan como personas naturales. En segundo lugar, la existencia de un amplio sistema de incentivos fiscales estaría erosionando la tributación procedente de personas jurídicas.
} 
trabajadores asalariados en los países sobre los que se dispone de información (entre ellos, Ecuador, El Salvador, México y Perú). Las mayores posibilidades de evasión y elusión de los trabajadores independientes y el tratamiento preferencial que reciben las rentas de capital limitan el recaudo de ingresos no salariales.

\section{Cuadro II.2}

América Latina, Organización de Cooperación y Desarrollo Económicos (OCDE) y Unión Europea (15 países): recaudación del impuesto sobre

la renta de empresas y personas naturales, 2010 (En porcentajes del PIB y porcentajes de participación relativa)

\begin{tabular}{|c|c|c|c|c|c|}
\hline & \multicolumn{3}{|c|}{$\begin{array}{c}\text { Recaudación } \\
\text { (en porcentajes del PIB) }\end{array}$} & \multicolumn{2}{|c|}{$\begin{array}{l}\text { Participación relativa } \\
\text { (en porcentajes) }\end{array}$} \\
\hline & $\begin{array}{l}\text { Personas } \\
\text { físicas }\end{array}$ & Empresas & Total & $\begin{array}{l}\text { Personas } \\
\text { físicas }\end{array}$ & Empresas \\
\hline Argentina & 1,7 & 3,7 & 5,3 & 31,1 & 68,9 \\
\hline $\begin{array}{l}\text { Bolivia (Estado } \\
\text { Plurinacional de) }\end{array}$ & 0,2 & 3,4 & 3,6 & 4,6 & 95,4 \\
\hline Brasil & 2,4 & 3,7 & 6,1 & 39,6 & 60,4 \\
\hline Chile & 1,4 & 6,3 & 7,7 & 18,6 & 81,4 \\
\hline Colombia & 0,2 & 4,6 & 4,8 & 4,4 & 95,6 \\
\hline Costa Rica & 1,3 & 2,7 & 4,0 & 32,9 & 67,1 \\
\hline Ecuador & 0,6 & 3,5 & 4,1 & 14,8 & 85,2 \\
\hline El Salvador & 2,2 & 2,4 & 4,5 & 48,1 & 51,9 \\
\hline Guatemala & 0,2 & 2,9 & 3,1 & 7,7 & 92,3 \\
\hline Honduras & 1,2 & 3,5 & 4,7 & 26,1 & 73,9 \\
\hline México & 2,6 & 2,5 & 5,1 & 50,7 & 49,3 \\
\hline Nicaragua & 2,1 & 4,0 & 6,1 & 34,7 & 65,3 \\
\hline Panamá & 1,6 & 3,3 & 4,9 & 33,4 & 66,6 \\
\hline Paraguay $^{a}$ & $\ldots$ & 2,6 & 2,6 & $\ldots$ & $\ldots$ \\
\hline Perú & 1,9 & 4,0 & 5,8 & 32,1 & 67,9 \\
\hline República Dominicana & 0,9 & 2,1 & 2,9 & 30,5 & 69,5 \\
\hline Uruguay & 2,6 & 2,6 & 5,2 & 49,7 & 50,3 \\
\hline $\begin{array}{l}\text { Venezuela (República } \\
\text { Bolivariana de) }\end{array}$ & 0,6 & 3,0 & 3,6 & 16,8 & 83,2 \\
\hline $\begin{array}{l}\text { Promedio de América Latina } \\
\text { y el Caribe ( } 18 \text { países) }\end{array}$ & 1,4 & 3,4 & 4,7 & 28,0 & 72,0 \\
\hline $\begin{array}{l}\text { Promedio de la OCDE } \\
\text { (34 países) }\end{array}$ & 8,4 & 2,9 & 11,3 & 74,3 & 25,7 \\
\hline $\begin{array}{l}\text { Promedio de la Unión } \\
\text { Europea (15 países) }\end{array}$ & 10,0 & 2,7 & 12,7 & 78,8 & 21,2 \\
\hline
\end{tabular}

Fuente: Elaboración propia, sobre la base de información de CEPALSTAT, Banco Interamericano de Desarrollo (BID), Centro Interamericano de Administraciones Tributarias (CIAT) y Organización de Cooperación y Desarrollo Económicos (OCDE).

a En el Paraguay, el impuesto sobre la renta de las personas físicas entró en vigencia el 1 de agosto de 2012.

b En la República Bolivariana de Venezuela, la separación entre las personas físicas y las empresas se ha estimado de acuerdo con su participación relativa en la información del presupuesto. 


\section{B. Factores que limitan la recaudación del impuesto sobre la renta personal en la región}

Más allá de las reformas tributarias y de las mejoras en los niveles de recaudación del impuesto sobre la renta personal de los últimos años, existe consenso en señalar tres factores que han condicionado un mejor desempeño de ese tributo en los países de América Latina:

i) la evolución de las alícuotas legales, que llevó a una reducción de las tasas marginales máximas aplicadas en el promedio de los países;

ii) la estrecha base imponible como consecuencia de un gran número de exenciones y deducciones permitidas, y por los niveles mínimos no imponibles, todo lo cual deja fuera del gravamen una cantidad importante de los ingresos, y

iii) los altos niveles de incumplimiento (evasión y morosidad) que se observan en casi todos los países.

Esos factores conllevan la existencia de tasas efectivas sustancialmente bajas como para lograr los efectos económicos y redistributivos deseados. A continuación se analiza con mayor detalle cada uno de esos condicionantes.

\section{La evolución de las tasas legales del impuesto}

En el gráfico II.3 se muestra la evolución de las tasas legales máximas y mínimas aplicables a la tributación sobre la renta de las personas físicas en un promedio de 18 países de América Latina.

Los promedios regionales de las alícuotas marginales máximas del impuesto sobre la renta de las personas físicas fueron descendiendo en América Latina, partiendo de tasas del 50,9\% en la década de 1980, de alrededor del $35,2 \%$ a principios de la década de 1990 y en torno al 26,6\% en 2016. Esta reducción paulatina ha hecho que las alícuotas máximas de algunos países latinoamericanos estén por debajo de los niveles internacionales. Por ejemplo, las tasas marginales máximas del impuesto sobre la renta personal llegaron en 2014 al 45\% en el promedio de 18 economías pertenecientes a la eurozona, o al 39,4\% si se considera el promedio de los 28 países de la Unión Europea. Cabe destacar que en varios países europeos (Austria, Bélgica, Dinamarca, España, Finlandia, Francia, Países Bajos, Portugal y Suecia) estas tasas son iguales o superiores al 50\% (Unión Europea, 2014). 


\section{Gráfico II.3}

América Latina (países seleccionados): evolución de las tasas marginales máximas y mínimas del impuesto sobre la renta de personas físicas, 1985-2016

(En porcentajes)

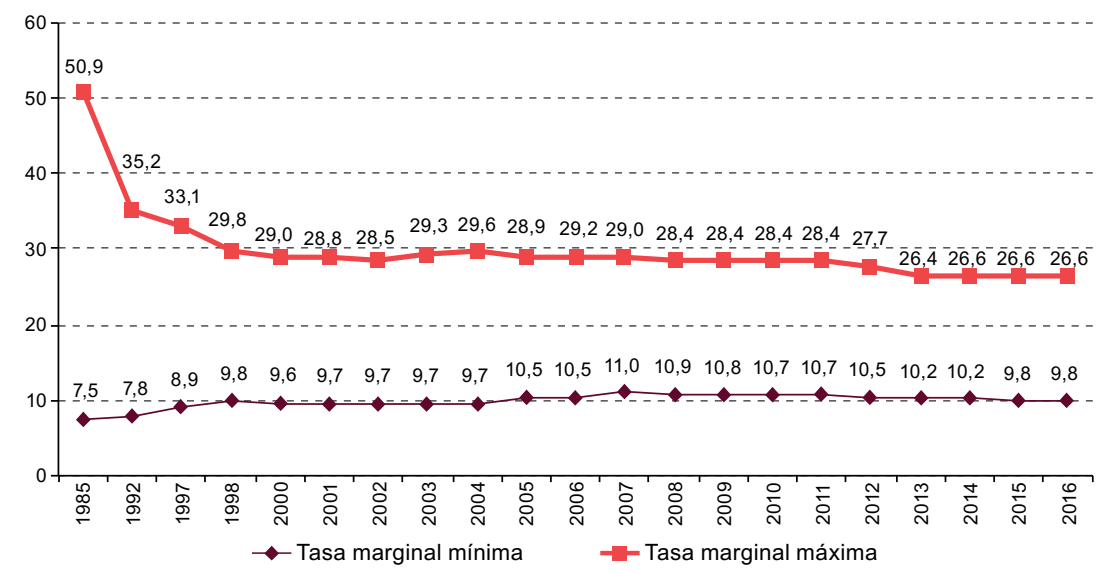

Fuente: Elaboración propia, sobre la base de V. Tanzi, "Taxation in Latin America in the last decade", documento presentado en la Conferencia sobre reformas fiscales y financieras en América Latina, Universidad de Stanford, noviembre de 2000; y datos de CEPALSTAT y el Centro Interamericano de Administraciones Tributarias (CIAT) .

En contraste, las tasas marginales mínimas evidenciaron un incremento en América Latina, al pasar de una tasa media del 7,5\% en la década de 1980 a un 9,8\% en 2016. Alcanzaron su mayor valor hacia 2007 , con una alícuota del 11\% para el promedio regional. De esa forma se observa una reducción de la brecha media entre las tasas marginales máximas y mínimas de la imposición a la renta de personas físicas, lo que influye en el grado de progresividad del tributo (véanse el gráfico II.3 y el cuadro II.3).

En relación con las tasas mínimas, el Brasil, Panamá y México han reducido estas alícuotas a partir del período 2008-2010, mientras que Chile y Guatemala las redujeron en 2013 y el Perú en 2014 (véase el cuadro II.3). En cambio, las tasas mínimas de Honduras y Nicaragua registraron un aumento, ya que pasaron del 10\% al 15\% en 2010 y 2013, respectivamente. Por otro lado, a diferencia de los demás países de la región, en el Ecuador (desde 2008), México (a partir de 2010 y nuevamente desde 2014) y el Uruguay (desde 2012) se han aumentado las alícuotas marginales máximas correspondientes al impuesto sobre la renta personal. 


\section{Cuadro II.3}

América Latina (18 países): tasas marginales máximas y mínimas del impuesto sobre la renta de las personas físicas por países, 1985-2016

(En porcentajes)

\begin{tabular}{|c|c|c|c|c|c|c|c|c|c|c|}
\hline \multirow{3}{*}{ Argentina } & \multirow{2}{*}{\multicolumn{2}{|c|}{$\frac{1985 \text { o } 1986}{\text { Mínimo Máximo }}$}} & \multirow{2}{*}{\multicolumn{2}{|c|}{$\frac{1992}{\text { Mínimo Máximo }}$}} & \multirow{2}{*}{\multicolumn{2}{|c|}{$\frac{2000}{\text { Mínimo Máximo }}$}} & \multirow{2}{*}{\multicolumn{2}{|c|}{$\frac{2008}{\text { Mínimo Máximo }}$}} & \multirow{2}{*}{\multicolumn{2}{|c|}{$\frac{2016}{\text { Mínimo Máximo }}$}} \\
\hline & & & & & & & & & & \\
\hline & 16,5 & 45 & 15 & 30 & 9 & 35 & 9 & 35 & 9 & 35 \\
\hline $\begin{array}{l}\text { Bolivia (Estado } \\
\text { Plurinacional } \\
\text { de) }\end{array}$ & n.a. & 30 & 10 & 10 & 13 & 13 & 13 & 13 & 13 & 13 \\
\hline Brasil & 0 & 60 & 10 & 25 & 15 & 27,5 & 15 & 27,5 & 7,5 & 27,5 \\
\hline Chile & 0 & 57 & 5 & 50 & 5 & 45 & 5 & 40 & 4 & 40 \\
\hline Colombia & n.a. & 49 & 5 & 30 & 10 & 35 & 19 & 33 & 19 & 33 \\
\hline Costa Rica & 5 & 50 & 10 & 25 & 10 & 25 & 10 & 15 & 10 & 15 \\
\hline Ecuador & 19 & 40 & 10 & 25 & 5 & 15 & 5 & 35 & 5 & 35 \\
\hline El Salvador & 3 & 60 & 10 & 30 & 10 & 30 & 10 & 30 & 10 & 30 \\
\hline Guatemala & 11 & 48 & 4 & 34 & 15 & 25 & 15 & 31 & 5 & 7 \\
\hline Honduras & 3 & 40 & 12 & 40 & 10 & 25 & 10 & 25 & 15 & 25 \\
\hline México & 3 & 55 & 3 & 35 & 3 & 40 & 1,92 & 28 & 1,92 & 35 \\
\hline Nicaragua & 15 & 50 & 8 & 35,5 & 10 & 30 & 10 & 30 & 15 & 30 \\
\hline Panamá & 13 & 56 & 3,5 & 56 & 2 & 30 & 16,5 & 27 & 15 & 25 \\
\hline Paraguay & n.a. & n.a. & n.a. & n.a. & n.a. & n.a. & n.a. & n.a. & 8 & 10 \\
\hline Perú & 2 & 56 & 6 & 37 & 15 & 30 & 15 & 30 & 8 & 30 \\
\hline $\begin{array}{l}\text { República } \\
\text { Dominicana }\end{array}$ & 2 & 73 & 3 & 70 & 15 & 25 & 15 & 25 & 15 & 25 \\
\hline Uruguay & n.a. & n.a. & n.a. & n.a. & n.a. & n.a. & 10 & 25 & 10 & 30 \\
\hline $\begin{array}{l}\text { Venezuela } \\
\text { (República } \\
\text { Bolivariana de) }\end{array}$ & 12 & 45 & 10 & 30 & 6 & 34 & 6 & 34 & 6 & 34 \\
\hline $\begin{array}{l}\text { América Latina } \\
\text { (18 países) }\end{array}$ & 7,5 & 50,9 & 7,8 & 35,2 & 9,6 & 29,0 & 10,9 & 28,4 & 9,8 & 26,6 \\
\hline
\end{tabular}

Fuente: Elaboración propia, sobre la base de V. Tanzi, "Taxation in Latin America in the last decade", documento presentado en la Conferencia sobre reformas fiscales y financieras en América Latina, Universidad de Stanford, noviembre de 2000; y datos de CEPALSTAT y el Centro Interamericano de Administraciones Tributarias.

Nota: n.a.: no se aplica.

\section{La estrechez de las bases imponibles: ingresos gravables y gastos tributarios}

Los bajos niveles de recaudación y la estrecha base imponible del impuesto sobre la renta de las personas físicas se relacionan tanto con el generoso tratamiento en materia de deducciones personales y ganancias no imponibles establecidos en la legislación impositiva, como con los numerosos regímenes de exención o gastos tributarios.

Respecto al primero de esos aspectos, una comparación entre distintas regiones del mundo indica que en América Latina el nivel de ingreso a partir del cual comienza a pagarse el impuesto sobre la renta personal es mayor al de las demás zonas geográficas, algo solo superado por las regiones de Asia meridional y África Subsahariana (véase el cuadro II.4). Mientras que en los 
países de América Latina el ingreso mínimo exento equivale, en promedio, a 1,4 veces el PIB per cápita, en los países de Europa occidental el gravamen se tributa, en promedio, a partir de un tercio del PIB per cápita y, en los Estados Unidos, desde un nivel de 0,2 veces ese indicador. De cierta forma, esta diferencia en el ingreso gravable para aplicar la alícuota mínima del impuesto en las distintas regiones se encuentra justificada por la diferencia en los niveles de ingreso per cápita y por la necesidad de dejar fuera del gravamen un nivel de ingreso que considere valores de subsistencia familiar. A la inversa, resulta más difícil justificar el monto desde el que comienza a aplicarse la tasa marginal máxima. Mientras que en los países desarrollados esa tasa se establece a partir de 3 o 4 veces el PIB per cápita, en los países latinoamericanos dicha alícuota comienza a tener efecto a partir de ingresos superiores a 7,3 veces el ingreso per cápita, con tasas significativamente más bajas que en los países desarrollados (véase el cuadro II.4).

\section{Cuadro II.4}

América Latina y otras regiones: ingreso gravable y alícuotas del impuesto sobre la renta personal, alrededor de 2012-2013

(En número de veces del PIB per cápita y en porcentajes)

\begin{tabular}{|c|c|c|c|c|}
\hline & \multicolumn{2}{|c|}{ Ingreso gravable ${ }^{a}$} & \multicolumn{2}{|c|}{$\begin{array}{c}\text { Alícuota } \\
\text { (en porcentajes) }\end{array}$} \\
\hline & Mínimo & Máximo & Mínima & Máxima \\
\hline América Latina (18 países) ${ }^{b}$ & 1,40 & 7,34 & 9,8 & 26,6 \\
\hline El Caribe (11) & 1,37 & 4,30 & 17,7 & 31,1 \\
\hline Asia oriental y el Pacífico (29) & 1,06 & 11,17 & 9,1 & 28,2 \\
\hline Europa oriental y Asia central (31) & 0,94 & 3,67 & 13,7 & 19,2 \\
\hline Oriente Medio y África septentrional (15) & 0,77 & 6,27 & 9,4 & 26,6 \\
\hline Asia meridional (7) & 2,27 & 27,44 & 5,6 & 25,7 \\
\hline África Subsahariana (47) & 2,17 & 12,89 & 10,4 & 35,0 \\
\hline Europa occidental (20) & 0,31 & 3,98 & 14,6 & 40,9 \\
\hline Estados Unidos y Canadá (2) & 0,60 & 5,56 & 12,5 & 32,0 \\
\hline
\end{tabular}

Fuente: Para América Latina: elaboración propia, sobre la base de legislación oficial e información del Centro Interamericano de Administraciones Tributarias (CIAT) y de la Comisión Económica para América Latina y el Caribe (CEPAL); para las otras regiones: Agencia de los Estados Unidos para el Desarrollo Internacional (USAID), "Collecting Taxes 2012-2013" [en línea] https://www.usaid. gov/data/dataset/cdeb8a1b-3440-4e88-b6cb-81b2428f8cea.

a Corresponde a los niveles de ingreso a partir de los cuales comienzan a aplicarse las alícuotas mínima y máxima del impuesto sobre la renta personal, respectivamente, expresados como múltiplos del PIB per cápita de cada país o región (promedio simple de países).

b Información correspondiente a 2016.

Una vez más, el panorama entre distintos países es muy diverso, aunque prácticamente en todos se aprecia una tendencia a reducir el ingreso gravable a partir del cual se aplica la alícuota mínima. Esto es resultado de reformas en el diseño de los tramos de ingresos imponibles y la eliminación de exenciones y deducciones personales, que permitieron reducir el nivel de exención en un 36\%, en promedio, entre 2007 y 2016 (véase el cuadro II.5). 
Entre los países que tienen un menor nivel de exención están la Argentina, el Brasil, Chile, México, Panamá, el Uruguay y Venezuela (República Bolivariana de), donde el ingreso mínimo para comenzar a tributar el impuesto sobre la renta se sitúa por debajo del ingreso per cápita ${ }^{6}$. Los demás países presentan un nivel de exención que se ubica en un rango entre 1,3 y 2 veces el PIB per cápita, con la excepción del Paraguay, donde la aplicación del tributo es más reciente y este indicador equivale a 5,8 veces la renta per cápita.

El nivel de ingreso a partir del cual se aplica la máxima tasa marginal descendió, en promedio, un 38\% en el período 2007-2016, aunque la situación dentro de la región continúa siendo heterogénea. Por un lado, en un grupo de países integrado por la Argentina, el Brasil, Costa Rica, Panamá y la República Dominicana, la tasa marginal máxima tiene efecto a partir de un nivel de ingresos similar (o incluso inferior) al valor medio de cuatro veces el PIB per cápita que registran los países desarrollados. En cambio, en otras economías latinoamericanas (Ecuador, Guatemala, México, Paraguay y Uruguay) la alícuota máxima solo alcanza a los contribuyentes que ganan un valor cercano o superior a diez veces el ingreso per cápita del país.

Los altos gastos tributarios en los países de la región constituyen otro factor que reduce las bases imponibles. Mediante el uso de exenciones, deducciones, alícuotas reducidas, regímenes especiales y otros gastos tributarios, los países han buscado lograr diferentes objetivos, como la atracción de la inversión extranjera directa, el estímulo del ahorro, el desarrollo de mercados financieros, el desarrollo de regiones atrasadas, la promoción de exportaciones, la industrialización, la generación de empleo, el cuidado del medio ambiente, la transferencia de tecnología, la diversificación de la estructura económica y la formación de capital humano. Más allá de que la eficacia y la eficiencia en el logro de esos múltiples objetivos ha sido muy cuestionada y escasamente evaluada, lo cierto es que esos gastos tributarios han llevado a una erosión de las bases tributarias y han entrañado un costo en términos de recaudación.

A pesar de las diferencias metodológicas entre los distintos países para medir esas renuncias tributarias, que limitan la comparación entre ellos, en el cuadro II.6 se observa que la magnitud de los gastos tributarios resulta significativa en todos los casos, ya que se sitúan en un rango entre dos y siete puntos del PIB y representan entre un $7 \%$ y un $40 \%$ de la presión tributaria, según el país analizado.

6 En la Argentina la reducción del mínimo no imponible también se debe a un crecimiento del PIB en términos reales y a la falta de actualización por inflación de los parámetros nominales del impuesto; en el Estado Plurinacional de Bolivia, el nivel de aplicación del impuesto también se ubica por debajo del PIB per cápita, pero se aplica una alícuota plana. 


\section{Cuadro II.5}

\section{América Latina: niveles de renta para la aplicación de tasas mínimas y máximas del impuesto sobre la renta, 2007 y 2016}

(En número de veces del PIB per cápita)

\begin{tabular}{|c|c|c|c|c|}
\hline & \multicolumn{2}{|c|}{$\begin{array}{c}\text { Nivel de ingreso para } \\
\text { la aplicación de la tasa } \\
\text { mínima (nivel de exención) }\end{array}$} & \multicolumn{2}{|c|}{$\begin{array}{c}\text { Nivel de ingreso para } \\
\text { la aplicación de la tasa } \\
\text { marginal máxima }\end{array}$} \\
\hline & 2007 & 2016 & 2007 & 2016 \\
\hline Argentina $^{c}$ & 0,5 & 0,2 & 4,7 & 2,4 \\
\hline Bolivia (Estado Plurinacional de) & 0,1 & 0,2 & 0,1 & 0,2 \\
\hline Brasil & 1,5 & 0,8 & 3,0 & 1,9 \\
\hline Chile & 1,2 & 0,8 & 13,6 & 9,1 \\
\hline Colombia & 2,4 & 1,8 & 10,1 & 6,9 \\
\hline Costa Rica & 1,8 & 1,5 & 2,7 & 2,2 \\
\hline Ecuador & 2,7 & 1,9 & 23,5 & 19,0 \\
\hline El Salvador & 1,1 & 1,3 & 10,4 & 5,8 \\
\hline Guatemala & 3,1 & 1,9 & 13,9 & 9,5 \\
\hline Honduras & 3,2 & 2,0 & 22,9 & 8,5 \\
\hline México & 0,1 & 0,7 & 4,7 & 19,6 \\
\hline Nicaragua & 3,3 & 1,6 & 33,4 & 8,0 \\
\hline Panamá & 1,9 & 0,8 & 6,3 & 3,6 \\
\hline Paraguay & $\ldots$ & 5,8 & $\ldots$ & 9,7 \\
\hline Perú & 2,5 & 1,4 & 19,3 & 8,8 \\
\hline República Dominicana & 2,3 & 1,3 & 4,9 & 2,7 \\
\hline Uruguay & $\ldots$ & 0,6 & $\ldots$ & 9,8 \\
\hline Venezuela (República Bolivariana de) $^{d}$ & 1,6 & 0,6 & 9,2 & 4,6 \\
\hline América Latina (16 países) ${ }^{e}$ & 1,8 & 1,2 & 11,4 & 7,0 \\
\hline América Latina (18 países) & 1,8 & 1,4 & 11,4 & 7,3 \\
\hline
\end{tabular}

Fuente: Para 2016: elaboración propia, sobre la base de legislación oficial e información del Centro Interamericano de Administraciones Tributarias (CIAT) y de la Comisión Económica para América Latina y el Caribe (CEPAL); para 2007: Agencia de los Estados Unidos para el Desarrollo Internacional (USAID), "Collecting Taxes 2012-2013" [en línea] https://www.usaid.gov/data/dataset/cdeb8a1b3440-4e88-b6cb-81b2428f8cea.

a Corresponde al nivel de ingreso a partir del cual se impone la tasa marginal mínima del impuesto sobre la renta de las personas naturales (IRPN) (expresado como múltiplo del PIB per cápita). Cuando existe una deducción personal o un mínimo vital, este indicador equivale a ese valor expresado como múltiplo del PIB per cápita.

b Es el nivel de ingreso más bajo al que se impone la tasa marginal máxima del IRPN (expresado como múltiplo del PIB per cápita). Cuando el país aplica una tasa única a todos los ingresos personales, ambos indicadores son iguales (como sucede en el Estado Plurinacional de Bolivia).

c En la Argentina, el nivel de ingreso neto para la aplicación de la tasa máxima se calculó tomando como referencia el caso de un trabajador en relación de dependencia, casado y con dos hijos.

d Corresponde a 2015 en vez de 2016.

e No incluye al Paraguay ni al Uruguay, que no aplicaban este tributo en 2007. 


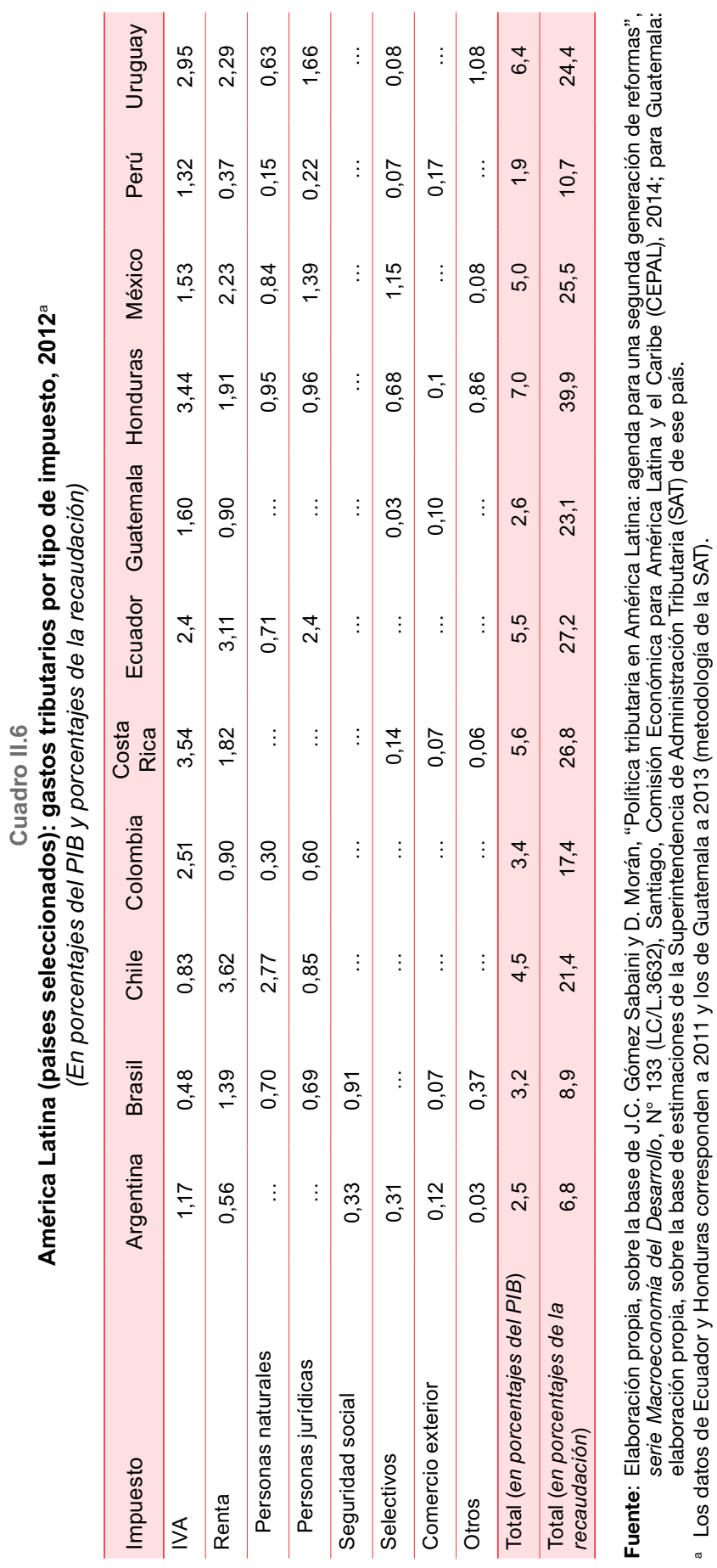


Además, en los países sobre los que se dispone de información oficial, se observa que la mayor parte de los gastos tributarios se concentra en los dos tributos principales, es decir, el impuesto sobre la renta y el IVA. En el caso particular del impuesto sobre la renta personal, el nivel de los gastos tributarios es muy variado entre países, tanto por la diferente importancia de las exenciones y demás beneficios tributarios como por las distintas metodologías aplicadas. Así, en algunos casos se ubican por debajo de medio punto del PIB y en otros sobrepasan el 2\% del PIB.

Es importante resaltar que la existencia de gastos tributarios implica una serie de costos o efectos negativos. Uno de los principales es la pérdida de recaudación ya que, al reducirse la carga tributaria de los sectores beneficiarios, se genera una menor recaudación para el fisco, lo que limita el espacio fiscal, la inversión, el gasto social y la implementación de políticas públicas. Además, los gastos tributarios vuelven más complejos los sistemas impositivos, incrementan los costos de administración y cumplimiento, crean espacios de evasión y elusión y restan transparencia a la política fiscal, debido a que no están sujetos a los mismos mecanismos de control ni rendición de cuentas que tienen los gastos directos, no están incluidos en el presupuesto y, por lo general, se renuevan automáticamente todos los años (Jiménez y Podestá, 2009) 7 .

A su vez, los gastos tributarios distorsionan la asignación de recursos y tienen un impacto negativo sobre la eficiencia y la equidad. Tal como señalan Gómez Sabaini y Morán (2014), en términos de eficiencia, los gastos tributarios han creado problemas de competencia tributaria interjurisdiccional, así como otras distorsiones en las decisiones de localización y producción industrial. En lo que se refiere a la equidad, al concederse beneficios a un grupo determinado de contribuyentes o actividades, se ha ocasionado una pérdida de equidad horizontal, ya que pueden generarse diferentes cargas tributarias en contribuyentes con igual nivel de renta. En el caso de los impuestos progresivos, como el impuesto sobre la renta personal, los gastos tributarios llevan a una pérdida de progresividad y de equidad vertical debido a que los grupos de bajos ingresos no están afectados y, por lo tanto, no se benefician de los gastos tributarios.

Además, la aplicación de gastos tributarios presenta mayores oportunidades para la evasión y elusión. Según Slemrod (1989), esto se debe a cuatro razones: i) se genera una mayor incertidumbre en cuanto a la correcta interpretación de las normas legales; ii) la capacidad de fiscalización de la administración tributaria disminuye, ya que la complejidad de la normativa

En el capítulo VIII de este libro, Agostini y Jorratt examinan los aspectos teóricos y las evidencias empíricas de un caso particular (y muy representativo) de gastos tributarios a nivel regional: los incentivos a la inversión en sus diversas variantes. 
exige auditorías más rigurosas; iii) ante la mayor dificultad para cumplir sus obligaciones tributarias, los contribuyentes tienden a incumplir parte de ellas, ya sea por desconocimiento o para compensar los costos que el sistema impone, y iv) la aplicación de gastos tributarios aumenta la complejidad de la normativa tributaria, y crea mayores oportunidades para manipular el sistema tributario y mayores espacios para la evasión y elusión (Villela, Lengruber y Jorrat, 2009).

\section{Los niveles de incumplimiento: evasión y morosidad en el pago del impuesto sobre la renta}

Por último, otro factor limitante de la capacidad de recaudación del impuesto sobre la renta es el bajo nivel de cumplimiento y las altas tasas de evasión. Las estimaciones de las tasas de evasión del pago del impuesto sobre la renta y, en especial, del que recae sobre las personas físicas, son escasas en la región. Los estudios disponibles muestran que los niveles de evasión en América Latina son altos en comparación con otras regiones del mundo y mayores en los impuestos sobre la renta que en los impuestos al valor agregado (con una tasa media de incumplimiento del $51 \%$ frente al $27 \%$, respectivamente) ${ }^{8}$.

Los altos niveles de incumplimiento reducen los recursos disponibles para que el Estado, a través de la política fiscal, desempeñe sus funciones de estabilización y provisión de bienes y servicios públicos y su rol redistributivo. Además, la evasión y elusión fiscal atentan contra la capacidad redistributiva del impuesto sobre la renta, en la medida que se afecta tanto la equidad horizontal como la equidad vertical de los sistemas tributarios. En relación con la equidad horizontal, la evasión puede hacer que individuos con una misma capacidad de pago no soporten una misma carga tributaria, debido a que los evasores terminan pagando menos impuestos que otros contribuyentes con igual capacidad de pago que sí cumplen sus obligaciones tributarias. La equidad vertical puede verse afectada cuando las personas que tienen mayor capacidad de pago no aportan proporcionalmente un monto mayor del tributo. Esto puede ocurrir porque las personas de rentas más altas suelen tener mayor acceso a las asesorías profesionales que muchas veces promueven estrategias de elusión o reducen los riesgos de incumplimiento (Gómez Sabaini, Jiménez y Podestá, 2010).

En el capítulo XII de este libro, Gómez Sabaini y Morán aportan información adicional acerca del cálculo de la evasión de esos impuestos en los países de la región. 


\section{Análisis de los principales aspectos normativos del impuesto sobre la renta de personas físicas en los países de la región}

En esta sección se describen los principales aspectos de la legislación del impuesto sobre la renta personal de los países latinoamericanos.

\section{Naturaleza del tributo y principio de imposición jurisdiccional}

La naturaleza del impuesto sobre la renta personal puede corresponder a un modelo de tributación global (también conocido como sintético o integral) o a un modelo de naturaleza cedular. En el caso de un impuesto global, se tiene una base imponible única donde se suman todas las rentas del contribuyente, aunque provengan de diferentes fuentes (como el trabajo o el capital) y a esa base se le aplica la estructura de tasas vigentes que generalmente son progresivas. En un sistema cedular, se clasifican las rentas de acuerdo con la fuente que las produce y se aplica una alícuota de impuesto diferencial para cada caso particular. Un tipo especial de modelo cedular es la imposición dual, en que las rentas del trabajo tributan de acuerdo a una escala progresiva de tasas, mientras que las rentas de capital son gravadas con tasas proporcionales.

En el cuadro II.7 se constata que gran parte de los países de la región tienen, en teoría, un sistema de renta global (Argentina, Bolivia (Estado Plurinacional de), Brasil, Chile, Colombia, Ecuador y México) mientras que, en otros, la naturaleza del impuesto se corresponde con un modelo cedular (Guatemala, Nicaragua, Panamá, Paraguay, Perú y Uruguay).

Por otra parte, el principio de imposición jurisdiccional puede responder a un criterio de renta nacional (o territorial) o a uno de renta mundial. Esta última grava la renta obtenida por los residentes tanto en el país como en el exterior, en tanto el enfoque de renta fuente grava la renta obtenida dentro del país por residentes y no residentes. Así, en el caso del criterio de renta nacional, se estaría dejando de recaudar impuestos sobre las rentas de capital que los residentes generan en el exterior.

El escenario al respecto es algo diverso entre los países de la región, ya que algunos han establecido un enfoque de renta nacional (Bolivia (Estado Plurinacional de), Guatemala, Nicaragua, Panamá y Paraguay), mientras que otros siguen el criterio de renta mundial (Argentina, Brasil, Chile, Colombia, Ecuador, México y Perú). En estos últimos, se utiliza el concepto de renta mundial para los residentes (tributan por los ingresos obtenidos dentro y fuera del país) y se complementa con el principio de territorialidad 
para los no residentes (pagan el impuesto sobre la renta exclusivamente por sus rentas de fuente nacional). En el caso particular del Uruguay, si bien se aplica el criterio de territorialidad o renta nacional, en virtud de la Ley núm. 18.718 se incorporó el principio de renta mundial para las rentas de capital mobiliario originadas en depósitos, préstamos y, en general, en toda colocación de capital o de crédito de cualquier naturaleza, provenientes de entidades no residentes.

\section{Cuadro II.7}

América Latina (13 países): naturaleza del impuesto sobre la renta y principio de imposición jurisdiccional, 2015

\begin{tabular}{|c|c|c|c|c|}
\hline \multirow{2}{*}{ País } & \multicolumn{2}{|c|}{ Naturaleza del impuesto } & \multicolumn{2}{|c|}{$\begin{array}{l}\text { Principio de imposición } \\
\text { jurisdiccional }\end{array}$} \\
\hline & $\begin{array}{l}\text { Impuesto } \\
\text { global }\end{array}$ & $\begin{array}{l}\text { Impuesto } \\
\text { cedular }\end{array}$ & $\begin{array}{c}\text { Renta } \\
\text { nacional }\end{array}$ & $\begin{array}{l}\text { Renta } \\
\text { mundial }\end{array}$ \\
\hline Argentina & $x^{a}$ & $X^{b}$ & & $X^{a}$ \\
\hline Bolivia (Estado Plurinacional de) & $x$ & & $x$ & \\
\hline Brasil & $x$ & & & $x$ \\
\hline Chile & $x$ & & & $x$ \\
\hline Colombia & $x$ & & & $x$ \\
\hline Ecuador & $x^{c}$ & & & $X^{d}$ \\
\hline Guatemala & & $x$ & $x$ & \\
\hline México & $x$ & & & $x$ \\
\hline Nicaragua & & $x$ & $x$ & \\
\hline Panamá & & $x$ & $x$ & \\
\hline Paraguay & & $x$ & $x$ & \\
\hline Perú & & $x$ & & $x$ \\
\hline Uruguay & & $x$ & $x$ & $X^{e}$ \\
\hline
\end{tabular}

Fuente: Elaboración propia, sobre la base de la legislación vigente de cada país.

a Para residentes.

b Para no residentes y residentes, respecto de ciertas rentas financieras.

c A pesar de que la ley establece un impuesto global, en la práctica existen algunas características de impuesto cedular, por algunos tratamientos especiales de rentas que no se consideran parte de la renta global, como sucede en el caso de las herencias, los legados, las donaciones, las rifas y sorteos, y los ingresos por la actividad productiva de banano, entre otros.

d La ley considera también como parte de la renta global los ingresos obtenidos en el exterior por personas naturales domiciliadas en el país o por sociedades ecuatorianas. Se aplica el método de exención para corregir la doble imposición internacional.

- En el caso de las rentas de capital mobiliario originadas en depósitos, préstamos y, en general, en toda colocación de capital o de crédito de cualquier naturaleza, provenientes de entidades no residentes, la norma adopta el principio de renta mundial. 


\section{Rentas objeto de gravamen y principales rentas exentas}

En todos los países, la legislación contempla como objeto del gravamen las rentas provenientes del trabajo y del capital mobiliario e inmobiliario (véase el cuadro II.8). Además, en la mayoría de las legislaciones referidas al impuesto sobre la renta de las personas físicas también se incluyen las ganancias patrimoniales, las rentas agrícolas y las rentas empresariales. Sin embargo, en algunos países estas últimas no se consideran porque son alcanzadas por otros impuestos, por ejemplo, el impuesto sobre las utilidades de la empresas en el Estado Plurinacional de Bolivia o el impuesto sobre la renta agropecuaria (IMAGRO) en el Paraguay, que grava con una tasa plana las rentas provenientes de esa actividad, obtenidas por personas naturales y jurídicas.

Cuadro II. 8

América Latina (13 países): rentas objeto de gravamen, 2015

\begin{tabular}{lccccccc}
\hline País & Trabajo & $\begin{array}{c}\text { Capital } \\
\text { mobiliario }\end{array}$ & $\begin{array}{c}\text { Capital } \\
\text { inmobiliario }\end{array}$ & Empresariales & Agrícolas & $\begin{array}{c}\text { Ganancias } \\
\text { patrimoniales }\end{array}$ & Otras \\
\hline Argentina & $\mathrm{X}$ & $\mathrm{X}$ & $\mathrm{X}$ & $\mathrm{X}$ & $\mathrm{X}$ & $\mathrm{X}$ & $\mathrm{X}$ \\
\hline $\begin{array}{l}\text { Bolivia (Estado } \\
\text { Plurinacional de) }\end{array}$ & $\mathrm{X}$ & $\mathrm{X}$ & $\mathrm{X}$ & $\mathrm{X}$ & $\mathrm{X}$ & $\mathrm{X}$ \\
\hline Brasil & $\mathrm{X}$ & $\mathrm{X}$ & $\mathrm{X}$ & $\mathrm{X}$ & $\mathrm{X}$ & $\mathrm{X}$ & \\
\hline Chile & $\mathrm{X}$ & $\mathrm{X}$ & $\mathrm{X}$ & $\mathrm{X}$ & $\mathrm{X}$ & $\mathrm{X}$ & \\
\hline Colombia & $\mathrm{X}$ & $\mathrm{X}$ & $\mathrm{X}$ & $\mathrm{X}$ & $\mathrm{X}$ & $\mathrm{X}$ & \\
\hline Ecuador & $\mathrm{X}$ & $\mathrm{X}$ & $\mathrm{X}$ & $\mathrm{X}$ & $\mathrm{X}$ & $\mathrm{X}$ & $\mathrm{X}$ \\
\hline Guatemala & $\mathrm{X}$ & $\mathrm{X}$ & $\mathrm{X}$ & $\mathrm{X}$ & $\mathrm{X}$ & $\mathrm{X}$ & \\
\hline México & $\mathrm{X}$ & $\mathrm{X}$ & $\mathrm{X}$ & $\mathrm{X}$ & $\mathrm{X}$ & $\mathrm{X}$ & $\mathrm{X}$ \\
\hline Nicaragua & $\mathrm{X}$ & $\mathrm{X}$ & $\mathrm{X}$ & $\mathrm{X}$ & $\mathrm{X}$ & & $\mathrm{X}$ \\
\hline Panamá & $\mathrm{X}$ & $\mathrm{X}$ & $\mathrm{X}$ & $\mathrm{X}$ & $\mathrm{X}$ & $\mathrm{X}$ & $\mathrm{X}$ \\
\hline Paraguay & $\mathrm{X}$ & $\mathrm{X}$ & $\mathrm{X}$ & & & $\mathrm{X}$ & \\
\hline Perú & $\mathrm{X}$ & $\mathrm{X}$ & $\mathrm{X}$ & $\mathrm{X}$ & $\mathrm{X}$ & $\mathrm{X}$ & $\mathrm{X}$ \\
\hline Uruguay & $\mathrm{X}$ & $\mathrm{X}$ & $\mathrm{X}$ & & & $\mathrm{X}$ & \\
\hline
\end{tabular}

Fuente: Elaboración propia, sobre la base de la legislación vigente de cada país.

A pesar del gran número de tipos de rentas que estarían sujetas al gravamen, también existe una gran cantidad de rentas exentas. Si bien las exenciones varían de país en país, en general incluyen, por ejemplo, las remuneraciones obtenidas por diplomáticos extranjeros y funcionarios de organismos internacionales, los ingresos de instituciones de beneficencia pública, las rentas de títulos de la deuda pública, los intereses por depósitos y los rendimientos provenientes de cuentas de ahorro. A su vez, en algunos países se excluyen de la base imponible ciertas indemnizaciones (como las 
otorgadas por accidente de trabajo, enfermedad o cesantía), subsidios por incapacidad laboral y maternidad, jubilaciones, pensiones, aguinaldos, becas de estudio, donaciones a determinadas instituciones, exenciones en beneficio de personas discapacitadas y adultos mayores, entre otras.

\section{Sujetos pasivos, tratamiento de las rentas obtenidas por un no residente y regímenes especiales}

En la gran mayoría de los países latinoamericanos, la tributación es exclusivamente individual, es decir, no está contemplada la posibilidad de tributación conjunta. Solo cuatro países permiten la acumulación de ingresos por unidades familiares: Brasil, Panamá, Perú y Uruguay (véase el cuadro II.9).

\section{Cuadro II.9}

América Latina (13 países): sujetos pasivos, tratamiento de las rentas obtenidas por los no residentes y regímenes especiales, 2015

\begin{tabular}{|c|c|c|c|c|c|c|}
\hline \multirow[b]{2}{*}{ País } & \multicolumn{2}{|c|}{ Sujetos pasivos } & \multicolumn{2}{|c|}{$\begin{array}{c}\text { Tratamiento de las rentas } \\
\text { de los no residentes }\end{array}$} & \multicolumn{2}{|c|}{ Regímenes especiales } \\
\hline & $\begin{array}{l}\text { Tributación } \\
\text { individual }\end{array}$ & $\begin{array}{l}\text { Unidades } \\
\text { familiares }\end{array}$ & $\begin{array}{l}\text { Impuesto } \\
\text { autónomo }\end{array}$ & $\begin{array}{l}\text { En el impuesto } \\
\text { sobre la } \\
\text { renta de las } \\
\text { personas } \\
\text { físicas general }\end{array}$ & $\begin{array}{c}\text { Pequeños } \\
\text { y medianos } \\
\text { contribuyentes }\end{array}$ & Agricultores \\
\hline Argentina & $x$ & & $x$ & & $x$ & $x$ \\
\hline $\begin{array}{l}\text { Bolivia } \\
\text { (Estado } \\
\text { Plurinacional de) }\end{array}$ & $\mathrm{x}$ & & & $\mathrm{x}$ & $x$ & $\mathrm{X}$ \\
\hline Brasil & $x$ & $x$ & & $x$ & $x$ & $x$ \\
\hline Chile & $x$ & & $x$ & & $x$ & $x$ \\
\hline Colombia & $x$ & & & $x$ & $x$ & \\
\hline Ecuador & $x$ & & & $x$ & $x$ & $x$ \\
\hline Guatemala & $x$ & & & $x$ & & \\
\hline México & $x$ & & $x$ & & $x$ & $x$ \\
\hline Nicaragua & $x$ & & & $x$ & & $x$ \\
\hline Panamá & $x$ & $x$ & & $x$ & & $x$ \\
\hline Paraguay & $x$ & & $x$ & & & \\
\hline Perú & $x$ & $x$ & & $x$ & $x$ & $x$ \\
\hline Uruguay & $x$ & $x$ & $x$ & & & \\
\hline
\end{tabular}

Fuente: Elaboración propia, sobre la base de la legislación vigente de cada país.

Tal como señala Roca (2010), el diseño técnicamente correcto es el que da al contribuyente la opción de tributar en forma individual o por núcleo familiar, ya que la obligatoriedad de la tributación individual introduce inequidad horizontal. Ante la igualdad de ingresos en un matrimonio 
(o familia), resultará perjudicado (o sea, deberá tributar en mayor proporción) aquel en el que el segundo perceptor no obtenga ingresos o estos sean muy bajos. Si bien esto se corrige cuando se admite que la unidad contribuyente sea la familia y no el individuo, la obligatoriedad de la tributación conjunta introduce dos problemas: i) existe evidencia empírica de que desincentiva la participación del trabajador secundario (o segundo perceptor) en el mercado de trabajo, pues grava sus rentas a la tasa marginal (más alta) del perceptor principal, y ii) crea una "multa matrimonial", debido a que el mínimo no imponible del núcleo familiar, basado en la existencia de economías de escala en el consumo del hogar, es inferior a dos veces el mínimo no imponible individual ${ }^{9}$.

En cuanto al tratamiento de las rentas obtenidas por los no residentes en la mayoría de los países analizados, la tributación en ese caso forma parte de la normativa general del impuesto sobre la renta de las personas físicas, mientras que en unos pocos países se considera un impuesto autónomo.

Por otro lado, en la mayor parte de los países, la legislación del impuesto sobre la renta personal contempla regímenes especiales de tributación aplicables a los pequeños y medianos contribuyentes o a los agricultores. Para determinar el rendimiento en los regímenes especiales, en los países de la región se utiliza tanto el enfoque de magnitudes físicas como el volumen de ventas o ingresos, aunque este último es el que se usa con mayor frecuencia.

\section{Base imponible y deducciones}

Prácticamente en todas las legislaciones relativas al impuesto sobre la renta personal, las contribuciones y aportes realizados a la seguridad social no forman parte de la base imponible. A su vez, en 9 de los 13 países analizados, la normativa permite deducir un valor en concepto de mínimo vital (o mínimo exento), monto que en teoría sirve para cubrir los gastos familiares básicos (véase el cuadro II.10).

Por otra parte, las legislaciones vigentes en los distintos países permiten una gran variedad de otras deducciones que van desde un monto por hijo y cónyuge, gastos médicos familiares, gastos en educación de los hijos, cuotas por cobertura médica, ciertas primas de seguros y los gastos necesarios para el ejercicio de una profesión, hasta los intereses por préstamos hipotecarios destinados a la adquisición o construcción de la vivienda principal, entre otras.

Véanse mayores detalles en Roca (2010). 


\section{Cuadro II.10}

América Latina (13 países): principales deducciones de la base imponible, 2015

\begin{tabular}{lccc}
\hline \multirow{2}{*}{ País } & \multicolumn{3}{c}{ Deducciones de la base imponible } \\
\cline { 2 - 4 } & Mínimos vitales & $\begin{array}{c}\text { Aportaciones a la } \\
\text { seguridad social }\end{array}$ & Otras \\
\hline Argentina & $\mathrm{X}$ & $\mathrm{X}$ & $\mathrm{X}$ \\
\hline Bolivia (Estado Plurinacional de) & $\mathrm{X}$ & $\mathrm{X}$ & $\mathrm{X}$ \\
\hline Brasil & $\mathrm{X}$ & $\mathrm{X}$ & $\mathrm{X}$ \\
\hline Chile & & $\mathrm{X}$ & $\mathrm{X}$ \\
\hline Colombia & $\mathrm{X}$ & $\mathrm{X}$ & $\mathrm{X}$ \\
\hline Ecuador & $\mathrm{X}$ & $\mathrm{X}$ & $\mathrm{X}$ \\
\hline Guatemala & $\mathrm{X}$ & $\mathrm{X}$ & $\mathrm{X}$ \\
\hline México & & $\mathrm{X}$ & $\mathrm{X}$ \\
\hline Nicaragua & $\mathrm{X}$ & $\mathrm{X}$ & $\mathrm{X}$ \\
\hline Panamá & $\mathrm{X}$ & $\mathrm{X}$ & $\mathrm{X}$ \\
\hline Paraguay & $\mathrm{X}$ & & $\mathrm{X}$ \\
\hline Perú & & $\mathrm{X}$ & \\
\hline Uruguay & &
\end{tabular}

Fuente: Elaboración propia, sobre la base de la legislación vigente de cada país.

\section{Tasas del impuesto y tramos}

A excepción del Estado Plurinacional de Bolivia (que aplica una tasa proporcional), en todos los países de América Latina el diseño del impuesto sobre la renta de las personas físicas se basa en una escala progresiva de tasas. En la mayoría de los casos, la normativa contempla un tramo con tasa cero (véase el cuadro II.11).

Cuadro II.11

América Latina (13 países): tasas y tramos del impuesto sobre la renta, 2015

\begin{tabular}{|c|c|c|c|c|}
\hline \multirow[t]{2}{*}{ País } & \multicolumn{2}{|c|}{$\begin{array}{l}\text { Tasas marginales } \\
\text { (en porcentajes) }\end{array}$} & \multirow{2}{*}{$\begin{array}{l}\text { Tramo con } \\
\text { tasa cero }\end{array}$} & \multirow{2}{*}{$\begin{array}{l}\text { Número de } \\
\text { tramos }^{\mathrm{a}}\end{array}$} \\
\hline & Mínima & Máxima & & \\
\hline Argentina & 9 & 35 & & 7 \\
\hline Bolivia (Estado Plurinacional de) & 13 & 13 & $x$ & 1 \\
\hline Brasil & 7,5 & 27,5 & $\mathrm{x}$ & 4 \\
\hline Chile & 4 & $40^{\mathrm{b}}$ & $x$ & 7 \\
\hline Colombia & 19 & 33 & $\mathrm{x}$ & 3 \\
\hline Ecuador & 5 & 35 & $x$ & 8 \\
\hline Guatemala & 5 & 7 & & 2 \\
\hline México & 1,92 & 35 & & 11 \\
\hline Nicaragua & 15 & 30 & $x$ & 4 \\
\hline Panamá & 15 & 25 & $x$ & 2 \\
\hline Paraguay & 8 & 10 & $x$ & 2 \\
\hline Perú & 8 & 30 & $x$ & 5 \\
\hline Uruguay & 10 & 30 & $x$ & 6 \\
\hline
\end{tabular}

Fuente: Elaboración propia, sobre la base de la legislación vigente de cada país.

a Cantidad de tramos sin considerar el tramo con tasa cero.

b La reforma tributaria chilena aprobada en 2014 reduce del $40 \%$ al 35\% la tasa marginal máxima a partir de 2017. 
Las tasas mínimas y máximas que aplican los países de la región son muy heterogéneas. Así, por ejemplo, la tasa marginal mínima de México se sitúa en un 1,92\%, en tanto la alícuota mínima legal de Colombia alcanza un 19\%. En los demás países las tasas mínimas se ubican entre un $4 \%$ y un $15 \%$.

En el caso de las tasas marginales máximas, Guatemala y el Paraguay tienen las alícuotas más bajas, del 7\% y el 10\%, respectivamente. Además, figuran entre los países de menor carga tributaria de la región, tal como se describió en el capítulo I. Las alícuotas marginales máximas alcanzan sus valores más altos en la Argentina, Chile, el Ecuador y México (con un 35\%).

La cantidad de tramos en los que se estructura el impuesto sobre la renta de las personas físicas también es diferente entre países. En un extremo se hallan Guatemala, Panamá y el Paraguay, con solo dos tramos (sin incluir el tramo con tasa cero), mientras que en el otro se encuentran México, con 11 tramos de tarifas, y el Ecuador y la Argentina, con 8 y 7 rangos de ingresos, respectivamente.

Por último, en varios países (como Guatemala, Nicaragua, Panamá, Perú y Uruguay) los intereses, rentas y ganancias de capital, los dividendos y las participaciones de utilidades, entre otros, tributan a una tasa fija. Según la legislación de cada país, esa tasa puede ser desde el 3\% o el $4 \%$ hasta el $10 \%$ o el $12 \%$.

\section{Conclusiones}

A lo largo de este capítulo se han analizado las características principales del impuesto sobre la renta y su evolución durante las últimas décadas, con especial énfasis en la tributación sobre las personas naturales.

Si bien en los últimos años se han registrado avances en materia de imposición a la renta, los países de América Latina siguen presentando una baja recaudación del impuesto sobre la renta personal, tanto en comparación con lo que aportan las personas jurídicas como en relación con las economías desarrolladas. Además, la recaudación de este tributo en la región muestra una estructura desequilibrada, ya que la mayor parte recae en los trabajadores asalariados, a quienes se les retiene el impuesto en el momento del pago de su remuneración. En tanto, los trabajadores independientes tienen mayores posibilidades de evasión y elusión del impuesto. Por su parte, las rentas de capital se benefician de un tratamiento preferencial, ya sea porque generalmente tributan a una tasa menor o porque simplemente no se encuentran gravadas.

Diversos factores limitan el desempeño del impuesto sobre la renta de las personas físicas en los países latinoamericanos. Por un lado, ha tenido lugar una reducción sostenida de las tasas marginales máximas del tributo, 
que generalmente se encuentran por debajo de las alícuotas existentes en los países desarrollados. Además, el gran número de exenciones, deducciones personales y gastos tributarios erosiona la base imponible del tributo $y$, por lo tanto, hacen que disminuya la cantidad de recursos recaudados. Los elevados niveles de evasión, morosidad y elusión constituyen otro factor que ayuda a explicar el magro desempeño del impuesto sobre la renta de las personas naturales en los países de América Latina.

En efecto, dado que todo lo anterior reduce los recursos disponibles y limita el espacio fiscal para la ejecución de políticas públicas, resulta crucial que los países trabajen en pos del fortalecimiento del impuesto sobre la renta de las personas naturales. Con ese fin, es fundamental que se promuevan medidas encaminadas a combatir la evasión y la elusión fiscal, sobre todo en relación con ese tributo específico. Además, se debe tender a una base amplia y general del impuesto, en cuya base gravable se consideren todas las rentas del contribuyente, otorgándose a las rentas de capital un tratamiento similar al aplicado a las rentas provenientes del trabajo.

Del mismo modo, deben revisarse y reducirse los tratamientos preferenciales, así como las deducciones permitidas. A su vez, pueden modificarse los tramos de ingresos imponibles de manera que se rebaje el nivel de ingreso a partir del que se aplican las tasas máximas del impuesto sobre la renta personal, para que concuerden con los rangos establecidos en otras regiones. En varios países se podría tender también a una reducción del mínimo exento para que sea igual o inferior a su ingreso per cápita, y así ampliar la base del impuesto e incluir a contribuyentes de clase media alta.

Tales reformas tendrían importantes implicancias respecto de la ejecución de políticas públicas y el logro de un crecimiento sostenible, duradero e inclusivo, ya que se dispondría de mayores recursos para la inversión y el gasto social. Ello permitiría prestar un mayor apoyo a las funciones de estabilización, provisión de bienes y servicios públicos y redistribución del ingreso. 


\section{Bibliografía}

Arenas, A. (2016), Sostenibilidad fiscal y reformas tributarias en América Latina (LC/G.2688-P), Santiago, Comisión Económica para América Latina y el Caribe (CEPAL).

Cabrera, M. y V. Guzmán (2010), “El Salvador: la tributación directa, evasión y desafíos", Evasión y equidad en América Latina, J.P. Jiménez, J.C. Gómez Sabaini y A. Podestá (comps.), Documentos de Proyectos, No 309 (LC/W.309/Rev.1), Santiago, Comisión Económica para América Latina y el Caribe (CEPAL).

CEPAL (Comisión Económica para América Latina y el Caribe) (2015), Panorama Fiscal de América Latina y el Caribe 2015. Dilemas y espacios de políticas (LC/L.3961), Santiago.

Gómez Sabaini, J.C., J.P. Jiménez y A. Podestá (2010), “Tributación, evasión y equidad en América Latina y el Caribe", Evasión y equidad en América Latina, J.P. Jiménez, J.C. Gómez Sabaini y A. Podestá (comps.), Documentos de Proyectos, No 309 (LC/W.309/Rev.1), Santiago, Comisión Económica para América Latina y el Caribe (CEPAL).

Gómez Sabaini, J.C., J.P. Jiménez y D. Rossignolo (2012), “Imposición a la renta personal y equidad en América Latina: nuevos desafíos", serie Macroeconomía del Desarrollo, N 119 (LC/L.3477-P), Santiago, Comisión Económica para América Latina y el Caribe (CEPAL).

Gómez Sabaini, J.C y D. Morán (2014), “Política tributaria en América Latina: agenda para una segunda generación de reformas", serie Macroeconomía del Desarrollo, No 133 (LC/L.3632), Santiago, Comisión Económica para América Latina y el Caribe (CEPAL).

Jiménez, J.P. y A. Podestá (2009), “Inversión, incentivos fiscales y gastos tributarios en América Latina”, serie Macroeconomía del Desarrollo, No 77 (LC/L.3004-P), Santiago, Comisión Económica para América Latina y el Caribe (CEPAL).

OCDE/CEPAL/CIAT/BID (Organización de Cooperación y Desarrollo Económicos / Comisión Económica para América Latina y el Caribe/Centro Interamericano de Administraciones Tributarias/Banco Interamericano de Desarrollo) (2016), Estadísticas tributarias en América Latina y el Caribe 1990-2014, París, OECD Publishing.

Roca, J. (2010), “Ecuador: la tributación directa, evasión y desafíos”, Evasión y equidad en América Latina, J.P. Jiménez, J.C. Gómez Sabaini y A. Podestá (comps.), Documentos de Proyectos, No 309 (LC/W.309/Rev.1), Santiago, Comisión Económica para América Latina y el Caribe (CEPAL).

Slemrod, J. (1989), "Optimal taxation and optimal tax systems", NBER Working Paper Series, $N^{\circ}$ 3038, Cambridge, Massachusetts, National Bureau of Economic Research (NBER).

Tanzi, V. (2000), "Taxation in Latin America in the last decade", documento presentado en la Conferencia sobre reformas fiscales y financieras en América Latina, Universidad de Stanford, 9 y 10 de noviembre.

Unión Europea (2014), "Taxation trends in the European Union. Data for the EU member states, Iceland and Norway", Luxemburgo, Oficina de Publicaciones de la Unión Europea.

Villela, L., A. Lemgruber y M. Jorratt (2009), “Los presupuestos de gastos tributarios: conceptos y desafíos de implementación", Documento de Trabajo, $\mathrm{N}^{\circ} 131$, Washington, D.C., Banco Interamericano de Desarrollo (BID). 



\title{
Capítulo III \\ La tributación en los gobiernos subnacionales ${ }^{1}$
}

\author{
Juan C. Gómez Sabaini ${ }^{2}$ \\ Juan Pablo Jiménez $z^{3}$
}

\section{Introducción}

Las relaciones entre niveles de gobierno, así como la reasignación de responsabilidades y su financiamiento han sido un elemento de crucial importancia en el desarrollo económico, político e institucional de la mayoría de los países de América Latina. En las últimas décadas, la región ha registrado un intenso y generalizado proceso de descentralización de funciones entre niveles de gobierno. No obstante el tiempo transcurrido, el impacto de esta serie de reformas (heterogéneas y no siempre comparables) no ha sido lo suficientemente evaluado y, en algunos casos, sus resultados han sido de dudosa efectividad.

La forma en que se financia la provisión de servicios y bienes públicos, y su eventual asignación entre niveles de gobierno, es un tema central

Este capítulo constituye una versión resumida y actualizada de Gómez Sabaini y Jiménez (2011). Consultor de la Comisión Económica para América Latina y el Caribe (CEPAL), el Banco Interamericano de Desarrollo (BID), el Fondo Monetario Internacional (FMI) y el Centro Interamericano de Administraciones Tributarias (CIAT) especializado en temas de política tributaria en países de América Latina. Profesor de posgrado en la Universidad Nacional de Buenos Aires. Correo electrónico: gomezsabaini@gmail.com.

3 Oficial de Asuntos Económicos de la División de Desarrollo Económico de la Comisión Económica para América Latina y el Caribe (CEPAL). Correo electrónico: juanpablo.jimenez@cepal.org. 
para lograr un sistema intergubernamental sano y estable y un proceso de descentralización sostenible. Dado que los gobiernos subnacionales suelen contar con distintos instrumentos para financiar sus responsabilidades de gasto público, el nivel de financiamiento y la forma en que se combinen esos instrumentos van a determinar, en gran parte, el resultado de estos procesos.

Con el propósito de analizar un aspecto de esta problemática, en este capítulo se describe y analiza la estructura de financiamiento de los gobiernos subnacionales, con especial énfasis en la composición de los recursos propios (tributarios y no tributarios). A través del análisis de una serie de casos, se pretenden mostrar las opciones de financiamiento propio de que disponen estas jurisdicciones (ya sean intermedias o locales), más allá de la predominancia de las transferencias del Gobierno Central, así como las principales líneas de acción que pueden adoptar para su fortalecimiento ${ }^{4}$.

A su vez, en los países con grandes dotaciones de recursos naturales no renovables (principalmente hidrocarburos y minerales), la distribución física de los yacimientos constituye un elemento muy fuerte de desigualdad territorial, al proveer cuantiosas fuentes de recursos propios a las jurisdicciones donde se efectúa la explotación económica. Esta característica hace necesaria la implementación de regímenes de distribución y asignación de los recursos fiscales generados en estas actividades (otro de los aspectos que se abordan en este capítulo).

\section{A. El camino hacia el fortalecimiento fiscal de los gobiernos subnacionales}

En las últimas décadas, se ha observado en América Latina el afianzamiento de una gradual y clara tendencia en pos de la descentralización fiscal desde el Gobierno Central hacia niveles inferiores de gobierno. Vale señalar que este fenómeno se ha visto reflejado tanto en los países federales tradicionales, como la Argentina y el Brasil, que traspasaron parte de las funciones del gobierno federal hacia los niveles inferiores de gobierno, como en países unitarios donde, según el caso, se produjo una transferencia importante de funciones hacia los gobiernos locales o se crearon nuevos niveles intermedios de gobierno a los que se encomendó la formulación y ejecución - o exclusivamente la gestión- de trascendentales políticas públicas (Jiménez y Viñuela, 2004).

\footnotetext{
A pesar de que en la mayoría de los países latinoamericanos existen sistemas de transferencias intergubernamentales que adquieren notable relevancia en cuanto al financiamiento de los gobiernos subnacionales, el presente capítulo se concentra en las fuentes de recursos propios (tributarios y no tributarios). Véase un análisis exhaustivo de la problemática de las transferencias intergubernamentales en América Latina en Martínez Vázquez y Sepúlveda (2012a), Rezende y Veloso (2012) y Jiménez y Podestá (2009).
} 
Rezende y Veloso (2012) destacan que el proceso de descentralización en la región tuvo dos grandes oleadas. La primera de ellas ganó impulso en los últimos años de la década de 1980 con la visión de que la descentralización permitiría una asignación más eficiente de los bienes públicos hacia una ciudadanía subnacional territorialmente diversa, lo que, a su vez, mejoraría los canales de participación ciudadana, de responsabilidad política y de rendición de cuentas.

En una segunda etapa, marcada por la crisis macroeconómica de mediados de los años noventa, las reformas descentralizadoras tomaron un enfoque diferente. No se priorizaron los regímenes de coparticipación de impuestos (habitualmente de libre disponibilidad), como en los años anteriores, sino que se dio preferencia a canalizar los recursos federales hacia los gobiernos subnacionales para su uso en cuestiones de educación y salud, fortaleciendo los mecanismos de transferencia con asignación específica.

En sus diferentes períodos, este proceso se dio principalmente a través del gasto público (en lugar de los ingresos), si bien la situación resulta bastante heterogénea si se realiza una comparación entre países. Sin embargo, la forma en que los gobiernos subnacionales financian sus responsabilidades (asignadas) de gasto es una preocupación clave. Este financiamiento se logra mediante una de las siguientes tres modalidades (o una combinación de las tres): generación de recursos propios, ya sean tributos $u$ otros ingresos no tributarios (regalías, tasas municipales, derechos y otros); transferencias intergubernamentales, y endeudamiento.

Debe aclararse que, en sentido estricto, los ingresos subnacionales propios se definen como aquellos tributos en que los gobiernos subnacionales tienen potestades discrecionales para determinar la carga impositiva sobre los ciudadanos (Brosio y Jiménez, 2012). Esta potestad puede ejercerse mediante tres instrumentos diferentes: administración tributaria, fijación de alícuota impositiva y determinación de la base imponible. En este capítulo, no obstante, se ha escogido una definición más laxa de recursos propios, ya que en América Latina se observa una combinación de estas tres dimensiones y no se cuenta con la información necesaria en todos los casos. Es por ello que un impuesto se definirá como subnacional en la medida en que el gobierno subnacional sea quien lo administre y disponga de los recursos que pueda generar.

Como se puede observar en el gráfico III.1, los ingresos fiscales totales de estos gobiernos han aumentado de manera sostenida en los últimos 15 años. Sin embargo, esto se debe fundamentalmente a la gran importancia que han tenido las transferencias provenientes de los Gobiernos Centrales y no tanto al más limitado incremento de los recursos propios corrientes (tributarios y no tributarios) de los niveles intermedios y locales. En promedio, las transferencias totales aumentaron del 2,7\% del PIB en 1997 al 5,0\% del 
PIB en 2013, en tanto que los recursos propios pasaron del 2,8\% del PIB al $3,9 \%$ del PIB en ese mismo período. La participación del resto de los recursos disponibles, como los provenientes de la venta de activos y otros ingresos de capital, es cada vez menos significativa.

Gráfico III.1

América Latina (8 países): evolución de la estructura de los ingresos totales de los gobiernos subnacionales, promedio simple, 1997-2013

(En porcentajes del PIB)

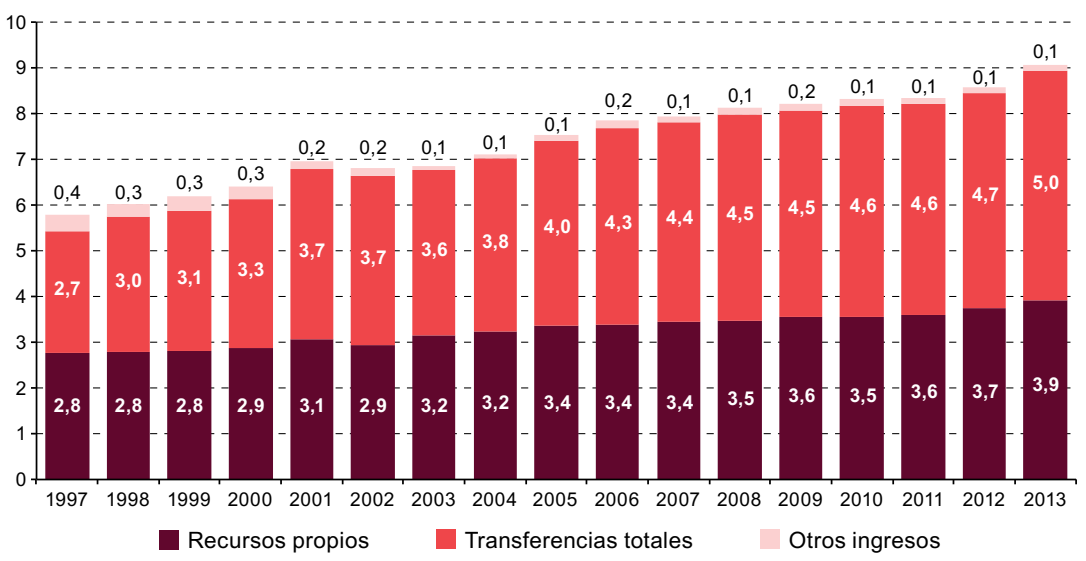

Fuente: Comisión Económica para América Latina y el Caribe (CEPAL), sobre la base de cifras oficiales. Nota: En el análisis estadístico se asume que el concepto de gobiernos subnacionales se referirá a provincias en el caso de la Argentina, a prefecturas y municipios en Bolivia (Estado Plurinacional de), a estados y municipios en el Brasil, a municipios en Chile, a departamentos y municipios en Colombia, a gobiernos locales (cantones) en Costa Rica, a consejos provinciales y municipios en el Ecuador y a estados y municipios en México. Los datos de 2013 para Colombia y México corresponden a proyecciones realizadas por la CEPAL.

En el cuadro III.1 puede observarse la estructura actual de financiamiento de los gobiernos subnacionales en los países latinoamericanos analizados en este capítulo. El primer hecho saliente lo constituyen las diferencias en el peso relativo que poseen los recursos propios (tributarios y no tributarios) dentro del total de ingresos percibidos por estos niveles de gobierno. $\mathrm{Al}$ respecto, puede comprobarse que los estados y municipios del Brasil obtienen la mayor porción de los ingresos $(77,7 \%)$ a partir de sus recursos propios, lo que representa el 10,7\% en términos del PIB (más del 75\% de los cuales corresponden a ingresos tributarios). Por su parte, pese al bajo nivel respecto del PIB (1,1\%), los recursos propios en Costa Rica representan prácticamente la totalidad de los ingresos totales (99,8\%). No obstante, se reconoce que el proceso de descentralización fiscal en este país no ha experimentado avances significativos a partir de una adecuada delegación de responsabilidades de gasto ni de potestades tributarias hacia niveles inferiores de gobierno. 


\section{Cuadro III.1}

América Latina (8 países): estructura de los ingresos totales de los gobiernos subnacionales, 2013

(En porcentajes del PIB y porcentajes del total de recursos)

\begin{tabular}{|c|c|c|c|c|c|c|c|}
\hline \multirow[b]{2}{*}{ Países } & \multicolumn{2}{|c|}{ Recursos propios ${ }^{a}$} & \multicolumn{2}{|c|}{ Transferencias totales ${ }^{b}$} & \multicolumn{2}{|c|}{ Otros ingresos $^{c}$} & \multirow{2}{*}{$\begin{array}{c}\begin{array}{c}\text { Ingresos } \\
\text { totales }\end{array} \\
\begin{array}{c}\text { (en } \\
\text { porcentajes } \\
\text { del PIB) }\end{array}\end{array}$} \\
\hline & $\begin{array}{c}\text { (en } \\
\text { porcentajes } \\
\text { del } P I B)\end{array}$ & $\begin{array}{c}\text { (en } \\
\text { porcentajes } \\
\text { del total } \\
\text { de recursos) }\end{array}$ & $\begin{array}{c}(e n \\
\text { porcentajes } \\
\text { del PIB })\end{array}$ & $\begin{array}{c}\text { (en } \\
\text { porcentajes } \\
\text { del total } \\
\text { de recursos) }\end{array}$ & $\begin{array}{c}(e n \\
\text { porcentajes } \\
\text { del PIB })\end{array}$ & $\begin{array}{c}\text { (en } \\
\text { porcentajes } \\
\text { del total } \\
\text { de recursos) }\end{array}$ & \\
\hline Argentina & 6,2 & 43,2 & 8,1 & 56,3 & 0,1 & 0,5 & 14,3 \\
\hline $\begin{array}{l}\text { Bolivia } \\
\text { (Estado } \\
\text { Plurinacional } \\
\text { de) }\end{array}$ & 4,8 & 35,4 & 8,8 & 64,6 & 0,0 & 0,0 & 13,6 \\
\hline Brasil & 10,7 & 77,7 & 2,9 & 21,2 & 0,2 & 1,1 & 13,8 \\
\hline Chile & 2,0 & 62,4 & 1,2 & 37,4 & 0,0 & 0,3 & 3,2 \\
\hline Colombia & 4,1 & 42,5 & 4,8 & 49,4 & 0,8 & 8,0 & 9,7 \\
\hline Costa Rica & 1,1 & 99,8 & 0,0 & $-0,3$ & 0,0 & 0,5 & 1,1 \\
\hline Ecuador & 1,0 & 21,4 & 3,7 & 77,9 & 0,0 & 0,6 & 4,7 \\
\hline México & 1,4 & 13,8 & 8,7 & 86,2 & 0,0 & 0,0 & 10,1 \\
\hline
\end{tabular}

Fuente: Comisión Económica para América Latina y el Caribe (CEPAL), sobre la base de cifras oficiales.

a Se toman en cuenta los ingresos corrientes netos de transferencias, es decir, que abarcan tanto recursos tributarios (impuestos) como no tributarios (tasas y derechos, rentas patrimoniales y otros).

b Incluye transferencias corrientes y de capital.

c Según el país, este conjunto puede incluir recursos por ventas de activos, ingresos de capital y otros.

Una situación similar se observa en Chile, donde los recursos propios de los municipios representan el 62,4\% de los ingresos totales. Sin embargo, vale notar que en este país la preponderancia de los recursos propios como fuente principal de ingresos subnacionales posee dos componentes: los ingresos propios permanentes y los ingresos provenientes del Fondo Común Municipal. Dado que este mecanismo de igualación horizontal solidaria entre municipios se nutre en un $99 \%$ de los mismos recursos tributarios recaudados por estas jurisdicciones, en este capítulo se considera la influencia antes de su distribución, o sea, dentro del conjunto de recursos propios disponibles, para reflejar mejor su potencialidad en materia de financiamiento subnacional ${ }^{5}$.

En el resto de los países de la región, por el contrario, la principal fuente de recursos públicos de los gobiernos subnacionales proviene del sistema de transferencias que cada Gobierno Central implementa para complementar el financiamiento de sus responsabilidades de gastos, es decir, la provisión de bienes públicos a los ciudadanos. Las administraciones centrales de gobierno de países como la Argentina, Bolivia (Estado Plurinacional de) y

\footnotetext{
Véase un análisis detallado del funcionamiento, la composición y la distribución del Fondo Común Municipal en el Sistema Nacional de Información Municipal (SINIM) de la Subsecretaría de Desarrollo Regional y Administrativo (SUBDERE), Chile (véase [en línea] http:/ /www.sinim. gov.cl/desarrollo_local/selfcm.htm).
} 
México aportan más del $8 \%$ del PIB en concepto de transferencias hacia los niveles inferiores de gobierno. En los casos de Colombia y el Ecuador, esta fuente de ingresos subnacionales representa un $4,8 \%$ y un $3,7 \%$ del PIB, respectivamente, mientras que en el Brasil y Chile estos recursos también son relevantes, pero en una menor magnitud relativa ${ }^{6}$.

\section{B. Los ingresos tributarios de los gobiernos subnacionales: estructura y evolución}

Como se ha señalado, la descentralización de potestades tributarias hacia los gobiernos subnacionales ha sido relativamente débil en la mayoría de los países, si bien ha estado sujeta a las particularidades propias de cada país.

En el gráfico III.2 se pone en evidencia la dispar y mayoritariamente escasa participación de los gobiernos subnacionales en la recaudación total de los países latinoamericanos. La excepción la constituye el Brasil, donde los estados y los municipios aportan conjuntamente más del 30\% de los ingresos tributarios nacionales, lo que denota un importante grado de descentralización de potestades tributarias hacia dichos niveles de gobierno. En un segundo escalafón de países se encuentran la Argentina y Colombia, donde los niveles subnacionales han aportado aproximadamente un 15\% de la recaudación total.

En el resto de los países, sin embargo, los Gobiernos Centrales no han logrado avances significativos en la descentralización de los recursos tributarios y, en promedio, la recaudación tributaria subnacional representa alrededor del 3\% al 4\% de los ingresos tributarios totales.

Se observa, además, que la recaudación tributaria de los gobiernos subnacionales en los países de la región ha permanecido estancada durante los últimos diez años y esta pobre evolución se vincula con la debilidad en el nivel y la estructura de la imposición subnacional, lo que, a su vez, tiene relación con las bases tributarias disponibles por parte de estos niveles de gobierno.

En el trabajo que dio origen a este capítulo (Gómez Sabaini y Jiménez, 2011) se muestra la estructura de los ingresos totales de los gobiernos subnacionales a 2008 y se incluye el caso del Brasil, donde las transferencias se acercan al 8\% del PIB. Las notables diferencias con los datos aquí presentados (véase el cuadro III.1), cuya fuente es el Tesoro Nacional brasileño, tienen una explicación metodológica que se relaciona con la ponderación de las transferencias realizadas entre gobiernos subnacionales que se constituyen, principalmente, por el $25 \%$ de la recaudación del impuesto sobre la circulación de mercancías y servicios (ICMS) de los estados a los municipios. La inclusión, o no, de este concepto dentro del monto total de transferencias explicaría las diferencias señaladas con los datos oficiales. 


\section{Gráfico III.2}

América Latina (8 países): ingresos tributarios, según nivel de gobierno, 2013 (En porcentajes del total de recursos)

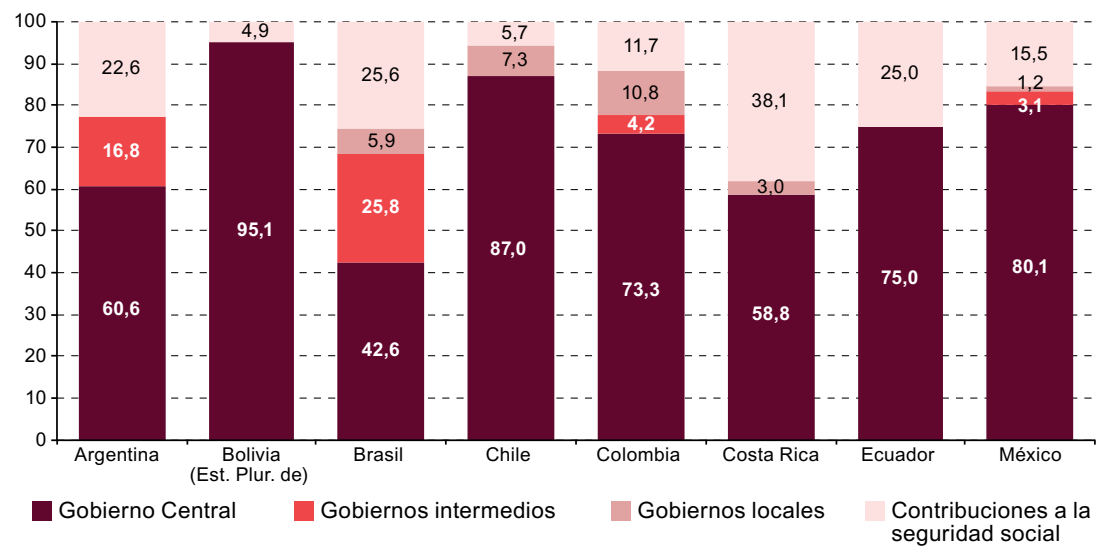

Fuente: Elaboración propia, sobre la base de Organización de Cooperación y Desarrollo Económicos (OCDE)/Comisión Económica para América Latina y el Caribe (CEPAL)/Centro Interamericano de Administraciones Tributarias (CIAT)/Banco Interamericano de Desarrollo (BID), Estadísticas tributarias en América Latina y el Caribe 1990-2014, París, OECD Publishing, 2016.

Si bien la baja recaudación de impuestos propios es un problema, debe señalarse que cuando se evalúa la cantidad de gastos que los gobiernos intermedios y locales tienen que financiar, no parece que haya mucho margen adicional para reasignar potestades tributarias. Al respecto, lo que surge claramente es que a los gobiernos subnacionales les resulta difícil aprovechar las potestades tributarias ya disponibles, como se observa en los magros ingresos generados por el impuesto predial en los países de América Latina (véase el cuadro III.2).

\section{Cuadro III.2}

América Latina (8 países): estructura de los ingresos tributarios de los gobiernos subnacionales, 2014

A. En porcentajes del PIB

\begin{tabular}{lcccccc}
\hline Países & $\begin{array}{c}\text { Propiedad } \\
\text { inmueble }\end{array}$ & $\begin{array}{c}\text { Actividad } \\
\text { económica }\end{array}$ & Automotores & $\begin{array}{c}\text { Renta } \\
\text { personal }\end{array}$ & Otros & Total \\
\hline Argentina & 0,4 & 4,1 & 0,3 & 0,0 & 0,7 & 5,5 \\
\hline $\begin{array}{l}\text { Bolivia (Estado } \\
\text { Plurinacional de) }\end{array}$ & 0,4 & 0,0 & 0,3 & 0,0 & 3,4 & 4,1 \\
\hline Brasil & 0,4 & 7,6 & 0,6 & 0,0 & 0,0 & 8,6 \\
\hline Chile & 0,6 & 0,9 & 0,1 & 0,0 & 0,0 & 1,6 \\
\hline Colombia & 0,7 & 1,3 & 0,0 & 0,0 & 1,0 & 3,0 \\
\hline Costa Rica & 0,3 & 0,4 & 0,0 & 0,0 & 0,0 & 0,7 \\
\hline Ecuador & 0,2 & 0,0 & 0,0 & 0,0 & 0,3 & 0,6 \\
\hline México & 0,2 & 0,0 & 0,1 & 0,3 & 0,1 & 0,7 \\
\hline
\end{tabular}


Cuadro III.2 (conclusión)

B. En porcentajes de los ingresos totales

\begin{tabular}{lcccccc}
\hline Países & $\begin{array}{c}\text { Propiedad } \\
\text { inmueble }\end{array}$ & $\begin{array}{c}\text { Actividad } \\
\text { económica }\end{array}$ & Automotores & $\begin{array}{c}\text { Renta } \\
\text { personal }\end{array}$ & Otros & Total \\
\hline Argentina & 7,3 & 74,5 & 5,5 & 0,0 & 12,7 & 100,0 \\
\hline $\begin{array}{l}\text { Bolivia (Estado } \\
\text { Plurinacional de) }\end{array}$ & 10,3 & 0,0 & 7,1 & 0,0 & 82,7 & 100,0 \\
\hline Brasil & 4,7 & 88,4 & 7,0 & 0,0 & 0,0 & 100,0 \\
\hline Chile & 37,5 & 56,3 & 6,3 & 0,0 & 0,0 & 100,0 \\
\hline Colombia & 23,3 & 43,3 & 0,0 & 0,0 & 33,3 & 100,0 \\
\hline Costa Rica & 42,9 & 57,1 & 0,0 & 0,0 & 0,0 & 100,0 \\
\hline Ecuador & 37,8 & 0,0 & 0,0 & 8,0 & 54,2 & 100,0 \\
\hline México & 22,5 & 3,2 & 13,8 & 40,7 & 19,8 & 100,0 \\
\hline
\end{tabular}

Fuente: Comisión Económica para América Latina y el Caribe (CEPAL), sobre la base de cifras oficiales.

a Los datos de Bolivia (Estado Plurinacional de) y el Ecuador corresponden a 2013.

A continuación, se expone un análisis detallado de los principales impuestos presentados en el cuadro III.2, con las características propias de cada uno de los países seleccionados como casos de estudio en el presente capítulo.

\section{Imposición sobre la propiedad inmueble}

Los trabajos de investigación más recientes, junto con la información estadística disponible, confirman que la imposición patrimonial, en términos del PIB y en relación con el total recaudado (si se excluye de esta categoría a los impuestos que gravan las transacciones financieras), no resulta significativa en ninguno de los sistemas tributarios latinoamericanos. Aun así, los tributos que afectan el patrimonio constituyen el principal instrumento de generación de recursos propios con que los gobiernos subnacionales de la región cuentan para financiar sus responsabilidades de gasto.

Simultáneamente, dentro de la amplia gama de impuestos que suelen recaer sobre el patrimonio de los contribuyentes, el impuesto a la propiedad inmueble, o impuesto predial, es el instrumento más aceptado y explotado como fuente de recursos fiscales en los niveles inferiores de gobierno, pese a su escaso peso relativo que lo ubica por debajo del $0,7 \%$ del PIB en la mayoría de los $\operatorname{casos}^{7}$. No obstante, el impuesto predial adquiere una importancia relativa muy desigual respecto de la totalidad de recursos tributarios subnacionales según el país analizado.

En el Estado Plurinacional de Bolivia, el impuesto a la propiedad de bienes inmuebles (IPBI), cuya recaudación en 2014 ascendió al 0,4\% del PIB (poco más del $10 \%$ del total), es recaudado por los municipios y se caracteriza por la posibilidad de que el contribuyente determine cuánto debe pagar sobre

Véanse más detalles sobre el desempeño de los impuestos a la propiedad inmueble en América Latina en Martínez Vázquez y Sepúlveda (2012b). 
la base de tablas de valores y zonas homogéneas preestablecidas por dichas jurisdicciones y aprobadas por el Gobierno Central (Brosio, 2015). De este modo, los montos recaudados se asignan con exclusividad a los municipios, aunque las tasas son establecidas y el impuesto en sí es regulado desde la órbita nacional. La base imponible se calcula a partir de autovaloraciones de los contribuyentes y no de la valoración fiscal de tierras y edificaciones de un sistema de catastro como en la mayoría de los países.

En el caso de México, cada estado es autónomo en las atribuciones asignadas en la Constitución, inclusive en la creación de impuestos. El impuesto a la propiedad inmueble es un tributo eminentemente municipal y representa una de las principales fuentes tributarias de ingresos subnacionales (un 22,5\% del total en 2014) ${ }^{8}$. Por otro lado, como señala Ruelas Ávila (2015), si bien la importancia relativa de este impuesto promedió el $55 \%$ de los ingresos tributarios municipales en el período 1989-2013, esta ha sido históricamente baja (alrededor del 7\%) cuando se compara con los ingresos totales de los municipios ${ }^{9}$. El registro catastral y la valoración fiscal es responsabilidad de cada uno de los municipios, por lo que la unificación de criterios solo puede lograrse mediante acuerdos entre jurisdicciones.

Por su parte, el impuesto territorial (IT) chileno, que fija el pago de contribuciones de bienes raíces, representa el principal componente de los ingresos tributarios municipales. Como se desprende del cuadro III.2, en 2014 contribuyó con ingresos equivalentes al 0,6\% del PIB y al 37,5\% del total de recursos tributarios subnacionales ${ }^{10}$. Para este impuesto, tanto la tasa como la base imponible y las exenciones de pago se encuentran fijadas por ley (nacional), y los municipios, en la práctica, solo son los beneficiarios de los recursos que se recaudan. La base del impuesto territorial está determinada por la valoración fiscal de la propiedad realizada por el Servicio de Impuestos Internos (SII) y la tasa del impuesto se fija por ley. Esto lleva a que se trate de un impuesto patrimonial que no tiene relación con el pago por bienes y servicios locales que el municipio entrega al entorno donde se encuentra emplazado el bien inmueble.

Además, de lo que se recauda por el impuesto territorial, en la mayoría de los municipios, el 60\% —el 65\% en 4 municipios de la Región Metropolitana (Santiago, Providencia, Las Condes y Vitacura, según la Ley

8 De Cesare y Lazo Marín (2008) aclaran que los municipios deben proponer anualmente sus tarifas y tablas de valores unitarios de terreno y construcción ante los Congresos Estatales.

9 Ruelas Ávila (2015) muestra, además, que el 90\% de la recaudación del tributo se concentra solo en el $12 \%$ de los municipios.

10 En los cálculos de carga tributaria subnacional para el caso chileno, se siguió la metodología de la Dirección de Presupuestos (DIPRES), en la que se eliminan las duplicaciones originadas en la aplicación del Fondo Común Municipal. De este modo, al sumar la diferencia residual a los respectivos tributos que lo forman, es posible visualizar exactamente lo recaudado por cada concepto de ingresos de operación, aunque se pierde información de lo recibido por cada municipio a través de la participación en este Fondo. 
de Rentas Municipales) - debe aportarse al Fondo Común Municipal, en tanto que el $40 \%$ o el $35 \%$ restante va en beneficio directo del municipio de la comuna donde se encuentra ubicada la propiedad. De esta manera, se intentan introducir criterios distributivos a un impuesto que habitualmente justifica su asignación a través del principio del beneficio (Horst, 2010).

En el Ecuador, el impuesto predial aporta una porción similar (un $37,8 \%$ en 2014) de los ingresos tributarios subnacionales, lo que equivale a poco más del $0,2 \%$ del PIB. La base gravable del tributo corresponde al valor global del predio determinado y actualizado cada dos años por la oficina de catastro municipal sobre la base del valor del suelo, el valor de las edificaciones y el valor de reposición, conforme a lo dispuesto por el Concejo Municipal. No obstante, el método de valoración catastral conjuga la información provista directamente por el propietario con los datos de escrituración debido a dificultades logísticas observadas en la mayoría de las jurisdicciones. Las tasas del impuesto para propiedades urbanas varían entre 0,25 puntos por 1.000 y 5 puntos por 1.000 del valor del inmueble, mientras que para las áreas rurales se ubican entre 0,25 puntos por 1.000 y 3 puntos por 1.000 .

En Colombia, aunque el impuesto predial unificado originalmente fue de jurisdicción departamental, la Constitución Política de Colombia de 1991 lo asigna a los municipios, que fueron dotados del poder para determinar las tasas (dentro de un rango preestablecido), las exenciones, los tratamientos preferenciales y los usos específicos de lo recaudado por el tributo. Como cabría esperar, pueden existir (y, de hecho, existen) tantos marcos regulatorios para la imposición a la propiedad inmueble como municipios, lo que refleja las necesidades particulares de cada uno de estos. Así, el impuesto predial colombiano, que recauda 0,7 puntos porcentuales del PIB, se impone sobre todas las propiedades inmuebles, urbanas y rurales, con o sin edificaciones, ubicadas dentro de los límites geográficos de cada municipio. Además, este es el segundo impuesto que más recaudación reporta a los niveles inferiores de gobierno, con una participación relativa del $23,3 \%$ respecto de los ingresos totales de estas jurisdicciones.

La base imponible en este caso está determinada por la valoración catastral realizada por oficinas de catastro descentralizadas en Bogotá, Antioquia, Cali y Medellín, y por un instituto privado en los otros departamentos. Si bien los valores de los inmuebles se actualizan anualmente aplicando un ratio que toma en cuenta el índice de precios al consumidor, en varios municipios de Colombia se han evidenciado problemas con la actualización de los valores catastrales respecto de los valores de mercado y se ha recurrido al mecanismo de valoración autodeterminada o autovaloración catastral. En cuanto a las alícuotas del impuesto, estas pueden ser establecidas por las autoridades municipales dentro de cierto rango respecto de la valoración 
catastral, con una estructura diferenciada y progresiva en función del tipo de estratificación social y de utilización de las tierras en las áreas urbanas que determinan, en última instancia, el valor fiscal de los inmuebles afectados por el impuesto predial.

Como ya se mencionó, el aporte de recaudación tributaria de los cantones en Costa Rica resulta poco significativo respecto del total nacional. La razón principal es que los municipios tienen solo la responsabilidad de administración tributaria de algunos impuestos a la propiedad y a las ventas. $\mathrm{Al}$ respecto, los niveles locales de gobierno deben realizar las valoraciones, recaudar y exigir el pago de los tributos en sus jurisdicciones. En particular, el impuesto predial en este país aporta gran parte de los recursos tributarios subnacionales: un $42,9 \%$ en 2014 , que equivale al $0,3 \%$ del PIB. La alícuota vigente, decidida por el Gobierno Central, es del 0,25\% sobre el valor del inmueble y es de aplicación en todo el territorio nacional.

En la Argentina y el Brasil, los dos países de la región con mayor participación subnacional dentro de los ingresos tributarios totales, los niveles inferiores de gobierno también recaudan el impuesto a la propiedad inmueble, aunque este se encuentra subordinado a otro tipo de impuestos que reportan mayores recursos tributarios, como los impuestos que gravan la actividad económica (véase el apartado B.2).

En la Argentina, el impuesto inmobiliario es el tercer impuesto en importancia de la recaudación provincial (segundo nivel de gobierno) y representa poco menos de la décima parte del total obtenido por estas jurisdicciones (un 7,3\% en 2014). Además, el 88\% de los recursos que genera este tributo se concentra en 5 de las 24 provincias, especialmente en la Capital Federal (32,8\%) (Gobierno de la Ciudad Autónoma de Buenos Aires (GCBA)) y la provincia de Buenos Aires (32,2\%), que, a su vez, explican más del $65 \%$ de la recaudación del impuesto. La forma de valoración más utilizada en la Argentina tiene en cuenta tanto el suelo como la construcción, o sea que la base se determina por el inmueble completo. Otro método utilizado puntualmente en la provincia de Buenos Aires consiste en valuar por separado el suelo y la construcción o mejoras de un inmueble para aplicar tasas diferentes (las tarifas de las mejoras son más bajas que las del suelo).

En el Brasil existen dos impuestos que gravan la propiedad inmueble, según sea urbana o rural. Por una parte, el impuesto a la propiedad predial y territorial urbana (IPTU) está asignado como potestad exclusiva de los municipios y del Distrito Federal, por lo que su base legal depende de normas directamente establecidas por cada jurisdicción. El IPTU, que aportó ingresos tributarios por un monto equivalente al 0,4\% del PIB en 2014, grava la propiedad o posesión de bienes inmuebles en las zonas urbanas y su base está determinada por el valor de mercado de dichos bienes (se aplican tasas 
fijadas por cada municipio $)^{11}$. Dentro de la estructura de los ingresos tributarios municipales, el peso relativo de este impuesto ronda el $20 \%$, mientras que comparado con todos los ingresos tributarios subnacionales la importancia se reduce al 4,7\%. El IPTU se distingue del impuesto a la propiedad territorial rural (ITR), un impuesto asignado al Gobierno Central, cuya base imponible es la tierra libre de mejoras y edificaciones en zonas rurales.

\section{Imposición sobre la actividad económica}

A diferencia de los impuestos que recaen sobre la propiedad inmueble, donde las diferencias de alícuotas impositivas entre las jurisdicciones no revisten mayores problemas debido a la inmovilidad de las bases imponibles, los tributos relacionados a la actividad económica implican mayores riesgos de coordinación tributaria, en la medida en que las diferencias entre las tasas aplicadas en regiones vecinas pueden inducir a los contribuyentes a "exportar" decisiones de consumo y de producción o comercialización hacia las áreas de menor carga tributaria relativa dentro de un mismo país.

En general, los países suelen utilizar dos tipos diferenciados de impuestos a las ventas o consumos: a) de única etapa, no acumulativos, como el impuesto general a las ventas al consumidor final utilizado en los Estados Unidos y como suelen ser los impuestos selectivos sobre determinados bienes o servicios, y b) de etapas múltiples, no acumulativos, como el impuesto sobre el valor agregado (IVA) utilizado en todos los países de América Latina. Los impuestos acumulativos, o "en cascada", que gravan cada una de las etapas de producción, distribución y comercialización son menos frecuentes, pero existen en la región a nivel subnacional. Estos tributos logran generar una significativa recaudación con una baja alícuota en razón de gravar reiteradamente la misma base imponible.

Asimismo, los impuestos específicos o selectivos pueden ser una buena fuente de ingresos para estos niveles de gobierno gracias a la relativa facilidad de administrarlos y a la posibilidad de diferenciación por alícuotas entre regiones, aunque el aspecto que debe destacarse está relacionado con el principio jurisdiccional aplicado.

En la medida en que tanto los impuestos generales a las ventas o consumos como los impuestos específicos se cobran en el lugar en donde residen los consumidores (principio de destino) y no en el lugar donde se producen los bienes o se prestan los servicios (principio de origen), estos tributos no generan efectos distorsivos sobre las decisiones económicas de los contribuyentes (Larios, Alvarado y Conterno, 2004).

${ }^{11}$ Véase un análisis detallado de este impuesto en Bruno de Carvalho (2006). 
Resulta evidente que si para un mismo bien se aplica el principio del destino, pero con distintos niveles de tasas entre las jurisdicciones, se estará creando un incentivo a efectuar compras fuera de la propia jurisdicción y, por lo tanto, se generarán efectos distorsivos en la asignación de los recursos, que resultarán muy difíciles de evitar a menos que se logre armonizar los niveles de imposición entre las distintas jurisdicciones.

Las diversas alternativas técnicas utilizadas para solucionar el problema de la doble imposición a nivel local van desde establecer cajas compensadoras entre las jurisdicciones hasta diferir el pago del gravamen en el momento de la venta o conformar un sistema integrado donde participe tanto el Gobierno Central como los gobiernos locales para evitar la duplicación del gravamen. La experiencia de la Unión Europea, no obstante, señala que estas alternativas no están libres de complejidades y cuestionamientos técnicos.

Cuatro de los países analizados se destacan por asignar la potestad exclusiva sobre determinados impuestos a las ventas a sus gobiernos subnacionales, constituyéndolos, en todos los casos, en la principal fuente de recursos tributarios propios de su respectivo nivel de gobierno.

En el caso de la Argentina, la principal fuente de ingresos tributarios de las provincias es el impuesto sobre los ingresos brutos (que también está asignado, en porcentajes mucho menores, a algunos municipios). En 2014, este tributo contribuyó con un $74,5 \%$ de la recaudación total provincial, lo que equivale a 4,1 puntos porcentuales del PIB (véase el cuadro III.2). Las tasas aplicadas son diferenciadas entre provincias y actividades, y también existen diferencias en el peso relativo del impuesto en cada provincia (con una oscilación entre el $60 \%$ y el $85 \%$ ), aunque en todas resulta el tributo de mayor recaudación. A pesar de ser criticado por las ineficiencias que genera como impuesto "en cascada" (distorsiona la asignación de recursos al cambiar la estructura de precios relativos y perjudica a los productores internos respecto de la competencia internacional), este impuesto ha mostrado un elevado rendimiento tributario y contribuye a la autonomía provincial en cuanto a necesidades de financiamiento.

En el Brasil, los tres niveles de gobierno adoptaron impuestos a las ventas, lo que implica dificultades de coordinación interjurisdiccional. Además del impuesto sobre productos industrializados (IPI), recaudado por el gobierno federal sobre una extensa lista de bienes producidos, y cuyo monto se determina siguiendo el de un gravamen al valor agregado, los gobiernos estatales poseen potestad tributaria plena sobre el impuesto sobre la circulación de mercaderías y servicios (ICMS), que también grava a los bienes y servicios en todas las etapas, pero de manera general, es decir, cubre una base de imposición mucho más amplia que el IPI. Asimismo, los municipios administran y recaudan el impuesto sobre los servicios (ISS), que grava toda prestación de servicios estipulada en la legislación que se realice 
dentro de los límites geográficos de cada municipio. Al ser potestad exclusiva, cada municipio puede establecer la alícuota que considere oportuna, con un máximo del $5 \%$ sobre la facturación.

Si se consideran conjuntamente el ICMS y el ISS, se observa que los gobiernos subnacionales brasileños recaudan casi el $90 \%$ de sus recursos tributarios a partir de la imposición a las ventas o, visto de otra manera, disponen de recursos fiscales equivalentes al 7,6\% del PIB merced a ese tipo de tributación. Ello transforma estos impuestos, sobre todo el ICMS estadual, en la principal y fundamental fuente de ingresos de los niveles inferiores de gobierno en dicho país.

Colombia, por su parte, también asigna a los impuestos a las ventas de bienes y servicios un papel preponderante en el conjunto de recursos tributarios de jurisdicción subnacional. La recaudación de estos tributos en 2014 fue del 1,3\% del producto, lo que representa un $43,3 \%$ del total de ingresos tributarios subnacionales.

Cabe destacar que los recursos mencionados se pueden dividir en dos grupos diferenciados. Por una parte, los gobiernos departamentales aportan el $24,2 \%$ de la recaudación tributaria subnacional y concentran un $62,5 \%$ de sus ingresos a partir de la aplicación de 3 impuestos selectivos al consumo de licores, cervezas y cigarrillos. Por otra parte, los municipios, que contribuyen con más del $75 \%$ de la recaudación consolidada de las entidades territoriales colombianas, poseen como principal fuente de ingresos tributarios propios el impuesto de industria y comercio (ICA), que supera al impuesto predial como principal tributo subnacional en cuanto a recaudación generada. En 2012, este último representó un $36 \%$ del total de la recaudación municipal y un 29\% del consolidado subnacional (Sánchez, España Eljaiek y Zenteno, 2015).

En Chile, los gobiernos subnacionales también disponen de los recursos generados a partir del cobro de patentes comerciales, que se aplican por la municipalidad respectiva al ejercicio de toda profesión, oficio, industria, comercio, arte u otra actividad lucrativa secundaria o terciaria, sea cual fuere su naturaleza o denominación (incluidas las patentes de alcoholes). Este tributo aportó en 2014 el 56,3\% de los ingresos tributarios municipales, lo que equivale al 0,9\% del PIB.

Finalmente, el impuesto de patentes constituye el principal tributo recaudado por los gobiernos locales de Costa Rica, ya que en 2014 aportó más de la mitad de la recaudación tributaria de estos gobiernos (un 57,1\% del total y un $0,4 \%$ del PIB). En este caso, la base imponible es la renta líquida gravable y las ventas o ingresos brutos anuales que perciban las personas físicas o jurídicas que se dediquen al ejercicio de actividades lucrativas, con una alícuota que oscila entre el $0,1 \%$ y el 0,2\%, según el cantón o la jurisdicción considerados. 


\section{Imposición sobre los automotores}

En los países de la región existen diversas alternativas para gravar los vehículos automotores de los contribuyentes. Una posibilidad es que el hecho imponible del tributo sea directamente la tenencia o propiedad de un automotor, en la medida en que representa una manifestación parcial del patrimonio del contribuyente. Otra opción es que el impuesto recaiga sobre aquellos que utilizan este bien para circular en la vía pública (también conocidos como "derechos de circulación"). Por último, casi todos los países, a través de sus gobiernos subnacionales, imponen un tributo a la transferencia de los vehículos entre los ciudadanos.

En virtud de la gama de variantes para su aplicación y aprovechamiento como fuente de recursos fiscales en los niveles inferiores de gobierno, el impuesto sobre automotores está presente en varios países latinoamericanos, aunque solo en algunos resulta moderadamente significativo en la recaudación tributaria subnacional.

La justificación de su uso radica principalmente en que es un tributo fácil de administrar, sus registros son fáciles de llevar y es una fuente permanente y estable de ingresos, especialmente en gobiernos subnacionales con un alto grado de urbanización. Por otra parte, la información sobre la cantidad de automóviles en una ciudad es útil para fijar impuestos ecológicos que limiten el uso de vehículos y combatir la contaminación ambiental; es decir, el gravamen puede utilizarse con otros fines, no necesariamente recaudatorios.

Si bien se trata de un objetivo de mayor responsabilidad y peso a nivel central, en algunos países se ha tratado de utilizar el impuesto a los vehículos como parte de una política redistributiva y se puede admitir un impuesto progresivo cuya tasa grave la compra de vehículos nuevos. En la Argentina, por ejemplo, la provincia de San Juan cuenta con un impuesto progresivo a los vehículos: la tasa del impuesto es del 3\%, pero el valor que se aplica va en función del modelo, la antigüedad y el peso del vehículo. Esta forma de gravar los vehículos es compleja desde el punto de vista administrativo y puede penalizar a vehículos nuevos que son más eficientes y contaminan menos que los vehículos más antiguos.

De modo similar, en México existe el impuesto sobre tenencia o uso de vehículos (ISTUV), que se encuadra como potestad exclusiva de los estados y Ciudad de México. Este tributo ofrece varias ventajas desde el punto de vista recaudatorio y equitativo. La base del impuesto suele ser relativamente estable en la medida en que el número de automóviles tiende a aumentar a un ritmo similar o superior a la tasa de crecimiento poblacional y su nivel de ingresos. Además, la base es relativamente difícil de ocultar y el impuesto recae sobre los individuos de mayor poder adquisitivo. En el caso de México, 
este gravamen se impone en dos modalidades: impuesto sobre tenencia o impuesto sobre uso de vehículos. El gobierno federal aplica, además, un gravamen sobre los automóviles nuevos.

En el Brasil, el impuesto sobre la propiedad de vehículos automotores (IPVA) es, a nivel recaudatorio, el segundo tributo estadual. No obstante, debido a la alta concentración de la tributación de los gobiernos subnacionales en los impuestos sobre las ventas (ICMS e ISS), solo representa un 7\% de los ingresos tributarios de estos niveles de gobierno, lo que equivale al $0,6 \%$ del PIB (véase el cuadro III.2) ${ }^{12}$.

En Chile, con una recaudación escasa del 0,1\% en términos del PIB, el tributo que recae sobre los propietarios de vehículos automotores (y que comprende tanto la compra como el permiso anual para circular) aporta el 6,3\% de los recursos tributarios subnacionales. Al respecto, el valor del permiso de circulación se determina, en la mayoría de los casos, sobre la base de la tasación de los vehículos motorizados que realiza el Servicio de Impuestos Internos y, en virtud de esta tasación, la Ley de Rentas Municipales fija las diferentes tasas. Vale señalar que este tributo constituye uno de los principales ingresos municipales, aun cuando el 62,5\% de su recaudación debe entregarse al Fondo Común Municipal (se estima que en 2014 esto representó el 8,9\% de los fondos asignados a través de este mecanismo de redistribución solidaria entre municipios).

En el caso del Estado Plurinacional de Bolivia, el impuesto vehicular atribuido a los municipios también resulta relevante en la estructura tributaria de estos niveles de gobierno y constituye el segundo recurso tributario subnacional en razón de que contribuye con un $7,1 \%$ de su recaudación. Este gravamen comprende tanto la propiedad como las transferencias de automotores entre contribuyentes y, por ser de recaudación municipal, posee algunas debilidades, como los problemas derivados de la radicación de los vehículos en un municipio vecino para pagar un impuesto menor.

\section{Otros impuestos subnacionales relevantes en los países de la región}

Además de los impuestos típicos utilizados por los gobiernos subnacionales que se han analizado, resulta indispensable comentar algunos ejemplos de tributos que amplían la vasta gama de instrumentos fiscales a partir de los cuales estos gobiernos obtienen su financiamiento.

El impuesto sobre nóminas, por ejemplo, es un tributo asignado a los gobiernos estatales de México, que en 2014 contribuyó con el 40,7\% de la recaudación subnacional (monto equivalente al 0,3\% del PIB mexicano). Este

12 Véase Ter Minassian (2015). 
tipo de impuesto tiene ventajas y desventajas. Por una parte, resulta fácil de administrar, especialmente si se aplica a empresas grandes, y cuando la economía tiene un alto grado de formalización laboral, con tasas relativamente bajas se pueden recaudar recursos significativos para los gobiernos regionales. Por otra parte, como señalan Larios, Alvarado y Conterno (2004), la principal desventaja es que este impuesto actúa como una barrera a la generación de empleo en el sector formal y puede constituir una forma encubierta de exportar impuestos a otras jurisdicciones al gravar en virtud del principio del origen en el supuesto de que este afecte los costos de producción.

En la Argentina no debe dejar de mencionarse el impuesto sobre los sellos como una importante fuente de recursos tributarios para los gobiernos provinciales. Desde el punto de vista de la eficiencia económica, este tributo resulta perjudicial por cuanto conspira contra el crecimiento económico al establecer una carga fiscal para que los actos jurídicos onerosos realizados por las personas y las empresas queden encuadrados dentro del régimen legal. Sin embargo, el impuesto sobre los sellos constituye el tercer gravamen de mayor recaudación para estas jurisdicciones, con una porción de casi el 10\% del total en 2014, lo que equivale a 0,5 puntos porcentuales del producto ${ }^{13}$.

En el cuadro III. 2 también se muestra que más del $50 \%$ de los ingresos tributarios de los gobiernos subnacionales del Ecuador no corresponde a los tributos mencionados en párrafos anteriores. Esto se debe principalmente a la gran cantidad de recursos fiscales aportados por dos impuestos recaudados por esos niveles de gobierno: el impuesto a los activos totales y el impuesto de alcabalas. El primero grava las actividades comerciales, industriales y financieras que están obligadas a llevar contabilidad, ejercidas por todas las personas naturales y jurídicas, sociedades de hecho y negocios individuales, nacionales o extranjeros, que tengan domicilio u oficinas, agencias o sucursales en el cantón en el cual se aplica. El segundo tributo alcanza a los actos y contratos sobre bienes inmuebles que tengan por objeto: i) el traspaso del dominio, a título oneroso, de bienes raíces y buques; ii) la constitución, traspaso, usufructo, uso y habitación de bienes, y iii) las donaciones que se hicieren a favor de quienes no fueren legitimarios ${ }^{14}$.

Los municipios del Estado Plurinacional de Bolivia también poseen la potestad exclusiva sobre dos impuestos complementarios a los patrimoniales: el impuesto municipal a las transferencias de inmuebles y vehículos automotores y el impuesto al consumo específico de la chicha de maíz, que en conjunto representan más del $11 \%$ de la recaudación tributaria

13 El resto de la categoría "Otros" (véase el cuadro III.2) corresponde, principalmente, a impuestos a la generación de energía eléctrica.

14 Asimismo, se incluyen los ingresos en concepto de la contribución especial de mejoras que, aunque su clasificación como tributo pueda ser controversial, aporta una parte significativa del financiamiento subnacional. 
subnacional. Sin embargo, la mayor parte de los recursos tributarios a nivel subnacional la reciben los departamentos a través del impuesto directo a los hidrocarburos (IDH) que, si bien es recaudado por el Estado, se distribuye en una proporción mayoritaria a estos niveles de gobierno de acuerdo con una serie de criterios objetivos (con diferencias entre ellos, según sean estos productores o no productores). Los recursos vinculados a los departamentos alcanzaron un monto equivalente al 3,4\% del PIB en 2014, lo que representa el $82,7 \%$ del total de recaudación tributaria subnacional.

En el caso del Brasil, los recursos tributarios subnacionales explicitados anteriormente se complementan con los impuestos relacionados con la transmisión gratuita de bienes en todas sus variantes. Por una parte, la transmisión gratuita de bienes se grava con el impuesto a la transmisión "inter-vivos" (ITBI), de potestad municipal; por la otra, el impuesto sobre transmisiones de bienes por causa de muerte (herencias) y donaciones (ITCD) se asigna a los estados y al Distrito Federal.

\section{Las fuentes no tributarias de financiamiento: la relevancia de los recursos no renovables}

Además de los distintos tributos con que cuentan para financiar sus necesidades de gasto, los gobiernos subnacionales suelen disponer de una importante fuente de recursos no tributarios que complementan a los anteriores y, en algunos países, hasta los superan en importancia cuantitativa.

Los recursos no tributarios de los niveles inferiores de gobierno comprenden una amplia gama de instrumentos fiscales en la que se incluyen, según el país, tasas por la prestación de servicios y derechos de uso, explotación y circulación, rentas de la actividad empresarial, rentas patrimoniales y regalías o cargos por la explotación de recursos naturales, como los hidrocarburos o los minerales.

Excepto en este último caso, en general ocurre que en los municipios más poblados y urbanizados es donde este tipo de ingresos reviste más relevancia en razón, por una parte, a la mayor actividad económica registrada dentro de sus límites geográficos, y, por la otra, a un mayor cúmulo de necesidades de los ciudadanos por satisfacer ${ }^{15}$. Además, el principio del beneficio es el que rige la aplicación de este tipo de recursos, ya que está directamente relacionado con la prestación, efectiva o potencial, de las tareas asignadas por parte de los gobiernos locales. El límite entre la prestación pública y privada suele resultar muy tenue y variable según las circunstancias y, por

15 Dado que los yacimientos de recursos naturales suelen estar ubicados en regiones relativamente poco pobladas, la proporción de ingresos fiscales obtenidos poco tiene que ver, en primera instancia, con el tamaño poblacional de las jurisdicciones. 
ello, la similitud entre los derechos o tasas públicas y los precios privados en muchos casos resulta difícil de diferenciar.

En el gráfico III.3 se exponen las diferencias existentes entre los países analizados en el presente capítulo en cuanto al peso relativo de los ingresos no tributarios respecto del total de recursos propios de los gobiernos subnacionales para 2013. Así, pueden identificarse dos grupos de países que guardan cierta relación entre sí en la forma en que se proveen de recursos fiscales.

\section{Gráfico III.3 \\ América Latina (8 países): estructura de los recursos propios corrientes de los gobiernos subnacionales, 2013 \\ (En porcentajes del PIB y porcentajes del total de recursos)}

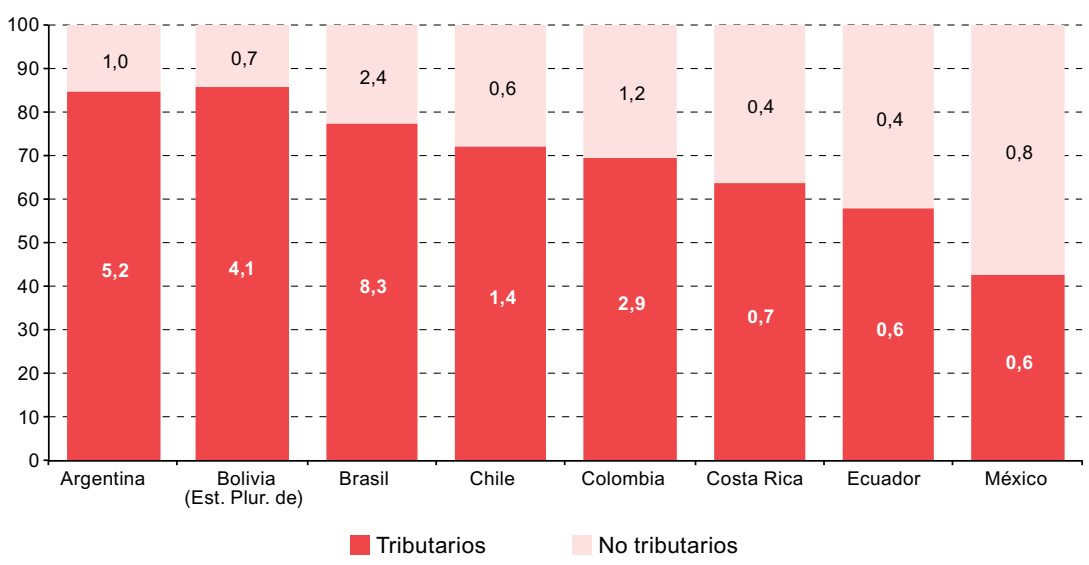

Fuente: Comisión Económica para América Latina y el Caribe (CEPAL), sobre la base de cifras oficiales.

Por una parte, la Argentina, Bolivia (Estado Plurinacional de) y el Brasil muestran una tendencia clara en lo que hace a la dotación de potestades tributarias hacia sus respectivas entidades descentralizadas. En estos países (entre los que también cabría agregar a Chile), los recursos propios se componen principalmente de impuestos, lo que no implica que el financiamiento por medio de esta vía sea suficiente. En la mayoría de los países de la región, de hecho, se requiere la implementación simultánea de un sistema de transferencias desde el Gobierno Central.

Con la excepción de Costa Rica y el Ecuador, donde los recursos propios de los cantones resultan muy acotados y cercanos al 1\% en términos del PIB, los demás países evidencian una preponderancia creciente en el porcentaje que representan los ingresos no tributarios respecto del total recaudado. Dentro de los últimos, las regalías aplicadas por aquellos gobiernos subnacionales dentro de cuyos límites geográficos existen dotaciones de recursos naturales no renovables constituyen un componente muy relevante. 
En relación con ello, los países ubicados a la derecha en el gráfico III.3 (Ecuador y México) son precisamente aquellos donde la extracción y comercialización de productos primarios básicos resulta ser una fuente cuantiosa de ingresos subnacionales, especialmente a partir de la aplicación de regalías $^{16}$. En la mayoría de los casos, la predominancia de este tipo de recurso fiscal dentro de las finanzas públicas de los niveles inferiores de gobierno conlleva un aumento de la volatilidad de los ingresos (en contraposición con la mayor estabilidad relativa de la recaudación tributaria propia) y la presencia de mayores disparidades interregionales en función de la dotación existente de recursos no renovables dentro de cada jurisdicción subnacional, lo que representa un desafío de coordinación macroeconómica muy relevante.

En la práctica, los países latinoamericanos muestran una amplia variedad de soluciones al momento de distribuir las rentas provenientes de recursos naturales, que se asocian a diferentes arreglos intergubernamentales que abarcan desde las federaciones clásicas, como la Argentina y el Brasil, hasta los estados unitarios típicos, como Chile y el Ecuador. A pesar de esta heterogeneidad, vinculada a las trayectorias históricas y a los procesos sociales y políticos específicos de cada país, en un reciente trabajo de la CEPAL (2014) se lograron identificar tres tendencias generales en lo que respecta a la distribución regional de estos recursos que vale la pena señalar:

i) Se observa una asignación excluyente o preferencial de los recursos fiscales que proceden de las rentas extractivas a las regiones o localidades productoras respecto de las no productoras, con cierta escasez de mecanismos de compensación para asignar también recursos a estas últimas (véase el cuadro III.3). En América Latina, las desigualdades creadas por la asignación de las rentas extractivas se corrigen parcialmente mediante la expansión de estas rentas hacia las áreas no productoras a través de sistemas de distribución de impuestos de recursos naturales, como ocurre en Bolivia (Estado Plurinacional de), Colombia o Venezuela (República Bolivariana de). Aquí, los argumentos de tipo político, normativo y legal suelen prevalecer sobre los criterios técnicos (de índole ambiental, económica y social).

ii) Existe una propensión a gastar los recursos en el presente, con una débil apuesta por su gestión financiera mediante fondos para fines de ahorro o estabilización o de equidad intergeneracional, si bien estos mecanismos se han multiplicado en los últimos años a nivel regional ${ }^{17}$. En la mayoría de los países aún prima la idea de que

16 En el caso del Estado Plurinacional de Bolivia, los recursos del IDH se clasifican como tributarios aunque su estructura se asemeja a la de una regalía tradicional aplicada sobre el valor de producción (véase el cuadro III.3).

17 Actualmente existen nueve instrumentos de este tipo en los siguientes países e la región: Brasil, Chile (dos), Colombia, México, Panamá, Perú, Trinidad y Tabago y Venezuela (República Bolivariana de). 
es necesario usar en el presente la renta extractiva en: i) atención a problemas de pobreza, ii) inversión en infraestructura social y iii) mantenimiento de altos niveles de reservas internacionales.

iii) En cuanto a los instrumentos utilizados para captar las rentas extractivas, se advierte la prevalencia de las regalías sobre los impuestos - que fundamentalmente dependen del valor de producción - como base de la asignación de una parte de la renta extractiva a los gobiernos subnacionales. Los casos de Bolivia (Estado Plurinacional de), con la distribución del IDH, y el Perú, con el canon minero y gasífero a través del cual los gobiernos subnacionales participan del $50 \%$ de los ingresos por concepto de impuesto sobre la renta que pagan las empresas productoras, constituyen dos ejemplos paradigmáticos que se apartan de la tendencia señalada a nivel regional.

\section{Cuadro III.3}

América Latina y el Caribe (10 países): marcos legales que rigen la distribución y asignación de ingresos fiscales derivados de los sectores de hidrocarburos y minerales

\begin{tabular}{|c|c|c|c|c|c|}
\hline Países & $\begin{array}{l}\text { Sector } \\
\text { extractivo }\end{array}$ & $\begin{array}{l}\text { Ingresos } \\
\text { asignados/ } \\
\text { distribuidos }\end{array}$ & $\begin{array}{l}\text { Determinación de } \\
\text { los ingresos }\end{array}$ & $\begin{array}{l}\text { Distribución } \\
\text { a regiones } \\
\text { productoras }\end{array}$ & $\begin{array}{l}\text { Mecanismo de } \\
\text { compensación } \\
\text { a otras } \\
\text { regiones }\end{array}$ \\
\hline \multirow[t]{2}{*}{ Argentina } & Hidrocarburos & Regalías & $\begin{array}{l}12 \% \text { valor } \\
\text { de roducción }\end{array}$ & $\begin{array}{l}\text { Sí (recaudan } \\
\text { las provincias) }\end{array}$ & No \\
\hline & Minería & Regalías & $\begin{array}{l}1 \% \text { al } 3 \% \text { valor } \\
\text { de producción }\end{array}$ & $\begin{array}{l}\text { Sí (recaudan } \\
\text { las provincias) }\end{array}$ & No \\
\hline \multirow{2}{*}{$\begin{array}{l}\text { Bolivia } \\
\text { (Estado } \\
\text { Plurinacional } \\
\text { de) }\end{array}$} & Hidrocarburos & Regalías e IDH & $\begin{array}{l}18 \% \text { y } 32 \% \text { valor } \\
\text { de producción }\end{array}$ & Sí & Sí \\
\hline & Minería & Regalías & $\begin{array}{l}1 \% \text { al } 7 \% \text { valor bruto } \\
\text { de venta }\end{array}$ & Sí & No \\
\hline \multirow[t]{2}{*}{ Brasil } & Hidrocarburos & Regalías & $\begin{array}{l}10 \% \text { valor } \\
\text { de producción }\end{array}$ & Sí & No \\
\hline & Minería & $\begin{array}{l}\text { Regalías } \\
\text { (CFEM) }^{\text {a }}\end{array}$ & $\begin{array}{l}0,2 \% \text { al } 3 \% \text { valor } \\
\text { de ventas netas }\end{array}$ & Sí & No \\
\hline Chile & Minería & $\begin{array}{l}\text { Patente e } \\
\text { impuesto a las } \\
\text { ventas (cobre) }\end{array}$ & $\begin{array}{l}0,5 \% \text { al } 5 \% \text { de } \\
\text { las ventas }\end{array}$ & No & No \\
\hline \multirow[t]{2}{*}{ Colombia } & Hidrocarburos & Regalías & $\begin{array}{l}5 \% \text { al } 25 \% \text { valor } \\
\text { de producción }\end{array}$ & Sí & Sí \\
\hline & Minería & Regalías & $\begin{array}{l}1 \% \text { al } 12 \% \text { valor } \\
\text { en boca de mina }\end{array}$ & Sí & Sí \\
\hline \multirow[t]{2}{*}{ Ecuador } & Hidrocarburos & Regalías & $\begin{array}{l}12,5 \% \text { al } 18 \% \text { valor } \\
\text { de producción; tasa } \\
1 \text { dólar por barril } \\
\text { en Amazonia }\end{array}$ & Sí (mínimo) & No \\
\hline & Minería & Regalías & $\begin{array}{l}3 \% \text { valor } \\
\text { de producción }\end{array}$ & Sí & No \\
\hline \multirow[t]{2}{*}{ México } & Hidrocarburos & $\begin{array}{l}\text { Todos los } \\
\text { ingresos fiscales }\end{array}$ & & Sí & $S i^{b}$ \\
\hline & Minería & $\begin{array}{l}\text { Todos los } \\
\text { ingresos fiscales }\end{array}$ & & $S i^{c}$ & No \\
\hline
\end{tabular}


Cuadro III.3 (conclusión)

\begin{tabular}{|c|c|c|c|c|c|}
\hline Países & $\begin{array}{l}\text { Sector } \\
\text { extractivo }\end{array}$ & $\begin{array}{l}\text { Ingresos } \\
\text { asignados/ } \\
\text { distribuidos }\end{array}$ & $\begin{array}{l}\text { Determinación de } \\
\text { los ingresos }\end{array}$ & $\begin{array}{l}\text { Distribución } \\
\text { a regiones } \\
\text { productoras }\end{array}$ & $\begin{array}{l}\text { Mecanismo de } \\
\text { compensación } \\
\text { a otras } \\
\text { regiones }\end{array}$ \\
\hline \multirow[t]{2}{*}{ Perú } & Hidrocarburos & $\begin{array}{l}\text { Regalías, Fondo } \\
\text { de Desarrollo } \\
\text { Económico } \\
\text { del proyecto } \\
\text { Camisea } \\
\text { (Focam) e } \\
\text { impuesto sobre } \\
\text { la renta (canon } \\
\text { petrolero y } \\
\text { canon gasífero) }^{\text {d }}\end{array}$ & $\begin{array}{l}\text { Regalías: } 5 \% \text { al } 37 \% \\
\text { valor de producción; } \\
\text { FOCAM: } 25 \% \\
\text { regalías gasíferas } \\
\text { de algunos pozos } \\
\text { determinados; } \\
\text { canon petrolero: } \\
50 \% \text { regalías } \\
\text { pagadas; } \\
\text { canon gasífero: } \\
50 \% \text { impuesto sobre } \\
\text { la renta de empresas } \\
\text { privadas más un } \\
50 \% \text { regalías }\end{array}$ & Sí & No \\
\hline & Minería & $\begin{array}{l}\text { Regalías, } \\
\text { derechos } \\
\text { de vigencia } \\
\text { de minas e } \\
\text { impuesto sobre } \\
\text { la renta (canon } \\
\text { minero) }\end{array}$ & $\begin{array}{l}\text { Regalías: } 1 \% \text { al } 3 \% \\
\text { de las ventas brutas; } \\
\text { derechos de } \\
\text { vigencia: } 3 \text { dólares } \\
\text { por hectárea; } \\
\text { canon minero: } 50 \% \\
\text { impuesto sobre la } \\
\text { renta de empresas } \\
\text { mineras }\end{array}$ & Sí & No \\
\hline $\begin{array}{l}\text { Trinidad y } \\
\text { Tabago }\end{array}$ & Hidrocarburos & & $\begin{array}{l}12,5 \% \text { valor de } \\
\text { producción }\end{array}$ & No & No \\
\hline $\begin{array}{l}\text { Venezuela } \\
\text { (República } \\
\text { Bolivariana de) }\end{array}$ & Hidrocarburos & $\begin{array}{l}\text { Regalías y un } \\
\text { porcentaje del } \\
\text { presupuesto } \\
\text { nacional }\end{array}$ & $\begin{array}{l}20 \% \text { al } 30 \% \text { valor } \\
\text { de producción }\end{array}$ & Sí (mínimo) & Sí \\
\hline
\end{tabular}

Fuente: Comisión Económica para América Latina y el Caribe (CEPAL), Pactos para la igualdad: hacia un futuro sostenible (LC/G.2586 (SES.35/3)), Santiago, 2014.

a Compensación financiera por explotación de los minerales.

b Acceso a recursos fiscales a través de la Ley de Coordinación Fiscal.

c Incluye tanto a los estados como a los municipios.

d La distribución de los fondos del canon minero, gasífero y petrolero comprende: un $10 \%$ para las municipalidades distritales donde se encuentra la concesión, un 25\% para las municipalidades de las provincias donde se encuentra la concesión, un $40 \%$ para las municipalidades de los departamentos donde se encuentra la concesión y un $25 \%$ para los gobiernos regionales donde se explota el recurso natural (un $20 \%$ de esta porción se transfiere a las universidades nacionales de su jurisdicción) (Del Valle, 2013).

\section{Conclusiones}

Un sistema de relaciones fiscales estable y un proceso de descentralización exitoso requieren un adecuado sistema de financiamiento para poder llevar adelante de forma satisfactoria las funciones asignadas a los distintos niveles de gobierno. Sin embargo, no solo es importante el grado de financiamiento de cada nivel de gobierno, sino también la combinación, en el caso de los gobiernos subnacionales, de los ingresos tributarios y no tributarios propios, las transferencias intergubernamentales y, en algunos casos, la opción de endeudamiento. 
Una de las características centrales de las relaciones intergubernamentales en América Latina es el alto nivel de asimetría vertical. La escasa importancia cuantitativa de la recaudación de los gobiernos locales respecto de la presión tributaria nacional es la característica más común entre los países de la región, lo que se traduce en una escasa autonomía de los gobiernos locales en materia de recursos propios de libre disponibilidad y acrecienta la dependencia financiera de la mayoría de estas jurisdicciones respecto de las transferencias intergubernamentales que pueden recibir del Gobierno Central.

Asimismo, se observan grandes disparidades en el nivel de los ingresos propios entre distintos gobiernos locales según el tamaño de sus poblaciones, la disponibilidad de recursos naturales y la existencia de bases tributarias propias, no solo en los sistemas federales, sino también en los países de gobierno unitario.

En cuanto a los recursos tributarios, a pesar de que los impuestos sobre bienes inmuebles son el instrumento más apto para captar ingresos tributarios a nivel local, su recaudación es baja en todos los países. Los problemas catastrales, las valuaciones alejadas de los valores de mercado, la ausencia de procesos automatizados de gestión y, sobre todo, la falta de voluntad política para cobrar el gravamen con un criterio progresivo constituyen las principales falencias observadas.

Los gravámenes generales sobre las actividades productivas, patentes o ventas a nivel local tienen serios problemas técnicos para evitar la traslación del gravamen a otras jurisdicciones y su carácter acumulativo tiende a generar distorsiones en la asignación de recursos. No obstante, en los países que asignan a sus gobiernos subnacionales la potestad tributaria plena para este tipo de tributos, este resulta ser el gravamen que más recursos aporta a esas jurisdicciones en la actualidad.

Los impuestos selectivos al consumo de bienes y servicios, siguiendo el principio de destino, podrían constituir una destacada fuente de recursos adicionales que no está totalmente explotada. Lo mismo cabe decir respecto de los gravámenes sobre algunas expresiones patrimoniales, como es el caso de la tenencia de vehículos.

Otra característica particular de América Latina en lo que se refiere a la asignación de impuestos entre niveles de gobierno, sobre todo si se compara con otras regiones del mundo, es la ausencia de recaudación subnacional en el impuesto sobre la renta, ni siquiera bajo el uso de sobretasas (adicionales a una alícuota federal, tal como se aplica en Alemania o el Canadá).

El abanico de instrumentos fiscales disponibles para los gobiernos subnacionales también incluye otros de índole no tributaria que pueden ser aún más importantes que los impuestos mencionados como fuente de recursos propios. En este campo sobresalen las regalías y otros cargos que 
gravan la explotación de recursos naturales no renovables en varios países de la región. Dado que esto constituye un factor de elevada heterogeneidad, tanto entre países como entre regiones de un mismo país, resulta fundamental considerar las distintas implicancias de los regímenes fiscales aplicados sobre estas industrias a nivel central, los mecanismos de distribución y compensación de estos recursos fiscales entre jurisdicciones y los efectos indirectos que causan sobre el resto de las fuentes (propias y no propias) de financiamiento subnacional.

\section{Bibliografía}

Afonso, J.R. y K. Pacheco (2016), “Carga tributaria en Brasil: redimensionada y repensada", Revista de Administración Tributaria, $\mathrm{N}^{\circ}$ 40, Centro Interamericano de Administraciones Tributarias (CIAT)/Agencia Estatal de Administración Tributaria (AEAT)/Instituto de Estudios Fiscales (IEF), febrero.

Brosio, G. (2015), "Step on the gas: Bolivia's reliance on natural resource revenue", Decentralizing Revenue in Latin America: Why and How, V. Fretes Cibils y T. Ter Minassian (eds.), Washington D.C., Banco Interamericano de Desarrollo.

Brosio, G. y J.P. Jiménez (2012), “The intergovernmental allocation of revenue from natural resources: finding a balance between centripetal and centrifugal pressure", Decentralization and Reform in Latin America: Improving Intergovernmental Relations, G. Brosio y J.P. Jiménez (eds.), Cheltenham, Edward Elgar Publishing.

Bruno de Carvalho Jr., P. (2006), "IPTU no Brasil: progressividade, arrecadação e aspectos extra-fiscais", Texto para Discussão, No 1251, Brasilia, Instituto de Investigación Económica Aplicada (IPEA) [en línea] http:/ /www.ipea.gov.br.

CEPAL (Comisión Económica para América Latina y el Caribe) (2014), Pactos para la igualdad: hacia un futuro sostenible (LC/G.2586 (SES.35/3)), Santiago.

De Cesare, C. y J.F. Lazo Marín (2008), “Impuestos a los patrimonios en América Latina", serie Macroeconomía del Desarrollo, N 66 (LC/L.2902-P), Santiago, Comisión Económica para América Latina y el Caribe (CEPAL).

Del Valle, M. (2013), "Ingresos fiscales por explotación de recursos mineros e hidrocarburos en Perú", Resumen de Políticas, N 197, Washington D.C., Banco Interamericano de Desarrollo.

Gómez Sabaini, J.C. y J.P. Jiménez (2011), “El financiamiento de los gobiernos subnacionales en América Latina (un análisis de casos)", serie Macroeconomía del Desarrollo, No 111 (LC/L.3336), Santiago.

Horst, B. (2010), "Fuentes de financiamiento para gobiernos subnacionales y descentralización fiscal", Informe Económico, $\mathrm{N}^{\mathrm{N}}$ 202, Santiago, Libertad y Desarrollo.

Jiménez, J.P. y A. Podestá (2009), “Las relaciones fiscales intergubernamentales y las finanzas subnacionales ante la crisis" (LC/R.2155), Santiago, Comisión Económica para América Latina y el Caribe (CEPAL).

Jiménez, J.P. y J. Viñuela (2004), “Marco institucional para la gestión del gasto público en países descentralizados", Washington D.C., Departamento de Finanzas Públicas, Fondo Monetario Internacional.

Larios, J., B. Alvarado y E. Conterno (eds.) (2004), “Descentralización fiscal. Análisis conceptual y revisión de experiencias de nueve países", Documento Técnico, $\mathrm{N}^{\circ} 7$, Lima, Agencia de los Estados Unidos para el Desarrollo Internacional (USAID). 
Martínez-Vázquez, J. y C. Sepúlveda (2012a), “Intergovernmental transfers: a policy reform perspective", Decentralization and Reform in Latin America: Improving Intergovernmental Relations, G. Brosio y J.P. Jiménez (eds.), Cheltenham, Edward Elgar Publishing.

(2012b), "Explaining property tax collections in developing countries: the case of Latin America", Decentralization and Reform in Latin America: Improving Intergovernmental Relations, G. Brosio y J.P. Jiménez (eds.), Cheltenham, Edward Elgar Publishing.

OCDE/CEPAL/CIAT /BID (Organización de Cooperación y Desarrollo Económicos / Comisión Económica para América Latina y el Caribe/Centro Interamericano de Administraciones Tributarias/Banco Interamericano de Desarrollo), Estadísticas tributarias en América Latina y el Caribe 1990-2014, París, OECD Publishing.

Rezende, F. y J. Veloso (2012), "Intergovernmental transfers in subnational finances", Decentralization and Reform in Latin America: Improving Intergovernmental Relations, G. Brosio y J.P. Jiménez (eds.), Cheltenham, Edward Elgar Publishing.

Ruelas, I. (2015), "Evaluación de las características del impuesto predial en México", Revista Iberoamericana de Estudios Municipales (RIEM), $\mathrm{N}^{\mathrm{o}} 12$, año VI.

Sánchez Torres, F., I. España Eljaiek y J. Zenteno (2015), “Fiscal cumbia: Colombia's revenue dynamism", Decentralizing Revenue in Latin America: Why and How, V. Fretes Cibils y T. Ter Minassian (eds.), Washington D.C., Banco Interamericano de Desarrollo.

Ter Minassian, T. (2015), "Elusive goal: Brazil's subnational revenue system reform", Decentralizing Revenue in Latin America: Why and How, V. Fretes Cibils y T. Ter Minassian (eds.), Washington D.C., Banco Interamericano de Desarrollo. 

Parte 2

La tributación y sus efectos sobre la desigualdad 

Capítulo IV

\title{
La incidencia distributiva de la fiscalidad en América Latina ${ }^{1}$
}

\author{
Michael Hanni ${ }^{2}$ \\ Ricardo Martner ${ }^{3}$ \\ Andrea Podestá ${ }^{4}$
}

\section{Introducción}

Si bien la desigualdad de los países de América Latina es un hecho ampliamente conocido, las políticas públicas, y especialmente las fiscales, no se han orientado a ese objetivo con la fuerza requerida. En CEPAL (2008) se resalta que el gasto social tiene repercusiones muy importantes en los estratos de menores ingresos, pero no en las mediciones de la desigualdad. Los cambios positivos registrados en materia de desigualdad en la última década provienen principalmente de una mejor distribución de los ingresos laborales y, en bastante menor medida, del papel redistributivo del Estado.

A pesar de las dificultades metodológicas y de la escasa fiabilidad de los datos disponibles, existe en la región una tradición de estudios de incidencia

Este capítulo es una versión resumida del Hanni, Martner y Podestá (2015).

2 Oficial de Asuntos Económicos de la División de Desarrollo Económico de la Comisión Económica para América Latina y el Caribe (CEPAL). Correo electrónico: michael.hanni@cepal.org.

3 Jefe de la Unidad de Asuntos Fiscales de la División de Desarrollo Económico de la Comisión Económica para América Latina y el Caribe (CEPAL). Correo electrónico: ricardo.martner@cepal.org.

4 Consultora de la Comisión Económica para América Latina y el Caribe (CEPAL). Correo electrónico: andrea.podesta@cepal.org. 
de la política fiscal que data de hace por lo menos tres décadas (Gómez Sabaini y Morán, 2013). Durante el primer decenio del siglo XXI se realizó una serie de estudios sobre la política fiscal en los países centroamericanos, andinos y otros países de América del Sur ${ }^{5}$. Entre los resultados se destaca que el impuesto sobre el valor agregado (IVA) tiene un efecto redistributivo modesto, aunque regresivo, y que el impuesto sobre la renta personal presenta una elevada progresividad, pero un efecto redistributivo muy moderado, sobre todo si se lo compara con la capacidad redistributiva del gasto público social. Se concluye que la política fiscal, en su conjunto, tiene un papel redistributivo muy inferior al calculado en los países desarrollados.

Más recientemente, se han publicado varios trabajos en los que se evalúa la incidencia de los gastos y los impuestos en la desigualdad y la pobreza en siete países de la región: Argentina, Bolivia (Estado Plurinacional de), Brasil, México, Paraguay, Perú y Uruguay ${ }^{6}$. En esas investigaciones se estima el efecto de los tributos directos e indirectos, de los subsidios indirectos y de las transferencias en efectivo y en especie a partir de las encuestas de hogares. Las conclusiones, a pesar de las diferencias metodológicas, coinciden con los estudios previos, ya sea en cuanto a la limitada capacidad redistributiva de la política fiscal (y, sobre todo, de los sistemas tributarios) en los países de América Latina o al marcado contraste respecto de lo observado en los países de la Organización de Cooperación y Desarrollo Económicos (OCDE).

A partir de esos antecedentes, los autores se han propuesto como primer objetivo estimar la incidencia del impuesto sobre la renta y de las transferencias monetarias públicas en la distribución del ingreso disponible respecto de un grupo amplio de 17 países de América Latina, sobre los que generan mediciones comparables con las metodologías internacionales. Un segundo objetivo consiste en simular los eventuales efectos de las posibles reformas de los sistemas impositivos con el fin de mostrar que los instrumentos tributarios (y, sobre todo, el buen uso del aumento derivado en la recaudación) sí pueden tener impactos significativos sobre la distribución del ingreso.

\section{A. Métodos de estimación de la incidencia de la acción fiscal}

Al igual que en los estudios disponibles en la región, la metodología consiste en aplicar un análisis de incidencia estándar con el fin de evaluar la progresividad o regresividad de la política fiscal y su efecto sobre la

\footnotetext{
En esos estudios se incluyen los siguientes países: Bolivia (Estado Plurinacional de), Brasil, Colombia, Costa Rica, Chile, Ecuador, El Salvador, Guatemala, Honduras, Nicaragua, Panamá, Paraguay, Perú, República Dominicana, Uruguay y Venezuela (República Bolivariana de). Véanse los documentos sobre equidad fiscal del Banco Interamericano de Desarrollo (BID): Barreix, Roca y Villela (2006); Barreix, Bès y Roca (2009), y Jorratt (2010).

6 Véanse Lustig, Pessino y Scott (2013), y Higgins y otros (2013).
} 
redistribución del ingreso. En ese tipo de análisis estático no se tienen en cuenta los efectos del comportamiento (por ejemplo, en la oferta de trabajo y en las estrategias de evasión o elusión de los contribuyentes), del ciclo de vida ni del equilibrio general. Por lo tanto, no se consideran las funciones de reacción de los agentes económicos ante la introducción o modificación de los impuestos y las transferencias.

A grandes rasgos, en esas investigaciones se compara la distribución del ingreso antes y después del pago de impuestos (véase el recuadro IV.1) o de las transferencias públicas, o ambas. Así se evalúa si los sistemas tributarios, las transferencias, o la política fiscal en su conjunto, cumplen su papel redistributivo.

\section{Recuadro IV.1 \\ Progresividad y redistribución de los impuestos: principales indicadores}

Dado que en la tercera sección se analizará el potencial redistributivo del impuesto sobre la renta en América Latina a partir de una serie de simulaciones de reforma tributaria, resulta útil especificar el significado de los indicadores que se utilizarán.

Por un lado, para medir la progresividad o la regresividad de un determinado tributo, la progresión de tasas medias indica el pago del impuesto que hace cada decil, expresado como porcentaje de su ingreso (tasa efectiva del impuesto). Así, un impuesto es progresivo cuando a mayor nivel de ingreso, mayor es la proporción que se tributa.

Con la misma finalidad, el índice de Kakwani $(K)$ compara la curva de Lorenz del ingreso antes de impuestos con la curva de concentración del impuesto, es decir: $K$ = cuasi Gini (impuesto) - Gini (ingreso antes de impuestos). Su valor expresa el apartamiento de la condición de proporcionalidad a partir de la diferencia de esos dos indicadores, donde, si $K$ es mayor (o menor) que cero, el impuesto es progresivo (o regresivo).

Por otro lado, para medir la capacidad redistributiva de un impuesto (o de varios al mismo tiempo), el índice de Reynolds y Smolensky (RS) es el más conocido en la literatura. En rigor y en su versión original (Reynolds y Smolensky, 1977), ese índice equivale a la diferencia entre el índice de Gini antes de la aplicación del gravamen y el índice de concentración del ingreso después del impuesto. En esta definición se supone que no se producen cambios en el ordenamiento de los individuos de acuerdo al nivel de ingreso después de la aplicación del tributo ${ }^{a}$. Sin embargo, una aproximación más realista, como la que se adopta en este trabajo, consiste en incorporar la posibilidad de esos efectos en el cálculo de impacto redistributivo. Por lo tanto, se define el índice de Reynolds y Smolensky (RS) como una diferencia entre índices de Gini: $R S$ = Gini (ingreso antes impuestos) - Gini (ingreso después de impuestos), donde, si RS es mayor (o menor) que cero, su valor indica la contribución del impuesto a reducir (o incrementar) la desigualdad. 
Recuadro IV.1 (conclusión)

En relación con lo anterior, para captar el efecto de reordenamiento, o sea, evaluar si se preserva el ordenamiento de los individuos según su nivel de ingresos después del pago de impuestos, se recurre al índice AtkinsonPlotnick $(A P)$. Se define como $A P=G(Y)-C X(Y)$, donde $G(Y)$ es el Gini del ingreso después de impuestos y $C X(Y)$ es el Gini del ingreso después de impuestos, pero con el ordenamiento de individuos antes de impuestos. Si el índice equivale a 0 , significa que no hubo reordenamiento y, si equivale a 1 , se ha invertido totalmente el ordenamiento original. También suele tomarse como una medida de la equidad horizontal de uno o varios tributos ${ }^{b}$.

Fuente: Elaboración propia, sobre la base de P. Lambert, Distribution and Redistribution of Income, Manchester University Press, 1993; y G. Verbist y F. Figari, "The redistributive effect and progressivity of taxes revisited: an international comparison across the European Union", GINI Discussion Paper, № 88, 2013.

a Véase una referencia más detallada en el trabajo de Verbist y Figari (2013).

b En la sección B del capítulo Il de este libro, Jorratt desarrolla esa aproximación, explica con mayor detalle los índices mencionados y provee aplicaciones concretas para tres casos de estudio.

La fuente de información utilizada es la última encuesta disponible en cada país respecto de los ingresos y gastos de los hogares. No obstante, un problema conocido de los datos de ingresos provenientes de las encuestas de hogares es que aparecen subestimados debido a diversos factores. Por ejemplo, el hecho de que las encuestas no suelen captar a los individuos de muy altos ingresos, o la falta de respuesta parcial o total y la subdeclaración de ingresos (sobre todo en la parte alta de la distribución del ingreso).

En general, dado que en las encuestas de hogares suele haber casos de subdeclaración o no respuesta, los datos de ingreso han sido corregidos por la División de Estadísticas de la CEPAL. Así, en la corrección en casos de no respuesta de ingresos, se imputa a cada persona la renta media declarada por individuos similares; en tanto que el ajuste por subdeclaración consiste en multiplicar los ingresos de cada fuente por un factor igual a la discrepancia con el correspondiente ingreso per cápita indicado en las cuentas nacionales ${ }^{7}$. Esa práctica eleva los ingresos medios y también suele modificar su distribución. En particular, se tiende a aumentar la desigualdad, sobre todo porque la brecha de los ingresos de capital se imputa exclusivamente al quintil más rico (CEPAL, 2012c) ${ }^{8}$.

Sin embargo, el ajuste por subdeclaración no está exento de inconvenientes, y la disponibilidad y calidad de la información proveniente de las cuentas nacionales varía entre países y períodos objeto de estudio. Además, los países introducen modificaciones al proceso de construcción de las cuentas

Para obtener más detalles, véase el trabajo pionero de Altimir (1987).

8 No fue posible el ajuste por subdeclaración de los ingresos en los siguientes países: Colombia, El Salvador, Honduras, Nicaragua y Uruguay. 
nacionales, ya sea en el año base de las series o en el marco metodológico. Esas modificaciones, distintas entre países, sin duda constituyen una mejora del sistema de cuentas, pero afectan a la estimación de los ingresos y gastos de los hogares en la medida en que varían algunas fuentes de información, cobertura de conceptos, ponderaciones entre sectores y actividades de la economía. Además, cada nuevo esquema metodológico no representa solo un simple reordenamiento de su predecesor, sino que modifica el trato de ciertas partidas, incorpora nuevas categorías y elimina algunas clasificaciones utilizadas anteriormente (CEPAL, 2012a) ${ }^{9}$.

Por último, es importante hacer algunas precisiones metodológicas. La unidad de análisis es el hogar y se considera como indicador de bienestar el ingreso per cápita equivalente; la definición de ingresos es la propuesta por la OCDE (2008) para que los resultados sean comparables entre países. Se aplican ciertos supuestos respecto del pago de los impuestos, pues se supone que el impuesto sobre la renta personal es abonado por la persona física gravada y que los trabajadores afrontan completamente las contribuciones a la seguridad social, aunque los impuestos solo se pagan en los sectores formales de la economía.

\section{B. Resultados de 17 países de América Latina}

Para iniciar el análisis, es importante considerar un rasgo distintivo de la desigualdad en la región: la elevada fracción del ingreso que capta el estrato más alto, es decir, el 10\% de los hogares más ricos (véase el gráfico IV.1). En promedio, ese grupo concentra un $32 \%$ de los ingresos totales, aunque la dispersión entre países se mueve en diez puntos porcentuales hacia arriba de ese valor (Brasil, Chile, Guatemala, Honduras y Paraguay), o hacia abajo (Uruguay y Venezuela (República Bolivariana de)).

A continuación se presentan y analizan las estimaciones realizadas respecto de los efectos del impuesto sobre la renta personal, de las contribuciones a la seguridad social y de las transferencias públicas en efectivo en la equidad distributiva. En este estudio se consideran 17 países latinoamericanos alrededor del año 2011 y se comparan los resultados con los de los países pertenecientes a la OCDE y, en particular, con el promedio de 15 países de la Unión Europea.

Actualmente, la CEPAL se encuentra en un proceso de revisión de la metodología de ajuste de los ingresos a cuentas nacionales con el fin de mejorar su coherencia y la comparabilidad de los resultados entre distintos países y a lo largo del tiempo. 


\section{Gráfico IV.1 \\ América Latina (18 países): participación en el ingreso por grupos de deciles, alrededor de 2012a \\ (En porcentajes)}

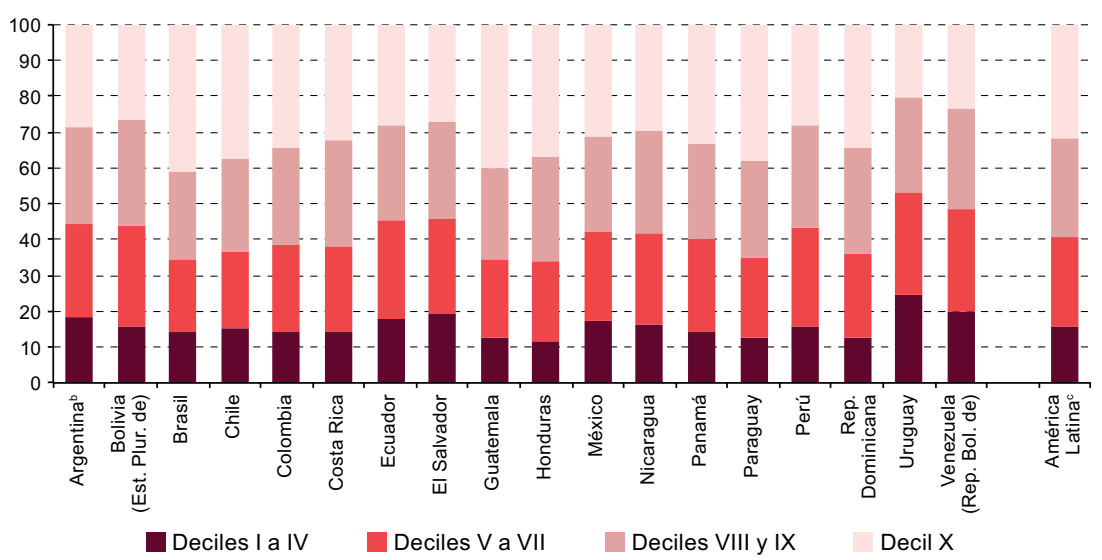

Fuente: Comisión Económica para América Latina y el Caribe (CEPAL), Panorama Social de América Latina, 2013 (LC/G.2580), Santiago, 2013.

a Los datos corresponden al año 2012, excepto en los casos de Bolivia (Estado Plurinacional de), Chile, Panamá y el Paraguay (2011), Honduras (2010), Nicaragua (2009) y Guatemala (2006).

b Áreas urbanas.

c Promedio simple.

Los resultados sugieren que la política fiscal beneficia a los grupos de ingresos más bajos de la población, principalmente mediante las jubilaciones y pensiones públicas y otras transferencias directas en efectivo, ya que el impacto obtenido mediante el impuesto sobre la renta y las contribuciones a la seguridad social es más acotado (véase el cuadro IV.1).

Como era de esperar, la eficacia de la política fiscal en la reducción de la desigualdad es diferente entre países. Por una parte, se destacan la Argentina, el Brasil y el Uruguay, donde los impuestos sobre la renta personal, las contribuciones a la seguridad social y las transferencias públicas en efectivo (incluidas las jubilaciones y pensiones) reducen, en conjunto, la desigualdad (medida por el coeficiente de Gini) en torno a un 13\% en promedio.

Otros países donde la reducción de la desigualdad supera el promedio de la región son Chile, Costa Rica, México y Panamá, sobre todo por la incidencia de las transferencias y subsidios directos, como el programa Oportunidades en México, Chile Solidario, el programa Avancemos en Costa Rica o la Red Oportunidades en Panamá. En esos tres últimos también tienen un efecto igualador los programas de pensiones y jubilaciones públicas, mientras que en México se destaca el impacto de los impuestos directos. 


\section{Cuadro IV.1}

América Latina (17 países): coeficientes de Gini antes y después de impuestos y transferencias públicas, alrededor de 2011

\begin{tabular}{|c|c|c|c|c|}
\hline País & $\begin{array}{l}\text { Ingreso de } \\
\text { mercado }(A)\end{array}$ & $\begin{array}{l}\text { Ingreso bruto } \\
\text { solo con } \\
\text { pensiones }(B) \\
(B=A+ \\
\text { pensiones } \\
\text { públicas) }\end{array}$ & $\begin{array}{c}\text { Ingreso bruto }(C) \\
(C=B+ \\
\text { transferencias } \\
\text { públicas en } \\
\text { efectivo) }\end{array}$ & $\begin{array}{c}\text { Ingreso } \\
\text { disponible en } \\
\text { efectivo (D) } \\
\left(D=C-I^{a}-\right. \\
\left.C^{2} S^{b}\right)\end{array}$ \\
\hline Argentina & 0,536 & 0,490 & 0,484 & 0,469 \\
\hline $\begin{array}{l}\text { Bolivia (Estado } \\
\text { Plurinacional de) }\end{array}$ & 0,502 & 0,493 & 0,491 & 0,487 \\
\hline Brasil & 0,573 & 0,528 & 0,518 & 0,502 \\
\hline Chile & 0,546 & 0,526 & 0,510 & 0,499 \\
\hline Colombia & 0,531 & 0,537 & 0,531 & 0,520 \\
\hline Costa Rica & 0,528 & 0,510 & 0,503 & 0,491 \\
\hline Ecuador & 0,481 & 0,467 & 0,461 & 0,453 \\
\hline El Salvador & 0,442 & 0,445 & 0,443 & 0,430 \\
\hline Honduras $^{c}$ & 0,551 & $\ldots$ & $\ldots$ & 0,546 \\
\hline México & 0,496 & 0,494 & 0,484 & 0,460 \\
\hline Nicaragua & 0,465 & 0,464 & 0,465 & 0,452 \\
\hline Panamá & 0,546 & 0,524 & 0,519 & 0,504 \\
\hline Paraguay $^{d}$ & 0,523 & 0,524 & 0,523 & 0,520 \\
\hline Perú & 0,487 & 0,485 & 0,482 & 0,461 \\
\hline República Dominicana & 0,560 & 0,555 & 0,551 & 0,545 \\
\hline Uruguay & 0,449 & 0,411 & 0,400 & 0,381 \\
\hline $\begin{array}{l}\text { Venezuela (República } \\
\text { Bolivariana de) }\end{array}$ & 0,393 & 0,384 & 0,384 & 0,379 \\
\hline
\end{tabular}

Fuente: Elaboración propia sobre la base de encuestas de hogares.

a Impuesto sobre la renta personal.

b Contribuciones a la seguridad social.

- En Honduras no se pudo tener acceso a las variables sobre jubilaciones, pensiones y subsidios en la encuesta de hogares, por lo que no fue posible estimar su efecto en el coeficiente de Gini.

d En el caso del impuesto sobre la renta en el Paraguay, corresponde a una simulación de acuerdo con el impuesto actualmente vigente.

En el otro extremo se sitúan Colombia y el Paraguay, que presentan un leve impacto de las transferencias públicas en efectivo y de los impuestos directos en la distribución del ingreso, ya que el índice de Gini disminuye en menos de un $2 \%$ luego de la acción fiscal. Además, esos países se encuentran entre los de mayor desigualdad de ingresos de mercado y justamente en ellos la política fiscal debería tener un papel redistributivo más activo. En cambio, los países de la OCDE, que presentan una distribución más desigual de los ingresos de mercado, tienden a redistribuir más (Joumard, Pisu y Bloch, 2012). En ese sentido, la Argentina, el Brasil y Chile presentan una alta desigualdad antes de la acción fiscal, que en parte se corrige mediante pensiones y jubilaciones públicas, programas de transferencias e impuestos directos. 
Más allá de las diferencias entre países, en mayor o menor medida, en todos los casos las transferencias públicas en efectivo (como los programas de transferencias condicionadas u otros similares) y el impuesto sobre la renta personal hacen que disminuya la desigualdad en la distribución del ingreso (véase el gráfico IV.2). En general, los sistemas de pensiones públicas también contribuyen a una distribución más igualitaria, excepto en tres países donde la desigualdad aumenta como consecuencia de las pensiones (Colombia, El Salvador y Paraguay).

Gráfico IV.2

América Latina (16 países): reducción de la desigualdad, según instrumento de la política fiscal, alrededor de 2011

(En puntos porcentuales del coeficiente de Gini)

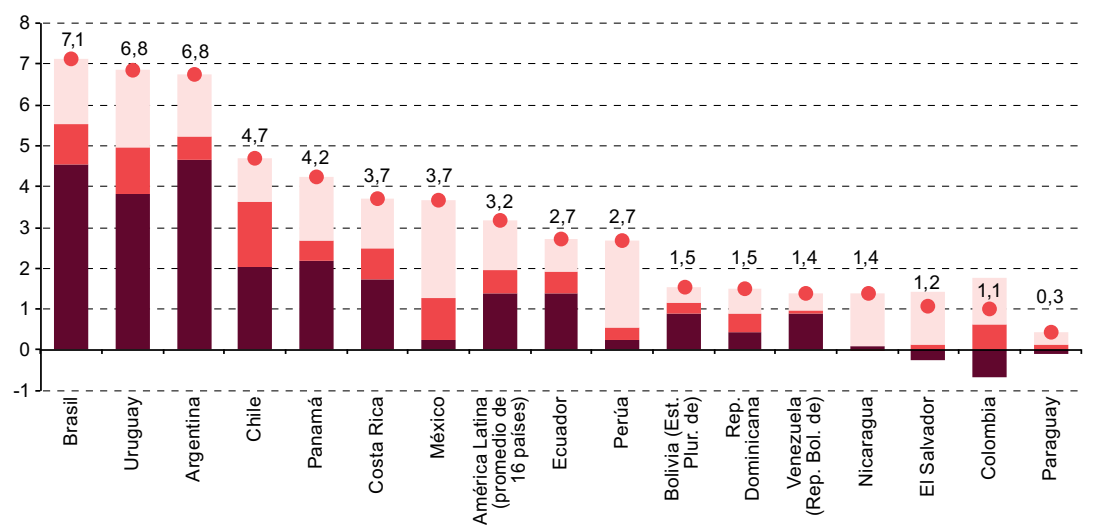

Pensiones públicas Otras trasferencias públicas en efectivo

ISR $^{\text {a }}$ personal y CSS $^{\mathrm{b}}$ Efecto global

Fuente: Elaboración propia, sobre la base de encuestas de hogares.

a Impuesto sobre la renta personal.

b Contribuciones a la seguridad social.

En promedio, el $61 \%$ de la reducción del coeficiente de Gini de los ingresos de mercado proviene de las transferencias públicas en efectivo (incluidas las pensiones) y el resto de la disminución corresponde al efecto del impuesto sobre la renta y el pago de las contribuciones a la seguridad social. Ese resultado, donde las transferencias públicas tienen un mayor papel redistributivo que los impuestos directos, es coherente con los hallazgos de otros estudios regionales.

Una de las ventajas de la metodología aplicada en estas estimaciones es que se ha seguido el enfoque de la OCDE respecto de las distintas definiciones de ingresos, lo que permite la comparación entre ambos grupos de países. En el gráfico IV.3 se ilustra la gran diferencia respecto del papel que juega la política fiscal en la reducción de la desigualdad del ingreso. Los países de América Latina parten de un coeficiente de Gini para los ingresos de mercado 
(es decir, antes de transferencias e impuestos directos), que es un tanto superior al promedio de la OCDE ( 0,50 y 0,47 , respectivamente). Sin embargo, la política fiscal en los países de la OCDE cumple un papel significativo en la reducción de la desigualdad, ya que el coeficiente de Gini cae un 36\% (un $39 \%$ en el promedio de 15 países de la Unión Europea) y se sitúa en un valor de 0,30 (en términos absolutos, el coeficiente de Gini desciende 17 puntos porcentuales en la OCDE y 19 puntos en la Unión Europea (15 países). En contraste, la disminución media de la desigualdad en la región apenas llega al 6\% (o en términos absolutos, a 3 puntos porcentuales del coeficiente de Gini respecto del promedio de 17 países), por lo que el Gini del ingreso disponible alcanza un valor medio de 0,47 (el mismo valor del coeficiente de Gini del ingreso de mercado de la OCDE).

\section{Gráfico IV.3}

América Latina (17 países), OCDE y Unión Europea (15 países): desigualdad de los ingresos de mercado, de los ingresos brutos y de los ingresos disponibles, alrededor de 2011

(Coeficientes de Gini)

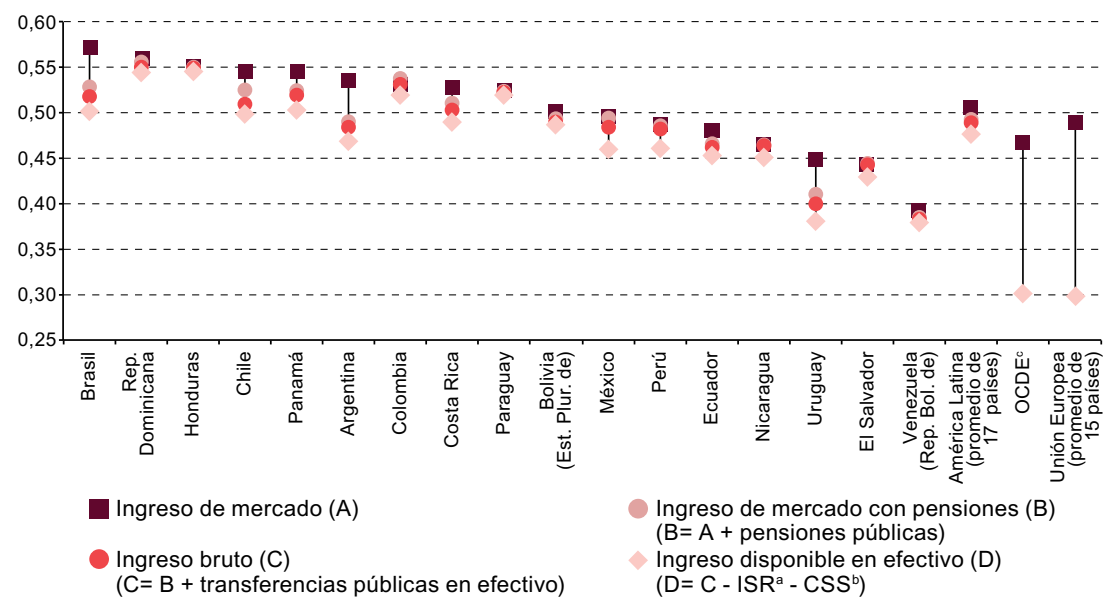

Fuente: Elaboración propia sobre la base de encuestas de hogares para América Latina y OECD.Stat.

a Impuesto sobre la renta personal.

b Contribuciones a la seguridad social.

- Organización de Cooperación y Desarrollo Económicos (considera el promedio de 30 países, excluidos Chile y México).

Las disparidades entre ambos grupos de países también pueden apreciarse en el gráfico IV.4, en que se aprecia el coeficiente de Gini antes y después de transferencias e impuestos directos. La gran mayoría de los países latinoamericanos permanecen cercanos a la recta de $45^{\circ}$, pues el Gini apenas se mueve por el efecto de la política fiscal. En contraposición, los países de la OCDE están muy por debajo de esa recta, lo que indica un efecto mucho más significativo de los instrumentos fiscales. 


\section{Gráfico IV.4}

América Latina (17 países), OCDE y Unión Europea (15 países): desigualdad de los ingresos de mercado y de los ingresos disponibles, alrededor de 2010 y 2011

(En coeficientes de Gini)

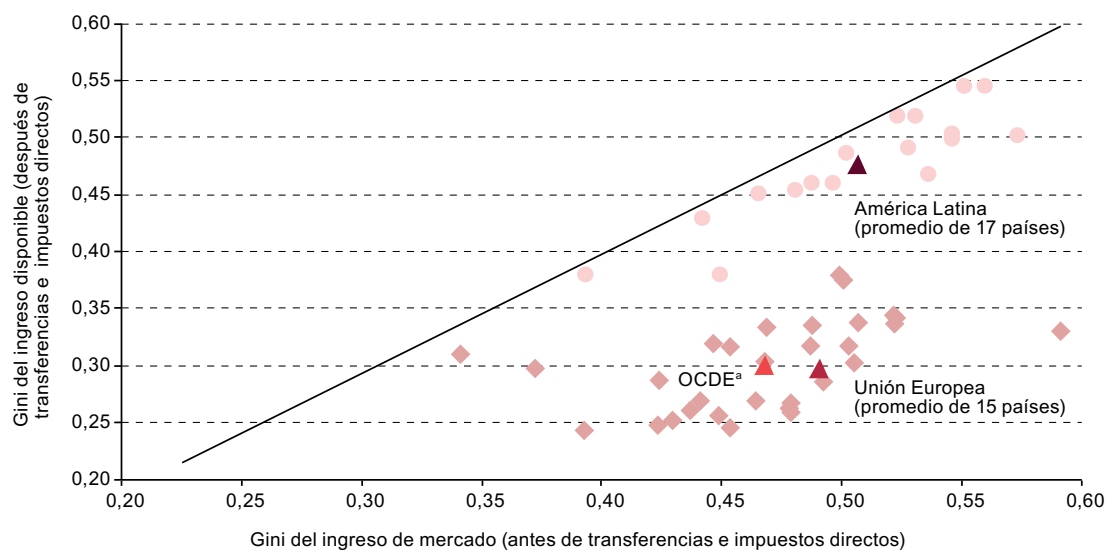

Fuente: Elaboración propia sobre la base de encuestas de hogares para América Latina y OCDE.Stat.

Nota: Los círculos representan países de América Latina; los rombos, países de la OCDE, y los triángulos, los promedios correspondientes.

a Promedio de 30 países de la Organización de Cooperación y Desarrollo Económicos (excluidos Chile y México).

Una razón de esa diferencia en el poder de la política fiscal para mejorar la distribución del ingreso en América Latina guarda relación con la menor carga tributaria que, si bien ha mejorado en los últimos años, aún se encuentra muy por debajo de los niveles de los países pertenecientes a la $\mathrm{OCDE}^{10}$. Esa carga más baja condiciona el nivel del gasto público y de los programas sociales y, por lo tanto, la amplitud del impacto de la política fiscal en el ingreso de los estratos más bajos. Además, no solo el nivel de la carga tributaria es diferente, sino también su estructura, ya que en los países de la región dicha estructura está sesgada hacia los impuestos indirectos, mientras que en los países de la OCDE se recauda una importante fracción de impuestos directos, en especial, del impuesto sobre la renta personal, que es el que tiene una mayor repercusión redistributiva. Por ejemplo, el promedio de recaudación en la OCDE por concepto de impuesto sobre la renta de los individuos llega al 8,4\% del producto interno bruto (PIB). En cambio, en América Latina y el Caribe apenas promedia 1,4 puntos del PIB.

Aparte de lo anterior, la diferencia en la cobertura previsional entre los países de la región y los de la OCDE también es un factor que puede explicar el distinto impacto de la política fiscal. Una fracción importante de los adultos mayores en países con amplia cobertura recibe una pensión no contributiva: en el Uruguay, el 11\%; en la Argentina, el 25\%; en Chile, el 26\%, y en el Brasil, el 36\% (Bosch, Melguizo y Pagés, 2013). De acuerdo con los

10 Véanse CEPAL (2013a) y OCDE/CEPAL/CIAT (2014). 
resultados aquí estimados, en esos cuatro países, además de Costa Rica, los efectos de las pensiones en la desigualdad son más relevantes que en los otros casos latinoamericanos.

Otro indicador que sirve para evaluar la repercusión de las transferencias y los impuestos directos es la razón entre el ingreso medio del decil superior y el inferior respecto de las diferentes definiciones de ingreso (véase el cuadro IV.2). Esa relación es útil para complementar el análisis de los coeficientes de Gini. Dado que la mayoría de los programas de transferencias públicas se centran en la población más vulnerable (primeros deciles de ingresos) y el impuesto sobre la renta personal se centra en los dos deciles superiores, la distribución no se modifica sustancialmente.

\section{Cuadro IV.2 \\ América Latina (17 países): relación del ingreso medio per cápita entre los deciles X y I, alrededor de 2011 \\ (En número de veces)}

\begin{tabular}{|c|c|c|c|c|}
\hline País & $\begin{array}{l}\text { Ingreso de } \\
\text { mercado (A) }\end{array}$ & $\begin{array}{c}\text { Ingreso de } \\
\text { mercado con } \\
\text { pensiones }(B) \\
(B=A+\text { pensiones } \\
\text { públicas })\end{array}$ & $\begin{array}{c}\text { Ingreso bruto }(\mathrm{C}) \\
(\mathrm{C}=\mathrm{B}+ \\
\text { transferencias } \\
\text { públicas en } \\
\text { efectivo) }\end{array}$ & $\begin{array}{c}\text { Ingreso } \\
\text { disponible en } \\
\text { efectivo (D) } \\
\left(D=C-I^{a}-\right. \\
\left.C S S^{b}\right)\end{array}$ \\
\hline Argentina & 38,1 & 31,5 & 27,8 & 24,8 \\
\hline $\begin{array}{l}\text { Bolivia (Estado } \\
\text { Plurinacional de) }\end{array}$ & 51,2 & 51,1 & 47,5 & 46,1 \\
\hline Brasil & 52,0 & 58,7 & 38,2 & 34,2 \\
\hline Chile & 33,1 & 31,6 & 27,7 & 24,7 \\
\hline Colombia & 34,6 & 39,1 & 36,1 & 33,7 \\
\hline Costa Rica & 39,8 & 36,9 & 32,4 & 29,5 \\
\hline Ecuador & 28,4 & 25,2 & 23,3 & 21,9 \\
\hline El Salvador & 17,9 & 18,7 & 18,3 & 16,8 \\
\hline Honduras $^{c}$ & 40,6 & $\ldots$ & $\ldots$ & 39,2 \\
\hline México & 27,9 & 28,6 & 24,1 & 20,8 \\
\hline Nicaragua & 21,8 & 22,2 & 22,3 & 20,7 \\
\hline Panamá & 43,8 & 44,5 & 38,9 & 34,8 \\
\hline Paraguay $^{d}$ & 36,0 & 37,7 & 37,1 & 35,8 \\
\hline Perú & 35,1 & 36,5 & 33,3 & 29,0 \\
\hline $\begin{array}{l}\text { República } \\
\text { Dominicana }\end{array}$ & 47,7 & 47,7 & 43,9 & 41,9 \\
\hline Uruguay & 15,6 & 15,0 & 13,0 & 11,3 \\
\hline $\begin{array}{l}\text { Venezuela } \\
\text { (República } \\
\text { Bolivariana de) }\end{array}$ & 13,8 & 14,4 & 14,3 & 13,8 \\
\hline
\end{tabular}

Fuente: Elaboración propia sobre la base de encuestas de hogares.

a Impuesto sobre la renta personal.

b Contribuciones a la seguridad social.

c En Honduras no se pudo tener acceso a las variables sobre jubilaciones, pensiones y subsidios en la encuesta de hogares, por lo que no fue posible estimar su efecto en el coeficiente de Gini.

d En el caso del impuesto sobre la renta en el Paraguay, corresponde a una simulación de acuerdo con el impuesto actualmente vigente. 
De acuerdo con ese indicador, en varios países los beneficios de los sistemas de seguridad social hacen que aumenten en mayor proporción los ingresos del decil superior que los del decil I, por lo que la distribución del ingreso se torna menos igualitaria. Lo contrario sucede con los programas de transferencias públicas directas que benefician notablemente al decil de más bajo ingreso, siendo el instrumento que tiene mayor impacto redistributivo. El Brasil, Costa Rica, México y Panamá están entre los países en que esos programas surten los mayores efectos, ya que la razón de ingreso disminuye en mayor magnitud. Después del pago del impuesto sobre la renta y de las cotizaciones sociales, la cantidad de veces que representa el ingreso del decil $X$ en el ingreso del decil I vuelve a reducirse, siendo el Brasil, Chile, Costa Rica y México los países que muestran las caídas más significativas.

El efecto final de la acción fiscal sobre el promedio de los países de la región indica que esa razón pasa de 34 respecto de los ingresos de mercado a 28 respecto de los ingresos disponibles en efectivo (después de transferencias e impuestos directos). Si bien ello implica una disminución en la desigualdad de ingresos entre el decil más alto y el más bajo, la región se encuentra muy alejada de los parámetros de la OCDE o de la Unión Europea (15 países), donde el ingreso medio del decil X es solo 8 veces el del decil I, después de considerar los impuestos y transferencias directas.

\section{Progresividad y potencial redistributivo del impuesto sobre la renta personal}

Con el fin de evaluar la progresividad o regresividad del impuesto sobre la renta de las personas físicas, en primer lugar se estiman las tasas medias que paga cada decil. En general, se aprecia que, a mayor nivel de ingresos (deciles superiores), mayor es la proporción de impuestos que se paga. Es decir, el impuesto con base en la renta personal es progresivo (véase la parte izquierda del cuadro IV.3). Sin embargo, la curva de progresión de tasas medias no es siempre creciente (por ejemplo, en Colombia y el Paraguay), por lo que también se estima el índice de Kakwani que determina que ese tributo es progresivo en todos los países, ya que su valor es positivo.

En la mayor parte de los países, el $90 \%$ (o más) del impuesto es soportado por el $20 \%$ de los contribuyentes de ingresos más elevados, mientras que el grupo de hogares pertenecientes al $80 \%$ de ingresos inferiores no aporta a la recaudación del tributo o lo hace en una proporción muy pequeña. 


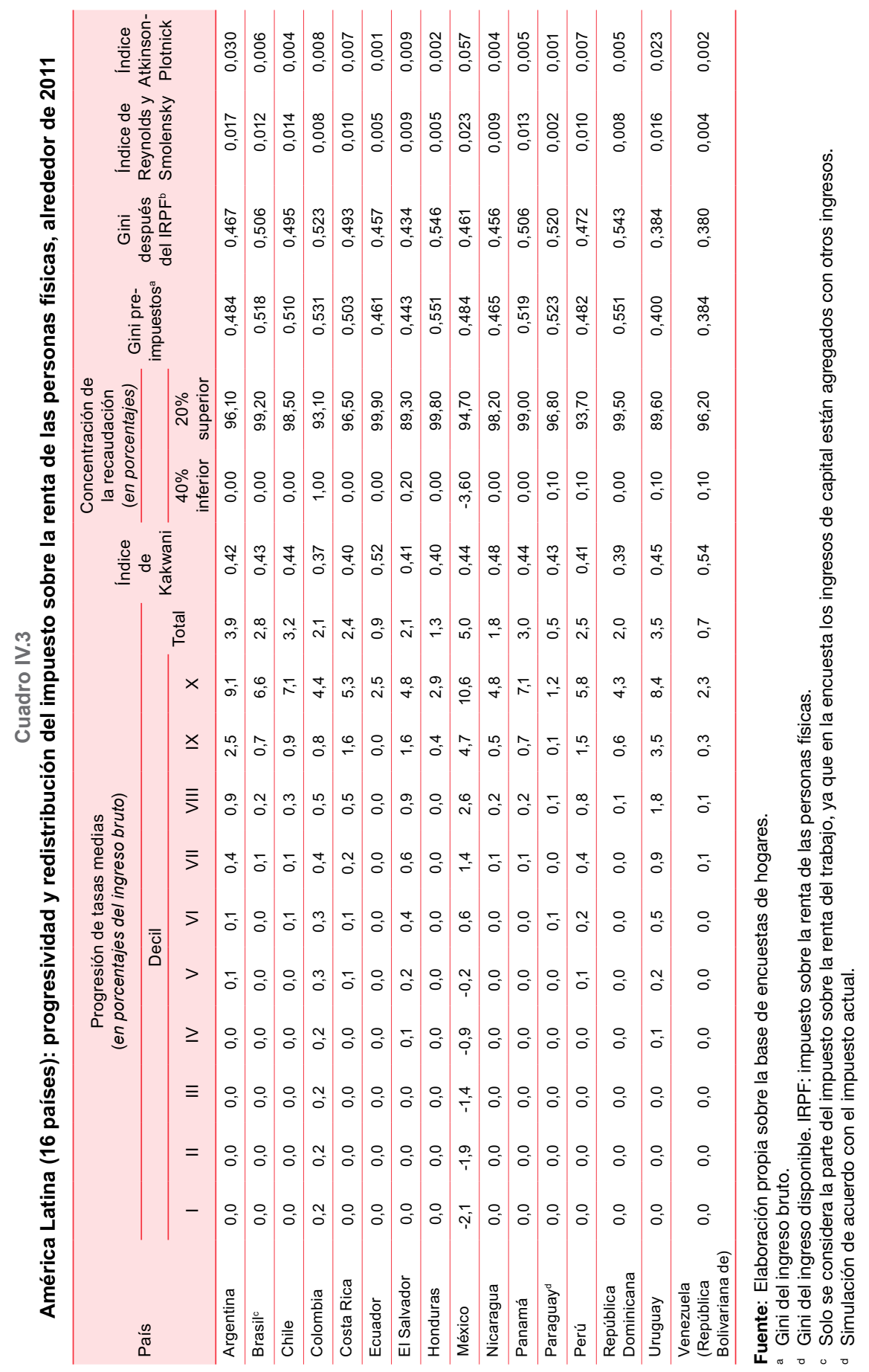


No obstante, se observa que la tasa efectiva que pagan los individuos pertenecientes al decil de mayores ingresos apenas alcanza un valor medio del $5,4 \%$. Hay países donde se paga solo entre el $1 \%$ y el $3 \%$ del ingreso bruto. $\mathrm{Si}$ bien las tasas legales máximas del impuesto sobre la renta personal se sitúan entre el $25 \%$ y el $40 \%$, las tasas efectivas que paga el decil superior son muy bajas, como consecuencia de la evasión y la elusión, las exenciones, las deducciones y el trato preferencial de las rentas de capital, que en algunos países no están gravadas y en otros tributan a una tasa más baja que las rentas del trabajo.

Además, cabe destacar que, si bien el diseño del impuesto sobre la renta personal es progresivo en todos los países, su impacto redistributivo es muy limitado como consecuencia de los bajos niveles de recaudación. En otras palabras, según el índice de Reynolds y Smolensky, el índice de Gini se reduce, en promedio, 0,01 puntos (un 2\%) por la acción de ese impuesto, con ciertas diferencias entre un país y otro (véase la parte derecha del cuadro IV.3) ${ }^{11}$. En México, por ejemplo, la distribución del ingreso (medida por el índice de Gini) mejora en casi un 5\% gracias al impacto de los impuestos que gravan la renta personal. Otros países que se destacan por un mayor efecto redistributivo son la Argentina y el Uruguay, con una mejora de la equidad vertical del orden del 3,5\% y el 4\%, respectivamente. En el extremo opuesto se encuentran el Ecuador, Honduras, el Paraguay y Venezuela (República Bolivariana de), donde la reducción del coeficiente de Gini es cercana al 1\%.

Esas características han transformado el impuesto sobre la renta personal en la principal debilidad estructural de los sistemas tributarios de América Latina. En décadas pasadas, la política tributaria ha privilegiado la eficiencia. Se ha intentado hacer que el tributo afecte lo menos posible las decisiones de ahorro e inversión y, en ciertos casos, se ha aproximado la base imponible a una base de consumo en vez de la tradicional base de ingresos.

No obstante, se han sacrificado los atributos de equidad y simplicidad. El principal aspecto que afecta a la equidad del impuesto sobre la renta personal es el trato preferencial que reciben las rentas de capital, lo que provoca una asimetría con respecto a la tributación de las rentas del trabajo. También afecta a la equidad el hecho de que se trata de una unidad de tributación que considera a los individuos en vez de los hogares, lo que estimula el fraccionamiento de las rentas a fin de reducir la tributación, además de las rentas exentas que favorecen más a los percentiles de mayores ingresos (Jorratt, 2011).

11 En este trabajo, ese índice se define como RS = Gini antes de impuesto - Gini después de impuesto, y capta tanto los cambios de la equidad vertical (que se obtienen del índice RS convencional sin reordenamiento) como de la equidad horizontal (por el efecto de reordenamiento, calculado de forma aislada mediante el índice Atkinson-Plotnick). 
En los últimos años, varios países de la región han llevado a cabo una serie de reformas tributarias con que se ha procurado mejorar la recaudación mediante el aumento de las tasas, la reducción de las exenciones, la implementación de sistemas de imposición dual en algunos casos, la modificación o creación de impuestos mínimos, y el aumento de la fiscalización a los grandes contribuyentes ${ }^{12}$. Sin embargo, la incidencia de esas reformas en la desigualdad sigue siendo muy limitada en la mayoría de los países, como lo muestran los estudios recientes de la CEPAL ${ }^{13}$. Para una mejora sustantiva de la equidad tributaria es fundamental incrementar la tributación de las rentas del capital y las tasas medias efectivas de los últimos deciles o centiles, que son comparativamente bajas.

En consecuencia, es importante evaluar las reformas bajo el prisma de la equidad en la distribución del ingreso disponible. Con tal objetivo, a continuación se describen las reformas potenciales del impuesto sobre la renta personal que se han considerado en esta investigación:

- Derogación de los principales gastos tributarios que benefician a las personas naturales, sin modificar los tramos de la escala ni las tasas marginales. Es decir, se gravan todos los ingresos percibidos, incluidos los de capital y de transferencias de cualquier origen. En los países en que el impuesto sobre la renta de las personas físicas (IRPF) contiene tasas diferenciadas, según fuente de ingreso, se aplican los tramos y las tasas progresivas que gravan los ingresos laborales a todos los tipos de ingresos.

- Impuesto sobre la renta familiar, donde se consideren los siguientes elementos ${ }^{14}$ :

- La unidad de tributación son los hogares en vez de los individuos.

- Se utiliza la misma base imponible del escenario i), pero expresada como renta equivalente y sobre la que se aplica la escala actual de tasas.

- Se ajustan todos los tramos de la escala de tasas con un mismo factor, de tal forma que la recaudación sea igual a la obtenida en el escenario i).

- Impuesto estándar: se evalúa la aplicación de una escala de tasas idéntica para todos los países sobre una base imponible amplia,

12 Véase en CEPAL (2014a) y (2013) una descripción detallada de las reformas implementadas en la región durante el período 2007-2013.

13 Los estudios relacionados con Bolivia (Estado Plurinacional de), Chile, Ecuador, El Salvador, Guatemala, Honduras y el Perú muestran que la incidencia en la distribución del ingreso de las reformas del impuesto a la renta ha sido más bien limitada.

14 Si bien esa medida puede ser de difícil aplicación en la práctica, en este estudio se realiza una serie de ejercicios donde se evalúa un amplio espectro de reformas potenciales, sin considerar su factibilidad jurídica. 
sin gastos tributarios. Con ello se pretende evaluar las diferencias de potencial redistributivo del impuesto en los distintos países. Se considera la misma base imponible del escenario i) y se reemplaza la escala de tasas del impuesto personal de cada país por una escala común.

Como se sabe, el indicador de Gini apenas varía con las simulaciones que afectan marginalmente a los ingresos de los deciles superior o inferior, como en este tipo de ejercicios. En otras palabras, desde el punto de vista impositivo, más que simular medidas detalladas, también es interesante invertir el ejercicio. Partiendo del supuesto de que se logra incrementar las tasas medias efectivas de los deciles más altos (sin precisar cómo), luego se estima su incidencia en la distribución del ingreso ${ }^{15}$. Por lo tanto, se agregan dos ejercicios:

i) Sobre la base del escenario i) se incrementa al $20 \%$ la tasa efectiva del último decil. Con ese fin se levanta el supuesto de que los trabajadores informales no pagan el impuesto sobre la renta personal en el último decil.

ii) Además de aplicar una tasa efectiva del $20 \%$ al decil $X$, se aumenta al 10\% la carga de los deciles VIII y IX, también sobre la base del escenario i).

Además, en cada uno de los cinco escenarios se evalúa el efecto de redistribuir, mediante transferencias en efectivo, la mayor recaudación obtenida con respecto a la situación actual. Como se trata de simulaciones estáticas, donde no se toman en cuenta los efectos de segunda vuelta, no es necesario precisar cómo se asignan esos mayores recursos, pues se supone una distribución en partes iguales entre los individuos pertenecientes a los tres deciles de menores ingresos.

Los resultados indican que existe un amplio espacio para mejorar el poder redistributivo del impuesto sobre la renta personal en América Latina (véase el gráfico IV.5). La equidad vertical y la horizontal mejoran con la eliminación de los principales gastos tributarios del impuesto sobre la renta (aún sin considerar el efecto de redistribuir la recaudación adicional). Cuando se pasa a un régimen de impuesto familiar, la desigualdad disminuye un poco más ${ }^{16}$. La aplicación de un impuesto estándar (escenario iii) en todos los países, sobre una base imponible amplia, también mejora el papel

15 Este ejercicio dista de ser vano. Por ejemplo, en Chile la reforma tributaria de 2014 apunta a más que doblar, mediante cambios de tasas, eliminación de exenciones y una mayor fiscalización, la tasa media efectiva del decil 10, la que alcanzaría en régimen una cifra superior al 20\%, similar a la de la Unión Europea (véase el documento "Artículo 1, el corazón de la reforma tributaria" [en línea] http://reformatributaria.gob.cl/documentos.html).

16 Ese mayor efecto redistributivo del impuesto familiar es coherente con los resultados obtenidos por Jorratt (2011) en sus simulaciones respecto del Ecuador, Guatemala y el Paraguay, que se resumen en la sección B del capítulo II de este libro. 
redistributivo del impuesto sobre la renta, aunque muestra un mayor cambio en el ordenamiento de los individuos (índice Atkinson-Plotnick).

\section{Gráfico IV.5}

América Latina: tasa media efectiva del decil $X$, redistribución y efecto de reordenamiento del impuesto sobre la renta de personas físicas bajo distintos escenarios ${ }^{a}$

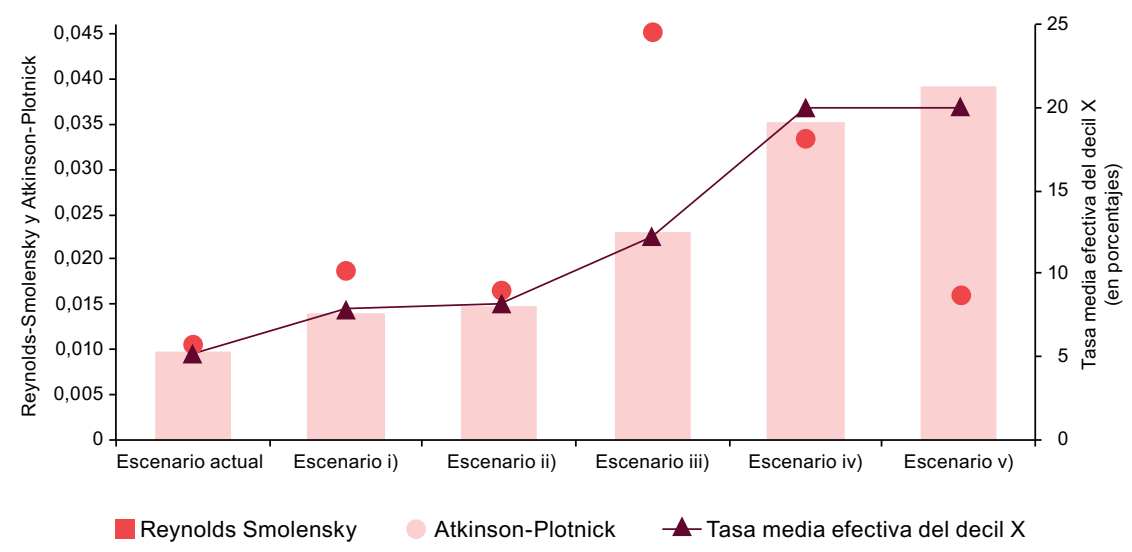

Fuente: Elaboración propia sobre la base de encuestas de hogares.

Nota: Escenario i) impuesto sobre la renta de personas físicas sin gastos tributarios; ii) impuesto familiar; iii) impuesto estándar; iv) tasa del $20 \%$ al decil X, y v) tasa del $20 \%$ al decil X, y del $10 \%$ a los deciles VIII y IX.

a Escenarios sin redistribuir la recaudación adicional hacia los deciles inferiores.

Si los países de la región lograran incrementar hasta en un $20 \%$ la tasa efectiva que paga el decil superior de la escala de ingresos, el efecto redistributivo del impuesto sobre la renta personal, medido por el índice de Reynolds y Smolensky, aumentaría considerablemente. Con el fin de lograr ese aumento en la tasa efectiva se han eliminado los principales gastos tributarios, las rentas de capital han recibido el mismo trato impositivo que las del trabajo y se ha levantado el supuesto de evasión. De acuerdo con las estimaciones realizadas, para alcanzar tal efecto, la tasa media legal aplicable a los contribuyentes del último decil se ubicaría entre un $20 \%$ y un $30 \%$, según el país. Esos valores son inferiores o cercanos a las tasas máximas vigentes en cada legislación, con excepción del Paraguay, que tiene una alícuota legal máxima del $10 \%$.

El hecho de gravar adicionalmente los deciles VIII y IX con una tasa media efectiva del 10\% también disminuye la desigualdad.

Los resultados de los últimos dos escenarios ilustran ciertas debilidades del impuesto sobre la renta personal en los países de la región: en particular, el alto nivel de evasión y elusión; las estructuras impositivas que suelen dejar sin gravar ciertos ingresos y el elevado nivel de ingreso a partir del que se aplican las tasas máximas. 
A pesar de que, en los primeros escenarios, la ampliación de la base imponible incrementa las tasas medias efectivas, especialmente las de los últimos deciles, dichas tasas aún se mantienen relativamente bajas (véase el gráfico IV.5). Entre las razones de ese comportamiento se destaca que, a diferencia de los países de la OCDE, los países de la región han reducido sus tasas máximas y las han hecho converger hacia las tasas de las personas jurídicas (Cetrángolo y Gómez Sabaini, 2007). Ese factor se ve agravado por el alto nivel de ingreso a partir del que se aplican las tasas máximas. En promedio, en América Latina la tasa máxima empieza a aplicarse a ingresos 9 veces mayores que el PIB per cápita, en comparación con 6,5 veces en el conjunto de los países de ingreso medio (Ter-Minassian, 2012). Los resultados de los últimos dos escenarios, y en menor medida el del escenario iii), demuestran que el hecho de lograr un aumento en las tasas medias efectivas (superando ciertas debilidades en la estructura del impuesto actual junto con una diminución de la evasión fiscal) conduciría a alcanzar una mayor redistribución del ingreso.

Un argumento común en contra de reformas como las aquí simuladas es que podrían reducir la progresividad del impuesto, ya que en la mayoría de los países las deducciones permitidas buscan dar mayor progresividad al sistema. Al parecer, la disminución del índice de Kakwani en el escenario de eliminación de los principales gastos tributarios valida ese argumento (el indicador cae de un valor medio de 0,44 a 0,37 ). Sin embargo, de acuerdo con lo señalado por Díaz de Sarralde, Garcimartín y Ruiz-Huerta (2010), la descomposición propuesta por Kakwani tal vez no sea apropiada para analizar reformas tributarias que aumenten la recaudación, similares a las aquí presentadas. Esto se debe a que, si el cálculo del índice de Kakwani se ve influido por cambios en la tasa media efectiva, una caída de ese índice podría reflejar una disminución de la progresividad del impuesto o, simplemente, un cambio en la tasa media efectiva, como lo que ocurre en estas simulaciones. Así, la ampliación de la base imponible conduce a un incremento de las tasas efectivas del impuesto, sobre todo en los dos deciles de mayores ingresos, y el efecto redistributivo es mayor que en el caso actual (véase el gráfico IV.5).

De hecho, en los escenarios considerados, la mayor equidad vertical se alcanza por medio del importante incremento de las tasas medias efectivas. Por otra parte, es relevante notar que el aumento de dichas tasas se debe a que los deciles superiores pagan una mayor proporción del impuesto en relación con su ingreso. Además, el diferencial entre las tasas que pagan los deciles superiores y los inferiores se amplía como consecuencia de esas medidas.

A su vez, se observa que los efectos sobre el Gini son relativamente menores en los escenarios antes descritos, donde no se redistribuyen los recursos generados por la mayor recaudación obtenida. Suele afirmarse, sobre la base de este tipo de ejercicios, que el efecto de los sistemas tributarios 
(y en particular del impuesto sobre la renta) es relativamente menor en la distribución del ingreso. No obstante, es importante estimar el efecto total, considerando el destino que se da a aquellos recursos.

En efecto, el aumento de las tasas efectivas, junto con la posterior redistribución de esos ingresos hacia los tres deciles inferiores, permitiría reducir el Gini para el promedio de la región en un rango que va desde 3 puntos porcentuales, en el caso del impuesto sin gastos tributarios y el familiar, hasta 13 puntos porcentuales en el escenario de aumento de la tasa efectiva que se aplica a los tres deciles superiores de la escala de ingresos (véase el gráfico IV.6). De esa forma, el Gini medio del ingreso disponible en la región se ubicaría entre 0,45 y 0,36, dependiendo del escenario de política considerado. Esta última cifra se acerca bastante al índice medio de los países de la OCDE o de 15 países de la Unión Europea, que se sitúa en torno al 0,30.

\section{Gráfico IV.6}

América Latina: reducción media del coeficiente de Gini debido al impuesto sobre la renta de las personas físicas bajo distintos escenarios (Índice de Reynolds y Smolensky)

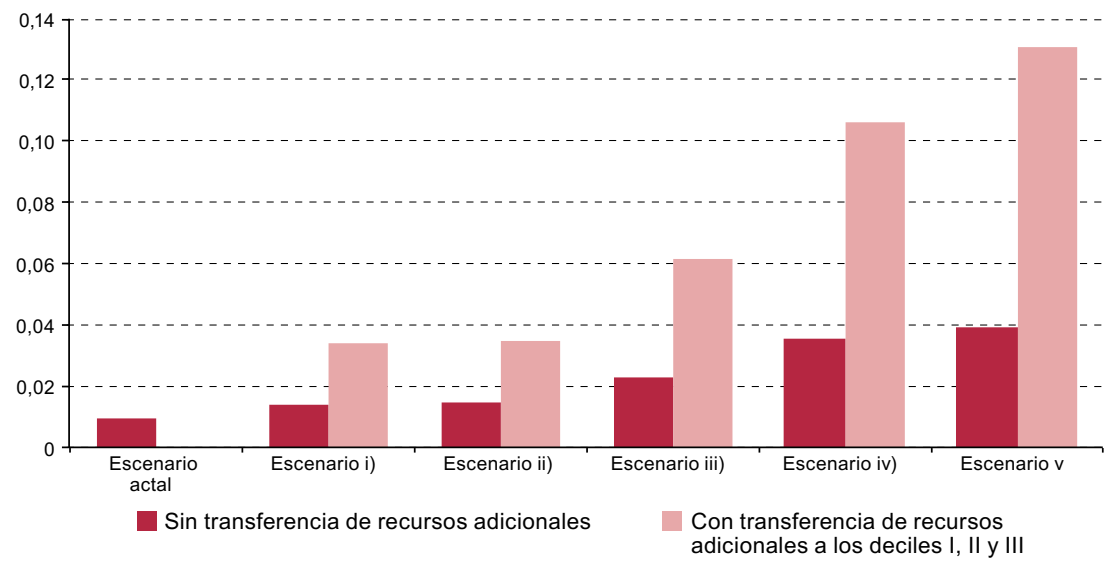

Fuente: Elaboración propia sobre la base de encuestas de hogares.

Nota: Escenario i) impuesto sobre la renta de las personas físicas sin gastos tributarios; ii) impuesto familiar; iii) impuesto estándar; iv) tasa del $20 \%$ al decil X, y v) tasa del $20 \%$ al decil X, y del $10 \%$ a los deciles VIII y IX.

Dado que el impuesto sobre la renta recae en mayor medida sobre el decil superior, la cantidad de veces que representa el ingreso del decil $X$ en el ingreso del decil I se reduce de 29,5 a 27,9 en la situación actual del promedio de los países de la región (véase el gráfico IV.7). La eliminación de las principales deducciones y exenciones y las demás alternativas de políticas apenas llevan esta razón a 26 o 27, según el escenario considerado. Entretanto, las simulaciones que aumentan hasta en un $20 \%$ la tasa efectiva del decil X, reducen a un 23,6 las veces que el ingreso medio de ese decil se representa en el decil más bajo. 


\section{Gráfico IV.7 \\ América Latina: relación media del ingreso medio per cápita entre el decil $\mathbf{X}$ y el decil I bajo distintos escenarios}

(En número de veces)

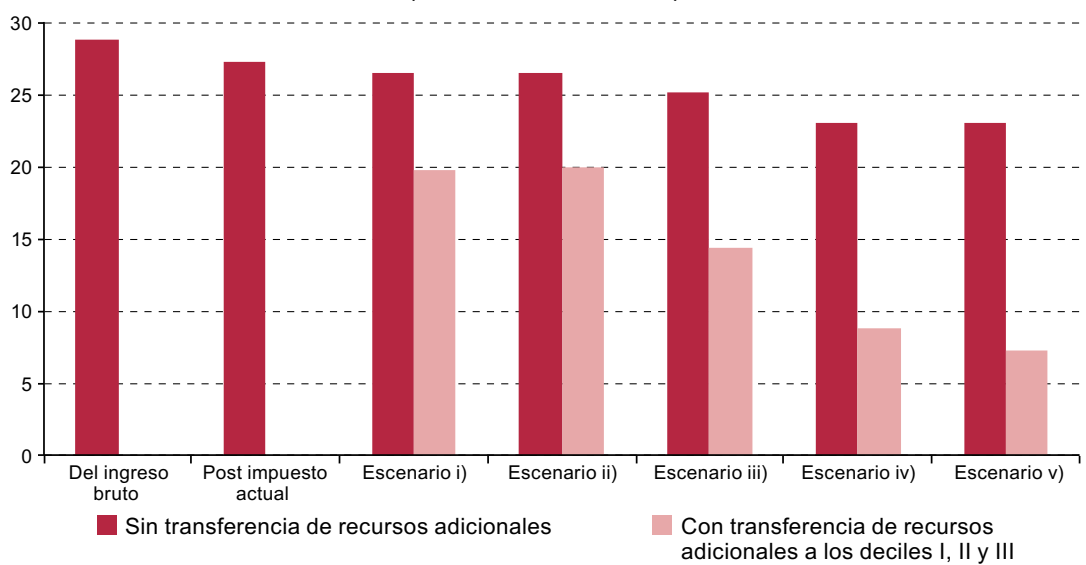

Fuente: Elaboración propia sobre la base de encuestas de hogares.

Nota: Escenario i) impuesto sobre la renta de las personas físicas sin gastos tributarios; ii) impuesto familiar; iii) impuesto estándar; iv) tasa del $20 \%$ al decil X, y v) tasa del $20 \%$ al decil X, y del $10 \%$ a los deciles VIII y IX.

El efecto final de estas políticas, es decir, cuando se redistribuye la recaudación excedente a los tres deciles inferiores, sitúa esa razón en un rango entre 21 y 7, según el escenario de política analizado. Este último valor implica una significativa disminución en la desigualdad de ingresos entre el decil más alto y el más bajo, y deja a la región en una relación de ingresos similar al promedio de los países de la OCDE y de 15 países de la Unión Europea (cuyas razones son de 8,3 y 7,8, respectivamente).

\section{Conclusiones y reflexiones finales}

En América Latina la política fiscal juega aún un papel limitado a la hora de mejorar la distribución del ingreso disponible. Si bien los países de la región parten de niveles de desigualdad de los ingresos de mercado solo levemente superiores a los de la OCDE, la política fiscal en estos últimos cumple un papel significativo en la reducción de la desigualdad, ya que el coeficiente de Gini cae un 36\% después de las transferencias e impuestos directos, en comparación con solo un $6 \%$ en los países latinoamericanos (en términos absolutos, el coeficiente de Gini cae 17 puntos porcentuales en la OCDE y apenas 3 puntos porcentuales en el promedio de 17 países de América Latina).

Más allá de las claras diferencias entre países que se han ilustrado en los cálculos anteriores, en promedio, el 61\% de la reducción del coeficiente de Gini en América Latina proviene de las transferencias públicas en efectivo (incluidas las pensiones), y del resto del impuesto sobre la renta personal y el pago de las 
contribuciones a la seguridad social. Ello indica que dicho impuesto constituye una de las principales áreas de la política fiscal que es necesario fortalecer.

En ese sentido, las simulaciones de posibles reformas del impuesto sobre la renta personal evidencian que en la región existe espacio para ampliar su poder redistributivo. La equidad vertical mejora con la eliminación de los principales gastos tributarios, y también con un régimen de impuesto familiar. La aplicación de un impuesto estándar, sobre una base imponible amplia, incrementa aún más el papel redistributivo del impuesto. En el caso hipotético de que los países de la región incrementaran hasta en un 20\% la tasa efectiva que paga el decil superior en la escala de ingresos, el efecto redistributivo del impuesto sobre la renta personal aumentaría considerablemente. $\mathrm{Si}$, además, la mayor recaudación obtenida se redistribuyera hacia los deciles inferiores, la acción fiscal tendría un impacto significativo en el coeficiente de Gini.

La evaluación del efecto redistributivo de esas posibles reformas reafirma la importancia de promover la adopción de medidas contra la evasión y elusión fiscal (en especial del impuesto sobre la renta personal) y de otorgar a las rentas de capital un trato similar al aplicado a las rentas provenientes del trabajo. También sería importante reducir los tratos preferenciales y rebajar el nivel de ingreso a partir del que se aplican las tasas máximas en concordancia con los rangos establecidos en otras regiones.

Además, si la mayor recaudación obtenida a través de esas medidas se destina a reforzar las transferencias percibidas por los deciles de menores ingresos, se puede triplicar el efecto redistributivo de la política fiscal.

En conclusión, los resultados del presente estudio sugieren que uno de los grandes desafíos que sigue enfrentando la región es mejorar el poder redistributivo de la política fiscal, tanto en lo que se refiere a los impuestos como a los gastos, con el fin de promover una mayor igualdad en la distribución del ingreso disponible y una mayor reducción de los niveles de pobreza. Una ampliación de este análisis que contemple el efecto de las transferencias en especie (básicamente por servicios educativos y de salud), así como la aplicación del ejercicio a diferentes momentos en el tiempo, representaría un gran aporte para tener una perspectiva más acabada de la acción de la política fiscal y de su evolución a lo largo del tiempo.

Como la distribución del ingreso "primaria" (previa a la intervención del Estado) está determinada por diversas herencias de la riqueza tangible y material y del capital humano, la persistencia de la desigualdad refleja la inexistencia de políticas capaces de modificar esa situación en la región. Por supuesto, y como lo ha enfatizado la CEPAL en su trilogía de la igualdad (CEPAL, 2010, 2012b y 2014b), es menester desplegar múltiples iniciativas para el cambio estructural con igualdad. Las políticas fiscales redistributivas son ciertamente uno de los mecanismos que han de contribuir en el futuro a cambiar ese estigma regional. 


\section{Bibliografía}

Altimir, O. (1987), "Income distribution statistics in Latin America and their reliability", Review of Income and Wealth, vol. 33, junio.

Barreix, A., M. Bès y J. Roca (2009), “Equidad fiscal en Centroamérica, Panamá y República Dominicana”, Washington, D.C., Banco Interamericano de Desarrollo (BID)/EUROsociAL.

Barreix, A., J. Roca y L. Villela (2006), "La equidad fiscal en los países andinos", Washington, D.C., Banco Interamericano de Desarrollo (BID)/EUROsociAL.

Bosch, M., A. Melguizo y C. Pagés (2013), Mejores pensiones, mejores trabajos: hacia la cobertura universal en América Latina y el Caribe, Washington, D.C., Banco Interamericano de Desarrollo (BID).

CEPAL (Comisión Económica para América Latina y el Caribe) (2008), Panorama Social de América Latina, 2007 (LC/G.2351-P), Santiago. Publicación de las Naciones Unidas, $\mathrm{N}^{\circ}$ de venta: S.07.II.G.124.

(2010), La hora de la igualdad: brechas por cerrar, caminos por abrir (LC/G.2432 (SES.33/3)), Santiago.

(2012a), "La medición de los ingresos en la encuesta CASEN 2011-R2. Versión preliminar", Santiago, agosto, inédito.

(2012b), Cambio estructural para la igualdad: una visión integrada del desarrollo (LC/G.2524 (SES.34/3)), Santiago de Chile.

(2012c), Panorama Social de América Latina, 2011 (LC/G.2514-P), Santiago. Publicación de las Naciones Unidas, $\mathrm{N}^{\circ}$ de venta: S.12.II.G.6.

(2013), Panorama Fiscal de América Latina y el Caribe, 2013: reformas tributarias y renovación del pacto fiscal (LC/L.3580), Santiago.

(2014a), Panorama Fiscal de América Latina y el Caribe, 2014: hacia una mayor calidad de las finanzas públicas (LC/L.3766), Santiago.

(2014b), Pactos para la igualdad: hacia un futuro sostenible (LC/G.2586 (SES.35/3)), Santiago.

Cetrángolo, O. y J.C. Gómez Sabaini (2007), “La tributación directa en América Latina y los desafíos a la imposición sobre la renta", serie Macroeconomía del Desarrollo, Nº 60 (LC/G.2838-P), Santiago, Comisión Económica para América Latina y el Caribe (CEPAL).

Díaz de Sarralde, S., C. Garcimartín y J. Ruiz-Huerta (2010), "La paradoja de la progresividad en países de baja tributación: el impuesto sobre la renta en Guatemala", Revista CEPAL, Nº 102 (LC/G.2468-P), Santiago, Comisión Económica para América Latina y el Caribe (CEPAL).

Gómez Sabaini, J.C y D. Morán (2013), “Política tributaria en América Latina: agenda para una segunda generación de reformas", serie Macroeconomía del Desarrollo, N 133 (LC/L.3632), Santiago, Comisión Económica para América Latina y el Caribe (CEPAL).

Hanni, M., R. Martner y A. Podestá (2015), “El potencial redistributivo de la fiscalidad en América Latina", Revista CEPAL, No 116, Santiago, Comisión Económica para América Latina y el Caribe (CEPAL), agosto [en línea] http:/ / repositorio.cepal. org/bitstream/handle/11362/38781/RVE116Hanni_es.pdf?sequence=1.

Higgins, S. y otros (2013), "Social spending, taxes and income redistribution in Paraguay", CEQ Working Paper, N 11. 
Jorratt, M. (2011), “Evaluando la equidad vertical y horizontal en el impuesto al valor agregado y el impuesto sobre la renta: el impacto de reformas tributarias potenciales. Los casos del Ecuador, Guatemala y el Paraguay", serie Macroeconomía del Desarrollo, N 113 (LC/L.3347), Santiago, Comisión Económica para América Latina y el Caribe CEPAL.

2010), "Equidad fiscal en Chile: un análisis de la incidencia distributiva de los impuestos y el gasto social", Equidad fiscal en Brasil, Chile, Paraguay y Uruguay, Washington, D.C., Banco Interamericano de Desarrollo (BID).

Joumard, I., M. Pisu y D. Bloch (2012), "Less income inequality and more growth Are they compatible? Part 3 . Income redistribution via taxes and transfers across OECD countries", OECD Economics Department Working Papers, N 926, París, OECD Publishing.

Lambert, P. (1993), The Distribution and Redistribution of Income, Manchester University Press.

Lustig, N., C. Pessino y J. Scott (2013), "The impact of taxes and social spending on inequality and poverty in Argentina, Bolivia, Brazil, Mexico, Peru and Uruguay: An overview", CEQ Working Paper, $\mathrm{N}^{\circ} 13$.

OCDE (Organización de Cooperación y Desarrollo Económicos) (2008), Growing Unequal? Income Distribution and Poverty in OECD Countries, París, OECD Publishing.

OCDE/CEPAL/CIAT (Organización de Cooperación y Desarrollo Económicos/ Comisión Económica para América Latina y el Caribe/Centro Interamericano de Administraciones Tributarias) (2014), Estadísticas tributarias de América Latina, París, OECD Publishing.

Ter-Minassian, T. (2012), "More than revenue: Main challenges for taxation in Latin America and the Caribbean", Policy Brief, N IDB-PB-175, Washington, D.C, Banco Interamericano de Desarrollo (BID).

Verbist G. y F. Figari (2013), "The redistributive effect and progressivity of taxes revisited: an International Comparison across the European Union", AIAS, GINI Discussion Paper, $\mathrm{N}^{\mathrm{o}} 88$. 



\section{Capítulo V \\ La equidad vertical y horizontal de los impuestos ${ }^{1}$}

Michel Jorratt ${ }^{2}$

\section{Introducción}

La política tributaria puede influir en la distribución de ingresos de un país de dos formas distintas. En primer lugar, mediante el financiamiento de gastos públicos que persiguen ese objeto, en rubros tales como la salud, la educación y las transferencias asistenciales. En segundo lugar, mediante el diseño de impuestos que conforman la estructura tributaria, que pueden ser progresivos, proporcionales o regresivos, determinando su combinación un efecto agregado redistributivo.

La característica redistributiva de los impuestos se asocia principalmente con el concepto de equidad vertical, que significa que las personas de mayor capacidad contributiva deben pagar proporcionalmente más impuestos. La equidad también se entiende en un sentido horizontal: los impuestos deben

1 Este trabajo constituye una versión resumida del siguiente documento: M. Jorratt, “Evaluando la equidad vertical y horizontal en el impuesto al valor agregado y el impuesto a la renta: el impacto de reformas tributarias potenciales. Los casos del Ecuador, Guatemala y el Paraguay", Serie Macroeconomía del Desarrollo, N ${ }^{\circ}$ 113, (LC/L.3347), Santiago, Comisión Económica para América Latina y el Caribe (CEPAL), 2011 [en línea] http://repositorio.cepal.org/bitstream/ handle/11362/5345/S1100385_es.pdf?sequence=1.

2 Consultor especializado en política y administración tributaria y profesor del Departamento de Ingeniería Industrial de la Universidad de Chile. Correo electrónico: michel.jorrat@gmail.com. 
afectar de igual manera a personas que tengan igual capacidad contributiva. La equidad horizontal juega un rol importante, e indirecto, en la redistribución del ingreso, pues contribuye a la aceptación del sistema tributario, que es un factor clave para el cumplimiento tributario.

$\mathrm{Al}$ respecto, cabe preguntarse cuánto se sabe en la región sobre el fenómeno de la equidad en relación con la imposición, y si es factible llegar a plantear metodologías que permitan analizar y cuantificar ese fenómeno. Esa interrogante requiere respuesta, ya que los análisis de equidad no han tenido un desarrollo adecuado en los países de la región, al contrario de lo que se observa en los países desarrollados, donde se hace énfasis en lograr políticas públicas que garanticen la igualdad.

Con ese fin, el objetivo principal de este estudio es evaluar la equidad horizontal y vertical de los impuestos al consumo y a la renta. Ello puede desglosarse en los siguientes objetivos específicos:

- Diseñar una metodología básica que permita evaluar la equidad vertical y horizontal de los principales impuestos al consumo de los distintos países. La metodología considerará aspectos de diseños que suelen ser obviados en los estudios similares, pero que pueden provocar diferencias significativas en los resultados. Por ejemplo, la traslación del impuesto sobre el valor agregado (IVA) de los insumos en el caso de bienes exentos, que determina un impacto menor de lo esperado en las exenciones progresivas, o el efecto de cascada de las exenciones intermedias, que eleva la tasa efectiva del IVA de los productos afectos.

- Diseñar una metodología básica que permita estimar el impacto distributivo del impuesto sobre la renta y evaluar la equidad vertical y horizontal de distintas reformas legales, tales como la aplicación de un impuesto de tasa uniforme, un impuesto dual y un impuesto familiar.

- Aplicar cada una de las metodologías propuestas a tres países de la región: Ecuador, Guatemala y el Paraguay.

De esa manera, se busca apoyar a los gobiernos de la región en la introducción de un sistema impositivo más equitativo y sostenible, sobre la base de un mejoramiento en la imposición al consumo y a la renta.

\section{A. Aspectos metodológicos}

En términos generales, la metodología a utilizar consiste en comparar la distribución del ingreso de los hogares antes y después de impuestos. La estimación de los ingresos y de los impuestos pagados por hogar se realizará 
a partir de la información recogida en las encuestas de ingresos y gastos de los hogares, que se aplican periódicamente en cada país y que están disponibles en la División de Estadísticas de la CEPAL.

A continuación se describen con mayor detalle las definiciones y convenciones básicas adoptadas, las metodologías de estimación de ingresos e impuestos, las metodologías de medición de la equidad vertical y horizontal y las reformas tributarias que se simularán en los estudios de casos de países.

\section{Definiciones y convenciones básicas}

\section{a) Indicador de bienestar}

Una primera consideración metodológica se refiere a la elección de un indicador de bienestar que sirva como referencia para la medición del efecto distributivo tanto del IVA como del impuesto sobre la renta. Las opciones tradicionales son dos: ingreso y consumo. Los estudios de equidad fiscal mayoritariamente han optado por el ingreso. Sin embargo, se debe tener en consideración que, en un estudio de corte anual como el presente, la utilización del ingreso presenta algunos problemas que tienen que ver con su componente transitorio. Por ejemplo, es posible que una persona momentáneamente desocupada, pero con un patrimonio y nivel de consumo considerables, sea clasificada en el decil más pobre. A fin de evitar esos errores de clasificación, sería necesario medir el ingreso permanente, una variable que no es fácil de estimar a partir de las encuestas de hogares.

En ese sentido, el consumo tiene la ventaja de ser un buen estimador del ingreso permanente. No obstante lo anterior, en atención a la información disponible sobre los países analizados, se ha optado por utilizar el ingreso familiar como medida del bienestar.

\section{b) Unidad de análisis}

La unidad de análisis escogida es el hogar, entendido como el conjunto de personas que ocupan en común una vivienda o parte de ella y que consumen con cargo a un mismo presupuesto. Así, las variables de ingresos e impuestos se estiman primero a nivel de individuos, para luego consolidar la información a nivel de hogares, valiéndose de los enlaces entre individuos y hogares disponibles en las encuestas.

\section{c) Escala de equivalencia}

Una vez escogido el hogar como unidad de análisis, surge el problema de cómo comparar hogares de distinto tamaño. Evidentemente, dos hogares con igual renta total, pero con distinto número de integrantes, tendrán distintos niveles de bienestar. En particular, el hogar que tenga menos integrantes gozará de un mayor bienestar. La forma más frecuente de abordar ese problema 
consiste en calcular el ingreso per cápita, o sea, dividir el ingreso total entre el número de integrantes del hogar. Sin embargo, en esa fórmula no se toman en cuenta las economías de escala de los hogares. Muchos gastos asociados a la vivienda tienen características de costos semifijos. La forma de abordar esa característica es mediante las denominadas escalas de equivalencia, que permiten convertir el ingreso del hogar en una medida de bienestar equivalente, de modo que se puedan comparar hogares de distintos tamaños.

Para este trabajo se ha escogido la escala de equivalencia propuesta por Buhmann y otros (1988) y Coulter, Cowell y Jenkins (1992). Según esa escala, la renta $Y$ se transforma en la renta equivalente $Y^{e}$ mediante la siguiente fórmula:

$$
Y^{e}=\frac{Y}{n^{\alpha}}
$$

Donde $n$ es el número de integrantes del hogar, con o sin renta, y $\alpha$ un factor que refleja las economías de escala que se producen en el hogar a medida que aumenta el número de integrantes. Para los cálculos se utilizará un valor de $\alpha$ igual a 0,8 .

\section{d) Impuestos considerados y supuestos de incidencia}

Se considerarán los dos principales impuestos que afectan a los hogares: el impuesto sobre la renta personal y el impuesto sobre el valor agregado (IVA).

Se aplicarán los mismos supuestos de incidencia que reconocen la mayoría de trabajos de este tipo. Es decir, se atribuirá el pago del impuesto sobre la renta a los factores gravados y el pago del IVA a los consumidores.

\section{e) Período de estimación}

Se considerará el último año calendario disponible en las encuestas de ingresos y gastos. Un marco de análisis más general supondría una evaluación bajo una perspectiva plurianual o de ciclo de vida de los individuos. Sin embargo, debido a las dificultades de modelación y los requisitos de información asociados a ese tipo de estimaciones, se optó por aplicar una estimación anual.

\section{f) Ajustes por no declaración y subdeclaración de ingresos}

La evidencia empírica muestra que en las encuestas de hogares algunas personas no ofrecen datos respecto de algunas rentas y otras omiten una parte significativa de algunas corrientes de ingreso. Teniendo esto en cuenta, las variables de ingreso de la encuesta que se utilizarán en este trabajo han sido ajustadas con anterioridad por la División de Estadísticas de la CEPAL. En términos simples, el ajuste ante la falta de respuesta consiste en imputar a 
cada persona la renta promedio declarada por individuos similares. Mientras tanto, en el ajuste por subdeclaración, los valores originales se amplifican por un factor de corrección para hacerlos coincidir con los ingresos reportados en las cuentas nacionales.

\section{g) Imputación por uso de la vivienda propia}

El beneficio que produce el uso de la vivienda propia debe ser contabilizado como un ingreso del grupo familiar. Ese ingreso suele captarse en las encuestas cuando se pregunta a los encuestados respecto del monto que pagarían si tuviesen que arrendar la vivienda propia en que habitan. A diferencia de lo que ocurre con las demás variables de ingreso, el valor locativo presenta un ostensible grado de sobreestimación (Feres, 2007), por lo que se ajusta a la baja para hacerlo coincidir con las cifras de las cuentas nacionales.

\section{h) Autoconsumo y autosuministro}

Ambos conceptos forman parte de los ingresos familiares y, por lo tanto, deben tomarse en consideración a los fines de este estudio ${ }^{3}$. Las encuestas suelen incorporar en su cuestionario preguntas respecto de ambos ítems, por lo que quedan correctamente reflejados en las variables de ingresos.

\section{Estimación del ingreso antes de la política fiscal}

La variable de las encuestas que más se aproxima al ingreso antes de la política fiscal es el ingreso autónomo, que incorpora los ingresos líquidos del trabajo dependiente (después de impuestos y cotizaciones sociales), los ingresos del trabajo independiente, las rentas de capitales mobiliarios, las ganancias de capital realizadas, los ingresos por arriendo de bienes raíces, los retiros de utilidades, los dividendos de acciones, las pensiones y jubilaciones, otras transferencias del Estado, el autoconsumo, el autosuministro, el valor locativo y las donaciones.

Sin embargo, esa variable debe someterse a algunos ajustes. En primer lugar, se deben estimar y sumar las cotizaciones a la seguridad social, pues las encuestas recogen información sobre los ingresos líquidos. En segundo lugar, y por la misma razón, se debe sumar el impuesto sobre la renta. Por último, se deben restar las transferencias del Estado que no tengan un componente de contraprestación, puesto que forman parte de la política fiscal.

\section{Estimación de los impuestos pagados}

La principal dificultad para estimar la carga tributaria a partir de los datos contenidos en las encuestas de ingresos y gastos es que en ellas no se consigna el dato de los impuestos pagados. Tampoco es posible conocer la identidad de

Véase el anexo metodológico de Barreix, Bès y Roca (2009). 
cada encuestado para así poder vincularlo directamente con el impuesto sobre la renta que declaró ante la autoridad tributaria. Más aún, en el caso de los impuestos indirectos, ni siquiera existe una declaración individual asociable al consumidor. Para resolver ese problema hay dos caminos alternativos. El primero consiste en asignar la recaudación efectiva a los individuos, en función de alguna variable que guarde relación con la base tributaria. Por ejemplo, el impuesto sobre la renta se puede distribuir en proporción a las variables de ingreso tributable contenidas en la encuesta, mientras que el IVA se puede distribuir en proporción al consumo afecto de los hogares. La principal limitación de ese método es que dificulta la realización posterior de simulaciones de cambios legales, toda vez que no es posible reproducir en las bases de datos el cálculo del impuesto como una multiplicación de tasa y base tributaria.

El segundo camino consiste en estimar los impuestos teóricos, aplicando las tasas impositivas sobre las bases tributarias estimadas a partir de las variables recogidas en las encuestas. El problema de esa alternativa es que el impuesto resultante es de carácter teórico y no necesariamente guarda relación con lo que cada individuo pagó en la realidad. Esa disparidad puede deberse a evasión, elusión o exoneraciones legales no recogidas en la encuesta.

En este trabajo se optó por el segundo enfoque, con algunas excepciones que se comentarán más adelante.

\section{a) Cálculo del impuesto personal a la renta}

El primer paso para determinar el impuesto personal a la renta consiste en calcular la base tributaria a partir de las variables de ingreso de la encuesta. Con ese fin, al ingreso antes de la política fiscal se le deben restar los ingresos no afectos, los ingresos exentos y las deducciones. Esas magnitudes varían de país en país, dependiendo de las características de la normativa tributaria. No obstante, en la mayor parte de las legislaciones no se consideran dentro de la base imponible las cotizaciones a la seguridad social, el autoconsumo, el autosuministro ni el valor locativo. Mientras tanto, puede ser necesario sumar algunos subsidios monetarios en la medida en que la ley los considere tributables.

En casi todas las legislaciones del impuesto sobre la renta existen algunos gastos tributarios, en forma de deducciones o créditos contra el impuesto, cuyo monto no guarda relación con ninguna de las variables disponibles en las encuestas, pero que deben tomarse en consideración porque pueden afectar significativamente el monto de los impuestos pagados. En esos casos, se deberá hacer una imputación aleatoria, a nivel de deciles, de los montos efectivos.

Sobre la base tributaria neta de las deducciones por gastos tributarios, se debe aplicar la escala de tasas. Del impuesto así determinado, se deben 
restar los créditos contra el impuesto, obteniendo de esa manera el impuesto sobre la renta de cada individuo.

\section{b) Cálculo del IVA}

Con el fin de calcular el IVA pagado por los hogares, es necesario contar con una encuesta de presupuestos familiares que incluya información sobre el gasto de los hogares a nivel de productos. Con base en los consumos por productos de esa encuesta y un cuadro de oferta-utilización de las cuentas nacionales, es posible estimar las tasas efectivas de IVA por producto. En la tasa efectiva se debe considerar el IVA trasladado de los insumos al precio final, en el caso de los productos de consumo final exentos, así como el efecto de cascada que eleva la tasa efectiva de los productos afectos, debido a las exenciones que afectan a las transacciones intermedias.

El primer componente de la tasa efectiva corresponde a la tasa legal que soportan los bienes gravados, expresada como porcentaje del precio de venta al público $(t /(1-t))$. En segundo lugar, se debe calcular la tasa implícita por traslación de los bienes exentos, considerando el impuesto que pagaron los bienes afectos que sirvieron de insumos para la producción de esos bienes exentos. Luego se debe calcular la tasa implícita por traslación a los bienes gravados en cuya producción se utilizaron bienes exentos intermedios, toda vez que al usarse como insumos, agregan una carga extra de IVA denominada de "cascada" o "piramidación". Esos dos últimos cálculos se realizan a partir de la información sobre transacciones intermedias, extraída del cuadro de oferta-utilización.

$\mathrm{Al}$ adicionar los tres componentes descritos se determina una tasa implícita de IVA total por producto (si es gravado, se utiliza el efecto estándar del gravamen en el producto; si es exento, se utiliza la carga contenida en los insumos y, si es gravado y utiliza insumos exentos, se utiliza la carga de "cascada" contenida en el producto). Esa tasa implícita de IVA total por producto se aplica luego al gasto de cada hogar en el respectivo producto. Por último, se agrega la información para obtener el IVA efectivo pagado por cada hogar.

\section{4. Índice de equidad}

\section{a) Índices de equidad vertical ${ }^{4}$}

Una vez que se ha estimado el ingreso de los hogares antes y después de impuestos, será necesario evaluar cómo estos han afectado la distribución del ingreso. Es decir, se busca conocer si el impuesto analizado es progresivo y en qué grado lo es. Con ese fin, se recurrirá a tres indicadores ampliamente

Véase en Barreix, Bès y Roca (2009) una descripción detallada de los índices de equidad vertical que aquí se mencionan. 
utilizados en estudios recientes sobre redistribución de la política fiscal, a saber, la progresión de tasas medias, el índice de Kakwani y el índice de Reynolds y Smolensky.

La progresión de tasas medias muestra la tasa efectiva del impuesto, definida como el cociente entre el impuesto y el ingreso, respecto de los distintos percentiles de ingreso equivalente. El impuesto será progresivo si la tasa efectiva crece junto con el ingreso equivalente de los hogares. Queda implícito que, si la progresión de tasas medias es creciente, el ingreso después del impuesto habrá disminuido en mayor medida, proporcionalmente, para los percentiles de mayores ingresos, lo que conduce a una mejora en la distribución del ingreso. Cuando la curva de progresión de tasas medias no es monótona, se dificulta establecer conclusiones respecto de la progresividad del impuesto (con ese indicador).

El índice de Kakwani compara la curva de Lorenz del ingreso equivalente de los hogares antes de impuestos con la curva de concentración del impuesto (Kakwani, 1977). En el eje horizontal de la curva de Lorenz se muestra el porcentaje acumulado de los hogares y, en el eje vertical, el porcentaje acumulado de los ingresos, después de ordenar los hogares de menor a mayor ingreso. Así, el punto $(x, y)$ de la curva indicará que el $x \%$ de los hogares recibe el $y \%$ de los ingresos. Por su parte, la curva de concentración del impuesto muestra, para el mismo ordenamiento de los hogares según el nivel de ingresos, el porcentaje acumulado del impuesto que se paga con un determinado porcentaje acumulado de los hogares. Es decir, un punto $(x, z)$ sobre la curva de concentración del impuesto indicará que el $x \%$ de los hogares paga el $z \%$ del impuesto.

Si la curva de concentración del impuesto está siempre por debajo de la curva de Lorenz ( $z<y$ para todo $x$ ), no cabe duda de que el impuesto es progresivo, pues significa que la tasa media de tributación crece con el ingreso. En cambio, si la curva de concentración está a veces por debajo y a veces por encima de la curva de Lorenz, no es fácil llegar a una conclusión respecto de la progresividad del impuesto, a menos que se recurra a un índice como el coeficiente de Gini, que resume en un número, entre 0 y 1, la desigualdad de la distribución de una variable, como pueden ser el ingreso o la concentración del impuesto.

En términos del gráfico de la curva de Lorenz, el índice de Gini se define como el área encerrada entre la recta de $45^{\circ}$ y la curva de Lorenz, dividida por el área total bajo la recta de $45^{\circ}$. En condiciones de perfecta igualdad, la curva de Lorenz coincide con la recta de $45^{\circ}$ y, por lo tanto, el índice de Gini será igual a cero. En el otro extremo, en condiciones de máxima desigualdad, la curva de Lorenz coincide con el eje horizontal, por lo que el índice de Gini será igual a uno. Así, el índice de Kakwani (K) se define como la diferencia entre el Gini de la curva de concentración del impuesto 
(lo que se conoce como cuasi-Gini del impuesto) y el Gini del ingreso antes de impuestos, es decir:

$$
K=\text { cuasi-Gini (impuesto) - Gini (ingreso antes de impuestos) }
$$

Si $K$ es mayor que cero, significa que el impuesto es progresivo; si $K$ es menor que cero, el impuesto es regresivo.

Es decir, el índice de Kakwani permite concluir, sin ambigüedad, si un impuesto es o no progresivo, y hasta qué punto lo es, en términos de su distribución porcentual. Sin embargo, no dice nada respecto de su contribución absoluta a la redistribución del ingreso. Una forma de responder a esa pregunta sería comparar el índice de Gini del ingreso antes de impuestos con el índice de Gini del ingreso después del impuesto. Esa es la finalidad del índice de Reynolds y Smolensky (RS), que se define como la diferencia entre ambos índices, es decir:

\section{$R S=$ Gini (ingreso antes de impuestos) - Gini (ingreso después del impuesto)}

Si $R S$ es mayor que cero, indica evidentemente que el impuesto es progresivo. Además, el valor de la diferencia indica la contribución que hace el impuesto a reducir o incrementar la desigualdad.

\section{b) Índices de equidad horizontal}

El atributo de la equidad horizontal indica que los contribuyentes de igual capacidad contributiva deben ser tratados de igual manera por el sistema tributario. Si la capacidad contributiva se mide sobre la base del ingreso equivalente de los hogares, el sistema tributario será horizontalmente equitativo cuando dos hogares con el mismo ingreso equivalente paguen el mismo impuesto y, por lo tanto, sus ingresos después de impuestos sigan siendo iguales.

La principal dificultad para medir ese atributo radica en que, en la realidad, es muy difícil encontrar a dos individuos iguales. En la literatura se hallan al menos dos enfoques que hacen frente a ese problema.

Según el primer enfoque, atribuible a Feldstein (1976), un impuesto es horizontalmente equitativo si, después de su aplicación, se preserva la ordenación inicial. Es decir, si se organizan los hogares en orden creciente de ingreso equivalente, habrá equidad horizontal si la posición relativa de cada hogar es la misma independientemente de que el ordenamiento se realice con el ingreso antes o después del impuesto. Esa idea ha dado origen a una serie de índices que miden el reordenamiento después de aplicar el impuesto.

Como señala Perrote (2003), ese enfoque ha sido criticado porque el reordenamiento es una condición suficiente, pero no necesaria, para que exista inequidad horizontal. En consecuencia, ha surgido un segundo enfoque, que considera la equidad horizontal como tratamiento similar de contribuyentes 
similares (Berliant y Strauss (1983), y Aronson, Johnson y Lambert (1994)). Ese enfoque se aproxima más a la definición teórica de equidad horizontal, pues reemplaza el concepto de contribuyentes iguales, inexistentes en la práctica, por el de similares. Los índices que se construyen sobre la base de ese concepto suelen agrupar a los contribuyentes en pequeños tramos de renta y consideran iguales a todos los pertenecientes a un tramo. Álvarez y Prieto (2003) señalan que ese tipo de índice presenta dos problemas o limitaciones. En primer lugar, la arbitrariedad que puede existir al definir los tramos de renta y, por lo tanto, la discrecionalidad al agrupar a individuos similares. En segundo lugar, los individuos situados en los extremos de los tramos se parecen más a los ubicados en los tramos próximos que a los del propio tramo.

En este estudio se utilizarán dos índices de equidad horizontal, uno de cada enfoque. En primer lugar, se describe el índice de Atkinson-Plotnick, que mide la inequidad horizontal como el área entre la curva de Lorenz de la distribución del ingreso después de impuestos y la curva preordenada de Lorenz. Esa curva representa la concentración del ingreso después de impuestos, pero con los contribuyentes ordenados de acuerdo a su ingreso antes de impuestos. Tiene la característica de que siempre estará por encima de la curva de Lorenz del ingreso después de impuestos. En el extremo, cuando el ordenamiento de los individuos se invierte por completo, será un espejo de esta última, por encima de la recta de $45^{\circ}$.

Plotnick (1981) propone cuantificar el reordenamiento aplicando el índice de Gini sobre ambas curvas, según la siguiente fórmula:

$$
A-P=\frac{G(Y)-G\left(Y_{p r e}\right)}{2 G(Y)} \times 100
$$

Donde $G(Y)$ representa el índice de Gini de la distribución del ingreso después de impuestos y $G\left(Y_{\text {pre }}\right)$ representa el índice de Gini de la curva preordenada de Lorenz. Si el índice es igual a cero, significa que no hubo reordenamiento, por lo que ambas curvas son iguales. Si el índice es igual a 1, quiere decir que se ha invertido completamente el orden.

El segundo indicador, propuesto por Rodríguez, Salas y Perrote (2005), se basa en un enfoque no paramétrico, que mide la inequidad horizontal como la distancia entre la curva de Lorenz de la distribución del ingreso después de impuestos y la curva de Lorenz de la distribución del ingreso estimado no paramétricamente después de impuestos.

Se entiende que $X$ y $Y$ se refieren a la distribución del ingreso antes y después de impuestos, respectivamente. Si se representan ambas variables en un mismo gráfico $(x, y)$, se observará una nube de puntos, lo que indica que personas con similar nivel de ingresos reciben un tratamiento tributario distinto. El método intenta ajustar una curva a esa nube de puntos. Mientras 
más dispersa sea la nube en torno a la curva ajustada, mayor será la inequidad horizontal.

La estimación no paramétrica consiste en ajustar localmente una función a los datos existentes, es decir, se calcula un promedio local de la variable dependiente " $y$ " en las cercanías de " $x$ ".

Si se utiliza la variable $Z$ para referirse a la distribución del ingreso estimado no paramétricamente después de impuestos, el indicador de inequidad horizontal $(I H)$ propuesto por los autores antes citados se define de la siguiente manera:

$$
I H=G(Y)-G(Z)
$$

A partir del enfoque anterior, en este trabajo se usará un indicador alternativo, cuyo resultado es más fácil de interpretar. Se entiende que $T^{y}$ es el impuesto efectivo y que $T^{z}$ es el impuesto estimado no paramétricamente. El índice $I H$ se definirá como:

$$
I H=\frac{\sum\left|T^{y}-T^{z}\right|}{\sum T^{z}} \times 100
$$

El índice así definido representa la fluctuación media del impuesto en torno a un punto medio, para un nivel de renta dado. Dicho de otra manera, para un determinado monto de renta, el impuesto pagado por un contribuyente puede ser, en promedio, un $I H$ por ciento mayor o menor que el impuesto no paramétrico $T^{z}$.

\section{Simulaciones de reformas tributarias}

Uno de los propósitos de esta investigación es evaluar la factibilidad de mejorar la progresividad y la equidad horizontal de los sistemas tributarios, lo que se hará mediante la simulación de reformas tributarias potenciales, tanto en el IVA como en el impuesto sobre la renta. Dichas modalidades de reforma se describen a continuación.

\section{a) Aplicación al caso del impuesto sobre la renta}

Se evaluarán cuatro reformas potenciales: i) la derogación de gastos tributarios; ii) el impuesto de tasa uniforme; iii) el impuesto dual, y iv) el impuesto familiar.

i) Simulación de impuesto actual sin gastos tributarios

Se evaluará, desde el punto de vista de la equidad horizontal y vertical, un paquete de reforma que considere la derogación de los principales gastos tributarios que benefician a las personas naturales, sin modificar ni los tramos de la escala ni las tasas marginales. 


\section{ii) Simulación de un impuesto de tasa uniforme}

Se evaluará, desde el punto de vista de la equidad horizontal y vertical, un paquete de reforma que considere los siguientes elementos:

- Utilizar la misma base imponible de i).

- Reemplazar la escala de tasas de impuesto personal por otra de dos tramos, uno exento $(X)$ y otro afecto a una tasa marginal $t$.

- Regular las tasas $X$ y $t$ para que la recaudación sea igual a la obtenida en $i$ ).

iii) Simulación de un impuesto dual

Se evaluará, desde el punto de vista de la equidad horizontal y vertical, un paquete de reforma que considere los siguientes elementos:

- La misma base imponible de $i$ ).

- Mantener la escala de tasas del impuesto personal, pero aplicarla solo a las rentas del trabajo, dependiente e independiente (cuenta propia).

- Aplicar una tasa $t$ a las rentas del capital, que incluye personas jurídicas y rentas del capital obtenidas por personas naturales (empresariales, dividendos, intereses, entre otras).

- Ajustar $t$ de tal forma que la recaudación sea igual a la obtenida en $i$ ).

iv) Simulación de un impuesto familiar

Se evaluará, desde el punto de vista de la equidad horizontal y vertical, una modificación del impuesto personal a la renta que considere los siguientes elementos:

- La unidad de tributación serán los hogares en vez de los individuos.

- La base imponible será la renta equivalente, definida como:

$$
Y^{e}=\frac{Y}{n^{0,8}}
$$

Donde $Y$ es igual a la base imponible calculada en i) y $n$ es el número de integrantes del hogar.

- Sobre la renta equivalente se aplicará la escala de tasas y se obtendrá así el impuesto basado en los cuadros. El impuesto total a pagar, $T$, será igual a:

$$
T=I S T \times n^{0,8}
$$


- Se ajustarán todos los tramos de la escala de tasas con un mismo factor, de forma tal que la recaudación sea igual a la obtenida en $i$ ).

Además, en cada caso se evaluará el efecto en la equidad de redistribuir, mediante el gasto público, la mayor recaudación obtenida respecto de la situación actual. A falta de mayores antecedentes sobre cómo se podrían asignar esos mayores ingresos, se supondrá una distribución en partes iguales entre los individuos pertenecientes a los tres deciles de menores ingresos.

\section{b) Aplicación para el caso del IVA}

Se evaluará, desde el punto de vista de la equidad horizontal y vertical, una reforma que considere los siguientes elementos:

- Derogar todas las exenciones del IVA, salvo las exenciones a los intereses financieros, los servicios domésticos y las tasas pagadas al sector público.

- En el caso de los bienes inmuebles de uso habitacional, se supone la aplicación de un IVA sin doble tributación. Hay dos mecanismos para lograr ese objetivo: el primero, de fácil aplicación en la realidad, grava la venta de las viviendas y exime los arriendos; el segundo, de difícil aplicación práctica, exime la venta y grava los arriendos y el uso de la vivienda propia. Ambos procedimientos conducen a los mismos resultados en términos del valor presente del IVA pagado a lo largo de la vida útil del bien inmueble. No obstante, a efectos de medir el impacto en la equidad, se escogió el segundo, por dos razones. La primera es que el supuesto de incidencia adoptado señala que el IVA lo paga el consumidor final que, en el caso de una vivienda, no es el comprador, sino el usuario o arrendatario. Siendo así, el IVA se debe trasladar al canon de arriendo o a la imputación por uso de la vivienda propia. La segunda es la factibilidad de cálculo, pues las encuestas de gastos de los hogares en general no aportan suficiente información sobre las compras de bienes raíces, aunque sí lo hacen respecto de los arriendos y el valor locativo.

- Se supondrá también que la mayor recaudación lograda con la derogación de exenciones se redistribuye a la población por la vía del gasto público, en partes iguales entre los individuos pertenecientes a los tres deciles de menores ingresos.

Sobre este último punto, en Barreix, Bès y Roca (2009) se recalca el hecho de que el IVA es el tributo que presenta menor erosión en su base. Prueba de esto es que la razón IVA/PIB es similar tanto en los países de la Organización de Cooperación y Desarrollo Económicos (OCDE) como 
en los de América Latina. Por eso, Barreix, Bès y Roca (2010) proponen un financiamiento alternativo, que denominan "IVA personalizado" y consiste en la generalización de la base tributaria del IVA, compensada con la "devolución" del impuesto a los tres deciles inferiores. A una mayor tasa y una base imponible más perforada, mayor rendimiento de esa personalización. La simulación planteada en c) es aritméticamente parecida a esta propuesta de personalización del IVA 5 .

\section{B. Consideraciones específicas de los casos de estudio}

En esta sección se presentará, de manera resumida, el procedimiento de cálculo propuesto aplicable a tres casos de estudio (Ecuador, Guatemala y Paraguay), con las adaptaciones metodológicas que requiere su aplicación sobre cada caso en particular. A su vez, se diferenciará entre el análisis aplicado al IVA, por un lado, y al impuesto sobre la renta, por el otro.

\section{Ecuador}

\section{a) Equidad vertical y horizontal del IVA}

La principal fuente de información utilizada para evaluar la equidad del IVA en el Ecuador fue la Encuesta Nacional de Ingresos y Gastos de los Hogares Urbanos (ENIGHU), de 2003, llevada a cabo por el Instituto Nacional de Estadística y Censos (INEC). El objetivo principal de esa encuesta consiste en estimar el nivel y la estructura de los gastos de los hogares que permiten actualizar los coeficientes de ponderación del índice de precios al consumidor. También aporta información respecto del nivel y la estructura de los ingresos de los hogares. La encuesta distingue más de 2.000 productos, clasificados de acuerdo a la Clasificación del Consumo Individual por Finalidades (CCIF) del año 2000. El universo considerado son los hogares urbanos en centros poblados de 20.000 o más habitantes. La muestra fue de 11.240 hogares.

Además, con el objeto de calcular la tasa efectiva de IVA aplicable a cada producto, se usó el cuadro de utilización del año 2006, preparado por el Departamento de Cuentas Nacionales del Banco Central del Ecuador. Ese cuadro muestra el consumo intermedio respecto de 48 actividades económicas y 60 productos y el consumo final desagregado en hogares, Gobierno, formación bruta de capital fijo, variación de existencias y exportaciones. Sobre esa base se construyó un modelo de IVA no deducible, que permitió estimar

Aunque desde el punto de vista conceptual no lo es, pues no se evalúa la "devolución" del IVA pagado por los tres deciles más pobres, sino solo el impacto de gastar de manera focalizada la mayor recaudación tributaria que produce la reforma. Evidentemente, una mayor recaudación permanente debería transformarse en un mayor gasto público. 
la tasa efectiva de IVA por producto, desagregada en sus tres componentes: IVA por afectación del consumo final, IVA en cascada e IVA de traslación en productos exentos.

Las tasas efectivas anteriores se aplicaron sobre el consumo de cada hogar y cada producto incluido en la encuesta, determinándose de esa manera el IVA que habría pagado cada hogar con la estructura tributaria vigente (IVA actual). Con el mismo método, se calculó el IVA que pagaría cada hogar suponiendo la derogación de todas las exenciones, salvo las que recaen sobre los intereses financieros, los servicios domésticos y las tasas o impuestos cobrados por el Gobierno (IVA sin exenciones).

\section{b) Equidad vertical y horizontal del impuesto sobre la renta}

La principal fuente de información utilizada para evaluar la equidad del impuesto sobre la renta en el Ecuador fue la Encuesta de Empleo, Desempleo y Subempleo en el Área Urbana y Rural, de diciembre de 2007, llevada a cabo por el Instituto Nacional de Estadística y Censos (INEC). La información de esa encuesta tiene cobertura nacional y abarcó 18.933 hogares, compuestos por un total de 76.922 individuos. Se utilizaron principalmente las variables de ingresos a nivel de individuos construidas por la CEPAL y se incorporaron las correcciones por subdeclaración de ingresos que ya se mencionaron.

Para el cálculo de la base imponible actual se consideraron las remuneraciones del trabajo dependiente. Se excluyeron las remuneraciones decimotercera y decimocuarta, así como las cotizaciones previsionales y los ingresos de los independientes. De esa cantidad se restó una estimación de la deducción por gastos personales.

De acuerdo a lo señalado en la primera sección de este trabajo, se evaluaron cuatro reformas potenciales: derogación de gastos tributarios, impuesto de tasa uniforme, impuesto dual e impuesto familiar.

En el escenario de derogación de gastos tributarios se simuló la eliminación de las exenciones a las remuneraciones decimotercera y decimocuarta y de la deducción por gastos personales. Además, se incorporaron a la base imponible las rentas por transferencias, que incluyen jubilaciones, donaciones, remesas del exterior y bono de desarrollo humano, y las rentas del capital, que comprenden intereses, arriendos y dividendos. Sobre la base imponible así estimada se aplicó la escala de tasas actualmente vigente.

En el caso del impuesto de tasa uniforme, la misma base imponible anterior se sometió a una tasa uniforme del $18,85 \%$, con un tramo exento de 10.000 dólares, combinación con la que se logra la misma recaudación del escenario de derogación de gastos tributarios.

En la simulación del impuesto dual, la misma base imponible anterior se separó en rentas del trabajo y rentas del capital. Sobre las primeras se aplicó 
la escala de tasas actual y sobre las segundas una tasa uniforme del 5,7\%, con la que se logra igualar la recaudación de los dos escenarios anteriores.

Por último, en el caso del impuesto familiar se cumplió el objetivo de igualar la recaudación mediante la aplicación de una escala con las mismas tasas marginales actuales, pero ajustando cada tramo por el factor de 0,5513 .

\section{Guatemala}

\section{a) Equidad vertical y horizontal del IVA}

La principal fuente de información utilizada para evaluar la equidad del IVA en Guatemala fue la Encuesta Nacional de Condiciones de Vida (ENCOVI), llevada a cabo por el Instituto Nacional de Estadística (INE) de Guatemala entre marzo y septiembre de 2006. Esa encuesta tiene cobertura nacional y se refiere a la población de los hogares particulares del país. Considera una muestra de 13.686 hogares, compuestos por 68.739 personas. El módulo de gastos distingue 250 productos.

Además, con el objeto de calcular la tasa efectiva de IVA para cada producto, se usó el cuadro de oferta y utilización del año 2006, preparado por el Banco Central de Guatemala. El cuadro de utilización muestra el consumo intermedio respecto de 30 actividades económicas y 65 productos, y el consumo final desagregado en hogares, Gobierno, formación bruta de capital fijo, variación de existencias y exportaciones. Sobre esa base se construyó un modelo de IVA no deducible, que permitió estimar la tasa efectiva del IVA por producto, con las desagregaciones señaladas (IVA de consumo final, IVA en cascada e IVA de traslación en productos exentos).

El procedimiento es análogo al del caso anterior, donde las tasas efectivas obtenidas se aplicaron sobre el consumo de cada hogar y cada producto informado en la encuesta con el fin de determinar el IVA pagado por cada hogar con la estructura tributaria vigente. Además, se calculó el IVA que pagaría cada hogar si se derogaran todas las exenciones detalladas en la metodología estándar propuesta (IVA sin exenciones).

\section{b) Equidad vertical y horizontal del impuesto sobre la renta}

$\mathrm{Al}$ igual que en el caso del IVA, la principal fuente de información utilizada para evaluar la equidad del impuesto sobre la renta en Guatemala fue la Encuesta Nacional de Condiciones de Vida (ENCOVI), llevada a cabo por el Instituto Nacional de Estadística (INE) de Guatemala entre marzo y septiembre de 2006. En esta ocasión se utilizaron principalmente las variables de ingresos a nivel de individuos construidas por la CEPAL y se introdujeron correcciones por subdeclaración de ingresos. 
Para el cálculo de la base imponible actual del impuesto al trabajo dependiente se consideraron las remuneraciones del trabajo dependiente, ya sea como actividad principal o secundaria, excluidos los ingresos por bono 14 y aguinaldos, y las cotizaciones previsionales. Estos tres montos se recogen en la encuesta. También se dedujo una estimación de los gastos personales en salud, efectuada a partir de los datos del módulo de gastos de la misma encuesta. Sobre esa base imponible, se aplicó la actual escala de tasas, incluida la deducción general, y luego se restó el crédito por el IVA, estimado como el valor mínimo entre el IVA pagado y el $12 \%$ de las rentas del trabajo dependiente, que es lo que establece la legislación.

En cuanto a las rentas por cuenta propia, se distinguieron dos casos. En primer lugar, a las personas que declaran obtener rentas del trabajo independiente (códigos de ocupación 5 y 7) se les atribuyó un margen de utilidad del $90 \%$, con el objeto de calcular sus ingresos brutos. Luego, se calcularon las dos alternativas de impuesto que ofrece la ley (un 31\% sobre la renta neta, incluyendo deducciones de 36.000 quetzales, cotizaciones previsionales y gastos de salud, y el crédito por IVA y un $5 \%$ sobre los ingresos brutos) y se seleccionó el mínimo entre ambos. En segundo lugar, a quienes declaran obtener rentas como empresarios individuales o patrones (códigos de ocupación 6 y 8) se les atribuyó un ingreso bruto estimado como el cociente entre el ingreso neto y el margen de utilidad sobre las ventas medias del sector económico al que pertenecen. Ese margen se determinó a partir de las estadísticas de las cuentas nacionales. Posteriormente, se calcularon las dos alternativas de impuesto que ofrece la ley (un 31\% sobre la renta neta y un $5 \%$ sobre los ingresos brutos) y se seleccionó el mínimo entre ambos. Luego, se evaluaron las cuatro reformas potenciales propuestas en la metodología: derogación de gastos tributarios, impuesto de tasa uniforme, impuesto dual e impuesto familiar.

En el escenario de derogación de gastos tributarios, se simuló la eliminación de las exenciones a los aguinaldos y el bono 14, la deducción por gastos personales y el crédito del IVA. Además, se incorporaron a la base imponible las rentas por transferencias, que incluyen jubilaciones, donaciones y remesas del exterior, entre otras cosas, y las rentas del capital, que comprenden intereses, arriendos y dividendos. Sobre la base imponible así estimada se aplicó la escala de tasas actualmente vigente para los trabajadores dependientes, incluida la deducción de 36.000 quetzales, que hace las veces de un tramo exento.

En el caso del impuesto de tasa uniforme, la misma base imponible anterior se sometió a una tasa uniforme del $19,4 \%$, con un tramo exento de 36.000 quetzales, combinación con la que se logra la misma recaudación del escenario de derogación de gastos tributarios. 
En la simulación del impuesto dual, la misma base imponible anterior se separó en rentas del trabajo, dependiente e independiente, y rentas del capital. Sobre las primeras se aplicó la escala de tasas actual y, sobre las segundas, una tasa uniforme del 9\%, con la que se logra igualar la recaudación de los dos escenarios anteriores.

Por último, respecto del impuesto familiar se cumplió el objetivo de igualar la recaudación mediante la aplicación de una escala con las mismas tasas marginales actuales, pero ajustando cada tramo por el factor 0,5604 .

\section{Paraguay}

\section{a) Equidad vertical y horizontal del IVA}

La fuente de información utilizada para evaluar la equidad del IVA en el Paraguay fue la Encuesta de Presupuestos Familiares 2005-2006, realizada por la Dirección General de Estadística, Encuestas y Censos (DGEEC), entre julio de 2005 y junio de 2006, y cuyo objetivo principal era estimar el nivel y estructura de los gastos de los hogares que permiten actualizar los coeficientes de ponderación del índice de precios al consumidor. La encuesta distingue más de 7.000 productos. En la muestra se consideraron 1.243 hogares, compuestos por 5.517 individuos.

No fue posible contar con los cuadros de oferta y utilización, necesarios para calcular la carga de IVA por efecto de cascada y traslación en productos exentos. Por ello, el IVA en cascada se omitió, en tanto que para el IVA de traslación se usó el promedio de los coeficientes insumo-producto de los cuadros de utilización del Ecuador y Guatemala, respecto de cada sector exento del IVA en el Paraguay. No obstante esas limitaciones, se aplicó el mismo procedimiento con las tasas efectivas resultantes a fin de determinar tanto el IVA pagado por cada hogar con la estructura tributaria vigente (IVA actual) como el IVA hipotético que pagaría cada hogar si se derogaran las exenciones señaladas en la metodología (IVA sin exenciones).

\section{b) Equidad vertical y horizontal del impuesto sobre la renta}

La fuente de información utilizada para evaluar la equidad del impuesto sobre la renta en el caso del Paraguay es la Encuesta Permanente de Hogares, llevada a cabo por la Dirección General de Estadística, Encuestas y Censos (DGEEC) del Paraguay en los meses de octubre a diciembre de 2007.

En este caso, la evaluación de la situación actual responde a un escenario hipotético, que supone la entrada en vigor del impuesto sobre la renta personal, cuya aplicación fue postergada para el año 2013. 


\section{Resultados de las estimaciones}

El análisis de la equidad vertical del IVA muestra que, si se utiliza el ingreso como medida de bienestar, el impuesto es regresivo en los tres países. Tal como se resume en el cuadro V.1, los índices RS y de Kakwani resultan negativos para todos los países, independientemente de si se evalúa el IVA actual o el IVA sin exenciones.

\section{Cuadro V.1}

Equidad vertical en el IVA con base de ingreso

\begin{tabular}{lccc}
\hline & Ecuador & Guatemala & Paraguay \\
\hline Gini del ingreso antes de impuestos & 0,5421 & 0,5632 & 0,4501 \\
\hline Gini del ingreso después del IVA & 0,5478 & 0,5802 & 0,4527 \\
\hline Índice de Reynolds y Smolensky & $-0,0056$ & $-0,0170$ & $-0,0026$ \\
\hline Índice de Kakwani & $-0,1356$ & $-0,1883$ & $-0,0386$ \\
\hline Gini del ingreso después del IVA sin exenciones & 0,5575 & 0,5860 & 0,4543 \\
\hline Índice de Reynolds y Smolensky & $-0,0154$ & $-0,0227$ & $-0,0042$ \\
\hline Índice de Kakwani & $-0,2215$ & $-0,2096$ & $-0,0470$ \\
\hline Gini del ingreso después del IVA sin exenciones & 0,5169 & 0,5695 & 0,4421 \\
y con transferencia a los tres deciles más pobres & & & \multirow{2}{*}{0}
\end{tabular}

Fuente: Elaboración propia.

Por su parte, si se toma como base el consumo, el IVA resulta ser progresivo en el Ecuador y Guatemala, pero regresivo en el Paraguay. Tal como se muestra en el cuadro V.2, los índices RS y de Kakwani son positivos para los primeros dos países en el caso del IVA actual, pero son levemente negativos para el Paraguay. Sin embargo, al tomar el IVA sin exenciones, este resulta ser regresivo también en el caso de Guatemala.

Cuadro V.2

Equidad vertical en el IVA con base de consumo

\begin{tabular}{lccc}
\hline & Ecuador & Guatemala & Paraguay \\
\hline Gini del ingreso antes de impuestos & 0,4297 & 0,4473 & 0,4484 \\
\hline Gini del ingreso después del IVA & 0,4248 & 0,4459 & 0,4488 \\
\hline Índice de Reynolds y Smolensky & 0,0049 & 0,0014 & $-0,0004$ \\
\hline Índice de Kakwani & 0,0674 & 0,0162 & $-0,0046$ \\
\hline Gini del ingreso después del IVA sin exenciones & 0,4297 & 0,4477 & 0,4497 \\
\hline Índice de Reynolds y Smolensky & 0,0000 & $-0,0004$ & $-0,0013$ \\
\hline Índice de Kakwani & 0,0000 & $-0,0033$ & $-0,0143$ \\
\hline $\begin{array}{l}\text { Gini del ingreso después del IVA sin exenciones } \\
\text { y con transferencia a los tres deciles más pobres }\end{array}$ & 0,3825 & 0,4332 & 0,4386
\end{tabular}

Fuente: Elaboración propia. 
Además, se comprueba que la ampliación de la base imponible del IVA aumenta la regresividad del impuesto, sobre todo en la primera de las alternativas metodológicas. Sin embargo, en ambos casos, al transferir la mayor recaudación que se obtendría, la redistribución del ingreso mejora respecto de la situación actual.

Con respecto a la equidad horizontal en el IVA, el índice de AtkinsonPlotnick muestra un nivel similar de inequidad en el Ecuador y Guatemala, y una mayor equidad en el Paraguay. Por un lado, al utilizar como punto de partida el ingreso, la ampliación de la base, tal como se muestra en el cuadro V.3, eleva el nivel de inequidad horizontal, lo que está asociado al aumento de recaudación más que a una estructura de mayor inequidad. En cambio, si se parte del consumo, tal como se muestra en el cuadro V.4, la ampliación de la base mejora la equidad horizontal.

Cuadro V.3

Equidad horizontal en el IVA con base de ingreso

\begin{tabular}{lccc}
\hline & Ecuador & Guatemala & Paraguay \\
\hline Índice de Atkinson-Plotnick del IVA & 0,0741 & 0,0798 & 0,0262 \\
\hline Gini del ingreso después del IVA & 0,5478 & 0,5802 & 0,4527 \\
\hline Pre-Gini del ingreso después del IVA & 0,5470 & 0,5793 & 0,4525 \\
\hline Índice de Atkinson-Plotnick del IVA sin exenciones & 0,0940 & 0,1037 & 0,0365 \\
\hline Gini del ingreso después del IVA sin exenciones & 0,5575 & 0,5860 & 0,4543 \\
\hline Pre-Gini del ingreso después del IVA sin exenciones & 0,5565 & 0,5847 & 0,4540 \\
\hline
\end{tabular}

Fuente: Elaboración propia.

Cuadro V.4

Equidad horizontal en el IVA con base de consumo

\begin{tabular}{lccc}
\hline & Ecuador & Guatemala & Paraguay \\
\hline Índice de Atkinson-Plotnick del IVA & 0,0122 & 0,0046 & 0,0026 \\
\hline Gini del ingreso después del IVA & 0,4248 & 0,4459 & 0,4488 \\
\hline Pre-Gini del ingreso después del IVA & 0,4247 & 0,4458 & 0,4487 \\
\hline Índice de Atkinson-Plotnick del IVA sin exenciones & 0,0000 & 0,0033 & 0,0011 \\
\hline Gini del ingreso después del IVA sin exenciones & 0,4297 & 0,4477 & 0,4497 \\
\hline Pre-Gini del ingreso después del IVA sin exenciones & 0,4297 & 0,4476 & 0,4497 \\
\hline
\end{tabular}

Fuente: Elaboración propia.

En relación con la equidad vertical del impuesto sobre la renta, los resultados muestran que es progresivo para los tres países objeto de estudio (véase el cuadro V.5). El índice de Kakwani muestra que el impuesto sobre la renta en el Ecuador es el que tiene el mayor potencial redistributivo, seguido 
del Paraguay y Guatemala, en ese orden. No obstante, la contribución absoluta a la equidad, medida por el índice RS, resulta ser escasa, como consecuencia de la baja recaudación del impuesto en los tres países, lo que a su vez se deriva de un uso generalizado de exenciones, deducciones, créditos y otros tratamientos preferenciales.

Cuadro V.5

Equidad vertical en el impuesto sobre la renta

\begin{tabular}{lccc}
\hline & Ecuador & Guatemala & Paraguay \\
\hline Gini del ingreso antes de impuestos & 0,5311 & 0,5632 & 0,5375 \\
\hline Gini del ingreso después del impuesto sobre la renta & 0,5239 & 0,5569 & 0,5334 \\
\hline Índice de Reynolds y Smolensky & 0,0072 & 0,0064 & 0,0041 \\
\hline Índice de Kakwani & 0,4555 & 0,2954 & 0,3123 \\
\hline Gini del ingreso después del impuesto sobre la renta & 0,5150 & 0,5386 & 0,5178 \\
\hline sin gasto tributario & 0,0161 & 0,0246 & 0,0196 \\
\hline Índice de Reynolds y Smolensky & 0,4314 & 0,3485 & 0,4487 \\
\hline Índice de Kakwani & 0,5151 & 0,5399 & 0,5188 \\
\hline Gini del ingreso después de un impuesto de tasa uniforme & 0,0160 & 0,0233 & 0,0187 \\
\hline Índice de Reynolds y Smolensky & 0,4264 & 0,3277 & 0,4391 \\
\hline Índice de Kakwani & 0,5264 & 0,5559 & 0,5272 \\
\hline Gini del ingreso después de un impuesto dual & 0,0047 & 0,0073 & 0,0103 \\
\hline Índice de Reynolds y Smolensky & 0,1272 & 0,1068 & 0,2437 \\
\hline Índice de Kakwani & 0,5124 & 0,5351 & 0,5160 \\
\hline Gini del ingreso después de un impuesto familiar & 0,0187 & 0,0281 & 0,0215 \\
\hline Índice de Reynolds y Smolensky & 0,4368 & 0,3678 & 0,4498 \\
\hline Índice de Kakwani & & & 0,030 \\
\hline
\end{tabular}

Fuente: Elaboración propia.

Las alternativas de reforma, con excepción del impuesto dual, conducen a impuestos con similar potencial redistributivo (Kakwani) que, en los casos de Guatemala y el Paraguay, es significativamente mayor que el del impuesto actual. No obstante, el supuesto de una base imponible más amplia lleva a que todas las alternativas, salvo el impuesto dual, tengan una contribución absoluta a la equidad (RS) significativamente superior al impuesto actual.

En efecto, la ampliación de la base, o la eliminación de gastos tributarios, permitiría triplicar la recaudación en Guatemala y el Paraguay y aumentarla en 2,3 veces en el Ecuador. Además, la ampliación de la base y la posterior redistribución de la mayor recaudación resultante permitirían reducir el Gini de los tres países en un rango que va desde los 0,03 puntos, en el caso del Ecuador, hasta los 0,06 puntos, en el caso de Guatemala (véase el cuadro V.6). 


\section{Cuadro V.6}

Equidad vertical en el impuesto sobre la renta con exenciones y transferencias

\begin{tabular}{lccc}
\hline & Ecuador & Guatemala & Paraguay \\
\hline $\begin{array}{l}\text { Gini del ingreso después del impuesto sobre la renta sin } \\
\text { gasto tributario y transferencia a los tres deciles más pobres }\end{array}$ & 0,4960 & 0,4980 & 0,4942 \\
\hline $\begin{array}{l}\text { Gini del ingreso después de un impuesto de tasa uniforme } \\
\text { y transferencia a los tres deciles más pobres }\end{array}$ & 0,4961 & 0,4993 & 0,4951 \\
\hline $\begin{array}{l}\text { Gini del ingreso después de un impuesto dual y transferencia } \\
\text { a los tres deciles más pobres }\end{array}$ & 0,5073 & 0,5148 & 0,5034 \\
\hline $\begin{array}{l}\text { Gini del ingreso después de un impuesto familiar } \\
\text { y transferencia a los tres deciles más pobres }\end{array}$ & 0,4934 & 0,4945 & 0,4923
\end{tabular}

Fuente: Elaboración propia.

El impuesto familiar es el que presenta el mayor poder redistributivo para los tres países. En las otras alternativas, el impuesto actual sin gasto tributario resulta ser más progresivo que una tasa uniforme o dual, aunque las diferencias con respecto a la tasa uniforme no son significativas. Por otro lado, la pérdida de progresividad asociada a los impuestos de tasa uniforme y dual no es tan pronunciada como suele suponerse, lo que lleva a pensar que sus ventajas en cuanto a simplicidad y eficiencia podrían hacer recomendable su implementación.

Por último, el análisis de la equidad horizontal del impuesto sobre la renta, resumido en el cuadro V.7, arroja como resultado una alta inequidad en la tributación actual en los tres países, pero sobre todo en el caso del Paraguay y Guatemala. El índice IH oscila entre el 20\% (Ecuador) y el 56\% (Paraguay), lo que refleja una variabilidad de esas magnitudes en el pago del impuesto sobre la renta de personas con similar nivel de renta.

\section{Cuadro V.7}

Equidad horizontal en el impuesto sobre la renta

\begin{tabular}{lcrc}
\hline & Ecuador & Guatemala & Paraguay \\
\hline Índice de Atkinson-Plotnick del impuesto sobre la renta & 0,0008 & 0,0162 & 0,0075 \\
\hline $\begin{array}{l}\text { Índice de Atkinson-Plotnick del impuesto sobre la renta } \\
\text { sin gasto tributario }\end{array}$ & 0,0029 & 0,0108 & 0,0019 \\
\hline $\begin{array}{l}\text { Índice de Atkinson-Plotnick de un impuesto de tasa uniforme } \\
\text { Índice de Atkinson-Plotnick de un impuesto dual }\end{array}$ & 0,0046 & 0,0162 & 0,0036 \\
\hline Índice de Atkinson-Plotnick de un impuesto familiar & 0,0000 & 0,0000 & 0,0000 \\
\hline Índice IH del impuesto sobre la renta (en porcentajes) & 20 & 44 & 56 \\
\hline $\begin{array}{l}\text { Índice IH del impuesto sobre la renta sin gasto tributario } \\
\text { (en porcentajes) }\end{array}$ & 21 & 13 & 7 \\
\hline Índice IH de un impuesto de tasa uniforme (en porcentajes) & 25 & 16 & 11 \\
\hline Índice IH de un impuesto dual (en porcentajes) & 42 & 21 & 35 \\
\hline Índice IH de un impuesto familiar (en porcentajes) & 2 & 1 & 1 \\
\hline
\end{tabular}

Fuente: Elaboración propia. 
El impuesto familiar muestra el mejor desempeño en cuanto a equidad horizontal, pues ambos índices asumen valores cercanos a cero. Le siguen el impuesto actual sin gasto tributario, el impuesto de tasa uniforme y el impuesto dual. Es probable que las alternativas no evaluadas de un impuesto de tasa uniforme familiar o un impuesto dual familiar presenten también un buen desempeño en ese atributo.

\section{Conclusiones}

El presente trabajo se ha concentrado en una temática poco desarrollada a nivel regional, como es la evaluación de la equidad horizontal y vertical en el IVA y en el impuesto sobre la renta. Para ello, en el caso del IVA, se ha propuesto una metodología estándar que incorpora la traslación del impuesto de los insumos en el caso de bienes exentos y el efecto de cascada de las exenciones intermedias. Mientras tanto, en el impuesto sobre la renta, la metodología propuesta procura no solo estimar su impacto distributivo dentro de las estructuras tributarias vigentes, sino que permite evaluar la equidad de distintas reformas tributarias típicas, que pueden consistir en un impuesto de tasa uniforme, un impuesto dual o un impuesto familiar, entre otras.

El análisis de la equidad vertical del IVA muestra que, si se utiliza el ingreso como medida de bienestar, el impuesto es regresivo en los tres países, tanto en el IVA actual como en el escenario hipotético de un IVA sin exenciones. Cuando se toma como base el consumo, el IVA actual es progresivo en el Ecuador y Guatemala, pero regresivo en el Paraguay, mientras que el IVA sin exenciones es regresivo también para Guatemala. Una posible mejora en la redistribución del ingreso se obtendría en todos los casos si se transfiriera la mayor recaudación de la eventual derogación de exenciones hacia los tres deciles más pobres. Por su parte, se encuentra un nivel similar de inequidad horizontal del IVA en el Ecuador y Guatemala, y una mayor equidad en el Paraguay.

En relación con el impuesto sobre la renta, se concluye que es progresivo en los tres países, aunque la contribución absoluta a la equidad es escasa. Las alternativas de reforma, con excepción del impuesto dual, tienen similar potencial redistributivo, pero una base imponible más amplia contribuye más a la equidad y permite duplicar o triplicar la recaudación. La redistribución de esa mayor recaudación reduce significativamente el Gini, siendo el impuesto familiar el que presenta mayor poder redistributivo. Por último, se observa una alta inequidad horizontal en la tributación actual a la renta, característica que mejoraría significativamente con la aplicación de un impuesto familiar $y$, en menor medida, con la estructura actual sin gasto tributario y con un impuesto de tasa uniforme. 


\section{Bibliografía}

Álvarez, S. y J. Prieto (2003), “Tributación de la familia y la equidad horizontal en el impuesto sobre la renta de las personas físicas", Madrid, Instituto de Estudios Fiscales (IEF), Madrid.

Aronson, S., P. Johnson y P.J. Lambert (1994), "Redistributive effect and unequal income tax treatment in the U.K.", Economic Journal, vol. 104, $\mathrm{N}^{\circ} 423$, Royal Economic Society.

Barreix, A., M. Bès y J. Roca (2010), “El IVA personalizado. Aumentando la recaudación y compensando a los más pobres", Washington, D.C., Banco Interamericano de Desarrollo.

(2009), Equidad fiscal en Centroamérica, Panamá y República Dominicana, Washington, D.C., Banco Interamericano de Desarrollo.

Berliant, M.C. y P. Strauss (1983), "Measuring the distribution of personal income taxes", What Role for the Government? Lessons from Policy Research, R. Zeckhauser y D. Leebaert (eds.), Durham, N.C., Duke University Press.

Buhmann, B. y otros (1988), "Equivalence scales, well-being, inequality, and poverty: sensitivity estimates across ten countries using the Luxembourg Income Study (LIS) Database", Review of Income and Wealth, vol. 34, $\mathrm{N}^{\circ} 2$, Wiley.

Coulter, F., F. Cowell y S. Jenkins (1992), "Difference in needs and assessment of income distributions", Bulletin of Economic Research, vol. 44, $\mathrm{N}^{\circ} 2$, Wiley.

Feldstein, M. (1976), "On the theory of tax reform", Journal of Public Economics, vol. 6, $\mathrm{N}^{\circ} 1-2$, Amsterdam, Elsevier.

Feres, J. (2007), "La medición de los ingresos en la Encuesta CASEN 2006”, Santiago, Comisión Económica para América Latina y el Caribe (CEPAL).

Kakwani, N. (1977), "Applications of Lorenz curves in economic analysis", Econometrica, vol. 45, N³, Nueva York, The Econometric Society.

Perrote, I. (2003), "Medición de la inequidad horizontal: una aplicación al IRPF", Redistribución y bienestar a través de la imposición sobre la renta personal, J. Onrubia Fernández y J.F. Sanz Sanz (eds.), Madrid, Instituto de Estudios Fiscales.

Plotnick, R. (1981), "A measure of horizontal inequity", The Review of Economics and Statistics, vol. 63, $\mathrm{N}^{\circ}$ 2, Cambridge, Massachusetts, The MIT Press.

Rodríguez, J.G., R. Salas e I. Perrote (2005), “Partial horizontal inequity orderings: a non-parametric approach", Oxford Bulletin of Economics and Statistics, vol. 67, N 3. 
Capítulo VI

\title{
La tributación sobre las altas rentas en los países de la región ${ }^{1}$
}

\author{
Juan C. Gómez Sabaini² \\ Darío Rossignolo
}

\section{Introducción}

Tras las consecuencias económicas y sociales de la crisis económica internacional de 2008-2009, en la mayoría de los países desarrollados resurgió un antiguo debate respecto de quién debe soportar el peso y los costos de la necesaria recuperación de las economías nacionales. La respuesta a esta pregunta se ha centrado en la posibilidad concreta de exigir un mayor esfuerzo a aquellos individuos que tienen un patrimonio más elevado o que obtienen regularmente muy altos ingresos, y que, por diversas razones, no están contribuyendo de manera acorde al nivel de dichos ingresos. Esto permitiría obtener nuevos recursos para el financiamiento de programas

Este capítulo constituye una versión resumida y actualizada de Gómez Sabaini y Rossignolo (2014).

Consultor de la Comisión Económica para América Latina y el Caribe (CEPAL), el Banco Interamericano de Desarrollo (BID), el Fondo Monetario Internacional (FMI) y el Centro Interamericano de Administraciones Tributarias (CIAT) especializado en temas de política tributaria en países de América Latina. Profesor de posgrado en la Universidad Nacional de Buenos Aires. Correo electrónico: gomezsabaini@gmail.com.

3 Investigador y consultor de organismos internacionales. Especialista en el análisis de los efectos económicos de las políticas tributarias y fiscales. Profesor de grado y posgrado de la Universidad de Buenos Aires. Correo electrónico: darossignolo@yahoo.com. 
sociales que apuntalen la recuperación económica y conduciría a una mejora de la percepción de la sociedad respecto a los efectos de la política tributaria sobre la equidad distributiva.

En los países desarrollados, y en especial en los Estados Unidos, donde este tema se configuró como uno de los debates centrales más recientes, la disponibilidad de una gran cantidad de información acerca de los ingresos y el patrimonio de los hogares e individuos más ricos y —lo que es aún más importante- de los impuestos que estos pagan anualmente ha permitido la realización de una serie de estudios muy detallados y precisos acerca de los posibles efectos (recaudatorios y distributivos) de una reforma impositiva orientada a gravar de manera diferencial a los sectores de altas rentas.

En América Latina, por el contrario, este debate aún no se ha incorporado a la agenda de la discusión en materia de equidad distributiva. Además, por el momento no se cuenta con un indispensable contenido estadístico que haga factible, por una parte, un análisis específico en aquellos países donde se intenta dotar de mayor progresividad al sistema tributario vigente $y$, por la otra, una comparación coherente entre países de la región para evaluar la calidad y efectividad de las medidas aplicadas.

El objetivo fundamental de este capítulo es brindar un marco conceptual que permita reconocer la importancia de los sectores de más elevados ingresos dentro de la distribución del ingreso, su incidencia sobre las estimaciones cuantitativas relacionadas y su vinculación con los factores más importantes que han limitado la capacidad recaudatoria del impuesto sobre la renta (ISR) en América Latina. En la sección A se describen las consideraciones metodológicas y las cuestiones relacionadas con la información de base generalmente utilizada. En la sección B se resumen los resultados de los principales estudios en la materia realizados acerca de los países desarrollados, mientras que en la sección $C$ se revisan algunos estudios existentes sobre América Latina, en particular de la Argentina, Chile, Colombia y el Uruguay. Por último, en la sección D se presentan las conclusiones y reflexiones finales.

\section{A. Aspectos metodológicos para definir e identificar a los individuos de altas rentas}

Hay varias definiciones estadísticas de los ricos y superricos basadas en medidas del ingreso (flujo), del patrimonio (acervo) o de ambos. También se puede distinguir entre definiciones absolutas y relativas. Las definiciones basadas en los deciles o percentiles superiores son definiciones relativas, en tanto que la línea de afluencia y los umbrales de riqueza son medidas absolutas ${ }^{4}$.

4 Esta sección se basa en el trabajo de Jiménez y Solimano (2012). 
- Deciles, ventiles o percentiles superiores: esta es una definición relativa de los ricos. En este caso, los ricos serían el sector de la población ubicado en el tramo superior de la distribución del ingreso, es decir en el 10\% y el 5\% superior, en tanto que los pertenecientes al $1 \%$ o al $0,1 \%$ superior podrían caracterizarse como "superricos".

- Línea de afluencia: de manera similar al método de línea de pobreza, que corresponde al tramo inferior de ingresos, se puede identificar el tramo superior y determinar la proporción de individuos que pueden definirse como ricos a partir de una línea de afluencia (ingreso) (Sen, 1988). Quienes se ubican sobre la línea de afluencia pueden considerarse ricos y, al igual que en el caso de la línea de pobreza, para medir la proporción de ricos en una sociedad puede bastar con emplear criterios numéricos o cuantitativos.

- Umbrales de riqueza: según Atkinson (2007), se puede definir a los ricos como las personas cuyo patrimonio equivale a 30 veces el ingreso medio per cápita de un país. El múltiplo elegido se basa en una tasa de rentabilidad del 3,5\% anual (rendimiento de los activos de largo plazo), dado que ese nivel generaría intereses iguales al ingreso medio per cápita. Dicho nivel de patrimonio permitiría a una persona vivir de los intereses (retorno) devengados por su patrimonio y tener un nivel estándar (o promedio) de vida ${ }^{5}$. En esa misma línea de razonamiento, Atkinson (2007) considera "superricos" (multimillonarios) a quienes tienen un patrimonio equivalente a $30 \times 30$ veces el ingreso medio, es decir aquellos que pueden vivir de los "intereses de los intereses". También define como "globalmente ricos" a quienes poseen un ingreso más de 20 veces superior al ingreso medio mundial. A su vez, los "megarricos" o billonarios serían quienes tienen un patrimonio equivalente a 30×30×30 veces el ingreso medio per cápita. Las personas clasificadas en esta última categoría de Atkinson corresponden aproximadamente a los billonarios incluidos en la lista de la revista Forbes.

Los globalmente ricos constituían en 1990 el 0,14\% de la población mundial (alrededor de 7,4 millones de personas), pero recibían el 5,4\% del ingreso mundial. Este número se redujo respecto del 0,23\% de 1910, pasó por un 0,1\% en 1950 y volvió a incrementarse entre 1970 y 1990, cuando la cantidad de superricos en los Estados Unidos llegó a duplicarse.

Este límite es similar al aplicado por las empresas comerciales de gestión de activos, como Capgemini, que consideran ricos a quienes tienen un patrimonio líquido de un millón de dólares (se excluyen de esta definición las casas y otros bienes raíces de su propiedad). 
De un tiempo a esta parte, los investigadores han vuelto a interesarse por el estudio de la distribución de los individuos de altos ingresos. Se ha advertido un marcado esfuerzo por revitalizar los análisis sobre la distribución de los ingresos más elevados utilizando información de las declaraciones juradas del impuesto sobre la renta personal, que se habían dejado de lado como fuente de información primaria ante el surgimiento de los microdatos provenientes de las encuestas de hogares.

Este tipo de estudios comienzan siguiendo las fuentes y métodos tradicionales utilizados en el trabajo pionero de Kuznets (1955) sobre la participación de los ingresos más elevados en los Estados Unidos ${ }^{6}$. Los análisis de Kuznets tuvieron continuidad en el trabajo de Piketty (2003) sobre la distribución de los ingresos más altos en Francia en el largo plazo y concluyeron en la sucesión de estudios que han avanzado en la construcción de las participaciones de los ingresos más elevados a lo largo del tiempo (abarcando gran parte del siglo XX y los inicios del siglo XXI) en más de 20 países. Estos trabajos han sido compilados en varias publicaciones recientes, las más importantes de las cuales están reunidas en las obras de Atkinson y Piketty (2007 y 2010).

Cabe consignar que la información sobre ingresos permite, siempre de acuerdo con las características legislativas de cada país, discriminar el ingreso según la fuente, lo que habilita para analizar los cambios en la composición de los ingresos (asalariados, renta del capital, cuenta propia, empleadores y demás) de los tramos más elevados. De hecho, una buena cantidad de países han publicado, de manera sistemática y regular, tabulaciones basadas en las declaraciones juradas del ISR. En estas tabulaciones se presentan los ingresos declarados segmentados por tramos de ingresos antes de impuestos, divididos por fuente de ingreso según el caso, con información sobre las deducciones que reducen el impuesto determinado.

Sin embargo, y sin entrar en detalles específicos, el uso de esta información encierra tres problemas de índole metodológica al momento de intentar calcular las participaciones de los tramos superiores en el ingreso total. Los dos primeros se relacionan con controles totales de consistencia. El primer problema consiste en la necesidad de relacionar el número de personas declarantes de impuestos con algún control para poder determinar cuánto representan los que han declarado impuestos en relación con el total. El segundo busca determinar, una vez definido el ingreso disponible, el nivel de ingreso de control que se considerará como denominador del ingreso de los tramos de ingresos más altos en la estimación. Por último, el tercer problema radica en que, dado que los ingresos se presentan por tramos y que no se

En los años sesenta, por ejemplo, Herschel (1963), quien empleaba datos de ingresos provenientes de declaraciones juradas de impuestos, realizó uno de los trabajos pioneros en la Argentina sobre el análisis del impacto distributivo de los impuestos. 
dispone de la base de datos de las declaraciones juradas, se requiere una metodología de interpolación para construir la distribución continua asociada a los ingresos presentados (la más utilizada es la interpolación de Pareto) ${ }^{7}$.

\section{B. Principales resultados de los estudios realizados en los países desarrollados}

Con una creciente difusión en los ámbitos académicos, los estudios disponibles sobre las altas rentas tienen tres objetivos: i) analizar la evolución de la participación de los tramos de ingresos más elevados sobre el total de ingresos en diferentes países, ii) fragmentar la participación de los tramos de ingresos elevados en segmentos más reducidos para analizar la concentración de los ingresos y iii) evaluar los cambios en la composición de los ingresos de los tramos de rentas más elevadas en función de la fuente del ingreso.

En primer lugar, se observa que la mayoría de los países ha experimentado una importante caída de las participaciones de los tramos de ingresos más elevados en la primera mitad del siglo XX, con descensos más marcados en los períodos cercanos a la Segunda Guerra Mundial o la Gran Depresión.

En la segunda parte del siglo XX, los ingresos concentrados en los tramos superiores comenzaron a experimentar un crecimiento paulatino y constante, que, sin embargo, varía de un país analizado a otro. En los países angloparlantes de Europa, América del Norte, Australia y Nueva Zelandia, China y la India se advierte un incremento importante en las participaciones de los tramos más elevados; en los países del sur de Europa y los países nórdicos también se aprecia un incremento en las participaciones de los ingresos más elevados, aunque de menor envergadura que en los casos anteriores. Por el contrario, los otros países de Europa continental (Alemania, Francia, Países Bajos, Suiza) y el Japón experimentaron modestos incrementos en los tramos de ingresos elevados en las últimas décadas.

Sin embargo, en contraste con el comportamiento anterior, en donde los incrementos están relacionados con el percentil superior, los aumentos resultan ser de menor alcance en los tramos que les siguen inmediatamente en la distribución. Asimismo, en oposición a la primera etapa del siglo, la mejora de las participaciones de los ingresos más altos estuvo asociada a los ingresos laborales, provenientes del salario, lo que implica que la proporción de ingresos correspondientes a la renta del salario era sustancialmente mayor que en los momentos anteriores.

Véase una explicación detallada y estimaciones de largo plazo para varios casos de estudio en Atkinson, Piketty y Saez (2011). 
Los datos disponibles muestran que, en efecto, la participación de los tramos de altos ingresos ha crecido de manera significativa en la mayoría de los países a lo largo del último siglo. En los Estados Unidos se registró una importante recuperación a partir de la década de 1970 y en 2011 se alcanzaron los valores más altos de la historia, de acuerdo con los datos relevados (46,5\%). Italia y el Japón exhiben un comportamiento similar, aunque en el primer caso la serie disponible no abarca un período tan extenso (1974-2009).

En Francia, por ejemplo, si bien la porción de ingresos que concentra los ingresos más altos crece, no alcanza a recuperar la significación alcanzada en los años treinta. Lo mismo acontece en Australia y Suecia, donde, si bien la concentración de los tramos más elevados se incrementa, no llega a los niveles máximos de la serie. La India y Noruega muestran comportamientos similares: elevadas concentraciones del ingreso en las décadas de 1940 y 1930, respectivamente, una caída de relevancia alrededor de los años setenta y una recuperación de la participación de los tramos de ingresos elevados a partir de la década de 1990, aunque los valores aún están muy alejados de los máximos en el caso de la India, mientras que en Noruega los superan. El Canadá muestra estabilidad en las series, pero la concentración crece desde mediados de los años noventa.

Alvaredo y otros (2013) identifican, a grandes rasgos, dos tipos de comportamientos: países como los Estados Unidos experimentan curvas con forma de U (curva de Kuznets invertida), mientras que Europa continental y el Japón muestran patrones con forma de L, en donde las concentraciones de ingresos en los tramos superiores aún no han recuperado el nivel alcanzado hacia mediados del siglo XX.

Las tendencias señaladas pueden apreciarse en el cuadro VI.1. En la comparación entre períodos cercanos a 1949 y 2005 se observa que, en algunas economías emergentes de gran tamaño, como la India, se redujo la concentración del ingreso en los niveles superiores (descenso de la participación de las rentas más altas). En los últimos años se ha observado una tendencia similar de menor desigualdad en países del sur de Europa, como España.

También se advierten notorias diferencias entre países en lo que respecta a la participación del $0,1 \%$ y el $1 \%$ y los siguientes cuatro cuantiles más altos. Alrededor de 2005, el Canadá, los Estados Unidos, el Reino Unido y Singapur integraban el grupo de países en los que el 1\% más rico (ingresos más altos) tenía una participación superior al 12\% (Atkinson, Piketty y Saez, 2011). Por otra parte, Australia, China, España, Finlandia, Francia, la India, Indonesia, Italia, el Japón, Nueva Zelandia, los Países Bajos, Portugal, Suecia y Suiza integraban el grupo en que la participación del $1 \%$ más rico fluctuaba entre el $5 \%$ y el $10 \%$. 
Cuadro VI.1

Evolución de la participación de los tramos de ingresos elevados, alrededor de 1949 y 2005

(En porcentajes)

\begin{tabular}{|c|c|c|c|c|c|c|}
\hline \multirow[b]{2}{*}{ Países } & \multicolumn{3}{|c|}{ Participación del $1 \%$ superior } & \multicolumn{3}{|c|}{ Participación del $0,1 \%$ superior } \\
\hline & $\begin{array}{c}\text { Alrededor } \\
\text { de } 1949\end{array}$ & $\begin{array}{l}\text { Alrededor } \\
\text { de } 2005\end{array}$ & $\begin{array}{c}\text { Tasa de } \\
\text { crecimiento }\end{array}$ & $\begin{array}{c}\text { Alrededor } \\
\text { de } 1949\end{array}$ & $\begin{array}{l}\text { Alrededor } \\
\text { de } 2005\end{array}$ & $\begin{array}{c}\text { Tasa de } \\
\text { crecimiento }\end{array}$ \\
\hline Indonesia & 19,87 & 8,46 & $-57,42$ & 7,03 & 1,34 & $-80,94$ \\
\hline Irlanda & 12,92 & 10,30 & $-20,28$ & 4,00 & $\ldots$ & $\ldots$ \\
\hline Países Bajos & 12,05 & 5,38 & $-55,35$ & 3,80 & 1,08 & $-71,58$ \\
\hline India & 12,00 & 8,95 & $-25,42$ & 5,24 & 3,64 & $-30,53$ \\
\hline Alemania & 11,60 & 11,10 & $-4,31$ & 3,90 & 4,40 & 12,82 \\
\hline Reino Unido & 11,47 & 14,25 & 24,24 & 3,45 & 5,19 & 50,43 \\
\hline Australia & 11,26 & 8,79 & $-21,94$ & 3,31 & 2,68 & $-19,03$ \\
\hline Estados Unidos & 10,95 & 17,42 & 59,09 & 3,34 & 7,70 & 130,54 \\
\hline Canadá & 10,69 & 13,56 & 26,85 & 2,91 & 5,23 & 79,73 \\
\hline Singapur & 10,38 & 13,28 & 27,94 & 3,24 & 4,29 & 32,41 \\
\hline Nueva Zelandia & 9,98 & 8,76 & $-12,22$ & 2,42 & 2,51 & 3,72 \\
\hline Suiza & 9,88 & 7,76 & $-21,46$ & 3,23 & 2,67 & $-17,34$ \\
\hline Francia & 9,01 & 8,73 & $-3,11$ & 2,61 & 2,48 & $-4,98$ \\
\hline Noruega & 8,88 & 11,82 & 33,11 & 2,74 & 5,59 & 104,01 \\
\hline Japón & 7,89 & 9,20 & 16,60 & 1,82 & 2,40 & 31,87 \\
\hline Finlandia & 7,71 & 7,08 & $-8,17$ & $\ldots$ & 2,65 & $\ldots$ \\
\hline Suecia & 7,64 & 6,28 & $-17,80$ & 1,96 & 1,91 & $-2,55$ \\
\hline España & $\ldots$ & 8,79 & $\ldots$ & $\ldots$ & 2,62 & $\ldots$ \\
\hline Portugal & $\ldots$ & 9,13 & $\ldots$ & 3,57 & 2,26 & $-36,69$ \\
\hline Italia & $\ldots$ & 9,03 & $\ldots$ & $\ldots$ & 2,55 & $\ldots$ \\
\hline China & $\ldots$ & 5,87 & $\ldots$ & $\ldots$ & 1,20 & $\ldots$ \\
\hline
\end{tabular}

Fuente: Elaboración propia, sobre la base de A.B. Atkinson, T. Piketty y E. Saez, "Top incomes in the long run of history", Journal of Economic Literature, vol. 49, $\mathrm{N}^{\circ} 1$, Nashville, Tennessee, American Economic Association, 2011.

Si se descompone el decil de ingresos más elevados en diferentes tramos (el 0,1\% más rico, del 0,1\% al 0,5\% más rico, del 0,5\% al 1\% más rico, del 1\% al 5\% más rico y el tramo que va del 5\% más rico al 10\% más afluente), los datos disponibles muestran comportamientos muy diferentes según el país analizado.

En el caso de los Estados Unidos, se advierte un crecimiento importante de la relevancia del tramo del 0,1\% del total de ingresos, con una curva en forma de $\mathrm{U}$; es decir que hacia los períodos más recientes se advierte un cambio en la composición del decil de ingresos más elevados, en donde el percentil de mayores ingresos gana relevancia en el percentil más alto. Francia, entretanto, presenta el comportamiento opuesto: la participación del 0,1\% superior cae significativamente hacia la Segunda Guerra Mundial 
y después experimenta un crecimiento moderado. En Suecia, si bien hacia mediados de la década de 1970 las participaciones de las dos particiones más relevantes alcanzan proporciones similares, a partir de ese período la brecha se hace cada vez mayor. Algunos países poseen características particulares. En la India, por ejemplo, el tramo de mayor concentración en los últimos períodos relevados resulta ser el 0,1\% superior y se relega a un segundo lugar al tramo comprendido entre el 0,1\% y el 0,5\%. El Japón muestra, después de la Segunda Guerra Mundial, un importante aumento de la brecha entre los tramos que más ingreso concentran (del 1\% al 5\% superior y del 5\% al 10\% superior) y los que menos ingreso concentran.

En la primera parte del siglo XX, la gran mayoría de los ingresos estaban compuestos por ingresos del capital (en oposición a los ingresos laborales), lo que implica que la caída de la participación de los altos ingresos corresponde principalmente a una disminución de este tipo de ingresos. En contraste, las participaciones de los tramos inmediatos subsiguientes, cuya composición mayoritaria corresponde a la renta de asalariados, no experimentó en esos períodos una caída semejante. En los Estados Unidos, en el 0,1\% de los ingresos más altos es decreciente la proporción de ingresos correspondiente a salarios (y también los ingresos de empleadores), mientras que en el caso de Francia los salarios se mantienen prácticamente constantes y la participación de la renta del capital se eleva a expensas de la renta empresarial. El crecimiento de la participación de los salarios también se aprecia en el Canadá y España.

Atkinson, Piketty y Saez (2011) identifican tres razones para subrayar la importancia de analizar la evolución de la participación de estos sectores en la concentración del ingreso, además de la preocupación por la desigualdad en la distribución, que determina que los países apliquen políticas de transferencias monetarias, subsidios e impuestos progresivos con el objeto de lograr una distribución del ingreso más igualitaria.

Si bien los individuos que concentran los ingresos superiores constituyen una parte muy reducida (insignificante en términos estadísticos) del total de la población, su participación en el ingreso nacional es muy significativa.

En los Estados Unidos, por ejemplo, si bien el 1\% superior de ingresos concentra una proporción muy reducida de la población, hacia 2007 capturaba un $23,5 \%$ del total del ingreso (Atkinson, Piketty y Saez, 2011). Además, el incremento de la participación de los ingresos elevados tiene un impacto importante en el crecimiento del PIB. En el cuadro VI.2 puede verse que el ingreso real por hogar en los Estados Unidos se incrementó alrededor de un 1,2\%, en promedio, en el período comprendido entre 1976 y 2007. 


\section{Cuadro VI.2}

\section{Estados Unidos: concentración de ingresos en el 1\% superior} y crecimiento medio del ingreso, 1976-2007

(En porcentajes)

\begin{tabular}{lccc}
\hline & $\begin{array}{c}\text { Período } \\
1976-2007\end{array}$ & $\begin{array}{c}\text { Período } \\
1993-2000\end{array}$ & $\begin{array}{c}\text { Período } \\
2002-2007\end{array}$ \\
\hline Tasa de crecimiento medio anual del ingreso real & 1,2 & 4,0 & 3,0 \\
\hline $\begin{array}{l}\text { Tasa de crecimiento medio anual del ingreso } \\
\text { del 1\% superior }\end{array}$ & 4,4 & 10,3 & 10,1 \\
\hline $\begin{array}{l}\text { Tasa de crecimiento medio anual del ingreso } \\
\text { del 99\% inferior }\end{array}$ & 0,6 & 2,7 & 1,3 \\
\hline $\begin{array}{l}\text { Fracción del crecimiento del ingreso total captado } \\
\text { por el 1\% superior }\end{array}$ & 58,0 & 45,0 & 65,0 \\
\hline
\end{tabular}

Fuente: A.B. Atkinson, T. Piketty y E. Saez, "Top incomes in the long run of history", Journal of Economic Literature, vol. 49, № 1, Nashville, Tennessee, American Economic Association, 2011.

El ingreso medio que surge de excluir el 1\% más rico creció a una tasa del 0,6\%, mientras que el tramo más rico aumentó su ingreso medio un $4,4 \%$. Al dividir el último período en dos etapas (correspondientes a las expansiones económicas de los períodos de Clinton y Bush), puede advertirse que, si bien en ambas etapas los ingresos medios del $1 \%$ superior crecieron a tasas similares, la tasa de crecimiento del ingreso medio del $99 \%$ inferior fue del $2,7 \%$ en la primera, mientras que en el otro lapso esta tasa se redujo al 1,3\%. Esto confirma el hecho de que la parte del crecimiento del ingreso total medio fue capturada en una proporción mucho mayor por el tramo de ingresos más elevados.

En una comparación internacional del comportamiento evidenciado por los Estados Unidos y Francia se observa que, mientras que en el primero el ingreso real por hogar total creció un 32,2\% entre 1975 y 2006 y el ingreso del $99 \%$ inferior se incrementó un 17,9\%, en el segundo caso, el porcentaje de crecimiento del ingreso total fue del $27,1 \%$, mientras que el alza fue del $26,4 \%$ si se excluye el $1 \%$ más alto. De esta manera, puede verse que, si bien el crecimiento fue mayor, en promedio, en los Estados Unidos, este ocurre a expensas de reducir la participación del $99 \%$ inferior en el total del ingreso.

Dada su considerable relevancia en términos de ingresos, la inclusión de los individuos más ricos determina una parte importante de los cambios en la desigualdad. No obstante, las mediciones convencionales de este fenómeno, a través del coeficiente de Gini calculado con datos de las encuestas de hogares, tienden a ignorar sistemáticamente los ingresos superiores, por lo que no presentan una verdadera perspectiva de la evolución de la desigualdad en los países (véase el recuadro VI.1). El coeficiente de Gini corregido sería, entonces, varios puntos superior al coeficiente estándar sin la corrección cuando la concentración del ingreso en los niveles más altos es elevada. 


\section{Recuadro VI.1 \\ El ajuste de los altos ingresos en las mediciones de desigualdad}

El indicador más utilizado en las mediciones de desigualdad es el coeficiente de Gini, que mide el área que se encuentra por debajo de la curva de Lorenz, es decir, entre el gráfico de esta y la línea de perfecta igualdad. Dicho de otro modo, el coeficiente de Gini compara las áreas que están por encima y por debajo de la curva. Los valores extremos para este índice son 1 para la perfecta desigualdad y 0 para la perfecta igualdad.

El coeficiente de Gini depende, sin embargo, del orden de los individuos en la distribución, y cambia de acuerdo con la diferencia de rango entre ellos. A la vez, establece que una transferencia de una persona rica a una persona pobre de la distribución tiene mucho mayor efecto en la caída del indicador si se realiza entre individuos más próximos a la media de la distribución que si estos estuviesen más alejados de dicha media y, por ende, más próximos a los extremos. Entonces, la medición convencional efectuada a través del coeficiente de Gini debe corregirse para captar estos tramos de la distribución, dado que este índice, por construcción, otorga mayor peso relativo a las transferencias realizadas en la parte central de la distribución. A esto se suma el hecho de que en las encuestas de hogares se suele subestimar considerablemente la proporción de ingresos más altos.

Atkinson (2007) desarrolló una fórmula mediante la cual se corrige el coeficiente de Gini convencional para tomar en cuenta la proporción de los individuos con ingresos más altos, a los que considera numéricamente infinitesimales. Si el parámetro $S$ se define como la participación en el ingreso de los individuos con más altos ingresos (por ejemplo, el $1 \%$ superior) y $G^{*}$ se define como el coeficiente de Gini del resto de la población (por ejemplo, el $99 \%$ inferior), se puede demostrar que el Gini total "real" o corregido es igual a $G^{*}(1-S)+S$.

Mediante la aplicación de la fórmula de Atkinson (2007), y usando datos de la Argentina y los Estados Unidos, Alvaredo (2010) demuestra que el aumento del coeficiente de Gini en ambos países en las últimas décadas puede atribuirse, en gran medida, al incremento de la participación en el ingreso de los individuos de rentas más altas, lo que refleja la importancia de considerar la participación de los ingresos más altos en una medición adecuada del coeficiente de Gini.

Fuente: Elaboración propia, sobre la base de A. Atkinson, "Measuring top incomes: methodological issues", Top Incomes over the Twentieth Century: a Contrast between Continental European and English-Speaking Countries, A.B. Atkinson y T. Piketty (eds.), Oxford, Oxford University Press, 2007; y F. Alvaredo, "A note on the relationship between top income shares and the Gini coefficient”, CEPR Discussion Paper, N 8071, Londres, Centro de Investigación sobre Políticas Económicas, 2010.

En ese sentido, Atkinson, Piketty y Saez (2011) estimaron que un incremento del $14 \%$ en la participación del 1\% superior, como la que ocurrió en los Estados Unidos entre 1976 y 2006, generó un aumento del 8,8\% en el coeficiente de Gini (o del 10,8\% si se incluyen las ganancias de capital), lo que resulta superior al 7,2\% de la medición oficial. En el cuadro VI.3 puede advertirse la comparación de la evolución de los coeficientes de Gini, tanto para el caso de las encuestas de hogares como para la encuesta "corregida" (esta última considerando la participación en el ingreso del 1\% más rico a 
partir de información proveniente de declaraciones juradas de impuestos). Así, en 1976, el coeficiente de Gini pasa de 39,8 a 40,5 si se excluyen las rentas del capital y a 41,1 si se incluyen los ingresos del capital. En 2006, de acuerdo con la encuesta de hogares, el coeficiente de Gini había aumentado a 47,0, mientras que, si se corrige por la inclusión del $1 \%$ superior, el índice crece a 49,3 si se excluyen las ganancias de capital y a 51,9 si se las incluye.

Cuadro VI.3

Estados Unidos: evolución del coeficiente de Gini según la Encuesta Continua de Población ${ }^{a}, 1976$ y 2006

\begin{tabular}{lcc}
\hline & 1976 & 2006 \\
\hline Encuesta Continua de Población & 39,8 & 47,0 \\
\hline Encuesta Continua de Población, tomando solo el 99\% inferior según ingresos & 35,5 & 38,6 \\
\hline $\begin{array}{l}\text { Encuesta Continua de Población, corrigiendo el 1\% superior sin considerar } \\
\text { las ganancias de capital }\end{array}$ & 40,5 & 49,3 \\
\hline $\begin{array}{l}\text { Encuesta Continua de Población, corrigiendo el 1\% superior e incluyendo } \\
\text { las ganancias de capital }\end{array}$ & 41,1 & \multirow{2}{*}{51,9} \\
\hline
\end{tabular}

Fuente: A.B. Atkinson, T. Piketty y E. Saez, "Top incomes in the long run of history", Journal of Economic Literature, vol. 49, № 1, Nashville, Tennessee, American Economic Association, 2011.

a La Encuesta Continua de Población es la fuente primaria de estadísticas laborales de la población de los Estados Unidos.

Por añadidura, es evidente que los individuos pertenecientes a los tramos de ingresos elevados no solo tienen relevancia dentro de cada país, sino que también afectan la desigualdad del ingreso mundial. De acuerdo con estimaciones de Bourguignon y Morrisson (2002), el valor del coeficiente de Gini mundial se incrementó de 0,61 en 1910 a 0,64 en 1950 y a 0,657 en 2002.

Atkinson, Piketty y Saez (2011) dan cuenta de un fenómeno similar en los Estados Unidos. En términos netos de los impuestos federales, el percentil de ingresos más altos recibía en 1976 el 5,8\% del total del ingreso antes de impuestos y soportaba el $24 \%$ del total de impuestos a nivel federal. En 2007, ese tramo de ingresos concentraba el 17,3\% del total del ingreso antes de impuestos y aproximadamente el $74 \%$ del total de impuestos, lo que muestra un significativo incremento en la capacidad contributiva de este tramo de ingresos.

\section{Estudios sobre las altas rentas en América Latina}

Dado el menor grado de desarrollo de los países, las diferentes prioridades económicas que han tenido en los últimos años $\mathrm{y}$, sobre todo, la escasa disponibilidad estadística en la materia, los estudios realizados para identificar y evaluar la incidencia de los sectores de muy altas rentas dentro de la distribución del ingreso de los países latinoamericanos son muy recientes, de alcance acotado y limitados en cuanto a los resultados obtenidos y a 
las conclusiones que permiten extraer. En esta sección se presentarán los principales resultados de los trabajos pioneros realizados para la Argentina, Chile, Colombia y el Uruguay ${ }^{8}$.

\section{Argentina}

Alvaredo (2007 y 2010b) señala que la Argentina, pese a sus recurrentes crisis macroeconómicas, tradicionalmente se ha identificado como una de las economías con menor desigualdad de América Latina y ostenta un mayor grado de igualdad en la distribución del ingreso que el Brasil, Chile y México.

Este autor tomó como base de información la Encuesta Permanente de Hogares (EPH), relevada por el Instituto Nacional de Estadística y Censos (INDEC), en la que se han ido incorporando, en forma paulatina, aglomerados poblacionales hasta alcanzar actualmente a más del $60 \%$ de la población total (un $70 \%$ de la población urbana). Sin embargo, como la información relevada por esta encuesta - en relación con los ingresos elevados- es deficiente por varios motivos (no inclusión explícita por diseño muestral, falta de respuesta o eliminación ex post de valores extremos), se optó por complementarla con los datos provenientes de las declaraciones juradas del impuesto sobre la renta personal. No obstante, estos últimos datos no están exentos de inconvenientes, entre los que se encuentran las variaciones normativas en la legislación tributaria a lo largo del tiempo, la subdeclaración de ingresos y otras acciones tendientes a reducir la carga tributaria, inclusive de manera legal (elusión).

Alvaredo (2007 y 2010b) realiza estimaciones para el caso de la Argentina y construye una serie histórica, a partir de la información disponible de la Administración Federal de Ingresos Públicos (AFIP), desde 1932 hasta 2004. De esta manera, se comprueba que la Argentina presentó elevadas concentraciones del ingreso en las décadas de 1930 y 1940, una caída de relevancia alrededor de los años setenta y una recuperación de la participación de los tramos de ingresos elevados a partir de la década de 1990 (aunque los valores están muy alejados de los máximos). A su vez, aunque no se cuenta con una serie de datos exenta de interrupciones, Atkinson, Piketty y Saez (2011) pudieron comprobar que el 1\% más rico (ingresos más altos) tenía una participación del 19,34\% alrededor de 1949, mientras que en 2005 esta decreció hasta el $16,75 \%$. En el mismo período, la participación del 0,1\% superior también descendió del 7,87\% al 7,02\%.

Con la excepción del trabajo de Chile, los estudios aquí presentados forman parte de un proyecto de investigación denominado World Wealth and Income Database, con el que se ha intentado construir series estadísticas acerca de la dinámica de largo plazo en la distribución del ingreso en un número muy importante de países. En lo que respecta a América Latina, además de los mencionados, existen trabajos en proceso para los casos del Brasil, Chile (una nueva estimación, distinta a la que aquí se presenta) y México (véase [en línea] http://www.wid.world/). 
Para el período más reciente, los resultados del estudio muestran que entre 1997 y 2004 la participación del 1\% de ingresos más elevados se incrementó un 35\%, al pasar del $12,4 \%$ al 16,8\% del ingreso, con una caída al 12,9\% en 2001 (véase el gráfico VI.1). El incremento señalado se explica por un crecimiento de la proporción que concentra el 0,01\% más afluente, que pasó del 1,4\% al 2,5\% (un 79\% más), mientras que el tramo entre el 0,01\% y el $0,1 \%$ también aumenta, del $2,9 \%$ al $4,5 \%$, y el tramo entre el $0,1 \%$ y el $1 \%$ experimenta un incremento del 8,1\% al 9,7\% entre dichos años.

\section{Gráfico VI.1 \\ Argentina: participación en el ingreso total de los tramos de ingreso más elevados, 1997-2004}

(En porcentajes)

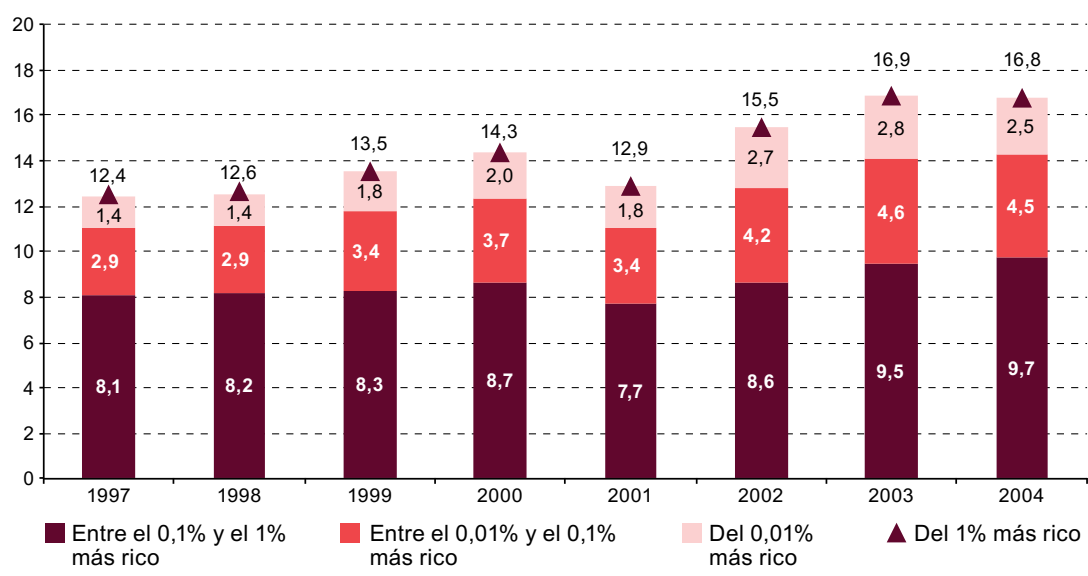

Fuente: Elaboración propia, sobre la base de F. Alvaredo, "The rich in Argentina over the Twentieth Century, 1932-2004", Top Incomes: a Global Perspective, A.B. Atkinson y T. Piketty (eds.), Oxford, Oxford University Press, 2010.

A partir del procesamiento de las declaraciones juradas del ISR, Alvaredo (2010b) comprobó que en la encuesta de hogares utilizada no se incluía a los individuos (presentaciones) de los tramos de ingresos más elevados. Esto obligaría a "corregir" el coeficiente de Gini que proviene de la información muestral, incluidos los tramos de ingresos más elevados no relevados en la $\mathrm{EPH}$.

En el gráfico VI.2 se muestra la evolución del coeficiente de Gini del ingreso por adulto equivalente para el período 1997-2004, junto con el comportamiento de este índice de desigualdad "corregido", alternativamente, a través de la inclusión tanto del 1\% más rico como del 0,1\% más afluente. El coeficiente de Gini según las encuestas creció un 2,9\% entre 1997 y 2004 (de 0,461 a 0,474); si se incluye al 1\% más rico, el incremento en la desigualdad sería del $6,5 \%$ (de 0,528 a 0,562), mientras que la inclusión del 0,1\% más 
afluente habría expandido el índice del 0,484 de 1997 al 0,511 de 2004 (5,6\%). Sin embargo, al considerar los datos de 2003, se constata que los aumentos fueron del $9,9 \%$ para la desigualdad de las encuestas, del $11,8 \%$ si se incluye el $1 \%$ más rico y del $12,3 \%$ si se incorpora el $0,1 \%$ superior.

\section{Gráfico VI.2}

Argentina: evolución del coeficiente de Gini según la Encuesta Permanente de Hogares (EPH) y ajustado con datos de declaraciones juradas del impuesto sobre la renta, 1997-2004

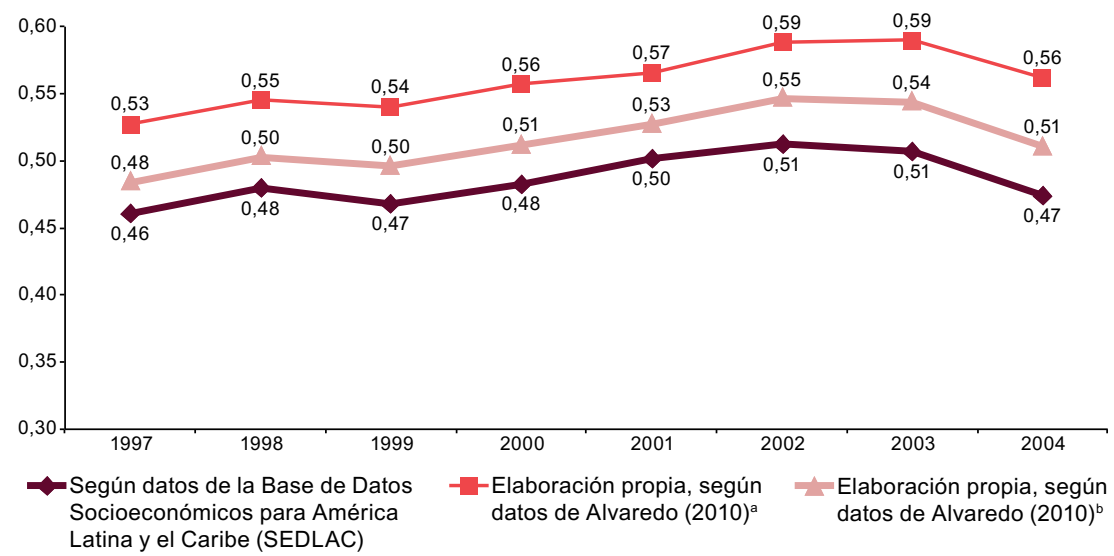

Fuente: Elaboración propia, sobre la base de F. Alvaredo, "The rich in Argentina over the Twentieth Century, 1932-2004", Top Incomes: a Global Perspective, A.B. Atkinson y T. Piketty (eds.), Oxford, Oxford University Press, 2010.

a Coeficiente de Gini calculado a partir de estimaciones que corrigen por el ingreso del 1\% más rico de la población.

b Coeficiente de Gini calculado a partir de estimaciones que corrigen por el ingreso del 0,1\% más rico de la población.

En el gráfico VI.2 puede advertirse que la desigualdad crece inequívocamente al incorporar el 1\% superior en la distribución que surge de las encuestas; de allí lo relevante de utilizar este tipo de estudios para analizar la evolución de la distribución del ingreso. Sin embargo, si se examinan los incrementos experimentados en el coeficiente de Gini al incluir el ajuste por subdeclaración, se constata que el aumento en la desigualdad evidenciado por el valor del coeficiente de Gini es superior.

La razón subyacente a este resultado estriba en el hecho de que el ajuste por subdeclaración, si bien se realiza en mayor medida en los tramos de ingresos superiores, abarca toda la distribución; por el contrario, el ajuste de ingresos realizado al incorporar el tramo de rentas mayores solo comprende el percentil más alto. Como el coeficiente de Gini pondera en mayor medida a los tramos intermedios de la distribución en relación con los extremos, el cambio en el coeficiente de Gini medido a partir de corregir por subdeclaración debería ser superior al corregido mediante declaraciones 
juradas de impuestos. Es menester combinar los dos enfoques para arribar a una definición más acabada sobre los cambios en la desigualdad.

Por último, resulta interesante analizar la composición de los ingresos más elevados en función de las fuentes de generación de dichos ingresos. En el gráfico VI.3 puede advertirse una caída, del 49,2\% en 2001 al 30,3\% en 2004, de la participación de los ingresos salariales en el 1\% más rico. Este descenso en la participación de los salarios se compensa con un crecimiento de las rentas empresariales o por cuenta propia, cuya participación aumenta del 34,7\% en 2001 al 45,0\% en 2004. Si bien las rentas del capital también muestran un crecimiento relativo, están sujetas a la estrechez de la base imponible en función del alcance de las normativas particulares sobre cuáles son las rentas de este tipo alcanzadas por el impuesto a los ingresos. Vale agregar que estos comportamientos en las diferentes fuentes de ingresos también se comprueban cuando se analizan los ingresos del 0,1\% más rico, aunque allí es más acentuada la participación de las rentas empresariales o por cuenta propia, que se incrementa del 54,9\% en 2001 al 63,8\% en 2004.

\section{Gráfico VI.3}

Argentina: composición del 1\% de ingresos más elevados, 2001-2004

(En porcentajes)

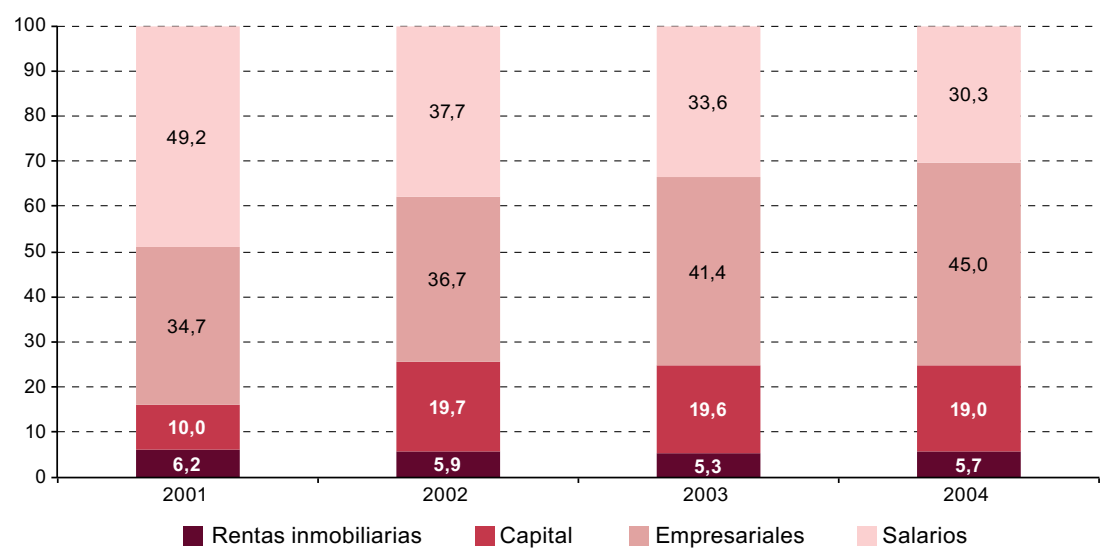

Fuente: Elaboración propia, sobre la base de F. Alvaredo, "The rich in Argentina over the Twentieth Century, 1932-2004", Top Incomes: a Global Perspective, A.B. Atkinson y T. Piketty (eds.), Oxford, Oxford University Press, 2010.

\section{Colombia}

Colombia se ha caracterizado como uno de los países de América Latina con mayores niveles de desigualdad medidos por el coeficiente de Gini (Ferreira y Ravallion, 2008). Resulta interesante evaluar en qué medida esto se modifica con la incorporación de los tramos de ingresos elevados. 
Para este caso, Alvaredo y Londoño (2013) realizan un análisis considerando el período 1993-2010, a partir de datos de las declaraciones juradas del ISR, provistos por la Dirección de Impuestos y Aduanas Nacionales (DIAN). Desde el punto de vista metodológico, se enfrentó el problema de adecuar los microdatos de las declaraciones juradas en relación con el ingreso declarado al fisco debido a la amplitud de conceptos que podrían estar incluidos entre las deducciones que los contribuyentes declaran y que les permiten reducir sus obligaciones impositivas. Para salvar este inconveniente, los autores definen, como una corrección ad hoc, el ingreso total como "ingreso bruto" menos la sexta parte de los "costos y deducciones" declarados por los contribuyentes.

Los resultados del estudio determinan que el ingreso en Colombia está muy concentrado, dado que el $1 \%$ superior de la distribución concentró el 20,5\% del ingreso bruto en 2010. Entre 1993 y 2010, la participación del 1\% de ingresos más elevados se mantuvo prácticamente constante entre los extremos, con algunas fluctuaciones de relevancia (cayó al 17,3\% en 2000 y 2001), mientras que la participación del $0,1 \%$ bajó del 8,4\% al 7,4\% en ese mismo lapso, con mínimos del 6,0\% en el período 2001-2003.

En el gráfico VI.4 se descompone la evolución de la participación del 1\% más rico en el ingreso total para los períodos en que se cuenta con la información de los porcentajes de ingreso que concentran el 0,1\% y el 0,01\% de mayor capacidad económica (2006-2010). El incremento del ingreso del 1\% de mayores ingresos, del 19,9\% al 20,5\%, se explica por un crecimiento de la proporción que concentra el tramo entre el 0,1\% y el 1\%, que pasa del 12,3\% al $13,1 \%$ del total, con lo que se compensan los leves descensos de las participaciones del 0,01\% más afluente, que cayó del 2,9\% al 2,6\% del total, y del tramo entre el $0,01 \%$ al 0,1\%, que bajó del 4,8\% al 4,7\%.

Mientras las encuestas de hogares muestran que la desigualdad medida a través del coeficiente de Gini se redujo más de un 6\% (de 0,59 en 2007 a 0,55 en 2010), la incorporación del 1\% superior corrigiendo los datos de la encuesta matiza ligeramente ese panorama (véase el gráfico VI.5). No solo los niveles de desigualdad son mayores, sino que, además, las referidas disminuciones del coeficiente de Gini son menos marcadas. Para el caso de Colombia, el coeficiente de Gini basado en encuestas era de 0,59 en 2007 y descendió a 0,54 en 2008 para volver a crecer a 0,544 en 2009 y llegar a 0,554 en 2010. Al corregir por la información de las declaraciones juradas, el coeficiente de Gini era de 0,612 en 2007, se redujo a 0,572 en 2008 y volvió a crecer a 0,575 en 2009 y a 0,587 en 2010. 


\section{Gráfico VI.4}

Colombia: participación en el ingreso total de los tramos de ingresos más elevados, 2006-2010

(En porcentajes)

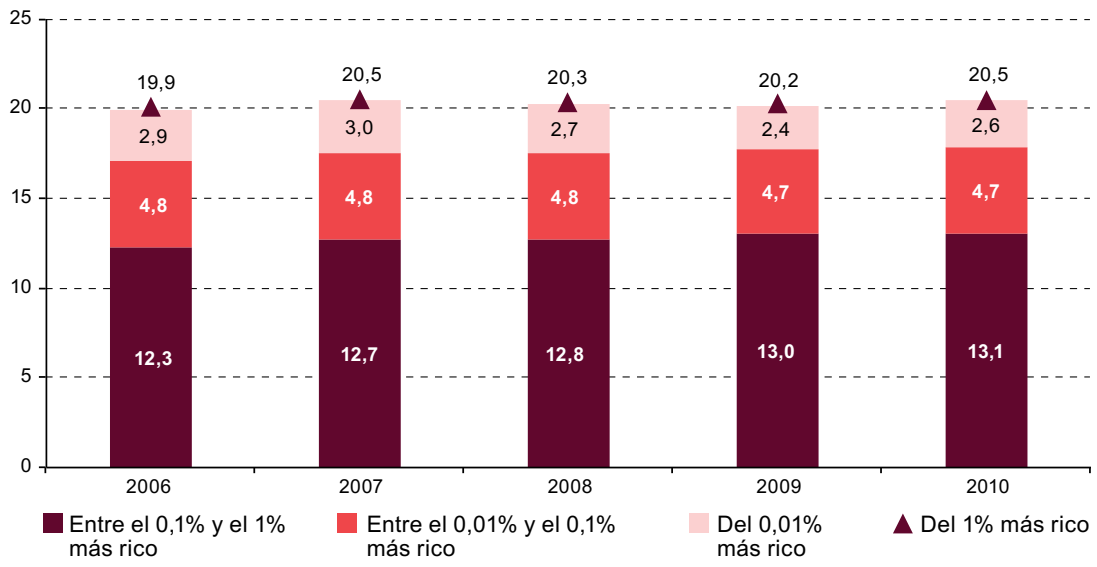

Fuente: Elaboración propia, sobre la base de F. Alvaredo y J. Londoño, "High incomes and personal taxation in a developing economy: Colombia 1993-2010", Commitment to Equity (CEQ) Working Paper Series, $N^{\circ}$ 12, Universidad de Tulane, 2013.

\section{Gráfico Vl.5}

Colombia: evolución del coeficiente de Gini según encuestas de hogares y ajustado con datos de declaraciones juradas del impuesto sobre la renta, 2007-2010

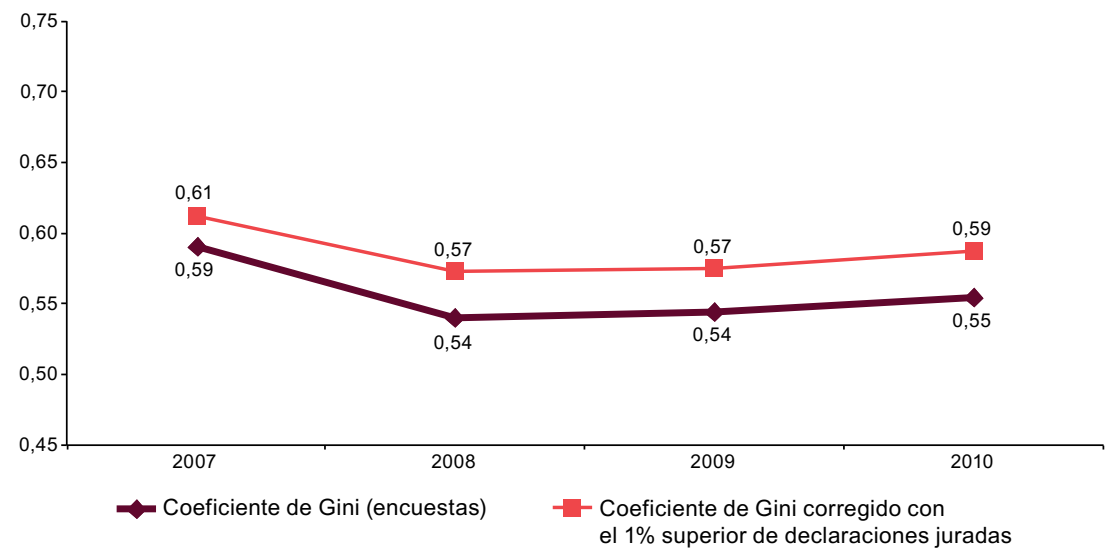

Fuente: Elaboración propia, sobre la base de F. Alvaredo y J. Londoño, "High incomes and personal taxation in a developing economy: Colombia 1993-2010", Commitment to Equity (CEQ) Working Paper Series, $N^{\circ}$ 12, Universidad de Tulane, 2013.

Los individuos de ingresos elevados en Colombia son esencialmente rentistas y propietarios del capital, característica que difiere de lo observado en otros países de América Latina, como la Argentina, en donde puede apreciarse 
que la mayor proporción de los ingresos de los más ricos corresponde a salarios (si bien, como ya se mostró, esta tendencia fue revertida en el período de análisis). Alvaredo y Londoño (2013) puntualizan que Colombia sigue teniendo un patrón más tradicional de ingresos, en el cual, a diferencia de los Estados Unidos y el Reino Unido, los perceptores de ingresos más elevados aún son los propietarios del acervo de capital.

En el gráfico VI.6, que abarca el período 2006-2010, se aprecia una constancia en la participación de los ingresos del capital en alrededor del $41 \%$ al $42 \%$ en el caso del 1\% superior. La participación de los ingresos salariales cae del $29,7 \%$ al 28,6\%, y aumentan ligeramente los ingresos empresariales y por cuenta propia al 5,5\% y al 18,4\%, respectivamente. Esta estructura y su evolución también se observan en el $0,1 \%$ más rico, aunque con una preponderancia sustancialmente mayor de las rentas del capital (un 57,6\% en 2010) sobre los salarios y las rentas empresariales o por cuenta propia (un $11,5 \%$ y un $16,5 \%$ en 2010 , respectivamente).

\section{Gráfico VI.6}

Colombia: composición del 1\% de ingresos más elevados, 2006-2010 (En porcentajes)

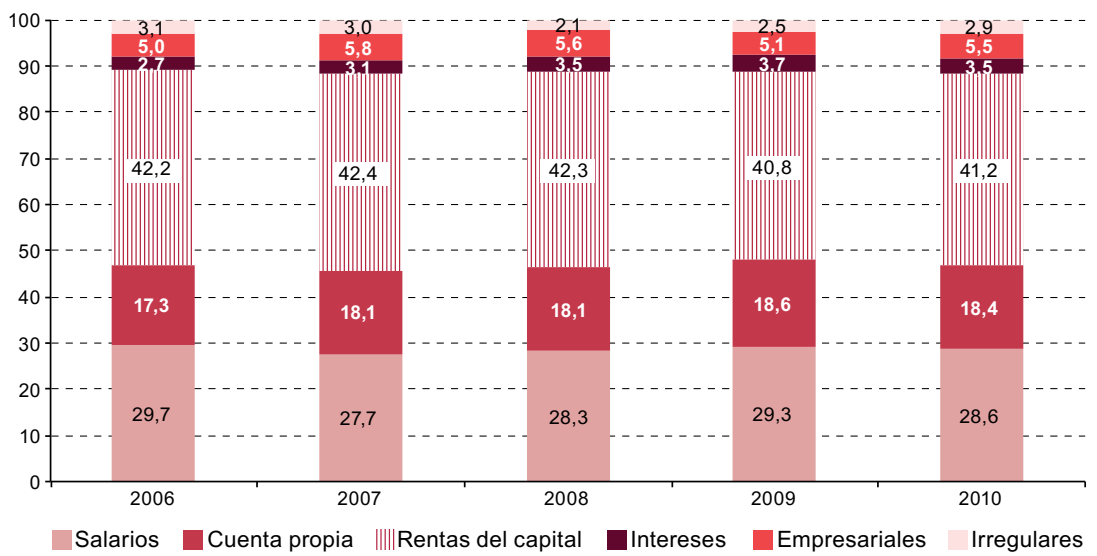

Fuente: Elaboración propia, sobre la base de F. Alvaredo y J. Londoño, "High incomes and personal taxation in a developing economy: Colombia 1993-2010", Commitment to Equity (CEQ) Working Paper Series, N 12, Universidad de Tulane, 2013.

\section{Chile}

En un trabajo reciente, López, Figueroa y Gutiérrez (2013) utilizan la metodología desarrollada en Atkinson y Piketty (2007 y 2010), Atkinson, Piketty y Saez (2011), Alvaredo (2007 y 2010b) y Alvaredo y Londoño (2013) para calcular las participaciones relativas de los individuos de altos ingresos a partir 
de los datos que surgen de las declaraciones juradas del ISR, con algunas particularidades de adaptación al caso chileno para el período 2005-20109.

Los datos utilizados para las estimaciones se basan en información oficial del Servicio de Impuestos Internos (SII) de Chile sobre ingresos declarados por las personas naturales en ocho tramos de ingreso total individual (ITI) declarado y también como proporción del ingreso total declarado al SII por las personas naturales. El ITI incluye los ingresos del trabajo más las utilidades distribuidas de las empresas (UDN), pero excluye las utilidades no distribuidas de las empresas o ganancias de capital; los tres tramos tributarios más altos incluyen aproximadamente al 1\% más rico de los contribuyentes. Para el trabajo, López, Figueroa y Gutiérrez (2013) contaron con información oficial sobre el ingreso efectivo declarado por los contribuyentes al SII. Además, se contó con datos sobre la participación de los trabajadores por cuenta propia y con estimaciones sobre las tasas de evasión del ISR. Para calcular el ingreso total de control se partió de los datos sobre el ingreso declarado efectivo, al que se sumó una estimación del ingreso imponible no declarado utilizando las tasas de evasión tributaria calculadas por Jorratt (2012).

Los resultados del estudio muestran que entre 2005 y 2010 la participación del $1 \%$ de ingresos más elevados cayó un $8 \%$, al pasar del $21,6 \%$ del ingreso al 19,9\% (véase el gráfico VI.7). Esta disminución se explica por el descenso en la proporción que concentra tanto el 0,01\% más afluente (del 2,0\% al $1,8 \%$ ), como el tramo entre el $0,01 \%$ y el $0,1 \%$ (del $4,6 \%$ al $4,2 \%$ ) y el tramo entre el $0,1 \%$ y el $1 \%$ (del $15,0 \%$ al $13,9 \%$ ).

Sin embargo, las estimaciones presentadas no incluyen las utilidades no distribuidas ni las ganancias de capital. Particularmente en el caso de Chile, esto podría derivar en una subestimación de las participaciones relativas de los grupos más ricos en el ingreso total, dada la gran importancia de estos dos componentes ${ }^{10}$.

Si bien en el trabajo de López, Figueroa y Gutiérrez (2013) se calcula la participación de los más ricos en virtud de información tributaria, la metodología no es estrictamente comparable con la de otros estudios disponibles para América Latina.

10 En un trabajo más reciente, Fairfield y Jorratt (2014) realizaron una serie de ajustes a la metodología convencional a fin de incluir efectivamente una gran proporción de los beneficios retenidos por las firmas. Así comprobaron que el 1\% más rico de la población concentraría el 15\% de los ingresos totales pero que dicha proporción se elevaría a un mínimo del $23 \%$ cuando el concepto de ingreso se expande para incluir las utilidades no distribuidas, las cuales fueron asignadas a los contribuyentes de acuerdo a los registros tributarios disponibles. 
Gráfico VI.7

Chile: participación en el ingreso total de los tramos de ingresos más elevados, 2005-2010

(En porcentajes)

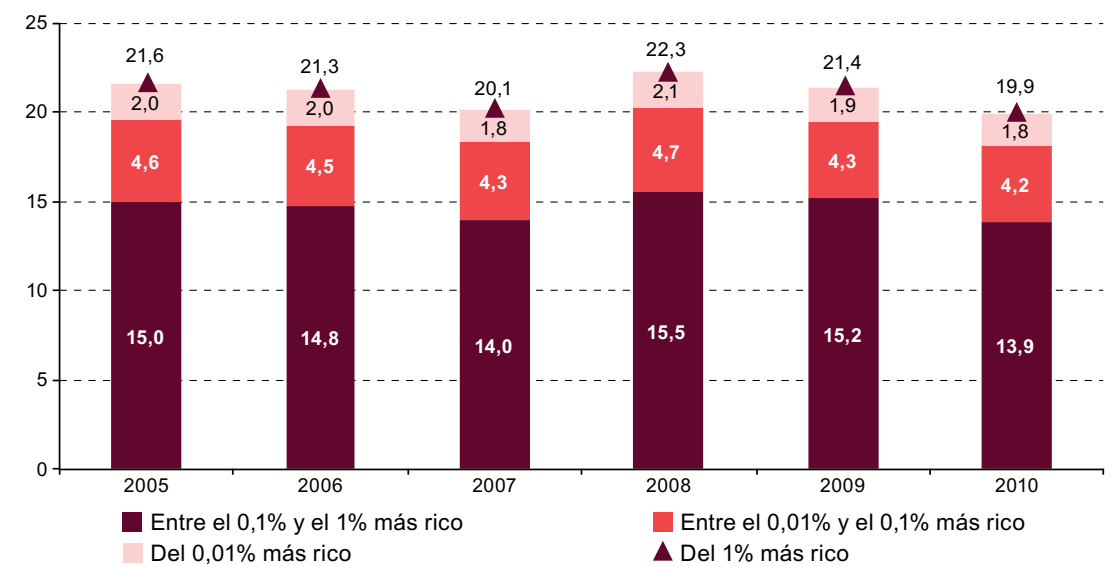

Fuente: Elaboración propia, sobre la base de R. López, E. Figueroa y P. Gutiérrez, “La 'parte del león': nuevas estimaciones de la participación de los súper ricos en el ingreso de Chile", Documentos de Trabajo, №379, Santiago, Universidad de Chile, 2013.

Por una parte, la propiedad del capital en Chile está mucho más concentrada que en la mayoría de los demás países de América Latina y, a su vez, la concentración del capital en manos de los estratos más ricos es mucho mayor que la concentración de los ingresos declarados al SII por estos grupos. Además, al menos hasta que entre en vigor lo establecido por la última reforma tributaria aprobada en 2014, en Chile existen incentivos para que los propietarios de acciones de empresas retengan las utilidades y así eviten pagar el ISR que deberían abonar como receptores de dichas utilidades cuando estas se distribuyen ${ }^{11}$. Al momento de la realización de estas estimaciones, el impuesto a las ganancias de capital era igual a cero para las acciones de empresas compradas después de 2001, con un sistema integrado para el tratamiento de las rentas percibidas ${ }^{12}$. La tasa marginal

11 Entre otras numerosas modificaciones de aplicación gradual, la reciente reforma tributaria contempló el reemplazo del Fondo de Utilidades Tributables (FUT) por dos nuevos regímenes tributarios alternativos a los cuales los contribuyentes tienen el derecho de optar y que entrarán en vigencia a partir de 2017: i) el régimen de renta atribuida, que utilizará el criterio de renta devengada (sean o no distribuidas las utilidades correspondientes), tendrá una tasa del $25 \%$ y permitirá utilizar el 100\% del monto de impuesto pagado a nivel de la sociedad como crédito contra los impuestos finales en cabeza del accionista (integración total), y ii) el régimen parcialmente integrado, que se rige por el criterio de renta percibida, donde los contribuyentes solo tributan por las rentas efectivamente recibidas a una tasa del impuesto societario mayor (un 25,5\% en 2017 y un $27 \%$ a partir de 2018) y con un límite máximo (65\%) para el crédito del impuesto pagado a nivel de la sociedad imputable contra los impuestos finales de los accionistas.

12 El impuesto de primera categoría a las utilidades generadas por las empresas podía utilizarse como un crédito tributario $(100 \%)$ para el pago del impuesto sobre la renta personal que deben hacer los individuos naturales propietarios (accionistas) de la empresa. 
del ISR para los contribuyentes de más altos ingresos (que era del $40 \%$ hasta la mencionada reforma y hoy es del 35\%) es mucho más elevada que la del impuesto directo a las utilidades devengadas por las empresas $(18,5 \%)$, lo que provee incentivos muy claros para postergar indefinidamente la distribución de utilidades (o para distribuir solo el 30\% que la ley exige como mínimo).

Con el objeto de corregir este sesgo, los autores desarrollan ajustes para incluir ambos factores. Así, presentan los resultados de los distintos cálculos realizados tomando como referencia diversos instrumentos: i) la Encuesta de Caracterización Socioeconómica Nacional (CASEN), ii) los datos de declaraciones juradas del SII, iii) los datos de declaraciones juradas ajustados por utilidades no distribuidas y iv) los datos de ingresos ajustados por ganancias de capital. De este modo pudo comprobarse que, en línea con los resultados de Atkinson, Piketty y Saez (2011) sobre varios países, en el caso de Chile, las participaciones en el ingreso del país estimadas a partir de los datos de la encuesta CASEN subestiman significativamente la participación del $1 \%$ más rico.

Por ejemplo, en 2010, según los datos informados por la encuesta CASEN, la participación en el ingreso total del país del 1\% de los chilenos más ricos fue solamente del 14,9\%, mientras que las estimaciones a partir de los datos del SII muestran que esta participación fue del 19,9\%. El ajuste por utilidades no distribuidas incrementa la participación del 1\% más acaudalado, determinándose, para 2010, que esta categoría concentra el 31,6\% del ingreso total, cifra que es algo menor cuando se incorporan las ganancias de capital $(29,0 \%)$, aunque también se ubica muy por encima de los resultados obtenidos a partir de la encuesta de hogares CASEN. Los autores encuentran que estos patrones de comportamiento se mantienen en el caso de las participaciones relativas en el ingreso tanto del 0,1\% como del 0,01\% de los individuos más ricos del país.

Asimismo, el coeficiente de Gini correspondiente a la desigualdad de la distribución del ingreso en el período 2005-2010 calculado con los datos de la encuesta CASEN resulta ser de 0,55 para este último año, mientras que las estimaciones a partir de los datos del SII muestran que su valor fue de 0,57 si se utilizan datos de declaraciones juradas sin corregir (véase el gráfico VI.8). Esto indica que la desigualdad existente en Chile resulta ser mucho mayor que la reportada oficialmente. La inclusión de ganancias de capital hace crecer el coeficiente a 0,62 para 2010, y este se incrementa aún más, a 0,67, si en lugar de estas se incorporan las utilidades retenidas o no distribuidas. A lo largo del período analizado, la desigualdad medida por el coeficiente de Gini es mayor al incluir las utilidades retenidas que al incluir las ganancias de capital, excepto para 2008. 


\section{Gráfico VI.8}

Chile: evolución del coeficiente de Gini según encuestas de hogares y ajustado con datos de declaraciones juradas del impuesto sobre la renta, 2005-2010

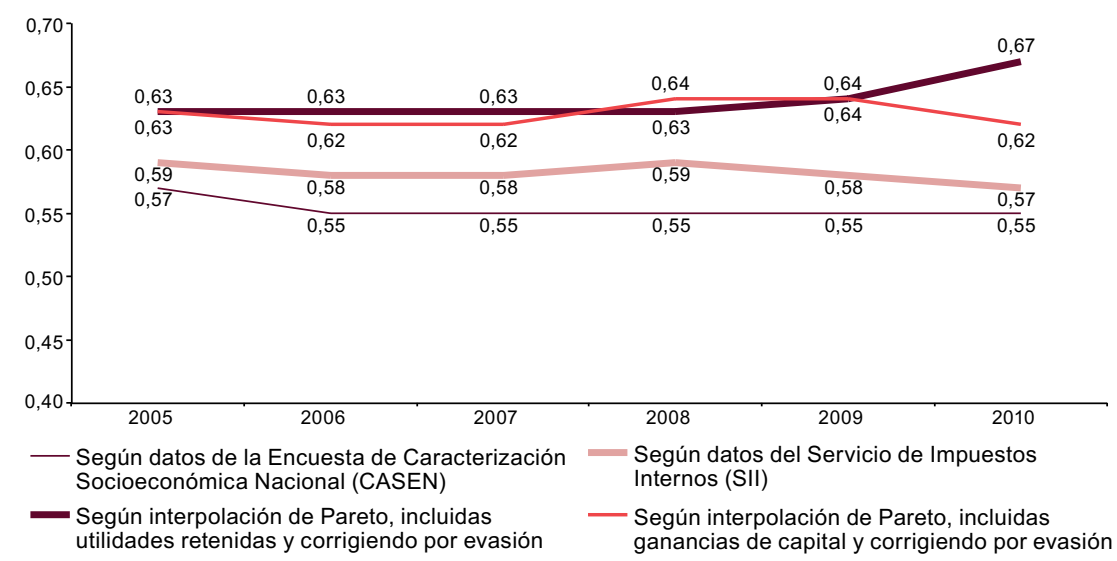

Fuente: R. López, E. Figueroa y P. Gutiérrez, La 'parte del león': nuevas estimaciones de la participación de los súper ricos en el ingreso de Chile”, Documentos de Trabajo, N379, Santiago, Universidad de Chile, 2013

\section{Uruguay}

En el estudio más reciente referido a un país de América Latina, Burdín, Esponda y Vigorito (2014) analizan la distribución del ingreso en el Uruguay para el período 2009-2011 y usan por primera vez los microdatos tributarios de imposición a la renta personal recabados por la Dirección General Impositiva (DGI). Estos autores miden la desigualdad, con énfasis en la participación de los sectores de mayores ingresos relativos (un $1 \%$, un $0,5 \%$ y un $0,1 \%$ superior). Posteriormente, las estimaciones se comparan con las que se obtienen utilizando la Encuesta Continua de Hogares (ECH), que constituye la principal fuente de información de los estudios de esta naturaleza.

Para ello, se compatibilizan ambas fuentes de información en virtud de una definición de ingreso primario o de mercado (ingresos laborales, de capital y jubilaciones) a nivel de personas. Además, se computan coeficientes de Gini ajustados sobre la base de la metodología propuesta en Atkinson, Piketty y Saez (2011) y Alvaredo (2010a). La comparación resulta de interés, dado que en algunos trabajos de investigación previos, basados en la ECH para el mismo período que se analiza, se muestra una reducción de la desigualdad de ingresos de los hogares, lo que revierte la tendencia concentradora evidenciada en la década previa.

Los resultados del estudio citado muestran que la participación del 1\% superior en el ingreso se ubica, en los años de análisis, ligeramente por encima del $12 \%$ tomando la información de la DGI, con una ligera tendencia 
ascendente en los tres años considerados (véase el cuadro VI.4) ${ }^{13}$. Este valor se ubica por debajo del estimado para Colombia por Alvaredo y Londoño (2013) y por encima de los correspondientes a la mayoría de los países desarrollados, con excepción de los Estados Unidos y Suiza.

\section{Cuadro VI.4}

Uruguay: participación en el ingreso total de grupos de ingresos altos y variación del ingreso medio, según fuente de información, 2009-2011

(En porcentajes)

\begin{tabular}{|c|c|c|c|c|c|c|c|c|}
\hline \multirow[b]{2}{*}{ Grupo } & \multicolumn{2}{|c|}{2009} & \multicolumn{2}{|c|}{2010} & \multicolumn{2}{|c|}{2011} & \multicolumn{2}{|c|}{$\begin{array}{c}\text { Índice de } \\
\text { ingreso medio }\end{array}$} \\
\hline & $\begin{array}{c}\text { Encuesta } \\
\text { Continua } \\
\text { de } \\
\text { Hogares } \\
\text { (ECH) }\end{array}$ & $\begin{array}{l}\text { Dirección } \\
\text { General } \\
\text { Impositiva } \\
\text { (DGI) }\end{array}$ & $\begin{array}{c}\text { Encuesta } \\
\text { Continua } \\
\text { de } \\
\text { Hogares } \\
\text { (ECH) }\end{array}$ & $\begin{array}{l}\text { Dirección } \\
\text { General } \\
\text { Impositiva } \\
\text { (DGI) }\end{array}$ & $\begin{array}{c}\text { Encuesta } \\
\text { Continua } \\
\text { de } \\
\text { Hogares } \\
(\mathrm{ECH})\end{array}$ & $\begin{array}{c}\text { Dirección } \\
\text { General } \\
\text { Impositiva } \\
\text { (DGI) }\end{array}$ & $\begin{array}{c}\text { Encuesta } \\
\text { Continua } \\
\text { de } \\
\text { Hogares } \\
\text { (ECH) }\end{array}$ & $\begin{array}{l}\text { Dirección } \\
\text { General } \\
\text { Impositiva } \\
\text { (DGI) }\end{array}$ \\
\hline $1 \%$ superior & 11,5 & 12,3 & 10,2 & 12,6 & 9,3 & 12,6 & 100,6 & 136,0 \\
\hline $0,5 \%$ superior & 7,7 & 8,6 & 6,6 & 9,0 & 5,9 & 9,0 & 95,3 & 138,8 \\
\hline $0,1 \%$ superior & 3,0 & 3,9 & 2,3 & 4,2 & 2,0 & 4,3 & 84,3 & 144,7 \\
\hline $0,05 \%$ superior & 1,9 & 2,9 & 1,5 & 3,1 & 1,3 & 3,2 & 79,6 & 145,2 \\
\hline $0,01 \%$ superior & $\ldots$ & 1,5 & $\ldots$ & 1,5 & $\ldots$ & 1,7 & $\ldots$ & 142,3 \\
\hline
\end{tabular}

Fuente: G. Burdín, F. Esponda y A. Vigorito, "Desigualdad y altos ingresos en Uruguay. Un análisis en base a registros tributarios y encuestas de hogares para el período 2009-2011", Montevideo, Instituto de Economía, Facultad de Ciencias Económicas y de Administración, Universidad de la República, 2014.

Si bien los valores estimados a partir de la ECH son muy similares para 2009, presentan la tendencia opuesta y dan cuenta de un descenso de dos puntos porcentuales en el lapso considerado. Esta diferencia se manifiesta también en la caída de la relación entre el ingreso medio del 1\% superior en la ECH con respecto a la DGI, que resulta de un estancamiento del ingreso captado por la ECH y un aumento significativo de su valor en el segundo registro. Según Burdín, Esponda y Vigorito (2014), esto podría deberse tanto a un aumento genuino del ingreso, como a una mejor captación del ingreso por parte de la DGI.

13 El ingreso de control utilizado para estimar las participaciones de los estratos de muy altos ingresos deriva de una estimación de los autores del ingreso de los hogares de las cuentas nacionales, dado que el Uruguay no dispone de información desagregada por agente institucional. En el trabajo de Burdín, Esponda y Vigorito (2014) se consideró como ingreso de control alternativo la suma del ingreso total incluido en los registros tributarios y una estimación del ingreso de los trabajadores informales, cuyos ingresos, por definición, no están comprendidos en los registros de la DGI. Como resultado, las participaciones estimadas sobre la base de este ingreso de control alternativo resultaron sistemáticamente superiores a las aquí presentadas, aunque mantienen las tendencias señaladas: para el 1\% más rico, por ejemplo, la participación resultó ser del 13,8\% en 2009, del 14,3\% en 2010 y del 14,1\% en 2011. 
En el cuadro VI.5 se presenta la composición del ingreso de los sectores altos por fuente en los registros de la DGI. Se constata que la participación de los ingresos de capital crece a medida que aumenta el ingreso y llega a representar un 35\% del total en el 0,01\% superior en 2011. En el período estudiado, se observa un notorio cambio en la estructura de ingresos de los estratos muy altos, con una disminución del peso relativo de los ingresos laborales en favor de los ingresos de capital. Esto podría explicar las crecientes divergencias entre la ECH y la DGI, aunque resta determinar qué parte del aumento del ingreso en esta última fuente corresponde a un aumento genuino y qué parte se debe a una mejor captación tributaria.

\section{Cuadro VI.5}

Uruguay: composición del ingreso de los sectores altos, 2009-2011 (En porcentajes)

\begin{tabular}{|c|c|c|c|c|}
\hline Percentil & $\begin{array}{l}\text { Ingresos } \\
\text { laborales }\end{array}$ & $\begin{array}{l}\text { Ingresos } \\
\text { de capital }\end{array}$ & Jubilaciones & Total \\
\hline \multicolumn{5}{|c|}{2009} \\
\hline $50-10 \%$ & 48,3 & 1,4 & 50,2 & 100,0 \\
\hline $10-1 \%$ & 69,6 & 1,3 & 29,0 & 100,0 \\
\hline $1-0,5 \%$ & 78,7 & 2,3 & 18,7 & 100,0 \\
\hline $0,5-0,1 \%$ & 84,1 & 4,6 & 11,0 & 100,0 \\
\hline $0,1-0,05 \%$ & 89,3 & 6,9 & 3,5 & 100,0 \\
\hline $0,05-0,01 \%$ & 86,6 & 12,0 & 1,1 & 100,0 \\
\hline $0,01 \%$ & 77,5 & 21,3 & 0,7 & 100,0 \\
\hline Total & 72,8 & 3,7 & 23,3 & 100,0 \\
\hline \multicolumn{5}{|c|}{2010} \\
\hline $50-10 \%$ & 45,0 & 1,4 & 53,6 & 100,0 \\
\hline $10-1 \%$ & 69,8 & 1,3 & 28,8 & 100,0 \\
\hline $1-0,5 \%$ & 78,4 & 2,4 & 18,9 & 100,0 \\
\hline $0,5-0,1 \%$ & 84,3 & 4,8 & 10,6 & 100,0 \\
\hline $0,1-0,05 \%$ & 88,1 & 8,3 & 3,3 & 100,0 \\
\hline $0,05-0,01 \%$ & 80,1 & 18,5 & 1,2 & 100,0 \\
\hline $0,01 \%$ & 64,5 & 34,5 & 0,7 & 100,0 \\
\hline Total & 72,2 & 4,3 & 23,3 & 100,0 \\
\hline \multicolumn{5}{|c|}{2011} \\
\hline $50-10 \%$ & 43,6 & 1,5 & 54,9 & 100,0 \\
\hline $10-1 \%$ & 72,3 & 1,3 & 26,3 & 100,0 \\
\hline $1-0,5 \%$ & 78,9 & 2,4 & 18,5 & 100,0 \\
\hline $0,5-0,1 \%$ & 84,1 & 5,8 & 9,9 & 100,0 \\
\hline $0,1-0,05 \%$ & 86,3 & 10,4 & 3,1 & 100,0 \\
\hline $0,05-0,01 \%$ & 78,2 & 20,6 & 0,9 & 100,0 \\
\hline $0,01 \%$ & 63,8 & 35,3 & 0,5 & 100,0 \\
\hline Total & 72,4 & 4,8 & 22,6 & 100,0 \\
\hline
\end{tabular}

Fuente: G. Burdín, F. Esponda y A. Vigorito, “Desigualdad y altos ingresos en Uruguay. Un análisis en base a registros tributarios y encuestas de hogares para el período 2009-2011", Montevideo, Instituto de Economía, Facultad de Ciencias Económicas y de Administración, Universidad de la República, 2014. 
Por otra parte, a partir de la ECH se estimaron medidas de desigualdad corregidas con el ingreso del 1\% más rico calculado con los registros de la DGI (véase el cuadro VI.6). Vale aclarar que se trabajó con perceptores de ingresos según la fuente generadora por lo que estas estimaciones difieren de las que se presentan habitualmente en función del ingreso per cápita de los hogares. Al mismo tiempo, no contienen las transferencias no contributivas en dinero y en especie ni el valor locativo de la vivienda. Siguiendo la práctica de estudios similares, lo que se analiza es la desigualdad de ingresos primarios o de mercado, esto es, la concentración de ingresos - incluyendo pensiones- antes de impuestos y transferencias no contributivas.

\section{Cuadro VI.6}

Uruguay: evolución del coeficiente de Gini según encuestas de hogares y ajustado con datos de declaraciones juradas de la Dirección General Impositiva (DGI), 2009-2011

\begin{tabular}{lcc}
\hline Año & $\begin{array}{c}\text { Coeficiente de Gini } \\
\text { según datos de la Encuesta } \\
\text { Continua de Hogares }(\mathrm{ECH})\end{array}$ & $\begin{array}{c}\text { Coeficiente de Gini corregido } \\
\text { con la inclusión del } 1 \% \text { superior } \\
\text { según registros tributarios }\end{array}$ \\
\hline 2009 & 0,511 & 0,532 \\
\hline 2010 & 0,497 & 0,524 \\
\hline 2011 & 0,480 & 0,512 \\
\hline Variación 2009-2011 & $-0,031$ & $-0,019$ \\
\hline
\end{tabular}

Fuente: G. Burdín, F. Esponda y A. Vigorito, “Desigualdad y altos ingresos en Uruguay. Un análisis en base a registros tributarios y encuestas de hogares para el período 2009-2011", Montevideo, Instituto de Economía, Facultad de Ciencias Económicas y de Administración, Universidad de la República, 2014.

Como puede observarse, el ajuste de ingresos conlleva un aumento del coeficiente de Gini para todos los años abarcados. Además, la brecha entre ambos coeficientes de Gini crece a lo largo del tiempo. Un aspecto a destacar es la tendencia decreciente de la desigualdad en el período 20092011 la cual, si bien no se revierte al corregir con la inclusión de los ingresos del $1 \%$ superior, es menos pronunciada que la observada cuando se utiliza el Gini sin corregir calculado a partir de la ECH.

En definitiva, más allá de que la ECH subestima ligeramente la participación de estos estratos en el ingreso total, las diferencias encontradas respecto de las estimaciones realizadas a partir de datos tributarios (DGI) ponen de manifiesto la principal utilidad de este procedimiento. No es que se pretenda sustituir las medidas de desigualdad calculadas en virtud de las ECH por sus versiones corregidas; en todo caso, se apunta a generar un sistema de indicadores donde se presenten ambas, de manera de monitorear la evolución en la captación de los sectores altos por parte de las ECH y alertar así sobre posibles divergencias en las tendencias de la desigualdad. 


\section{Reflexiones finales}

A partir de los primeros años del nuevo siglo se ha podido verificar una mejora sustancial en la distribución del ingreso en casi todos los países de la región, y este fenómeno se ha vinculado a varias causas políticas, sociales y macroeconómicas (Gasparini y otros, 2009; López-Calva y Lustig, 2010). No obstante, son conocidas las limitaciones de los estudios en materia distributiva cuando incluyen estimaciones cuantitativas basadas en datos provenientes de las encuestas de ingresos y gastos de los hogares. En particular, habitualmente se reconoce que estos relevamientos suelen fallar en la captación de ingresos de naturaleza más fluctuante, como los derivados del trabajo independiente, al tiempo que subestiman las rentas de capital. Además, los hogares de más altos ingresos se destacan por ser los más renuentes a participar en estas encuestas.

Es por esta razón que resulta de suma relevancia analizar la evolución de la participación en el ingreso de los tramos de renta más elevada, que no son captados adecuadamente por el decil de ingresos más altos de las encuestas y que corresponden al 1\% o al 0,1\% más rico de la población. Este sector ha sido objeto de análisis de una serie de estudios llevados a cabo en los países desarrollados, y ello ha tenido su correlato en algunas investigaciones realizadas en América Latina. En esta serie de trabajos se analiza la evolución de la concentración del ingreso de los tramos más elevados a partir de datos fiscales provenientes de las declaraciones juradas del ISR, que suelen diferir de manera notoria de la información recolectada en las encuestas.

Las mediciones convencionales de la desigualdad de ingresos a partir de los datos de las encuestas probablemente estén soslayando un fenómeno de concentración de los ingresos que, debido al propio diseño muestral, no puede analizarse con la información disponible. Esta limitación no es nueva y ha estado implícita, en menor o mayor medida, en todas las estimaciones de este tipo. Por lo tanto, resta analizar el alentador cambio de tendencia en materia distributiva que en los últimos años se ha observado en los países de América Latina, una vez que se hacen los ajustes correspondientes. De hecho, el aumento de la participación de los estratos más ricos de la población ( $1 \%$ o menor) en los últimos años - tanto en países desarrollados como en desarrollo- permite pensar que el sesgo de estimación sería mayor en los cálculos más recientes y, por ende, la mencionada disminución de la desigualdad habría sido de menor cuantía a la oportunamente cuantificada en la mayoría de los estudios en la materia.

En general, se ha observado que, dado que el coeficiente de Gini, por construcción, otorga mayor peso relativo a las transferencias realizadas en la parte central de la distribución del ingreso y que las encuestas de hogares tienden a subestimar la proporción de ingresos más altos, los resultados 
obtenidos en las estimaciones no alcanzan a presentar una verdadera perspectiva de la evolución de la desigualdad en los países. Esto es lo que puede observarse en los recientes estudios de este tipo aplicados a países de la región, donde, a pesar de las especificidades inherentes a cada caso, se ha podido comprobar que los coeficientes de Gini resultantes (y la desigualdad) serían mayores una vez efectuados los ajustes necesarios.

En definitiva, los estudios enfocados en el análisis de los tramos más ricos de la población resultan muy útiles en la medida en que permiten corregir las mediciones convencionales sobre desigualdad considerando la participación de dichos hogares en el total del ingreso para evaluar con mayor exactitud la concentración de los ingresos en la sociedad, compatibilizando la información fiscal proveniente de las declaraciones juradas con los datos obtenidos a través de las encuestas de hogares.

Si bien se han registrado notables avances en el análisis de las participaciones de los altos ingresos en la distribución y en advertir sobre su aporte a la recaudación del ISR, aún queda mucho camino por recorrer, particularmente en los países de América Latina, donde este tipo de estudios es bastante reciente o muy escaso. Es menester profundizar el análisis sobre el particular con nuevos estudios en los que se procure investigar la desigualdad en la distribución a partir de la mejora de la información existente, incorporando nuevas herramientas de análisis, como ajustes por subdeclaración de ingresos o datos de declaraciones juradas de impuestos.

Finalmente, vale preguntarse qué caminos podrían seguirse a fin de atender con nuevas reformas a los sectores de altos ingresos en América Latina para que estos contribuyan con una mayor participación en la recaudación. Dicho de otro modo, restaría indagar qué reformas tributarias aún están pendientes en la región para aumentar la recaudación y el alcance efectivo de los impuestos sobre los individuos de más altos ingresos, lo que mejoraría el impacto distributivo de los sistemas tributarios de la región. 


\section{Bibliografía}

Alvaredo, F. (2010a), "A note on the relationship between top income shares and the Gini coefficient", CEPR Discussion Paper, N 8071, Londres, Centro de Investigación sobre Políticas Económicas.

(2010b), "The rich in Argentina over the Twentieth Century, 1932-2004", Top Incomes: a Global Perspective, A.B. Atkinson y T. Piketty (eds.), Oxford, Oxford University Press.

(2007), "The rich in Argentina over the Twentieth Century. From the conservative republic to the Peronist experience and beyond 1932-2004", Working Paper, $\mathrm{N}^{\circ}$ 2007-02, París, Jourdan Sciences Economiques.

Alvaredo, F. y J. Londoño (2013), “High incomes and personal taxation in a developing economy: Colombia 1993-2010", Commitment to Equity (CEQ) Working Paper Series, $\mathrm{N}^{\circ} 12$, Universidad de Tulane.

Alvaredo, F. y otros (2013), "The top 1 percent in international and historical perspective", NBER Working Paper, N 19075, Cambridge, Massachusetts, National Bureau of Economic Research.

Atkinson, A. (2007), "Measuring top incomes: methodological issues", Top Incomes over the Twentieth Century: a Contrast between Continental European and English-Speaking Countries, A.B. Atkinson y T. Piketty (eds.), Oxford, Oxford University Press.

Atkinson, A. y T. Piketty (eds.) (2010), Top Incomes: A Global Perspective, Oxford, Oxford University Press.

(2007), Top Incomes over the Twentieth Century: A Contrast between Continental European and English-Speaking Countries, Oxford, Oxford University Press.

Atkinson, A.B., T. Piketty y E. Saez (2011), "Top incomes in the long run of history", Journal of Economic Literature, vol. 49, $\mathrm{N}^{\circ}$ 1, Nashville, Tennessee, American Economic Association.

Bourguignon, F. y C. Morrisson (2002), "Inequality among world citizens: 18201992", American Economic Review, vol. 92, N 4, Nashville, Tennessee, American Economic Association.

Burdín, G., F. Esponda y A. Vigorito (2014), “Desigualdad y altos ingresos en Uruguay. Un análisis en base a registros tributarios y encuestas de hogares para el período 2009-2011", Montevideo, Instituto de Economía, Facultad de Ciencias Económicas y de Administración, Universidad de la República.

Fairfield, T. y M. Jorratt (2014), "Top income shares, business profits, and effective tax rates in contemporary Chile". ICTD working paper, 17. Institute of Development Studies, Brighton, Reino Unido.

Ferreira, F. y M. Ravallion (2008), “Global poverty and inequality: a review of the evidence", Policy Research Working Paper Series, N 4623, Washington, D.C., Banco Mundial.

Gasparini, L. y otros (2009), “A turning point? Recent developments on inequality in Latin America and the Caribbean", Documentos de Trabajo, $\mathrm{N}^{\circ} 0081$, La Plata, Centro de Estudios Distributivos, Laborales y Sociales (CEDLAS).

Gómez Sabaini, J.C. y D. Rossignolo (2014), “La tributación sobre las altas rentas en América Latina", serie Estudios y Perspectivas, N ${ }^{\circ} 13$ (LC/L.3760), Montevideo, Oficina de la CEPAL en Montevideo [en línea] http://repositorio.cepal.org/ bitstream/handle/11362/35896/S2014013_es.pdf?sequence $=4$.

Herschel, F.J. (1963), Política fiscal en la Argentina, vol. 6, Buenos Aires, Consejo Nacional de Desarrollo. 
Jiménez, J.P. y A. Solimano (2012), “Elites económicas, desigualdad y tributación", serie Macroeconomía del Desarrollo, N 126 (LC/L.3552), Santiago, Comisión Económica para América Latina (CEPAL).

Jorratt, M. (2012), "Gastos tributarios y evasión tributaria en Chile: evaluación y propuestas", inédito.

Kuznets, S. (1955), "Economic growth and income inequality", American Economic Review, vol. 45, № 1, Nashville, Tennessee, American Economic Association.

López, R., E. Figueroa y P. Gutiérrez (2013), “La 'parte del león': nuevas estimaciones de la participación de los súper ricos en el ingreso de Chile", Documentos de Trabajo, $\mathrm{N}^{\circ} 379$, Santiago, Universidad de Chile.

López-Calva, L. y N. Lustig (2010), "Explaining the decline in inequality in Latin America: technological change, educational upgrading and democracy", Declining Inequality in Latin America: a Decade of Progress?, L. López-Calva y N. Lustig (eds.), Brookings Institution Press/Programa de las Naciones Unidas para el Desarrollo (PNUD).

Piketty, T. (2003), "Income inequality in France, 1901-1998”, Journal of Political Economy, vol. 111, N ${ }^{\circ}$, Chicago, The University of Chicago Press.

Sen, P.K. (1988), "The harmonic Gini coefficient and affluence indexes", Mathematical Social Sciences, vol. 16, $\mathrm{N}^{\circ} 1$, Amsterdam, Elsevier. 

Parte 3

Tributación, crecimiento e inversión 



\title{
Políticas fiscales y crecimiento económico ${ }^{1}$
}

\author{
Ricardo Martner ${ }^{2}$ \\ Andrea Podestá ${ }^{3}$ \\ Ivonne González ${ }^{4}$
}

\section{Introducción}

La teoría económica clásica supone que existe un planificador benevolente y omnisciente, que puede definir las condiciones de eficiencia y, por tanto, la delimitación entre bienes públicos y privados, siendo los primeros aquellos que se consideran bienes no rivales ni excluibles. Según esa tradición, al existir relativamente pocos bienes públicos "genuinos", el tamaño óptimo del Estado debería limitarse al costo de sus funciones esenciales, la defensa, la seguridad, la administración de justicia y la infraestructura, como describió Adam Smith lo que hoy se denomina el Estado mínimo.

Fue apenas a partir de la segunda mitad del siglo XX que comenzó a cambiar la visión respecto del papel del Estado, principalmente con la introducción del concepto de "bienes públicos meritorios". Un bien público

Este capítulo constituye una versión resumida de Martner, Podestá y González (2013).

Jefe de la Unidad de Asuntos Fiscales de la División de Desarrollo Económico de la Comisión Económica para América Latina y el Caribe (CEPAL). Correo electrónico: ricardo.martner@cepal.org.

3 Consultora de la Comisión Económica para América Latina y el Caribe (CEPAL). Correo electrónico: andrea.podesta@cepal.org.

4 Asistente de Investigación de la División de Desarrollo Económico de la Comisión Económica para América Latina y el Caribe (CEPAL). Correo electrónico: ivonne.gonzalez@cepal.org. 
meritorio puede definirse como un bien subconsumido en una economía de mercado, que crea externalidades positivas, en un marco de miopía de los agentes. Esas argumentaciones dieron espacio para legitimar la función pública en los más diversos ámbitos económicos y sociales. Los gobiernos democráticos, esencialmente europeos, desarrollaron funciones sociales y redistributivas, dando nacimiento al Estado de bienestar y sus cuatro pilares: educación, salud, pensiones universales e inclusión social.

La crisis financiera y de endeudamiento público en los países desarrollados ha reflotado una vez más la discusión sobre el papel del gasto público, pues han debido destinarse grandes sumas a los ámbitos productivo (incluidas las grandes empresas) y bancario. Ante esas limitaciones, surgen periódicamente presiones para reducir el activismo fiscal. La idea subyacente es que se pueden mejorar o mantener los indicadores de desarrollo humano con un gasto público mucho menor, apelando a la prestación privada de servicios de salud, educación y pensiones y a la sustitución progresiva de programas universales por esquemas orientados a los más pobres (Tanzi, 2008).

Además del peso de la deuda pública, a menudo se argumenta que un tamaño elevado del propio gasto estatal es perjudicial para el crecimiento ${ }^{5}$. Se aduce que, en términos marginales, el impacto positivo del gasto público sería menor que las distorsiones que introducen los impuestos requeridos para su financiamiento, o que dicho gasto desplazaría el gasto privado.

Ante tales aseveraciones, y en el contexto de países en desarrollo, el desafío consiste en potenciar el papel catalizador del sector público con políticas de alta rentabilidad social, evitando los efectos de desplazamiento asociados a un manejo financiero inadecuado y a eventuales distorsiones del sistema tributario.

Resulta muy difícil evidenciar una relación causal entre las políticas fiscales y el crecimiento económico, tanto por la complejidad de las interacciones mutuas como por la dificultad de establecer mediciones satisfactorias de la multiplicidad de acciones del Estado en la economía. Sin embargo, es incuestionable la influencia del nivel y la composición de gastos e ingresos públicos en el ciclo macroeconómico y en la tendencia de mediano plazo del producto interno bruto (PIB).

Por ese motivo, es importante para el crecimiento y la igualdad diseñar políticas fiscales con capacidad anticíclica, amplia incidencia en la distribución del ingreso disponible, creciente calidad del gasto y sistemas tributarios con capacidad recaudatoria, eficientes y equitativos.

En el documento original en que se basa este capítulo (Martner, Podestá y González, 2013) se describe la evolución histórica y reciente de la deuda pública en América Latina. Allí se analizan sus determinantes y se hace hincapié en la importancia de una arquitectura anticíclica que permita enfrentar con éxito la excesiva volatilidad de ingresos y gastos públicos que suelen experimentar los países de América Latina y el Caribe. 
En ese contexto, vale recordar las tres funciones tradicionales de la política fiscal (Musgrave y Buchanan, 1999): i) proveer bienes públicos (e impulsar el proceso político por el que se establece la disponibilidad de esos bienes); ii) proveer ajustes en la distribución del ingreso, y iii) contribuir a la estabilización macroeconómica. Además, como señala Tanzi (2008), en la política fiscal concurren múltiples factores que explican el potencial de crecimiento de las economías.

Para llevar a cabo esas funciones, que inciden decididamente en los objetivos de desarrollo, el crecimiento, la equidad distributiva y la inclusión social, la política fiscal cuenta con diversos instrumentos. Entre ellos cabe mencionar el gasto público, los impuestos y el déficit o endeudamiento. A su vez, todos esos intrumentos requieren instituciones que se encarguen de su gestión adecuada. Sin embargo, existen factores de economía política y de capacidad institucional, problemas de sostenibilidad fiscal y costos de eficiencia de los impuestos y del endeudamiento que pueden limitar la capacidad de implementar las políticas fiscales.

Con el fin de hacer frente a esas limitaciones, es preciso fortalecer la conexión entre las prioridades gubernamentales y la programación del gasto público, de forma que se acelere el tránsito de una gestión pública basada en insumos y procesos a otra orientada a objetivos de desarrollo e indicadores de desempeño, en sintonía con las demandas ciudadanas ${ }^{6}$. El logro de mayores avances en ese campo podría favorecer un pacto fiscal tendiente a reconocer una relación más directa entre la gestión pública de los recursos y su recaudación por la vía de la tributación.

En las páginas siguientes se analiza en primer lugar la relación existente entre la política fiscal y el crecimiento económico a partir de la consulta de la literatura empírica sobre el tema en países desarrollados y de la región de América Latina y el Caribe. Luego, se examina de manera más detallada la evolución de los componentes principales del gasto público. Se hace distinción entre el gasto corriente y de capital, y entre los gastos sociales o de otra índole (sección B), y se analiza el papel de los sistemas tributarios (sección C). Por último, en la sección D se presenta una serie de reflexiones finales.

\section{A. Evidencia empírica del vínculo entre política fiscal y crecimiento}

Los efectos de la política fiscal sobre el crecimiento económico pueden ser muy diferentes a corto y mediano plazo. En general, los efectos a corto plazo operan a través de la demanda agregada, mientras que los de mediano y largo plazo lo hacen a través de la oferta agregada. Hay muchos modelos

\footnotetext{
Véase en CEPAL/SEGIB (2011) un análisis de estas materias.
} 
teóricos antagónicos. Por una parte, los keynesianos y los neokeynesianos predicen que los estímulos fiscales hacen que aumente el consumo agregado, la demanda y por lo tanto el PIB. Por otra, los neoclásicos anticipan efectos nulos o incluso negativos. Los efectos de la política fiscal sobre el crecimiento (véase el cuadro VII.1) dependen del horizonte considerado, de los supuestos sobre el comportamiento de los agentes privados y de la credibilidad de las estrategias utilizadas, como se detalla a continuación.

\section{Cuadro VII.1}

Efectos de corto plazo de la política fiscal sobre el crecimiento: modelos alternativos

\begin{tabular}{|c|c|c|c|}
\hline Modelo teórico & Supuestos principales & Mecanismos & Efecto neto sobre el PIB \\
\hline $\begin{array}{l}\text { Modelos } \\
\text { neokeynesianos }\end{array}$ & $\begin{array}{l}\text { Horizonte de corto plazo; } \\
\text { expectativas adaptativas } \\
\text { o miopía de los agentes; } \\
\text { rigidez de precios y } \\
\text { recursos ociosos. }\end{array}$ & $\begin{array}{l}\text { Multiplicador lineal de } \\
\text { gasto; eventuales efectos } \\
\text { de desplazamiento. }\end{array}$ & $\begin{array}{l}\text { Ajuste fiscal es recesivo; } \\
\text { déficit expansivo. }\end{array}$ \\
\hline $\begin{array}{l}\text { Modelos } \\
\text { ricardianos }\end{array}$ & $\begin{array}{l}\text { Consumidores de } \\
\text { horizonte infinito y con } \\
\text { expectativas racionales. }\end{array}$ & $\begin{array}{l}\text { Desplazamiento uno a uno } \\
\text { del consumo privado por } \\
\text { el consumo público. }\end{array}$ & $\begin{array}{l}\text { Política fiscal neutra a } \\
\text { corto y largo plazo. }\end{array}$ \\
\hline $\begin{array}{l}\text { Modelos } \\
\text { neoclásicos } \\
\text { con impuestos } \\
\text { distorsivo }\end{array}$ & $\begin{array}{l}\text { Efecto distorsivo de los } \\
\text { impuestos: su aumento } \\
\text { reduce la producción por } \\
\text { la menor oferta de trabajo. }\end{array}$ & $\begin{array}{l}\text { Una disminución } \\
\text { permanente del gasto } \\
\text { público reduce los } \\
\text { impuestos esperados } \\
\text { y aumenta el } \\
\text { consumo privado. }\end{array}$ & $\begin{array}{l}\text { El ajuste fiscal es } \\
\text { recesivo, con alza de } \\
\text { impuestos; ajuste fiscal } \\
\text { expansivo con caída } \\
\text { del gasto. } \\
\text { Déficit expansivo si se } \\
\text { reducen impuestos; déficit } \\
\text { contractivo si aumentan } \\
\text { los gastos. }\end{array}$ \\
\hline $\begin{array}{l}\text { Modelos } \\
\text { keynesianos } \\
\text { con "puntos } \\
\text { de inflexión" }\end{array}$ & $\begin{array}{l}\text { Comportamiento } \\
\text { keynesiano mientras } \\
\text { el nivel de deuda } \\
\text { pública es sostenible; } \\
\text { comportamiento de } \\
\text { repudio de la deuda } \\
\text { pública cuando existe } \\
\text { posibilidad de no pago. }\end{array}$ & $\begin{array}{l}\text { No linealidades atribuibles } \\
\text { a la probabilidad } \\
\text { de insolvencia del } \\
\text { sector público. }\end{array}$ & $\begin{array}{l}\text { Ajuste fiscal recesivo } \\
\text { y déficit expansivo en } \\
\text { niveles normales de } \\
\text { deuda; ajuste expansivo y } \\
\text { déficit recesivo cuando la } \\
\text { deuda es elevada. }\end{array}$ \\
\hline
\end{tabular}

Fuente: Elaboración propia.

En la teoría neokeynesiana tradicional se toma como referencia un horizonte de mediano plazo, con agentes míopes que no incorporan la restricción intertemporal del sector público en sus decisiones, y se presupone la existencia de capacidad instalada ociosa en la economía y de precios y salarios rígidos. Aunque puedan existir efectos parciales de desplazamiento (por la vía de alguna representación basada en el modelo IS-LM tradicional), el multiplicador de gasto público es positivo, y superior o igual a uno a corto plazo si el gasto público se financia con igual monto de impuestos. Así, el ajuste del sector público es recesivo y el déficit es expansivo (Martner, 2000).

Por su parte, la teoría neoclásica presupone la existencia de consumidores racionales y de horizonte infinito, que integran la restricción intertemporal del sector público a su propia restricción presupuestaria y 
toman decisiones de consumo en función de las perspectivas a largo plazo (teoría del ciclo de vida de Modigliani y teoría del ingreso de Friedman). El alza del gasto público presente conduciría inevitablemente a un aumento de impuestos futuros y, por lo tanto, el ingreso disponible actualizado no cambiaría. Se comprende que los agentes prevén esa situación, y que no van a modificar su consumo, ni presente ni futuro, ante cambios en el gasto público. Existe entonces neutralidad de la política fiscal o equivalencia ricardiana: independientemente de la forma de su financiamiento (ya sea por impuestos o por emisión de deuda), un alza del gasto público no tiene ningún efecto sobre el PIB, ni sobre el consumo privado.

Si se introduce el supuesto de que los tributos son distorsivos (Alesina y Perotti, 1995), un alza de impuestos implicaría una disminución de la producción. Si se cumple la restricción intertemporal del sector público, y si los consumidores son racionales y los impuestos distorsivos, una caída del gasto público percibida como permanente supone una reducción de los impuestos futuros. Ello repercutiría en un aumento del ingreso disponible esperado, haría que se incrementara el consumo actual y produciría efectos de oferta positivos que harían aumentar el PIB a corto plazo. Los modelos de oferta con impuestos distorsivos suponen entonces que el ajuste fiscal es expansivo, si se contraen los gastos, y contractivo, si se aumentan los impuestos.

Otra categoría de modelos incorpora no linealidades para explicar los cambios de régimen. Según Sutherland (1995), los agentes se comportan de manera keynesiana cuando el volumen de deuda pública es bajo, y de manera antikeynesiana cuando el endeudamiento excesivo y la perspectiva de insolvencia amenazan no solo a las generaciones futuras, sino a los propios agentes. En ese caso, las no linealidades se atribuyen a la probabilidad de insolvencia del sector público. Si es baja, los agentes no se preocupan de los impuestos futuros. En cambio, si existe posibilidad de impago de la deuda, los consumidores anticipan un alza futura de los impuestos y ahorran en consecuencia.

Tras la gran recesión que comenzó en 2008, se realizaron diversos estudios al respecto en países de la Organización de Cooperación y Desarrollo Económicos (OCDE) 7 . Se determinó que el efecto de los estímulos fiscales sobre el crecimiento económico depende de las circunstancias de la economía. Entre esas circunstancias, cabe mencionar la existencia de recursos ociosos; la eficacia de la política monetaria (por ejemplo, cuando la tasa de interés se aproxima a cero); el porcentaje de población con restricciones crediticias; el carácter temporal o permanente de las medidas implementadas; el grado de confianza sobre las perspectivas económicas futuras; la competitividad, la apertura comercial y el régimen cambiario. 
A largo plazo, en los modelos neoclásicos de crecimiento económico, la política fiscal puede afectar los incentivos al ahorro y la inversión y, por lo tanto, la relación capital-producto de equilibrio y el nivel del PIB, pero no puede influir en la tasa de crecimiento del estado estacionario. En esos modelos, los impuestos y los gastos públicos pueden provocar cambios transitorios mientras la economía se mueve de un equilibrio a otro, pero la tasa de crecimiento volvería de nuevo a su situación inicial.

Sin embargo, la falta de convergencia de las tasas de crecimiento entre distintos países debilita esas conclusiones. De esta forma surgen los modelos de crecimiento endógeno (Barro, 1990; Futagami, Morita y Shibata, 1993; Devarajan, Swaroop y Zou, 1996). Esos modelos dan un mayor papel a la política fiscal, que puede afectar tanto al nivel del PIB como su tasa de crecimiento a largo plazo. Suponen la existencia de ciertos gastos públicos "productivos" que entran en la función de producción y afectan la productividad del sector privado, mientras que hay otros gastos públicos "improductivos" que solo afectan la función de utilidad de los hogares. Además, para financiar esos gastos se recurre a impuestos que distorsionan las decisiones de inversión.

Así, Barro (1990) analiza cómo la tributación y el gasto público afectan el crecimiento bajo el supuesto de no existencia de déficit financiero. Su modelo sugiere un rol positivo del gobierno en la promoción del crecimiento económico mediante la provisión de bienes públicos y servicios que elevan la productividad marginal del capital e incentivan una mayor inversión. No obstante, ese efecto positivo depende del nivel inicial de los impuestos, dado que una carga tributaria excesiva reduce la tasa de crecimiento.

Sin embargo, según Cornia, Gómez-Sabaini y Martorano (2011), los impuestos pueden afectar positivamente el crecimiento a través de diversos canales. Por ejemplo, mediante la provisión de bienes públicos, como carreteras, agua y saneamiento, salud y educación, que aumenta la tasa de rendimiento de las inversiones privadas. Una segunda vía es la estabilidad macroeconómica, ya que los gobiernos que recaudan cantidades adecuadas de ingresos tienen menos probabilidades de monetizar el déficit fiscal o endeudarse en el extranjero, lo que reduce la probabilidad de crisis macroeconómicas. Una mayor estabilidad macroeconómica y una posición fiscal más sólida posibilitan la adopción de políticas anticíclicas durante las crisis, lo que reduce la pérdida de producción durante los períodos difíciles. Un tercer canal mediante el cual un incremento de los impuestos puede contribuir a un mayor crecimiento es la disminución de la desigualdad de los ingresos. Una alta desigualdad deprime el crecimiento, ya que causa efectos de economía política (Alesina y Rodrik, 1994); exacerba las imperfecciones del mercado de capitales (Aghion, Caroli y García-Peñalosa, 1999); aumenta la inestabilidad política y las tasas de criminalidad que causan incertidumbre entre los inversionistas y reducen el crecimiento (Venieris y Gupta, 1986; 
Bourguignon, 1998), y, por último, erosiona los incentivos microeconómicos e incrementa los costos de mano de obra (Cornia, 2005).

En suma, el efecto neto de la política fiscal sobre el crecimiento parece ser un asunto empírico, pues abundan argumentos en ambos sentidos. La mayoría de los estudios empíricos proceden a la estimación con paneles de datos de ecuaciones del tipo (Salinas y Delgado, 2012):

$$
g_{i t}=f\left(p f_{i t}, X_{i t}\right)
$$

Donde: $i$ denota el país y $t$ refleja el año, $g$ es la tasa de crecimiento, $p f$ es la presión fiscal (agregada o por componentes) y X es un vector de variables de control, entre las que se incluye el nivel inicial de renta, el crecimiento de la población, el capital humano y otras variables relevantes. Además, en otros estudios se incorpora el gasto en la ecuación:

$$
0_{i t}=f\left(p f_{i t}, g p_{i t}, X_{i t}\right)
$$

Parte de la evidencia empírica que analiza el impacto de los impuestos sobre el crecimiento económico no encuentra que esos efectos sean significativos. Por ejemplo, Mendoza, Milesi-Ferretti y Asea (1997), utilizando datos de panel de los países de la OCDE con medias de cinco años, no encuentran un efecto significativo de los impuestos en el crecimiento económico. Solo hallan efectos limitados de los impuestos sobre la inversión. En relación a los impuestos sobre las rentas del trabajo, Piketty, Saez y Stantcheva (2011) analizan una muestra de 18 países de la OCDE y no encuentran evidencia de que los países que han reducido esos gravámenes hayan experimentado un mayor crecimiento de la productividad ni del PIB. Esos autores concluyen que las tasas máximas de impuestos sobre las rentas del trabajo pueden aumentarse más allá de los niveles actuales sin perjudicar el crecimiento económico.

Gemmell, Kneller y Sanz (2011a) tampoco encuentran evidencia de efectos robustos de los tipos medios de las rentas del capital en la actividad económica a partir de una muestra de 17 países de la OCDE. Estos autores sí hallan un impacto negativo y significativo del tipo impositivo medio y marginal de las rentas del trabajo sobre el crecimiento, así como del de sociedades. Sin embargo, también muestran evidencia de que las disminuciones de los impuestos de sociedades de los países que disponen de tipos más bajos afectan negativamente al crecimiento económico.

En cuanto a los efectos sobre el crecimiento económico de los distintos tipos de impuestos, Johansson y otros (2008) y Romero-Ávila y Strauch (2008) encuentran, a partir de una muestra de países de la OCDE y de la Unión Europea, que el mayor efecto distorsivo corresponde al impuesto de sociedades, seguido del impuesto sobre la renta personal, mientras que los del consumo son los menos perjudiciales. A su vez, Harju y Kosonen (2012) señalan que, cuanto mayor sea la progresividad de los impuestos, 
mayor es su efecto negativo sobre el esfuerzo de los emprendedores y el crecimiento económico.

Del análisis de la literatura disponible, Salinas y Delgado (2012) sistematizan los principales resultados y extraen las siguientes conclusiones de los estudios realizados en países de la OCDE:

- En general se observa un efecto negativo entre impuestos y crecimiento económico. La mayor parte de los estudios revisados concluyen una relación de signo negativo, aunque no es despreciable el número de trabajos que no alcanzan una conexión significativa $(33,3 \%)$.

- Cuando se estudian las tasas medias, efectivas y marginales, la relación hallada con el crecimiento es también negativa. Aunque el número de trabajos analizados es reducido, cuatro de los seis estudios sostienen esa conclusión, mientras que los dos restantes no llegan a un resultado estadísticamente significativo.

- Sí hay consenso en las repercusiones del grado de progresividad del sistema tributario sobre el crecimiento económico. Los seis trabajos en esa materia coinciden en una relación negativa, es decir, a mayor progresividad de los sistemas tributarios, menor crecimiento.

- También hay unanimidad en los estudios que analizan el impacto de un cambio en la estructura tributaria (o tax mix) consistente en el incremento del peso de la imposición indirecta (impuestos que gravan el consumo) en detrimento de la directa (impuestos sobre la renta de empresas e individuos). Los cinco trabajos revisados prevén mejoras de crecimiento económico con ese cambio (véase el cuadro VII.2).

\section{Cuadro VII.2}

Literatura empírica sobre la relación entre impuestos y crecimiento económico: principales resultados

\begin{tabular}{lccc}
\hline Número de trabajos & $\begin{array}{c}\text { Número y porcentaje } \\
\text { de trabajos } \\
\text { que concluyen } \\
\text { relación positiva }\end{array}$ & $\begin{array}{c}\text { Número y porcentaje } \\
\text { de trabajos } \\
\text { que concluyen } \\
\text { relación negativa }\end{array}$ & $\begin{array}{c}\text { Número y porcentaje } \\
\text { de trabajos que } \\
\text { concluyen relación } \\
\text { no significativa }\end{array}$ \\
\hline Impuestos (21) & $1(4,8 \%)$ & $13(61,9 \%)$ & $7(33,3 \%)$ \\
\hline $\begin{array}{l}\text { Tipos medios, efectivos } \\
\text { y marginales }(6)\end{array}$ & $0(0 \%)$ & $4(66,7 \%)$ & $2(33,3 \%)$ \\
\hline Progresividad (6) & $0(0 \%)$ & $6(100 \%)$ & $0(0 \%)$ \\
\hline $\begin{array}{l}\text { Cambio de tax mix: más } \\
\text { impuestos indirectos en } \\
\text { detrimento de directos }(5)\end{array}$ & $5(100 \%)$ & $0(0 \%)$ & $0(0 \%)$ \\
\hline
\end{tabular}

Fuente: J. Salinas y F. Delgado, "Impuestos, crecimiento económico y bienestar: una visión panorámica", documento presentado en el XXIV Seminario Regional de Política Fiscal, Santiago, 2012 [en línea] http://www.cepal.org/ilpes/noticias/paginas/4/45764/Trabajo_Salinas-Delgado.pdf. 
Respecto de la evidencia empírica sobre América Latina, Cornia, Gómez-Sabaini y Martorano (2011) evalúan econométricamente el impacto de los impuestos sobre la tasa de crecimiento del PIB per cápita en 18 países de esta región en el período 1990-2008. Controlan diversas variables (inversión, educación, déficit presupuestario, términos del intercambio, coeficiente de Gini) y aplican cuatro modelos. Los resultados sugieren que el aumento medio del 3\% al 4\% en la relación impuestos-PIB observado entre 2002 y 2009 hizo que se elevara la tasa de crecimiento del PIB per cápita entre el $0,3 \%$ y el $1 \%$. Según los autores, ello contradice las afirmaciones de la teoría neoclásica sobre los costos de eficiencia de impuestos distorsivos, tales como los impuestos directos.

En definitiva, la evidencia empírica disponible sobre el efecto de los impuestos en el crecimiento económico no es concluyente y muestra la necesidad de incorporar los gastos en las estimaciones. En efecto, el gasto público puede contribuir al crecimiento económico al afectar el nivel de los factores de producción y aumentar su productividad. Por ejemplo, los gobiernos pueden proveer ciertos tipos de bienes y servicios (infraestructura, investigación y desarrollo, educación, entre otros) que elevan la productividad marginal del capital y del trabajo en el proceso de producción. Además, el aumento de la productividad incrementa los rendimientos de la inversión privada, lo que resulta en un mayor volumen de capital privado y una mayor producción.

Sin embargo, la financiación de esos gastos tiene costos que pueden superar los beneficios. En el caso de los impuestos, las distorsiones y costos de eficiencia afectan negativamente el crecimiento. La emisión de deuda pública implica mayores impuestos en el futuro y también puede afectar el crecimiento, por ejemplo, al desplazar al sector privado en el acceso a financiamiento o afectando el grado de confianza que tienen los inversores sobre la sostenibilidad de las finanzas públicas.

De ahí la importancia de considerar el efecto conjunto de los gastos públicos y de su forma de financiamiento a la hora de evaluar el impacto de un cambio en el gasto público sobre el crecimiento. En última instancia, el efecto neto de la política fiscal sobre el crecimiento económico depende del nivel y composición de los gastos e impuestos. En el cuadro VII.3 se presentan los efectos sobre el crecimiento de las distintas combinaciones posibles de ejecución del gasto público (productivos, no productivos y déficit) y su financiación (impuestos distorsivos, no distorsivos y déficit).

De esa forma, el efecto sobre el crecimiento de un aumento de los impuestos distorsivos destinado a financiar gastos públicos productivos dependerá del tamaño del sector público. Si el país dispone ya de un alto nivel de tipos impositivos y un gran volumen de capital público, por encima del umbral óptimo, entonces el efecto sobre el crecimiento será negativo. 
En caso contrario, será positivo. En cambio, la financiación de gastos públicos no productivos mediante impuestos distorsivos tendrá efectos claramente negativos, mientras que el impacto de un incremento de impuestos distorsivos para hacer que disminuya el déficit público es ambiguo, dado que se crean nuevas distorsiones en la economía para reducir otras ya existentes.

\section{Cuadro VII.3}

Aumentos de impuestos, gastos y déficit y su efecto en el crecimiento

\begin{tabular}{lllll}
\hline \multirow{2}{*}{ Financiado por } & \multicolumn{3}{c}{ Gasto público } & Déficit público \\
\cline { 3 - 5 } & Distorsivos & $\begin{array}{l}\text { Negativo o positivo } \\
\text { (gastos elevados o bajos) }\end{array}$ & Negativo & Ambiguo \\
\cline { 2 - 5 } & No distorsivos & Positivo & Cero & Positivo \\
\hline Déficit público & & Ambiguo & Negativo & - \\
\hline
\end{tabular}

Fuente: N. Gemmell, R. Kneller e I. Sanz, "The timing and persistence of fiscal policy impacts on growth: evidence from OECD countries", Economic Journal, vol. 121, №550, Wiley.

Por otro lado, cuando los impuestos no distorsivos se destinan a gastos públicos productivos o a reducir el déficit fiscal, los efectos sobre el crecimiento económico serán positivos. Si financian gastos públicos no productivos, el impacto sobre la actividad económica no será significativo. Por último, el efecto sobre el crecimiento de un mayor déficit fiscal para incrementar los gastos públicos productivos dependerá del volumen de capital público existente (mientras más elevado, mayor será la probabilidad de un efecto negativo). Si el aumento del déficit se destina a financiar gastos públicos no productivos, el impacto sobre el crecimiento económico será negativo.

En cuanto a la evidencia empírica sobre la relación entre el gasto público y el crecimiento económico, puede agruparse en dos generaciones según se considere o no la restricción presupuestaria del gobierno (Gemmell, 2010). En los estudios de primera generación, realizados hasta mediados de la década de 1990 no se considera esa restricción presupuestaria. Es decir, no se tiene en cuenta que todo aumento del gasto público debe financiarse con mayores impuestos u otros ingresos, aumento del déficit fiscal o reasignación de partidas de gastos. Además, varios de esos estudios consideran solo el gasto público total, donde hay componentes que influyen de manera positiva en la actividad económica (como transporte, comunicaciones y educación) y otros que lo hacen de manera neutral o negativa. Como consecuencia de esas limitaciones, generalmente los resultados de esos estudios no son robustos ${ }^{8}$.

\footnotetext{
Nijkamp y Poot (2004) revisan 93 artículos de esa primera generación de estudios sobre la relación entre gasto público y crecimiento económico, y encuentran que los componentes del gasto que más positivamente influyen en la actividad económica son los de infraestructura (transporte y comunicaciones) y educación.
} 
Por otra parte, en los estudios de segunda generación, realizados a partir de la segunda mitad de los años noventa, se tiene en cuenta la restricción presupuestaria del gobierno y, por lo tanto, sus resultados son más robustos. En esos modelos, para considerar la restricción presupuestaria del gobierno se incluyen entre las variables explicativas del crecimiento económico los gastos, los ingresos totales y el déficit o superávit presupuestario, además de otras variables de control que tienen efectos sobre el crecimiento. A su vez, se tiene en cuenta que el crecimiento puede verse afectado no solo por el nivel de los gastos totales, sino también por la participación de cada categoría de gasto en el total.

En algunos de los estudios empíricos sobre la materia se dividen los gastos del gobierno en productivos e improductivos a partir de la clasificación funcional del gasto. Se utiliza una definición a priori de gasto productivo que es común en esa literatura e incluye educación, salud, vivienda, transporte y comunicaciones, servicios generales y defensa. En términos generales, esos estudios encuentran que los gastos más productivos tienen un impacto positivo sobre el crecimiento, ya sea que se financien a través de reducciones en gastos menos productivos o mediante la generación de déficit fiscales relativamente pequeños, o una combinación de ambos. Por ejemplo, en el caso de los países en desarrollo, Bose, Haque y Osborn (2007) cruzan información entre el sector o función del gasto (educación, sanidad, transporte, comunicaciones, entre otros) y su naturaleza económica (inversión, consumo o transferencias). Encuentran que la inversión pública y el gasto total en educación son los únicos gastos que se asocian de forma positiva y significativa con el crecimiento.

En otros estudios empíricos se descompone el gasto público según la clasificación económica, es decir, entre gasto corriente y gasto en capital. Los efectos de los gastos de capital sobre el crecimiento dependen de la forma en que se financien. No hay ganancia de crecimiento si se sustituye el gasto corriente por el gasto en capital. En el caso de los países en desarrollo, Ghosh y Gregoriou (2008), Rocha y Giuberti (2007), Devarajan, Swaroop y Zou (1996) y Haque (2004) muestran que la reasignación de partidas de gasto corriente hacia gasto de capital implica efectos negativos del crecimiento (un aumento de 1 punto porcentual de la participación del gasto de capital en el gasto total reduce la tasa de crecimiento entre 0,01 y 0,36 puntos porcentuales). Ello indicaría la complementariedad entre ambos tipos de gastos.

Respecto de la composición de los gastos, Gemmell, Kneller y Sanz (2009) concluyen que un aumento del gasto en infraestructura y educación financiado con disminuciones proporcionales del resto de las partidas tiene un impacto positivo para el crecimiento económico en una muestra de 17 países de la OCDE en el período 1970-2004. Lo mismo ocurre si se restan recursos del consumo público para financiar más inversiones. A partir de esa misma muestra de países, Gemmell, Kneller y Sanz (2011b) estiman que un 
aumento de los gastos públicos productivos en un 1\% del PIB incrementa la tasa de crecimiento en 0,12 puntos si se financia con déficit, y en 0,26 puntos si es a través de aumentos en los impuestos no distorsivos o disminuciones de gastos no productivos.

En síntesis, la evidencia empírica no es concluyente, pero sugiere que, tanto en los países desarrollados como en desarrollo, la política fiscal en su conjunto tiende a afectar positivamente el crecimiento a largo plazo, lo que confirma ampliamente las predicciones de los modelos de crecimiento endógeno con finanzas públicas (Gemmell, Misch y Moreno-Dodson, 2012).

Lo anterior también se ve documentado en las regresiones de panel del cuadro VII.4, donde se verifica que el gasto público ha tenido un impacto positivo sobre el PIB per cápita, en el período 1990-2010, en 20 países de América Latina. Ante las dificultades de colinealidad reseñadas entre el gasto público, los ingresos fiscales y el déficit, se optó por privilegiar en las estimaciones las variables de gasto, distinguiéndose entre el gasto corriente primario y el gasto de capital. Implícitamente, al incluir como variable explicativa la deuda pública, se están considerando los déficit acumulados y, por lo tanto, se puede diferenciar la forma de financiamiento del gasto.

La elasticidad del gasto público primario con relación al PIB per cápita es positiva y significativa, como también lo son las de la inversión total y del tipo de cambio real. A su vez, tanto la deuda pública como la inflación tienen un impacto negativo sobre el crecimiento. Las variables de capital humano, de estabilidad política y de derechos civiles son muy relevantes, pues reafirman la importancia de los "determinantes profundos" del nivel y del crecimiento del PIB per cápita en la región, así como el tipo de cambio real (Rodrik, 2008). Conviene destacar que el coeficiente rezagado del PIB per cápita también es significativo, lo que indica un claro componente inercial $\mathrm{y}$ un impacto mucho mayor a mediano plazo de las variables explicativas.

Si se desagrega el efecto del gasto y se incluyen las variables de control mencionadas, se observa que tanto el gasto corriente primario como la formación bruta de capital fijo del sector público inciden de forma positiva y significativa sobre el PIB per cápita (ecuaciones 2 y 3). Dado el período considerado y la cantidad de países en la estimación de panel, parece notable recoger un efecto tan significativo de las variables fiscales sobre el crecimiento. Es probable que, debido al bajo nivel del período inicial, la recuperación de los gastos públicos corrientes y de inversión hayan tenido un impacto retroalimentador sobre el crecimiento económico. Vale recordar que la evidencia empírica muestra que los efectos del gasto público varían según su composición; son positivos en rangos moderados y pueden tornarse negativos si se exceden ciertos límites. 


\section{Cuadro VII.4}

América Latina (20 países): efectos del gasto público sobre el producto, 1990-2010a (Variables valoradas a precios constantes y expresadas en logaritmos)

\begin{tabular}{|c|c|c|c|}
\hline \multicolumn{4}{|c|}{ Variable explicada: producto interno bruto por habitante } \\
\hline Regresiones & (1) & (2) & (3) \\
\hline \multicolumn{4}{|l|}{ Variables explicativas } \\
\hline \multicolumn{4}{|l|}{ Fiscales } \\
\hline \multirow[t]{2}{*}{ Gasto público primario } & $0,05^{* * *}$ & $0,10^{* * *}$ & $\ldots$ \\
\hline & $(0,01)$ & $(0,03)$ & \\
\hline \multirow[t]{2}{*}{ Gasto corriente primario } & $\ldots$ & $\ldots$ & $0,12 * * *$ \\
\hline & & & $(0,03)$ \\
\hline \multirow[t]{2}{*}{ Deuda pública } & $-0,017 *$ & $-0,005$ & $-0,035 *$ \\
\hline & $(0,006)$ & $(0,01)$ & $(0,01)$ \\
\hline \multicolumn{4}{|l|}{ Macroeconómicas } \\
\hline \multirow[t]{2}{*}{ Formación bruta de capital fijo } & $0,13^{* * *}$ & $\ldots$ & $\ldots$ \\
\hline & $(0,01)$ & & \\
\hline \multirow[t]{2}{*}{ Formación bruta de capital fijo (sector público) } & $\ldots$ & $\ldots$ & $0,07^{* * *}$ \\
\hline & & & $(0,01)$ \\
\hline \multirow[t]{2}{*}{ Formación bruta de capital fijo (sector privado) } & $\ldots$ & $0,084^{* * *}$ & $0,083^{* * *}$ \\
\hline & & $(0,01)$ & $(0,01)$ \\
\hline \multirow[t]{2}{*}{ Tipo de cambio real } & $0,05^{* * *}$ & $0,08^{* *}$ & 0,079 * \\
\hline & $(0,01)$ & $(0,02)$ & $(0,03)$ \\
\hline \multirow[t]{2}{*}{$\Delta$ Índice de precios al consumidor (IPC) } & $-0,003$ & $-0,005$ & $-0,06 *$ \\
\hline & $(0,002)$ & $(0,01)$ & $(0,02)$ \\
\hline \multirow[t]{2}{*}{ Producto por habitante $(-1)$} & $0,65 * * *$ & $0,70^{* * *}$ & $0,36 * * *$ \\
\hline & $(0,09)$ & $(0,10)$ & $(0,06)$ \\
\hline \multicolumn{4}{|l|}{ Logros en educación } \\
\hline Indicador de capital humano & 0,026 *** & 0,06 * & 0,06 ** \\
\hline $\begin{array}{l}\text { (población adulta con educación terciaria y } \\
\text { secundaria o adultos con educación primaria) }\end{array}$ & $(0,006)$ & $(0,02)$ & $(0,01)$ \\
\hline \multicolumn{4}{|l|}{ Institucionales } \\
\hline \multirow[t]{2}{*}{ Estabilidad política } & 0,02 ** & 0,018 & $0,024 *$ \\
\hline & $(0,005)$ & $(0,01)$ & $(0,009)$ \\
\hline \multirow[t]{2}{*}{ Derechos civiles } & $0,04^{* * *}$ & $0,06^{* *}$ & 0,045 ** \\
\hline & $(0,01)$ & $(0,02)$ & $(0,02)$ \\
\hline Número de observaciones & 310 & 218 & 218 \\
\hline
\end{tabular}

Fuente: Elaboración propia.

Nota: Errores estándar entre paréntesis. ${ }^{\star \star \star}$ significativo al $1 \%$; ${ }^{\star \star}$ significativo al $5 \%$; ${ }^{*}$ significativo al $10 \%$.

a Modelo de datos de panel, incluidos efectos fijos y corrección de sección cruzada.

Como lo muestran esas regresiones de panel, en la inmensa mayoría de los países de la región el nivel de gasto público es inferior al óptimo, aun si su único objetivo fuese el crecimiento económico. En otras palabras, todos los tipos de gastos públicos, corrientes, de capital, transferencias o gastos directos pueden hacer que aumente la eficiencia macroeconómica, en la 
medida en que favorecen la oferta laboral y la formación de capital físico y humano. Por supuesto, ello no excluye la posibilidad de obtener mejoras en su productividad.

\section{B. La incidencia del gasto público sobre el crecimiento}

Cuando se evalúa el desempeño económico simultáneamente por el crecimiento del ingreso disponible y por su distribución, los impactos de la política fiscal pueden ser positivos para ambos objetivos. La evidencia empírica reciente muestra la importancia de esas complementariedades (Hoeller y otros, 2012).

Como se señaló, la mera distinción entre gastos corrientes y de capital, aunque muy importante, no es suficiente para establecer prioridades. Tampoco lo es la separación entre el gasto social y el resto, cuando se sabe que el crecimiento y la generación de empleos tienen un papel importante en la reducción de la pobreza. A continuación se examina de manera más detallada la evolución de los componentes principales del gasto público.

\section{La clasificación económica: prioridad a la inversión}

Durante las décadas de 1980 y 1990, la consolidación fiscal en la región se logró mediante una importante reducción de la inversión pública, con el consiguiente impacto negativo sobre el crecimiento de las economías. En particular, la inversión en infraestructura disminuyó de 3,1 a 1,5 puntos del PIB en los años ochenta (Perrotti y Sánchez, 2011), y mantuvo esos niveles hasta 2008. Sobre todo como reacción a la crisis de dicho año, muchos países han puesto en marcha un proceso de recuperación. En términos de composición, es notable el espacio que ha ganado la inversión pública si se compara con 1990, pues ha aumentado a la par de la disminución del pago de intereses de la deuda pública (véase el gráfico VII.1). En América Latina, el promedio simple de los gastos públicos de capital de 20 países aumentó de 2 a 4,7 puntos del PIB entre 1990 y 2012. En el Caribe, el promedio de 13 países pasó de 4,8 a 5,5 puntos del PIB en el mismo período.

De esa manera, varios países de América Latina han vuelto a registrar un gran crecimiento de la inversión pública, incluso desde antes de la crisis financiera de 2009. El desventajoso punto de partida ayuda a explicar un comportamiento más dinámico de la inversión: se observa una vigorosa recuperación cuando se compara con 1990, en países como la Argentina, el Brasil, Bolivia (Estado Plurinacional de), Colombia, Dominica, el Ecuador, Haití, México, Panamá, el Paraguay, Trinidad y Tabago y Venezuela (República Bolivariana de) (véase el gráfico VII.2). Otros países, que tenían 
un alto coeficiente público de inversión en 1990, como Guyana, Cuba, Granada, Belice, Honduras, San Vicente y las Granadinas y Barbados, han tenido por el contrario una caída, en algunos casos acentuada, de sus gastos de capital.

\section{Gráfico VII.1}

\section{América Latina (20 países) y el Caribe (13 países): composición del gasto público}

(En porcentajes)

A. América Latina

1990

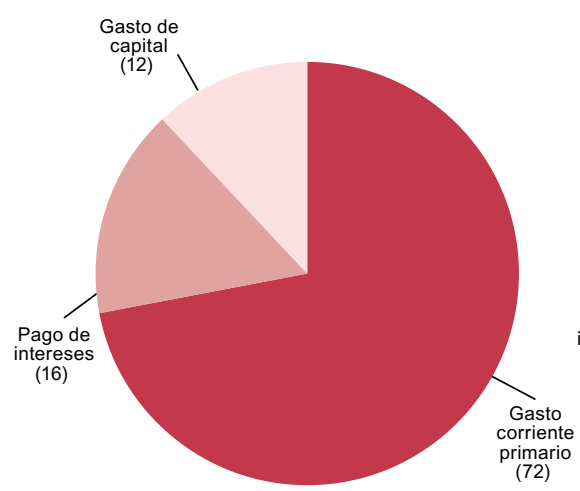

B. El Caribe
2012

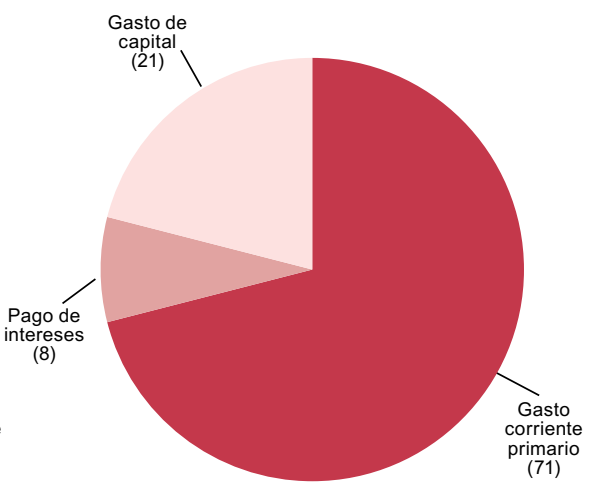

(71)
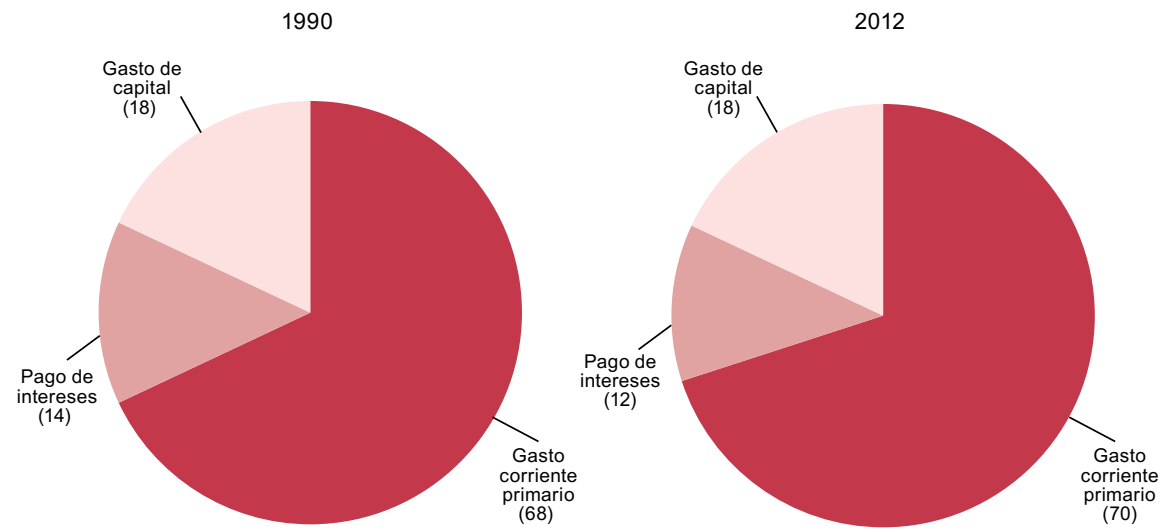

Fuente: Elaboración propia, sobre la base de datos oficiales. 
Gráfico VII.2

América Latina (19 países) y el Caribe (13 países): gastos públicos de capital (En porcentajes del PIB)

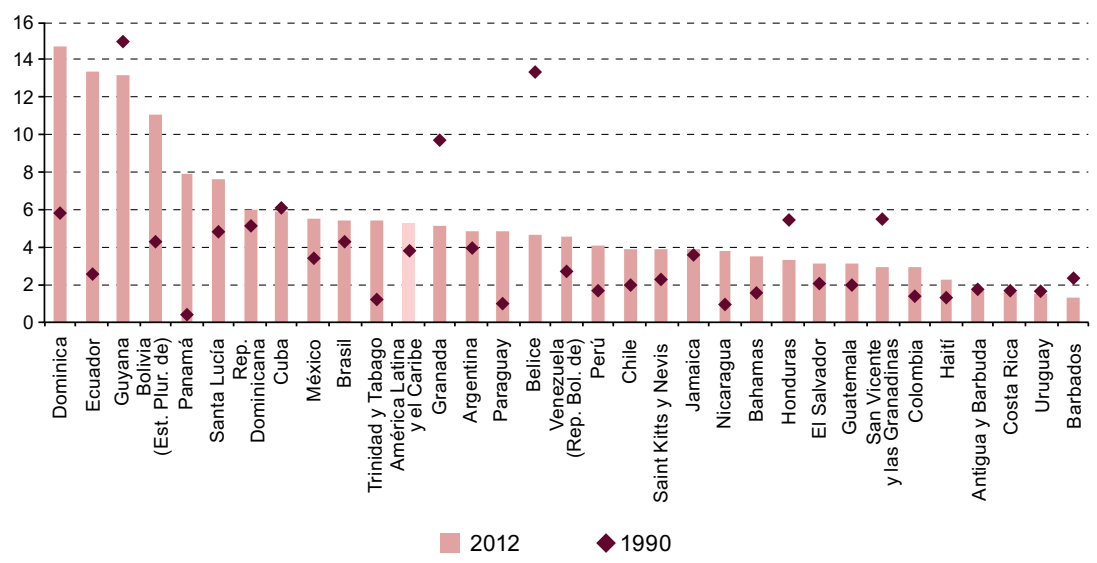

Fuente: Elaboración propia, sobre la base de datos oficiales.

Si bien la respuesta ante la contracción de la demanda agregada no ha sido inmediata, se observa que la inversión pública ha tenido un papel anticíclico, sobre todo en los países de América Latina en el período reciente. No obstante, las brechas de infraestructura requieren un esfuerzo continuo de muchos años.

Hay diversas alternativas para estimular a mediano plazo el proceso de inversión con características de bien público. La primera, y la más radical, consiste en adoptar la regla de oro como norma de manejo de las finanzas públicas. Según esa regla, los gastos corrientes deben financiarse con ingresos corrientes, y los gastos de capital con deuda pública, pues estos últimos representan ingresos futuros, como cualquier inversión privada. Así, la regla de oro estipula que es necesario que haya equilibrio o superávit en la cuenta corriente, pero puede existir un déficit estructural en la cuenta de capital.

En el Manual de estadísticas de finanzas públicas 2001 del Fondo Monetario Internacional (FMI), el concepto de variación del patrimonio fiscal neto define como ingreso todas las transacciones que incrementan el patrimonio neto del gobierno, mientras el gasto se define como una disminución de ese patrimonio. La inversión se registra como un incremento en los activos no financieros, cuya contrapartida puede ser una disminución en los activos financieros. Por lo tanto, el patrimonio neto no se ve afectado y la inversión pública no se considera como gasto.

Si los ajustes fiscales se han hecho principalmente reduciendo activos (entre los que cabe mencionar la inversión pública y los gastos de 
mantenimiento), la reducción de los pasivos del gobierno no se acompaña necesariamente de una mejoría del patrimonio neto del gobierno. Aunque muy atractivos, esos principios contables distan de aplicarse en la región, y tampoco van a reemplazar las tradicionales metas de caja de saldo público.

A pesar de la claridad del concepto, la puesta en práctica generalizada de la regla de oro ha resultado compleja, pues subsiste la tentación de opacar la contabilidad gubernamental. Existen problemas de definición que no son menores, en especial respecto del tratamiento de los costos de depreciación del capital. Por otra parte, al no recibir necesariamente el sector público la totalidad del retorno de sus inversiones, la analogía con el sector privado pierde consistencia. Las propias inversiones acarrean muchas veces gastos corrientes adicionales de operación, lo que hace que la separación contable no sea trivial.

Así pues, se hace necesario considerar alternativas parciales de mayor flexibilidad fiscal, que apunten a incentivar cierto tipo de inversiones. En particular, parece necesario eximir a algunas o a todas las empresas públicas de las metas consolidadas de balance fiscal. Si las empresas públicas no tienen funciones cuasifiscales, o si las transferencias desde el Gobierno central están debidamente registradas en el presupuesto, no tiene mayor sentido incluirlas en los objetivos de déficit y de deuda pública, pues de esa forma se eliminan las restricciones artificiales a la inversión en infraestructura.

Asimismo, han surgido con mucha fuerza las iniciativas de asociación público-privada (APP) en los países de América Latina. Ese término resulta difícil de definir, y en muchas ocasiones se confunde con privatizaciones parciales o con las tradicionales concesiones de infraestructura, que pueden dar lugar a pasivos contingentes, pero que no implican gastos corrientes futuros. En su acepción más amplia, las APP se definen como "arreglos en que el sector privado ofrece infraestructura y servicios cuya provisión ha sido tradicionalmente realizada por el sector público" (Martner y Tromben, 2005). Ello incluye la construcción y operación de hospitales, escuelas, prisiones, instalaciones de agua y saneamiento, carreteras, túneles y puentes, redes ferroviarias, aeropuertos y sistemas de control de tráfico aéreo.

Como se observa, los proyectos que ocupan los primeros lugares de esa lista dan lugar a gastos públicos corrientes en el futuro. Como se trata de inversiones en bienes públicos "puros", esta práctica representa una alternativa real que podría ser muy atractiva para reducir contablemente el sesgo antiinversión. No obstante, supone obligaciones fiscales futuras y, por lo tanto, no constituye una panacea.

Al final del camino, una adecuada combinación entre reglas adaptadas al entorno macroeconómico y algunas dosis de discrecionalidad podría ser la mejor receta para lograr los equilibrios apropiados entre gasto corriente e inversión, endeudamiento y saldo público. 


\section{La clasificación funcional: preponderancia para el gasto social}

Es interesante reseñar que determinados componentes sociales del gasto público, que en algunos casos combinan gastos corrientes y gastos de capital, además de favorecer una mejor redistribución del ingreso, tienden a potenciar el crecimiento económico a largo plazo. El gasto público, en ciertos componentes clave, engloba o conlleva un doble dividendo, pues se atienden simultáneamente los objetivos de crecimiento y de redistribución del ingreso disponible (Lindert, 2003).

Los gastos en concepto de educación, salud, exclusión social, vivienda, familia y niños, pensiones y desempleo aumentan la eficiencia macroeconómica, en la medida en que favorecen la formalidad, el empleo de calidad, las tasas de participación de las mujeres y los jóvenes en el mercado del trabajo y la inserción laboral de las personas excluidas. Muchas transferencias sociales, además del gasto directo en educación y salud, tienen la característica de ser potencialmente progresivas y favorables al crecimiento. En esa categoría cabría mencionar las transferencias relacionadas con seguridad alimentaria y nutricional, protección social y del medio ambiente, vivienda, cultura y recreación (véase el cuadro VII.5).

Conviene destacar que los países que poseen altos coeficientes de gasto público también muestran en general los mayores avances en gasto social (véase el gráfico VII.3). En ese sentido, la participación del gasto social en el presupuesto se ha visto incrementada de un 45\% en el período 1990-1991 a cerca del 63\% en 2009-2010 (CEPAL, 2012b). En los últimos años, las políticas fiscales han permitido dar sostenibilidad a un gasto público social creciente, pasando de 9,4 a 15,3 puntos del PIB como promedio de la región.

Destacan los fuertes aumentos en países que ya tenían un gasto social elevado en 1990, como Cuba, la Argentina, el Brasil, el Uruguay y Costa Rica. Por otra parte, México, Panamá, Honduras, Jamaica, el Paraguay, el Ecuador, el Perú, Guatemala, Trinidad y Tabago y la República Dominicana destinan 12 puntos de PIB o menos al gasto social, lo que representa un serio obstáculo al potencial de crecimiento de esas economías. Como lo consigna el Panorama Social de América Latina 2012 (CEPAL, 2012b), en muchos de esos países se ha otorgado reciente prioridad macroeconómica al gasto social, sobre todo en lo que se refiere a recursos destinados a educación.

En cuanto a la composición de ese gasto social, se observa una elevada dispersión (véase el gráfico VII.4), que refleja la diversidad de modalidades de provisión de bienes y servicios públicos, especialmente en salud y pensiones. También se pone de relieve el escaso grado de cobertura de la protección social en algunos países. 


\section{Cuadro VII.5}

\section{Ejemplos de impactos económicos de las funciones sociales}

\begin{tabular}{|c|c|}
\hline Función social & Ejemplos de impacto económico \\
\hline Educación & $\begin{array}{l}\text { La teoría del capital humano es el principal marco teórico bajo el cual se puede ver } \\
\text { que la educación tiene impacto económico. La educación fomenta la productividad } \\
\text { de los trabajadores, haciendo que estén más capacitados y habilitados para el } \\
\text { mercado laboral, por lo que tiene un impacto en el crecimiento económico. }\end{array}$ \\
\hline Salud & $\begin{array}{l}\text { La inversión en salud genera un incremento en la capacidad productiva, con } \\
\text { beneficios para las personas y las unidades productivas. }\end{array}$ \\
\hline $\begin{array}{l}\text { Seguridad } \\
\text { alimentaria y } \\
\text { nutricional }\end{array}$ & $\begin{array}{l}\text { Tanto la desnutrición como el sobrepeso y la obesidad generan costos personales } \\
\text { y sociales, por lo que su disminución supone ahorros directos para la economía } \\
\text { de los paises en salud, educación y, sobre todo, en productividad, A su vez implica } \\
\text { incentivos en sectores clave de la economía, como la producción y la distribución } \\
\text { de alimentos. }\end{array}$ \\
\hline $\begin{array}{l}\text { Protección } \\
\text { social }\end{array}$ & $\begin{array}{l}\text { Al asegurar un nivel de recursos a las personas y mitigar los efectos de las crisis } \\
\text { económicas o del desempleo, facilita la existencia de un nivel mínimo de consumo } \\
\text { en la población, mediante la inyección de recursos directamente al mercado } \\
\text { por la vía de la demanda. Además, tiene un efecto directo en el empleo, pues } \\
\text { comprende entre sus funciones la regulación del mercado laboral y la promoción } \\
\text { del trabajo decente. }\end{array}$ \\
\hline $\begin{array}{l}\text { Protección del } \\
\text { medioambiente }\end{array}$ & $\begin{array}{l}\text { La protección del medio ambiente puede tener un impacto económico mediante la } \\
\text { aplicación de métodos que contribuyan a reducir la contaminación. También hay un } \\
\text { impacto en el sector de la construcción con el "enverdecimiento" de las viviendas } \\
\text { y edificios. }\end{array}$ \\
\hline $\begin{array}{l}\text { Vivienda y } \\
\text { servicios } \\
\text { relacionados }\end{array}$ & $\begin{array}{l}\text { El impacto indirecto mediante el gasto en vivienda afecta el sector de la } \\
\text { construcción, que tiene una importante participación en el PIB de la región. El sector } \\
\text { público genera alianzas con el sector privado para la ejecución de proyectos de } \\
\text { infraestructura y de construcción de viviendas. }\end{array}$ \\
\hline $\begin{array}{l}\text { Cultura y } \\
\text { recreación }\end{array}$ & $\begin{array}{l}\text { La producción de bienes y servicios culturales lleva generalmente a la activación } \\
\text { de actividades económicas privadas. Por ejemplo, mediante las remuneraciones } \\
\text { pagadas en el empleo privado. }\end{array}$ \\
\hline
\end{tabular}

Fuente: R. Martínez y otros, “El impacto económico de las políticas sociales”, Documentos de Proyectos (LC/W.531), Santiago, Comisión Económica para América Latina y el Caribe (CEPAL), 2013.

\section{Gráfico VII.3 \\ América Latina y el Caribe (21 países): gasto público social} (En porcentaje del PIB)

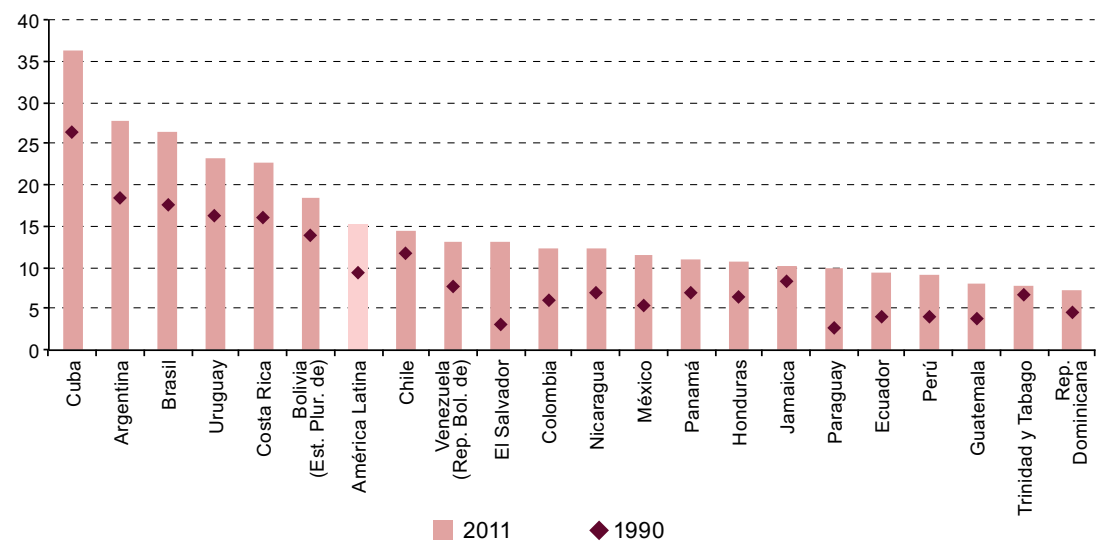

Fuente: Elaboración propia, sobre la base de cifras oficiales. 


\section{Gráfico VII.4}

América Latina y el Caribe (21 países): composición del gasto público social, 2011 (En porcentajes del PIB)

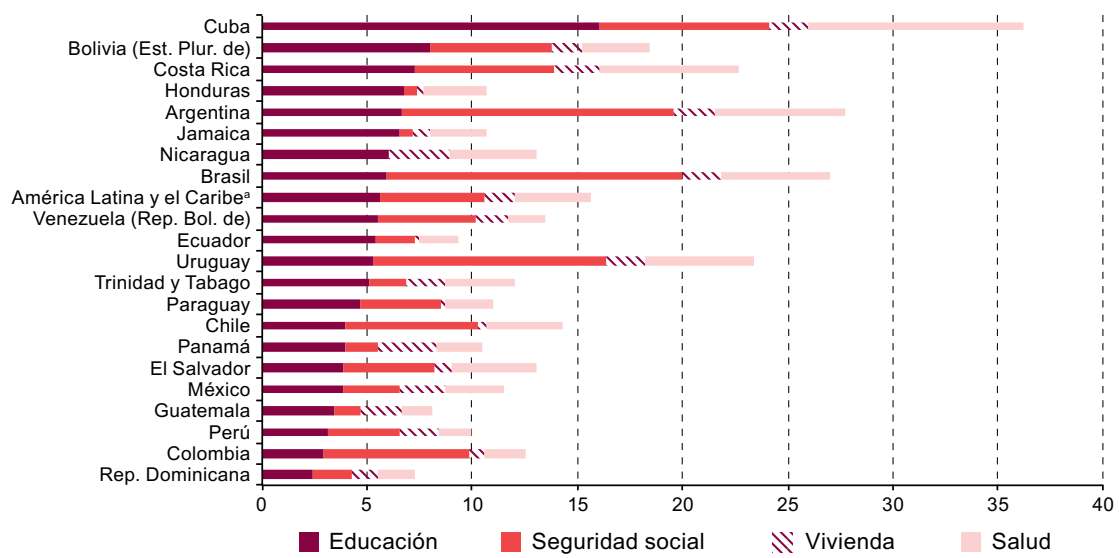

Fuente: Elaboración propia, sobre la base de cifras oficiales.

a Promedio simple de los 21 países seleccionados.

Destaca la fuerte heterogeneidad del gasto en educación, que se explica en parte por la variedad en la composición público-privada de la provisión de servicios de educación en sus diversos niveles, pero también por la insuficiente capacidad del Estado para generar los recursos necesarios. El impacto del gasto directo del sector público en educación, con los cambios en la cobertura preescolar y escolar primaria y secundaria, ha sido muy relevante en los países de la región (OCDE/CEPAL, 2011).

Basta una mirada a la clasificación cruzada del gasto público, económica y funcional, para darse cuenta de las grandes dificultades que se interponen al tratar de jerarquizar y asignar gastos sobre esas bases, sin tomar en cuenta las especificidades, la situación, ni las prioridades programáticas de cada país. Por ejemplo, aunque está clara la importancia de asignar recursos a las diversas categorías de protección social, sería difícil hacerlo en desmedro de otras, que también son clave en el desarrollo económico y social. En particular, parece un ejercicio vano separar los gastos entre "productivos" e "improductivos", según su clasificación económica (corriente o de capital) o funcional (gasto social u otro).

Las dicotomías entre crecimiento e igualdad, siempre latentes, pierden preponderancia cuando aumentan los gastos que tienen efectos positivos en el crecimiento económico, el empleo formal y el acceso a los bienes públicos. Para conseguir esos impactos, la tarea de mejorar la calidad del gasto público supone ampliar coberturas en muchos programas, continuar el esfuerzo 
de disminución de la carga de intereses, aumentar la inversión en capital humano y conocimiento y acelerar la inversión en infraestructura. Todo lo anterior requiere una mayor movilización de recursos domésticos.

\section{Los límites al financiamiento: el papel de los sistemas tributarios}

Los impuestos surgen de la necesidad de financiar los gobiernos, y resultan de un acuerdo social en que los agentes económicos acuerdan ceder parte de sus ingresos con el fin de proveer recursos para la administración, los gastos sociales y los bienes públicos necesarios para que los países funcionen adecuadamente.

Desde una perspectiva política, ese pacto fiscal se basa en la existencia de reciprocidad entre el Estado y los ciudadanos, "expresada en la voluntad de la mayoría de los hogares de pagar más impuestos en la medida en que mejore la calidad de los servicios públicos de salud, educación y seguridad, y haya menos corrupción y más control de la evasión" (CEPAL, 2013). El vínculo entre tributos y calidad del gasto público se hace, por tanto, indisoluble en las sociedades democráticas. Por añadidura, el sistema tributario ha de contemplar con mayor preponderancia que antaño los objetivos de desarrollo sostenible.

En América Latina y el Caribe, más del $60 \%$ de los ingresos tributarios (sin considerar la seguridad social) proviene de impuestos indirectos, mientras que cerca del $37 \%$ de la carga tributaria grava la renta o la propiedad (véase el gráfico VII.5). En la última década, los países de América Latina incrementaron la participación de los impuestos directos, sobre todo debido al crecimiento de la imposición sobre la renta de las empresas9. Además, como consecuencia del fortalecimiento del impuesto sobre el valor agregado (IVA), de los procesos de simplificación tributaria y de la liberalización del comercio, aumentó la importancia relativa de los impuestos generales sobre bienes y servicios. Entretanto, los impuestos específicos y los tributos sobre el comercio internacional continuaron perdiendo peso relativo en la composición de la recaudación. Sin embargo, en el Caribe estos últimos aún representan una porción importante de la estructura tributaria (casi un cuarto del total).

Diversos factores determinaron esa evolución. Por ejemplo, la ampliación parcial de algunas bases tributarias que gravan los servicios, la aplicación de impuestos mínimos o sustitutivos del impuesto sobre la renta, una mejor fiscalización de los contribuyentes y, en varios países, la apropiación de mayores recursos originados en la producción y exportación de bienes primarios. 


\section{Gráfico VII.5}

América Latina (19 países) y el Caribe (13 países): estructura tributaria (sin seguridad social)

(En porcentajes)

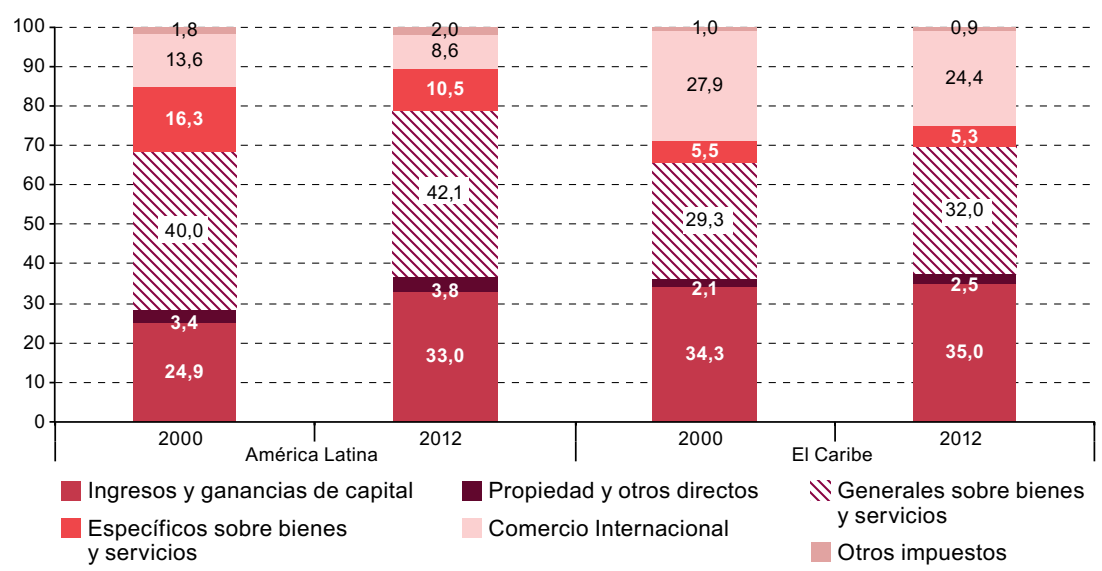

Fuente: Elaboración propia sobre la base de cifras oficiales.

Si potenciar el ahorro y la inversión y, por esa vía, el crecimiento económico, es un objetivo adicional para los sistemas tributarios, la búsqueda de eficiencia y neutralidad ha de ser un principio que guíe el diseño de los impuestos. Cuando las personas adoptan sus decisiones por razones fiscales, en vez de razones basadas en los costos o la productividad económica, ello causa pérdidas de bienestar que se proyectan de manera tangible en un deterioro del crecimiento económico. No obstante, la neutralidad impositiva absoluta es imposible (Sanz-Sanz y Sanz Labrador, 2013), e incluso indeseable, cuando se definen metas prioritarias como la suficiencia recaudatoria y la justicia distributiva. Los costos de la tributación pueden resumirse en cuatro categorías:

i) los costos asociados a la transferencia de rentas del sector privado al sector público (o "efecto renta");

ii) los costos de eficiencia vinculados a las distorsiones generadas en los procesos de elección de los agentes económicos, debido a los cambios de los precios relativos de bienes y factores productivos (o "efecto sustitución");

iii) los costos de la administración tributaria para asegurar el cobro de los impuestos, $\mathrm{y}$

iv) los costos de cumplimiento en los que debe incurrir el contribuyente para cumplir con sus obligaciones. 
Ante lo inevitable del efecto renta, el diseño eficiente de los sistemas fiscales deberá ir encaminado a minimizar los excesos de gravamen y los costos de administración y cumplimiento que produce.

Un punto fundamental de la discusión entre impuestos, crecimiento y distribución del ingreso disponible tiene que ver con la definición conceptual de los sistemas tributarios, y si están orientados a gravar la renta o a gravar el gasto. Si se privilegia el segundo concepto, prevalecerán impuestos indirectos (como en el gráfico VII.5) y se eximirán los instrumentos de ahorro e inversión (caso típico en la región, lo que tiene amplias consecuencias sobre la equidad vertical de los sistemas).

Si se adopta el primero y se prioriza un objetivo de redistribución, se privilegiará el impuesto sobre la renta (ISR). Tradicionalmente se considera como base imponible el ingreso o renta de las personas. De acuerdo a la definición de Haig-Simons, este equivale a la variación que experimenta el patrimonio individual entre dos momentos concretos, más el consumo durante el período intermedio (de manera que abarca la totalidad de la renta). Sin embargo, en décadas recientes, la arquitectura del impuesto sobre la renta se ha ido desmantelando progresivamente (Tanzi, 2013) mediante la distinción entre diversos tipos de ingresos, y el trato especial a aquellos que potencialmente estimulan el ahorro y la inversión privada.

El contexto legal del impuesto sobre la renta, a lo largo de su historia, ha sufrido diversas modificaciones que apuntan en la dirección de gravar el gasto y no la renta, con la clara intención legislativa de desgravar el ahorro y la inversión. Por esa y otras razones, los países de América Latina en general han encontrado grandes dificultades para aplicar un impuesto sobre la renta personal global o sintético que alcance a todas las fuentes de ingresos de un mismo contribuyente de acuerdo a una estructura de tasas marginales progresivas. En la mayoría de los casos hay una larga serie de exoneraciones y tratos diferenciales según la fuente generadora de ingresos, que atentan contra la equidad horizontal y vertical del tributo y limitan su potencial recaudatorio y redistributivo (Gómez-Sabaini y Morán, 2013).

En repetidas ocasiones, ante la eventualidad de crisis económicas, las autoridades fiscales han respondido mediante la multiplicación de incentivos y exenciones tributarias, con la esperanza (muchas veces vana) de estabilizar la demanda agregada y controlar los efectos de las recesiones sobre el empleo. Como es sabido, sin embargo, esos instrumentos representan respuestas de oferta a problemas de demanda, por lo que suelen ser menos eficientes que las medidas monetarias y que los multiplicadores asociados al estímulo del gasto público.

En lo tocante a los incentivos tributarios a la inversión, pueden ser generales (como la reducción de la tasa del IVA para los bienes de capital, la 
depreciación acelerada, las exenciones de aranceles a la importación de bienes de capital, la exención de dividendos), localizados en determinadas áreas geográficas (por ejemplo, en zonas extremas) o sectoriales, o en determinadas industrias o actividades específicas. En los países de América Latina pueden encontrarse ejemplos de los tres tipos de incentivos tributarios, que implican tratos especiales que se aplican principalmente al impuesto sobre el valor agregado y al impuesto sobre la renta ${ }^{10}$.

Sin embargo, aun cuando puedan encontrar justificación en algunos casos puntuales, los incentivos tributarios a la inversión pueden tener un impacto negativo tanto sobre la equidad como sobre la eficiencia de los sistemas. En términos de eficiencia, los incentivos han creado problemas de competencia tributaria interjurisdiccional (que han dado lugar a una "convergencia a la baja" de los impuestos tanto a nivel nacional como regional) y otras distorsiones en las decisiones de localización y producción industrial.

De esa manera, instrumentos con los que se pretendía incentivar las inversiones privadas, como los impuestos cedulares, las bajas tasas a las utilidades reinvertidas sin importar el tamaño de las empresas, la depreciación acelerada, los pactos tributarios o los regímenes sectoriales específicos, constituyen en muchos casos obstáculos insalvables para alcanzar objetivos de suficiencia recaudatoria y de equidad y, además, dificultan la administración tributaria.

\section{Síntesis y conclusiones}

Como consecuencia de la crisis financiera internacional de 2008-2009, la discusión sobre la política fiscal en los últimos años (y tal vez en el futuro cercano) ha estado muy marcada por el dilema entre estabilización macroeconómica y sostenibilidad de la deuda pública. Las realidades observadas en varios países de Europa han demostrado que no basta con políticas de austeridad fiscal para reducir la incertidumbre y dinamizar el crecimiento, sobre todo porque los multiplicadores fiscales son mucho más elevados que lo previsto (Blanchard y Leigh, 2013). Más allá de los matices, es importante encauzar este dilema hacia una perspectiva de mediano plazo. No solo se trata de aplicar paquetes de estímulo fiscal en condiciones cíclicas adversas, sino de delinear estrategias que apunten a potenciar el crecimiento de las economías.

Podrían parafrasearse las palabras de Sachs (2011), y afirmar que no basta con gastar y reducir impuestos para que la economía se recupere y vuelva a la normalidad. Sachs cree fuertemente en el papel de la inversión pública para satisfacer las necesidades de la sociedad y en la necesidad

10 El trabajo de Agostini y Jorratt (2013), que se resume en el capítulo VIII, aporta evidencia actualizada sobre esas prácticas a nivel regional. 
de modernizar la infraestructura, renovar el sistema eléctrico, mejorar las ciudades y entrenar a una nueva fuerza laboral. Ello requiere programas de gobierno bien diseñados y una buena coordinación con los gobiernos locales. Esas políticas deben incluir aumentos de ingresos provenientes de la imposición a la riqueza y a los ingresos altos, a las transacciones financieras, a las ganancias de capital y a las emisiones de carbono.

Aunque, afortunadamente, América Latina ha podido crecer y controlar su deuda pública en los últimos años, los desafíos de mediano plazo son muy similares a los reseñados. Solo un gasto público de mayor calidad, debidamente respaldado por un sistema tributario eficiente y equitativo, podrá permitir transitar hacia esquemas de desarrollo sostenible y con grados crecientes de igualdad e inclusión social.

Superar los dilemas de corto plazo entre estabilidad macroeconómica, crecimiento de largo plazo, protección social y tributación supone la creación o consolidación de instituciones orientadas a construir políticas fiscales transparentes y con objetivos claros. El consenso social y la legitimidad del gobierno y del Estado se construyen sobre la base de la confianza que los ciudadanos tienen respecto de la acción estatal.

\section{Bibliografía}

Aghion, P., E. Caroli y C. García-Peñalosa (1999), "Inequality and economic growth: the perspective of the new growth theories", Journal of Economic Literature, vol. 37, $\mathrm{N}^{\circ}$ 4, Nashville, Tennessee, American Economic Association.

Agostini, C. y M. Jorratt (2013), "Política tributaria para mejorar la inversión y el crecimiento en América Latina", serie Macroeconomía del Desarrollo, Nº 130 (LC/L.3589), Santiago, Comisión Económica para América Latina y el Caribe (CEPAL).

Alesina, A. y R. Perotti (1995), "Fiscal expansions and adjustments in OECD countries", Economic Policy, vol. 10, N²1, Oxford University Press.

Auerbach, A. e Y. Gorodnichenko (2012), "Measuring the output responses to fiscal policy", American Economic Journal: Economic Policy, vol. 4, $\mathrm{N}^{\circ} 2$, Nashville, Tennessee, American Economic Association.

Barro, R. (1990), "Government spending in a simple model of endogenous growth", Journal of Political Economy, vol. 98, N5, Chicago, The University of Chicago Press.

Blanchard, O. y D. Leigh (2013), "Growth forecast errors and fiscal multipliers", IMF Working Paper, $\mathrm{N}^{\circ}$ WP/13/1, Washington, D.C., Fondo Monetario Internacional.

Bose, N., M.E. Haque y D.R. Osborn (2007), "Public expenditure and economic growth: a disaggregated analysis for developing countries", Manchester School, vol. 75, N5, John Wiley \& Sons.

Bourguignon, F. (1998), "Distribution, redistribution and development: where do we stand?", DELTA Working Papers, N 98-11.

CEPAL (Comisión Económica para América Latina y el Caribe) (2013), Panorama fiscal de América Latina y el Caribe. Reformas tributarias y renovación del pacto fiscal (LC/G.3580), Santiago. 
(2012a), Cambio estructural para la igualdad: una visión integrada del desarrollo (LC/G.2524(SES.34/3)), Santiago.

(2012b), Panorama Social de América Latina 2012 (LC/G.2557-P), Santiago.

CEPAL/SEGIB (Comisión Económica para América Latina y el Caribe/Secretaría General Iberoamericana) (2011), Espacios iberoamericanos. Hacia una nueva arquitectura del Estado para el desarrollo (LC/G.2507), Santiago.

Cornia, G.A. (2005), Inequality, Growth and Poverty in an Era of Liberalization and Globalization, Oxford University Press.

Cornia, G.A., J.C. Gómez Sabaini y B. Martorano (2011), “A new fiscal pact, tax policy changes and income inequality. Latin America during the last decade", Documento de Trabajo, $\mathrm{N}^{\circ}$ 2011/70, Instituto Mundial de Investigaciones de Economía del Desarrollo (UNU-WIDER).

Devarajan, S., V. Swaroop y H. Zou (1996), "The composition of public expenditure and economic growth", Journal of Monetary Economics, vol. 37, $\mathrm{N}^{\circ}$ 2, Amsterdam, Elsevier.

FMI (Fondo Monetario Internacional) (2001), Manual de estadísticas de las finanzas públicas 2001, Washington, D.C.

Futagami, K., H. Morita y A. Shibata (1993), “Dynamic analysis of an endogenous growth model with public capital", Scandinavian Journal of Economics, vol. 95, $\mathrm{N}^{\circ} 4$, Wiley.

Gemmell, N. (2010), "Public expenditure and economic growth. What do we know?", presentación en el Workshop on Fiscal Policy for Growth and Development, Washington, D.C.

Gemmell, N., R. Kneller e I. Sanz (2011a), "The growth effects of corporate and personal tax rates in the OECD", Bond University Working Paper Series, $\mathrm{N}^{\circ} 49$, Bond University.

(2011b), "The timing and persistence of fiscal policy impacts on growth: evidence from OECD countries", Economic Journal, vol. 121, $\mathrm{N}^{\circ}$ 550, Wiley.

(2009), "The composition of government expenditure and economic growth: some evidence from OECD countries", The Quality of Public Finances and Economic Growth. Proceedings to the Annual Workshop on Public Finances, S. Barrios, L. Pench y A. Schaechter (eds.), Bruselas, Comunidades Europeas.

Gemmell, N., F. Misch y B. Moreno-Dodson (2012), “Public spending and long-run growth in Practice: concepts, tools, and evidence", Is Fiscal Policy the Answer? A Developing Country Perspective, B. Moreno-Dodson (ed.), Washington, D.C., Banco Mundial.

Ghosh, S. y A. Gregoriou (2008), "The composition of government spending and growth: is current or capital spending better?", Oxford Economic Papers, vol. 60, $\mathrm{N}^{\circ} 3$, Oxford University Press.

Giavazzi, F. y M. McMahon (2012), "The household effects of government spending", Fiscal Policy After the Great Recession, A. Alesina y F. Giavazzi (eds.), Chicago, University of Chicago Press.

Gómez Sabaini, J.C. y D. Morán (2013), “Política tributaria en América Latina: agenda para una segunda generación de reformas", serie Macroeconomía del Desarrollo, No 133 (LC/L.3632), Santiago, Comisión Económica para América Latina y el Caribe (CEPAL).

Haque, M.E. (2004), "The composition of public expenditures and economic growth in developing countries", Global Journal of Finance and Economics, vol. 1, N 1. 
Harju, J. y T. Kosonen (2012), “The impact of tax incentives on the economic activity of entrepreneurs", NBER Working Paper, N 18442, Cambridge, Masscahusetts, National Bureau of Economic Research.

Hoeller, P. y otros (2012), "Less income inequality and more growth. Are they compatible? Part 1. Mapping income inequality across the OECD", OECD Economics Department Working Papers, N 924, París, OECD Publishing.

Johannson, A. y otros (2008), "Taxation and economic growth", OECD Economics Department Working Papers, $\mathrm{N}^{\circ}$ 620, París, OECD Publishing.

Lindert, P. (2003), "Why the welfare state looks like a free lunch", Working Papers, $N^{\circ} 27$, Davis, Universidad de California.

Martínez, R. y otros (2013), “El impacto económico de las políticas sociales”, Documentos de Proyectos (LC/W.531), Santiago, Comisión Económica para América Latina y el Caribe (CEPAL).

Martner, R. (2000), "Estrategias de política económica en un mundo incierto: reglas, indicadores, criterios", serie Cuadernos del ILPES, N 45 (LC/IP/G.123-P), Santiago, Comisión Económica para América Latina y el Caribe (CEPAL).

Martner, R., A. Podestá e Ivonne González (2013), "Políticas fiscales para el crecimiento y la igualdad", serie Macroeconomía del Desarrollo, No 138 (LC/L.3716), Santiago, Comisión Económica para América Latina y el Caribe (CEPAL) [en línea] http:/ / repositorio.cepal.org/bitstream/handle/11362/5372/LCL3716.pdf?sequence=1.

Martner, R. y V. Tromben (2005), “Opciones para enfrentar el sesgo anti-inversión pública", serie Gestión Pública, Nº 50 (LC/L.2321-P), Santiago.

Mendoza, E., G. Milesi-Ferretti y P. Asea (1997), “On the ineffectiveness of tax policy in altering long-run growth: Harberger's superneutrality conjecture", Journal of Public Economics, vol. 66, $\mathrm{N}^{\circ} 1$, Amsterdam, Elsevier.

Musgrave, R. y J. Buchanan (1999), Public Finance and Public Choice: Two Contrasting Visions of the State, Cambridge, Massachusetts, The MIT Press.

Nijkamp, P. y J. Poot (2004), "Meta-analysis of the effects of fiscal policies on long-run growth", European Journal of Political Economy, vol. 20, № 1, Amsterdam, Elsevier.

OCDE/CEPAL (Organización de Cooperación y Desarrollo Económicos/Comisión Económica para América Latina y el Caribe) (2011), Perspectivas económicas de América Latina 2012: transformación del Estado para el desarrollo, París, OECD Publishing.

Perrotti, D. y R. Sánchez (2011), “La brecha de infraestructura en América Latina y el Caribe", serie Recursos Naturales e Infraestructura, N 153 (LC/L.3342), Santiago, Comisión Económica para América Latina y el Caribe (CEPAL).

Piketty, T., E. Saez y S. Stantcheva (2011), “Optimal taxation of top labor incomes: a tale of three elasticities", CEPR Discussion Paper, $\mathrm{N}^{\circ}$ 8675, Centro de investigación sobre políticas económicas.

Rocha, F. y A.C. Giuberti (2007), "Composição do gasto público e crescimento econômico: uma avaliação macroeconômica da qualidade dos gastos dos Estados brasileiros", Economia Aplicada, vol. 11, N 4, São Paulo, Universidad de São Paulo.

Rodrik, D. (2008), "The real exchange rate and economic growth", Brookings Papers on Economic Activity, N ${ }^{\circ}$ 2, Washington, D.C., Brookings Institution.

Romero-Ávila, D. y R. Strauch (2008), "Public finances and long-term growth in Europe: Evidence from a panel data analysis", European Journal of Political Economy, vol. 24, N 1, Amsterdam, Elsevier.

Sachs, J. (2011), The Price of Civilization: Reawakening American Virtue and Prosperity, Nueva York, Random House Trade Paperbacks. 
Salinas, J. y F. Delgado (2012), “Impuestos, crecimiento económico y bienestar: una visión panorámica", documento presentado en el XXIV Seminario Regional de Política Fiscal, Santiago [en línea] http://www.cepal.org/ilpes/noticias/ paginas /4/45764/Trabajo_Salinas-Delgado.pdf.

Sanz-Sanz, J.F. e I. Sanz Labrador (2013), "Política fiscal y crecimiento económico: consideraciones microeconómicas y relaciones macroeconómicas", serie Macroeconomía del Desarrollo, № 134 (LC/L.3638), Santiago, Comisión Económica para América Latina y el Caribe (CEPAL).

Sutherland, A. (1995), "Fiscal crises and aggregate demand: can high public debt reverse the effects of fiscal policy?", CEPR Discussion Paper, $\mathrm{N}^{\circ} 1246$, Centro de investigación sobre políticas económicas.

Tanzi, V. (2013), "Tax reform In Latin America: A long term assessment”, documento presentado en el XXC Seminario Regional de Política Fiscal, Santiago, Comisión Económica para América Latina y el Caribe (CEPAL). (2008), "Las finanzas públicas y el pacto fiscal en América Latina”, R. Martner (ed.), serie Seminarios y Conferencias, N 54 (LC/L.2977-P), Santiago, Comisión Económica para América Latina y el Caribe (CEPAL).

Venieris, Y.P. y D.K. Gupta (1986), “Income distribution and sociopolitical instability as determinants of savings: a cross-sectional model", Journal of Political Economy, vol. 94, N 4, Chicago, The University of Chicago Press. 


\section{Política tributaria para mejorar la inversión y el crecimiento en América Latina ${ }^{1}$}

Claudio Agostini $i^{2}$

Michel Jorratt ${ }^{3}$

\section{Introducción}

La principal finalidad de un sistema tributario es recaudar los ingresos necesarios para que el Estado financie los bienes y servicios públicos, el gasto social y otras actividades que tengan efectos económicos positivos para la sociedad. Sin embargo, también es frecuente que los Gobiernos usen la estructura tributaria para promover ciertos objetivos de política económica, como incentivar el ahorro, estimular el empleo o proteger la industria nacional. En tales circunstancias, el sistema tributario cumple un papel similar al del gasto público, pero por la vía de la renuncia del Estado a la totalidad o una parte de la recaudación que correspondería obtener de determinados contribuyentes o actividades. Esta renuncia es lo que se conoce como gasto tributario, concepto que en los últimos años ha cobrado relevancia, dada la

Este capítulo es una versión resumida de Agostini y Jorratt (2013).

2 Profesor titular de la Escuela de Gobierno de la Universidad Adolfo Ibáñez de Chile. Correo electrónico: claudio.agostini@uai.cl.

3 Consultor especializado en política y administración tributaria y profesor del Departamento de Ingeniería Industrial de la Universidad de Chile. Correo electrónico: michel.jorrat@gmail.com. 
necesidad de transparentar esta intervención estatal, que de otra manera queda oculta en las cifras de ingresos.

Los incentivos a la inversión, muy utilizados en los países de América Latina, constituyen un tipo particular de gastos tributarios. En mayor o menor medida, todos los países otorgan concesiones en la estructura tributaria, que buscan aumentar los niveles de inversión interna o atraer inversión extranjera. La aplicación de estos incentivos conlleva una serie de costos - tales como pérdida de recaudación, costos de administración y cumplimiento, espacios de evasión y elusión, y pérdida de progresividad-que los Gobiernos están dispuestos a asumir con la esperanza de aumentar la inversión y, por esa vía, obtener efectos positivos sobre el crecimiento económico, el empleo y la adopción de nuevas tecnologías.

Debido a que los incentivos tributarios a la inversión compiten con otras políticas por el uso de recursos limitados dentro de un determinado espacio fiscal, resulta imprescindible evaluar su efectividad y los costos que tiene para la sociedad el uso de estos instrumentos. Al igual que algunos países hacen con los programas de gasto directo, el establecimiento de incentivos tributarios debería estar sujeto a una evaluación ex ante, en la que se justifique su necesidad y se establezcan objetivos y metas concretas, y también a una evaluación ex post, en la que se verifique empíricamente el cumplimiento de los objetivos, se cuantifiquen los costos y se adopten medidas correctivas cuando sea necesario. Lamentablemente, este tipo de evaluaciones no son frecuentes en los países de la región.

\section{A. Revisión de la literatura sobre incentivos tributarios a la inversión}

\section{Efectividad de los incentivos a la inversión}

Si bien el objetivo principal del sistema tributario de un país es recaudar los recursos necesarios para que el Estado provea servicios y bienes públicos, los impuestos corporativos se utilizan como instrumentos de política en sí mismos. En particular, muchos Gobiernos generan — a través de modificaciones en la tributación de las empresas - incentivos que intentan aumentar los niveles de inversión interna o atraer inversión extranjera. La razón para ello es que un aumento en la inversión tiene efectos positivos sobre el crecimiento económico, el empleo y la adopción de nuevas tecnologías.

La pregunta relevante, entonces, es si las modificaciones en la base o la tasa de los impuestos corporativos pueden tener un efecto relevante en las decisiones de inversión. Desde el punto de vista teórico, la respuesta a esta pregunta se ha basado, con distintas variaciones, en el modelo de inversión 
neoclásico de Jorgenson (1963) y Hall y Jorgenson (1967), que establece que una empresa va a invertir hasta el punto en el que el producto marginal del capital sea igual al costo de uso del capital. Esto se puede expresar como:

$$
q(\rho+\delta) \frac{(1-k-\tau z)}{(1-\tau)}
$$

donde $q$ es el precio relativo de los bienes de capital, $\rho$ es la tasa real de descuento, $\delta$ es la tasa geométrica de depreciación económica, $k$ es el crédito tributario a la inversión, $\tau$ es el impuesto sobre las sociedades y $z$ es el valor presente por peso invertido de la depreciación permitida para fines tributarios.

La evidencia empírica respalda el uso del modelo de inversión neoclásico y muestra, en general, una correlación positiva entre el capital social y su costo de uso, con magnitudes en torno a 0,6 (Meyer, Prakken y Varvares, 1993). En otras palabras, una reducción del $10 \%$ en el costo de uso del capital aumenta un $6 \%$ el capital social en el largo plazo, asumiendo que no hay cambios en la tasa de interés producto del incremento de la inversión.

En este modelo de inversión, el impuesto sobre las sociedades afecta el costo de uso del capital de dos formas. Por una parte, un aumento en la tasa incrementa el costo de uso, ya que se requiere un aumento en el producto marginal del capital antes de impuestos para que un inversionista obtenga la mínima tasa de retorno necesaria para invertir. Por otra parte, un impuesto sobre las sociedades más alto aumenta el valor de la deducción tributaria de la depreciación, lo que reduce el costo de uso del capital. Si se permite la depreciación instantánea, los dos efectos son iguales en magnitud y un aumento en la tasa de impuestos no afecta el costo de capital. Como, en la práctica, los países tienen esquemas con una depreciación tributaria menor que la depreciación instantánea, los aumentos en la tasa de impuestos incrementan el costo de uso del capital y desincentivan la inversión.

Sin embargo, en el trabajo de Gordon (1985) se muestra que, cuando se incorpora incertidumbre explícitamente al modelar los efectos de los impuestos, un impuesto al ingreso del capital puede dejar intactos los incentivos a invertir y los incentivos al ahorro de las personas, a pesar de generar una recaudación tributaria de magnitud importante. La razón es que si bien los inversionistas reciben una tasa de retorno esperada menor debido a los impuestos, también soportan menos riesgo al invertir, y estos efectos se cancelan mutuamente. Incluso el impuesto puede generar ganancias de eficiencia al producir una reasignación del riesgo entre individuos y entre generaciones.

La pregunta relevante desde el punto de vista de la política pública es netamente empírica y se refiere a cuál es la magnitud de los efectos tributarios sobre la inversión. Esta es una pregunta empírica relevante pero compleja, ya que, implícitamente, supone analizar el impacto de distintos 
efectos tributarios: la tasa de impuestos, la base del impuesto, los créditos tributarios, las exenciones tributarias y otros.

\section{a) Efectos de la tasa de impuestos}

Gran parte de la literatura empírica en economía ha intentado responder a la pregunta respecto del efecto de la tasa de impuestos sobre la inversión, tanto en la magnitud de la inversión como en su ubicación geográfica. La tasa impositiva marginal es la que mejor capta ambos efectos tributarios (De Mooij y Ederveen, 2003; Devereux y Griffith, 1998), lo que dificulta el análisis empírico, ya que la información de microdatos de las empresas permite estimar la tasa impositiva efectiva media y no la tasa impositiva marginal. La solución estándar en la literatura ha sido utilizar la tasa impositiva legal y ajustarla o controlar por otras consideraciones relevantes del sistema tributario.

Además, debido a la disponibilidad de datos y al hecho de que muchos Gobiernos concentran sus esfuerzos en atraer inversión extranjera, en gran parte de los trabajos empíricos se estudia si los cambios en los impuestos a las utilidades de las empresas afectan las decisiones de inversión de los inversionistas extranjeros ${ }^{4}$.

Si bien puede existir cierto consenso respecto de la magnitud del efecto de la tasa de impuestos en la inversión, es importante tener en cuenta que dicho consenso existe en torno a elasticidades que se han estimado con datos de países desarrollados, en especial de los Estados Unidos. Estas magnitudes no son necesariamente extrapolables a países no desarrollados y no hay gran cantidad de evidencia respecto de la situación en estos países. En particular, no existe mucha literatura que estudie los efectos de los impuestos en la inversión para América Latina.

Una excepción al respecto es el trabajo de Agostini y Jalile (2009), que realizan estimaciones adaptando un modelo logit de demanda de productos diferenciados, mediante el uso de datos de panel para la inversión extranjera realizada por 30 países en 11 países latinoamericanos durante el período 1990-2002. Los resultados muestran que la inversión extranjera responde a cambios en las tasas de impuesto a las utilidades de las empresas y dichos efectos no son despreciables. Un aumento de 1 punto porcentual en la tasa de impuesto a las utilidades se asocia a una disminución de entre un $0,75 \%$ y un $0,96 \%$ en la proporción de inversión extranjera directa (IED) que un país recibe, asumiendo que todos los otros factores se mantienen constantes.

En otras dimensiones que inciden en la inversión, sí existe evidencia empírica para América Latina (por ejemplo, respecto de que la calidad de las instituciones juega un papel importante en la atracción de inversión extranjera) (Agosin y Machado, 2007).

4 En el trabajo que dio origen a este capítulo (Agostini y Jorratt, 2013) se presenta evidencia empírica (con resultados variados) sobre esta cuestión. 
Este tipo de evidencia coincide con algunos resultados empíricos incluidos en la literatura respecto de otros factores importantes que se toman en cuenta a la hora de decidir ubicar la IED en distintos estados o países. En diversos estudios se ha mostrado que los principales factores son: el tamaño del mercado, las características de la fuerza laboral, la dotación de materias primas y algunos aspectos institucionales. Coughlin y otros (1991), por ejemplo, estiman un modelo logit condicional para analizar la ubicación de empresas extranjeras en los Estados Unidos en el período 1981-1983. Sus resultados muestran que los impuestos tienen efectos negativos, al igual que los salarios más altos. Sin embargo, un ingreso per cápita más elevado, una densidad poblacional mayor y una extensa red de transporte tienen efectos positivos importantes en magnitud.

En esta misma línea, James (2009) sostiene que el clima de inversión es especialmente crucial para determinar la eficacia de los incentivos tributarios para atraer la IED. Aunque la reducción de las tasas efectivas de impuestos ayuda a aumentar esta inversión, el efecto es ocho veces más fuerte en los países con buen clima de inversión.

Por último, es importante mencionar que, si bien la literatura se ha concentrado mucho en generar evidencia empírica respecto del efecto de la tasa de impuestos corporativos en la inversión extranjera, en algunos trabajos se analizan los efectos en la inversión interna. Sobre la base de datos de 12 países de la zona de habla francesa de África, Van Parys y James (2010) calculan una elasticidad de entre $-0,67$ y $-0,175$ para la inversión interna respecto de la tasa de impuestos corporativos. Con datos de 85 países en 2004, Djankov y otros (2008) estiman una elasticidad de $-0,22$ para la inversión interna respecto de la tasa de impuestos corporativos.

\section{b) Efectos de los créditos tributarios}

Uno de los mecanismos utilizados en varios países para incentivar la inversión, tanto interna como extranjera, es la introducción de un crédito tributario contra los impuestos corporativos. Un crédito tributario a la inversión reduce, en alguna medida, el pago de impuestos sobre el gasto que supone la compra de bienes de capital, y con ello disminuye el costo de uso del capital.

Un crédito tributario a la inversión puede tener carácter temporal, como parte de una política fiscal contracíclica, o permanente, como una política de más largo plazo para aumentar el capital social y la productividad laboral en la economía. Sin embargo, el uso de créditos tributarios a la inversión enfrenta una importante contraposición entre los incentivos y la pérdida de recaudación: el incentivo a invertir depende del crédito tributario recibido por la unidad marginal de capital, mientras que la pérdida de recaudación depende del crédito medio recibido. 
Dada esta contraposición, no es evidente qué tipo de crédito tributario constituye una mejor política para incentivar la inversión. Por una parte, un crédito tributario a la inversión bruta de capital, que no distingue aumento de capital de reemplazo de capital, entrega un crédito marginal igual al crédito medio. Por esta razón, ofrece el mayor incentivo posible, pero también con la mayor pérdida de recaudación posible. Por otra parte, un crédito tributario a la inversión neta, que solo considera la inversión que aumenta el capital social, reduce la pérdida de recaudación, pero también disminuye mucho el incentivo. En general, los países utilizan uno de estos dos tipos de créditos tributarios.

Los créditos tributarios que se entregan a la inversión bruta sobre una base fija (idealmente igual a los niveles de depreciación) son una mejor alternativa a las dos opciones indicadas. Estos ofrecen los mismos incentivos que un crédito a la inversión bruta, pero con menores pérdidas de recaudación, ya que reducen significativamente el crédito medio respecto del crédito marginal. Aún mejor es un crédito tributario a la inversión bruta sobre una base que aumenta con el crecimiento anual de la economía.

\section{c) Efectos de corto plazo y efectos de largo plazo}

Otro aspecto relevante a considerar en la implementación de incentivos tributarios a la inversión es la temporalidad de sus efectos. Empíricamente, la evidencia muestra que los incentivos tributarios temporales a la inversión tienen efectos de corto plazo mayores que los incentivos permanentes (Auerbach, 1989). A nivel teórico, House y Shapiro (2008) muestran que, en el caso de bienes de capital de larga duración (baja depreciación), el valor del capital no es sensible a cambios en el momento de la inversión y, como resultado de ello, hay fuertes incentivos para cambiar el momento de la inversión frente a estímulos tributarios temporales. En este sentido, una política temporal de incentivos a la inversión puede tener efectos importantes en el corto plazo, pero, como su principal resultado es adelantar inversiones, el efecto de largo plazo en el capital social es muy bajo.

Además, el efecto en el corto plazo puede ser menor que lo esperado si la oferta de bienes de capital es relativamente inelástica. En ese caso, aunque la demanda de inversión en realidad responda en forma significativa, pero en el corto plazo, el efecto se traduce en un notorio incremento de los precios de los bienes de capital, más que en un aumento en la cantidad de inversión. Así, los beneficiarios de una rebaja tributaria o de un subsidio a la inversión son principalmente los productores de bienes de capital. Esta es la evidencia que provee Goolsbee (1998) al estimar, mediante datos, que un aumento del $10 \%$ en un crédito tributario para inversión genera un incremento de entre un $3,5 \%$ y un $7 \%$ en los precios de los bienes de capital. Las estimaciones de incidencia tributaria muestran que un $60 \%$ de los subsidios a la inversión llega a los compradores y el otro $40 \%$ a los productores de bienes de capital. 
Este resultado coincide, además, con el cabildeo de los productores de equipos de capital para que existan subsidios a la inversión (King, 1993).

\section{d) Efectos de los incentivos tributarios locales}

En 1981 se pusieron en marcha en Inglaterra programas de incentivos en zonas geográficas específicas (11 zonas iniciales que se expandieron a 24 en 1983). Estos programas incluían, por un período de diez años, exenciones a los impuestos sobre la propiedad, un 100\% de deducción de impuestos al ingreso de todos los gastos en bienes de capital y edificios, y una exención de impuestos en la compra de terrenos no urbanizados. Distintas evaluaciones de estas iniciativas mostraron, invariablemente, que no hubo efectos positivos en el empleo ni en la inversión en dichas zonas geográficas (Barnes y Preston, 1985; Talbot, 1988). Como resultado de esta evidencia, el Gobierno decidió terminar con estas zonas industriales en 1991 y los beneficios de las dos últimas zonas que seguían funcionando - que fueron aprobadas en 1989, cuando el programa aún estaba vigente- se terminaron en 1999.

En los Estados Unidos la evidencia es similar. En 1984 se establecieron en el estado de Indiana seis zonas industriales y comerciales con beneficios tributarios que se eligieron en virtud de los niveles de desempleo y las tasas de pobreza de cada ciudad. Las empresas que operaran en esas zonas tendrían, durante diez años, una exención del impuesto al ingreso para todas las ventas realizadas dentro de la zona geográfica establecida, un crédito tributario en el impuesto al ingreso por cada trabajador contratado residente en la zona, un crédito tributario en el impuesto a las propiedades por el $100 \%$ del valor de los inventarios de la empresa en la zona y un crédito tributario del $5 \%$ de los intereses recibidos por préstamos otorgados a residentes en la zona. Además, los residentes en la zona geográfica reciben una deducción de impuestos por la mitad de su ingreso tributable. Los efectos estimados de estos incentivos tributarios solo se perciben en la acumulación de inventarios en las zonas geográficas elegidas para estos beneficios (Papke, 1993). No hay efectos positivos en la inversión y los efectos en el empleo solo muestran una sustitución de empleos entre la zona geográfica favorecida y las que la rodean.

El uso de zonas geográficas específicas con incentivos tributarios, como los de Indiana, para aumentar el empleo, la inversión y la actividad económica en zonas económicamente deprimidas se hizo extensivo a mediados de los años ochenta en los Estados Unidos, y a mitad de la década de 1990 ya había 37 estados que utilizaban este recurso. Sin embargo, la evidencia empírica sigue mostrando que el impacto es muy bajo.

Con una metodología similar a la de Papke, que utiliza un panel para considerar la heterogeneidad no observada y controlar el sesgo de selección, Boarnet y Bogart (1996) evalúan las zonas empresariales en Nueva Jersey mediante el uso de datos de 14 municipalidades durante 9 años. Sus resultados 
muestran que no hay efectos significativos en el empleo ni en la actividad económica de las municipalidades que tienen beneficios tributarios en zonas geográficas específicas. La evidencia para las zonas industriales y comerciales en California es similar respecto de que no tienen efectos positivos en la generación de empleo (Neumark y Kolko, 2010).

\section{Costos de los incentivos tributarios}

Incluso aunque los incentivos tributarios lograran un aumento significativo de la inversión, es necesario considerar los costos involucrados más allá de la pérdida de recaudación.

En general, los incentivos tributarios generan costos importantes (Zee, Stostky y Ley, 2002): distorsionan la inversión entre sectores económicos o tipos de inversión; reducen la recaudación tributaria, que si tiene que compensarse aumenta las distorsiones que generan otros impuestos; aumentan los costos de administración y fiscalización del sistema tributario, y producen costos sociales de corrupción y captación de rentas. Lamentablemente, en muchos países en desarrollo no se evalúan ni los beneficios ni los costos de los incentivos tributarios que se establecen. Realizar esta evaluación puede ser importante si se considera que los incentivos que se usan en los países en desarrollo son muy distintos de los que se utilizan en países desarrollados.

Desde el punto de vista de las desventajas de usar incentivos tributarios a la inversión, también es importante señalar que la generación de una competencia tributaria entre distintas jurisdicciones supone costos para cualquier país. Es así como los incentivos tributarios que introducen los gobiernos estatales o locales (no nacionales) no suelen tener un gran efecto a la hora de generar mayor actividad económica o aumentar la inversión (Bradbury, Kodrzycki y Tannenwald, 1997). En el trabajo de Chirinko y Wilson (2007), donde se utiliza un panel de 48 estados de los Estados Unidos durante 20 años, se muestra empíricamente que, además, los efectos son de suma cero entre los estados locales. El resultado empírico principal es que un aumento equiproporcional del costo de uso del capital en un estado y en los estados con los que compite por atraer capital tiene un efecto nulo en la formación de capital en dicho estado. La evidencia es similar para los países de África, donde los incentivos tributarios de todo tipo no tienen ningún efecto a la hora de atraer inversiones (Klemm y Van Parys, 2012). Esto demuestra que, en ambientes económicos desfavorables para la inversión, los efectos tributarios no logran compensar otras variables relevantes que son mucho más importantes, como el capital humano, la infraestructura, el cumplimiento de la ley y el bajo nivel de corrupción (Van Parys y James, 2010). En estos casos, una rebaja tributaria tiene notorios efectos en una menor recaudación, que no se ven compensados por una mayor inversión. 


\section{Efectividad relativa de los incentivos tributarios}

A pesar de la escasa evidencia sobre la efectividad de los incentivos, cuando se decide aplicarlos, se debe tener en cuenta que hay algunos que son mejores que otros, en términos de costo-efectividad. Tanzi y Zee (2001) y Zee, Stostky y Ley (2002) revisan las principales ventajas y desventajas de los incentivos más utilizados en los países en desarrollo y este análisis se resume a continuación.

Entre los incentivos tributarios directos, los más utilizados en los países en desarrollo, especialmente en América Latina, son las exoneraciones (también llamadas moratorias fiscales), que consisten en la exención del impuesto sobre la renta (ISR) durante un período determinado. Su principal ventaja es que son fáciles de administrar. Sin embargo, presentan varias desventajas: al eximir a las utilidades independientemente de su magnitud, se favorece más a las inversiones con alta rentabilidad, que se habrían efectuado aun sin la exoneración; crean estímulos a la elusión, pues a través de precios de transferencia es posible traspasar utilidades desde empresas afectas hacia empresas favorecidas con la exoneración; es posible extender el plazo de la exoneración más allá del término legal mediante la transformación de una sociedad para la que ya expiró el beneficio en otra nueva, pero con los mismos dueños y los mismos activos, e incentivan preferentemente las inversiones de corto plazo, que en general no son tan beneficiosas para los países como otras de largo plazo.

En vez de establecer una exoneración, a veces se opta por una tasa reducida, que tiene la ventaja de provocar un menor costo fiscal que la exoneración y también mayor control y transparencia, puesto que persiste la obligación de declarar. Las desventajas son las mismas de las exoneraciones, pero se suma un mayor costo administrativo.

También existen las deducciones por inversión, que permiten que un determinado porcentaje de la inversión en activos fijos, adicional a la depreciación, se rebaje como gasto de manera instantánea, en el año en que se incorpora a la empresa. En relación con las exoneraciones y tasas reducidas, este es un incentivo mucho más focalizado, puesto que se otorga contra una inversión material, y además permite privilegiar cierto tipo de activos sobre otros. Una desventaja es que estimula las inversiones en activos de menor vida útil, puesto que el incentivo se puede usar en cada renovación de activos. Además, las empresas pueden intentar abusar del sistema, vendiendo y comprando los mismos activos con el objeto de disfrutar varias veces del beneficio.

A veces también se establecen créditos tributarios por inversiones, que permiten deducir un porcentaje de la inversión en activos fijos directamente del impuesto. El crédito es equivalente a la deducción, salvo cuando hay 
tasas múltiples. En ocasiones, cuando el crédito de un año es superior al impuesto, no se permite arrastrar el remanente a períodos futuros, lo que marcaría una diferencia con las deducciones, que siguen la suerte de las pérdidas tributarias.

Otro tipo de incentivos a la inversión son los esquemas de depreciación acelerada, que permiten deducir como gasto los montos invertidos, en un plazo inferior a la vida útil económica de los activos. La depreciación acelerada tiene todas las ventajas de las deducciones y los créditos por inversiones, pero no tiene las desventajas de estos últimos. No produce distorsión a favor de los activos de corto plazo, pues cualquiera sea la duración del activo, siempre se deprecia su costo de adquisición. También es menos propensa a los abusos porque el uso de figuras como la venta y recompra de un mismo activo no producen ahorros adicionales de impuestos en este caso ${ }^{5}$. Por último, la depreciación acelerada tiene un menor costo fiscal que los otros incentivos mencionados, puesto que solo difiere el pago del impuesto, es decir, la menor recaudación inicial se compensa con una mayor recaudación en los años siguientes.

Los incentivos tributarios indirectos también son de uso frecuente en los países en desarrollo y generalmente se usan como incentivo para las inversiones destinadas a producir bienes de exportación. Consisten, sobre todo, en la aplicación de exenciones del impuesto sobre el valor agregado (IVA) y aranceles a la compra de materias primas y activos fijos. Tanzi y Zee (2001) señalan que, como regla general, deben evitarse los incentivos tributarios indirectos, pues son susceptibles de abuso y su utilidad es dudosa. Las exenciones de IVA no son más que un anticipo de la recuperación del impuesto que de todas maneras obtendrá la empresa, ya sea como devolución o imputación, cuando se trata de un exportador, o como crédito de IVA, en el caso de un contribuyente afecto. De hecho, este tipo de beneficios en general no se cuantifican en las estimaciones oficiales de gasto tributario, por cuanto la pérdida fiscal es muy pequeña y equivalente al costo financiero de no disponer de la recaudación en el número de días que media entre la fecha de la operación comercial y la fecha en que legalmente se tendría derecho a la devolución del impuesto bajo el régimen general.

Sobre la base de la literatura existente, así como de varios estudios de caso y encuestas realizadas, James (2009) analiza cómo los incentivos a la inversión se pueden utilizar, o no, para fomentar la inversión privada, en especial en los países en desarrollo. En coincidencia con lo antes mencionado, concluye que los incentivos a la inversión se deben utilizar lo menos posible y principalmente para hacer frente a los fallos del mercado y generar efectos multiplicadores junto con un buen clima de inversión. Asimismo, en la

Al vender y comprar el mismo activo se produce una ganancia de capital que compensa exactamente a la segunda depreciación del bien. 
medida de lo posible, los incentivos tributarios deben estar vinculados al crecimiento de la inversión, mientras que deben evitarse beneficios como las moratorias fiscales y similares.

\section{Evaluación integral de los incentivos tributarios}

Los incentivos tributarios son una herramienta alternativa de intervención estatal con la que se busca conseguir resultados similares a los que se podrían obtener mediante el gasto público directo, pero a través de la reducción del pago de impuestos. Es por ello que las mejores prácticas en relación con los gastos tributarios sugieren que estos deberían revisarse en la misma forma que los gastos directos en el proceso presupuestario anual y someterse a procedimientos especiales de evaluación, incluida la revisión de programas, que comúnmente se aplica a los gastos directos.

Tokman, Rodríguez y Marshall (2006) proponen un marco de evaluación para los gastos tributarios, que en particular es aplicable a los incentivos tributarios a la inversión. A juicio de los autores, para evaluar la pertinencia de una excepción tributaria como herramienta de política pública es necesario efectuar dos análisis. En primer lugar, hay que verificar si existe una razón de eficiencia económica, de justicia distributiva u otra razón de interés público que fundamente una intervención estatal de excepción. En segundo término, se debe comprobar si la concesión tributaria es eficaz y eficiente en el cumplimiento del objetivo deseado, y que no existen instrumentos alternativos que puedan alcanzarlo de mejor forma. Es decir, asumiendo que existe una razón para la intervención estatal, la sola efectividad del incentivo no es suficiente para justificar su existencia. Tampoco basta con que los beneficios sean superiores a los costos. Se requiere, además, que no existan instrumentos alternativos que permitan alcanzar el objetivo de una manera más eficiente.

A partir de lo expuesto, los autores proponen, como dinámica de evaluación de los gastos tributarios, la siguiente secuencia de cuatro etapas:

i) Justificación de la intervención estatal: Se debe verificar la existencia de una razón para una intervención estatal de excepción, especificar su naturaleza (eficiencia económica, justicia distributiva u otra razón de interés público) y validar su vigencia.

ii) Efectividad en el cumplimiento del objetivo: Se debe verificar empíricamente que el incentivo tributario genere las conductas, transferencias y otros efectos deseados en los agentes económicos, en función del objetivo que justifica la intervención estatal.

iii) Eficiencia en el cumplimiento del objetivo: Se debe verificar que los beneficios atribuibles al incentivo tributario sean mayores que sus costos. Respecto de estos últimos, se debe considerar la 
pérdida de recaudación, la eventual evasión tributaria gatillada por el incentivo, los gastos de administración más elevados y los mayores costos de cumplimiento.

iv) Eficiencia relativa del instrumento: Se debe verificar que no existan instrumentos alternativos más eficaces en función de los costos que la excepción tributaria analizada. Ello implica estudiar los beneficios, costos, ventajas y desventajas relativas de otras herramientas de política pública alternativas.

En OCDE (2010) también se aborda el tema de la evaluación integral de los gastos tributarios y se propone usar como marco conceptual el "ciclo de evaluación de programas de gobierno", que utilizan varios países, tanto miembros como no miembros de la Organización de Cooperación y Desarrollo Económicos (OCDE). En el estudio se identifican tres fases en la aplicación de este proceso a la evaluación de una concesión tributaria:

i) Examinar la justificación del gasto tributario: analizar si hay una necesidad para la intervención estatal y cómo la concesión tributaria se hace cargo de esa necesidad.

ii) Identificar y establecer los objetivos del gasto tributario: establecer con claridad los productos y resultados deseados que, idealmente, deben ser específicos, medibles, realizables, pertinentes y de duración determinada. La identificación de los objetivos también ayuda a ver qué instrumentos de política alternativos pueden estar disponibles.

iii) Evaluar el gasto tributario frente a otras opciones alternativas: mediante la estimación de los efectos en la recaudación y los efectos distributivos y de comportamiento de cada opción.

Debido a que son pocos los países que hacen una evaluación sistemática de sus gastos tributarios, no es fácil encontrar ejemplos de aplicación de metodologías como las mencionadas. Los Estados Unidos constituyen una excepción, ya que el Servicio de Investigaciones del Congreso presenta periódicamente a la Comisión de Presupuesto del Senado un compendio de gastos tributarios que incluye varios ítems: una estimación de la pérdida de recaudación asociada a cada gasto tributario; una referencia a la normativa que establece el beneficio; una descripción del gasto tributario (incluido un ejemplo de su funcionamiento, cuando sea útil); un breve análisis del impacto de cada gasto tributario (incluidos antecedentes sobre el impacto en la distribución del ingreso, cuando los datos están disponibles); una breve exposición de los fundamentos tomados en cuenta al momento de su aprobación (incluida la historia legislativa pertinente); una evaluación, que considera los argumentos a favor y en contra de la disposición; y referencias bibliográficas relacionadas con cada incentivo. 


\section{B. Incentivos tributarios a la inversión en América Latina}

\section{Marco de análisis}

El propósito de este capítulo es analizar el uso de incentivos a la inversión en diez países de América Latina: Argentina, Chile, Colombia, Ecuador, El Salvador, Guatemala, Honduras, Nicaragua, Perú y República Dominicana.

Con el fin de sistematizar la información normativa vinculada a los incentivos a la inversión, se han usado tres variables de clasificación:

La primera variable de clasificación es el objetivo perseguido. Los incentivos a la inversión pueden ser de tres tipos: i) generales, cuando benefician a cualquier empresa que ejecute un proyecto de inversión; ii) de localización, cuando benefician a empresas que deciden invertir en áreas geográficas determinadas, o iii) sectoriales, cuando benefician a las inversiones vinculadas a ciertas actividades económicas.

La segunda variable de clasificación es la técnica tributaria utilizada para incentivar la inversión. Desde este punto de vista, los incentivos pueden clasificarse en las siguientes categorías:

i) Exenciones: ingresos o transacciones que se excluyen de las bases imponibles. En el ISR normalmente se exime a los ingresos generados por los proyectos de inversión, por un plazo fijo o indeterminado. En los impuestos indirectos por lo general se exime a la importación de bienes de capital o insumos esenciales para el desarrollo de la actividad que se desea incentivar. En las normas legales se las encuentra bajo distintas denominaciones: exenciones, exoneraciones, hechos no gravados y otras.

ii) Deducciones: cantidades que se permite rebajar de las bases imponibles. Por lo general, se trata de normas que admiten rebajar de la base imponible del ISR un porcentaje de la inversión realizada, por encima del gasto en depreciación que generan esas mismas inversiones.

iii) Créditos: cantidades que se permite rebajar directamente de los impuestos. Por lo general es un porcentaje de la inversión realizada.

iv) Tasas reducidas: alícuotas de impuestos inferiores a las de aplicación general.

v) Diferimientos: postergación o rezago en el pago de un impuesto. En el ISR suelen tomar la forma de esquemas de depreciación acelerada, en tanto que en los impuestos indirectos adoptan la forma de una extensión del plazo para el pago o la devolución anticipada de saldos a favor. 
vi) Contratos de estabilidad tributaria: contratos entre el Estado y el inversionista, que obligan al primero a mantener, respecto del segundo, algunas de las normas tributarias vigentes al momento de la inversión, por un plazo determinado.

La tercera variable de clasificación es el impuesto utilizado para otorgar el incentivo tributario. Para estos efectos se han definido cinco categorías: i) ISR, ii) IVA, iii) aranceles sobre el comercio exterior, iv) impuestos selectivos al consumo y v) otros.

Se debe tener en cuenta que el ejercicio de clasificar los incentivos tributarios no está exento de subjetividad. Una primera interrogante que surge se refiere a qué concesiones tributarias corresponden a los denominados incentivos a la inversión. En general, los gastos tributarios persiguen uno o varios de los siguientes objetivos (Villela, Lemgruber y Jorrat, 2009): i) mejorar la progresividad del sistema tributario, ii) otorgar mayor eficiencia a la estructura tributaria, iii) estimular el consumo de bienes estimados como "meritorios" y iv) incentivar la inversión en ciertos sectores o regiones. En la identificación de incentivos a la inversión se tuvo en cuenta el objetivo principal de cada concesión tributaria. Por ejemplo, una exención de IVA al transporte público busca, principalmente, mejorar la progresividad del sistema tributario, por lo que no se clasifica como incentivo a la inversión, aun cuando pueda tener como efecto indirecto aumentar la inversión privada en el sector.

Una segunda interrogante se refiere a cuál es la unidad básica que se clasifica como un incentivo, de tal manera que las estadísticas construidas para los distintos países sean comparables. Una posibilidad es que la unidad sea el cuerpo normativo que establece los incentivos, por ejemplo, una ley de incentivo al turismo. Sin embargo, al comparar las leyes de incentivo al turismo que existen en los distintos países, se concluye que hay una amplia diversidad en términos de los incentivos concretos que establecen. Por lo tanto, se estimó que la mejor forma de tener estadísticas comparables es definiendo como unidad una concesión respecto de un impuesto en particular y otorgada a un grupo de contribuyentes específico. Para el ejemplo anterior, un incentivo a la inversión sería la exención del ISR en favor de las empresas hoteleras, que sería distinta de una exención del mismo tributo a las empresas de transporte turístico o de una exención del IVA a la importación de bienes de capital efectuadas por las mismas empresas hoteleras, aun cuando las tres exenciones estén contenidas en el mismo cuerpo normativo.

\section{Panorama de los incentivos a la inversión en América Latina}

A partir del análisis de la legislación de los 10 países bajo estudio se han identificado un total de 337 incentivos a la inversión. La cantidad fluctúa 
bastante de un país a otro: desde los 6 incentivos identificados en Guatemala hasta los 101 incentivos con que cuenta la República Dominicana (véase el cuadro VIII.1).

Cuadro VIII.1

América Latina (10 países): número de incentivos a la inversión, por país y por objetivo

\begin{tabular}{lcccc}
\hline \multirow{2}{*}{ País } & \multicolumn{4}{c}{ Tipo de incentivo a la inversión } \\
\cline { 2 - 5 } & General & Localización & Sectorial & Total \\
\hline Argentina & 4 & 6 & 29 & 39 \\
\hline Chile & 10 & 7 & 2 & 19 \\
\hline Colombia & 4 & $\ldots$ & 12 & 16 \\
\hline Ecuador & 15 & $\ldots$ & 16 & 31 \\
\hline El Salvador & 2 & $\ldots$ & 8 & 10 \\
\hline Guatemala & 1 & $\ldots$ & 5 & 6 \\
\hline Honduras & 1 & 4 & 27 & 32 \\
\hline Nicaragua & $\ldots$ & 1 & 66 & 67 \\
\hline Perú & 2 & 6 & 8 & 16 \\
\hline República Dominicana & $\ldots$ & 7 & 94 & 101 \\
\hline Total & 39 & 31 & 267 & 337 \\
\hline
\end{tabular}

Fuente: Elaboración propia, sobre la base de la legislación e informes de gastos tributarios de cada país.

En el cuadro VIII.1 se muestra el número de incentivos a la inversión por país, clasificados por el objetivo que persiguen. Hay 39 incentivos (un $12 \%$ del total) que son de tipo general, esto es, que benefician a las empresas sin distinción del sector económico al que pertenecen o de la zona geográfica en la que operan. Otros 31 incentivos (un 9\% del total) son de localización y los restantes 267 incentivos (un 79\% del total) son de tipo sectorial.

Los incentivos generales a la inversión son más utilizados en el Ecuador (15) y Chile (10), mientras que los sectoriales son muy usados en la República Dominicana (94), Nicaragua (66), la Argentina (29) y Honduras (27). Solo seis de los diez países analizados usan incentivos de localización, y entre ellos se destacan Chile y la República Dominicana con siete y la Argentina y el Perú con seis.

Una primera conclusión es que la mayoría de los incentivos a la inversión usados en América Latina están orientados a sectores o actividades específicas. En el cuadro VIII.2 se muestra la cantidad de incentivos sectoriales que existen en cada país, según el sector económico al que benefician. A nivel agregado, destacan los incentivos al turismo, con una contabilización de 59 (un 22\% del total de incentivos de este tipo), los incentivos a las exportaciones, que alcanzan a 50 (un 19\% del total), y los incentivos al sector de la energía, que son 39 (un 15\% del total). 


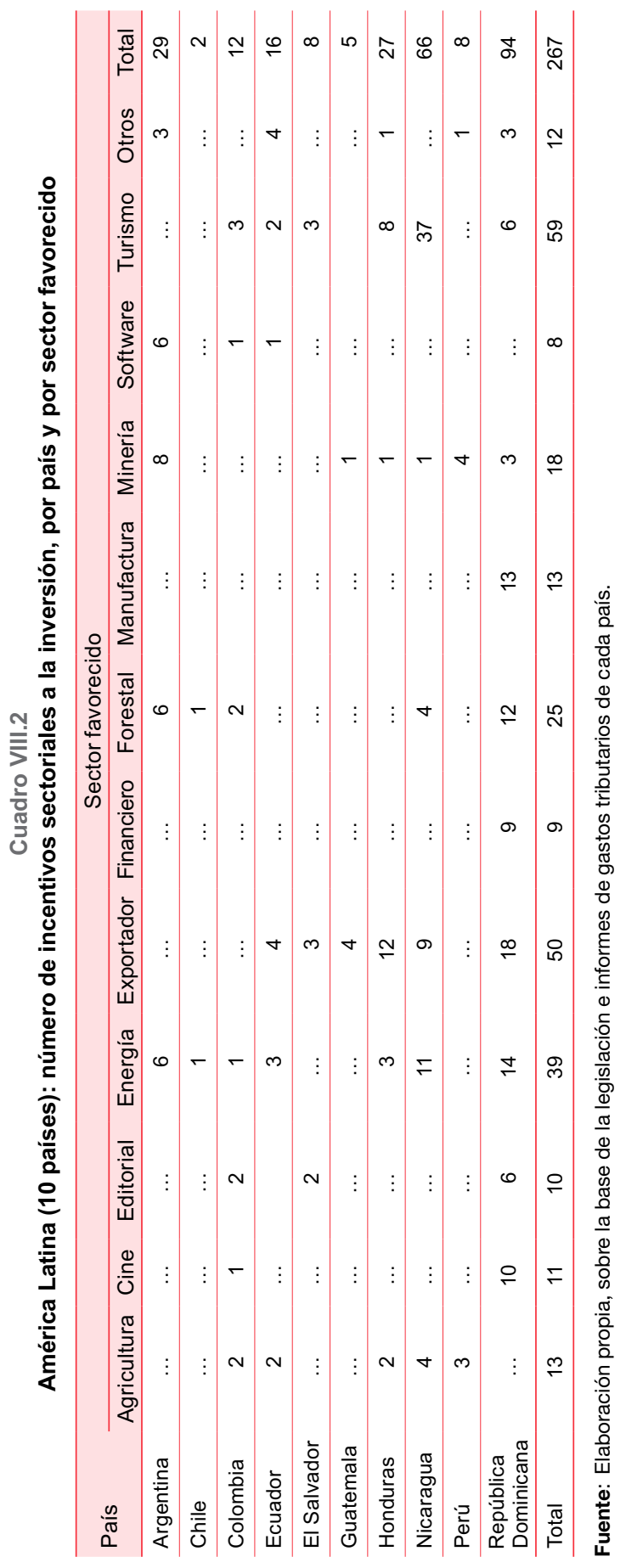


La gran cantidad de incentivos a la inversión en turismo está muy influida por Nicaragua, en cuya legislación es posible identificar 37 estímulos de este tipo. Otros países que los usan, aunque en menor medida, son Honduras (8), la República Dominicana (6), Colombia (3), El Salvador (3) y el Ecuador (2).

Los incentivos a las inversiones en el sector exportador están presentes sobre todo en los países de Centroamérica y el Caribe, en donde destacan la República Dominicana (18), Honduras (12) y Nicaragua (9). En América del Sur, solo el Ecuador (4) presenta este tipo de incentivos. Al respecto, conviene hacer un par de precisiones. En primer lugar, la Argentina, Chile y el Perú tienen regímenes de zonas francas, que comúnmente buscan promover la inversión vinculada al comercio exterior. Sin embargo, estas están relacionadas con localizaciones geográficas específicas, por lo que se han clasificado bajo ese objetivo. En segundo término, si bien todos los países aplican tasa cero de IVA a las exportaciones, dicha práctica se considera parte del diseño normal del IVA y, por lo tanto, no ha sido considerada como un incentivo.

Respecto de la técnica tributaria usada para otorgar incentivos (véase el cuadro VIII.3), en la gran mayoría de los casos se recurre a exenciones, que contabilizan 256 estímulos de este tipo (un 76\% del total). Estas se aplican en mayor medida en el ISR ( $40 \%)$, pero también en aranceles (26\%) e IVA (23\%). Todos los países analizados usan las exenciones como una herramienta tributaria de estímulo a las inversiones.

Cuadro VIII.3

América Latina (10 países): número de incentivos a la inversión, por país y por técnica tributaria

\begin{tabular}{|c|c|c|c|c|c|c|c|}
\hline \multirow[b]{2}{*}{ País } & \multicolumn{7}{|c|}{ Técnica tributaria del incentivo a la inversión } \\
\hline & Crédito & Deducción & Diferimiento & Estabilidad & Exención & $\begin{array}{c}\text { Tasa } \\
\text { reducida }\end{array}$ & Total \\
\hline Argentina & 2 & 2 & 5 & 11 & 18 & 1 & 39 \\
\hline Chile & 6 & $\ldots$ & 6 & 1 & 6 & & 19 \\
\hline Colombia & $\cdots$ & 5 & $\cdots$ & 1 & 9 & 1 & 16 \\
\hline Ecuador & $\ldots$ & 3 & 2 & $\ldots$ & 24 & 2 & 31 \\
\hline El Salvador & $\ldots$ & $\ldots$ & 2 & $\ldots$ & 8 & $\ldots$ & 10 \\
\hline Guatemala & $\ldots$ & $\ldots$ & 2 & $\ldots$ & 4 & $\ldots$ & 6 \\
\hline Honduras & $\ldots$ & $\ldots$ & $\ldots$ & $\ldots$ & 32 & $\ldots$ & 32 \\
\hline Nicaragua & 1 & 7 & $\ldots$ & $\ldots$ & 59 & $\ldots$ & 67 \\
\hline Perú & $\ldots$ & 1 & 5 & 1 & 6 & 3 & 16 \\
\hline $\begin{array}{l}\text { República } \\
\text { Dominicana }\end{array}$ & 3 & 6 & 1 & $\ldots$ & 90 & 1 & 101 \\
\hline Total & 12 & 24 & 23 & 14 & 256 & 8 & 337 \\
\hline
\end{tabular}

Fuente: Elaboración propia, sobre la base de la legislación e informes de gastos tributarios de cada país. 
También se utilizan deducciones (24), diferimientos (23), contratos de estabilidad (14), créditos contra los impuestos (12) y tasas reducidas (8). Las deducciones y los créditos se aplican solo en el ISR. Los diferimientos y las tasas reducidas, por su parte, existen tanto en el IVA como en el ISR.

Las deducciones se usan en seis de los diez países, con mayor intensidad en Nicaragua (7), la República Dominicana (6) y Colombia (5). Los créditos se usan en cuatro países y Chile es donde más se utiliza este instrumento (6). Los diferimientos se aplican en siete países y se concentran en Chile (6), la Argentina (5) y el Perú (5). Cinco países usan tasas reducidas -Argentina, Colombia, Ecuador, Perú y República Dominicana-, aunque este instrumento concentra la menor cantidad de incentivos (8). Por último, cuatro países usan contratos de estabilidad tributaria - Argentina, Chile, Colombia y Perú-, normalmente para el ISR, a excepción de la Argentina que los aplica a varios impuestos, pero solo en determinados sectores.

En el cuadro VIII.4 se muestra el número de incentivos en cada país, según el impuesto que se utiliza para estimular la inversión. En el agregado de los 10 países, 167 incentivos se otorgan a través del ISR (un 50\% del total), 70 corresponden a estímulos en los aranceles (un 21\% del total), 68 son incentivos del IVA (un 20\% del total) y 32 incentivos se otorgan en otros impuestos (un $9 \%$ del total).

Cuadro VIII.4

América Latina (10 países): número de incentivos a la inversión, por país y por impuesto

\begin{tabular}{lccccc}
\hline País & $\begin{array}{c}\text { Impuesto sobre } \\
\text { la renta (ISR) }\end{array}$ & $\begin{array}{c}\text { Impuesto sobre el } \\
\text { valor agregado (IVA) }\end{array}$ & Aranceles & Otros & Total \\
\hline Argentina & 14 & 8 & 8 & 9 & 39 \\
\hline Chile & 15 & 2 & 2 & $\ldots$ & 19 \\
\hline Colombia & 16 & $\ldots$ & $\ldots$ & $\ldots$ & 16 \\
\hline Ecuador & 25 & 3 & 1 & 2 & 31 \\
\hline El Salvador & 7 & 2 & 1 & $\ldots$ & 10 \\
\hline Guatemala & 6 & $\ldots$ & $\ldots$ & $\ldots$ & 6 \\
\hline Honduras & 11 & 10 & 10 & 1 & 32 \\
\hline Nicaragua & 22 & 23 & 20 & 2 & 67 \\
\hline Perú & 11 & 5 & $\ldots$ & $\ldots$ & 16 \\
\hline República Dominicana & 40 & 15 & 28 & 18 & 101 \\
\hline Total & 167 & 68 & 70 & 32 & 337 \\
\hline
\end{tabular}

Fuente: Elaboración propia, sobre la base de la legislación e informes de gastos tributarios de cada país.

En el cuadro VIII.5 se detalla el número de incentivos clasificados por impuesto y técnica tributaria utilizada. Esta información permite extraer algunas conclusiones interesantes respecto del diseño de los incentivos a la inversión que se usan en América Latina. La mayoría de ellos corresponden a exenciones en el ISR (102), es decir, las llamadas moratorias fiscales. 
Estas representan casi un tercio de todos los incentivos y dos tercios de los beneficios del ISR. Este tipo de incentivos son los menos recomendables porque presentan varias desventajas: favorecen más a las inversiones con alta rentabilidad, que se habrían efectuado aun sin la exoneración; facilitan la elusión, a través de precios de transferencia que permiten traspasar utilidades desde empresas gravadas hacia empresas exoneradas; transforman empresas antiguas en nuevas, con el propósito de aprovechar el beneficio, e incentivan preferentemente las inversiones de corto plazo, que en general no son tan beneficiosas para los países como otras de largo plazo. La única ventaja, que tal vez sea el motivo de su elevado número, es la facilidad para administrarlas.

\section{Cuadro VIII.5}

América Latina (10 países): número de incentivos a la inversión, por impuesto y por técnica tributaria

\begin{tabular}{lccccc}
\hline & Aranceles & $\begin{array}{c}\text { Impuesto sobre } \\
\text { la renta (ISR) }\end{array}$ & $\begin{array}{c}\text { Impuesto sobre el } \\
\text { valor agregado (IVA) }\end{array}$ & Otros & Total \\
\hline Crédito & $\ldots$ & 12 & $\ldots$ & $\ldots$ & 12 \\
\hline Deducción & $\ldots$ & 24 & $\ldots$ & $\ldots$ & 24 \\
\hline Diferimiento & $\ldots$ & 16 & 7 & $\ldots$ & 23 \\
\hline Estabilidad & 3 & 6 & 2 & 29 & 256 \\
\hline Exención & 62 & 102 & 1 & $\ldots$ & 8 \\
\hline Tasa reducida & $\ldots$ & 7 & 73 & 32 & 337 \\
\hline Total & 65 & 167 & & 3 & $\ldots$ \\
\hline
\end{tabular}

Fuente: Elaboración propia, sobre la base de la legislación e informes de gastos tributarios de cada país.

Se contabilizan solo 16 diferimientos en el ISR, que corresponden a esquemas de depreciación acelerada. En contraposición a las exenciones, la depreciación acelerada se considera el mejor instrumento para atraer inversiones, puesto que se focaliza en la inversión en bienes reales, limita la pérdida fiscal, al tratarse solo de un diferimiento del impuesto, es neutra respecto del plazo de las inversiones y es menos propensa a los abusos.

Los créditos y deducciones por inversiones en el ISR son menos efectivos que la depreciación acelerada, pero preferibles a las exenciones, pues, al igual que la depreciación acelerada, focalizan el beneficio en activos reales. No obstante, su uso también es limitado en relación con las exenciones.

Otros incentivos abundantes en la región, en cuanto a número, son las exenciones de IVA (63) y las exenciones de aranceles (62). Ambos casos se refieren principalmente a exenciones a la compra e importaciones de bienes de capital e insumos requeridos en la etapa de inversión de los proyectos. Cabe señalar que en el caso del IVA, si las empresas beneficiadas son contribuyentes del impuesto, la exención sobre las compras opera como un diferimiento, puesto que, en caso de pagarse el IVA al momento de la compra o importación, este podría recuperarse posteriormente como crédito. Es decir que, en ese 
caso, el incentivo consiste en evitar al inversionista el costo financiero que le significaría desembolsar recursos para pagar un IVA que se recuperaría en el futuro, una vez que el proyecto comience a generar ingresos.

Del análisis detallado de los incentivos vigentes en la región también se concluye que rara vez el diseño de estos incentivos busca diferenciar la inversión adicional de aquella que se habría realizado aun sin el incentivo, lo que se traduce en una mayor pérdida de ingresos.

\section{Costo fiscal de los incentivos tributarios a la inversión}

En esta sección se muestra el costo fiscal de los incentivos a la inversión en cinco países: Argentina, Chile, Colombia, Ecuador y Guatemala. Para los demás países no se cuenta con información suficiente. Si bien para todos ellos existen estimaciones oficiales de gastos tributarios, el detalle con que se presentan los datos no permite una estimación particular de los incentivos a la inversión ${ }^{6}$.

En el cuadro VIII.6 se muestra la distribución del gasto tributario para los cinco países mencionados. Como es lógico, los incentivos a la inversión de aplicación general son los que tienen mayor participación en el costo fiscal. En Chile, representan el $47,4 \%$ de todo el gasto tributario. Le siguen Colombia con un 28,4\%, el Ecuador con un 19,3\%, la Argentina con un 13,5\% y Guatemala con un 10,7\%.

Cuadro VIII.6

América Latina (5 países): distribución del gasto tributario, por objetivo, 2010 (En porcentajes del total)

\begin{tabular}{lrrrrr}
\hline & Argentina & Chile & Colombia & Ecuador & Guatemala \\
\hline Generales & 13,5 & 47,4 & 28,4 & 19,3 & 10,7 \\
\hline Localización & 23,2 & 1,8 & 0,0 & 0,2 & 0,2 \\
\hline Sectoriales & 14,0 & 0,6 & 1,3 & 7,1 & 1,6 \\
\hline Subtotal incentivos a la inversión & 50,7 & 49,9 & 29,7 & 26,6 & 12,6 \\
\hline Otros gastos tributarios & 49,3 & 50,1 & 70,3 & 73,4 & 87,4 \\
\hline Total & 100,0 & 100,0 & 100,0 & 100,0 & 100,0 \\
\hline
\end{tabular}

Fuente: Elaboración propia, sobre la base de informes de gastos tributarios de la Argentina, Chile y Guatemala; y M. Jorrat, "Análisis del gasto tributario y propuestas de incentivos fiscales a la inversión y al empleo en Ecuador", Revista Fiscalidad, № 4, Quito, Servicio de Rentas Internas, 2010 y "Diagnóstico de la estructura tributaria de Colombia y propuestas de reforma tributaria", Documento de Trabajo, N 75078, Washington, D.C., Banco Interamericano de Desarrollo, 2010.

En segundo lugar en orden de importancia aparecen los incentivos a la inversión sectorial, que se presentan como más importantes en la Argentina, con un $14 \%$ del gasto tributario total. Le siguen el Ecuador con un $7,1 \%$ y después Guatemala, Colombia y Chile con participaciones relativamente menores.

6 En algunos casos se publican informes anuales de gasto tributario, mientras que en otros, como Honduras y Nicaragua, solo hay estudios puntuales. 
Los incentivos de localización solo son relevantes, en términos de costo, en la Argentina, donde representan un $23,2 \%$ del gasto tributario total. En Chile representan solo un 1,8\%, mientras que en Colombia, el Ecuador y Guatemala son cercanos al 0\%.

Si se toma el conjunto de incentivos tributarios a la inversión, se observa que en la Argentina y Chile estos representan la mitad de todos los gastos tributarios. En Colombia y el Ecuador se acercan al 30\%, en tanto que en Guatemala apenas superan el $12 \%$.

En el cuadro VIII.7 se muestra la misma información, pero como porcentaje del PIB. La mayor pérdida fiscal se registra en Chile, con un 2,2\% del PIB, explicada casi en su totalidad por los incentivos generales a la inversión. Le siguen el Ecuador, con una pérdida de recaudación estimada en un 1,6\% del PIB, la Argentina (un 1,1\% del PIB), Guatemala (un 0,9\% del PIB) y Colombia (un $0,8 \%$ del PIB).

\section{Cuadro VIII.7}

América Latina (5 países): distribución del gasto tributario, por objetivo, 2010 (En porcentajes del PIB)

\begin{tabular}{lccccc}
\hline & Argentina & Chile & Colombia & Ecuador & Guatemala \\
\hline Generales & 0,3 & 2,1 & 0,7 & 1,2 & 0,8 \\
\hline Localización & 0,5 & 0,1 & 0,0 & 0,0 & 0,0 \\
\hline Sectoriales & 0,3 & 0,0 & 0,0 & 0,4 & 0,1 \\
\hline Subtotal incentivos a la inversión & 1,1 & 2,2 & 0,8 & 1,6 & 0,9 \\
\hline Otros gastos tributarios & 1,0 & 2,3 & 1,8 & 4,4 & 6,6 \\
\hline Total & 2,1 & 4,5 & 2,6 & 6,0 & 7,5 \\
\hline
\end{tabular}

Fuente: Elaboración propia, sobre la base de informes de gastos tributarios de Argentina, Chile y Guatemala y M. Jorrat, "Análisis del gasto tributario y propuestas de incentivos fiscales a la inversión y al empleo en Ecuador", Revista Fiscalidad, № 4, Quito, Servicio de Rentas Internas, 2010 y "Diagnóstico de la estructura tributaria de Colombia y propuestas de reforma tributaria", Documento de Trabajo, $N^{\circ} 75078$, Washington, D.C., Banco Interamericano de Desarrollo, 2010.

\section{Resumen y conclusiones}

El propósito de este trabajo fue analizar los puntos de contacto entre la política tributaria y la inversión en los países de América Latina. Para ello, se comenzó haciendo una revisión de la literatura sobre incentivos tributarios a la inversión, abarcando estudios teóricos y empíricos relativos a su efectividad y eficiencia, y estudios referidos a metodologías para su evaluación. Las principales conclusiones de esta revisión son las siguientes:

- La literatura empírica respecto del efecto de la tasa de impuestos sobre la inversión extranjera en países desarrollados muestra resultados diversos: algunos estudios exhiben efectos positivos, otros muestran efectos negativos y otros son neutros. No obstante, existe algún grado de consenso sobre que la elasticidad media de la inversión respecto de la tasa de impuestos sería del orden de -0,6. 
- Los pocos estudios de este tipo que existen para América Latina muestran que la inversión extranjera responde a cambios en las tasas de impuesto a las utilidades de las empresas y dichos efectos no son despreciables. Sin embargo, hay más evidencia empírica para otras dimensiones que afectan la inversión, como la calidad de las instituciones, el tamaño del mercado, las características de la fuerza laboral, la dotación de materias primas y algunos aspectos institucionales.

- También hay una serie de trabajos realizados en países desarrollados que evalúan empíricamente la efectividad de las zonas francas o zonas industriales especiales. Llama la atención que en todos ellos se concluye que estos incentivos no tienen efectos significativos sobre la inversión y el empleo, y en los pocos casos en que se observa un impacto en el empleo, solo se trata de un efecto de sustitución con zonas aledañas.

- Por último, los trabajos teóricos que abordan la efectividad relativa de los incentivos tributarios concluyen que los de mejor desempeño son los esquemas de depreciación acelerada, por su focalización, neutralidad y menor costo fiscal, en tanto que los peores son las exoneraciones o moratorias fiscales.

A continuación, se realizó un análisis de los incentivos tributarios a la inversión que se utilizan en diez países de América Latina, clasificándolos de acuerdo con su propósito específico, las técnicas tributarias escogidas y los impuestos usados para otorgar dichos incentivos. Se concluye que la mayoría de los incentivos a la inversión usados en América Latina están orientados a sectores o actividades específicas. A nivel agregado, destacan los incentivos al turismo (un 22\% del total), los incentivos a las exportaciones (un 19\% del total) y los incentivos al sector de la energía (un 15\% del total). Respecto de las técnicas tributarias usadas para otorgar incentivos, la gran mayoría corresponden a exenciones, contabilizándose 256 estímulos de este tipo, lo que representa un $76 \%$ del total. Estas se aplican en mayor medida en el ISR (40\%), pero también en aranceles (26\%) e IVA (23\%).

En cuanto a los impuestos usados para atraer inversión, 167 incentivos se otorgan a través del ISR (un $50 \%$ del total), 70 corresponden a estímulos en los aranceles (un 21\% del total), 68 son incentivos del IVA (un 20\% del total) y 32 incentivos se otorgan en otros impuestos (un 9\% del total). Contrariamente a lo que recomiendan los trabajos teóricos, la mayoría de los incentivos tributarios en el ISR (dos tercios, aproximadamente) son exenciones o moratorias fiscales. En cambio, el uso de la depreciación acelerada, considerado el mejor instrumento para atraer inversión, es bastante limitado. 
Por último, los informes oficiales de gastos tributarios permiten comprobar que los incentivos a la inversión de aplicación general son los que tienen mayor participación en el costo fiscal, sobre todo en Chile y Colombia. Si se toma el conjunto de incentivos tributarios a la inversión, se observa que en la Argentina y Chile representan la mitad de todos los gastos tributarios, en Colombia y el Ecuador se acercan al 30\% y en Guatemala rondan el 12\%. En términos del PIB, la mayor pérdida fiscal la muestra Chile $(2,2 \%)$, seguido por el Ecuador (1,6\%), la Argentina (1,1\%), Guatemala (0,9\%) y Colombia (0,8\%).

\section{Bibliografía}

Agosin, M. y R. Machado (2007), "Openness and the international allocation of foreign direct investment", Journal of Development Studies, vol. 43, $\mathrm{N}^{\circ}$ 7, Taylor \& Francis.

Agostini, C.A. e I. Jalile (2009), “Efectos de los impuestos corporativos en la inversión extranjera en América Latina", Latin American Research Review, vol. 44, Nº 2, Asociación de Estudios Latinoamericanos (LASA).

Agostini, C. y M. Jorratt (2013), "Política tributaria para mejorar la inversión y el crecimiento en América Latina", serie Macroeconomía del Desarrollo, $\mathrm{N}^{\circ} 130$ (LC/L.3589), Santiago, Comisión Económica para América Latina y el Caribe (CEPAL) [en línea] http://repositorio.cepal.org/bitstream/handle/11362/5361/ LCL3589_es.pdf?sequence=1.

Auerbach, A. (1989), "Tax reform and adjustment costs: the impact on investment and market value", International Economic Review, vol. 30, $\mathrm{N}^{\circ} 4$, Wiley.

Barnes, I. y J. Preston (1985), "The Scunthorpe enterprise zone: an example of muddled interventionism", Public Administration, vol. 63, $\mathrm{N}^{\circ} 2$, Wiley.

Boarnet, M.G. y W.T. Bogart (1996), “Enterprise zones and employment: evidence from New Jersey", Journal of Urban Economics, vol. 40, $\mathrm{N}^{\circ} 2$, Amsterdam, Elsevier.

Bradbury, K., Y. Kodrzycki y R. Tannenwald (1997), "The effects of states and local public policies on economic development: an overview", New England Economic Review, Banco de la Reserva Federal de Boston.

Chirinko, R.S. y D.J. Wilson (2007), “Tax competition among U.S. states: racing to the bottom or riding on a seesaw?", Working Paper Series, N ${ }^{\circ}$ 2008-03, San Francisco, Banco de la Reserva Federal de San Francisco.

Coughlin, C. y otros (1991), "State characteristics and the location of foreign direct investment within the United States", Review of Economics and Statistics, vol. 73.

De Mooij, R.A. y S. Ederveen (2003), "Taxation and foreign direct investment, a synthesis of empirical research", International Tax and Public Finance, vol. 10, $\mathrm{N}^{\circ} 6$, Springer.

Devereux, M. y R. Griffith (1998), "Taxes and the location of production: evidence from a panel of US multinationals", Journal of Public Economics, vol. 68, $\mathrm{N}^{\circ} 3$, Amsterdam, Elsevier.

Djankov, S. y otros (2008), "The effect of corporate taxes on investment and entrepreneurship", NBER Working Papers, $\mathrm{N}^{\circ}$ 13756, Cambridge, Massachusetts, National Bureau of Economic Research.

Goolsbee, A. (1998), "Investment tax incentives, prices, and the supply of capital goods", Quarterly Journal of Economics, vol. 113, N 1, Oxford University Press.

Gordon, R. (1985), "Taxation of corporate capital income: tax revenues versus tax distortions", Quarterly Journal of Economics, vol. 100, № 1, Oxford University Press. 
Hall, R. y D. Jorgenson (1967), "Tax policy and investment behavior", American Economic Review, vol. 57, N³, Nashville, Tennessee, American Economic Association.

House, C. y M. Shapiro (2008), "Temporary investment tax incentives: theory with evidence from bonus depreciation", American Economic Review, vol. 98, N³, Nashville, Tennessee, American Economic Association.

James, S. (2009), "Incentives and investments: evidence and policy implications", Documento de Trabajo, $\mathrm{N}^{\circ}$ 58816, Washington, D.C., Banco Mundial.

Jorgenson, D. (1963), "Capital theory and investment behavior", American Economic Review, vol. 53, N², Nashville, Tennessee, American Economic Association.

Jorratt, M. (2010a), "Análisis del gasto tributario y propuestas de incentivos fiscales a la inversión y al empleo en Ecuador", Revista Fiscalidad, № 4, Quito, Servicio de Rentas Internas.

(2010b), "Diagnóstico de la estructura tributaria de Colombia y propuestas de reforma tributaria", Documento de Trabajo, $N^{\circ} 75078$, Washington, D.C., Banco Interamericano de Desarrollo.

King, R. (1993), Money, Time, and Politics: Investment Tax Subsidies and American Democracy, New Haven, Yale University Press.

Klemm, A. y S. Van Parys (2012), "Empirical evidence on the effects of tax incentives", International Tax and Public Finance, vol. 19, $\mathrm{N}^{\circ} 3$, Springer.

Meyer, L.H., J.L Prakken y C.P. Varvares (1993), “Designing an effective investment tax credit", Journal of Economic Perspectives, vol. 7, $\mathrm{N}^{\circ}$ 2, Nashville, Tennessee, American Economic Association.

Neumark, D. y J. Kolko (2010), “Do enterprise zones create jobs? Evidence from California's enterprise zone program", Journal of Urban Economics, vol. 68, $\mathrm{N}^{\circ} 1$, Amsterdam, Elsevier.

OCDE (Organización de Cooperación y Desarrollo Económicos) (2010), Choosing a Broad Base - Low Rate Approach to Taxation, París, OECD Publishing.

Papke, L. (1993), "What do we know about enterprise zones?", Tax Policy and the Economy, J. Poterba (ed.), vol. 7, Cambridge, Massachusetts, National Bureau of Economic Research/The MIT Press.

Talbot, J. (1988), "Have enterprise zones encouraged enterprise? Some empirical evidence from Tyneside", Regional Studies, vol. 22, № 6, Taylor \& Francis.

Tanzi, V. y H. Zee (2001), "La política tributaria en los países en desarrollo", Temas de Economía, N²7, Washington, D.C., Fondo Monetario Internacional.

Tokman, M., J. Rodríguez y C. Marshall (2006), “Las excepciones tributarias como herramienta de política pública", Estudios Públicos, N 102, Santiago, Centro de Estudios Públicos (CEP).

Van Parys, S. y S. James (2010), "The effectiveness of tax incentives in attracting investment: panel data evidence from the CFA franc zone", International Tax and Public Finance, vol. 17, $\mathrm{N}^{\circ}$ 4, Springer.

Villela, L., A. Lemgruber y M. Jorratt (2009), “Los presupuestos de gastos tributarios. Conceptos y desafíos de implementación", Documento de Trabajo, N IDB-WP-131, Washington, D.C., Banco Interamericano de Desarrollo.

Zee, H.H., J.G. Stotsky y E. Ley (2002), “Tax incentives for business investment: a primer for policy makers in developing countries", World Development, vol. 30, $\mathrm{N}^{\circ}$ 9, Amsterdam, Elsevier. 
Capítulo IX

\title{
Reformas fiscales, crecimiento e inversión: el caso de la Argentina ${ }^{1}$
}

\author{
Oscar Cetrángolo 2 \\ Juan C. Gómez Sabaini ${ }^{3}$ \\ Dalmiro Morán ${ }^{4}$
}

\section{Introducción}

A lo largo del siglo XX, la política fiscal en la Argentina siempre ha estado en el centro del debate económico. La Argentina desarrolló tempranamente un Estado benefactor de amplio alcance y ha intervenido de manera decisiva en el desarrollo económico y la distribución del ingreso. Por ese motivo, las alternativas de sus políticas públicas y su financiamiento han sido un tema de constante debate.

1 Este trabajo constituye una versión resumida de Cetrángolo, Gómez Sabaini y Morán (2015).

2 Consultor de la Comisión Económica para América Latina y el Caribe (CEPAL) y de la Organización Internacional del Trabajo (OIT) especializado en política fiscal. Profesor de grado y posgrado en la Universidad Nacional de Buenos Aires y la Universidad Nacional de Tres de Febrero (Argentina). Correo electrónico: ocetrangolo@gmail.com.

3 Consultor de la Comisión Económica para América Latina y el Caribe (CEPAL), el Banco Interamericano de Desarrollo (BID), el Fondo Monetario Internacional (FMI) y el Centro Interamericano de Administraciones Tributarias (CIAT) especializado en temas de política tributaria en países de América Latina. Profesor de posgrado en la Universidad Nacional de Buenos Aires. Correo electrónico: gomezsabaini@gmail.com.

4 Consultor de la Comisión Económica para América Latina y el Caribe (CEPAL) y del Centro Interamericano de Administraciones Tributarias (CIAT) especializado en temas de política tributaria en países de América Latina. Correo electrónico: dalomoran@gmail.com. 
Del mismo modo en que el creciente endeudamiento condicionaba de manera significativa las posibilidades de los Gobiernos democráticos surgidos a partir de 1983, la Argentina debió afrontar al final del siglo XX una de las crisis económicas (sociales y políticas) más graves de su historia, entre otras cosas, por la incapacidad de los Gobiernos de atender sus obligaciones. Tal vez se trate de un caso extremo de una realidad común en la región donde, ante cada situación crítica, la discusión sobre la política fiscal se ve dominada por el dilema entre la estabilización macroeconómica y la sostenibilidad de la deuda pública (Martner, Podestá y González, 2013).

En el contexto internacional favorable que se presentó para los países latinoamericanos a partir de 2003, la Argentina logró encaminarse hacia un importante y sostenido proceso de crecimiento económico. En una primera etapa sacó provecho de una amplia capacidad instalada ociosa, pero en años más recientes fue surgiendo una serie de restricciones macroeconómicas que influyeron en la elección y formulación de las políticas de gastos e ingresos fiscales. En este trabajo se pone especial énfasis en analizar la experiencia argentina reciente en materia de políticas públicas de fomento de la inversión.

Con ese fin, después de presentar de manera resumida las principales tendencias macroeconómicas observadas en el país durante la última década, se revisa la trayectoria de la inversión pública de los diferentes niveles de gobierno y su estructura sectorial, así como el alcance de los cambios inducidos por la reforma previsional. Por otro lado, se analizan las iniciativas públicas tendientes a favorecer la inversión privada, tanto mediante programas de gasto como a través de incentivos tributarios.

\section{A. Crecimiento, formación bruta de capital e impactos en las finanzas públicas, 2000-2014}

La crisis de principios del siglo XXI en la Argentina estuvo dominada por la recesión, el incumplimiento de los pagos de la deuda pública, la ruptura de contratos, el cambio brusco de los precios relativos, la elevada incertidumbre y el deterioro de las condiciones de vida. Sin embargo, de manera paulatina (aunque en un plazo no muy extenso) se consolidó un nuevo esquema macroeconómico caracterizado por el establecimiento de un tipo de cambio real elevado, que permitió mejorar la competitividad de los sectores productores de bienes comerciables, lo que favoreció el incremento y la rápida recuperación del producto.

De ese modo, desde 2003, la economía comenzó a registrar elevadas tasas de crecimiento que se mantuvieron hasta 2009. Ese año se produjo una fuerte desaceleración debida, entre otros factores, a la crisis internacional y a la sequía que afectó al sector agropecuario. Asimismo, entre 2003 y 2008 se registró un alto nivel de creación de empleo que permitió revertir los 
elevados índices de desempleo. Tras la recuperación que tuvo lugar en el período 2010-2011, se registró un menor crecimiento en 2012 y 2013. La tasa de crecimiento medio del PIB entre 2003 y 2013 ascendió a un 6,2\% (véase el gráfico IX.1).

\section{Gráfico IX.1}

Argentina: evolución de los agregados macroeconómicos, 1993-2013

(En moneda constante de 1993)

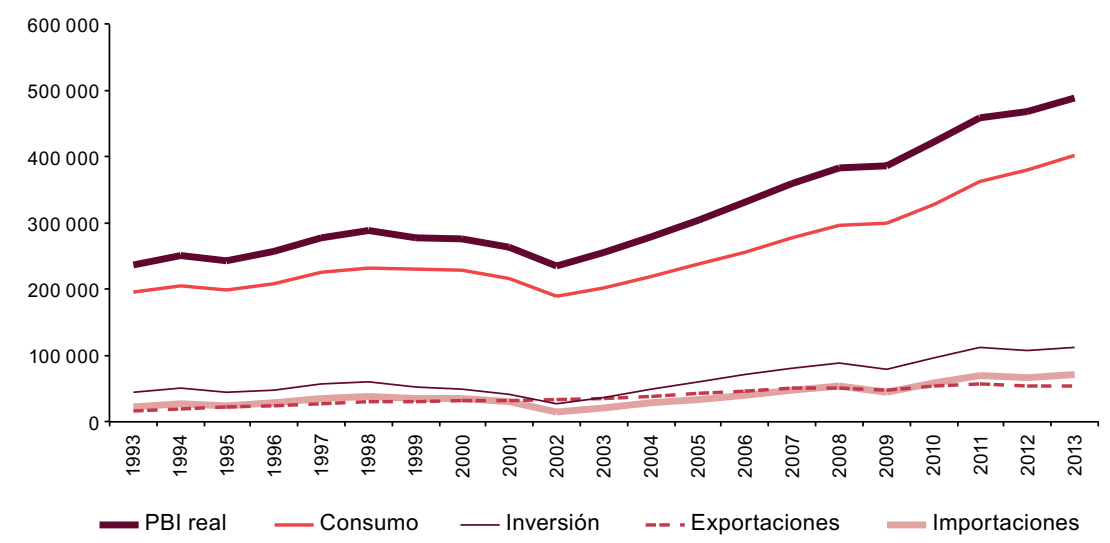

Fuente: Elaboración propia, sobre la base de datos del Instituto Nacional de Estadística y Censos (INDEC).

Tras la salida de la convertibilidad y la pronunciada devaluación que acompañó a ese proceso, se registró un importante vuelco en la balanza comercial, que pasó a mostrar importantes superávits. El cambio de los precios relativos y la introducción de medidas excepcionales derivaron, en el plano fiscal, en el logro de resultados significativamente superavitarios.

El volumen de inversión se recuperó desde los bajos registros de los años anteriores hasta niveles elevados en términos históricos. Ello fue especialmente importante en relación con el equipo durable de producción. Pasados los momentos iniciales posteriores a la crisis, cuando el crecimiento del nivel de actividad se relacionó con la utilización de la capacidad instalada, la acumulación siguió creciendo y generó aumentos del volumen de capital. Este mostró un crecimiento acumulado del 19\% entre 2002 y 2008 , y del $8 \%$ entre 2008 y 2010.

Vale señalar que, desde que se restableció la democracia en 1983, en la definición de la política fiscal se debió tener en cuenta la existencia de un contexto macroeconómico sumamente complejo, siendo la renegociación de la deuda externa y el control del proceso inflacionario las principales preocupaciones del período (aunque no las únicas). La gran volatilidad macroeconómica se evidenció con los grandes cambios del nivel de actividad, 
relacionados por lo general con las conmociones externas, y derivó en reducidos márgenes de maniobra para la política fiscal ${ }^{5}$.

Por ese motivo, la situación de solvencia fiscal alcanzada en la salida de la crisis de 2001-2002, si bien extraordinaria, debe entenderse como la culminación de un largo y persistente proceso de mejora en el resultado fiscal consolidado. Ese proceso, que se había iniciado en 1984, puede observarse en el gráfico IX.2. Allí se muestra que las cuentas públicas siguieron las fluctuaciones del entorno macroeconómico, pero con una clara tendencia positiva, hasta lograr la consolidación de equilibrios primarios durante los años noventa y superávits globales después de la crisis 6 . Así pues, una primera mirada de largo plazo de las cuentas públicas argentinas permite destacar la persistencia de resultados negativos (tanto financieros como primarios) durante un largo período, pero con una notable tendencia a la recuperación desde los años ochenta.

Argentina: resultado del sector público consolidado (nación y provincias), 1961-2013 (En porcentajes del PIB)

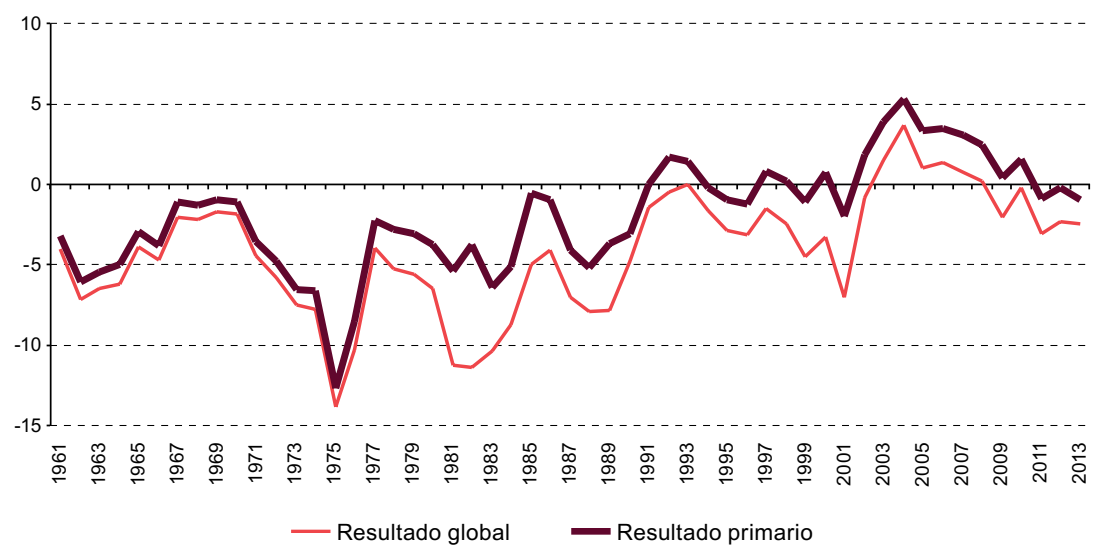

Fuente: Elaboración propia, sobre la base de datos de la Secretaría de Hacienda.

$5 \quad$ Más allá de la conocida prociclicidad de la política fiscal, en Albrieu y Cetrángolo (2011) se presenta evidencia sobre su comportamiento desestabilizador ante eventos extremos de colapso del nivel de actividad, que han hecho que los parámetros de la política fiscal sean condicionales a la magnitud y el tipo de conmoción que enfrente la economía.

6 En ese gráfico se presenta la evolución de largo plazo del resultado fiscal como porcentaje del PIB. Al igual que en las restantes referencias a magnitudes expresadas como porcentaje del PIB, y dado el amplio cuestionamiento de la información estadística oficial (Instituto Nacional de Estadística y Censos (INDEC)), aquí se ha optado por utilizar una serie estimada del PIB, que se ha publicado en el sitio electrónico [en línea] https://alquimiaseconomicas.com/2015/02/24/ en-busca-del-denominador-perdido/. 
Al ser la Argentina un país federal cuyas provincias poseen un alto grado de autonomía, conviene resaltar que la evolución del resultado fiscal consolidado ha estado determinada casi exclusivamente por la trayectoria de las cuentas de la nación. La situación de las provincias, pese a lo que suele decirse, no es muy pertinente para explicar el resultado fiscal consolidado y su importancia en la evaluación de los equilibrios macroeconómicos es relativa. No obstante, ha estado vinculada con importantes turbulencias políticas y complicaciones de diverso tipo en cada una de las jurisdicciones (Cetrángolo y Gómez Sabaini, 2012).

En síntesis, se puede establecer que, en la gestación del espacio fiscal durante los primeros dos años posteriores a la crisis, fue tan importante el incremento de recursos como la constancia de las erogaciones. Pasado ese primer momento, los aumentos del gasto a un ritmo mayor que los recursos determinaron la pérdida del superávit financiero. En la segunda mitad de la década, el incremento de los haberes previsionales y la posterior reforma del sistema, el aumento de las transferencias (a provincias, hogares y empresas) y gastos de capital, así como el alza de las remuneraciones determinaron una trayectoria ascendente de los gastos por sobre la de los recursos, lo que terminó por erosionar el superávit.

\section{B. Política fiscal e inversión en la Argentina}

Mucho se ha escrito y debatido acerca de las posibilidades de impulsar la inversión y el crecimiento de la economía a través de políticas públicas. En América Latina, el tema comenzó a ocupar un lugar central en el debate económico durante el período de industrialización sustitutiva de las importaciones, siendo el caso argentino uno de los más referenciados al respecto. No obstante, la relación entre política fiscal, inversión y crecimiento tiene antecedentes de larga data en la Argentina. El control territorial, la expansión de la infraestructura y la formación de recursos humanos se cuentan entre los aspectos destacados de la política fiscal que explican el temprano desarrollo de la inversión tanto pública como privada. Las limitaciones derivadas de la falta de financiamiento de la inversión llegaron a ser un motivo importante de su desaceleración (Díaz Alejandro, 1970; Mallon y Sourrouille, 1973).

La experiencia internacional acumulada y las enseñanzas del camino recorrido por el país definen un nuevo tipo de debate sobre temas que vuelven a ser objeto de análisis. Sin duda, un aspecto que suele considerarse en la relación entre política fiscal e inversión se refiere a la complementariedad o la competencia entre la inversión pública y la inversión privada. En el primer caso, la inversión pública en servicios públicos e infraestructura afecta positivamente la rentabilidad de la inversión privada porque reduce los costos privados de producción y puede aumentar la demanda y el uso de la capacidad instalada. 
La relación de complementariedad entre inversión pública e inversión privada se observa principalmente en la inversión en infraestructura y en educación.

Por otro lado, la inversión pública puede competir con la privada en la obtención de financiamiento y de insumos productivos. En los países en desarrollo, la competencia en el mercado financiero puede ser más importante debido a que la oferta de créditos es más restringida y, en cierta forma, desplaza la inversión privada mediante lo que se conoce como el efecto de desplazamiento negativo (crowding out). Sin embargo, la evidencia disponible ha mostrado una correlación positiva entre las tasas de crecimiento medio de la inversión privada y pública de América Latina y el Caribe. Al parecer, esta última genera externalidades positivas que incrementan la productividad global de las empresas?

Ante los numerosos obstáculos que ha encontrado la inversión pública, no solo en la Argentina sino en todos los países de América Latina en largos períodos de la historia, los distintos Gobiernos han recurrido a varias herramientas de política con el fin de incentivar la inversión privada. La intención ha sido complementar la inversión pública, ya sea de manera directa mediante el gasto público o de manera indirecta mediante el sistema impositivo.

Ciertamente, hoy el debate es más rico y complejo. No se trata solo de evaluar el impacto de la inversión pública sobre el crecimiento de la economía, sino de considerar el impacto de la política fiscal sobre el clima de negocios, así como la posibilidad de eliminar restricciones institucionales y organizacionales para la acumulación de capital (Fanelli, 2013) y la complementariedad entre inversión pública y privada, entre otros aspectos sustantivos. La mirada no debe estar puesta solamente sobre aspectos cuantitativos. Además del monto de inversión pública, importa analizar su calidad y productividad (Arslanalp, Bornhorst y Gupta, 2011).

En el gráfico IX.3 se muestra de forma elocuente la importancia que ha tenido en la Argentina la inversión pública hasta principios de los años ochenta, con un pico durante los años del último Gobierno militar (1976-1983). Pasado ese período, en que el Estado ocupaba una posición dominante en materia de formación de capital, la necesidad de ajustar las cuentas públicas a la salida de la crisis de la deuda obligó a reducir el gasto en capital durante los años ochenta. Posteriormente, se sumó a las restricciones fiscales el apogeo de una visión donde el Estado debía retirarse de muchos sectores de la economía. Durante esos años se privatizó una parte sustancial de las empresas que estaban en manos del Estado. En el gráfico también se puede observar la casi total desaparición de la inversión a cargo de las empresas

Martner y Tromben (2005) han comprobado, con una muestra de diez países de la región en el período 1980-2003, la existencia de una relación causal positiva entre inversión pública e inversión privada (el efecto de crowding in o desplazamiento positivo), lo que coincide con las conclusiones de estudios sobre la Unión Europea reseñados por estos autores. 
públicas, incorporada dentro del rubro "resto del sector público". Una vez alcanzados los mínimos de inversión pública durante la crisis, se observa una paulatina recuperación que, en el caso del sector público nacional, apenas vuelve a los niveles de principios de los años noventa.

\section{Gráfico IX.3}

Argentina: evolución de la inversión real directa del sector público, 1965-2013 (En porcentajes del PIB)

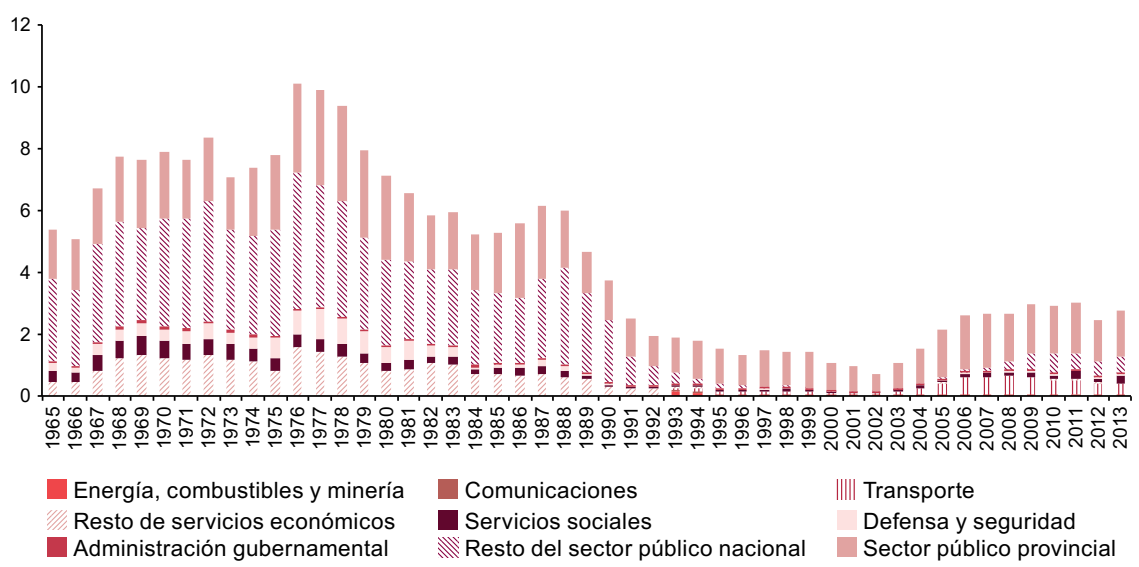

Fuente: Elaboración propia, sobre la base de datos de la Secretaría de Hacienda.

Sin duda, el aspecto de la estructura de la inversión pública que más llama la atención es su relativa constancia en el caso de los Gobiernos provinciales. Ello se debe, en parte, a que existe una porción de impuestos recaudados a nivel federal (sobre todo el impuesto sobre los combustibles) que desde hace décadas se asigna específicamente a los Gobiernos provinciales, aunque se condiciona su uso en ciertas obras de infraestructura vinculadas, de manera especial, a la energía, la vialidad y la vivienda. Precisamente, la caída de fines de los años noventa y principios del siglo XXI se debe a que los Gobiernos nacional y provinciales habían acordado reducir las asignaciones específicas para hacer frente a la crisis.

\section{Reforma previsional, espacio fiscal e inversión en proyectos productivos: el caso del Fondo de Garantía de Sustentabilidad}

La evolución del sistema previsional debe ser especialmente considerada para comprender los alcances de la crisis fiscal argentina, pero también debe ser indagada toda vez que se quiera comprender el financiamiento de la inversión pública hasta los años sesenta. 
Durante las primeras décadas de su establecimiento, el sistema de pensiones aportó sus excedentes al financiamiento de acciones públicas (Bertranou y otros, 2011). Si bien sus desequilibrios se acentuaron durante los años ochenta y noventa, eran importantes desde mediados de los años setenta. El agotamiento del excedente inicial propio de todo sistema que madura y utiliza sus fondos acumulados para financiar otras finalidades del gasto público derivó en un temprano desequilibrio al que contribuyeron de manera sustantiva los factores demográficos y macroeconómicos, además de las propias respuestas dadas por la política sectorial. En consecuencia, a lo largo de las últimas tres décadas debió recurrirse a diversos mecanismos de emergencia: el incremento de las alícuotas de las cargas sobre los salarios; el financiamiento de otras fuentes; la modificación de la tasa de sostenimiento mediante el cambio en la edad de jubilación o, en última instancia, el incumplimiento de la legislación.

Tras una profunda crisis, el sistema previsional argentino fue reformado de manera tardía e inconveniente en 1994. Si bien no se reconoció originalmente este hecho con el objeto de asegurar la solvencia fiscal a largo plazo, se comprometió seriamente la solvencia a corto plazo. De esa manera, la reforma entrañó una pesada carga financiera sobre las cuentas públicas que ya tenía serios problemas de solvencia. Como resultado de ello, el sistema de pensiones llegó a tener un desequilibrio equivalente al 3,3\% del PIB en el año $2000^{\circ}$. Para cubrir ese desequilibrio, el Gobierno nacional logró apropiarse de una porción importante $(15 \%)$ de la recaudación tributaria que formaba parte de las transferencias del sistema de coparticipación federal, lo que afectó la relación entre niveles de gobierno.

Después de varias reformas parciales de las pensiones, a partir de 2004 se decidió incrementar la cobertura mediante la medida excepcional de permitir el ingreso al sistema a personas que no cumplían los requisitos establecidos por la legislación. En 2008 se eliminó el esquema de capitalización para volver al sistema previo de reparto. De esa manera se ha logrado un importante crecimiento de la cobertura a corto plazo, por lo que ahora el sistema es el de mayor cobertura de la región. No obstante, quedan por determinarse aspectos esenciales a largo plazo, lo que hace difícil una proyección adecuada acerca de la trayectoria de mediano plazo. Más allá de esa dificultad, si no se introducen reformas estructurales o nuevas medidas de emergencia, la cobertura actual se verá erosionada a lo largo de los próximos años. Los aspectos más importantes que se deben definir se relacionan con la tasa efectiva de reemplazo que se promete y la cobertura que tendrán los trabajadores que no cumplan los requisitos exigidos para acceder a los beneficios, de acuerdo con la legislación vigente 9 .

De ese total, la pérdida correspondiente a los aportes transferidos al sistema de capitalización suma el 1,5\% del PIB; la reducción de contribuciones patronales, el 1,3\% del PIB, y el déficit de las cajas previsionales explica el restante 0,5\% del PIB. Véase Cetrángolo y Grushka (2004).

$9 \quad$ Este tema se analiza de manera exhaustiva en Bertranou y otros (2011). 
Hasta mediados de los años sesenta, el sistema previsional era uno de los elementos más importantes del espacio fiscal con que contó el Estado argentino. Después pasó a ser una de las principales causas de la pérdida de ese espacio fiscal y, a partir de su reestatización, volvió a convertirse en fuente de financiamiento. En ese sentido, ha jugado un papel importante en las relaciones entre el Estado y el sector privado de la economía, a través del Fondo de Garantía de Sustentabilidad (FGS).

El FGS se creó en julio del 2007, mediante el Decreto núm. 897/2007. En el momento de su creación, se componía de: i) los recursos de la Administración Nacional de la Seguridad Social (ANSES) que resultaran de libre disponibilidad al final de cada ejercicio anual; ii) los bienes recibidos por el régimen previsional público como consecuencia de la transferencia de los saldos de las cuentas de capitalización correspondientes a los afiliados que optaron por abandonar el régimen antes de su eliminación (Decreto núm. 313/2007); iii) las rentas provenientes de las inversiones que realice el Fondo, y iv) cualquier otro aporte que establezca el Estado Nacional mediante la Ley de Presupuesto. Asimismo, tras la creación del Sistema Integrado Previsional Argentino (SIPA), en diciembre de 2008 (Ley núm. 26425) y la consecuente eliminación de las Administradoras de Fondos de Jubilaciones y Pensiones (AFJP), el FGS se nutrió también de los bienes que recibió el SIPA como consecuencia del traspaso de los saldos de las cuentas de capitalización a las AFJP. De ese modo, el FGS adquirió una relevancia mucho mayor, ya que pasó a manejar una cartera que, a fines de 2008, equivalía a poco menos del 8\% del PIB.

En un principio y con una cartera considerablemente menor, el FGS tuvo como finalidad la preservación de los fondos que administraba con el fin de atender eventualidades del correcto devenir del sistema previsional. Después de la creación del SIPA y el traspaso de los fondos administrados por las AFJP (diciembre de 2008), se instrumentó mediante el Decreto núm. 2103/2008 un mayor rango de objetivos a perseguir en el manejo de esos fondos. En particular, dicha norma indica que el FGS debería tener entre sus finalidades la de "[p]rocurar contribuir, con la aplicación de sus recursos, de acuerdo a criterios de seguridad y rentabilidad adecuados, al desarrollo sustentable de la economía nacional, a los efectos de garantizar el círculo virtuoso entre el crecimiento económico sostenible (...)".

Como resultado de esas modificaciones, la composición de la cartera de fondos, antes atomizada en manos privadas, pasó a estar unificada bajo la estructura pública del FGS. Si bien no se registraron grandes modificaciones en líneas generales, se evidenciaron cambios relativos de cierta relevancia en las inversiones de menor tamaño del Fondo, que en parte se debieron a la nueva normativa. 
En el momento de la creación del SIPA, el total de fondos sumaba casi el $8 \%$ del PIB. De esa cantidad, más de un $60 \%$ consistía en títulos públicos, un $10 \%$ en depósitos a plazo fijo, un $9 \%$ en acciones de sociedades anónimas, y tan solo un $2 \%$ correspondía a proyectos productivos, mientras que el $19 \%$ restante se componía de reservas disponibles y de otras inversiones menores. Casi seis años después, de acuerdo con la última información disponible, de agosto de 2014, el fondo suma 443.410 millones de dólares, es decir, aproximadamente algo más del 10\% del PIB, con algunos cambios en su composición. En efecto, si bien el principal activo sigue siendo el de los títulos públicos, con más del $67 \%$ del total, en la actualidad el segundo lugar lo ocupan los proyectos productivos o de infraestructura, con el 13\% del total de la cartera (véase el gráfico IX.4). Vale recordar que, antes de la reforma del sistema de 2008, esa categoría no formaba parte de los activos financieros administrados por las distintas AFJP.

\section{Gráfico IX.4 \\ Argentina: composición de la cartera del Fondo de Garantía de Sustentabilidad, 2002-2014 \\ (En porcentajes del total)}

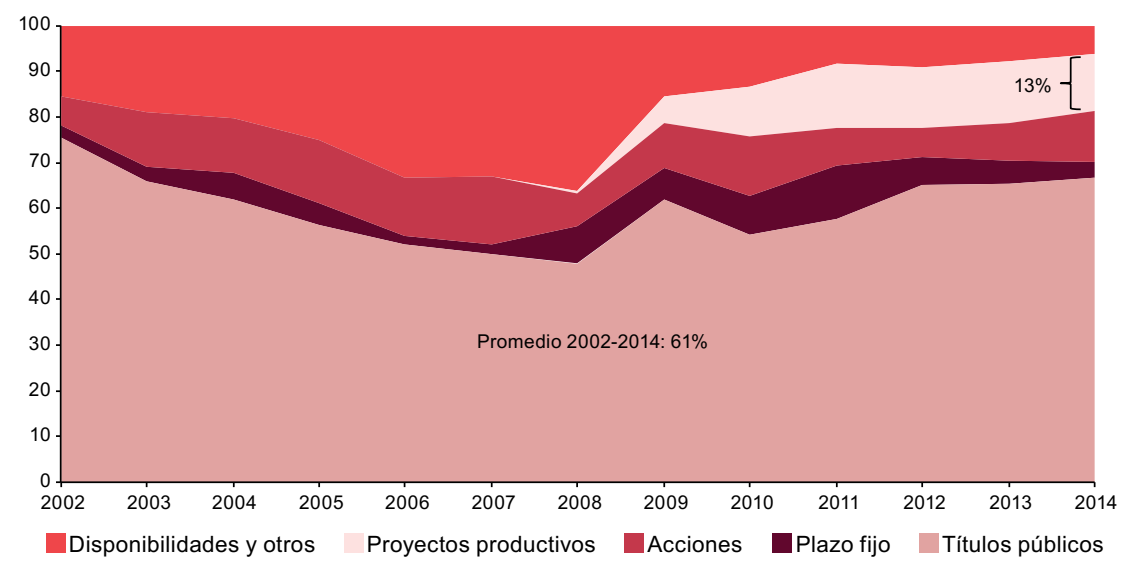

Fuente: Elaboración propia, sobre la base de datos de la Administración Nacional de la Seguridad Social (ANSES).

a Hasta diciembre de 2008, es la suma de las carteras administradas por cada una de las AFJP.

En 2014, el total de inversiones en proyectos productivos o de infraestructura sumó 55.455 millones de dólares (el 1,3\% del PIB), lo que constituyó una nueva fuente de recursos para proyectos de inversión productiva o de infraestructura. Entre las "nuevas" inversiones del FGS se destacan, por su participación mayoritaria, las destinadas a la fabricación de centrales atómicas y de generación eléctrica, obras públicas de vialidad y, desde 2013, el programa de crédito para la vivienda PROCREAR (véase el gráfico IX.5). 


\section{Gráfico IX.5 \\ Argentina: estructura de proyectos productivos o de infraestructura en la cartera del Fondo de Garantía de Sustentabilidad, 2009-2014}

(En porcentajes)

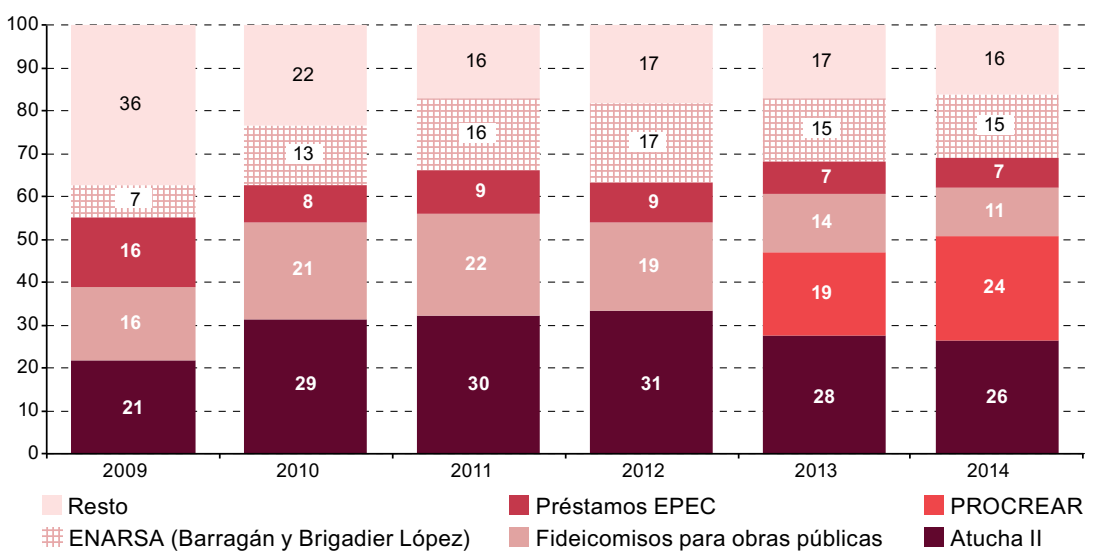

Fuente: Elaboración propia, sobre la base de datos de la Administración Nacional de la Seguridad Social (ANSES).

Según la última información disponible, la principal inversión, cercana a 14.600 millones de dólares (el $26 \%$ del total de inversiones productivas), es la de Nucleoeléctrica Argentina S.A. (NASA), que tiene como objetivo la finalización de la central nuclear Atucha II. En segundo lugar se encuentra, desde 2013, el plan de crédito para la construcción y compra de viviendas PROCREAR, que representa más del $24 \%$ de esos fondos (véase el gráfico IX.5). Por otra parte, las inversiones destinadas a Energía Argentina S.A. (ENARSA) para el suministro, construcción, montaje, puesta en marcha y mantenimiento de dos centrales de generación eléctrica (Brigadier López y Barragán), representaron en 2014 el 15\% del total de inversiones en infraestructura del FGS. A su vez, tras la puesta en marcha del plan PROCREAR, han perdido participación relativa los Fideicomisos Financieros para Obras Públicas. En la actualidad estos representan solo el 11\%, mientras que el resto de las inversiones ocupan el otro $24 \%$, entre las que se destacan principalmente los préstamos a la Empresa Provincial de Energía de Córdoba (EPEC).

En línea con la mayor cuantía de recursos administrados por la ANSES, que incrementaron lógicamente los fondos del FGS, también se crearon mayores instancias de control. Si bien la administración del FGS está a cargo de la ANSES, funciona con la asistencia de un Comité Ejecutivo de administración de las inversiones, integrado por el Director Ejecutivo de la propia ANSES y por los secretarios de finanzas, hacienda y política económica del Ministerio de Economía y Finanzas Públicas. Asimismo, con la creación del SIPA se creó el Consejo del FGS del SIPA con el objetivo de realizar un monitoreo de sus 
recursos ${ }^{10}$. Sumado a lo anterior, mediante la Ley núm. 26425, se estableció una Comisión Bicameral de Control de los Fondos de la Seguridad Social, en el ámbito del Congreso de la Nación, destinada a ejercer el control de los fondos de la seguridad social. Por último, dentro de la Unidad de Auditoría Interna de la ANSES, se creó una Gerencia de Auditoría con el mismo fin.

En suma, la reforma del sistema previsional de fines de 2008 afectó principalmente al sistema de seguridad social, su financiamiento y las finanzas públicas de la nación. No obstante, también generó una serie de "externalidades" de relativa magnitud. Entre ellas se destaca la modificación en el destino de las reservas derivadas del ahorro del sistema previsional. En efecto, si bien tras el cambio de manos de la administración de dichos fondos se mantuvo la deuda pública como principal activo financiero (más del $60 \%$ de la cartera), los proyectos productivos o de infraestructura pasaron a tener un rol protagónico en el resto de las inversiones. Así, el Estado nacional llegó a tener por primera vez una reserva que equivalía al 1,3\% del PIB (en 2014) para destinar a dichos fines. El Gobierno nacional, al menos en los últimos años, decidió centrar esos recursos en proyectos relacionados con la generación de energía (atómica y eléctrica), la creación y financiamiento de viviendas y, en menor medida, las obras públicas de infraestructura vial.

\section{Las políticas públicas directas para la promoción de la inversión privada}

Ante las insuficiencias observadas en materia de inversión pública durante largos períodos de la historia, los sucesivos Gobiernos de la Argentina han apelado de manera recurrente (y sobre todo durante la última década) a la implementación de distintas políticas públicas dirigidas a alentar mayores niveles de inversión privada, aprovechando las sinergias señaladas más arriba.

En ese sentido, existen dos caminos distintos pero complementarios. Por un lado, pueden diseñarse programas de financiamiento para los inversores privados, tendientes a facilitar su acceso a líneas de préstamos y créditos, bajo condiciones financieras favorables y limitados a determinados sectores o agentes económicos, que propicien de manera directa un aumento de los niveles de inversión ("lado del gasto público"). Por otro, pueden introducirse tratos tributarios diferenciales que apunten a beneficiar a ciertos contribuyentes o sectores productivos (con alguna condicionalidad en su otorgamiento) y que, de manera indirecta a partir de la reducción implícita de los costos

10 Integrado por un representante del ANSES, uno de la Jefatura del Gabinete de Ministros, dos del Órgano Consultivo de Jubilados y Pensionados, tres de los principales sindicatos, dos de las organizaciones empresariales más representativas, dos de las entidades bancarias más representativas y dos del Congreso de la Nación, uno por cada Cámara. 
privados, favorezcan un incremento inducido de la inversión privada y de la formación bruta de capital del total de un país ("lado de los impuestos").

Sobre la base de la información pública oficial, y haciendo un repaso de las distintas líneas de incentivos vigentes, es posible enumerar programas o incentivos dirigidos a estimular la inversión de bienes de capital, actividades sectoriales puntuales, el empleo, la localización, la innovación y el desarrollo tecnológico, y el financiamiento de la inversión. Los programas que involucran incentivos o gastos tributarios serán objeto de análisis en las secciones subsiguientes del presente capítulo. A continuación se resumen los principales programas de gasto público para la promoción de inversiones privadas presentes en la Guía del Inversor elaborada por el Ministerio de Relaciones Exteriores y Culto de la Argentina ${ }^{11}$.

\section{Incentivos a la innovación y el desarrollo tecnológico}

Como parte de las acciones que en el Presupuesto de la Administración Pública Nacional se clasifican como promoción y financiamiento de la ciencia y la técnica, la Agencia Nacional de Promoción Científica y Tecnológica promueve actividades relacionadas con la ciencia, la tecnología y la innovación productivas a través de cuatro fondos:

- Fondo Tecnológico Argentino (FONTAR)

- Fondo Fiduciario de Promoción de la Industria del Software (FONSOFT)

- Fondo para la Investigación Científica y Tecnológica (FONCYT)

- Fondo Argentino Sectorial (FONARSEC)

También promueve el financiamiento de proyectos tendientes a mejorar las condiciones sociales, económicas y culturales en la Argentina. Con esos fines, la Agencia dispone de fondos del Tesoro Nacional, préstamos del Banco Interamericano de Desarrollo (BID) y del Banco Internacional de Reconstrucción y Fomento (BIRF), del financiamiento reembolsable y otros fondos provenientes de convenios de cooperación con organismos o instituciones nacionales e internacionales. Además, en años recientes se crearon el Consejo Federal de Ciencia y Tecnología (COFECYT) y el Programa de Promoción y Fomento de la Innovación Tecnológica, en el marco del Ministerio de Ciencia, Tecnología e Innovación Productiva.

Esas instituciones tuvieron a su cargo en 2013 la ejecución de algo menos del 10\% del total del gasto público nacional en ciencia y técnica, que a su vez representaba alrededor del 0,35\% del PIB, de acuerdo con información de la

11 Véase [en línea] http://www.inversiones.gov.ar/es/incentivos-la-inversion. 
Oficina Nacional de Presupuesto. Por su parte, el gasto público provincial en esa función reviste poca significación (un $0,01 \%$ del PIB, de acuerdo con la Dirección Nacional de Coordinación Fiscal con las Provincias).

\section{Incentivos al empleo}

Los incentivos a la inversión productiva también abordan aspectos estrictamente vinculados al mercado laboral, en forma de abaratamiento del costo laboral para las nuevas contrataciones. En particular, cabe mencionar el Régimen de regulación impositiva y promoción y protección del empleo registrado (Ley núm. 26576), que reduce en un 50\% las contribuciones patronales durante el primer año de trabajo de una nueva contratación y en un $25 \%$ durante el segundo año. Asimismo, dentro del Programa de Inserción Laboral, todo empleador que contrate a un beneficiario del Seguro de Capacitación y Empleo (SCyE) podrá deducir del salario neto los beneficios que este recibía por los programas de empleo.

De igual forma, en el marco del Programa Jóvenes con Más y Mejor Trabajo, todo empleador que contrate a un joven beneficiario de dicho programa podrá descontar del salario neto una suma mensual no remunerativa, lo que le permitirá reducir sus costos laborales.

\section{Financiamiento de la inversión}

Desde el punto de vista financiero, el Estado ha llevado adelante una serie de programas orientados al otorgamiento de líneas de crédito blando, desde distintas entidades financieras públicas y privadas.

Entre las más difundidas se encuentran las líneas de crédito del Banco de la Nación Argentina (BNA) y el Programa de Financiamiento Productivo del Bicentenario. El primer caso se refiere al otorgamiento de líneas de crédito a empresas para la adquisición de capital de trabajo e inversiones, así como para el financiamiento de las importaciones y del sector turístico. El segundo consiste en un esquema de créditos por hasta 16.000 millones de dólares, con una tasa de interés fuertemente subsidiada (un 9,9\% anual durante cinco años), que se destinan a todos los sectores y tipo de empresas, con el objetivo de financiar inversiones productivas.

También se han desarrollado programas de menor magnitud, como las líneas de crédito del Banco de Inversión y Comercio Exterior (BICE). En ese caso, a diferencia de los anteriores, el destino del crédito abarca un espectro más amplio. Involucra el financiamiento para la compra de bienes de capital y proyectos de inversión en bienes y servicios, financiación a empresas pequeñas y medianas (pymes) y cooperativas, energía renovable, línea de turismo, innovación tecnológica, infraestructura regional y la pre- y posfinanciación de las exportaciones. 
Por último, hay también una serie de programas destinados casi exclusivamente a financiar el desarrollo productivo y las inversiones de la micro, pequeña y mediana empresa (MIPYME). El primero se refiere a las líneas de crédito del Consejo Federal de Inversiones (CFI), abocado a la reactivación productiva y a la producción regional exportable. También se encuentran los créditos a tasas subsidiadas para la MIPYME y el Fondo Nacional para el Desarrollo de la Micro, Pequeña y Mediana Empresa (FONAPyME). En ambos casos se trata de aportes del Estado nacional dirigidos a facilitar el acceso de las pymes al crédito para la adquisición de capital de trabajo, bienes de capital, inversiones en activo fijo, entre otras cosas. Por último, el Programa Nacional para el Desarrollo de Parques Industriales en el Bicentenario está destinado a brindar financiamiento a las pymes que deseen instalarse en un parque industrial público, o que ya se encuentren instaladas en tales parques.

\section{E. Políticas tributarias para favorecer la inversión}

Suele aceptarse que el objetivo principal del sistema tributario de un país consiste en recaudar los recursos necesarios para financiar la provisión de bienes y servicios públicos del Estado. Así, si con una determinada reforma tributaria se lograra generar mayores ingresos, una alternativa posible sería utilizar esos ingresos para incentivar las inversiones y estimular el crecimiento, en la medida en que permitiesen financiar no solo nueva inversión pública sino algunos mecanismos de promoción de la inversión privada. Sin embargo, los instrumentos tributarios también pueden utilizarse con los mismos fines, pero de una manera alternativa, es decir, mediante la reducción de la carga impositiva efectiva y la consecuente renuncia del Estado a una parte de la recaudación que correspondería obtener de determinados contribuyentes o actividades. Esa resignación de recursos se conoce como "gasto tributario", concepto que ha cobrado relevancia en los últimos años ante la necesidad de cuantificar y transparentar ese tipo de intervención estatal en la economía.

En realidad, los gastos tributarios suelen responder a una amplia serie de objetivos de política, por ejemplo, el estímulo del empleo formal, la protección de la industria nacional, o incluso la moderación del efecto regresivo de algunos tributos sobre sectores vulnerables de la población. Otro caso particular (y ampliamente difundido) de gasto tributario son los denominados "incentivos tributarios a la inversión". Se trata de beneficios y concesiones en el régimen general de tributación que buscan impulsar en los agentes económicos (de manera indirecta, al reducir los costos implícitos de las empresas) determinados comportamientos conducentes a lograr un aumento de los niveles de inversión doméstica o atraer inversión extranjera, aprovechando sus efectos positivos sobre el crecimiento económico, el empleo y la adopción de nuevas tecnologías. 
Esas prácticas de tratamiento diferenciado de los contribuyentes, tan difundidas y utilizadas en décadas pasadas, plantean interrogantes acerca de su justificación económica, tanto desde el punto de vista de la eficiencia como de la equidad que deberían prevalecer en todo sistema tributario.

En ese sentido, se advierte la necesidad de considerar si se podrían generar espacios fiscales (entendidos como fuente de financiamiento de gasto público) mediante la ampliación de la base imponible y la reducción de gastos tributarios redundantes (sobre todo de índole económica). Esto permitiría, además, fortalecer la inversión pública sin afectar de manera significativa el nivel de inversión privada, en tanto los beneficios tributarios no constituyan determinantes principales de esa inversión.

Los esquemas de beneficios tributarios incluidos en la legislación promocional que se afianzó en los años setenta dieron lugar a una importante reestructuración del aparato industrial local, en especial con la expansión de la producción local de productos básicos industriales de uso difundido (productos siderúrgicos y petroquímicos, celulosa y papel, aluminio, entre otros), en plantas de alta intensidad de capital con bajo contenido de ingeniería y valor agregado local. Los diferimientos impositivos habrían financiado una alta proporción de la inversión física en los nuevos establecimientos de esos sectores de actividad (Katz, 1993) ${ }^{12}$.

De manera simultánea, se incorporaron esquemas de desarrollo territorial destinados a compensar diferencias productivas regionales, siguiendo los objetivos compartidos por la introducción del Fondo de Desarrollo Regional en la Ley de Coparticipación Federal de Impuestos de 1973 (Ley núm. 20221). Un año antes se había creado el régimen especial para Tierra del Fuego (Ley núm. 19640). Entre 1979 y 1983, se estableció el régimen de promoción de las provincias de La Rioja, San Luis, Catamarca y San Juan, y en 1983, el de estímulo a las exportaciones por puertos patagónicos, prorrogado en 1996.

Los principales beneficios instituidos por el régimen de Tierra del Fuego y el de promoción de las cuatro provincias mencionadas fueron la doble liberación del pago del impuesto sobre el valor agregado (IVA) (compras y ventas), la exención del pago del impuesto a las ganancias y del impuesto a la ganancia mínima presunta, y la liberación de los derechos de importación de maquinarias e insumos, entre otros. Además, el régimen de promoción de las exportaciones por puertos patagónicos fijaba otros reembolsos sobre las ventas externas realizadas a través de esos puertos.

12 Antes de esa legislación, el desarrollo de la industrialización sustitutiva de importaciones desde los años treinta se había basado en instrumentos de protección arancelaria, tipos de cambio diferencial, financiamiento subsidiado y otros subsidios explícitos (Díaz Alejandro, 1970; Mallon y Sourrouille, 1973). 
De manera paralela, en 1977 el Gobierno militar dispuso un régimen de promoción industrial (Ley núm. 21608) por el que se otorgaron subsidios y protecciones que contribuyeron a la instalación o el crecimiento de grandes plantas productoras de insumos industriales, como cemento, pasta celulósica, productos químicos y petroquímicos, acero, aluminio y textiles. Por su carácter general, lejos de apuntar a consolidar una política industrial nacional, benefició solo a un número reducido de proyectos y empresas.

Por otro lado, se fueron introduciendo distintos regímenes sectoriales que se orientaron a estimular determinadas actividades y sectores. Tal ha sido el caso de los regímenes de promoción de la minería, instituidos en 1979 y continuados en 1993; de las ventas de bienes de capital de fabricación nacional, instaurado en el año 2001; de la industria del software, en 2004, y de la renovación del parque automotor (Plan Canje), de 1999. Los principales beneficios introducidos por tales regímenes han sido la estabilidad fiscal, que pone las actividades favorecidas fuera del alcance de cualquier reforma tributaria posterior a la sanción de la Ley durante un período de 10 a 30 años; las deducciones especiales en el pago del impuesto a las ganancias; los tratos preferenciales para la amortización de capital, el permiso de pago de impuestos nacionales con bonos de crédito fiscal y la exención del pago de derechos a la importación de bienes de capital.

Por último, otros regímenes han sido el de promoción de las pequeñas y medianas empresas (pymes), sancionado en 1995; el programa nacional de apoyo al empresariado joven, de 2004, y el plan de competitividad, de 2001. Los beneficios tributarios así establecidos fueron, básicamente, la concesión de exenciones o deducciones del pago del impuesto a las ganancias, el permiso de pago de impuestos nacionales con certificados de crédito fiscal, la exención en el pago del impuesto a la ganancia mínima presunta, entre otros.

Más recientemente, entre las principales medidas orientadas a incentivar y promover la inversión productiva mediante la compra de bienes de capital e infraestructura, se destaca la reducción del arancel de importación para importadores de bienes de capital nuevos, gestionado por la Dirección General de Aduanas. Además, se estableció un esquema de incentivos a la producción de bienes de capital, informática, telecomunicaciones y maquinaria agrícola, con un reintegro del $14 \%$ para los productores locales, aplicables al pago del IVA, el impuesto a las ganancias, los impuestos internos y la ganancia mínima presunta.

En lo que respecta a la promoción económica de carácter sectorial, en la última década se han creado y consolidado algunos regímenes especiales que incluyen la producción automotriz y de piezas de repuesto, el desarrollo y la producción de la biotecnología moderna, la producción y 
uso de biocombustibles, la producción de motocicletas y piezas de repuesto, la inversión en la explotación de hidrocarburos, las fuentes renovables de energía y el régimen de la industria audiovisual.

Vale señalar que la mayoría de los esquemas promocionales vigentes ha mostrado una gran inercia y resistencia a modificaciones en su estructura ${ }^{13}$. Ello ha dado lugar a la consolidación de los derechos adquiridos a lo largo de los últimos 40 años. Gracias a la gran coincidencia de intereses provinciales a favor de esos derechos, se ha garantizado una larga supervivencia de los beneficios originales. De hecho, se logró sortear con creces los límites que impusieron las graves crisis económicas y fiscales sufridas por el país y la creciente y generalizada convicción acerca de las severas limitaciones, irregularidades y distorsiones conexas.

Uno de los principales aspectos a la hora de analizar la relevancia de los gastos tributarios como herramienta de política radica en la cuantificación del costo fiscal incurrido. Ese concepto se refiere al monto de recaudación que se resigna al introducir ese tipo de excepciones en el régimen general de tributación. En la Argentina, esa tarea es responsabilidad de la Dirección Nacional de Investigación y Análisis Fiscal (Ministerio de Economía y Finanzas Públicas), donde se recopila la información legislativa y se realizan las estimaciones correspondientes a ese tipo de beneficios tributarios. La información sistematizada se presenta periódicamente en sendos presupuestos trienales de gastos tributarios.

De acuerdo con dichas estimaciones oficiales, se ha podido comprobar que el nivel de gastos tributarios en términos absolutos (en millones de pesos corrientes) se ha incrementado acentuadamente de 2001 a 2013, a la par del crecimiento de los recursos tributarios (véase el gráfico IX.6). En términos relativos, no obstante, los valores se han mantenido en torno al 2,4\% del PIB en el período analizado ${ }^{14}$.

13 A ello habría que sumar la muy heterogénea gama de instrumentos de promoción provinciales, que suelen incluir la exoneración temporal de los impuestos provinciales (ingresos brutos, propiedad inmueble, automotores y sellos, entre otros), así como la reducción de las tarifas de servicios públicos. En ese sentido, han adquirido una importancia creciente los denominados "parques industriales" de jurisdicción provincial o municipal, con coordinación en la órbita nacional, dentro de cuyos límites se contemplan incentivos tributarios provinciales y líneas de crédito subsidiadas, además de asegurar la infraestructura básica para el desarrollo de actividades productivas.

14 En realidad, el presupuesto de gastos tributarios en la Argentina adopta una metodología ex ante, según la cual es posible proyectar las cifras correspondientes a los tres años siguientes al momento de estimación. En virtud de ello, los cálculos oficiales sugieren que el nivel de franquicias tributarias ascendería al 2,70\% del PIB en 2014 y al 2,86\% en 2015 (siempre considerando las excepciones de carácter permanente y no transitorias, como podría ser el diferimiento de determinados tributos). Aquí se presentan los datos solo hasta 2013, el último año disponible en materia de carga tributaria a nivel nacional y de producto interno bruto. 


\section{Gráfico IX.6 \\ Argentina: gastos tributarios del gobierno central \\ (impuestos nacionales), 2001-2013}

(En millones de pesos, y en porcentajes del PIB y de la recaudación total)

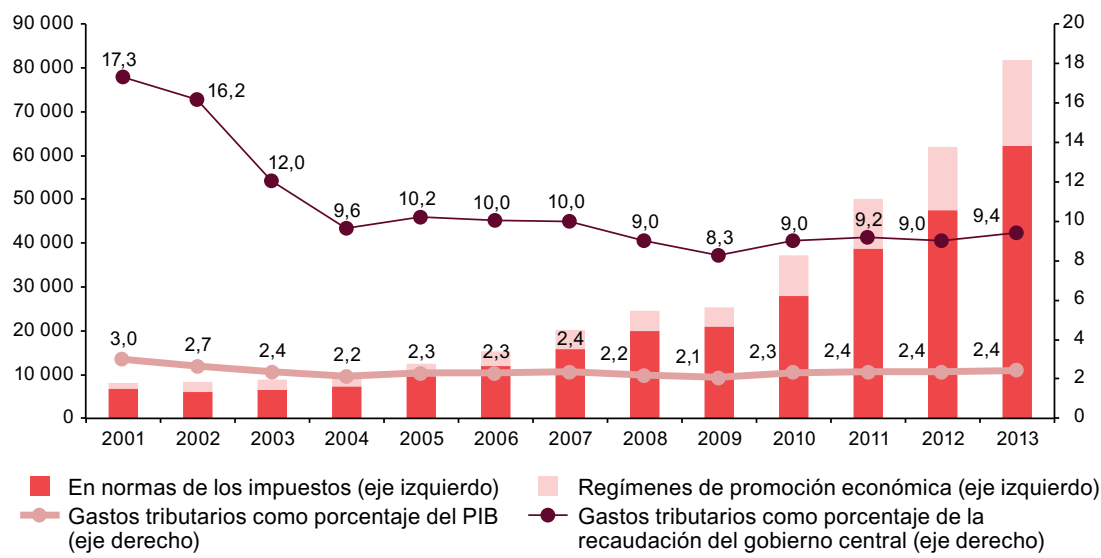

Fuente: Elaboración propia, sobre la base de información de la Dirección Nacional de Investigaciones y Análisis (DNIAF), Secretaría de Hacienda, Ministerio de Economía y Finanzas Públicas.

Respecto del nivel de recaudación total del gobierno central (sin incluir las provincias), el peso relativo de esos beneficios tributarios ha descendido de forma pronunciada en los primeros años de la década pasada, pasando del 17,3\% al 9,6\%, hasta estabilizarse a lo largo de los últimos años en un rango de participación relativa entre el $9 \%$ y el 10\% del total ingresado a nivel nacional (un 9,4\% en 2013). Aún con la dificultad que implica la comparación entre países debido a la falta de consenso metodológico, el nivel actual de gastos tributarios en la Argentina es uno de los más bajos de América Latina, tanto en porcentajes del PIB como del monto total de ingresos tributarios (Gómez Sabaini y Morán, 2014).

En cuanto a la estructura de composición de los gastos tributarios, puede afirmarse que la Argentina se halla en línea con la tendencia regional, según la cual esos tratamientos especiales se encuentran concentrados en el IVA (un 50\% del total) y en el impuesto a las ganancias (un $21,5 \%$ del total). El menú de franquicias tributarias vigentes se completa con una serie de exenciones y reducciones de alícuotas en las contribuciones a la seguridad social $(11,1 \%)$, el impuesto a los combustibles $(6,8 \%)$, los tributos sobre el comercio internacional $(4,6 \%$ ) y otros impuestos internos $(5,0 \%)$ (como el que grava los productos electrónicos), siendo marginal la participación del resto de los tributos (véase el gráfico IX.7). 


\section{Gráfico IX.7}

Argentina: composición de gastos tributarios por tipo de impuesto, 2013

(En porcentajes de la recaudación total del gobierno central)

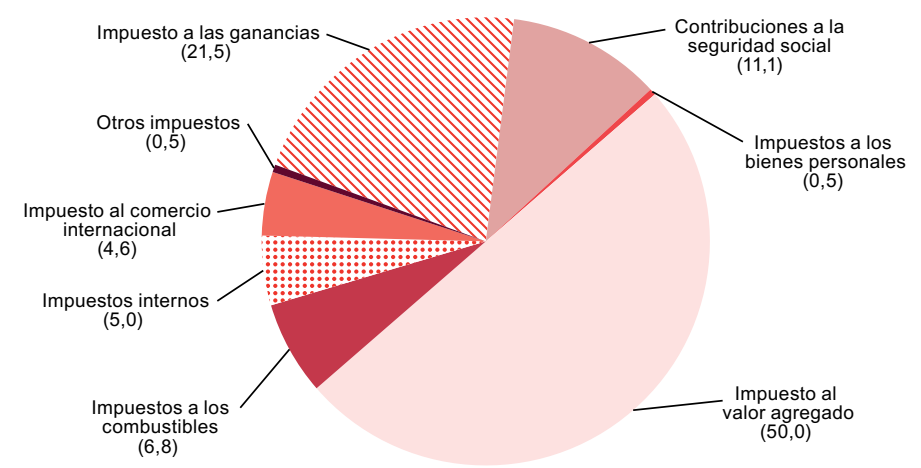

Fuente: Elaboración propia, sobre la base de información de la Dirección Nacional de Investigaciones y Análisis Fiscal (DNIAF), Secretaría de Hacienda, Ministerio de Economía y Finanzas Públicas.

Debe destacarse que, en los presupuestos de gastos tributarios disponibles, es posible distinguir los tratamientos diferenciales contenidos en la propia legislación tributaria (que responde a múltiples objetivos de política económica) de los incluidos en regímenes de promoción económica, que guardan una relación más directa con el propósito de favorecer las inversiones privadas. A lo largo del período analizado, la cuantía de los primeros siempre ha superado con creces la de los regímenes especiales, cuya representatividad en el monto total otorgado por el gobierno central se ha mantenido en un rango del $15 \%$ al $25 \%$.

A modo ilustrativo, en el caso de las franquicias contenidas en la legislación se destacan las referidas al IVA, ya sea mediante exenciones (servicios educativos y prestaciones médicas a obras sociales y al Instituto Nacional de Servicios Sociales para Jubilados y Pensionados (INSSJP), ventas e importaciones de medicamentos, intereses por préstamos de bancos a todos los niveles de gobierno, asociaciones deportivas y espectáculos deportivos de aficionados y venta de libros, folletos e impresos) o mediante la aplicación de alícuotas reducidas a determinados servicios (construcción de viviendas, transporte de pasajeros, medicina prepagada y sus prestadores) y bienes (carnes vacunas, frutas, legumbres y hortalizas frescas, productos de panadería) ${ }^{15}$.

En lo que respecta al impuesto a las ganancias, existen dos conceptos que han mostrado un notable crecimiento en los últimos cinco años (tanto en

15 Un elemento adicional, originalmente transitorio, pero que se ha prorrogado ininterrumpidamente desde 2001 hasta la actualidad, se refiere a la devolución parcial del IVA incluido (un 5\% nominal, un $4,13 \%$ efectivo sobre el precio final) en compras con tarjetas de débito o crédito (desde 2008 solo se mantiene vigente para tarjetas de débito). 
términos absolutos como relativos) y que actualmente representan alrededor del $60 \%$ del gasto tributario en ese gravamen: i) la exención del gravamen a las ganancias de asociaciones civiles, fundaciones, mutuales y cooperativas, y ii) la exención de su pago sobre los intereses de depósitos en entidades financieras y de obligaciones negociables. A ellos habría que agregar, en un segundo escalón, la exención de los intereses provenientes de títulos públicos $\mathrm{y}$ de los ingresos de magistrados y funcionarios de los poderes judiciales nacional y provinciales.

Otros gastos tributarios importantes incluidos en la legislación argentina son: i) la reducción de aportes patronales por zona geográfica (diferencia respecto de la vigente en la Ciudad Autónoma de Buenos Aires), que en 2013 representó, individualmente, la mayor franquicia en términos absolutos (más de 8.500 millones de pesos y alrededor del 0,25\% del PIB), y las diferencias entre las alícuotas aplicadas (del impuesto sobre los combustibles líquidos y el gas natural) respecto de las naftas (gasolinas) y la exención del gravamen a los combustibles líquidos utilizados en la zona sur del país.

Tal como se ha mencionado anteriormente, en lo que respecta específicamente a los regímenes de promoción económica, es posible definir varios beneficios tributarios referidos al IVA. El más destacado, por su magnitud económica, es el contemplado para la provincia de Tierra del Fuego (Ley núm. 19640), que representa el 17,3\% del gasto tributario total en este gravamen y un $8,6 \%$ del gasto tributario total a nivel nacional. En realidad, este paradigmático régimen de promoción económico-geográfica exime del pago de los impuestos nacionales por hechos, actividades $\mathrm{u}$ operaciones que se realicen en dicho territorio, a personas naturales, personas jurídicas y sucesiones indivisas, en tanto que las importaciones y las exportaciones están exentas de impuestos aduaneros.

En suma, el régimen de Tierra del Fuego representó en 2013 un costo fiscal de 15.383,6 millones de pesos, o el equivalente al 0,46\% del PIB. Resulta notable que ese monto represente casi el $78 \%$ del gasto tributario nacional en regímenes de promoción. Lo sigue muy de lejos el régimen aplicable a la producción y el uso sostenible de biocombustibles (bioetanol), en cuyo marco se establece la exención del impuesto sobre los combustibles líquidos y el gas natural (Ley núm. 23966) y del impuesto sobre la transferencia o importación de naftas y sobre el gas natural (Ley núm. 26181), que alcanzó los 1.925,8 millones de pesos en 2013.

Al igual que en el caso del IVA, la mayoría de los regímenes de promoción incluyen tratamientos particulares en el impuesto a las ganancias (quizás en mayor número, pero no en magnitud) entre los beneficios ofrecidos. Vale señalar que los gastos registrados en ese tributo suelen ser los que más perjudican la equidad del sistema tributario, ya que generalmente favorecen a sectores de la sociedad que se ubican en los deciles superiores de ingreso. 
En general, el tratamiento de los incentivos y gastos tributarios en la Argentina suele presentar obstáculos y debilidades similares a los encontrados en otros países latinoamericanos. En particular, varias veces se ha observado la falta de transparencia en el otorgamiento de las medidas promocionales en materia tributaria. No solo el monto de los beneficios otorgados puede considerarse significativo en términos de la carga tributaria del país, sino que los mecanismos utilizados en la aprobación de proyectos particulares y el mecanismo de diferimientos impositivos permitidos han hecho que el sistema se torne altamente proclive a la evasión y la corrupción.

En ese sentido, la inclusión masiva del IVA dentro del conjunto de las herramientas tributarias para incentivar las inversiones es lo que introduce mayores distorsiones y da lugar a maniobras claramente ilegales, lo que además crea serios problemas de administración del régimen.

En definitiva, suele argumentarse que gran parte de los incentivos tributarios tienen el objetivo primordial de favorecer el desarrollo de sectores productivos o regiones consideradas estratégicas, en la medida en que alienten un aumento de los niveles de inversión y crecimiento económico. Sin embargo, los exiguos resultados obtenidos muestran que, en muchos casos, esos instrumentos no solo no lograron traducirse en un aumento de la formación bruta de capital y un mayor nivel de actividad económica, sino que, en ocasiones, han estado asociados con episodios de corrupción. En gran parte fueron aprovechados de manera oportunista por empresas que los usufructuaron con el fin de aumentar su tasa de rentabilidad mediante la reducción del costo que implica el pago de determinados impuestos. Como resultado global, la utilización de esos incentivos ha logrado modificar la distribución regional o sectorial de la inversión dentro del propio país, pero sin aumentar sustancialmente la tasa de inversión nacional. El caso paradigmático en la Argentina ha sido, y sigue siendo, el régimen de promoción económica instrumentado en el territorio de Tierra del Fuego.

En cuanto a la generación de empleos, pudo comprobarse algo similar en décadas pasadas sobre el régimen de reparación histórica que se había aplicado en cuatro provincias (Catamarca, La Rioja, San Juan y San Luis). Los puestos de trabajo que aparecían en una localidad se perdían en otra, con lo que el costo fiscal de los empleos creados se hizo demasiado elevado, e incluso se generaba un valor agregado negativo al superar el sacrificio fiscal a los salarios pagados.

Por lo tanto, aunque puedan encontrar justificación en casos puntuales, los incentivos tributarios tienen un impacto negativo sobre la equidad y la eficiencia. La renuncia de un monto de ingresos tributarios limita el espacio fiscal y, por consiguiente, la inversión social. Por otra parte, al concederse beneficios a un grupo determinado de contribuyentes o actividades, se genera una pérdida de equidad horizontal. En términos de eficiencia, y como ya 
se señaló, esos instrumentos crean problemas de competencia tributaria interjurisdiccional y otras distorsiones en las decisiones de localización y producción industrial, sobre todo cuando introducen inequidades respecto de otras actividades o regiones que tributan normalmente. En todo caso, la escasez de estudios y estimaciones precisas sobre los efectos reales de los gastos tributarios sobre la inversión y la actividad económica no hace más que poner en duda la necesidad y la eficacia de esos gastos para cumplir esos objetivos, y refuerza los inconvenientes mencionados.

\section{F. Reflexiones finales}

Con una perspectiva de mediano plazo, puede decirse que, desde la recuperación de la democracia en 1983, en la definición de la política fiscal se debió tener en cuenta la existencia de un contexto macroeconómico sumamente complejo. En aquellos momentos, la renegociación de la deuda externa y el control del proceso inflacionario eran las preocupaciones principales (aunque no las únicas). A lo largo de la historia argentina se puede observar una elevada tensión entre los diversos objetivos de la política fiscal (fundamentalmente, la estabilización macroeconómica, la sostenibilidad de la deuda, la distribución del ingreso y la eficiencia). La gran volatilidad macroeconómica se evidenció mediante fuertes cambios del nivel de actividad, relacionados por lo general con las conmociones externas, y derivó en reducidos márgenes de maniobra para la política fiscal.

Bajo esas condiciones, las instituciones fiscales de la Argentina han sido el resultado de una sucesión de medidas de emergencia que, o bien debido a circunstancias económicas extremas, o bien por la adopción de soluciones con rédito político a corto plazo, no han encontrado o no han buscado soluciones coherentes a problemas estructurales (Cetrángolo, 2014). A pesar de la ruptura que significó el mayor espacio fiscal para las reformas, de la mano de modificaciones sustantivas en el nivel y la estructura impositiva, no se vio afectada la continuidad que, a lo largo de décadas, se ha mostrado como una ausencia de visión a largo plazo. Ello ha podido observarse, por ejemplo, en las modificaciones del sistema de protección de la población adulta mayor, el mantenimiento de una elevada conflictividad y precariedad en las relaciones entre la nación y las provincias y, sin duda, en la falta de revisión de las medidas tributarias de emergencia.

Por lo tanto, es imprescindible tener en cuenta esos rasgos característicos de la Argentina al evaluar la sostenibilidad de la política fiscal y los impactos sobre la inversión y el crecimiento a mediano plazo. Los desafíos que involucran los problemas estructurales del país exigen reglas explícitas, coherentes (tanto internamente como en relación con otras reglas), flexibles y sostenibles a lo largo del tiempo (Acuña y Chudnovsky, 2013). La dificultad para acordar 
reglas de funcionamiento estables, que se anticipen a las emergencias y no sean resultado de necesidades a corto plazo, es la causa principal de la precariedad institucional del Estado argentino. El "buen Estado" no es el que encuentra soluciones de emergencia cuando los problemas son inevitables, sino el que se anticipa a ellos.

Hay dos tendencias actuales en la esfera de la inversión pública que, al menos en América Latina y otros países en desarrollo, gozan de un creciente apoyo y difusión. Por un lado, se apunta a fortalecer la interacción entre el sector público y el privado para obtener mayores niveles de inversión global. Las asociaciones público-privadas (APP), como iniciativas de colaboración voluntaria entre ambos actores para lograr un propósito común o emprender tareas específicas, son un ejemplo moderno de ello. En la Argentina existen hoy algunos ejemplos incipientes (Energía Argentina S.A. (ENARSA), Empresa Argentina de Soluciones Satelitales Sociedad Anónima (ARSAT), Yacimientos Petrolíferos Fiscales (YPF)), sobre todo en los sectores económicos en que el Estado muestra interés por intervenir, pero carece de la capacidad que pueden brindarle las empresas. Por otro lado, existe consenso acerca de la importancia de consolidar los sistemas nacionales de inversión pública (Perroti y Rueda, 2015) de forma que se puedan encauzar distintos proyectos y se puedan evaluar objetivamente, tanto desde la óptica privada como social. La creciente injerencia de la ANSES como promotora de la inversión pública (más allá de contar con mecanismos institucionales de control y gestión) no parece coincidir con ese objetivo y plantea ciertos riesgos cuando se trata de establecer necesidades y prioridades en esa materia.

En un contexto caracterizado por la falta de preocupación por el largo plazo, la política de inversión pública y fomento de la inversión privada tampoco ha sido objeto de un debate serio a la luz de las dificultades del pasado. La necesidad de redefinir estrategias de mayor alcance temporal en relación con la inversión se suma a las importantes demandas de reformas estructurales en las políticas públicas. Por citar solo tres, puede decirse que, en primer lugar, hoy parece claro que la persistencia de cierto nivel de desempleo y la elevada informalidad laboral determinan la insuficiencia de las políticas sociales de base contributiva. Más que nunca, el cierre de las brechas sociales y el aseguramiento de la igualdad de derechos exigen una reformulación de las políticas de protección social para que puedan ser coherentes con un enfoque de derechos ciudadanos. Es indudable que la introducción del programa Asignación Universal por Hijo (AUH) representa un cambio significativo en esa dirección.

En segundo lugar, después de las reformas de la política y la administración tributarias que se sucedieron durante las últimas décadas, la Argentina logró alcanzar al fin una carga tributaria que superó la barrera de los 30 puntos porcentuales del PIB. Actualmente se ubica en el segundo 
lugar de la región, detrás del Brasil. Sin embargo, las reformas introducidas hasta el momento no han logrado configurar una estructura tributaria balanceada. Se ha mantenido el histórico sesgo a favor de la imposición indirecta y la presencia de instrumentos tributarios de emergencia. Es sabido que los mejores sistemas fiscales son los que obtienen de manera coherente un nivel de carga suficiente para solventar los gastos, y no los que requieren incrementos anuales por su mayor volatilidad, ya que introducen un factor de incertidumbre que afecta las decisiones privadas. El fortalecimiento de la administración tributaria y la lucha contra la evasión son caminos ineludibles para alcanzar dicho objetivo.

También queda un margen importante para aumentar la equidad y eficiencia de la tributación, en especial con la eliminación de los tratos diferenciales que carezcan de suficiente justificación. En ese sentido, la virtual inexistencia de mecanismos de evaluación periódica de los incentivos tributarios y de los programas de financiamiento público destinados a favorecer las inversiones privadas impide solucionar una serie de problemas comúnmente derivados de su aplicación. Entre estos figuran no solo la resignación de recursos públicos, sino los costos excesivos, la rigidez en la innovación y la falta de transparencia, que da pie a maniobras de corrupción.

\section{Bibliografía}

Acuña, C. y M. Chudnovsky (2013), "Cómo entender a las instituciones y su relación con la política: Lo bueno, lo malo y lo feo de las instituciones y los institucionalismos", ¿Cuánto importan las instituciones? Gobierno, Estado y actores en la política argentina, C. Acuña (comp.), Buenos Aires, Siglo XXI.

Albrieu, R. y O. Cetrángolo (2011), "Volatilidad macroeconómica y política fiscal en Argentina", Volatilidad macroeconómica y respuestas de política, J.M. Fanelli, J.P. Jiménez y O. Kacef (comps.), Documento de Proyecto (LC/W.396), Santiago, Comisión Económica para América Latina y el Caribe (CEPAL).

Arslanalp, S., F. Bornhorst y S. Gupta (2011), "Inversión y crecimiento", Finanzas y Desarrollo, Washington, D.C., Fondo Monetario Internacional.

Bertranou, F. y otros (2011), Encrucijadas en la seguridad social argentina: reformas, cobertura y desafíos para el sistema de pensiones, Buenos Aires, Comisión Económica para América Latina y el Caribe (CEPAL)/Organización Internacional del Trabajo (OIT).

Cetrángolo, O. (2014), "Política y economía de la política fiscal", Dilemas del Estado Argentino. Política exterior, económica y de infraestructura en el siglo XXI, C. Acuña (comp.), Buenos Aires, Siglo XXI.

Cetrángolo, O. y J.C. Gómez Sabaini (2012), “Evolución reciente, raíces pasadas y principales problemas de las cuentas públicas argentinas", Boletín Informativo Techint, $\mathrm{N}^{\circ}$ 338, Buenos Aires, Techint.

Cetrángolo, O., J.C. Gómez Sabaini y D. Morán (2015), “Argentina: reformas fiscales, crecimiento e inversión (2000-2014)", serie Macroeconomía del Desarrollo, No 165 (LC/L.4042), Santiago, Comisión Económica para América Latina y el Caribe (CEPAL). 
Cetrángolo, O. y C. Grushka (2004), "Sistema previsional argentino: crisis, reforma y crisis de la reforma", serie Financiamiento del Desarrollo, No 151 (LC/L.2219-P), Santiago, Comisión Económica para América Latina y el Caribe (CEPAL).

Díaz Alejandro, C. (1970), Ensayos sobre la historia económica argentina, Buenos Aires, Amorrortu.

Fanelli, J.M. (2013), "Política fiscal e inversión: un enfoque sistémico y de crecimiento inclusivo", serie Macroeconomía del Desarrollo, No 127 (LC/L.3556), Santiago, Comisión Económica para América Latina y el Caribe (CEPAL).

Gómez Sabaini, J.C. y D. Morán (2013), “Política tributaria en América Latina: agenda para una segunda generación de reformas", serie Macroeconomía del Desarrollo, No 133 (LC/L.3632), Santiago, Comisión Económica para América Latina y el Caribe (CEPAL).

Katz, J. (1993), “Organización industrial, competitividad internacional y política pública", El desafío de la competitividad. La industria argentina en transformación, B. Kosacoff (comp.), Buenos Aires, Comisión Económica para América Latina y el Caribe (CEPAL) / Alianza Editorial.

Mallon, R. y J. Sourrouille (1973), La política económica en una sociedad conflictiva, Buenos Aires, Amorrortu.

Martner, R. y V. Tromben (2005), “Opciones para enfrentar el sesgo anti-inversión pública", serie Gestión Pública, N 50 (LC/L.2321-P), Santiago.

Martner, R., A. Podestá e Ivonne González (2013), "Políticas fiscales para el crecimiento y la igualdad", serie Macroeconomía del Desarrollo, No 138 (LC/L.3716), Santiago, Comisión Económica para América Latina y el Caribe (CEPAL).

Perroti, D. y M. Rueda (2015), “Avances y retos de los sistemas nacionales de inversión pública de América Latina: resultados de la encuesta 2014", serie Gestión Pública, No 83 (LC/L.3988), Santiago, Comisión Económica para América Latina y el Caribe (CEPAL). 


\title{
Capítulo X \\ Reformas fiscales, crecimiento e inversión: los casos de Guatemala, Nicaragua y Panamá ${ }^{1}$
}

\author{
Maynor Cabrera ${ }^{2}$ \\ Juan Alberto Fuentes Knight ${ }^{3}$
}

\section{Introducción}

La Comisión Económica para América Latina y el Caribe (CEPAL) ha elaborado propuestas dirigidas a materializar pactos sociales que promuevan la igualdad y la sostenibilidad ambiental. En dichas propuestas, los pactos fiscales para la inversión resultan de especial importancia, pues requieren decisiones de política e iniciativas en materia tributaria, de gasto público y de asociaciones público-privadas. En años recientes, el nivel de recaudación se ha elevado en algunos casos como consecuencia de importantes reformas tributarias $\mathrm{y}$, en otros, por el pronunciado aumento de los ingresos provenientes de empresas exportadoras de materias primas en algunos países de la región. El gasto público también se ha incrementado, sobre todo en los rubros de inversión pública, transferencias condicionadas y pensiones mínimas. Sin embargo, las brechas de inversión siguen siendo significativas, por lo que

Este capítulo es una versión resumida de Cabrera (2015).

2 Director Asociado del Instituto Commitment to Equity (CEQ) de la Universidad de Tulane de los Estados Unidos. Correo electrónico: maynor.cabrera@ceqinstitute.org.

3 Ex-Director de la División de Desarrollo Económico de la Comisión Económica para América Latina y el Caribe (CEPAL). Correo electrónico: fuentesknight@yahoo.com. 
resulta necesario consolidar lo logrado, con miras a alcanzar los Objetivos de Desarrollo Sostenible.

En estudios como el de Manuelito y Jiménez (2015) se destaca el bajo nivel de inversión de América Latina, la reducción de la inversión pública en los años ochenta y su parcial recuperación junto con la inversión privada entre 2003 y 2010. En este capítulo se presentan tres casos de países de la región, dos de ellos con niveles de inversión como proporción del producto interno bruto (PIB) cercanos al promedio latinoamericano (Panamá y Nicaragua) y otro con niveles por debajo de dicho promedio (Guatemala).

Esos tres países han mostrado un desempeño económico relativamente favorable en la subregión centroamericana. Han registrado una recuperación de las tasas de crecimiento, aunque con escenarios diversos en materia de política fiscal y evolución de la inversión pública y privada. Tomando en cuenta el marco propuesto por Fanelli (2013), puede encontrarse en ellos un uso diferenciado de políticas fiscales para la inversión como incentivos fiscales, en mayor grado en Nicaragua y Guatemala, mientras que en Panamá hay una mayor dependencia de la inversión pública. La elección de esas políticas está condicionada por la disponibilidad de espacios fiscales. A priori, esto parecería favorecer a Nicaragua y a Panamá, por la mejora sustancial del crecimiento económico en ambos casos, así como por la inyección sustantiva de recursos que ha recibido Nicaragua por parte de la cooperación venezolana.

\section{A. Evolución de la inversión y de su composición}

En Centroamérica, la inversión aún no recupera los niveles previos a la crisis internacional de 2009. Durante 2007, en promedio equivalía a un 25,9\% del PIB, mientras que de 2010 a 2014 no ha superado el 22,5\% del producto. No se observa en los países una tendencia hacia la recuperación sostenida de los niveles de inversión, sino más bien hacia la baja, con la excepción de Panamá.

Un factor determinante de la tendencia negativa de la formación bruta de capital en los países centroamericanos ha sido la contracción de la inversión pública, explicada mayormente por una reducción generalizada del espacio fiscal. Sin embargo, de esa situación escapan Nicaragua y Panamá, donde la inversión pública ha aumentado y los déficit fiscales no se han ampliado, sino que han permanecido en niveles cercanos al 1,5\% del PIB. La inversión privada, en general, también ha estado contenida, en el marco de menores expectativas de crecimiento y un menor dinamismo de la inversión extranjera directa (IED). No obstante, en algunos países se observan niveles de IED crecientes y superiores a los mostrados antes de la crisis de 2009. 
Las cifras informadas por Guatemala, Nicaragua y Panamá revelan que existen situaciones con un alto coeficiente de inversión en las que se han superado algunos de estos problemas ${ }^{4}$. Tal es el caso de Panamá y Nicaragua, mientras que en Guatemala persisten dificultades. Como puede observarse en el gráfico X.1, tanto Panamá como Nicaragua han tenido niveles de inversión cercanos al 28\% del PIB durante los últimos años (2010-2014), mucho más estables en el caso de Panamá que en el de Nicaragua. Entretanto, Guatemala ha tenido un coeficiente de inversión equivalente a un $15 \%$ del PIB durante el mismo período (el más bajo de la región centroamericana) y ha mostrado una caída pronunciada después de la crisis, de la que aún no se ha podido recuperar.

\section{Gráfico X.1}

\section{Evolución de la formación bruta de capital fijo, 2004-2014 ${ }^{a}$}

(En porcentajes del PIB)

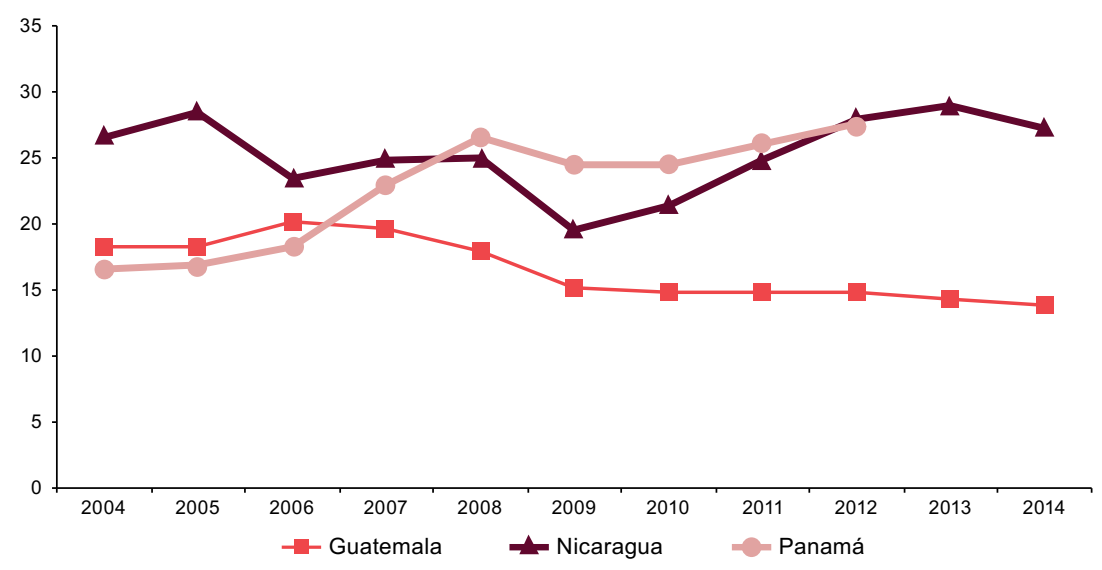

Fuente: Elaboración propia, sobre la base de datos oficiales.

a La información de Panamá está disponible hasta el año 2012.

En Panamá, el alza de la inversión se explica en mayor medida por el impulso proveniente de proyectos públicos de gran magnitud a partir de 2008 (la ampliación del canal de Panamá, la construcción del Metro de Panamá, entre otros). En Nicaragua también ha aumentado, aunque a un ritmo más lento, gracias a una menor presión sobre el gasto corriente

4 Se requiere cierta cautela con respecto a los datos sobre inversión, especialmente de Nicaragua y Panamá, puesto que han estado sujetos a revisiones o cuestionamientos debido a las diferentes formas en que se registran. En el caso de Nicaragua, los datos en que se basa este ejercicio corresponden a información disponible al primer trimestre de 2015, publicada por el Banco Central. En el caso de Panamá, es importante destacar que en el momento de recopilar los datos aquí presentados se estaba actualizando el sistema de cuentas nacionales, por lo que la información podría haber cambiado posteriormente. 
debido a la recepción de fondos de la cooperación venezolana y a la mejor perspectiva fiscal para obtener endeudamiento público. Mientras tanto, en Guatemala la inversión pública se redujo, en gran parte por la menor disponibilidad de espacio fiscal después de la crisis, a lo que se agrega que la contracción en la formación bruta de capital fijo privado no se recuperó de los niveles anteriores a la crisis de 2009 (véase el gráfico X.2). En Panamá, por el contrario, la inversión privada ha seguido creciendo al ritmo del PIB y en Nicaragua, por encima de este.

\section{Gráfico X.2}

Comportamiento de la inversión pública y privada, 2004-2014a

(En porcentajes del PIB)

A. Formación bruta de capital público

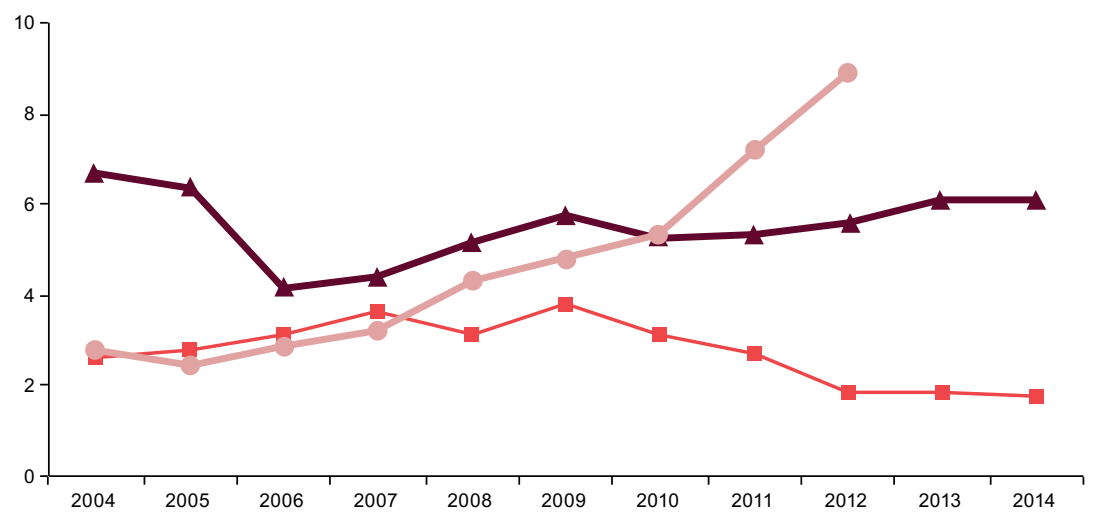

B. Formación bruta de capital privado

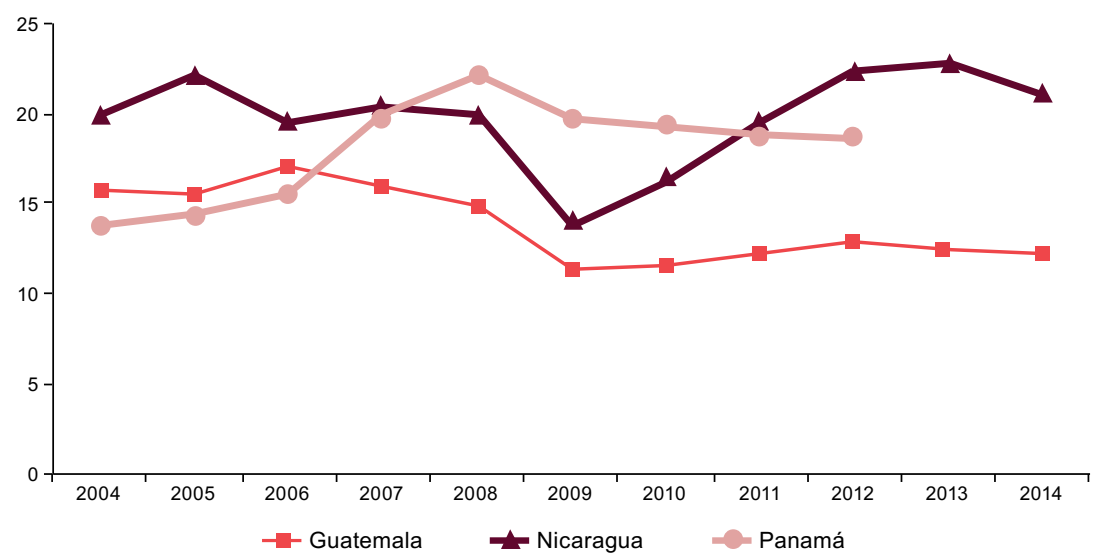

Fuente: Elaboración propia, sobre la base de datos oficiales.

a La información de Panamá está disponible hasta el año 2012. 


\section{B. Incidencia de factores sistémicos sobre los niveles de inversión}

Sobre la base de una revisión de la literatura referida a la inversión y la política fiscal en América Latina, Fanelli (2013) argumenta que se justifica acudir a la política fiscal para favorecer la inversión debido al bajo coeficiente que esta alcanza en la región, a lo que contribuyen problemas como las fallas de mercado, la existencia de complementariedades y la heterogeneidad de los agentes económicos. Según el esquema de análisis propuesto por dicho autor, se analiza en esta sección cuáles son las diferencias más importantes en términos de factores sistémicos y en qué medida estos factores pueden estar asociados a las diferencias en el comportamiento de la inversión expuestas en la sección anterior.

\section{Clima de inversión}

Los principales obstáculos que enfrentaban las empresas en 2010 varían según el país, de acuerdo con la Encuesta de Empresas del Banco Mundial ${ }^{5}$. En Guatemala, el principal problema era el delito, el robo y el desorden, fenómenos que representaban un inconveniente menor en los otros países. La electricidad era el obstáculo mas importante en Nicaragua, situación que afectó a la economía del país debido a las interrupciones de servicio que tuvieron mayor impacto durante la década anterior, pero que no representaron un problema tan importante en Panamá y Guatemala. Además, como se muestra en el cuadro X.1, se señaló la corrupción como el principal problema que afectaba a empresarios panameños, aunque también se determinó que era importante en Guatemala. En los tres países, se consideró que las prácticas de competidores del sector informal eran un problema relevante. Además, se reconoció la inestabilidad política como el tercer problema en orden de importancia en Guatemala y Nicaragua.

Al contrastar esas respuestas con los datos del informe de competitividad mundial 2014-2015, la corrupción figura como el primer obstáculo en Panamá, el segundo en Guatemala y el cuarto en Nicaragua ${ }^{6}$. La inadecuada oferta de infraestructura es el tercer problema en Guatemala y en Nicaragua, mientras que la educación de la fuerza laboral es el segundo factor problemático en Panamá y Nicaragua, y ocupa el quinto lugar en Guatemala. Además, cabe destacar la ineficiencia de la burocracia gubernamental como el tercer factor más problemático en Nicaragua y Panamá, y el cuarto en Guatemala. Por último, los temas tributarios que interfieren en los negocios se relacionan más con la administración tributaria en Guatemala y Nicaragua, mientras que

\footnotetext{
5 En esta sección se utilizan datos de la clasificación de competitividad mundial del Foro Económico Mundial y de las Encuestas de Empresas elaboradas por el Banco Mundial para evaluar el clima de inversión. Véase [en línea] http:/ / espanol.enterprisesurveys.org/.

6 Véase [en línea] http:/ / www3.weforum.org/docs/GCR2014-15/GCI_Dataset_2006-07-2014-15.xlsx.
} 
las tasas impositivas son un problema menor en todos los países analizados. Ninguno de esos factores parecería suficiente para explicar el desempeño diferente de Guatemala en relación con los otros dos países.

Cuadro X.1

Obstáculos principales para las empresas, 2010

(En porcentajes de respuestas a las encuestas)

\begin{tabular}{lrrrr}
\hline Países & $\begin{array}{c}\text { América } \\
\text { Latina }\end{array}$ & Guatemala & Nicaragua & Panamá \\
\hline Prácticas de competidores en el sector informal & 14,6 & 19,0 & 19,4 & 13,7 \\
\hline Corrupción & 7,5 & 11,4 & 7,2 & 32,5 \\
\hline Electricidad & 8,5 & 4,7 & 24,2 & 8,0 \\
\hline Delitos, robo y desorden & 9,0 & 20,8 & 7,2 & 8,8 \\
\hline Inestabilidad política & 7,8 & 16,4 & 8,8 & 2,3 \\
\hline Acceso al financiamiento & 14,7 & 6,5 & 8,8 & 3,6 \\
\hline Administración impositiva & 10,0 & 7,0 & 6,0 & 0,0 \\
\hline Otros & 28,0 & 14,3 & 18,4 & 31,2 \\
\hline
\end{tabular}

Fuente: Banco Mundial, Encuestas de Empresas [en línea] http://espanol.enterprisesurveys.org/.

a La categoría "Otros" incluye legislación laboral, transporte, tasas impositivas y acceso a terrenos.

Sin embargo, al examinar las características que distinguen a Panamá como el país de mayores niveles de inversión, surgen como factores contrastantes la estabilidad política, el acceso a financiamiento y la administración impositiva. Panamá se diferencia sobre todo de Guatemala en cuanto a la situación política, que se percibe como más inestable en el segundo país. El acceso al financiamiento es congruente con la naturaleza de Panamá como plaza financiera internacional y la ausencia de problemas en materia de administración impositiva se asocia a la importancia que tienen en ese país los puertos libres y a las facilidades tributarias que se ofrecen a los no residentes. Además de los obstáculos mencionados en el párrafo anterior, en Nicaragua y Guatemala son problemas importantes la falta de infraestructura adecuada y las deficiencias de la administración tributaria, pero no en Panamá.

\section{La menor volatilidad macroeconómica reciente}

La evidencia que existe sobre la estabilidad macroeconómica en los tres países sugiere que, aunque dicha estabilidad es una condición necesaria para realizar inversiones, las escasas diferencias en esa materia no explican el desempeño desigual en ese rubro en estos países. Las tasas de inflación de un dígito (algo mayores en Nicaragua que en Guatemala y Panamá), el uso del dólar como moneda nacional, la elevada dolarización de la economía (como la de Nicaragua) o una convertibilidad de la moneda sin restricciones (como en Guatemala) sugieren que las diferencias en ese campo tampoco son grandes. 
Aunque existen distintos niveles de calificación del riesgo soberano y la perspectiva de la situación fiscal de Guatemala es menos auspiciosa, en ningún caso su estado es crítico y el desempeño macroeconómico ha sido favorable en los últimos años. De hecho, en Guatemala, al igual que en Panamá, no se observó una caída del PIB durante la crisis de 2009. Por otra parte, en Nicaragua, país en que la trayectoria de estabilidad ha sido menos larga, no se ha firmado un acuerdo de estabilización con el Fondo Monetario Internacional (FMI) desde 2011. Con todo, el acompañamiento continuo y visible del FMI como fuente de asesoría y de monitoreo ha contribuido a la credibilidad macroeconómica reciente, aun cuando el déficit comercial, tradicionalmente alto, es fuente de vulnerabilidad macroeconómica en la medida en que se reduce la entrada de capitales.

\section{El espacio fiscal como factor relevante}

Durante los últimos años se han observado diferencias importantes en las finanzas públicas de los tres países, que han influido en el proceso de inversión tanto público como privado. En primer lugar, el desempeño de los ingresos fiscales o parafiscales ha sido un condicionante fundamental de la capacidad de contar con recursos para la inversión del sector público. En segundo lugar, la dominancia del gasto corriente, sobre todo durante etapas de menor crecimiento, ha restringido la inversión pública. En tercer lugar, la evidencia disponible sugiere que la inversión pública no ha desplazado a la privada, sino que ha sido un factor fundamental que contribuyó a dinamizarla. Por último, las brechas fiscales y la situación de sostenibilidad fiscal también han influido en la calificación de riesgo de estos países, lo que ha contribuido a generar expectativas de inversión más favorables.

En cuanto al desempeño de los ingresos fiscales, puede afirmarse que las reformas tributarias impulsadas en Panamá, Nicaragua y Guatemala tuvieron impactos diferenciados (véase el cuadro X.2) ${ }^{7}$. Las que se implementaron en Panamá contribuyeron al aumento de los ingresos tributarios como proporción del PIB. No obstante, la reducción de otros ingresos (no tributarios) derivados principalmente de la actividad del canal de Panamá (de alrededor de un $2,0 \%$ del PIB al comparar el período anterior a la crisis (2004-2008) con el período posterior (2010-2014)) neutralizó el efecto positivo de las reformas tributarias. Como resultado, el total de ingresos fiscales se redujo levemente entre los períodos anterior y posterior a la crisis.

Véase en la sección siguiente una síntesis de las reformas fiscales realizadas en Guatemala, Nicaragua y Panamá. 
Cuadro X.2

Evolución de los ingresos fiscales del sector público no financiero por períodos ${ }^{a}$ (En porcentajes del PIB)

\begin{tabular}{|c|c|c|c|c|c|c|c|c|}
\hline & \multicolumn{2}{|c|}{ Totales } & \multicolumn{2}{|c|}{ Tributarios } & \multicolumn{2}{|c|}{ Donaciones } & \multicolumn{2}{|c|}{ Otros } \\
\hline & $\begin{array}{c}2004- \\
2008\end{array}$ & $\begin{array}{l}2010- \\
2014\end{array}$ & $\begin{array}{c}2004- \\
2008\end{array}$ & $\begin{array}{c}2010- \\
2014\end{array}$ & $\begin{array}{c}2004- \\
2008\end{array}$ & $\begin{array}{c}2010- \\
2014\end{array}$ & $\begin{array}{c}2004- \\
2008\end{array}$ & $\begin{array}{c}2010- \\
2014\end{array}$ \\
\hline Guatemalab $^{\mathrm{b}}$ & 12,4 & 11,5 & 11,6 & 10,8 & 0,2 & 0,2 & 0,6 & 0,6 \\
\hline Nicaragua & 24,1 & 25,2 & 13,9 & 14,9 & 2,9 & 1,9 & 7,3 & 8,5 \\
\hline Panamá & 24,6 & 23,6 & 10,0 & 11,1 & 0,1 & 0,1 & 14,6 & 12,4 \\
\hline
\end{tabular}

Fuente: Elaboración propia, sobre la base de información de la Comisión Económica para América Latina y el Caribe (CEPAL) y datos oficiales.

a El promedio 2010-2014 para Panamá abarca hasta el año 2012.

b Gobierno central.

En Nicaragua se redujeron los ingresos provenientes de donaciones casi 1 punto porcentual del PIB, pero fueron compensados por el aumento de otros ingresos. Además, la carga tributaria aumentó gracias a un incremento de la tributación directa. Por otra parte, los fondos provenientes de la cooperación venezolana, no registrados en las cuentas fiscales, se destinaron a financiar proyectos sociales y productivos que, al menos en parte, liberaron recursos fiscales para destinarlos a otros propósitos. Se estima que el financiamiento de proyectos sociales equivalió al 1,7\% del PIB durante el período 2010-2014, mientras que para los proyectos socioproductivos habría ascendido en promedio a un 2,9\% del PIB durante el período mencionado ${ }^{8}$.

En Guatemala, los ingresos públicos se debilitaron a causa de la baja de la tributación, de la cual dependen en mayor grado que en los otros dos países. Además, no se registró una variación significativa de los ingresos no tributarios. Si bien se aprobó una reforma que incidió positivamente en los impuestos directos, su impacto se vio debilitado por un marcado deterioro de la administración tributaria, que afectó sobre todo a la tributación indirecta. También fue afectada por los procesos de apreciación cambiaria y los precios decrecientes de alimentos y combustibles, que redujeron la recaudación obtenida al aplicar impuestos a importaciones con valores menores (en moneda nacional).

En lo que se refiere a la sostenibilidad fiscal de los países, tanto en Nicaragua como en Panamá la combinación de mayores gastos del sector público y el estancamiento o alza modesta de los ingresos fiscales contribuyeron a ampliar la brecha entre ambos componentes durante el período 2004-2008 en comparación con el período anterior, aunque en bastante menor grado que en los demás países de la región. En Guatemala, el déficit fiscal estuvo por debajo del 3,5\% del PIB, mientras que en Honduras y Costa Rica superó el $5 \%$ del producto en el período posterior a la crisis (véase el gráfico X.3).

Según información del Banco Central de Nicaragua, recopilada por Consultores para el Desarrollo (COPADES). 
Gráfico X.3

Evolución del déficit fiscal y sus principales determinantes, 2004-2008 y 2010-2013a (En porcentajes del PIB)

A. Déficit fiscal
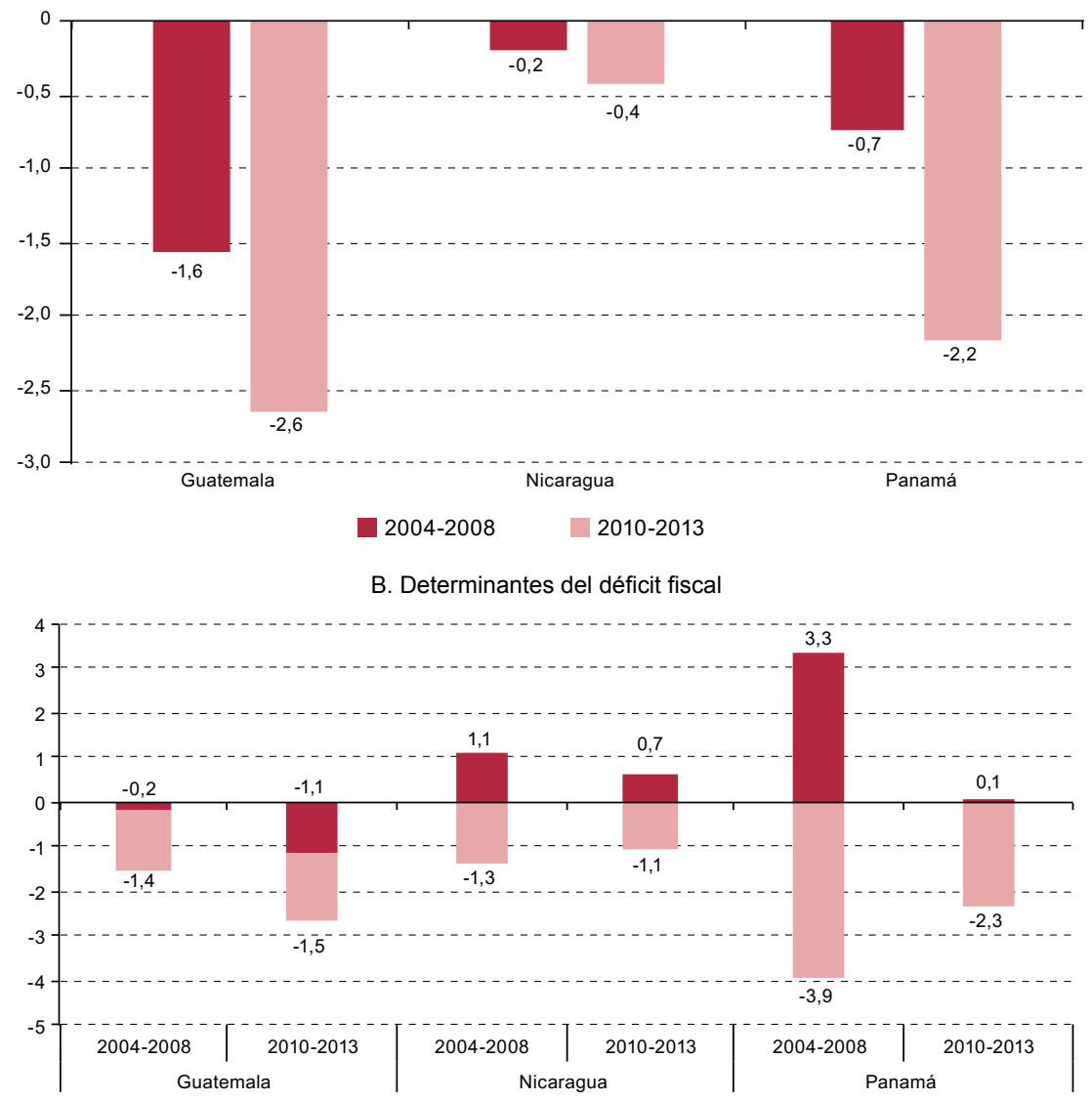

Superávit primario Intereses

Fuente: Elaboración propia, sobre la base de datos oficiales.

a Gobierno central en el caso de Guatemala y Panamá, y sector público no financiero (SPNF) en el caso de Nicaragua.

Sin embargo, esa situación de cierto balance fiscal tuvo bases muy diferentes en cada uno de los tres países y explica en buena parte la capacidad diferenciada de expandir la inversión pública en cada caso. En Guatemala, el moderado incremento de su brecha fiscal se debió a la caída de los ingresos fiscales, mientras que en Panamá se debió al incremento de la inversión pública y a la leve reducción de los ingresos. En Nicaragua el déficit aumentó, pero de manera muy modesta debido a que el aumento del gasto se equilibró con un aumento de los ingresos. 
Al descomponer la evolución del déficit según sus determinantes, se aprecia que, si bien los pagos de intereses se redujeron en Nicaragua y Panamá, los superávits primarios (la diferencia entre ingresos y gastos sin incluir el pago de intereses de la deuda) que habían existido en el período anterior a la crisis se desvanecieron durante el período 2010-2013, pero no llegaron a convertirse en déficits primarios. Guatemala, que antes de la crisis no tenía ni superávit ni déficit primario, experimentó un aumento del déficit primario en la etapa posterior, así como un leve aumento del pago de intereses, lo que puso de manifiesto su restrictivo margen de acción fiscal.

La reducción de los niveles de endeudamiento, combinada con las tasas elevadas de crecimiento que mostraron Panamá y Nicaragua, favoreció su sostenibilidad fiscal. En contraste, la situación fiscal de Guatemala era sostenible siempre que se mantuvieran niveles sumamente bajos de gasto público ante la debilidad de los ingresos fiscales. Es decir, el espacio fiscal para aumentar la inversión era prácticamente inexistente si no se fortalecían los ingresos fiscales.

En suma, el espacio fiscal disponible para la inversión pública se restringió debido a la expansión del gasto corriente en Guatemala y Nicaragua, pero no en Panamá. Se puede extraer esa conclusión al comparar su evolución después de la crisis (2010-2014) con lo ocurrido en el período previo a la crisis financiera mundial (2004-2008). En primer lugar, hubo aumentos importantes del gasto público en Nicaragua y Panamá equivalentes a alrededor de 2 puntos porcentuales del PIB, y los dos países tuvieron niveles de gasto superiores al $20 \%$ del PIB. En Guatemala, la proporción del PIB correspondiente a ambos períodos no cambió significativamente y el gasto público total se situó en alrededor del 14\% del PIB (véase el gráfico X.4).

En ese marco, se observó un gran aumento de la inversión pública en Panamá, un incremento moderado en Nicaragua y una reducción en Guatemala. En Panamá, durante el período posterior a la crisis no solo aumentó decididamente la proporción del PIB correspondiente a inversión pública, sino que lo hizo en un contexto de alto dinamismo de la economía en su conjunto. Por ese motivo, se registró en el país una tasa muy elevada de crecimiento real de la inversión pública. En cambio, de acuerdo con las estadísticas del gobierno central, en Nicaragua y Guatemala se redujo la inversión pública como proporción del PIB en la etapa posterior a la crisis en comparación con la etapa anterior. En el caso de Nicaragua se ha observado una recuperación gradual, mientras que en Guatemala la tendencia negativa ha continuado hasta 2014.

Aunque en Nicaragua disminuyó la proporción correspondiente a la inversión pública del gobierno central, la inversión total del sector público consolidado en términos del PIB parece haberse mantenido constante y se observa un alza de la inversión pública en términos reales, estimulada por 
el mayor dinamismo de la economía. Cabe agregar que algunos programas de interés gubernamental se financiaron con fondos de la cooperación venezolana y se registraron como actividad privada. Así, los programas sociales financiados con esos recursos, que equivalían al 1,7\% del PIB de 2010 a 2014, ya no tuvieron que costearse con recursos fiscales que probablemente habrían reducido el espacio fiscal disponible para la inversión pública. Además, la cooperación venezolana contribuyó a realizar otros tipos de inversiones productivas, equivalentes al 2,9\% del PIB.

\section{Gráfico X.4}

Gasto total del sector público no financiero por períodos ${ }^{a}$

(En porcentajes del PIB)

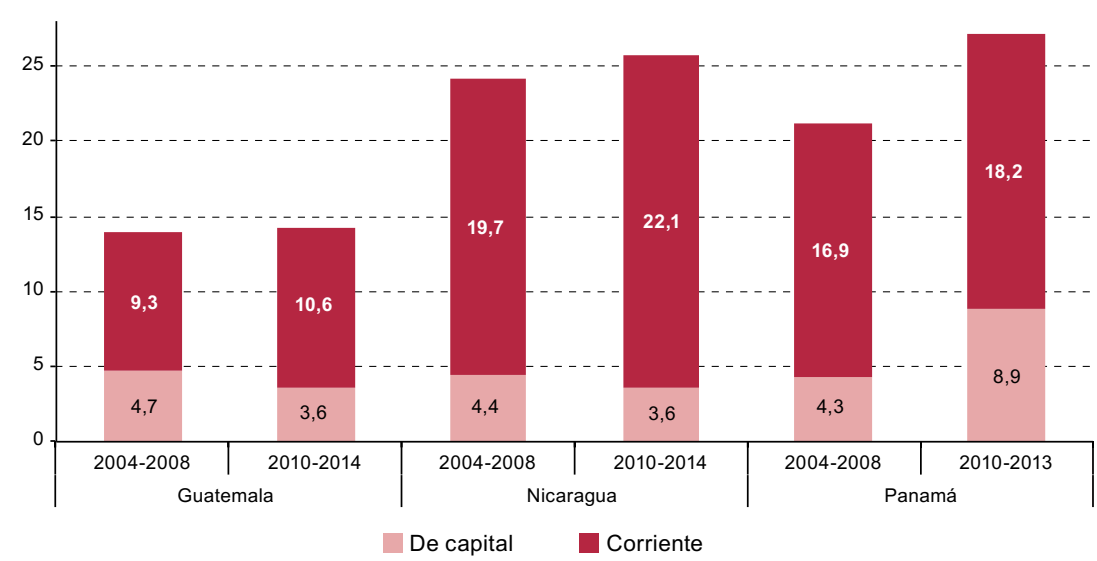

Fuente: Elaboración propia, sobre la base de información de la Comisión Económica para América Latina y el Caribe (CEPAL), y datos del Ministerio de Hacienda y los bancos centrales de los respectivos países.

a Los datos de Guatemala corresponden al gobierno central.

En Guatemala, en cambio, se combinó un moderado dinamismo del crecimiento económico con una proporción decreciente de la inversión pública en el PIB, que también disminuyó en términos reales. Esa situación estuvo influenciada por la debilidad de los ingresos fiscales, los compromisos crecientes de gastos corrientes (sobre todo salarios y transferencias) y los problemas relacionados con la gestión de la obra pública, de modo que se generaron pasivos contingentes derivados de compromisos legales que carecían del correspondiente respaldo contractual ${ }^{9}$. Inmediatamente después de la crisis financiera internacional, las restricciones se agudizaron más (véase el gráfico X.5).

\footnotetext{
Véase una descripción detallada en ICEFI (2015).
} 


\section{Gráfico X.5}

Evolución del gasto público del gobierno central, 2010-2014 respecto de 2004-2008

(En porcentajes del PIB)

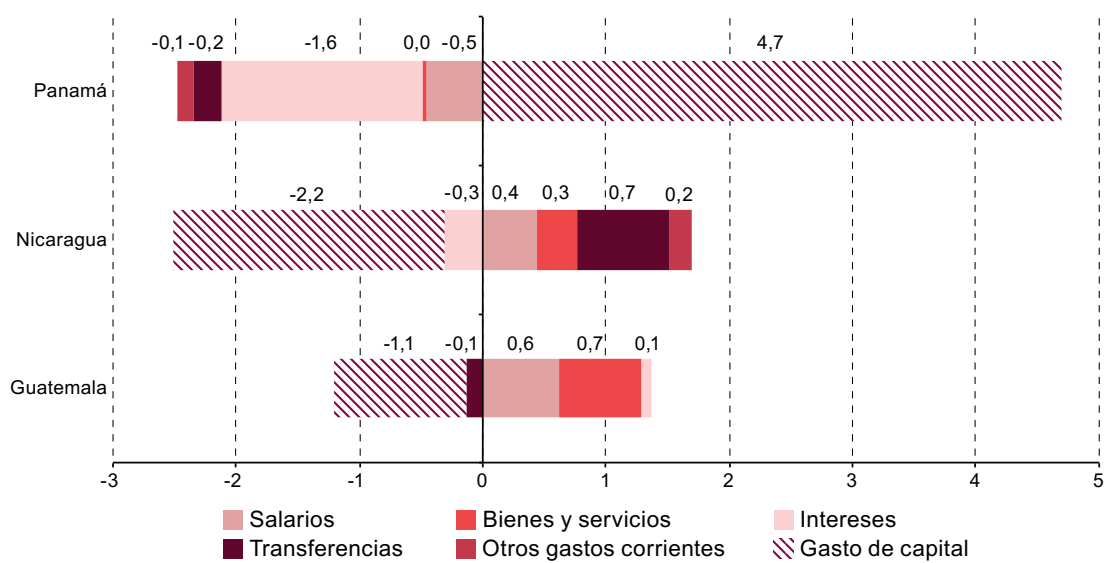

Fuente: Elaboración propia, sobre la base de información de la Comisión Económica para América Latina y el Caribe (CEPAL), y datos del Ministerio de Hacienda y los bancos centrales de los respectivos países.

En Panamá, la situación fue diferente. Junto con el aumento de la inversión pública se redujo la proporción del gasto corriente en el PIB durante el período posterior a la crisis. En la peculiar evolución de Panamá incidió la disminución del pago de intereses de su deuda, principal factor que explica la reducción de la proporción de gasto público corriente. Al mismo tiempo, el mayor crecimiento del PIB panameño permitió que aumentara el gasto corriente a la par del dinamismo económico, sin que se presentara en la misma medida el dilema de escoger entre el aumento del gasto corriente (especialmente salarios y transferencias sociales) y la inversión al estallar la crisis financiera.

\section{Políticas fiscales para la inversión}

En esta sección se analizan las diferencias entre las políticas fiscales en materia de inversión implementadas en los últimos años. En primer lugar, cabe mencionar los pasos iniciales hacia las alianzas público-privadas, que aún no han terminado de establecerse en los países centroamericanos. En segundo término, las reformas fiscales que han tenido efectos moderados en el fortalecimiento de los ingresos tributarios. En tercer lugar, los incentivos fiscales que siguen siendo un pilar de la estrategia de promoción de inversión a nivel regional, a pesar de los elevados costos y los ambiguos beneficios de esas iniciativas. Por último, la inversión pública como principal instrumento para promover la inversión privada, con las particularidades de cada caso. 


\section{Primeros pasos hacia las alianzas público-privadas}

Una de las estrategias de promoción de la inversión en Centroamérica se ha basado en las alianzas público-privadas (APP). Sin embargo, hasta 2014, solo se habían aprobado leyes al respecto en Honduras (2010), Guatemala (2010) y El Salvador (2013).

De los tres países que aquí se analizan, solamente Guatemala cuenta con legislación sobre el tema y con un organismo encargado de las APP. De acuerdo con información de la Agencia Nacional de Alianzas para el Desarrollo de Infraestructura Económica (ANADIE), ya se han identificado más de 1.700 millones de dólares en inversión privada para 13 proyectos de infraestructura que se encuentran actualmente en fase de estudio. Cabe destacar entre ellos un centro de oficinas para el Gobierno, sistemas de transporte terrestre (el tren del Pacífico, el tren urbano, la autopista CA2-CA9), proyectos relacionados con el transporte marítimo (los puertos Tecún Umán y Champerico), aeropuertos (del Pacífico y Retalhuleu) y la mejora del sistema carcelario, entre otros. De los proyectos mencionados, el centro de Gobierno es el más avanzado, ya que desde abril de 2015 rebasó la fase de precalificación. Sin embargo, tras cinco años de haberse aprobado la legislación pertinente, todavía está por verse si las alianzas público-privadas pueden llegar a ser un motor de la inversión en Guatemala.

Ese tipo de mecanismo no jugó un papel importante en el caso del auge de la inversión en Panamá y Nicaragua. En Panamá se intentó aprobar una normativa sobre APP en 2011, pero la iniciativa generó una fuerte oposición social, ya que se percibió como un medio para privatizar algunos servicios sociales. En Nicaragua aún no se ha discutido una legislación de ese tipo, aunque el sector privado organizado ha promovido la idea.

\section{Reformas fiscales}

Los Gobiernos de los tres países analizados fueron muy activos en la discusión y aprobación de medidas de política tributaria durante la última década, con efectos diferenciados sobre los ingresos, la estructura tributaria y la inversión.

Las reformas llevadas a cabo en Guatemala, Nicaragua y Panamá (véase el cuadro X.3) tenían como objetivo aumentar los ingresos tributarios. Su contenido principal se orientaba hacia la modificación de la base imponible, mediante la incorporación de ingresos como los dividendos al impuesto sobre la renta, la reducción de las exoneraciones del impuesto selectivo al consumo (como en Nicaragua) y la aplicación de gravámenes a otros servicios (como en Panamá). También se incrementaron o restituyeron los impuestos a los cigarrillos, aunque la medida que tuvo mayor impacto fue la elevación de la tasa del impuesto de transferencia de bienes muebles y servicios (ITBMS) (equivalente a un impuesto de ventas) en Panamá. En 
Guatemala y Nicaragua, las reformas del impuesto sobre la renta (ISR) introdujeron un esquema dual para el pago del régimen de utilidades y las rentas de capital, que conduce a la creación de tres regímenes de rentas: del trabajo, de actividades económicas y de capital.

Cuadro X.3

Principales medidas tributarias aprobadas en Guatemala, Nicaragua y Panamá

\begin{tabular}{|c|c|c|c|}
\hline & Guatemala & Nicaragua & Panamá \\
\hline \multirow{8}{*}{$\begin{array}{l}\text { Modificación } \\
\text { de tasas o } \\
\text { creación de } \\
\text { impuestos }\end{array}$} & \multirow{3}{*}{$\begin{array}{l}\text { 2012: Reducción de la tasa } \\
\text { máxima del impuesto sobre } \\
\text { la renta (ISR) corporativo } \\
\text { de ingresos netos, del } 31 \% \\
\text { al } 25 \% \text {, y aumento de la } \\
\text { tasa de ISR aplicable a los } \\
\text { ingresos brutos, del } 5 \% \text { al } 7 \% \text {. }\end{array}$} & \multirow{2}{*}{$\begin{array}{l}\text { 2012: Reducción gradual } \\
\text { de la tasa del ISR, del } 30 \% \\
\text { al } 25 \% \text {. }\end{array}$} & $\begin{array}{l}\text { 2010: Reducción de la tasa del } \\
\text { ISR, del } 30 \% \text { al } 25 \% \text {. }\end{array}$ \\
\hline & & & \multirow{2}{*}{$\begin{array}{l}\text { 2010: Aumento de la tasa del } \\
\text { impuesto de traslado de bienes } \\
\text { materiales y servicios (ITBMS) } \\
\text { (IVA), del } 5 \% \text { al } 7 \% \text {. }\end{array}$} \\
\hline & & $\begin{array}{l}\text { 2014: Eliminación de la } \\
\text { futura reducción de tasas } \\
\text { del ISR sobre asalariados. }\end{array}$ & \\
\hline & $\begin{array}{l}\text { 2014: Aumento de la tasa } \\
\text { de regalías mineras. }\end{array}$ & $\begin{array}{l}\text { 2012: Aumento de la } \\
\text { tasa del impuesto a } \\
\text { los cigarrillos. }\end{array}$ & $\begin{array}{l}\text { 2012: Gravamen a algunos } \\
\text { equipos electrónicos con } \\
\text { impuesto selectivo del } 5 \% \text {. }\end{array}$ \\
\hline & $\begin{array}{l}\text { 2014: Duplicación del } \\
\text { impuesto al cemento. }\end{array}$ & $\begin{array}{l}\text { 2009: Incremento de tasas } \\
\text { de uso particular. }\end{array}$ & \multirow[t]{4}{*}{$\begin{array}{l}\text { 2009: Aumento de la tasa } \\
\text { de impuesto a cigarrillos. }\end{array}$} \\
\hline & $\begin{array}{l}\text { 2012: Creación del impuesto } \\
\text { de primera matrícula. }\end{array}$ & \multirow{3}{*}{$\begin{array}{l}\text { 2009: Aumento del } 1 \% \text { al } \\
1,5 \% \text { de la retención para } \\
\text { bienes transados en la } \\
\text { Bolsa Agropecuaria. }\end{array}$} & \\
\hline & $\begin{array}{l}\text { 2012: Restitución del } \\
\text { impuesto a los cigarrillos. }\end{array}$ & & \\
\hline & $\begin{array}{l}\text { 2014: Impuesto a la telefonía } \\
\text { (suspendido por la Corte } \\
\text { de Constitucionalidad) }\end{array}$ & & \\
\hline \multirow{7}{*}{$\begin{array}{l}\text { Modificación } \\
\text { de la base } \\
\text { imponible }\end{array}$} & $\begin{array}{l}\text { 2012: Reducción de } \\
\text { deducciones del ISR. }\end{array}$ & \multirow{7}{*}{$\begin{array}{l}\text { 2014: Gravamen a las } \\
\text { rentas de cooperativas } \\
\text { superiores a un umbral } \\
\text { mínimo (cerca de } 1,5 \\
\text { millones de dólares), } \\
\text { inclusión en el ISR de } \\
\text { ciertos contribuyentes del } \\
\text { monotributo aplicado a } \\
\text { pequeños contribuyentes. } \\
\text { 2009: Gravamen de } \\
\text { intereses, ganancias de } \\
\text { capital, dividendos. } \\
\text { 2009: Eliminación de } \\
\text { exoneraciones del impuesto } \\
\text { selectivo al consumo para } \\
\text { bienes suntuarios, bebidas } \\
\text { alcohólicas, entre otros. }\end{array}$} & \multirow{3}{*}{$\begin{array}{l}\text { 2009: Incorporación a la base } \\
\text { de comisiones por ciertos } \\
\text { servicios financieros, servicios } \\
\text { profesionales a domiciliados } \\
\text { en el exterior, arrendamientos, } \\
\text { telefonía fija comercial y } \\
\text { servicios legales. }\end{array}$} \\
\hline & $\begin{array}{l}\text { 2012: Eliminación del crédito } \\
\text { fiscal del IVA aplicado al pago } \\
\text { del ISR. }\end{array}$ & & \\
\hline & \multirow{5}{*}{$\begin{array}{l}\text { 2012: Aplicación de una tasa } \\
\text { del 5\% a los dividendos. }\end{array}$} & & \\
\hline & & & $\begin{array}{l}\text { 2009: Aumento de la base del } \\
\text { impuesto sobre inmuebles. }\end{array}$ \\
\hline & & & \multirow{2}{*}{$\begin{array}{l}\text { 2012: Pago anual de tasa única } \\
\text { para empresas nacionales y } \\
\text { extranjeras; impuesto del } 3 \% \\
\text { sobre ganancias de capital de } \\
\text { venta de bienes inmuebles; } \\
\text { gravar la distribución de los } \\
\text { dividendos de empresas } \\
\text { establecidas en la Zona } \\
\text { Libre, retención para las que } \\
\text { no distribuyan. }\end{array}$} \\
\hline & & & \\
\hline & & & $\begin{array}{l}\text { 2012: Impuesto a los dividendos } \\
\text { del 10\% (fuente panameña) y } \\
\text { del } 5 \% \text { (fuente extranjera); la } \\
\text { distribución de dividendos de } \\
\text { acciones preferentes se exonera. }\end{array}$ \\
\hline \multirow[t]{4}{*}{$\begin{array}{l}\text { Medidas } \\
\text { administrativas }\end{array}$} & \multirow{2}{*}{$\begin{array}{l}\text { 2012: Normas de precios de } \\
\text { transferencia, capitalización } \\
\text { débil. Se crean controles } \\
\text { cruzados para aceptar } \\
\text { pagos deducibles. }\end{array}$} & \multirow{4}{*}{$\begin{array}{l}\text { 2012: Definición del ámbito } \\
\text { territorial de aplicación del } \\
\text { ISR, los paraísos fiscales } \\
\text { y la regulación de los } \\
\text { precios de transferencia, } \\
\text { y de los principios de la } \\
\text { libre competencia. }\end{array}$} & $\begin{array}{l}\text { 2009: Aspectos fiscales } \\
\text { de la operación de casinos. }\end{array}$ \\
\hline & & & $\begin{array}{l}\text { 2010: Normas sobre los tratados } \\
\text { o convenios para evitar la doble } \\
\text { tributación internacional. }\end{array}$ \\
\hline & \multirow[t]{2}{*}{$\begin{array}{l}\text { 2012: Nuevo Código } \\
\text { Aduanero (modificado } \\
\text { nuevamente en 2013). }\end{array}$} & & $\begin{array}{l}\text { 2010: Modificación } \\
\text { de procedimientos aplicables } \\
\text { a la ejecución del cobro } \\
\text { por jurisdicción coactiva. }\end{array}$ \\
\hline & & & $\begin{array}{l}\text { 2009: Negociación } \\
\text { de acuerdos de doble } \\
\text { tributación internacional. }\end{array}$ \\
\hline
\end{tabular}

Fuente: Elaboración propia. 
Como resultado de las reformas, aumentó la recaudación de la tributación directa en Nicaragua y en Guatemala, aunque el aumento fue neutralizado por una reducción de la tributación indirecta en el caso de Guatemala, principalmente debido al debilitamiento de la administración tributaria. En el caso de Nicaragua, se pudo sufragar con esos recursos cierta expansión de la inversión pública, aunque el proceso contó con un importante complemento financiero proveniente de la cooperación externa, y sobre todo del Gobierno de la República Bolivariana de Venezuela, como ya se explicó. En Panamá, se logró una mejora significativa en los impuestos indirectos, así como un alza en la recaudación de impuestos directos (véase el gráfico X.6). Aunque el conjunto de esas reformas generó debate y polémica en los tres países, su efecto disuasivo directo sobre la inversión privada no parece haber sido decisivo, especialmente si se toma en cuenta que las reformas más moderadas tuvieron lugar en Guatemala, que ha registrado el menor coeficiente de inversión de los tres países.

\section{Gráfico X.6 \\ Estructura impositiva, 2004-2008 y 2010-2013 \\ (En porcentajes del PIB)}

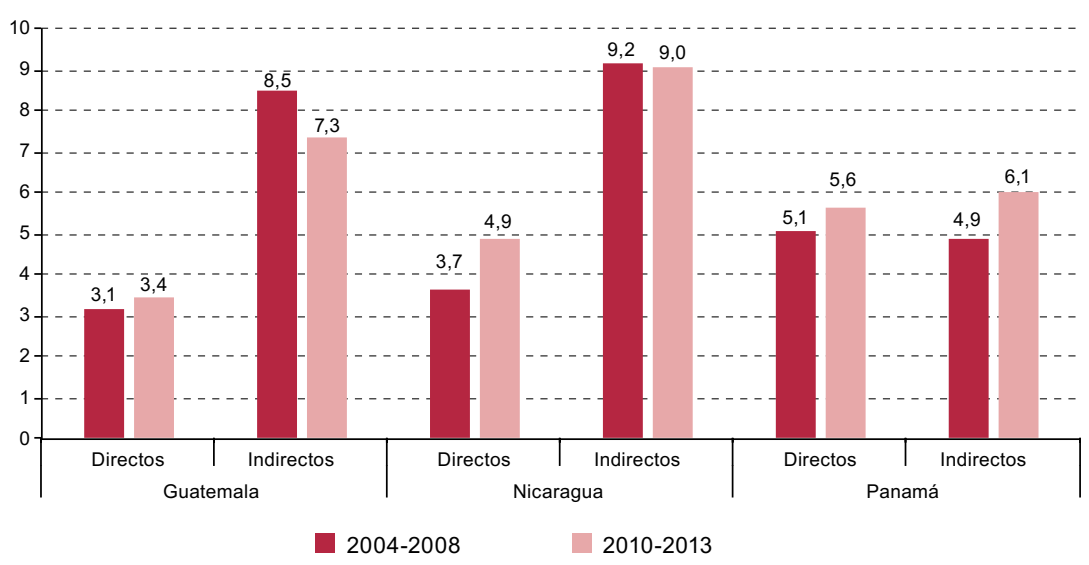

Fuente: Elaboración propia, sobre la base de información de la Comisión Económica para América Latina y el Caribe (CEPAL) y datos oficiales de los respectivos países.

\section{Incentivos fiscales}

La experiencia de los tres países estudiados en materia de incentivos tributarios introducidos durante los últimos años ha sido muy diferente. Mientras que en Guatemala las ampliaciones de incentivos no han sido muy significativas, en Nicaragua se han ampliado considerablemente y en Panamá se han reducido. Una vez más, la ausencia de una relación clara entre incentivos y el desempeño de la inversión impide concluir que los incentivos hayan 
tenido un impacto decisivo sobre la inversión, aun cuando su incidencia haya podido ser diferente en cada país.

En Guatemala se mantuvieron vigentes las exenciones de impuestos aplicadas a las exportaciones no tradicionales desde 1989. Esos incentivos, que en un inicio se aplicaban solamente a las exportaciones dirigidas a mercados fuera de Centroamérica, se ampliaron para sufragar las exportaciones dirigidas al mercado centroamericano a partir de 2004. En su calidad de miembro de la Organización Mundial del Comercio (OMC), Guatemala asumió el compromiso de eliminar las exoneraciones fiscales aplicadas a las exportaciones a partir del 31 de diciembre de 2015. Por ese motivo, la administración gubernamental del período 2012-2016 promovió, aunque sin éxito, diversas variaciones de leyes mediante las que se intentaba aplicar también esas exenciones a bienes vendidos en el mercado nacional, con el fin de evitar un trato discriminatorio a favor de las exportaciones. En síntesis, la ruta de ampliar las exoneraciones fiscales en Guatemala no se ha traducido en la aprobación de legislación conexa, aun cuando hubo cierta erosión de las reformas del impuesto sobre la renta debido al aumento de los costos deducibles y de las exoneraciones aplicables a proyectos inmobiliarios.

Por otra parte, en Nicaragua han aumentado los incentivos. La agencia de promoción de las inversiones y las exportaciones (PRONicaragua) ofrece "generosos incentivos fiscales" como parte de su atractivo para el inversionista. Esos incentivos incluyen los contenidos en la Ley de Concertación Tributaria, Régimen de Admisión Temporal (Ley núm. 382 de 2001), el Decreto de Zonas Francas Industriales de Exportación (Decreto núm. 46-91 de 1991), la Ley para la Promoción de la Generación Eléctrica con Fuentes Renovables (Ley núm. 532 de 2005), la Ley Especial sobre Exploración y Explotación de Minas (Ley núm. 387, aprobada en 2001), la Ley de Incentivos Turísticos (Ley núm. 306, aprobada en 2009) y la Ley de Pensionados y Retirados (Decreto núm. 628 de 2009).

Al ser Nicaragua uno de los miembros de la OMC de menor nivel de ingreso, tiene una dispensa para mantener las exoneraciones fiscales que favorecen las exportaciones. Por ese motivo no se han promovido recientemente leyes encaminadas a reformar el régimen de zonas francas. Sin embargo, tanto la Ley de Concertación Tributaria, aprobada en 2009, como sus reformas de 2012 y 2014, han modificado las exoneraciones fiscales vigentes en el país. En esa Ley se ampliaron los tratamientos especiales para los exportadores, los productores locales y el sector forestal, lo que refleja la incidencia del sector empresarial en la política tributaria. A ello se agregaron los beneficios fiscales para las empresas que producen, comercializan o emplean yates y helicópteros, azúcar o licores, o se dedican a la importación y distribución de vehículos. 
En Panamá se han reducido los incentivos. El país contaba con tres programas de subvenciones a las exportaciones: i) las zonas procesadoras para la exportación (ZPE), ii) el Registro Oficial de la Industria Nacional (ROIN) y iii) el Certificado de Abono Tributario (CAT). Para cumplir con su obligación de eliminar las subvenciones a la exportación, Panamá derogó la Ley núm. 25 del 30 de noviembre de 1992, por la que se establecía el régimen de ZPE. En su lugar, se promulgó la Ley núm. 32 del 5 de abril de 2011, por la que se establece un nuevo régimen de zonas francas y su reglamento, el Decreto Ejecutivo núm. 26, de 9 de febrero de $2012^{10}$. Los promotores y empresas que operaban al amparo del régimen de ZPE continuaron sus operaciones en el marco de la nueva Ley de Zonas Francas ${ }^{11}$. De acuerdo con datos de la Autoridad Nacional de Ingreso Públicos (ANIP), durante el período 2007-2012, los incentivos fiscales otorgados a las empresas de las antiguas zonas procesadoras para la exportación y, a partir de 2012, a las empresas de zonas francas amparadas por la Ley núm. 32, se han reducido desde 883,6 millones de dólares en 2007 hasta 323,4 millones de dólares en 2012.

En cuanto a la inversión impulsada por los incentivos fiscales, no están disponibles las cifras anuales de todos los países y, en algunos casos, solamente se pueden obtener de forma parcial. Nicaragua publicó cifras sobre la inversión en zonas francas correspondientes a los años 2007-2010 ${ }^{12}$. Según esos datos, la IED en ese sector osciló entre el 14\% y el 32\% del total de la IED bruta. No obstante, como se mencionó en párrafos anteriores, los incentivos fiscales abarcan otras áreas más allá de las zonas francas (véase el gráfico X.7). A su vez, en Guatemala, la mayor parte de la IED hacia zonas francas se dirige a la industria que, según datos del Banco Central, absorbió entre un $20 \%$ y un $26 \%$ de 2007 a $2014^{13}$. Además, algunas empresas mineras se han inscrito como maquilas en el país para reducir su carga impositiva, aunque la decisión de invertir no haya estado necesariamente sujeta al beneficio fiscal, sino al clima internacional favorable a la explotación de recursos minerales. En Panamá, el régimen preferencial para no residentes y las zonas libres existentes con un perfil más orientado a los servicios juegan un papel importante en el marco establecido para la inversión. Las cifras disponibles, que cubren parcialmente las inversiones atraídas por incentivos, muestran que la inversión neta hacia la Zona Libre de Colón ha oscilado entre

10 De acuerdo con la OMC (2014), la nueva legislación introdujo cambios sustanciales en el régimen tributario aplicable a esas empresas, obligándolas al pago del ISR, el ITBMS sobre las operaciones locales de arrendamiento y subarrendamiento, el impuesto de dividendos a una tasa del 5\%, independientemente de la fuente de origen, y el impuesto complementario del $2 \%$ que se aplica cuando no hay distribución de utilidades, entre otros tributos.

11 Valga señalar que las subvenciones a la exportación de las que gozaban finalizaron el 31 de diciembre de 2015.

12 Estas cifras fueron recopiladas por PRONicaragua.

13 También el sector de servicios (concretamente, los centros de atención telefónica o call-centers) atrae inversión bajo esquemas de exenciones fiscales. Sin embargo, las cifras de IED no se publican de forma desagregada para ese sector. 
el 13\% y el 18\% de 2008 a 2012, según información de la Contraloría General de la República de Panamá. En resumen, la inversión que se beneficia de los incentivos fiscales es diversa, aunque mayormente significativa.

\section{Gráfico X.7}

\section{Inversión extranjera directa vinculada a incentivos fiscales ${ }^{a}$}

A. En millones de dólares

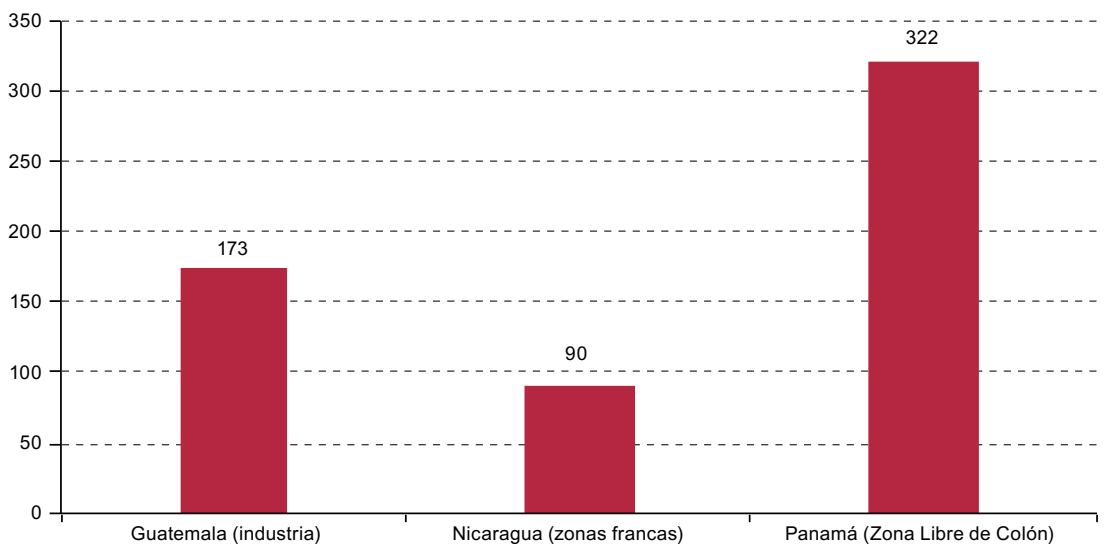

B. En porcentajes del PIB

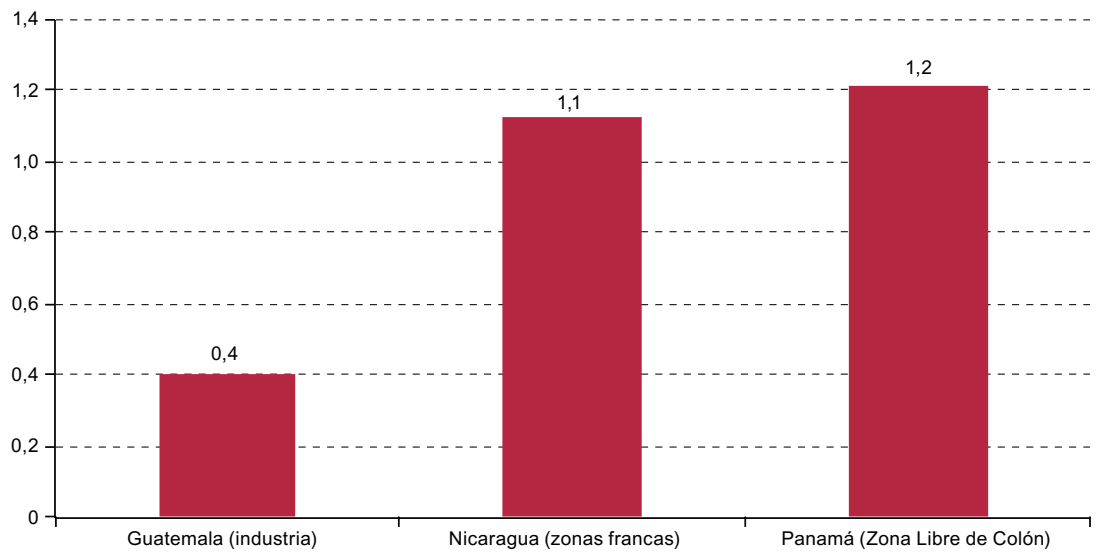

Fuente: Elaboración propia, sobre la base de datos de los bancos centrales de los respectivos países, la Contraloría General de la República de Panamá y PRONicaragua.

a Los datos de Guatemala corresponden al período 2007-2014; los de Nicaragua, a 2007-2010, y los de Panamá, a 2008-2012.

Además de que en los países incluidos en el estudio no existe información completa sobre la inversión que se genera a partir de los incentivos fiscales existentes, tampoco se realiza de forma periódica la medición de la renuncia fiscal o gasto tributario. Guatemala es el único país donde existe 
la obligación legal de publicar en el presupuesto público el monto estimado del gasto tributario. Nicaragua ha realizado algunos estudios sobre el tema, pero no es una práctica establecida publicar cifras sobre los beneficios fiscales existentes. En el caso de Panamá, solo existen publicaciones parciales sobre el gasto tributario.

Según los datos disponibles, solamente puede afirmarse que el monto de recursos que se destina a las exoneraciones fiscales es considerable en Guatemala y Nicaragua. En el caso de Panamá, no es posible tener una idea completa, aunque la renuncia fiscal derivada del impuesto general a las ventas es similar a la de Guatemala y muy inferior a la de Nicaragua. No obstante, no se cuenta con estimaciones desagregadas sobre los incentivos fiscales dirigidos específicamente a la inversión, ya que las cifras del gasto tributario incluyen otro tipo de beneficios fiscales (véase el gráfico X.8).

\section{Gráfico X.8}

Gasto tributario medio, 2008-2012

(En porcentajes del PIB)

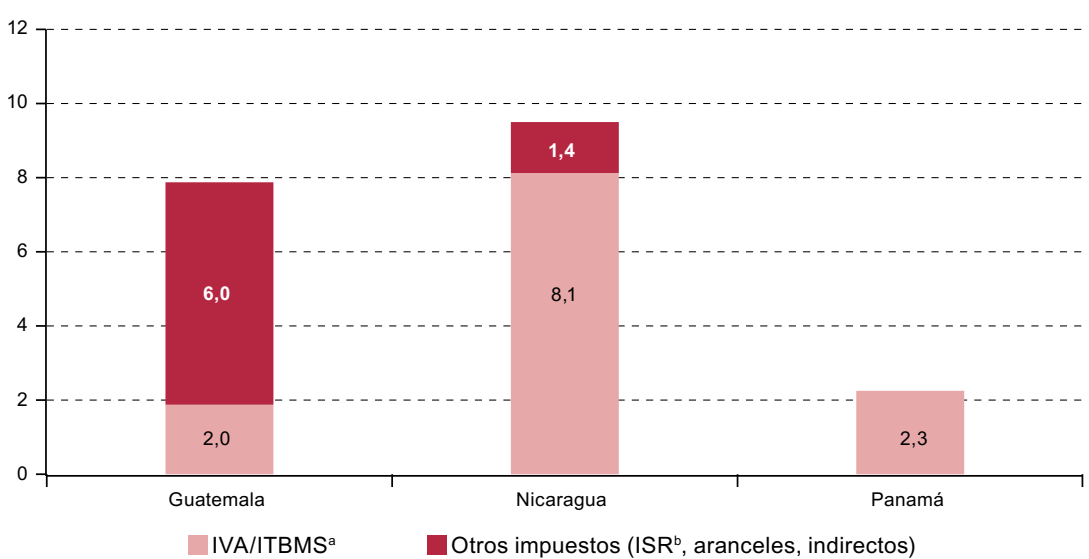

Fuente: Superintendencia de Administración Tributaria (SAT) de Guatemala; Ministerio de Hacienda de Nicaragua, El gasto tributario de Nicaragua", Managua, 2010; y M. Pecho Trigueros, "Gastos tributarios en América Latina: 2008-2012”, Documento de Trabajo, № 2-2014, Panamá, Dirección de Estudios e Investigaciones Tributarias, Centro Interamericano de Administraciones Tributarias (CIAT), 2014.

a Impuesto al valor agregado/impuesto de traslado de bienes materiales y servicios.

b Impuesto sobre la renta.

Las experiencias disímiles con los incentivos y los desempeños divergentes en materia de inversiones no permiten, a partir de este análisis comparativo, obtener conclusiones aplicables a los tres países acerca del efecto de los incentivos sobre la inversión durante la etapa considerada. 


\section{Inversión pública}

La inversión pública es un instrumento clave para fortalecer la competitividad de las actividades privadas y favorecer el desarrollo humano. En los países centroamericanos que cuentan con menores niveles de infraestructura, como Guatemala y Nicaragua, la formación de capital público es clave para aprovechar sus ventajas estratégicas e integrar distintos sectores del país al desarrollo. En el caso de Panamá, por ejemplo, la convergencia de obras de infraestructura de transporte marítimo y terrestre con la infraestructura vial ha contribuido de manera importante a potenciar el crecimiento económico del país.

La inversión pública también es resultado de factores sistémicos, como la coordinación entre el sector público y privado, que conlleva acuerdos sobre los sectores estratégicos con miras a impulsar la inversión, además de la necesidad de buscar medios para su financiamiento y contar con niveles de transparencia adecuados. Sobre ese tema pueden encontrarse luces y sombras en los tres países. Por un lado, los tres experimentaron problemas importantes en cuanto a la corrupción o la transparencia de las obras públicas ${ }^{14}$. Por el lado positivo, todos han contado con sistemas nacionales de inversión pública y esquemas de presupuesto multianual. Una buena práctica en esa materia ha sido la de Panamá, donde la Ley de Responsabilidad Social Fiscal ${ }^{15}$ establece el requisito de presentar un plan quinquenal de inversiones como parte del Plan Estratégico de Gobierno ${ }^{16}$. Esa herramienta ha brindado transparencia al plan de inversiones del Gobierno, lo que ha permitido dar seguimiento a su evolución y, a su vez, puede orientar las decisiones del sector privado en materia de inversión. De ese modo se aprovechan las externalidades resultantes de la coordinación del proceso de inversión en su conjunto.

Un factor clave en el impulso de la inversión pública se relaciona directamente con el espacio fiscal: la inversión se puede aumentar en la medida en que se disponga de mayores recursos. Por un lado, esto puede manifestarse en un patrón procíclico de la inversión pública ya que, al depender de los recursos fiscales disponibles, esta tiende a ajustarse en períodos de crisis y a aumentar en períodos de bonanza (véase el gráfico X.9). Sin embargo, Panamá logró utilizar la inversión pública como herramienta anticíclica en el marco de la crisis de 2009. Como puede verse en el gráfico, en los períodos en que el crecimiento económico se sitúa por encima de la tendencia de largo plazo, la inversión pública se reduce en todos los países ${ }^{17}$. En Nicaragua se

\footnotetext{
En ICEFI (2015) se ofrece un análisis de esos aspectos en el caso de Guatemala.

Decreto Ejecutivo núm. 1068, del 6 de septiembre de 2012.

Véase Ministerio de Economía y Finanzas de Panamá, "Plan Quinquenal de Inversiones" [en línea] http://mef.gob.pa/es/informes/Paginas/pqi.aspx.

17 Con la serie del crecimiento real del PIB 1990-2013, se estimó una tendencia empleando un filtro Hodrick-Prescott para seleccionar los años que estaban por encima y por debajo de la tendencia., y se promedió el gasto de capital como proporción del producto para cada período.
} 
observan las mayores diferencias entre el crecimiento de la inversión en períodos en que el crecimiento económico estaba por encima o por debajo del crecimiento a largo plazo. Ello sugiere que la inversión pública tendría un mayor carácter procíclico. Panamá muestra las menores diferencias a partir de 2009, cuando su situación fiscal era ya más sólida. Por último, en Guatemala, con un margen fiscal sumamente restringido, también existen diferencias entre los años en que la tendencia histórica de crecimiento se sitúa por debajo de la tendencia.

Gráfico X.9

Inversión pública según etapas del ciclo económico, 1990-2013a (En porcentajes del PIB)

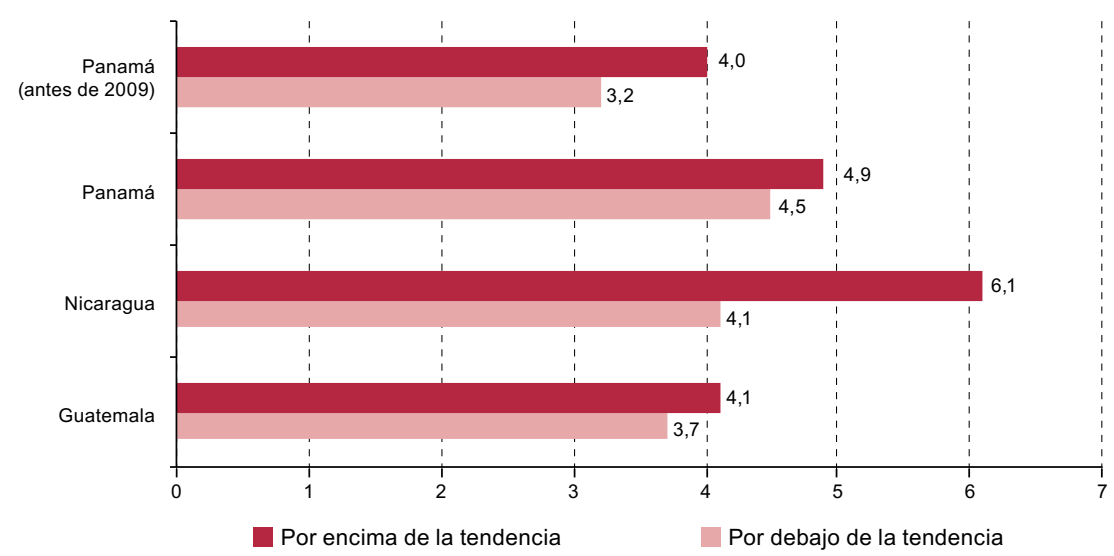

Fuente: Elaboración propia, sobre la base de información de la Comisión Económica para América Latina y el Caribe (CEPAL).

a Los datos corresponden al promedio del gasto de capital de los años en que el crecimiento se situó por debajo o por encima de la tendencia a largo plazo, estimada mediante un filtro Hodrick-Prescott.

Guatemala se ha visto más afectada que Nicaragua debido a su mayor dependencia de recursos propios en el financiamiento de la inversión pública, como puede apreciarse en el cuadro X.4. En el caso de los otros dos países, las cifras presentadas en el cuadro requieren una explicación adicional. Por un lado, si bien la estructura presupuestaria de la inversión muestra una alta dependencia de donaciones y de recursos del crédito público interno y externo, debe tomarse en cuenta que en Nicaragua no se registran como recursos públicos los provenientes de la cooperación venezolana. Por otro lado, en Panamá, que al parecer tiene una estructura de financiamiento similar a la de Guatemala, se ha hecho uso de figuras como los proyectos de "llave en mano" para diferir los pagos de la inversión pública, lo que tampoco se registra en su totalidad en las cuentas fiscales. 
Cuadro X.4

Fuentes de financiamiento de la inversión pública, 2010-2014a (En porcentajes)

\begin{tabular}{lrrc}
\hline & Guatemala & Nicaragua & Panamá \\
\hline Deuda pública externa & 14,1 & 35,9 & 16,2 \\
\hline Donaciones & 1,8 & 14,8 & 0,2 \\
\hline Deuda pública interna & 9,2 & 48,2 & 9,6 \\
\hline Recursos propios & 74,8 & 1,1 & 74,0 \\
\hline Total & 100,0 & 100,0 & 100,0 \\
\hline
\end{tabular}

Fuente: Elaboración propia, sobre la base de datos del Ministerio de Finanzas Públicas de Guatemala, Ministerio de Economía y Finanzas de Panamá y Ministerio de Hacienda de Nicaragua.

a En el caso de Panamá solo se incluyen los años 2012 y 2013.

\section{Conclusiones}

Nicaragua y Panamá, al haber alcanzado coeficientes de inversión superiores al 25\% del PIB, se han situado claramente por encima del promedio de la subregión centroamericana en esa materia. Por su parte, Guatemala muestra uno de los niveles de inversión más bajos del mundo, a lo cual contribuyen los exiguos niveles de inversión pública y privada, incluida la inversión extranjera directa.

El dinamismo de Panamá ha generado un círculo virtuoso entre inversión y crecimiento, aunque ello va más allá de la relación entre inversión privada y crecimiento del PIB, pues también incluye la relación positiva entre crecimiento e inversión pública que surge de la mayor sostenibilidad fiscal derivada del aumento de los ingresos, generado a su vez por un crecimiento mayor. Ese incremento de la sostenibilidad fiscal ha contribuido a mejorar el riesgo país. Esto ha sucedido también en Nicaragua a menor escala, aunque a Panamá le favorece su posición privilegiada como plaza financiera internacional. Ese factor, combinado con su mayor espacio fiscal, también ha contribuido a promover el financiamiento de grandes obras de inversión pública. La experiencia de Guatemala ha sido diferente. Si bien ha mejorado el desempeño de su economía en los últimos cuatro años y grandes empresas guatemaltecas han tenido acceso al mercado internacional de capitales, la inversión privada no ha despuntado y la precaria situación fiscal ha impedido un aumento notable de la inversión pública. Lo único que puede apreciarse es una mejora de la IED aunque, en comparación con la región, sus niveles han sido los más bajos con respecto al producto.

El subdesarrollo financiero ha tenido cierto impacto sobre las medianas y pequeñas empresas de todos los países, pero no parece ser una explicación decisiva de las divergencias en materia de inversión. Lo fundamental ha sido el conjunto de factores macroeconómicos y financieros, incluida la dimensión fiscal, que han contribuido a facilitar la inversión privada y pública. A ellos 
se agregan factores extraeconómicos, como la inseguridad y la percepción de inestabilidad política, que afectan negativamente a Guatemala en particular.

Un factor sistémico que surge como condicionante fundamental de la inversión es la relación estratégica entre el sector público y el privado. En Panamá ha sido evidente la mayor convergencia entre ambos sectores en torno a la inversión en los ámbitos de mayor dinamismo, derivados de una historia de especialización en la exportación de servicios. Por otro lado, en Nicaragua ha existido un clima armonioso entre el sector privado (sobre todo la cúpula empresarial nacional y los grandes inversionistas extranjeros) y el sector público que, sin tener las características de una relación estratégica como la de Panamá, se ha manifestado en lo que puede calificarse como un "arreglo de conveniencia", con reglas y beneficios mutuos claros. Ello no ha ocurrido en el caso de Guatemala, donde a pesar de que en ciertas etapas el sector privado ha cogobernado por la vía de ministros en el gabinete de numerosos Gobiernos, no se ha logrado alcanzar una relación estratégica entre el sector público y el privado. Tampoco ha existido un consenso sobre la orientación de largo plazo de la economía (más evidente en el ámbito fiscal), y la confrontación entre cámaras empresariales y el Gobierno ha sido intensa durante algunos períodos.

La comparación de los tres países sugiere que la sostenibilidad fiscal también ha sido un determinante fundamental del dinamismo de la inversión privada. En los tres casos se impulsaron reformas tributarias, pero con impacto diferente. Aumentó la recaudación de la tributación directa en Nicaragua y en Guatemala, aunque ese incremento fue neutralizado por una reducción de la tributación indirecta en el caso de este último, debido sobre todo al debilitamiento de la administración tributaria. En el caso de Nicaragua, en cambio, se pudo costear cierta expansión de la inversión pública. Ese proceso contó con un importante complemento financiero proveniente de la cooperación externa, y sobre todo del Gobierno de la República Bolivariana de Venezuela, con lo que se redujo la presión sobre las finanzas públicas. Las reformas tributarias de Panamá, por su parte, lograron una mejora significativa de los impuestos indirectos, así como un alza de la recaudación de impuestos directos, lo que fue clave para garantizar el financiamiento de grandes obras públicas (inicialmente con crédito privado).

La situación de Guatemala ilustra el carácter fundamental de la sostenibilidad fiscal como determinante de la inversión en su conjunto. En primer lugar, el desempeño insuficiente de los ingresos fiscales en Guatemala contrasta con el desempeño fiscal de Panamá y Nicaragua, impulsado por el crecimiento económico en el primer caso y por el surgimiento de recursos parafiscales en el segundo. En ambos casos, la situación fiscal favorable ha sido un condicionante fundamental de la disponibilidad de recursos para la inversión del sector público en general, además de dar credibilidad a la 
posibilidad de un pago (público) diferido de proyectos de inversión en el caso de Panamá. Ello ha complementado la inversión privada. En cambio, en el contexto de mayores restricciones fiscales en Guatemala, la dominancia del gasto corriente ha limitado marcadamente su inversión pública.

Por otra parte, y a pesar de su efecto negativo sobre la sostenibilidad fiscal, se siguieron realizando esfuerzos por aumentar los incentivos fiscales, que erosionaron la base fiscal de Guatemala y Nicaragua. En estos países aún existe la percepción de que las exoneraciones fiscales son importantes como medio para atraer inversión. Sin embargo, la ausencia de una relación clara entre los incentivos y el desempeño de la inversión no permite definir los beneficios concretos que se derivan de su aplicación. En los tres países analizados, las alianzas público-privadas tampoco han jugado un papel importante en la promoción de la inversión, aunque Guatemala cuenta con legislación sobre el tema desde 2010.

\section{Bibliografía}

Cabrera, M. (2015), “Estudio de los impactos de las reformas tributarias y de gasto público sobre el crecimiento y la inversión en Guatemala, Nicaragua y Panamá", serie Macroeconomía del Desarrollo, N 168 (LC/L.4099), Santiago, Comisión Económica para América Latina y el Caribe (CEPAL) [en línea] http:/ / repositorio. cepal.org/bitstream/handle/11362/39354/1/S1500876_es.pdf.

Fanelli, J. M. (2013), “Política fiscal e inversión: un enfoque sistémico y de crecimiento inclusivo", serie Macroeconomía del Desarrollo, No 127 (LC/L.3556), Santiago, Comisión Económica para América Latina y el Caribe (CEPAL).

ICEFI (Instituto Centroamericano de Estudios Fiscales) (2015), Política fiscal: expresión del poder de las élites centroamericanas, Guatemala, ICEFI/Center for Latin American \& Latino Studies/American University, F\&G Editores.

Manuelito, S. y L.F. Jiménez (2015), “Rasgos estilizados de la relación entre inversión y crecimiento en América Latina, 1980-2012", Revista de la CEPAL, N 15, Santiago, Comisión Económica para América Latina y el Caribe (CEPAL), abril.

Ministerio de Hacienda de Nicaragua (2010), "El gasto tributario de Nicaragua", Managua.

OMC (Organización Mundial del Comercio) (2014), Panamá: examen de las políticas comerciales. Informe de la Secretaría (WT/TPR/S/301), Ginebra.

Pecho Trigueros, M. (2014), "Gastos tributarios en América Latina: 2008-2012", Documento de Trabajo, N 2-2014, Panamá, Dirección de Estudios e Investigaciones Tributarias, Centro Interamericano de Administraciones Tributarias (CIAT). 
Parte 4

Evasión tributaria e informalidad: los obstáculos principales 

Capítulo XI

\title{
Economía informal y tributación: una exploración de los nexos ${ }^{1}$
}

\author{
Juan C. Gómez Sabaini \\ Dalmiro Morán ${ }^{3}$
}

\section{Introducción}

En los países de América Latina, ya sea porque se ven excluidos involuntariamente del mercado formal de trabajo o por elección de los propios trabajadores, una parte importante de la población realiza sus actividades económicas y obtiene una porción o la totalidad de sus ingresos monetarios en lo que se denomina "el sector informal" de la economía. Lo mismo sucede con los cuentapropistas y las empresas (especialmente las de menor tamaño), entre quienes, tanto por exclusión como por elección, se registran elevados niveles de informalidad ${ }^{4}$.

\footnotetext{
Este capítulo constituye una versión resumida y actualizada de Gómez Sabaini y Morán (2012).

2 Consultor de la Comisión Económica para América Latina y el Caribe (CEPAL), el Banco Interamericano de Desarrollo (BID), el Fondo Monetario Internacional (FMI) y el Centro Interamericano de Administraciones Tributarias (CIAT) especializado en temas de política tributaria en países de América Latina. Profesor de posgrado en la Universidad Nacional de Buenos Aires. Correo electrónico: gomezsabaini@gmail.com.

3 Consultor de la Comisión Económica para América Latina y el Caribe (CEPAL) y del Centro Interamericano de Administraciones Tributarias (CIAT) especializado en temas de política tributaria en países de América Latina. Correo electrónico: dalomoran@gmail.com.

4 Vale aclarar que en este capítulo se utilizan indistintamente los términos "informalidad" y "economía informal" para hacer referencia al fenómeno a partir del cual los agentes (individuos y empresas) realizan actividades económicas por fuera de los circuitos formales (legales, comerciales y administrativos).
} 
El problema radica en que la informalidad es un signo de subdesarrollo y, en algunos casos, de retraso económico, en tanto implica una ineficiente asignación de recursos y una pérdida de las ventajas que brinda el sistema formal de la economía, como la protección legal de los derechos, el acceso al crédito y la plena participación en los mercados de bienes y servicios.

En la búsqueda de soluciones para este problema, los países de la región han apelado, con distinto grado de éxito, a la implementación de diversas medidas e instrumentos de política económica con el fin de reducir los elevados niveles de informalidad. La política tributaria ha sido uno de los principales canales a través de los cuales los Gobiernos han intentado poner en marcha procesos de formalización de los trabajadores informales. Por este motivo, resulta de interés estudiar los nexos que pueden encontrarse, en uno u otro sentido, entre la informalidad y la tributación en América Latina.

En varios estudios se han presentado claras pruebas de que el sistema tributario influye en la economía informal, dado que los impuestos y los aportes a la seguridad social se suman a los costos de la mano de obra y constituyen factores clave en lo que respecta a las causas de la informalidad ${ }^{5}$. Además, los contextos de elevada informalidad pueden atentar contra los objetivos buscados por las distintas reformas tributarias, distorsionando sus efectos finales sobre la eficiencia y la equidad de la tributación. Siempre que se pretenda introducir cambios duraderos, todos estos aspectos requieren de un análisis profundo desde una perspectiva integradora.

Para cumplir con los objetivos que se propone el presente trabajo, en la sección A se procura identificar las relaciones conceptuales en torno a la economía informal y su incidencia sobre la tributación. En la sección B se exploran las evidencias recientes acerca del tamaño de la economía informal en los países de la región, que servirán de insumo principal para la sección $C$, donde se establecen una serie de relaciones recíprocas respecto de la evolución de la situación tributaria en América Latina. La sección D está destinada a revisar las respuestas de la política tributaria para combatir la informalidad, focalizándose en la aplicación de regímenes simplificados dirigidos a los pequeños contribuyentes en los países de la región. Por último, en la sección E se presentan las principales conclusiones del trabajo y se plantean algunos lineamientos de política tributaria ante el obstáculo que representa la economía informal para las economías latinoamericanas.

En relación con la influencia del sistema tributario en la economía informal pueden consultarse los siguientes estudios: Gerxhani (2004), donde se recopila una extensa serie de trabajos sobre estos aspectos; OCDE (2008), que analiza las implicancias fiscales de la informalidad; y Vuletin (2008), donde se evalúa la relevancia del sistema tributario como determinante del nivel de informalidad para los países de América Latina. 


\section{A. El complejo círculo de interacciones entre distintos factores}

La informalidad es un fenómeno que reconoce múltiples causas y genera distintas consecuencias. Una de estas causas, en muchos casos se relaciona con el nivel y la estructura del sistema tributario mediante el efecto que los impuestos ejercen sobre las decisiones racionales, de tipo individual, de pertenecer al sector formal de la economía, en tanto estos se perciban como un costo necesario para lograr dicha pertenencia (Schneider y Torgler, 2007). Por otra parte, el sistema tributario muchas veces también se ve afectado por el grado de informalidad que posee un determinado país y que puede representar una reducción considerable en el nivel de recursos tributarios efectivamente recaudados respecto del nivel potencial.

En segundo lugar, en reiteradas ocasiones se ha resaltado la existencia de una relación inversa entre el nivel de informalidad y el "tamaño medio" de los contribuyentes que se encuentran en esta situación (Perry y otros, 2007). Así, tanto en países desarrollados como en países en desarrollo, se observa que el problema de la informalidad se da con mucha mayor intensidad entre los pequeños contribuyentes, ya sean individuos (autónomos, asalariados, productores y vendedores ambulantes) o empresas (microemprendimientos y pequeñas y medianas empresas (pymes) $)^{6}$.

Asimismo, se puede derivar una relación de reciprocidad entre este tipo de contribuyentes y el fenómeno de la informalidad, debido a que precisamente los pequeños contribuyentes son los que encuentran mayores dificultades a la hora de cumplir con los requerimientos legales para pertenecer al sector formal de la economía (costos de entrada a los mercados, costos de cumplimiento tributario, costos de conformidad regulatoria y mayores riesgos económicos respecto de las empresas grandes) y también son los que suelen tener más oportunidades de salir del sistema formal, dada la mayor dificultad de control que implican para el Estado y sus instituciones.

\footnotetext{
El sector que conforman las pymes es esencialmente heterogéneo y la dificultad que reviste su comparación internacional se basa, sobre todo, en dos razones. Por una parte, existe una amplia diversidad de criterios para definir y clasificar a las empresas en microempresas, pequeñas, medianas y grandes empresas. Por la otra, en parte como consecuencia de la falta de consenso metodológico en los criterios de clasificación, la falta de información estadística sobre bases comparables representa un gran obstáculo a la hora de analizar y ponderar las características de las pymes. Aun con estas salvedades, las estimaciones de la CEPAL sugieren que, en promedio, estas empresas contribuyen con el $61 \%$ del empleo laboral de la región y realizan un aporte no menor al PIB, del orden del $29 \%$. A su vez, el sector de las pymes consiste en un universo muy numeroso (más del 95\% del total de las empresas en todos los países) y muy heterogéneo (abarca desde emprendimientos familiares de subsistencia hasta empresas medianas con capacidad exportadora). Sin embargo, su aporte a la recaudación tributaria solo representa una porción muy reducida del total.
} 
El tercer nexo de esta relación conecta a estos pequeños contribuyentes con la política y la administración tributaria. En años recientes, y dado que gran parte de la informalidad se concentra en este grupo de contribuyentes, se ha suscitado un creciente interés en implementar medidas de política tributaria especialmente diseñadas para lograr un aumento en el cumplimiento tributario y contribuir con su formalización.

Los regímenes de tributación simplificada son un claro ejemplo de adaptación de la política tributaria a este particular tipo de contribuyentes. Además, la administración tributaria se ha adecuado para mejorar su fiscalización y control. De este modo, se espera que el sistema tributario actúe sobre una gran cantidad de contribuyentes como un "puente" que viabilice el paso de una situación de informalidad (parcial o completa) a un ideal cumplimiento voluntario dentro del régimen general de tributación?.

En cuarto lugar, un factor que resulta cada vez más fundamental para explicar la realidad socioeconómica de los países en desarrollo radica en el nivel de gobernanza, es decir en los aspectos que hacen a la legitimidad del Estado y a la confianza de los ciudadanos en las instituciones públicas, la calidad de los bienes públicos que se ofrecen y la percepción individual y colectiva sobre el uso adecuado de los recursos públicos (Feld y Frey, 2007). Si el desempeño institucional es pobre, se incrementan los incentivos a la informalidad, ya que se reducen los beneficios del sector formal. Asimismo, si la informalidad es elevada, la acción del Estado queda acotada y limitada, lo que da lugar a un círculo vicioso de difícil resolución y acrecienta los incentivos de "escape" hacia la economía informal.

Resta mencionar que el componente central que articula las interacciones del complejo esquema "informalidad-tributación-pequeños contribuyentesgobernanza" viene dado por la existencia del problema de la evasión tributaria, ya que esta se relaciona con:

- $\quad$ El reflejo de las decisiones individuales o de la determinación social (según cuál sea el enfoque que se aplique) del fenómeno de la informalidad frente al pago de los impuestos.

- Una de las causas, conjuntamente con los gastos tributarios, de la brecha existente entre el monto de recursos tributarios potenciales y la recaudación efectiva, lo que limita el financiamiento de bienes y servicios públicos de calidad ofrecidos por el Estado.

- La dificultad de las administraciones tributarias para poder controlar a un número significativo de pequeños contribuyentes que son, a la vez, los que relativamente más necesitan de los bienes y servicios públicos.

La informalidad parcial se refiere a la evasión de impuestos y contribuciones a la seguridad social por parte de empleados informales en el sector formal de la economía (empresa formal). 
- La existencia de una pobre calidad institucional, una baja moral tributaria y una desconfianza generalizada en la capacidad del Estado para aplicar las políticas adecuadas que conduzcan al bienestar general de la población.

Todo esto desemboca en un escenario donde la informalidad encuentra vínculos cercanos con las raíces de la desigualdad en la distribución del ingreso. Mientras que esta última refuerza los determinantes de la primera bajo el enfoque de "exclusión", la baja legitimidad del Estado y el escaso valor percibido por los contribuyentes respecto de los beneficios de permanecer en el sector formal, tal como se señaló, incentivan la informalidad como vía de "escape". Así, ante una elevada desigualdad, el sistema tributario pierde capacidad para influir sobre la equidad, y los individuos y las pymes son los más afectados, relativamente, al enfrentar mayores riesgos y quedar más expuestos a las fuerzas del mercado.

La formalización de los contribuyentes, en tanto reduzca la evasión tributaria y promueva el cumplimiento voluntario, permite mejorar la equidad horizontal y vertical entre ellos, lo que fortalecerá la legitimidad del Estado en un círculo virtuoso. Por lo tanto, es esperable que toda política pública que apunte a reducir los niveles de informalidad produzca, directa o indirectamente, efectos positivos sobre la equidad entre los contribuyentes.

A su vez, las estimaciones sobre la economía informal pueden brindar una aproximación a la problemática de la evasión fiscal dado que estas cuantificaciones intentan medir los ingresos no incluidos en los cálculos del ingreso nacional y por lo general se trata de actividades que quedan sin declarar ${ }^{8}$. Las transacciones que se llevan a cabo en la economía subterránea reducen la recaudación tributaria y, por lo tanto, disminuyen la capacidad de financiamiento del gasto público. Además, el incremento de las tasas impositivas sin un adecuado control podría traducirse en un crecimiento de las actividades ocultas si ocurre un desplazamiento de empresas y trabajadores desde el sector formal hacia el sector informal, lo que dificultaría aún más la capacidad de los Gobiernos de generar recursos.

Como corolario, y dada la relación mencionada entre informalidad y evasión tributaria, los países de la región en los últimos años han diseñado distintas estrategias para incrementar sus recursos tributarios y, a su vez, aumentar el control sobre los contribuyentes. Para ello han aplicado instrumentos heterodoxos como los regímenes simplificados para pequeños contribuyentes (que se analizarán en la sección D del presente capítulo)

Sin embargo, estas aproximaciones no brindan un panorama completo sobre el grado de cumplimiento en el pago de impuestos, ya que, por una parte, no alcanzan a medir la evasión en que incurren los sectores registrados de la economía, y, por la otra, no todos los ingresos de los sectores informales estarían sujetos al pago de impuestos (por ejemplo, por la existencia de exenciones). 
y los impuestos mínimos o presuntivos del impuesto sobre la renta (ISR) empresarial. Además, en la administración tributaria se han introducido reformas tendientes a facilitar el pago de los impuestos y a aumentar el nivel de cumplimiento tributario.

En definitiva, la informalidad, en sentido amplio (productivo), está relacionada con la evasión de todos los impuestos, ya que cumplir con las obligaciones tributarias, al igual que con las condiciones y los requisitos del marco regulatorio vigente, es uno de los componentes fundamentales para considerar la pertenencia de un contribuyente al sector formal de la economía9 .

\section{B. El tamaño de la economía informal en América Latina: evidencias y tendencias}

En línea con lo señalado por Perry y otros (2007), la informalidad no es particularmente más elevada en los países de América Latina que en otros países en desarrollo con ingresos per cápita similares. Sin embargo, en años recientes, la consideración de este fenómeno ha adquirido una creciente relevancia en los países de la región a la hora de diseñar las políticas macroeconómicas, dadas las connotaciones negativas a él asociadas (malas condiciones de trabajo, empresas de baja productividad, falta de cumplimiento de las leyes, normas y obligaciones tributarias, y demás).

Debido a la amplitud y robustez de los resultados obtenidos, gracias a la utilización simultánea de tres de los métodos de estimación aquí explicados, los periódicos trabajos de Schneider constituyen una referencia obligada cuando se intenta dar una visión cuantitativa y global del tamaño de la economía informal en distintos países y regiones del mundo ${ }^{10}$. De estos trabajos se desprende que si bien la informalidad afecta en la actualidad a casi todos los países del mundo, no tiene en todos la misma dimensión (Schneider, 2012).

En el gráfico XI.1 se presentan los valores estimados de la economía informal durante el período 1999-2007 en distintas regiones o grupos de países. Si se considera el promedio simple de los países entre dichos años (columna derecha), se puede observar claramente la diferencia existente

\footnotetext{
Una visión "laboralista" de la informalidad (Organización Internacional del Trabajo (OIT)) estaría dada por la falta de protección social de los trabajadores derivada del incumplimiento o de la falta de cobertura, por distintas razones, de los sistemas de pensiones y los seguros de salud. Sin embargo, en este capítulo se adopta una visión más amplia de la informalidad que, generalmente, incluye a la primera.

10 Schneider, Buehn y Montenegro (2010) establecen que la economía oculta incluye toda la producción legal de bienes y servicios orientados al mercado que son deliberadamente apartados del control de las autoridades gubernamentales por alguna de las siguientes razones: i) evadir el pago de impuestos, ii) evadir el pago de contribuciones a la seguridad social, iii) evadir el cumplimiento de ciertos estándares legales del mercado laboral (salarios mínimos, jornada laboral, seguridad e higiene, y otros), y iv) evadir el cumplimiento de ciertos procedimientos administrativos (registro y control).
} 
en esta dimensión entre los países de altos ingresos pertenecientes a la Organización de Cooperación y Desarrollo Económicos (OCDE) y las demás regiones de menor grado de desarrollo. Además, si bien el promedio simple mundial (162 países) resulta elevado, en torno al 33\% del PIB oficial, existen regiones que superan dicho valor y se acercan al 40\%, como Europa y Asia Central y África Subsahariana ${ }^{11}$. América Latina y el Caribe, por su parte, es la región que cuenta con una economía informal, en promedio, de mayor tamaño a nivel internacional, con un $41,1 \%$ del PIB regional.

\section{Gráfico XI.1}

\section{Regiones o grupos de países: tamaño de la economía informal, promedio 1999-2007} (En porcentajes del PIB oficial)

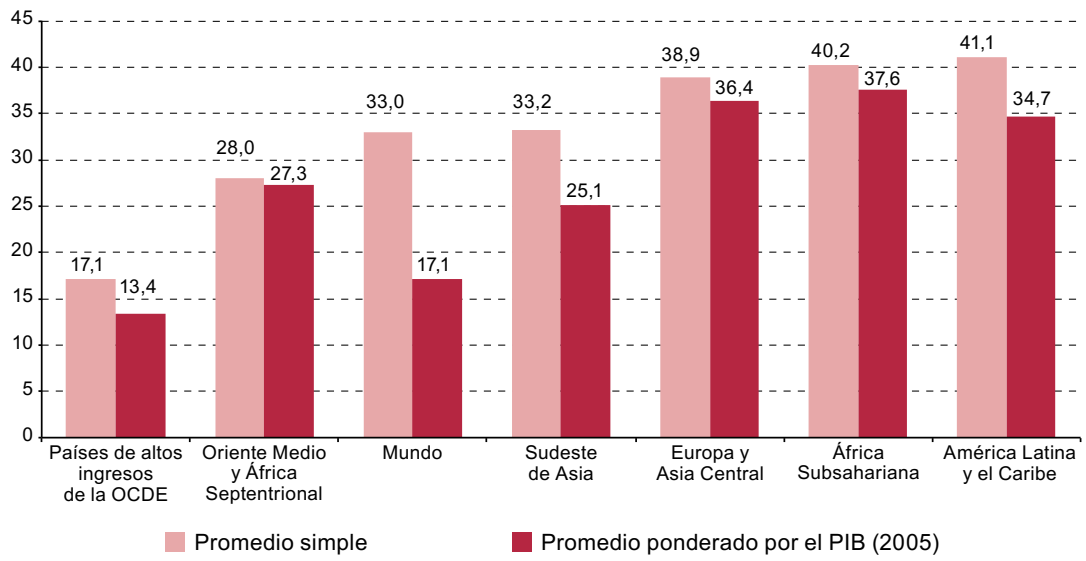

Fuente: Elaboración propia, sobre la base de F. Schneider, "The shadow economy and work in the shadow: what do we (not) know?", Discussion Paper Series, N 6423, Bonn, Instituto para el Estudio del Trabajo (IZA), 2012.

Si se toma como referencia el valor medio de dicha variable para el mismo período pero ponderando los resultados por el PIB de cada país en 2005, es posible advertir en el gráfico XI.1 que el estado de situación no varía significativamente, puesto que, mientras los países africanos se encuentran entre los más informales del mundo, en la OCDE el fenómeno representa alrededor de un tercio de ese nivel, ampliándose aún más la brecha señalada.

Así, los países desarrollados muestran valores de informalidad que se condicen con el promedio internacional (17,1\%). En un segundo escalón, los países del sudeste de Asia y de Oriente Medio y África Septentrional ${ }^{12}$ exhiben un valor medio entre el $25 \%$ y el $27 \%$. Por último, el tamaño de la

11 En este caso, Europa abarca los países europeos de menor grado de desarrollo y que no son miembros de la OCDE, la mayoría de los cuales se encuentran ubicados en la parte oriental del continente.

12 Se entiende por África Septentrional la parte del continente africano ubicada al norte del desierto del Sáhara y más próxima al mar Mediterráneo y al mar Rojo. Según las Naciones Unidas, esto incluye los territorios de Argelia, Egipto, Libia, Marruecos, Sudán y Túnez. 
economía informal en las regiones de América Latina y el Caribe (34,7\%), Europa Oriental y Asia Central (36,4\%) y África Subsahariana (37,6\%) alcanza valores medios que duplican la media mundial ponderada por el PIB, lo que refleja la gravedad del problema de la informalidad en muchos de estos países en desarrollo.

Además de los niveles estimados, también son importantes las características que tiene la informalidad en los diferentes países, principalmente en lo que respecta a la composición por sectores que conforman la economía informal de cada país. Los estudios realizados a nivel internacional muestran que existen grandes similitudes entre naciones de distinto grado de desarrollo con respecto a los sectores que presentan mayores índices de informalidad. De esta forma, los sectores de la agricultura, la construcción, el comercio minorista, el servicio doméstico y, en algunos casos, el transporte público se ubican por encima del resto cuando se los ordena según la magnitud de este fenómeno. Ello se debe a que estas actividades se caracterizan por la poca capacitación que demandan sus empleados y por la dificultad que tienen las autoridades competentes para controlarlas.

Sin embargo, los sectores que son típicamente informales poseen una importancia mayor dentro de la estructura económica en los países menos desarrollados. Este es el caso, principalmente, de la agricultura, el comercio minorista y el servicio doméstico. Asimismo, estos sectores por lo general concentran a los grupos de menor educación e ingresos más bajos, razón por la cual el enfoque de la dualidad o exclusión suele adaptarse mejor cuando se buscan las causas de la elevada informalidad en los países en desarrollo. No obstante, esto no quita que una parte importante del fenómeno obedezca a una decisión racional de los agentes económicos que optan por establecerse fuera del circuito formal de la economía para llevar adelante sus actividades.

La otra diferencia radica en las características que poseen estos sectores en cada grupo de países. En los países más desarrollados, la agricultura opera a gran escala y está orientada a la exportación, mientras que en las naciones más pobres una gran parte del sector se destina principalmente al mercado local (salvo en el caso de los productos básicos), y en algunos casos se trata incluso de una producción de subsistencia dirigida al autoconsumo. En los países más avanzados, el comercio minorista se realiza en establecimientos de cierta envergadura, con capacidad de crecimiento y de formalización, en tanto que en los países pobres esta actividad, que surge ante la imposibilidad de conseguir un empleo formal y es meramente de subsistencia, toma la forma extrema de venta ambulante y callejera.

Si bien América Latina registra, en promedio, uno de los mayores niveles de informalidad en el mundo, también presenta una elevada heterogeneidad de casos, con grandes diferencias en la dimensión y conformación de la economía informal que merecen ser destacadas. 
De acuerdo con Schneider (2012), en el cuadro XI.1 se muestran las estimaciones (en porcentajes del PIB oficial) correspondientes a los períodos 1999-2000 y 2006-2007, junto con el resultado medio (simple) entre 1999 y 2007, para cada país de América Latina, para la región, para la OCDE y para un amplio conjunto de 162 países. Vale mencionar que los países se ordenaron en función del valor medio latinoamericano para el período 1999-2007 $(41,1 \%)$. A su vez, y aunque todo criterio clasificatorio es susceptible de ser impugnado, parece adecuado agrupar a los países según estratos acordes con los niveles medios de informalidad (1999-2007), para lo cual se los ha dividido en tres grupos, tomando como criterio que se ubiquen un $25 \%$ por encima y por debajo del promedio regional.

\section{Cuadro XI.1}

América Latina: tamaño de la economía informal (En porcentajes del PIB oficial)

\begin{tabular}{|c|c|c|c|}
\hline Países & $1999-2000$ & $2006-2007$ & 1999-2007 \\
\hline \multicolumn{4}{|l|}{ Grupo 1} \\
\hline Bolivia (Estado Plurinacional de) & 67,1 & 63,2 & 66,1 \\
\hline Panamáa & 64,5 & 60,0 & 63,5 \\
\hline Perú & 60,0 & 54,7 & 58,0 \\
\hline \multicolumn{4}{|l|}{ Grupo 2} \\
\hline Uruguay & 50,8 & 47,3 & 50,6 \\
\hline Guatemala & 51,6 & 48,5 & 50,5 \\
\hline Honduras & 50,0 & 45,6 & 48,3 \\
\hline El Salvador & 46,4 & 43,4 & 45,1 \\
\hline Nicaragua & 45,5 & 43,3 & 44,6 \\
\hline Brasil & 40,3 & 37,2 & 39,0 \\
\hline Paraguay $^{a}$ & 38,9 & 37,4 & 38,8 \\
\hline Colombia & 39,3 & 34,3 & 37,3 \\
\hline Venezuela (República Bolivariana de) & 33,7 & 31,5 & 33,8 \\
\hline Ecuador & 34,3 & 30,4 & 32,4 \\
\hline República Dominicana & 32,3 & 30,8 & 31,9 \\
\hline \multicolumn{4}{|l|}{ Grupo 3} \\
\hline México & 30,5 & 29,0 & 30,0 \\
\hline Costa Rica & 26,2 & 24,5 & 25,7 \\
\hline Argentina & 25,3 & 23,4 & 25,3 \\
\hline Chile & 19,9 & 18,6 & 19,3 \\
\hline América Latina $^{b}$ & 42,0 & 39,1 & 41,1 \\
\hline OCDE (34 países) & 17,5 & 16,7 & 17,1 \\
\hline Promedio mundial $^{c}$ & 33,9 & 31,7 & 33,0 \\
\hline
\end{tabular}

Fuente: Elaboración propia, sobre la base de F. Schneider, "The shadow economy and work in the shadow: what do we (not) know?", Discussion Paper Series, N 6423, Bonn, Instituto para el Estudio del Trabajo (IZA), 2012; y F. Schneider, A. Buehn y C. Montenegro, "Shadow economies all over the world: new estimates for 162 countries from 1999 to 2007", Policy Research Working Paper, $N^{\circ}$ 5356, Washington, D.C., Banco Mundial, 2010.

Datos disponibles solo hasta fin de 2006.

b Promedio simple sin ponderar por el PIB de los países.

c Promedio simple para 162 países. 
El criterio aplicado configura una situación en la cual se incluyen 11 países en el Grupo 2 con un tamaño de economía informal relativamente cercano al promedio de la región, pero que en la mayoría de los casos resulta superior al promedio mundial (sin ponderar por el PIB) y duplica con creces el promedio exhibido por los países de la OCDE. Mientras tanto, en los extremos se encuentran Bolivia (Estado Plurinacional de), Panamá y el Perú (que conforman el Grupo 1), con niveles de informalidad que se encuentran no solo entre los más elevados de la región, sino de todo el mundo. Por su parte, el Grupo 3, conformado por la Argentina, Chile, Costa Rica y México, muestra valores mucho más acordes a los parámetros internacionales, aun ubicándose por encima de los correspondientes a los países más desarrollados ${ }^{13}$.

Aun con estas diferencias, un hecho alentador de la evolución económica reciente en América Latina, en consonancia con el acelerado crecimiento económico y la reducción de los niveles de desigualdad, es la reducción, moderada pero unánime, del tamaño de la economía informal en todos los países de la región. Así, es posible advertir que en la última década, y siguiendo la tendencia mundial en esta materia, los niveles de informalidad han descendido en todos los casos y muy especialmente en los países que mostraban mayores valores en el período 1999-2000, como los que integran el Grupo 1 y algunos del Grupo 2, como Guatemala, Honduras y el Uruguay.

Sin embargo, a pesar de esta generalizada tendencia favorable, una mirada de más largo plazo obliga a relativizar los logros alcanzados en los últimos años, ya que, de acuerdo con las evidencias disponibles aplicando una metodología similar a la de Schneider (2012) y Schneider, Buehn y Montenegro (2010), el tamaño de la economía informal se había incrementado muchísimo en la década de 1990 en la mayoría de los países de la región (también acompañando la tendencia mundial), hasta alcanzar valores máximos en el bienio 1999-2000 ${ }^{14}$.

\section{Interacciones entre la tributación y el tamaño de la economía informal}

Dos hechos estilizados constituyen los ejes centrales del presente trabajo. Por una parte, se señala una relativa disminución del tamaño de la economía informal que, pese a seguir mostrando valores muy elevados en la comparación internacional, exhibe evidentes mejoras logradas a partir de la implementación

13 Solo para tener una idea ilustrativa, para el promedio 1999-2007, el tamaño de la economía informal (en relación con el PIB oficial) estimado por Schneider (2012) fue del 8,5\% en Suiza, del 8,6\% en los Estados Unidos, del 12,7\% en China, del 16\% en Alemania, del 22,5\% en España y del 27\% en Italia.

14 Se reconoce, no obstante, que los valores estimados en distintos momentos del tiempo deben tratarse con cautela dado el progresivo perfeccionamiento de las metodologías aplicadas y la mayor disponibilidad de la información estadística requerida para llevar a cabo las estimaciones. 
de distintas políticas de formalización de los agentes económicos y de la adopción de técnicas avanzadas de administración tributaria.

Por otra parte, durante la pasada década se ha observado un aumento sostenido de la recaudación tributaria en casi todos los países y un proceso simultáneo de concentración de la estructura impositiva en sus principales componentes, lo que, en gran medida, ha marcado las posibilidades que actualmente encuentran la política y la administración tributarias en América Latina para continuar con esa tendencia ${ }^{15}$.

En ese contexto, este análisis consiste en observar la evolución conjunta del tamaño estimado de la economía informal y la carga tributaria para todos los países de los que se dispone de información estadística actualizada, comparando la situación existente entre dos períodos (1999-2000 y 2006-2007).

Se debe dejar en claro que, si bien puede suponerse una relación estrecha entre estas variables, con derivaciones e implicancias reales sobre la política tributaria de los países, no resulta posible establecer de una manera explícita y concluyente el orden de prelación o de la causalidad de estos factores. En todo caso, se entiende que, por los argumentos expuestos a lo largo de este capítulo, la recaudación tributaria y la informalidad interactúan formando círculos virtuosos o viciosos, según sea el caso, que involucran un conjunto de características tales como el nivel de cumplimiento tributario, la moral tributaria, la legitimidad del Estado y sus instituciones.

En el gráfico XI.2 se presentan los valores del tamaño de la economía informal (Schneider, 2012) y de la recaudación generada por el impuesto sobre el valor agregado (IVA) (en porcentajes del PIB) para los 18 países de la región y en dos momentos distintos (1999-2000 y 2006-2007). Puede advertirse que la reducción de la informalidad en todas las economías latinoamericanas durante la última década, aun con distintos grados de importancia, se ha visto acompañada de un considerable y generalizado aumento del monto de ingresos tributarios aportados por dicho gravamen, con la única excepción de Chile, donde se registró una leve merma en la recaudación.

Dado que el IVA —así como otros impuestos sobre bienes y serviciosestá relacionado con el nivel de actividad económica, puede influir sobre las decisiones tributarias de las empresas y los individuos por el lado de la oferta y, aun siendo un impuesto de autocumplimiento, puede disuadir a cualquier etapa de la cadena de valor para dejar de pertenecer a la economía formal. La informalidad puede convertirse en una cuestión importante para la recaudación efectiva del IVA dependiendo, entre otros factores, del hecho de que los intercambios fuera del sector formal sean de bienes finales 0 intermedios, ya que, en las transacciones de estos últimos entre una empresa

15 En el capítulo I de este libro se presenta un análisis más detallado de estas tendencias. 
formal y otra informal, aun cuando puedan evadir el pago del IVA, los pequeños distribuidores informales deberán asumir el IVA que se encuentra incluido en los precios de venta de sus proveedores formales (OCDE, 2008).

\section{Gráfico XI.2}

América Latina (18 países): tamaño de la economía informal y recaudación del impuesto sobre el valor agregado (IVA), 1999-2000 y 2006-2007

(En porcentajes de la economía total y en porcentajes del PIB)

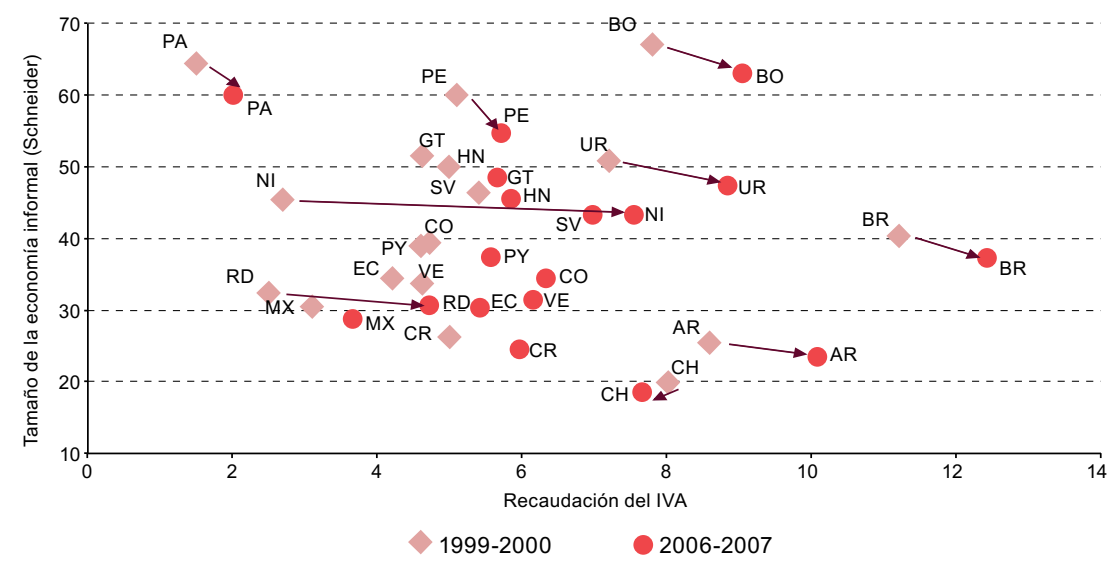

Fuente: Elaboración propia, sobre la base de F. Schneider, "The shadow economy and work in the shadow: what do we (not) know?", Discussion Paper Series, $N^{\circ} 6423$, Bonn, Instituto para el Estudio del Trabajo (IZA), 2012 y CEPALSTAT.

Nota: Las referencias corresponden a los siguientes países: Argentina (AR), Bolivia (Estado Plurinacional de) (BO), Brasil (BR), Chile (CH), Colombia (CO), Costa Rica (CR), Ecuador (EC), El Salvador (SV), Guatemala (GT), Honduras (HN), México (MX), Nicaragua (NI), Panamá (PA), Paraguay (PY), Perú (PE), República Dominicana (RD), Uruguay (UR) y Venezuela (República Bolivariana de) (VE).

Debe notarse entonces que, en virtud de las particulares características del gravamen, la mayor evasión tributaria de este impuesto y, en consecuencia, la mayor informalidad tenderían a ocurrir en la última etapa del proceso productivo, puesto que los agentes no perderían el beneficio del crédito que otorga el IVA en las etapas intermedias. Esto explica, en parte, la mayor informalidad laboral y productiva en determinados sectores, como los pequeños productores primarios (agricultura, ganadería, pesca y otros), el comercio minorista y los proveedores de servicios especializados, que suelen ser los que requieren un uso intensivo de mano de obra.

Por lo tanto, la pérdida de recaudación por evasión quedaría acotada a la etapa en que, efectivamente, se realizara un pago. Si esta etapa fuera la última del proceso productivo, aún se recaudaría todo el impuesto determinado en las etapas anteriores. Asimismo, los incentivos para evadir el IVA y permanecer fuera de los circuitos formales se reducen en las etapas intermedias debido a la mayor concentración económica que suele registrarse y que facilita la fiscalización por parte de la autoridad tributaria. 
Por otra parte, debe señalarse que la informalidad, no obstante la positiva evolución reciente del IVA en casi toda la región por su estrecho vínculo con la evasión impositiva, obstaculiza la recaudación y reduce la base gravable potencial del IVA en la mayoría de los casos. De esta manera, la productividad del gravamen disminuye, lo que se traduce en pérdidas de eficiencia y equidad. Sin embargo, una baja productividad del impuesto no es necesariamente producto de un cumplimiento tributario deficiente, puesto que este indicador no tiene en cuenta la existencia de exenciones y regímenes especiales en cada país, que pueden representar un monto muy importante de gastos tributarios en algunos casos, como en Chile, el Ecuador, Guatemala y México (Gómez Sabaini y Jiménez, 2011).

En este sentido, según la OCDE (2008), el énfasis puesto en el fortalecimiento del IVA y la histórica dependencia de los países de la región respecto de la imposición indirecta - que es menos progresiva por naturaleza, pero más fácil de recaudar- podrían tener que ver con una respuesta pragmática de la política tributaria ante la presencia de un extenso sector informal en América Latina.

Un comportamiento similar al descripto para el IVA se ha observado también en el ISR y su evolución reciente en la región. Según se desprende del gráfico XI.3, en los países analizados se ha comprobado un aumento significativo en los ingresos tributarios generados por la aplicación de este tributo (medido en porcentajes del PIB), al tiempo que el nivel de informalidad, tal como se expresó, descendió entre los períodos 1999-2000 y 2006-2007.

Vale decir que el impuesto sobre la renta de las personas físicas (IRPF) es un gravamen cuya base de recaudación, en la mayoría de los países y por razones intrínsecas a su diseño tributario, se nutre mayormente de los ingresos de asalariados formales (Gómez Sabaini, Jiménez y Rossignolo, 2012). Además, en la región se ha generalizado el cobro de este impuesto a través del método de retenciones en la fuente, lo que dificulta la evasión al vincular el pago del ISR con el puesto de trabajo y el cobro de las remuneraciones formales. Así, desde la óptica del trabajador, el ISR que debe pagar incide en la decisión de "salida" del sector formal de la economía y un aumento sustancial de dicho tributo podría incentivar su paso a la informalidad. Por el lado de la oferta, en tanto, tanto para las empresas como para los trabajadores autónomos que no se encuentran en relación de dependencia, el incentivo a evadir es mucho mayor, sobre todo entre los pequeños contribuyentes.

Por otra parte, como se ha planteado a lo largo de este capítulo, el tamaño de la economía informal tiene efectos en el sistema tributario a través de una mayor evasión impositiva con la considerable reducción de los recursos públicos que esto implica. La evasión impositiva, a su vez, puede reforzar algunos de los determinantes de la informalidad, en tanto representa un incumplimiento de las normas establecidas en el sector formal. Por lo tanto, 
entender los mecanismos que influyen sobre la evasión contribuye a explicar algunas dimensiones fundamentales del fenómeno de la informalidad.

\section{Gráfico XI.3}

América Latina (17 países): tamaño de la economía informal y recaudación del impuesto sobre la renta (ISR), 1999-2000 y 2006-2007 a

(En porcentajes de la economía total y en porcentajes del PIB)

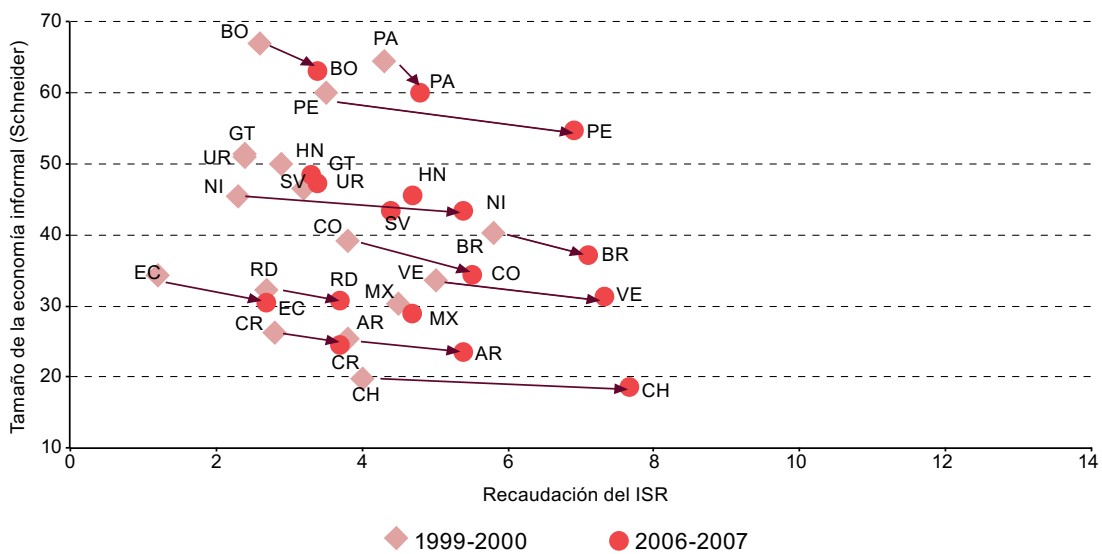

Fuente: Elaboración propia, sobre la base de F. Schneider, "The shadow economy and work in the shadow: what do we (not) know?", Discussion Paper Series, N 6423 , Bonn, Instituto para el Estudio del Trabajo (IZA), 2012 y CEPALSTAT.

Nota: Las referencias corresponden a los siguientes países: Argentina (AR), Bolivia (Estado Plurinacional de) (BO), Brasil (BR), Chile (CH), Colombia (CO), Costa Rica (CR), Ecuador (EC), El Salvador (SV), Guatemala (GT), Honduras (HN), México (MX), Nicaragua (NI), Panamá (PA), Perú (PE), República Dominicana (RD), Uruguay (UR) y Venezuela (República Bolivariana de) (VE).

a Se excluye al Paraguay debido a que no es comparable al resto de los países de la región por carecer de un gravamen real sobre los ingresos de las personas físicas.

En primer lugar, debe decirse que en muchos países de América Latina la debilidad de los sistemas tributarios se explica tanto por los elevados niveles de incumplimiento tributario, lo que genera un bajo nivel de imposición efectiva respecto de sus posibilidades potenciales, como por el sesgo marcado hacia la imposición indirecta en detrimento de la imposición directa (Cornia, Gómez Sabaini y Martorano, 2011).

Las estimaciones disponibles, tal como se presenta en detalle en el capítulo XII de este libro, demuestran que el fenómeno de la evasión es de mucha mayor profundidad en el ISR (personal y societaria) que en el IVA, pese a que ambos tributos se encuentran sustancialmente interrelacionados. En este sentido, se observa además que las iniciativas implementadas en materia de administración tributaria parecen haber estado enfocadas mucho más en combatir la evasión existente en el IVA, restando importancia al cumplimiento efectivo en los impuestos a los ingresos y a la tributación directa en general. 
Prueba de ello es que mientras que se han desarrollado sistemas y asignado fondos de cooperación externa a programas para campañas orientadas al combate a la evasión del IVA, las administraciones tributarias han destinado menores esfuerzos al control de la evasión relativa a la imposición sobre la renta. En cuanto al diagnóstico, llama la atención la falta de estimaciones de evasión en el ISR, a la vez que se observa la existencia de estimaciones de evasión en el IVA desde hace algunas décadas ${ }^{16}$.

El elevado nivel de incumplimiento en el ISR es un fenómeno generalizado en todos los países de América Latina y ello tiene implicancias no solo sobre la eficiencia del gravamen sino también sobre la equidad distributiva, puesto que relativiza y reduce considerablemente la incidencia que podría tener la tributación directa, y especialmente el IRPF, sobre la distribución del ingreso de la población.

Además, la falta de control de la evasión tiene consecuencias sobre la posibilidad de disponer de los recursos necesarios para aumentar el gasto social, por lo que este control resulta indispensable para satisfacer los criterios de equidad y progresividad de la estructura tributaria. Por lo tanto, se erige como un aspecto fundamental a tener en cuenta si se quiere mejorar no solo el nivel de la recaudación sino también la incidencia distributiva de los sistemas tributarios de la región.

Dado que aparecen como dos fenómenos estrechamente vinculados, en el gráfico XI.4 se puede identificar la correlación positiva que existe entre la magnitud de la informalidad y los niveles de evasión tributaria en los países de la región. Debe aclararse, no obstante, que en este caso se utilizan los datos de incumplimiento correspondientes al IVA como muestra del sistema tributario por una cuestión meramente estadística, aunque existen sólidas razones para pensar que los guarismos globales son superiores a los presentados.

Según Perry y otros (2007), la informalidad en América Latina se ve reflejada en varias dimensiones de la realidad socioeconómica de los países, que expresan la existencia de un contrato social "disfuncional", es decir, de una deficiente interacción individual y colectiva con el Estado, el cual no muestra la capacidad necesaria para llevar adelante, de manera eficiente y equitativa, sus funciones básicas y atenta contra el compromiso de los ciudadanos para desenvolverse en el marco de las normas sociales establecidas.

16 El trabajo de Jiménez, Gómez Sabaini y Podestá (2010) constituye uno de los escasos intentos de medir la evasión en el ISR mediante la aplicación de una metodología común para una muestra acotada de países de la región. 


\section{Gráfico XI.4}

América Latina (14 países): tamaño de la economía informal y evasión tributaria del impuesto sobre el valor agregado (IVA), 2006-2007

(En porcentajes de la economía total y en porcentajes)

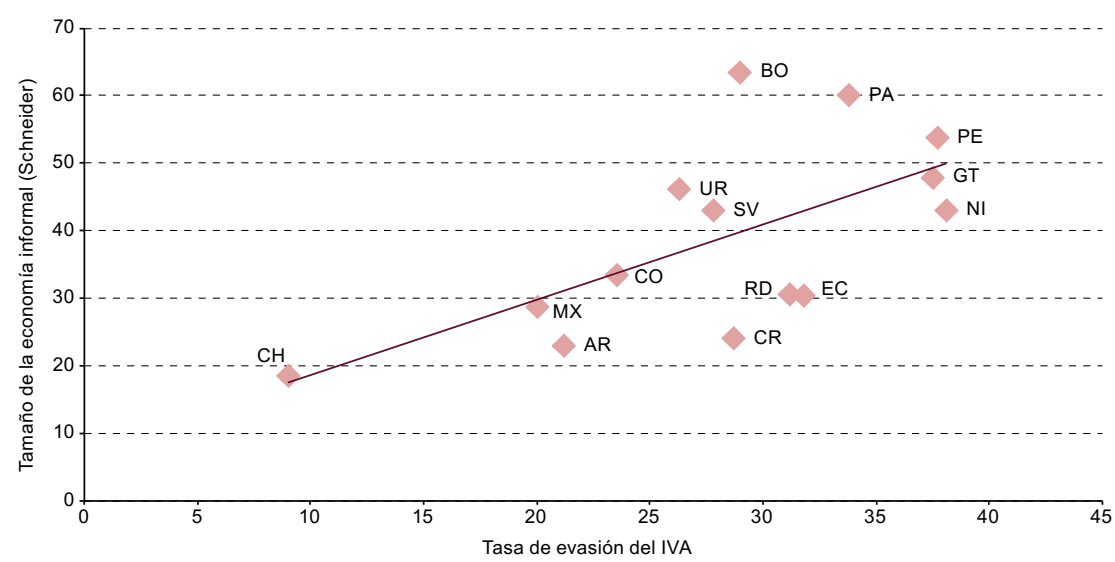

Fuente: Elaboración propia, sobre la base de F. Schneider, "The shadow economy and work in the shadow: what do we (not) know?", Discussion Paper Series, № 6423, Bonn, Instituto para el Estudio del Trabajo (IZA), 2012; y J.C. Gómez Sabaini y J.P. Jiménez, "Estructura tributaria y evasión impositiva en América Latina", Documento de Trabajo, N²011/08, Corporación Andina de Fomento (CAF), 2011.

Nota: Con fecha posterior a la realización de este trabajo, el Servicios de Impuestos Internos (SII) de Chile volvió a estimar la serie de tasas de evasión del IVA en virtud de la difusión de una nueva matriz de insumo-producto (MIP 2008). Esta serie se presenta en el capítulo XII de este libro. Las referencias corresponden a los siguientes países: Argentina (AR), Bolivia (Estado Plurinacional de) (BO), Chile (CH), Colombia (CO), Costa Rica (CR), Ecuador (EC), El Salvador (SV), Guatemala (GT), México (MX), Nicaragua (NI), Panamá (PA), Perú (PE), República Dominicana (RD) y Uruguay (UR).

Entre los factores que se pueden señalar como determinantes de esta situación (además de los que se relacionan con los sistemas de seguridad social y el marco regulatorio de los países), sobresalen dos: i) la existencia de una importante brecha entre la recaudación tributaria potencial y efectiva, producto de los elevados niveles de evasión impositiva y de las estrechas bases gravables de los principales tributos, y ii) la presencia de un elevado número de pequeños contribuyentes (empresas e individuos) que evaden completa o parcialmente el pago de impuestos, cargas salariales y regulaciones económicas (Gómez Sabaini y Jiménez, 2011).

Debe notarse que, aunque suele reconocerse que el empleo informal se concentra en las empresas de menor tamaño (pymes) y los trabajadores independientes, no existen evidencias irrefutables que corroboren la idea de que estos agentes sean la principal fuente de la evasión tributaria. Es decir que, aun cuando las tasas de evasión puedan ser mucho mayores entre estos contribuyentes respecto de las empresas más grandes, en la mayoría de los 
casos, la recaudación potencial que se podría obtener sería una porción muy reducida de los ingresos tributarios ${ }^{17}$.

De allí que las políticas de formalización de las empresas pequeñas y los trabajadores informales, así como la implementación de regímenes de tributación simplificada que se abordarán en la sección $\mathrm{D}$ del presente capítulo, no deban regirse solamente por objetivos recaudatorios - dado que el resultado potencial sería poco satisfactorio-, sino que además requieren la voluntad de fortalecer el vínculo entre la ciudadanía y el Estado para promover el cumplimiento voluntario de las obligaciones tributarias en contrapartida a la provisión de servicios públicos de calidad.

La debilidad del pacto fiscal en América Latina está relacionada con otros hechos estilizados que van más allá de lo estrictamente económico. La baja calidad de los servicios públicos prestados por el Estado, la deficiente capacidad para implementar las políticas públicas necesarias y la escasa confianza de la ciudadanía en las instituciones públicas son características que se repiten en los países de la región y conspiran contra el cumplimiento voluntario de los contribuyentes, al tiempo que favorecen el crecimiento de la economía informal (Loayza, Servén y Sugawara, 2009).

Asimismo, la baja moral tributaria - entendida como el grado de rechazo de los ciudadanos ante el incumplimiento de las obligacionescaracteriza a los países de la región y socava las raíces de dicho pacto social. Existen evidencias sobre la correlación negativa entre la moral tributaria y la informalidad (Perry y otros, 2007), lo que sugiere que este último fenómeno se observa con mayor frecuencia e intensidad en aquellos países en los que existe una percepción generalizada sobre la falta de equidad del sistema tributario, la poca efectividad del Estado para monitorear a los contribuyentes y la incapacidad de penalizar las acciones de evasión tributaria.

Desde esta perspectiva, la ciudadanía tenderá a comprometerse con el Estado (pagando debidamente sus impuestos) si percibe que este cumple con su parte del contrato social y que, a su vez, los demás contribuyentes también cumplen con el marco jurídico e institucional. Esto crea un círculo entre la informalidad, la tributación y el papel del Estado, que puede ser vicioso o virtuoso según cada caso. En contextos de elevada informalidad, como sucede en la mayor parte de América Latina, existirá más evasión y esta se incrementará si la moral tributaria es baja, lo que conduce a una reducción de los recursos disponibles y a un deterioro en la calidad de

17 En un trabajo reciente de Fuentes Castro y otros (2011) se señala esta particularidad para el caso mexicano, donde la tasa de incumplimiento tributario en el Régimen de pequeños contribuyentes (REPECOS), en vigencia durante el período 2000-2008, se ubicó por encima del 90\% (un 96\% en 2010), cifra que resulta muy superior a la tasa de evasión estimada para el sistema tributario mexicano en su conjunto (inferior al $40 \%$ ). 
los servicios públicos provistos por el Estado, que perderá legitimidad e incentivará, aún más, la informalidad y la evasión tributaria como respuesta de los contribuyentes.

\section{Las respuestas tributarias para atender los niveles de informalidad}

En los últimos años se ha incrementado el interés de la política tributaria por las pymes y los pequeños contribuyentes (DFI, 2007). Esto puede representar una respuesta lógica tras la persistente atención que se ha dado al grupo de los llamados "grandes contribuyentes" en décadas pasadas, pero también obedece a la relación existente entre la informalidad y el tamaño de las empresas, que ha conducido a concentrarse más en el tratamiento impositivo como elemento fundamental para contrarrestar, o al menos para no intensificar, los efectos de dicho fenómeno sobre la economía.

En la literatura sobre el tema se han esgrimido numerosos argumentos a favor de la implementación de instrumentos tributarios específicos aplicados a este tipo de contribuyentes. Sin embargo, al ser considerados parte integrante del segmento de contribuyentes "difíciles de gravar", parece existir consenso respecto de que la principal motivación para aplicar estos regímenes especiales, sobre todo en América Latina, radica en la necesidad de garantizar el cumplimiento voluntario de sus obligaciones tributarias, minimizando el costo implícito para las empresas más pequeñas y el costo que su administración representa para las administraciones tributarias, que se acrecienta en los países con menor grado de desarrollo.

Tratar de sintetizar el impacto que la existencia de un amplio sector de economía informal genera en las estructuras tributarias de los países de América Latina lleva, inexorablemente, al análisis de los regímenes tributarios simplificados, lo que supone una tarea compleja, ya que cada país tiene parámetros y dimensiones diferentes. Sin embargo, se pueden apreciar ciertas similitudes que se reseñarán más adelante, tras una breve síntesis sobre la reacción de los países frente a estas circunstancias.

En un contexto de fuerte crecimiento económico y reducción de la desigualdad, el diseño de tratamientos especiales para gravar a los pequeños contribuyentes, ya sean personas físicas o empresas, excluyéndolos de las normas generales del IVA o del ISR, estableciendo métodos presuntivos de determinación del impuesto o imponiéndoles tasas más reducidas, ha sido uno de los principales caminos que han adoptado los países de América Latina para "descomprimir" la carga de trabajo de las administraciones tributarias y mejorar así sus capacidades de fiscalización ${ }^{18}$.

18 Véase un análisis de las principales estrategias que siguieron las administraciones tributarias de la región en las últimas décadas en Gómez Sabaini y Jiménez (2011). 
Al respecto, González (2006) señala que "en la mayoría de los países la instrumentación de regímenes especiales de tributación para los pequeños contribuyentes, no ha tenido como objeto primordial la recaudación tributaria, sino resolver una problemática de administración tributaria con la finalidad de incorporar a la formalidad a un amplio sector de contribuyentes de escasa significación económica".

A partir de la implementación de estos regímenes en la mayoría de los países latinoamericanos, se ha buscado facilitar el pago de impuestos de contribuyentes que en general responden a las siguientes características: i) tienen bajos ingresos, ii) son muchos, lo que dificulta el control oficial, iii) son mayormente informales iv) tienen una pobre estructura organizacional y v) presentan una alta movilidad de entrada y salida. De esta manera, se busca simplificar las normas legales y los trámites administrativos que implica el cumplimiento de las obligaciones tributarias, apuntando con ello a brindar un "puente" para atraer a la formalidad a los agentes económicos y, al mismo tiempo, mejorar el manejo de los recursos de la administración tributaria.

Antes de avanzar con el análisis, debe quedar claro que la problemática que plantea el tratamiento tributario de los pequeños contribuyentes se presenta en casi todos los países del mundo, aun en los miembros de la $\mathrm{OCDE}^{19}$. Sin embargo, su impacto y relevancia toma mayor envergadura en los países en desarrollo, donde los niveles de eficiencia en la administración tributaria son menores y el grado de informalidad es mucho más elevado.

Los regímenes de tributación simplificada se hallan muy difundidos en América Latina. De hecho, con la excepción de El Salvador y Venezuela (República Bolivariana de), todos los países de la región han implementado algún sistema de tratamiento tributario diferencial sobre los pequeños contribuyentes. Asimismo, tal como se presenta en el cuadro XI.2, en algunos casos se aplican simultáneamente varios de estos esquemas, tal como sucede en la Argentina, Bolivia (Estado Plurinacional de), el Brasil, Chile, el Paraguay, el Perú, la República Dominicana y el Uruguay ${ }^{20}$. En todas las circunstancias, no obstante, el problema genérico de la tributación simplificada consiste en clasificar a los pequeños contribuyentes (o a algún grupo de estos en particular) en distintas categorías definidas por alguna noción de tamaño $\mathrm{y}$ en determinar de qué forma ( $\mathrm{y}$, de hecho, si corresponde) imponer sobre estos uno o varios de los gravámenes vigentes en el régimen general de tributación de cada país.

Véase OCDE (2009).

20 El monotributo argentino incluye una serie de regímenes complementarios que, si bien se rigen por una normativa común, poseen características particulares por estar dirigidos a grupos específicos de contribuyentes. 
Cuadro XI.2

América Latina: regímenes especiales para pequeños contribuyentes

\begin{tabular}{|c|c|c|c|}
\hline Países & Denominación & $\begin{array}{l}\text { Año de } \\
\text { inicio }\end{array}$ & Impuestos incluidos en el régimen \\
\hline \multirow[t]{2}{*}{ Argentina $^{a}$} & $\begin{array}{l}\text { 1) Monotributo y sus regímenes } \\
\text { complementarios: } \\
\text { a) Monotributo Social (efectores de } \\
\text { desarrollo local y economía social) } \\
\text { b) Régimen de inclusión } \\
\text { social y promoción del trabajo } \\
\text { independiente } \\
\text { c) Régimen especial para } \\
\text { trabajadores asociados } \\
\text { a cooperativas de trabajo }\end{array}$ & \multirow[t]{2}{*}{$\begin{array}{l}1998, \\
\text { excepto } \\
\text { servicio } \\
\text { doméstico } \\
(2005)\end{array}$} & \multirow[t]{2}{*}{$\begin{array}{l}\text { Sustituye a impuestos nacionales } \\
\text { (impuesto a las ganancias e IVA) } \\
\text { y a los aportes previsionales. } \\
\text { Además, incluye un seguro de } \\
\text { salud obligatorio. }\end{array}$} \\
\hline & $\begin{array}{l}\text { 2) Régimen simplificado para } \\
\text { trabajadores del servicio doméstico }\end{array}$ & & \\
\hline \multirow{4}{*}{$\begin{array}{l}\text { Bolivia (Estado } \\
\text { Plurinacional de) }\end{array}$} & \multirow{2}{*}{$\begin{array}{l}\text { 1) Régimen Tributario Simplificado } \\
\text { (RTS) }\end{array}$} & 1) 1997 & \multirow{4}{*}{$\begin{array}{l}\text { Sustituyen al impuesto sobre el } \\
\text { valor agregado, al impuesto sobre } \\
\text { las utilidades de las empresas y al } \\
\text { impuesto sobre las transacciones. } \\
\text { EI STI y el RAU también sustituyen } \\
\text { al régimen complementario del IVA. }\end{array}$} \\
\hline & & 2) 1996 & \\
\hline & 2) Sistema Tributario Integrado (STI) & 3) 1996 & \\
\hline & $\begin{array}{l}\text { 3) Régimen Agropecuario Unificado } \\
\text { (RAU) }\end{array}$ & & \\
\hline \multirow[t]{3}{*}{ Brasil } & \multirow{2}{*}{$\begin{array}{l}\text { 1) Régimen Especial Unificado } \\
\text { de Recaudación de Tributos y } \\
\text { Contribuciones sobre las Micro y } \\
\text { Pequeñas Empresas (SIMPLES } \\
\text { Nacional) }\end{array}$} & 1) 2007 & \multirow{3}{*}{$\begin{array}{l}\text { EI SIMPLES Nacional sustituye a } \\
\text { dos impuestos federales (impuesto } \\
\text { sobre la renta de personas jurídicas } \\
\text { (IRPJ) e impuesto sobre los productos } \\
\text { industrializados (IPI)), al impuesto } \\
\text { sobre la circulación de mercaderías y } \\
\text { servicios (ICMS) de alcance estadual, } \\
\text { al impuesto sobre los servicios } \\
\text { (ISS) de alcance municipal y a las } \\
\text { contribuciones a la seguridad social } \\
\text { (Programa de Integración Social } \\
\text { (PIS)/Programa de Formación del } \\
\text { Patrimonio del Funcionario Público } \\
\text { (PASEP), Contribución para el } \\
\text { Financiamiento de la Seguridad } \\
\text { Social (COFINS), Contribución Social } \\
\text { sobre el Lucro Líquido (CSLL) y } \\
\text { Contribución Previsional Patronal } \\
\text { (CPP)). EI SIMEI sustituye a la } \\
\text { contribución personal a la seguridad } \\
\text { social, el ICMS y el ISS (estos últimos } \\
\text { en caso de que corresponda). }\end{array}$} \\
\hline & & \multirow[t]{2}{*}{ 2) 2009} & \\
\hline & $\begin{array}{l}\text { 2) Sistema para el Microemprendedor } \\
\text { Individual (SIMEI) }\end{array}$ & & \\
\hline \multirow[t]{4}{*}{ Chile } & $\begin{array}{l}\text { 1) Régimen simplificado del impuesto } \\
\text { sobre la renta (minería, comercio, } \\
\text { industria y pesca) }\end{array}$ & \multirow[t]{4}{*}{2007} & \multirow{4}{*}{$\begin{array}{l}\text { El Régimen simplificado y el Régimen } \\
\text { de renta presunta sustituyen } \\
\text { exclusivamente al impuesto sobre } \\
\text { la renta. El Régimen de tributación } \\
\text { simplificada y el Régimen de cambio } \\
\text { de sujeto sustituyen exclusivamente } \\
\text { al impuesto al valor agregado. }\end{array}$} \\
\hline & $\begin{array}{l}\text { 2) Régimen de renta presunta } \\
\text { (agropecuario) }\end{array}$ & & \\
\hline & $\begin{array}{l}\text { 3) Régimen de tributación simplificada } \\
\text { para los pequeños contribuyentes }\end{array}$ & & \\
\hline & $\begin{array}{l}\text { 4) Régimen de cambio de sujeto del } \\
\text { impuesto sobre el valor agregado }\end{array}$ & & \\
\hline \multirow[t]{3}{*}{ Colombiab $^{\text {b }}$} & \multirow{2}{*}{$\begin{array}{l}\text { 1) Régimen simplificado del impuesto } \\
\text { sobre las ventas }\end{array}$} & 1) 1983 & \multirow{2}{*}{$\begin{array}{l}\text { 1) Sustituye al impuesto sobre las } \\
\text { ventas (IVA). }\end{array}$} \\
\hline & & \multirow{2}{*}{ 2) 2013} & \\
\hline & $\begin{array}{l}\text { 2) Impuesto mínimo alternativo simple } \\
\text { (IMAS) }\end{array}$ & & $\begin{array}{l}\text { 2) Sustituye al impuesto sobre } \\
\text { la renta. }\end{array}$ \\
\hline Costa Rica & $\begin{array}{l}\text { Régimen de tributación simplificada } \\
\text { para comerciantes minoristas y bares }\end{array}$ & 1996 & $\begin{array}{l}\text { Sustituye al impuesto general a las } \\
\text { ventas (tipo IVA) y al impuesto sobre } \\
\text { la renta. }\end{array}$ \\
\hline Ecuador & $\begin{array}{l}\text { Régimen Impositivo Simplificado } \\
\text { Ecuatoriano (RISE) }\end{array}$ & 2008 & $\begin{array}{l}\text { Sustituye al impuesto sobre el } \\
\text { valor agregado y al impuesto sobre } \\
\text { la renta. }\end{array}$ \\
\hline Guatemala & Régimen de pequeño contribuyente & $\begin{array}{l}1992 \\
\text { (ref. 2012) }\end{array}$ & $\begin{array}{l}\text { Sustituye al impuesto al valor } \\
\text { agregado y al impuesto sobre } \\
\text { la renta. }\end{array}$ \\
\hline
\end{tabular}


Cuadro XI.2 (conclusión)

\begin{tabular}{|c|c|c|c|}
\hline Países & Denominación & $\begin{array}{l}\text { Año de } \\
\text { inicio }\end{array}$ & Impuestos incluidos en el régimen \\
\hline Honduras & $\begin{array}{l}\text { Régimen Simplificado del Impuesto } \\
\text { sobre Ventas }\end{array}$ & 2003 & $\begin{array}{l}\text { Sustituye al impuesto sobre } \\
\text { las ventas. }\end{array}$ \\
\hline México & $\begin{array}{l}\text { Régimen de Incorporación Fiscal (RIF) } \\
\text { (reemplazó al Régimen de pequeños } \\
\text { contribuyentes (REPECOS), que } \\
\text { estaba vigente desde } 1998 \text { y era } \\
\text { administrado por los estados desde } \\
2004 \text {, y al régimen intermedio) }\end{array}$ & 2014 & $\begin{array}{l}\text { Sustituye al impuesto sobre la renta, } \\
\text { con una reducción gradual del } 10 \% \\
\text { anual, además del impuesto al valor } \\
\text { agregado y el impuesto especial } \\
\text { sobre producción y servicios (IEPS) } \\
\text { hasta cierto monto de facturación. }\end{array}$ \\
\hline Nicaragua & $\begin{array}{l}\text { Régimen especial de estimación } \\
\text { administrativa para contribuyentes } \\
\text { por cuota fija }\end{array}$ & 2003 & $\begin{array}{l}\text { Sustituye al impuesto al valor } \\
\text { agregado y al impuesto sobre } \\
\text { la renta. }\end{array}$ \\
\hline \multirow[t]{4}{*}{ Paraguay } & $\begin{array}{l}\text { 1) Impuesto sobre la renta de } \\
\text { pequeños contribuyentes (IRPC) }\end{array}$ & \multirow[t]{4}{*}{2007} & $\begin{array}{l}\text { 1) Sustituye al impuesto sobre la } \\
\text { renta de personas jurídicas. }\end{array}$ \\
\hline & 2) Régimen simplificado del IMAGRO & & 2) Sustituye al impuesto a la \\
\hline & 3) Régimen simplificado del IVA & & $\begin{array}{l}\text { renta de las actividades } \\
\text { agropecuarias (IMAGRO). }\end{array}$ \\
\hline & & & $\begin{array}{l}\text { 3) Sustituye al impuesto al valor } \\
\text { agregado (IVA). }\end{array}$ \\
\hline \multirow[t]{2}{*}{ Perú } & 1) Régimen Único Simplificado (RUS) & \multirow[t]{2}{*}{2004} & \multirow{2}{*}{$\begin{array}{l}\text { El RUS sustituye al impuesto general } \\
\text { a las ventas, al impuesto sobre la } \\
\text { renta y al impuesto de promoción } \\
\text { municipal. El RER sustituye solo al } \\
\text { impuesto sobre la renta. }\end{array}$} \\
\hline & 2) Régimen Especial de Renta (RER) & & \\
\hline \multirow[t]{3}{*}{$\begin{array}{l}\text { República } \\
\text { Dominicana }\end{array}$} & $\begin{array}{l}\text { 1) Procedimiento Simplificado } \\
\text { de Tributación (PST) basado } \\
\text { en compras }\end{array}$ & \multirow[t]{3}{*}{2009} & \multirow{3}{*}{$\begin{array}{l}\text { Sustituye al impuesto sobre la renta } \\
\text { y al impuesto sobre las transferencias } \\
\text { de bienes industrializados y } \\
\text { servicios (ITBIS). }\end{array}$} \\
\hline & $\begin{array}{l}\text { 2) Procedimiento Simplificado de } \\
\text { Tributación (PST) basado en ingresos }\end{array}$ & & \\
\hline & $\begin{array}{l}\text { 3) Procedimiento Simplificado para } \\
\text { el ITBIS }\end{array}$ & & \\
\hline \multirow[t]{5}{*}{ Uruguay } & 1) Monotributo & 1) 2007 & \multirow{5}{*}{$\begin{array}{l}\text { 1) El monotributo sustituye a todos } \\
\text { los impuestos nacionales vigentes } \\
\text { con excepción de los que gravan } \\
\text { la importación más los aportes } \\
\text { previsionales al Banco de } \\
\text { Previsión Social (BPS). Brinda } \\
\text { la opción de acceso a un seguro } \\
\text { de salud optativo. } \\
\text { 2) Ídem al monotributo. }\end{array}$} \\
\hline & $\begin{array}{l}\text { 2) Monotributo social Ministerio } \\
\text { de Desarrollo Social (MIDES) }\end{array}$ & 2) 2012 & \\
\hline & $\begin{array}{l}\text { 3) Régimen de IVA mínimo para la } \\
\text { pequeña empresa (reemplazó al } \\
\text { impuesto a la pequeña empresa } \\
\text { que estuvo vigente desde } 1991\end{array}$ & \multirow{3}{*}{ 3) 2007} & \\
\hline & & & \\
\hline & & & \\
\hline
\end{tabular}

Fuente: Elaboración propia, sobre la base de D. González, C. Martinoli y J.L. Pedraza, Sistemas tributarios de América Latina. Situación actual, reformas y políticas para promover la cohesión social, Madrid, Instituto de Estudios Fiscales, 2009; y M. Pecho Trigueros, "Regímenes simplificados de tributación para pequeños contribuyentes en América Latina", Documento de Trabajo, № 2-2012, Ciudad de Panamá, Centro Interamericano de Administraciones Tributarias (CIAT), 2012.

a En julio de 2016 se aprobó una normativa que simplifica y disminuye la carga impositiva y los costos de cumplimiento para las pequeñas y medianas empresas (pymes). Entre las medidas más significativas se incluyen la eliminación del impuesto a la ganancia mínima presunta, la compensación del impuesto a los créditos y débitos bancarios, la posibilidad de liquidar el IVA de manera trimestral, la desgravación del impuesto a las ganancias (hasta el $10 \%$ de las inversiones realizadas) y un crédito fiscal por el IVA de las inversiones.

b En diciembre de 2016 se aprobó la implementación de un nuevo régimen simplificado de tipo monotributo en reemplazo del pago del impuesto sobre la renta, el IVA y las contribuciones a la seguridad social que contempla la posibilidad de realizar pagos a una cuenta individual de ahorro previsional y ofrece acceso a coberturas para los riesgos de incapacidad, invalidez y muerte. 
Cabe aclarar que los esquemas simplificados de la región se aplican fundamentalmente sobre personas físicas que realizan actividades económicas, aunque en algunos casos se extienden también a ciertos tipos de personas jurídicas, como sucede en el Brasil, Chile, Costa Rica, Panamá y el Perú.

La mayoría de estos regímenes prevén la adhesión voluntaria y la autocategorización, y están dirigidos sobre todo a los sectores de comercio y prestación de servicios. Sin embargo, en algunos casos se extienden a otros sectores difíciles de gravar como pueden ser la industria manufacturera, la producción de artesanías, la ganadería, la agricultura y el transporte de personas ${ }^{21}$.

Entre las técnicas presuntivas aplicadas en la región se destaca la denominada "cuota fija", que se basa en el pago de una suma determinada de dinero que la legislación establece por categoría, que reemplaza una o más obligaciones tributarias para el contribuyente y que generalmente debe abonarse en forma mensual. Esta técnica permite simplificar al máximo la liquidación del impuesto y, por lo tanto, reduce de manera significativa el costo indirecto administrativo del cumplimiento de las obligaciones fiscales, adecuándose mejor a la realidad socioeconómica de los países de América Latina. Unos pocos países de la región aplican la técnica presuntiva de un porcentaje fijo sobre los ingresos brutos del contribuyente, aunque las administraciones tributarias enfrentan mayores dificultades de control a la hora de determinar la facturación de los pequeños contribuyentes con elevados niveles de informalidad.

Por otra parte, la aplicación de estos regímenes suele implicar la sustitución de algún gravamen del sistema tributario vigente en cada país. De allí puede derivarse una clasificación de regímenes simplificados en virtud de si estos sustituyen un único impuesto (regímenes unitarios), que generalmente es el IVA o el ISR, o si reemplazan un conjunto de dos o más obligaciones tributarias simultáneamente (regímenes integrados) ${ }^{22}$.

En lo que respecta a la región, Chile (con múltiples regímenes), Colombia, Honduras, Panamá y el Paraguay constituyen ejemplos de los primeros (ya sea que reemplacen el IVA o el ISR), mientras que el resto de los países analizados ha tendido a sustituir estos dos tributos de manera conjunta (Costa Rica, Ecuador y Perú) e incluso otros adicionales, como en el caso de Bolivia (Estado Plurinacional de).

21 La Argentina posee un régimen simplificado exclusivamente para pequeños productores agropecuarios. En el Estado Plurinacional de Bolivia, el Sistema Tributario Integrado (STI) tiene como actividad económica exclusiva el transporte urbano, interprovincial e interdepartamental, ya sea de pasajeros o de carga. En Chile, el Régimen de Tributación Simplificada (RTS) limita las actividades económicas a considerar, ya que no se puede tener por giro empresarial la tenencia o explotación de bienes raíces agrícolas, actividades de capital mobiliario y actividades financieras.

22 Véase González, Martinoli y Pedraza (2009). 
Entre estos últimos, un caso de particular interés es el de aquellos regímenes simplificados cuya estructura además incluye a las contribuciones o recursos tributarios de la seguridad social, como ocurre en la Argentina, el Brasil y el Uruguay (véase el recuadro XI.1). Esta característica resulta muy relevante dada la elevada informalidad y el nivel aún bajo de cobertura de protección social que muestran los pequeños contribuyentes (individuos) en los países de la región, permitiendo incentivar el cumplimiento voluntario de las obligaciones fiscales a través del otorgamiento de ciertos beneficios como puede ser el acceso a un plan de jubilaciones o a un seguro de salud.

\section{Recuadro XI.1}

\section{El monotributo en la Argentina, el Brasil y el Uruguay}

Si bien la utilización de regímenes simplificados para pequeños contribuyentes es una estrategia ampliamente difundida entre los países de América Latina, tres casos particulares (Argentina, Brasil y Uruguay) se han distinguido por incluir las contribuciones para el financiamiento de la seguridad social - con la consecuente provisión de beneficios sociales - en el conjunto de tributos sustituidos y conjugados en una única obligación impositiva mensual. Colombia, a partir de la reciente reforma tributaria de diciembre de 2016, se estaría sumando a esta tendencia con un régimen que comparte esa característica.

La Argentina cuenta con el régimen de monotributo, introducido en octubre de 1998, que se complementa con otros subregímenes enfocados en grupos específicos de contribuyentes, como pequeños productores agropecuarios, miembros de cooperativas de trabajo y empleados del servicio doméstico (que desde 2005 se rigen por una normativa específica). El Brasil, por su parte, ha sido pionero en la región: en 1996 se creó el SIMPLES Federal con el claro objetivo de favorecer el ingreso de pequeñas y medianas empresas (pymes) al sector formal de la economía y en 2006 se transformó en el SIMPLES Nacional con la incorporación de los principales impuestos subnacionales (impuesto sobre la circulación de mercaderías y servicios (ICMS) e impuesto sobre los servicios (ISS)). En 2009, la creación del Sistema para el Microemprendedor Individual (SIMEI) permitió incluir en un esquema simplificado complementario a los microemprendedores (individuos) con menores ingresos. En el caso del Uruguay, si bien su introducción lleva más de diez años, tanto el monotributo (para individuos y sociedades de hecho) como el Régimen de IVA mínimo (que prevé la aplicación gradual del IVA para pymes en un período de tres años) mostraron un punto de inflexión a partir de la reforma tributaria de 2006. También se destaca la incorporación del Monotributo social Ministerio de Desarrollo Social (MIDES), destinado específicamente a atender la necesidad de protección social de personas provenientes de hogares en situación de vulnerabilidad socioeconómica.

Más allá de las características en común, la comparación entre estos tres casos permite identificar algunas diferencias relevantes. Por ejemplo, el monotributo argentino y uruguayo se parecen en su concepción original $-\mathrm{y}$ también comparten la existencia de un régimen especial para trabajadores en situación de vulnerabilidad social (monotributo social) - , pero difieren en el diseño: el primero posee escalas de ingresos brutos de acuerdo con el tipo de actividad y provee, además de cobertura previsional, un seguro médico 
Recuadro XI.1 (conclusión)

obligatorio, en tanto que el segundo no tiene escalas de ingresos sino que exige el pago de distintos montos fijos (indexados), según si existen cónyuges o hijos, y la adopción de una obra social como parte del monotributo es optativa. El SIMEI brasileño es similar a estos dos regímenes en tanto también consiste en el pago de un monto fijo uniforme que resulta en tasas efectivas decrecientes a medida que crece el ingreso declarado. No obstante, el monotributo uruguayo y el SIMEI comparten la ventaja de poseer un ponderador indexable en la determinación del monto fijo mensual a pagar (en el Uruguay se ajusta por los precios internos y en el Brasil de acuerdo con el nivel del salario mínimo), lo que hace que el esquema sea más automático, a diferencia del caso argentino donde la actualización de los parámetros del régimen es más discrecional y queda expuesta a distorsiones ante procesos inflacionarios.

En lo que respecta a las pequeñas y medianas empresas (pymes), el SIMPLES Nacional consta de diversas tablas de alícuotas progresivas según la actividad, que implican la sustitución de todo un paquete de impuestos nacionales y subnacionales y contribuciones a la seguridad social. La aplicación de un régimen simplificado de estas características hace que el "salto" al régimen general sea menos traumático (en términos económicos) que uno estructurado con montos fijos de impuesto y alícuotas decrecientes como las versiones argentina y uruguaya del monotributo y el mismo SIMEI. El Régimen de IVA mínimo para la pequeña empresa del Uruguay, al ofrecer el cumplimiento de dicha obligación tributaria a través del pago de una suma fija establecida anualmente por la Dirección General Impositiva (DGI), no quedaría sujeto a los incentivos "perversos" señalados anteriormente y aparece como una alternativa interesante para actuar como "puente" entre el monotributo y el régimen general de tributación. A su vez, el mecanismo de aplicación gradual y reducida que se contempla para este régimen brinda la oportunidad de facilitar la formalización económica de las empresas de menor envergadura, que generalmente son las que enfrentan mayores costos relativos de conformidad con el sistema tributario vigente.

Fuente: Elaboración propia, sobre la base de O. Cetrángolo y otros, Regímenes tributarios simplificados e informalidad en América Latina, con especial referencia a los casos de Argentina, Brasil y Uruguay, Lima, Organización Internacional del Trabajo, 2013.

También debe señalarse que algunos de estos esquemas especiales no reemplazan la carga tributaria correspondiente al régimen general, sino que, como sucede en Chile con el Régimen de Tributación Simplificada (RTS) o en la República Dominicana con el Procedimiento Simplificado de Tributación (PST), solo brindan ciertas facilidades —en la forma de menores obligaciones formales en la presentación de declaraciones juradas, facturas, notas de venta y registros contables - que procuran una sensible disminución de los costos de cumplimiento para los contribuyentes de menor magnitud económica.

Precisamente, en lo que hace a los aspectos formales, la mayoría de los países coincide en la exigencia de dos obligaciones en común: la presentación periódica de una declaración jurada de ingresos y la realización de procesos de facturación. Además, cada país tiene regulaciones específicas en virtud de los requisitos del impuesto. 
En cuanto a la diferenciación de los pequeños contribuyentes, existen varios criterios para establecer umbrales y limitar la aplicación de los regímenes simplificados. En América Latina, la variable más utilizada es el ingreso del contribuyente (ingresos brutos o ventas totales), aunque también se observan otras restricciones para acotar la aplicación de estos esquemas dadas por la cantidad de tierra bajo explotación, el número de establecimientos, el consumo de electricidad, la cantidad de empleados y el capital disponible. En algunos países de la región, como la Argentina, Colombia y el Perú, se aplica más de un criterio simultáneamente.

A modo ilustrativo, en un estudio realizado por Fuentes Castro y otros (2011) se brinda una imagen más detallada de los topes o umbrales monetarios que limitan los regímenes simplificados en los distintos países de la región. En comparación con algunos ejemplos de países desarrollados que también utilizan estos esquemas, es posible advertir que en América Latina dichos montos de ingresos establecidos por las administraciones tributarias pueden ser muy elevados, lo que brinda la posibilidad de incluir a un número muy grande de contribuyentes que, en algunos casos, puede considerarse excesivo desde el punto de vista administrativo ${ }^{23}$.

\section{Cuadro XI.3}

Comparación de los umbrales máximos para la inclusión en el régimen simplificado (En dólares de 2011 y en porcentajes del PIB per cápita)

\begin{tabular}{lcc}
\hline Países & En dólares de 2011 & En porcentajes del PIB per cápita \\
\hline Brasil & 152592 & 13,9 \\
\hline Perú & 131256 (RUS) - 191415 (RER) & 24,6 (RUS) - 35,9 (RER) \\
\hline México & 148624 & 15,9 \\
\hline Argentina & 48760 (servicios) - 73 140 (comercio) & 5,36 (servicios) - 8,05 (comercio) \\
\hline Colombia & 60316 & 9,7 \\
\hline Ecuador & 60000 & 14,3 \\
\hline Uruguay & 21745 (Monotributo) - 36 242 (IPE) & 1,82 (Monotributo) - 3,03 (IPE) \\
\hline Bolivia (Estado & 19625 (RTS) & 10,0 (RTS) \\
Plurinacional de) & 121400 & 2,8 \\
\hline Canadá & 114072 & 3,2 \\
\hline Reino Unido & 48000 & 1,0 \\
\hline Estados Unidos & &
\end{tabular}

Fuente: Fuentes Castro, H. y otros, "Estudio de evasión fiscal en el régimen de pequeños contribuyentes", Ciudad de México, Instituto Tecnológico y de Estudios Superiores de Monterrey (ITESM), 2011, sobre la base de cifras oficiales de cada país.

Nota: En el caso de México, se considera el Régimen de pequeños contribuyentes (REPECOS) (derogado y reemplazado por el Régimen de Incorporación Fiscal (RIF)), aunque el monto límite de facturación anual continúe siendo de dos millones de pesos. RUS = Régimen Único Simplificado; RER = Régimen Especial de Renta; IPE = Impuesto a la pequeña empresa; RTS = Régimen Tributario Simplificado.

23 Aunque los valores nominales suelen variar en forma periódica en cada uno de los países, estas conclusiones son de carácter general y se han mantenido relativamente estables en los últimos años. 
Por otra parte, a pesar de la escasa e incompleta información estadística disponible, resulta oportuno destacar los reducidos niveles de recaudación de la tributación simplificada, que en algunas situaciones llega a tener ingresos muy por debajo de los costos que implica su administración ${ }^{24}$. Se puede señalar que el promedio de recaudación de estos regímenes en los países latinoamericanos actualmente ronda el $1 \%$ de los ingresos tributarios totales, aunque la mayoría se encuentra por debajo de dicho valor.

Como se aprecia en el cuadro XI.4, el país que más recauda a partir de la aplicación de estos esquemas simplificados es el Brasil con el SIMPLES Nacional, tanto en relación con el PIB como en porcentajes de la recaudación total. La Argentina, a través del monotributo, también supera el promedio regional de recaudación tributaria. Sin embargo, en la mayoría de los países de la región, e incluso en algunos casos donde existe más de un régimen simplificado simultáneamente (como en Bolivia (Estado Plurinacional de) o Chile), los ingresos tributarios obtenidos mediante su implementación para pequeños contribuyentes son visiblemente muy reducidos. Aun cuando muchos de estos regímenes simplificados se encuentran en vigencia desde hace más de una década, esta situación no parece haberse modificado sustancialmente en los últimos años.

En general, el bajo nivel de recaudación de estos regímenes en toda la región es consecuencia, entre otros, de los siguientes factores: i) la inclusión de los pequeños contribuyentes de menor nivel económico, ii) la "cuota fija", que suele ser de un bajo nivel económico y tiene una alta morosidad, y iii) el elevado nivel de evasión, en el caso de los países que aplican el régimen sobre la base de los ingresos (González, Martinoli y Pedraza, 2009).

Precisamente, y aunque solo hay estimaciones para un caso testigo como el de México, en los países de la región, los pequeños contribuyentes suelen presentar tasas de evasión más altas que las de empresas más grandes, en gran parte debido a que el costo que representa el cumplimiento de las obligaciones tributarias es proporcionalmente más alto para los primeros y al elevado nivel de informalidad que se advierte en las economías latinoamericanas ${ }^{25}$. $\mathrm{Al}$ respecto, se reconoce que no todas las pequeñas empresas son informales, ni todas las empresas informales son pequeñas. Pero existe una relación entre ambas, de manera que, como ya se mencionó, el adecuado diseño e implementación de los impuestos puede resultar crucial para reducir el grado de informalidad, que en muchos países menoscaba considerablemente la base tributaria y distorsiona la estructura de la actividad económica.

\footnotetext{
24 No obstante, los costos de administración de estos regímenes resultarán menores que los que demandaría la inclusión de esos contribuyentes en el régimen general de tributación.

25 Véase Fuentes Castro y otros (2011).
} 
Cuadro XI.4

América Latina (12 países): recaudación tributaria de regímenes simplificados, 2010 (En porcentajes de la recaudación total y en porcentajes del PIB)

\begin{tabular}{lcc}
\hline Países & $\begin{array}{c}\text { En porcentajes de la } \\
\text { recaudación total }\end{array}$ & En porcentajes del PIB \\
\hline Argentina & 1,16 & 0,34 \\
\hline Bolivia (Estado Plurinacional de) & 0,10 & 0,02 \\
\hline Brasil & 2,86 & 0,94 \\
\hline Chile & 0,02 & 0,01 \\
\hline Costa Rica & 0,08 & 0,02 \\
\hline Ecuador & 0,05 & 0,01 \\
\hline Guatemala & 0,59 & 0,07 \\
\hline México & 0,05 & 0,02 \\
\hline Paraguay & 0,07 & 0,01 \\
\hline Perú & 0,09 & 0,05 \\
\hline República Dominicana & 0,05 & 0,01 \\
\hline Uruguay & 0,40 & 0,10 \\
\hline
\end{tabular}

Fuente: Elaboración propia, sobre la base de información oficial y M. Pecho Trigueros, "Regímenes simplificados de tributación para pequeños contribuyentes en América Latina", Documento de Trabajo, № 2-2012, Ciudad de Panamá, Centro Interamericano de Administraciones Tributarias (CIAT), 2012.

Nota: Los ingresos tributarios presentados corresponden: en la Argentina, al monotributo (y sus regímenes complementarios); en Bolivia (Estado Plurinacional de), al Régimen Tributario Simplificado (RTS), al Sistema Tributario Integrado (STI) y al Régimen Agropecuario Unificado (RAU); en el Brasil, al Régimen Especial Unificado de Recaudación de Tributos y Contribuciones sobre las Micro y Pequeñas Empresas (SIMPLES Nacional, incluye el Sistema para el Microemprendedor Individual (SIMEI)); en Chile, al Régimen simplificado del impuesto sobre la renta (minería, comercio, industria y pesca) y al Régimen de tributación simplificada para los pequeños contribuyentes (IVA); en Costa Rica, al Régimen de tributación simplificada para comerciantes minoristas y bares; en el Ecuador, al Régimen Impositivo Simplificado Ecuatoriano (RISE); en Guatemala, al Régimen de pequeño contribuyente; en México, al Régimen de pequeños contribuyentes (REPECOS) (derogado y reemplazado por el Régimen de Incorporación Fiscal (RIF)); en Nicaragua, al Régimen especial de estimación administrativa para contribuyentes por cuota fija; en el Paraguay, al impuesto sobre la renta de pequeños contribuyentes (IRPC) y al tributo único (derogado); en el Perú, al Régimen Único Simplificado (RUS) y al Régimen Especial de Renta (RER); en la República Dominicana, al Procedimiento Simplificado de Tributación (PST); y en el Uruguay, al monotributo y al Régimen de IVA mínimo para la pequeña empresa.

En consecuencia, aun cuando la recaudación generada sea muy poco significativa, se suele destacar la utilidad de estos regímenes simplificados como herramientas para viabilizar la transición de una gran cantidad de contribuyentes que realizan sus actividades económicas en la economía informal hacia su inclusión efectiva en el régimen general de tributación vigente en cada país.

\section{E. Conclusiones y alternativas de política tributaria para reducir la informalidad}

Aunque se reconoce que la informalidad es un fenómeno que responde a múltiples causas y provoca múltiples consecuencias, el aspecto tributario se erige como uno de los factores más relevantes a la hora de analizar el problema de la economía informal en América Latina. 
Por una parte, el nivel y la estructura de los ingresos tributarios pueden incidir sobre el tamaño de la economía informal a través del efecto que ejercen los impuestos sobre las decisiones individuales para pertenecer al sector formal de la economía. A su vez, la tributación también resulta ser un factor central, ya que constituye uno de los principales instrumentos para incidir sobre las causas estructurales de la informalidad, ya sea mediante su impacto redistributivo directo o, indirectamente, a partir de la posibilidad que brinda de obtener los recursos necesarios que aseguren la provisión, en cantidad y calidad aceptables, de bienes y servicios públicos por parte del Estado.

Por otra parte, el problema de la informalidad se observa con mucha mayor frecuencia entre los pequeños contribuyentes (individuos y pymes), que representan un conjunto muy numeroso y heterogéneo y adquieren una gran relevancia económica en términos de generación de empleo y producción, pero implican un elevado costo para las administraciones tributarias. Como respuesta, en la mayoría de los países de la región se ha optado por la instrumentación de regímenes especiales de tributación simplificada que, hasta el momento, han mostrado numerosas falencias con implicancias negativas para el sistema tributario general, entre las cuales se destacan el muy bajo nivel de recaudación, el establecimiento de montos de ingresos muy elevados, que pueden conducir a una inclusión excesiva de contribuyentes, el alto nivel de evasión y la desactualización de los parámetros establecidos para establecer los límites de dichos esquemas.

Sin embargo, no puede dejar de reconocerse la utilidad de estos instrumentos para viabilizar el ingreso de empresas y trabajadores independientes al sector formal de la economía. La formalización de contribuyentes, en tanto reduzca la evasión tributaria y promueva el cumplimiento voluntario, permite mejorar la equidad horizontal y vertical entre contribuyentes, lo que fortalece la legitimidad del Estado en un círculo virtuoso. Estos instrumentos también han permitido reducir los costos de cumplimiento para los contribuyentes y descomprimir las tareas de las administraciones tributarias sobre un numeroso grupo de sujetos, con lo que se contribuye a reducir la evasión tributaria.

Reconocidas estas virtudes, el foco de las futuras reformas debería ponerse en el funcionamiento específico de estos regímenes de tributación $\mathrm{y}$ en los incentivos que influyen, positiva o negativamente, sobre el comportamiento tributario de los pequeños contribuyentes. En ese sentido, se deberá priorizar un acceso amplio a estos regímenes, favoreciendo el proceso de formalización que propician, aunque también se tendrá que poner énfasis en evitar su sobredimensionamiento.

El hecho de que suelen ofrecer condiciones de conformidad favorables para atraer a los contribuyentes de menores ingresos también puede actuar 
como incentivo para las empresas que se encuadran en estos esquemas a permanecer indefinidamente dentro del régimen especial, aun teniendo la capacidad de tributar bajo el régimen general de tributación. De este modo, la aplicación de este tratamiento tributario especial podría ser contraproducente tanto en materia de ingresos tributarios (si permite disminuir la carga tributaria de los contribuyentes del régimen general) y de eficiencia económica (si incentiva actitudes de "enanismo fiscal" en las empresas) como de equidad distributiva (si ofrece ventajas legales a contribuyentes que se aprovechan de los beneficios brindados por el régimen simplificado).

La concepción de estos instrumentos como un "puente transitorio" entre los regímenes tributarios diseñados especialmente para los sectores informales y el cumplimiento voluntario de las normas tributarias generales es la situación que debería prevalecer en los países donde se apliquen, acotando los requisitos y beneficios otorgados, procurando la reducción progresiva del tiempo de permanencia de los contribuyentes en estos sistemas y tendiendo a su definitiva eliminación en el largo plazo (dado que el régimen general es más justo y respeta mejor el principio de neutralidad impositiva). El ejemplo de México, a partir de una reforma reciente, constituye un avance concreto en ese sentido: el nuevo Régimen de Incorporación Fiscal (RIF), que reemplazó al régimen REPECOS desde 2014, contempla un mecanismo de reducción gradual del tratamiento diferencial (exención) en el ISR, el IVA y el impuesto especial sobre producción y servicios (IEPS) (un 10\% anual), lo que se traduce en un período de permanencia limitada (10 años) para los pequeños contribuyentes inscriptos.

En todos los países resultaría muy útil determinar con mayor precisión la potencialidad de los regímenes simplificados para establecer su alcance teórico y evaluar concretamente sus efectos sobre el sector informal. Al respecto, sería necesario realizar más estudios que aborden esta temática, como el de Amarante y Perazzo (2013) para el caso uruguayo, aunque esto dependerá mucho de la disponibilidad de información estadística contenida en los registros administrativos de los organismos públicos y las encuestas de hogares si lo que se pretende es evaluar y perfeccionar los regímenes aplicados en la actualidad y consolidar sus efectos positivos. 


\section{Bibliografía}

Amarante, V.e I. Perazzo (2013), "Trabajo por cuenta propia y monotributo en Uruguay", Serie Documentos de Trabajo, $\mathrm{N}^{\circ}$ 4/13, Montevideo, Universidad de la República.

Cetrángolo, O. y otros (2013), Regímenes tributarios simplificados e informalidad en América Latina, con especial referencia a los casos de Argentina, Brasil y Uruguay, Lima, Organización Internacional del Trabajo.

Cornia, G.A, J.C. Gómez Sabaini y B. Martorano (2011), "A new fiscal pact, tax policy changes and income inequality: Latin America during the last decade", Working Paper, $N^{\circ} 70 / 2011$, Instituto Mundial de Investigaciones de Economía del Desarrollo (UNU-WIDER).

DFI (Diálogo Fiscal Internacional) (2007), "Taxation of Small and Medium Enterprises", documento presentado en la Conferencia del Diálogo Fiscal Internacional, Buenos Aires.

Feld, L. y B. Frey (2007), "Tax compliance as the result of a psychological tax contract: the role of incentives and responsive regulation", Law and Policy, vol. 29, $\mathrm{N}^{\circ} 1$, Wiley.

Fuentes Castro, H. y otros (2011), "Estudio de evasión fiscal en el régimen de pequeños contribuyentes", Ciudad de México, Instituto Tecnológico y de Estudios Superiores de Monterrey (ITESM).

Gerxhani, K. (2004), "The Informal Sector in Developed and Less Developed Countries: A Literature Survey", Public Choice, Vol.120(3/4):267-300 [en línea] http:/ /www.jstor.org/ stable/30026032.

Gómez Sabaini, J.C. y J.P. Jiménez (2011), “Estructura tributaria y evasión impositiva en América Latina", Documento de Trabajo, No 2011/08, Corporación Andina de Fomento (CAF).

Gómez Sabaini, J.C. y D. Morán (2012), “Informalidad y tributación en América Latina: explorando los nexos para mejorar la equidad", Serie Macroeconomía del Desarrollo, N ${ }^{\circ} 124$ (LC/L.3534), Santiago, Comisión Económica para América Latina y el Caribe (CEPAL).

Gómez Sabaini, J.C., J.P. Jiménez y D. Rossignolo (2012), “Imposición a la renta personal y equidad en América Latina: nuevos desafíos", serie Macroeconomía del Desarrollo, No 119 (LC/L.3477-P), Santiago, Comisión Económica para América Latina y el Caribe (CEPAL).

González, D. (2009), "La política tributaria heterodoxa en los países de América Latina", serie Gestión Pública, Nº 70 (LC/L.2996-P), Santiago, Comisión Económica para América Latina y el Caribe (CEPAL).

(2006), "Regímenes especiales de tributación para pequeños contribuyentes en América Latina”, Washington, D.C., Banco Interamericano de Desarrollo (BID).

González, D., C. Martinoli y J.L. Pedraza (2009), Sistemas tributarios de América Latina. Situación actual, reformas y políticas para promover la cohesión social, Madrid, Instituto de Estudios Fiscales.

Jiménez, J.P., J.C. Gómez Sabaini y A. Podestá (comp.) (2010), “Evasión y equidad en América Latina", Documento de Proyectos, No 309 (LC/W.309), Santiago, Comisión Económica para América Latina y el Caribe (CEPAL).

Loayza, N., L. Servén y N. Sugawara (2009), "Informality in Latin America and the Caribbean", Policy Research Working Paper Series, ${ }^{\circ}$ 4888, Washington, D.C., Banco Mundial. 
OCDE (Organización de Cooperación y Desarrollo Económicos) (2009), “Taxation of SMEs. Key issues and policy considerations", Tax Policy Study, N 18, París, OECD Publishing. (2008), "Política fiscal e informalidad en América Latina", Perspectivas Económicas de América Latina 2009, París, Centro de Desarrollo de la OCDE.

Pecho Trigueros, M. (2012), "Regímenes simplificados de tributación para pequeños contribuyentes en América Latina", Documento de Trabajo, N 2-2012, Ciudad de Panamá, Centro Interamericano de Administraciones Tributarias (CIAT).

Perry, G. y otros (2007), Informality: Exit and Exclusion, Washington, D.C., Banco Mundial.

Schneider, F. (2012), "The shadow economy and work in the shadow: what do we (not) know?", Discussion Paper Series, $\mathrm{N}^{\circ}$ 6423, Bonn, Instituto para el Estudio del Trabajo (IZA).

Schneider, F., A. Buehn y C. Montenegro (2010), "Shadow economies all over the world: new estimates for 162 countries from 1999 to 2007", Policy Research Working Paper, N ${ }^{\circ}$ 5356, Washington, D.C., Banco Mundial.

Schneider, F. y B. Torgler (2007), "The impact of tax morale and institutional quality on the shadow economy", Discussion Paper Series, $N^{\circ} 2541$, Bonn, Instituto para el Estudio del Trabajo (IZA).

Vuletin, G. (2008), "Measuring the Informal Economy in Latin America and the Caribbean", IMF Working Paper, WP/08/102, Washington, D.C., Fondo Monetario Internacional. 



\title{
Capítulo XII
}

\section{La evasión tributaria en los países de la región ${ }^{1}$}

\author{
Oscar Cetrángolo ${ }^{2}$ \\ Juan C. Gómez Sabaini \\ Dalmiro Morán ${ }^{4}$
}

\section{Introducción}

Durante las últimas dos décadas, la mayoría de los países de América Latina han experimentado un gran incremento de sus recursos tributarios. Ese resultado fiscal encuentra explicación, por un lado, en varios factores externos, entre los que sobresalen el acelerado crecimiento de varias economías desarrolladas y emergentes, los mayores flujos comerciales por

1 Este trabajo constituye un extracto de Gómez Sabaini y Morán (2016).

2 Consultor de la Comisión Económica para América Latina y el Caribe (CEPAL) y de la Organización Internacional del Trabajo (OIT) especializado en política fiscal. Profesor de grado y posgrado en la Universidad Nacional de Buenos Aires y la Universidad Nacional de Tres de Febrero (Argentina). Correo electrónico: ocetrangolo@gmail.com.

3 Consultor de la Comisión Económica para América Latina y el Caribe (CEPAL), el Banco Interamericano de Desarrollo (BID), el Fondo Monetario Internacional (FMI) y el Centro Interamericano de Administraciones Tributarias (CIAT) especializado en temas de política tributaria en países de América Latina. Profesor de posgrado en la Universidad Nacional de Buenos Aires. Correo electrónico: gomezsabaini@gmail.com.

4 Consultor de la Comisión Económica para América Latina y el Caribe (CEPAL) y del Centro Interamericano de Administraciones Tributarias (CIAT) especializado en temas de política tributaria en países de América Latina. Correo electrónico: dalomoran@gmail.com. 
la demanda sostenida desde China y los países asiáticos, y el concomitante recorrido alcista de los precios internacionales de los productos primarios. También ha incidido de manera clara una serie de importantes cambios y reformas tributarias que apuntaron hacia la consolidación del impuesto sobre el valor agregado (IVA), una mayor participación relativa de los impuestos directos, y la introducción de impuestos sobre las transacciones financieras e impuestos mínimos.

Sin embargo, los sistemas tributarios de la región se han mostrado incapaces de resolver importantes debilidades estructurales en relación con el nivel de recursos que efectivamente recaudan, sus efectos sobre la eficiencia económica y, muy especialmente, su impacto distributivo. Uno de esos obstáculos se deriva del elevado nivel de incumplimiento observado en la mayoría de los impuestos vigentes.

En años recientes, varios países han realizado esfuerzos concretos con miras a combatir la evasión tributaria en el ámbito interno. Si bien en algunos casos se han obtenido resultados alentadores, existe la impresión generalizada de que hay un "núcleo duro" de evasión fiscal al que resulta muy difícil acceder. La mayor inversión de recursos humanos, tecnológicos y financieros para fortalecer las agencias de administración tributaria no parece ser suficiente en ese sentido. Las raíces del fenómeno parten de un contrato implícito entre el Estado y los ciudadanos, que solo puede mantenerse si estos perciben el sistema tributario como justo y equitativo. A pesar de que ahora hay mayor conciencia social sobre la gravedad del problema en los países de América Latina, existe una sorprendente escasez y dispersión de estudios específicos en la materia, lo que dificulta la tarea de establecer diagnósticos precisos acerca de la magnitud de los niveles de incumplimiento tributario.

En este trabajo se parte de la premisa básica de que toda política pública requiere de antemano la elaboración de un diagnóstico preciso para incrementar sus probabilidades de éxito. El objetivo principal consiste en investigar, recopilar y analizar los principales avances en términos de la cuantificación de los niveles de incumplimiento tributario por parte de los contribuyentes residentes dentro de las fronteras geográficas de los países. En la sección A, se repasan las alternativas metodológicas más relevantes en el momento de determinar una magnitud aproximada de sus implicancias fiscales. En las tres secciones subsiguientes se ofrecen evidencias recientes de la evasión interna en los países latinoamericanos, específicamente respecto del IVA, el impuesto sobre la renta (ISR) y las contribuciones de la seguridad social. Por último, la quinta sección contiene una serie de reflexiones finales acerca de esa problemática a nivel regional. 


\section{A. Importancia del problema y cuestiones metodológicas}

Ya sea por causas vinculadas a la falta de compromiso de las sociedades con la necesidad de generar fondos para el financiamiento de los gastos sociales, por cuestiones relacionadas con la complejidad de los sistemas tributarios para ciertos sectores económicos, o bien por el nivel de las alícuotas en la imposición indirecta y la existencia de amplios beneficios o franquicias para determinados contribuyentes, el fenómeno de la evasión en América Latina tiene que ver con que estas razones han perdurado a lo largo de los años en la vida tributaria de los países de la región.

De hecho, la distinción fundamental que se observa entre el pasado y el presente se refiere al grado de conciencia actual sobre este problema como una cuestión endémica que se debe atacar por todos los medios posibles, en el plano nacional o internacional.

Esa situación, de por sí, es sumamente grave por las consecuencias económicas sobre la competitividad y el desarrollo del mercado, y por la inequidad que produce ya que solo evaden los que tienen o consumen. Sin embargo, tiene una consecuencia aún mayor, que es la imposibilidad de cada Estado de aplicar políticas tributarias adecuadas al contexto de cada país y en el momento necesario. Es decir, la evasión, al limitar la cantidad de recursos fiscales recaudados respecto de su nivel potencial, se traduce en debilidad de las políticas públicas para llevar adelante cambios que impulsen el desarrollo y la equidad distributiva. Ello conduce a la aplicación de instrumentos tributarios sustitutivos o alternativos que solo generan beneficios cuantitativos a corto plazo con el fin de salvar las dificultades financieras del momento.

Tradicionalmente, las escuelas ortodoxas han atribuido el cumplimiento fiscal al temor del contribuyente a ser atrapado y castigado por las autoridades (Allingham y Sandmo, 1972). Sin embargo, dichas explicaciones no dan cuenta de aquellos Estados en que la probabilidad de sanción y auditoría es muy baja pero, paradójicamente, el nivel de cumplimiento es muy alto. Consecuentemente, el cumplimiento fiscal es un fenómeno que, aunque en gran medida dependa de la capacidad de fiscalización estatal, también se ve influido por múltiples factores, incluso de índole subjetiva.

En lo que respecta al control de la evasión impositiva, no basta con mejorar la administración tributaria y los mecanismos de control y fiscalización de los contribuyentes. Cuando se tratan esos temas, siempre resulta relevante considerar cómo las actitudes fiscales se relacionan con las acciones de los individuos. En particular, se ha podido establecer que existe una relación entre la moral fiscal y el nivel de cumplimiento tributario (Torgler, 2007). 
En ese sentido, la administración tributaria debe asumir un rol protagónico en la concientización de la ciudadanía acerca de la responsabilidad social que implica pagar debidamente los impuestos establecidos por el Estado. A su vez, la legitimidad de las instituciones condiciona la capacidad de las personas de aceptar el deber de pagar impuestos, es decir, su grado de moral fiscal (Bergman, 2009).

Por lo tanto, la evasión representa un obstáculo para el desarrollo, para el crecimiento equilibrado y, en general, para la justicia en que se debería basar el sistema tributario (Carrasco, 2010). Según ese autor, los esfuerzos para estimar la evasión se justifican no solo porque su conocimiento permitiría diseñar un sistema económico que garantizara un nivel mínimo de bienestar a los ciudadanos, sino porque constituye un insumo fundamental para la gestión de las administraciones tributarias.

Debe reconocerse que, en los últimos años, las agencias de recaudación han logrado importantes avances en cuanto a la disponibilidad de recursos financieros, la profesionalización del personal empleado, y el manejo e intercambio de información (Gómez Sabaini y Jiménez, 2011). Todos esos logros, aun cuando quede espacio para mejorar, han contribuido al aumento de la eficiencia de esos organismos y de su capacidad de control y fiscalización de los contribuyentes.

Sin embargo, la cuantificación de la evasión (y la difusión de los resultados) sigue siendo una cuenta pendiente en la mayor parte de América Latina. De hecho, no son muchos los países de la región que realizan estimaciones del nivel de incumplimiento tributario de forma coherente y periódica, lo que dificulta seriamente el seguimiento y la posibilidad de utilizar ese tipo de información para fijar metas y objetivos vinculados a la reducción del fenómeno, así como para monitorear la eficacia y eficiencia de las administraciones tributarias. Además, en los pocos casos en que la medición se realiza de forma periódica, se refiere generalmente al IVA. Solo en casos puntuales, se reservan para uso interno las estimaciones sectoriales de dicho tributo y las referidas al ISR de personas jurídicas, mientras que la evasión relacionada con el resto de los tributos prácticamente no es materia de análisis.

Por ejemplo, en Chile, el Servicio de Impuestos Internos (SII) mide la evasión del IVA anualmente y tiene metas ambiciosas, establecidas a nivel de Gobierno, para reducir el incumplimiento tributario. Colombia, por conducto de la Dirección de Impuestos y Aduanas Nacionales (DIAN), y el Uruguay, mediante la Dirección General Impositiva (DGI), también han venido elaborando, actualizando y (lo que es más importante) publicando una serie de estudios cuantitativos en los que se observa la evolución del nivel de incumplimiento en el IVA a lo largo de la última década. 
Un caso particular es el referido a México donde, desde hace ya varios años, el Servicio de Administración Tributaria (SAT) tiene la obligación legal de publicar anualmente estudios sobre evasión fiscal, en los que deben participar al menos dos instituciones académicas nacionales. En los trabajos realizados hasta el momento se han analizado profundamente distintas dimensiones de ese fenómeno en México, tanto de manera parcial, al centrarse en alguno de los impuestos principales como el IVA o el ISR, como de manera global respecto de un conjunto de tributos vigentes.

En general, los estudios disponibles ponen el acento en cuantificar el monto de los recursos potenciales no ingresados, pero en ningún caso brindan un análisis global y profundo sobre las razones, circunstancias y efectos vinculados con el problema. Además, dado que en la mayoría de los casos los resultados son muy sensibles a la metodología aplicada (que, a su vez, suele estar determinada por las limitaciones estadísticas), la falta de consenso acerca de un enfoque estándar atenta contra la comparabilidad internacional de los valores estimados.

Al respecto, si bien existen diversas metodologías para el cálculo y estimación de la evasión, según el trabajo de Jorratt y Podestá (2010) es factible clasificarlas en dos grandes grupos. Por una parte están los sistemas globales, consistentes en mediciones a nivel macro o enfoques indirectos, que comprenden los enfoques basados en agregados económicos (cuentas nacionales), los que se valen de información procedente de encuestas de hogares y los que relacionan la recaudación con el uso de determinados insumos físicos utilizados en la producción de bienes y servicios. Por otra parte, los sistemas parciales, consistentes en mediciones a nivel micro o enfoques directos, se refieren a programas especiales de auditoría o a fiscalizaciones concretas. A partir de estimaciones sobre una muestra considerada representativa, infieren comportamientos en relación con un grupo determinado de contribuyentes.

Entre los métodos más habituales se destaca el que se nutre de información de agregados económicos. Consiste en estimar la recaudación potencial de un impuesto a partir de las cuentas nacionales para, posteriormente, compararla con la recaudación real o efectiva. La brecha así obtenida suele atribuirse a la evasión tributaria. Ese enfoque resulta útil para cuantificar la evasión en impuestos con tasa plana y cuya base tiene relación con algún agregado macroeconómico, por lo que es el método más utilizado para la estimación de la evasión del IVA y del ISR empresarial. Como ventajas suelen citarse la facilidad del cálculo, su bajo costo y la posibilidad de medir la evasión en series anuales, lo que permite el análisis de su evolución a lo largo de un período determinado. La limitación más señalada alude a la confiabilidad de la fuente utilizada.

Sobre todo en el caso del IVA, el método del potencial tributario de la economía requiere calcular una recaudación teórica del tributo, que luego 
deberá compararse con la efectivamente ingresada, para lo que existen dos alternativas: i) el método de la producción, que consiste en estimar (con datos sectoriales provenientes de las cuentas nacionales) las ventas afectas y las compras con derecho a crédito, que a su vez determinan el débito y el crédito fiscal, a partir de los cuales se genera el IVA neto de toda la economía, y ii) el método de consumo o "IVA no deducible", mediante el que se busca calcular el monto total de las transacciones que generan IVA y que posteriormente no dan derecho a crédito fiscal dentro de la cadena de valor agregado, es decir, aquellas correspondientes al consumo final de bienes y servicios gravados, y a la compra de bienes y servicios gravados que se utilizan en la fabricación de productos exentos ${ }^{5}$. Esta segunda variante, por tener mayor independencia del nivel de desagregación de la información utilizada como insumo, es la más difundida entre los estudios realizados en los países de la región.

En lo que respecta al ISR empresarial, la metodología que suele utilizarse estima la recaudación teórica del impuesto a partir del excedente de explotación de las cuentas nacionales, el agregado macroeconómico que más se aproxima al concepto de utilidad tributaria. Este debe someterse a una serie de ajustes para arribar a la base imponible teórica, por ejemplo, la adición de las rentas de intereses y de la tierra, la deducción del excedente de explotación de sectores y actividades exentas y no afectas, o la agregación de las diferencias entre depreciación tributaria y financiera, entre otras correcciones. La aplicación de la tasa legal impositiva sobre esa base imponible teórica da origen a la recaudación teórica que, comparada con la recaudación efectiva, permite determinar la evasión del tributo.

En cambio, para el cálculo de la evasión del ISR de las personas físicas, las metodologías más utilizadas son las que se basan en la estimación de la recaudación potencial a partir de datos de las encuestas de hogares. Debido al carácter progresivo de esos impuestos, resulta más apropiada la utilización de esas bases de datos, que permiten aplicar distintas tasas a distintos grupos de individuos. El método consiste en calcular el impuesto que debería pagar cada encuestado, en función de la renta declarada (anualizada y ajustada por no respuesta y subdeclaración de ingresos) si se aplicara la escala de tasas correspondiente. Luego se agrupa la recaudación calculada en los distintos percentiles de ingreso y se compara con la recaudación efectiva obtenida por la administración tributaria para cada fracción análoga de población. Como ventajas principales suelen destacarse la simplicidad y el bajo costo. Como limitación suele citarse el hecho de que a menudo existe un nivel no insignificante de omisión y subdeclaración por parte del encuestado.

\footnotetext{
El consumo final de bienes y servicios gravados es realizado por los hogares y el Gobierno que, como consumidores finales, no pueden descontar el IVA incluido en sus compras. Por su parte, las compras de bienes y servicios gravados realizadas por las empresas con el fin de destinarlos a la fabricación de productos exentos generan un IVA no deducible, siempre que la legislación tributaria vigente no permita en esos casos descontar el impuesto.
} 
Otros enfoques más directos se basan en los métodos muestrales de punto fijo. En ellos, la administración tributaria se vale de auditorías a una muestra de contribuyentes para obtener información concreta sobre la tasa de evasión. Si bien su principal ventaja consiste en la posibilidad de aplicar todo tipo de técnicas estadísticas, su eficacia depende, entre otros factores, de la experiencia de quien lleve a cabo dichas auditorías. Además, resulta muy complejo extrapolar los resultados al resto de la población debido al sesgo implícito originado en la tendencia a focalizar las auditorías solo en los contribuyentes que tengan mayores probabilidades de evadir impuestos.

\section{B. La evasión del pago del IVA en los países de la región}

Como se ha señalado, en materia de medición del nivel de incumplimiento, el impuesto donde se han concentrado mayores esfuerzos y se han observado mayores avances es el IVA. Gracias a numerosas reformas a lo largo de las últimas décadas, ese gravamen se ha constituido en el principal instrumento generador de recursos tributarios de la mayoría de los países de América Latina. No obstante, en todos los casos persiste la idea de que su recaudación efectiva se encuentra aún bastante por debajo de su verdadero potencial teórico. Ello ha motivado la realización de numerosas estimaciones, tanto desde el ámbito académico como desde las propias administraciones tributarias, orientadas a calcular el nivel de evasión o, lo que es lo mismo, la recaudación resignada a causa del incumplimiento de esa obligación tributaria por parte de los sujetos que deberían pagar el tributo.

En primer lugar, la disponibilidad de algunas mediciones que incorporan un análisis temporal ha permitido definir ciertas tendencias generales de la evolución de los niveles de incumplimiento en el IVA del año 2000 en adelante. Como puede observarse en el gráfico XII.1, todos los estudios de carácter oficial, ya sea realizados por profesionales de las mismas administraciones tributarias o encargados a consultores externos y avalados por dichos organismos, muestran un marcado descenso en las tasas de evasión estimadas para ese tributo entre 2003 y 2007. A excepción de Chile, cuya tasa de evasión también descendió del 18\% al 15\% en ese período, el rango de valores calculados para la mayor parte de los países pasó de entre el $28,6 \%$ y el $45,9 \%$ a uno considerablemente menor, de entre el $19,6 \%$ y el $38,4 \%$. Estos valores correspondieron a los casos de Costa Rica (el mínimo) y Perú (el máximo) entre ambos años de referencia. Esa alentadora tendencia en una muestra de países de la región refleja los avances concretos alcanzados en materia de fiscalización y control de los contribuyentes, al menos en lo que se refiere a ese tributo. 


\section{Gráfico XII.1 \\ América Latina (países y años seleccionados): evolución de las tasas \\ de evasión del IVA, 2003-2012 \\ (En porcentajes)}

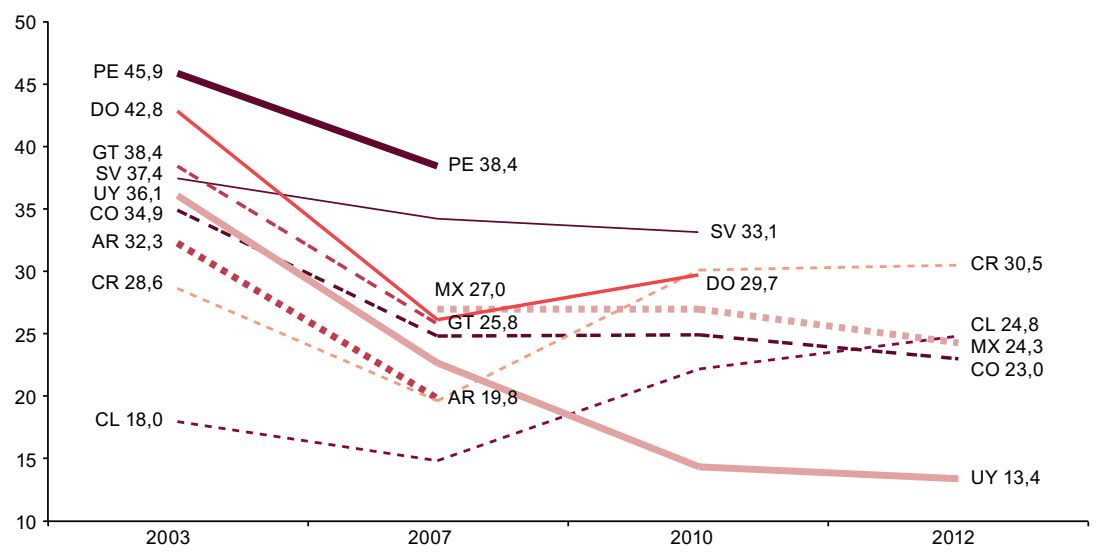

Fuente: Comisión Económica para América Latina y el Caribe (CEPAL), sobre la base de información oficial de los países.

Luego, entre 2007 y 2010, los efectos de la crisis financiera sobre las economías y los sistemas tributarios de la región parecen haber afectado la tendencia señalada. Como es sabido, el comportamiento de los contribuyentes puede estar condicionado, en forma anticíclica, por el contexto económico. Por ese motivo, en períodos recesivos, la evasión podría ser vista como una estrategia de supervivencia más aceptada.

De hecho, aun con menos datos disponibles, ha sido posible comprobar que los avances en la reducción de los niveles de evasión del IVA alcanzados en años anteriores se detuvieron bruscamente en la mayoría de los países. Tal ha sido el caso de El Salvador, Colombia y México. Incluso en algunos países, como la República Dominicana y Chile, las tasas de evasión estimadas muestran un aumento en el año 2010 (véase el gráfico XII.1) ${ }^{6}$.

Una clara excepción es el caso uruguayo, donde la tendencia decreciente se mantuvo, y posiblemente se capitalizó la profunda reforma tributaria introducida a finales de 2006. Además de modificar las tasas y ampliar la base imponible del IVA, esa reforma también incluyó un paquete de mejoras en términos de gestión y eficiencia de la administración tributaria, por ejemplo, la incorporación de agentes de retención del impuesto (DGI, 2013).

Los más recientes valores estimados toman como base la matriz insumo-producto de 2008 (MIP 2008). Las estimaciones anteriores, que se basaban en la MIP 2003, arrojaban valores inferiores, pero mostraban la misma tendencia creciente de las tasas de evasión del IVA a partir de 2008.

7 En Costa Rica también se advierte un aumento en ese período pero, dado que dicha tendencia corresponde al resultado conjunto de dos estudios distintos, las magnitudes deben considerarse con la debida cautela. 
En realidad, también se registró una disminución de la tasa de evasión del IVA en el Paraguay, cuya Secretaría de Estado de Tributación (SET) estimó que la tasa se redujo de un 45,3\% en 2007 a un 33,6\% en 2010 (véase el cuadro XII.1). Sin embargo, no se dispone de estimaciones de años anteriores, que permitan confirmar o refutar la tendencia general de los primeros años de la década pasada a nivel regional, ni de años posteriores, que servirían para comprobar la evolución de dichas estimaciones hasta la actualidad.

\section{Cuadro XII.1}

América Latina (11 países): tasa de evasión del IVA, 2000-2014

(En porcentajes)

\begin{tabular}{|c|c|c|c|c|c|c|c|c|c|c|c|c|c|c|c|}
\hline Países & 2000 & 2001 & 2002 & 2003 & 2004 & 2005 & 2006 & 2007 & 2008 & 2009 & 2010 & 2011 & 2012 & 2013 & 2014 \\
\hline Argentina & & 29,6 & 34,8 & 32,3 & 24,8 & 23,3 & 21,2 & 19,8 & & & & & & & \\
\hline Chile & & & & 18,0 & 18,1 & 16,7 & 15,9 & 14,8 & 22,5 & 20,2 & 22,2 & 23,6 & 24,8 & 24,3 & 22,2 \\
\hline Colombia & 37,9 & 36,6 & 37,5 & 34,9 & 31,8 & 30,2 & 27,7 & 24,8 & 23,7 & 26,1 & 24,9 & 22,6 & 23,0 & & \\
\hline \multirow[t]{2}{*}{ Costa Rica $^{a}$} & 27,1 & 26,4 & 27,4 & 28,6 & 23,6 & 25,7 & 22,4 & 19,6 & 18,2 & & & & & & \\
\hline & & & & & & & & & & & 30,1 & 29,1 & 30,5 & & \\
\hline El Salvador & 42,4 & 39,2 & 38,8 & 37,4 & 39,1 & 35,4 & 30,4 & 34,2 & 36,3 & 39,2 & 33,1 & & & & \\
\hline \multirow[t]{2}{*}{ Guatemalab $^{b}$} & & 34,6 & 35,4 & 38,4 & 33,6 & 36,2 & 33,1 & 25,8 & & & & & & & \\
\hline & & 32,7 & 31,4 & 32,0 & 30,2 & 36,4 & 32,0 & 26,3 & 37,9 & 40,8 & 38,0 & 34,6 & 32,6 & 39,4 & 40,3 \\
\hline \multirow[t]{2}{*}{ México $^{\circ}$} & 23,2 & 22,5 & 23,8 & 18,2 & 26,8 & 25,5 & 17,8 & 19,8 & 17,8 & & & & & & \\
\hline & & & & & 34,9 & 31,7 & 25,5 & 27,0 & 24,3 & 26,3 & 27,0 & 29,5 & 24,3 & & \\
\hline Paraguay & & & & & & & & 45,3 & 43,5 & 41,5 & 33,6 & & & & \\
\hline Perú & & 49,5 & 48,0 & 45,9 & 44,2 & 42,9 & 39,4 & 38,4 & 37,0 & & & & & & \\
\hline $\begin{array}{l}\text { República } \\
\text { Dominicana }\end{array}$ & 27,5 & 36,5 & 37,2 & 42,8 & 41,7 & 35,6 & 31,2 & 26,1 & 24,9 & 30,3 & 29,7 & & & & \\
\hline Uruguay & 39,9 & 37,4 & 40,1 & 36,1 & 30,8 & 30,1 & 27,8 & 22,7 & 20,2 & 17,2 & 14,4 & 14,0 & 13,4 & & \\
\hline
\end{tabular}

Fuente: Comisión Económica para América Latina y el Caribe (CEPAL), sobre la base de información oficial de los países.

a Se presentan los datos correspondientes al trabajo de la Contraloría General de la República (2010) para el período 2000-2008, y los de Molina y Muñoz (Ministerio de Hacienda, 2014) para el período 2010-2012.

b Las estimaciones oficiales de la SAT están disponibles para el período 2001-2007. El ICEFI, reconocida institución de investigación a nivel regional con sede en ese país, estimó la tasa de evasión del IVA entre 2000 y 2014, que es la que se presenta en este cuadro. Vale señalar que el ICEFI (2015) también provee un cálculo con ajustes para atender las distorsiones derivadas de la aplicación de retenciones y la política discrecional en la devolución de crédito fiscal del IVA al sector exportador. Se obtiene así una serie de tasas de evasión más estables en ese período.

c Los dos últimos estudios globales sobre la evasión fiscal fueron realizados por un equipo de académicos del Instituto Tecnológico y de Estudios Superiores de Monterrey (ITESM) a petición del SAT: el primero se refiere al período 2000-2008 (Fuentes Castro, 2010) y utiliza como base el sistema de cuentas nacionales (SCN) de 2003, mientras que el más reciente comprende el período 2004-2012 y toma como referencia el SCN de 2008.

Desafortunadamente, en años más recientes el número de estimaciones difundidas por las agencias de recaudación ha seguido disminuyendo, lo que hace más compleja la comparación entre países y mucho más la observación de tendencias generales a nivel regional. Sin embargo, resulta evidente la mayor dificultad encontrada para reducir los niveles de incumplimiento estimados con anterioridad a la crisis financiera y económica de 2008-2009. 
Así, mientras que México, Colombia y sobre todo el Uruguay (que registró la menor tasa de evasión de la región en 2012, con un 13,4\%) muestran leves mejoras en esa materia entre 2010 y 2012, Chile ha experimentado un preocupante incremento (si bien a menor ritmo que durante la crisis). Alcanzó una tasa del 24,8\% en 2012, con una leve reducción en 2013 y 2014, según lo informado por el Servicio de Impuestos Internos (SII, 2015).

El fenómeno de la evasión responde a una multiplicidad de factores específicos de cada país. No obstante, en el caso de Chile, más allá de algunos cambios metodológicos y estadísticos por parte de la institución mencionada, una posible explicación de esa llamativa reversión en la evolución del nivel de incumplimiento de ese tributo está relacionada con la amplia apertura comercial y financiera de la economía. Al ingresar gran parte de la recaudación del IVA por medio de las aduanas (donde es más difícil aunque no imposible evadir la obligación tributaria), es probable que los efectos recesivos de la crisis económica de 2008-2009 y la disminución global de los flujos comerciales en años posteriores haya modificado dicha tendencia hacia una mayor proporción de recursos captados en operaciones domésticas, donde la probabilidad de evasión es mayor, lo que habría incidido negativamente sobre la tasa estimada en años recientes. Como es de esperarse, este fenómeno también repercute sobre el pago efectivo de otros tributos que gravan el consumo interno, como los impuestos selectivos. A ese respecto, las estimaciones recientes han dado cuenta de importantes niveles de incumplimiento tanto en el caso de Chile como en el de México (véase el recuadro XII.1).

En Costa Rica, un estudio reciente patrocinado por el Ministerio de Hacienda (Molina y Muñoz, 2014) mostró que los niveles de incumplimiento del IVA rondaron el 30\% entre 2010 y 2012 (véase el cuadro XII.1). Ello contrasta claramente (más allá de algunas diferencias metodológicas) con los resultados que reflejaba el trabajo anterior de la Contraloría General de la República (2010), que mostraba una clara reducción de la tasa de evasión entre 2003 y $2008^{8}$. Por su parte, aun cuando la Superintendencia de Administración Tributaria (SAT) dejó de publicar estudios sobre la evasión del IVA en Guatemala desde 2009, una estimación reciente (ICEFI, 2015) detectó una cierta mejora en esa dimensión durante el período 2009-2012, aunque luego sobrevino un marcado aumento de la tasa de evasión, que alcanza un 40,3\% de su nivel teórico en 2014. En el cuadro XII.1 se presenta, de manera más detallada, una recopilación de los resultados de los estudios cuantitativos sobre la evasión del IVA en los países de la región donde estos han sido difundidos con cierta sistematicidad.

Si bien el cálculo utilizado fue similar en ambos estudios (y fue sugerido años atrás por el Fondo Monetario Internacional), en el más reciente se incluyó una serie de ajustes y mejoras en cuanto a la definición de supuestos y la cuantificación de algunos resultados. 
Recuadro XII.1

\section{Evasión de los impuestos selectivos sobre el consumo}

Más allá de su menor peso específico en términos del monto de recursos potenciales resignados, la evasión de los impuestos selectivos adquiere una relevancia particular debido a que esos gravámenes suelen aplicarse a bienes o servicios que producen algún tipo de externalidad negativa y actúan como desincentivo para reducir o desalentar su consumo excesivo. Un trabajo novedoso en ese sentido ha sido el de Jorratt (2012), que realizó un ejercicio para estimar los niveles de incumplimiento en los impuestos específicos que gravan el consumo de tabaco y de bebidas alcohólicas en Chile. Con la metodología utilizada se buscó estimar el potencial teórico a partir de encuestas que miden el consumo personal de los bienes gravados.

Así, para el año 2011, se estimó que la tasa de evasión del impuesto al tabaco fue del $17,3 \%$, mientras que en el caso de las bebidas alcohólicas se diferenció según el producto gravado, con tasas del 17,5\% en los vinos, el $20,3 \%$ en las cervezas y el $34,0 \%$ en el pisco, el ron y otros licores. Si en el caso de las bebidas sin alcohol se utiliza una tasa de evasión igual al promedio de las tasas de evasión medidas respecto de las bebidas alcohólicas $(24,1 \%)$, la magnitud de la evasión habría representado unos 1.200 millones de dólares en 2011, cifra que equivale a medio punto del PIB. Vale señalar que, en todos los casos, los resultados obtenidos van más allá de las pérdidas por el impuesto selectivo (efecto directo)a. También abarcan los efectos indirectos sobre otros tributos como el IVA dejado de recaudar (respecto de su valor teórico), así como el impacto indirecto que tiene esa evasión en el ISR de las empresas evasoras.

En el caso de México, Fuentes y otros (2013) calcularon la evasión fiscal respecto del impuesto especial sobre producción y servicios (IEPS) no petrolero (exceptúa los combustibles), centrados en cuatro rubros: cervezas, cigarros, telecomunicaciones y bebidas alcohólicas. Se pudo comprobar que las bebidas alcohólicas son las que muestran la mayor tasa de evasión, con un máximo del 33,1\% en 2010 y una sensible disminución en 2012 (5,1\%). La cerveza muestra una tasa del $10,6 \%$ en ese último año. El tabaco registró un $1,1 \%$ y las telecomunicaciones, un $13,3 \%$ en 2012 . En conjunto, la tasa de evasión del IEPS no petrolero es relativamente baja, pues se sitúa alrededor de 10 puntos porcentuales, pasando del 7,9\% en 2004 al 6,1\% en 2012 . Con respecto al PIB, la evasión del IEPS no petrolero tiene una importancia modesta $(0,029 \%$ en 2012$)$.

Fuente: Elaboración propia, sobre la base de M. Jorratt, "Estimación de la evasión tributaria en los impuestos selectivos al consumo: el caso de Chile", Revista de Administración Tributaria, $\mathrm{N}^{\circ} 34$, Centro Interamericano de Administraciones Tributarias (CIAT)/Agencia Estatal de Administración Tributaria (AEAT)/Instituto de Estudios Fiscales (IEF), 2012 y H.J. Fuentes (coord.), Estudio de evasión global de impuestos, Ciudad de México, Instituto Tecnológico y de Estudios Superiores de Monterrey (ITESM), 2013.

a En el caso del tabaco esto comprende un componente ad valorem sobre el precio de venta y otro ad quantum por cada cigarrillo comercializado. En cambio, las bebidas alcohólicas y analcohólicas están sujetas, además del IVA, a tasas adicionales que se aplican sobre las ventas e importaciones (solo hasta la penúltima etapa de comercialización), que varían según el tipo de bebida.

Por último, más allá de los hechos estilizados que puedan establecerse en lo que se refiere a la evolución de las tasas de evasión del IVA a nivel regional y de los avances alcanzados en esa materia, especialmente durante 
gran parte de la década pasada, cabe destacar que los resultados distan bastante de los registrados en los países desarrollados. En ese sentido, la Comisión Europea ha encargado y publicado una serie de estudios (siendo el más reciente el de Barbone, Bonch-Osmolovskiy y Poniatowski (2015)) tendientes a cuantificar la brecha tributaria del IVA, es decir, la diferencia entre la recaudación teórica y la efectiva, de los países de la Unión Europea a partir de una metodología estándar que facilita la comparación.

En el gráfico XII.2 se resume una serie de resultados en materia de evasión del IVA en los países de América Latina (último dato disponible entre 2010 y 2014) junto con los más recientes cálculos para los países europeos, correspondientes a 2013 (Barbone, Bonch-Osmolovskiy y Poniatowski, 2015). Allí puede observarse que los países latinoamericanos, a excepción del Uruguay, exhiben tasas de evasión por encima del 20\% (por ejemplo, Chile, Colombia y México), e incluso superiores al 30\% en varios países de Centroamérica. En cambio, se advierte una gran heterogeneidad de realidades entre los miembros de la Unión Europea (UE-26): mientras que los países más desarrollados muestran tasas de evasión del IVA dentro del rango del $8,9 \%$ (Francia) al 11,2\% (Alemania), en algunos países (como Italia (33,6\%) y Grecia $(34,0 \%)$ ) junto con varios miembros de Europa oriental (como Polonia $(26,7 \%)$, Hungría (24,4\%) y Rumania (41,1\%)), los niveles de incumplimiento son muy elevados y se asemejan a los observados en América Latina.

\section{Gráfico XII.2}

\section{América Latina (último año disponible) y Unión Europea (año 2013) (países seleccionados): tasas de evasión del IVA \\ (En porcentajes)}

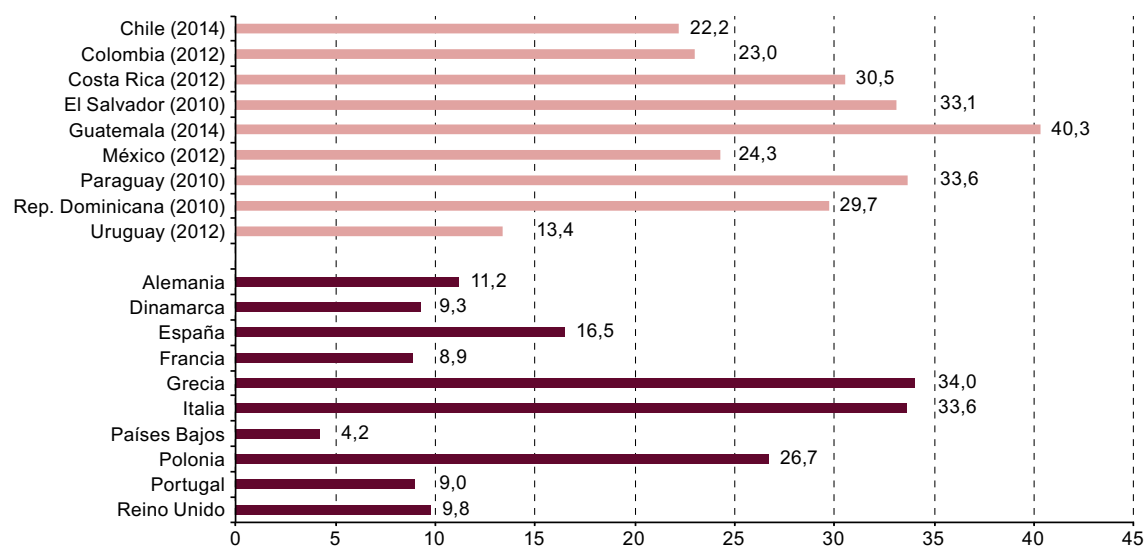

Fuente: Comisión Económica para América Latina y el Caribe (CEPAL), sobre la base de información oficial de los países para América Latina, y de L. Barbone, M. Bonch-Osmolovskiy y G. Poniatowski, Study to Quantify and Analyse the VAT Gap in the EU Member States. 2015 Report (TAXUD/2013/DE/321), La Haya, CPB Netherlands Bureau for Economic Policy Analysis, 2015 para los países europeos. 


\section{El caso del impuesto sobre la renta}

Aparte del IVA, el otro gran pilar de los sistemas tributarios latinoamericanos en la actualidad está constituido por el impuesto sobre la renta (ISR), cuya recaudación es aportada mayormente por las sociedades y, en menor proporción, por los individuos. Como componente principal de la imposición directa, la consolidación del ISR dentro de las estructuras tributarias de la región ha adquirido una importancia crucial en años recientes debido a su incidencia en el impacto distributivo global.

Al mismo tiempo, existe considerable consenso acerca de la existencia de una serie de obstáculos que ha venido y continúa enfrentando la imposición sobre los ingresos en la mayoría de los países. Como señalan Gómez Sabaini, Jiménez y Rossignolo (2012), se distinguen tres fundamentales: i) las tasas marginales máximas reducidas del ISR personal (las tasas uniformes del impuesto societario han venido descendiendo en línea con las tendencias internacionales); ii) una base imponible estrecha debido a la existencia de amplios beneficios tributarios (ISR de sociedades) y tratamientos diferenciales de acuerdo al tipo de ingreso gravado (ISR personal), y iii) el alto coeficiente de incumplimiento (evasión y morosidad) en el impuesto para ambos tipos de contribuyentes.

Sin embargo, mientras que los dos primeros factores son relativamente simples de confirmar a partir de datos estadísticos, la medición de la evasión del impuesto sobre la renta (quizás como consecuencia de que los mecanismos de control administrativo del gravamen son más acotados que con el IVA) siempre ha encontrado mayores dificultades a nivel regional. De hecho, en varios casos su comprobación ha debido descansar en una serie de indicios evidentes, pero aislados, generados por parte de las administraciones tributarias mediante auditorías y fiscalizaciones puntuales. Han sido muy escasas las estimaciones globales del nivel de incumplimiento en el ISR y, en su gran mayoría, se han visto limitadas al análisis de lo que ocurre con las personas jurídicas.

Un estudio que sigue siendo referencia en esa materia, aun cuando los resultados que contiene no sean tan recientes, es el elaborado por Jiménez, Gómez Sabaini y Podestá (2010), que permitió establecer ciertas pautas fundamentales a nivel regional. A partir de una muestra acotada de siete países de América Latina, y siguiendo una metodología de brechas tributarias entre el nivel potencial y el nivel efectivo de recaudación, se estimaron las tasas de evasión de ese tributo por los individuos y por las sociedades 9 . Se comprobó que, excepto en Guatemala, los coeficientes correspondientes

Los países analizados fueron la Argentina, Chile, el Ecuador, El Salvador, Guatemala, México y el Perú. 
al impuesto pagado por los primeros arrojan guarismos inferiores a los correspondientes al ISR de sociedades en todos los casos analizados (véase el gráfico XII.3).

\section{Gráfico XII.3}

América Latina (7 países): tasas estimadas de evasión impositiva del impuesto sobre la renta (En porcentajes)

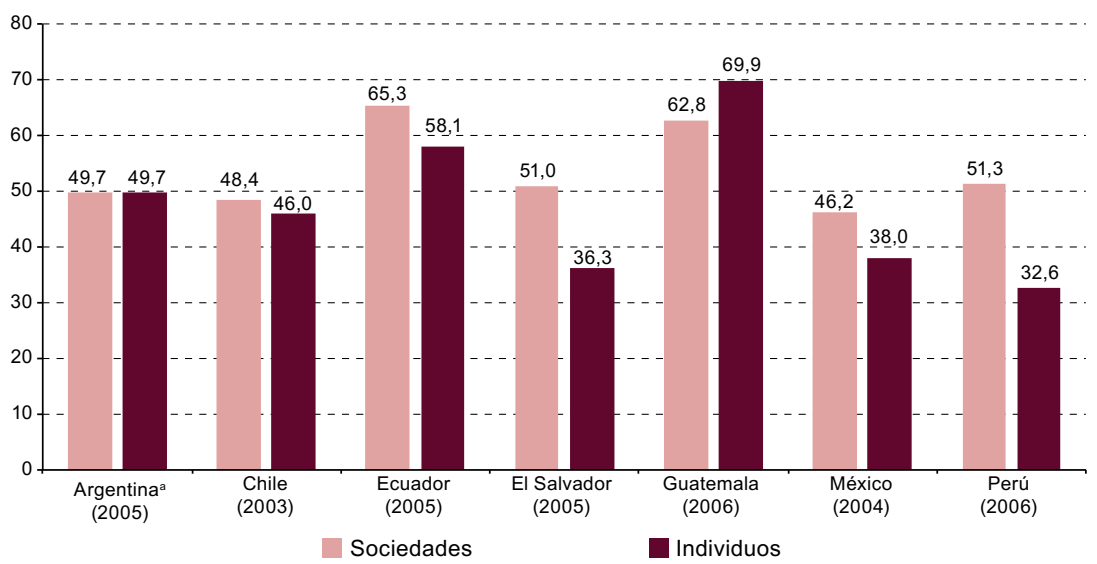

Fuente: J. C. Gómez Sabaini, J. P. Jiménez y A. Podestá, “Tributación, evasión y equidad en América Latina y el Caribe", Evasión y equidad en América Latina, Documentos de Proyecto, N 309 (LC/W.309), Santiago, Comisión Económica para América Latina y el Caribe (CEPAL).

a En el caso de la Argentina, la información disponible no permitió discriminar los ingresos del componente de ingreso mixto, ni los relativos al régimen de tributación simplificada (monotributo). Por esa razón los autores (Cetrángolo y Gómez Sabaini, 2009) decidieron estimar una única tasa de evasión conjunta del ISR.

Teniendo en cuenta que los datos estadísticos utilizados se refieren a situaciones tributarias vigentes entre 2003 y 2006, este particular resultado habría encontrado explicación en el alto contenido de retenciones en la fuente efectuadas a los ingresos de asalariados, quienes son los que aportan la mayor parte de la recaudación del ISR personal. Además, gran parte de otras fuentes de ingresos (como los dividendos, intereses, rentas de títulos públicos y ganancias de capital) se encontraban por entonces exentas del tributo en la mayoría de los países de la región.

Vale destacar que, en función de las numerosas y alentadoras reformas introducidas por varios países en el ISR en años más recientes, los valores estimados y las tendencias señaladas pueden haberse visto afectados en uno $\mathrm{u}$ otro sentido ${ }^{10}$. Por un lado, se amplió la base imponible del ISR personal (se destaca el caso de los sistemas duales utilizados en el Perú, el Uruguay

10 Véase una revisión actualizada de esas reformas tributarias en CEPAL (2015). 
y los países de Centroamérica) y, por otro, se difundieron los modelos de imposición presuntiva (impuestos mínimos aplicados sobre los activos de las sociedades) y los regímenes de tributación simplificada para pequeños contribuyentes, que pueden distorsionar las decisiones privadas de los contribuyentes sujetos al ISR de sociedades.

Por otra parte, en una reciente contribución realizada por Pecho, Peláez y Sánchez (2012) se recopilan las estimaciones existentes (tanto de fuentes oficiales como de organismos privados) en lo que respecta a la evasión del IVA y del ISR de personas jurídicas en la gran mayoría de los países latinoamericanos. Además, esos autores calcularon el nivel de incumplimiento tributario del ISR de las personas jurídicas, con el método del potencial teórico aplicado a las cuentas nacionales.

Más allá de las importantes diferencias entre países, se observan dos hechos estilizados. En primer lugar, los niveles de incumplimiento del ISR de las sociedades son relativamente más elevados que los del IVA a nivel regional, lo cual se relaciona con los mayores esfuerzos realizados (y logros obtenidos) en la administración del tributo durante las décadas pasadas. En segundo lugar, el aporte de esos autores confirma que, en todos los países (excepto la República Dominicana), las tasas de evasión de ambos impuestos parecen haberse reducido durante los últimos años: si se comparan los promedios simples de la región correspondientes a los períodos 2000-2005 y 2006-2010, el nivel de incumplimiento del IVA pasó del 36,1\% al 27,3\%, mientras que en el caso del ISR de sociedades bajó del 52,5\% al 46,4\%, respectivamente, entre dichos períodos. No obstante esa alentadora tendencia, el estudio mencionado expone que, en la mayoría de los casos, las tasas de evasión estimadas resultan inadmisibles, sobre todo en lo que refiere al impuesto sobre la renta.

Afortunadamente, la gravedad del problema ha motivado en los últimos años la realización de algunos trabajos de investigación en ese ámbito. En efecto, se han difundido algunos estudios sobre la evasión del ISR en casos específicos que, dada su escasez a nivel regional, merecen ser destacados. Es importante destacar que la comparación de sus resultados no resulta factible, debido a las numerosas diferencias metodológicas, aunque los estudios sí proveen indicios más actualizados acerca de las tendencias observadas en ese ámbito y la magnitud relativa del fenómeno en algunos países.

En primer lugar, el Servicio de Impuestos Internos (SII) de Chile publicó en 2012 una estimación acerca de la magnitud del fenómeno en el ISR de las empresas chilenas durante el período 2003-2009. Con una tasa general del $17,0 \%$ para el gravamen, y utilizando el método de recaudación potencial, la tasa de evasión resultó ser del $44 \%$ en 2003 , con un claro y progresivo 
declive hasta llegar al 23\% en $2006^{11}, 12$. De acuerdo al trabajo mencionado (SII, 2012a), a partir de allí se advierte un punto de inflexión en la serie y un crecimiento de los niveles de incumplimiento del ISR de sociedades, hasta un 29\% en 2007. Luego de un leve descenso en 2008 (25\%), alcanzó el 31\% en 2009. Complementaria y paralelamente, el SII (2012b) estimó la evasión del ISR personal para algunos años puntuales del mismo período, sobre la base de encuestas de ingresos (Encuesta de Caracterización Socioeconómica Nacional (CASEN)). Según esos cálculos, la evasión llegó al 46\% en 2003, bajó al 22\% en 2006 y repuntó hasta un $27 \%$ en 2009.

En Colombia existe una larga tradición de mediciones del nivel de incumplimiento del impuesto sobre la renta. En años anteriores, tanto la Dirección de Impuestos y Aduanas Nacionales (DIAN) como varios investigadores particulares realizaron trabajos en esa materia. Sin embargo, por lo general se trataba de ejercicios aislados en el tiempo, con diferentes enfoques metodológicos, lo que ha impedido contar con mediciones sistemáticas y fiables acerca de la magnitud del fenómeno ${ }^{13}$.

Durante los últimos años, la DIAN ha venido promoviendo la elaboración periódica de una serie de estudios para estimar los niveles de incumplimiento tributario de la economía colombiana. Así como en el caso del IVA, en un trabajo muy reciente de Ávila y Cruz Lasso (2015) se utiliza el método de la brecha tributaria y se obtienen resultados actualizados específicamente para el ISR de personas jurídicas durante el período 2007-2012. De acuerdo a esos autores, la tasa de evasión del gravamen (respecto del monto potencial) fue del $39,5 \%$ en 2007 , con un marcado aumento en los años inmediatamente posteriores a la crisis financiera de 2008 (un 45,2\% en 2009 y un 43,3\% en 2010), y luego una reducción aún mayor en 2011 y 2012, hasta valores del $34,0 \%$ y el $34,4 \%$, respectivamente. No obstante dicho comportamiento, la magnitud relativa de la pérdida de ingresos tributarios asociada a ese problema se mantuvo, durante el período analizado, dentro de un rango del 2,3\% al 2,7\% del PIB.

Otro caso que amerita mención especial es el de México. Como ya se expresó, el Servicio de Administración Tributaria (SAT) institucionalizó el proceso de medición de la evasión y encomendó dicha tarea a reconocidas entidades académicas. Esa decisión ha brindado valiosas enseñanzas

11 En realidad, la tasa general del ISR de empresas fue del 16,5\% en 2003 y del 17,0\% entre 2004 y 2009.

12 Se utilizó como fuente de información la matriz insumo-producto (MIP) de 2003, que fue actualizada por la MIP 2008, que es la que se ha utilizado para las estimaciones más recientes de la evasión del IVA.

13 Ávila Mahecha y Cruz Lasso (2015) revisan los principales estudios precedentes y encuentran que, más allá de las limitaciones metodológicas y de las amplias diferencias que se detectan, la mayoría coincide en dos tendencias generales. Por un lado, la evasión de las personas jurídicas es menor que la de las personas físicas. Por otro lado, la tasa de evasión de las primeras tiende a reducirse, mientras que en las segundas permanece estable o incluso se incrementa. 
y diagnósticos más precisos acerca de un problema que ha aquejado históricamente al sistema tributario de México. En el trabajo más reciente, elaborado por un equipo del Instituto Tecnológico y de Estudios Superiores de Monterrey (Fuentes, 2013), se estimó la tasa de evasión del ISR de personas morales (empresas) y del ISR de personas físicas (donde se diferenciaron tres fuentes principales de ingresos) durante el período 2004-2012.

En los datos presentados por esos autores se advierten comportamientos muy dispares según el tipo de contribuyente. En el caso del ISR de personas morales, la tasa de evasión se reduce de forma pronunciada entre 2004 y 2008 (de un $55,0 \%$ a un $24,0 \%$ ). Esa tendencia continúa con menor intensidad hasta $2011(22,1 \%)$ y con una sensible reversión al alza en el último año analizado (un 31,4\% en 2012). En cambio, en el ISR personal la evolución de los niveles de incumplimiento estimados no refleja semejante mejora y difiere según el tipo de ingreso gravado. Así, si bien ha mostrado valores considerablemente bajos (asociados a los sistemas de retención en la fuente), la evasión en el caso de los asalariados se redujo levemente a lo largo del período (pasó del 19,6\% en 2004 al 15,5\% en 2012). Esto es similar a lo observado en las rentas por arrendamiento, aunque a niveles de incumplimiento casi inadmisibles, pues pasó de un $88,7 \%$ a un $85,7 \%$ entre los mismos años, pero con un máximo del $90,5 \%$ en 2007. Incluso respecto de los ingresos por actividades empresariales, la tasa de evasión del ISR personal registró un aumento significativo desde el año 2007 (58,9\%), hasta alcanzar alrededor del 84\% en el trienio 2010-2012.

En Costa Rica, por otra parte, en un estudio pionero elaborado por la Contraloría General de la República (2009) se encontró que el incumplimiento en el ISR de personas jurídicas promedió un 72,4\% en el período 2000-2007, con un máximo del $77,5 \%$ en 2003 y una leve tendencia declinante, hasta un valor del $64,3 \%$ en 2007 . Tomando esto como base y mejorando aspectos metodológicos (al igual que en el caso comentado del IVA), un valioso trabajo más reciente publicado por el Ministerio de Hacienda (Molina y Muñoz, 2014) muestra que la evasión del ISR de sociedades se mantuvo a niveles muy elevados en los últimos años, con una leve disminución desde un 70,1\% de la recaudación potencial en 2010 hasta un 67,5\% en 2012. La gravedad de esa situación está dada por los recursos tributarios resignados que dicha tasa representa, del orden del 4,2\% del PIB en ese último año.

En ese mismo trabajo se estimó que la tasa de evasión del ISR de personas físicas alcanzó el 53,8\% (o un 1,4\% del PIB) en 2012, un descenso respecto del $58,2 \%$ en 2010. Así se pudo diferenciar la magnitud del incumplimiento entre los asalariados y pensionados, donde la evasión sería cercana al $12 \%$ respecto del potencial, y las personas físicas con actividad lucrativa, en quienes la brecha entre la recaudación efectiva y la potencial representa casi el 91\% de este último concepto (Molina y Muñoz, 2014). 
Otras estimaciones específicas también dan cuenta, con grandes diferencias entre países, de la magnitud de la evasión del ISR a nivel regional. En Guatemala, si bien un estudio patrocinado por la SAT encontró que la evasión del ISR global (personas físicas y sociedades) promedió un $62 \%$ entre los años 2005 y 2009 (Franco, 2011), recientemente el ICEFI (2015) estimó que el nivel de incumplimiento en el régimen de actividades lucrativas del ISR sería equivalente al $40,3 \%$ de su potencial recaudatorio total. De acuerdo a ese último trabajo, la amplia diferencia observada corresponde a un refinamiento metodológico que toma en cuenta el hecho de que muchas deducciones contempladas en la ley del tributo no son parte de las deducciones económicas que se consideran a efectos de estimar el PIB, el cual sirve de base de cálculo para aproximar el valor de la recaudación teórica.

Por último, un trabajo de Salim (2011), encargado por la Dirección General de Impuestos Internos (DGII) de la República Dominicana, mostró que el incumplimiento en el caso del ISR de sociedades de ese país alcanzó un porcentaje del $63,9 \%$ (4,6\% del PIB) en 2008 y del $68,9 \%$ (5,0\% del PIB) en 2009 , mientras que la tasa de evasión del ISR de personas físicas resultó ser del $42,9 \%$ en el primer año y del 51,8\% en el segundo (equivalente al 1,0\% del PIB). En ese caso, además de confirmar los elevados niveles de evasión del ISR observados en la mayoría de los países, también se advierte que la tasa de incumplimiento de las personas físicas es menor que la de las sociedades. Como ya se mencionó, esto se debe en parte a que la primera incluye el incumplimiento de los asalariados, que típicamente presentan un bajo margen de evasión debido a la existencia de retenciones en la fuente, y en parte también a que una porción de los trabajadores independientes (entre los que por lo general se detectan mayores niveles de incumplimiento) puede estar incluida dentro del cálculo correspondiente a las sociedades.

\section{La evasión contributiva (o el incumplimiento en los sistemas de seguridad social) ${ }^{14}$}

Más allá de las sucesivas reformas implementadas durante las últimas décadas, el financiamiento de los sistemas contributivos de protección social en salud y pensiones en los países de América Latina encuentra su base en los aportes y contribuciones de carácter obligatorio de los empleados y empleadores e incluso, en algunos casos, en aportes adicionales del Estado provenientes de rentas generales. En la mayoría de los esquemas vigentes, esos recursos, con mayor o menor éxito, procuran asegurar un adecuado nivel de cobertura prestacional a la población. Con ese fin se requiere el compromiso de cada uno de los actores mencionados en relación con el cumplimiento de sus obligaciones contributivas.

14 Esta sección se basa en Gómez Sabaini, Cetrángolo y Morán (2014). 
En la práctica se han podido observar diversas maneras de incumplimiento. Tanto empleados como empleadores pueden tener incentivos para reducir o, directamente, no efectuar el pago obligatorio de los aportes y contribuciones que establece la normativa por su condición laboral. Todas esas prácticas están vinculadas, en mayor o menor medida, a un aumento del empleo informal, que constituye el principal problema en el mercado laboral de varios países latinoamericanos y entraña serias consecuencias socioeconómicas como: i) la insuficiente protección social de los trabajadores; ii) obstáculos para el desarrollo profesional; iii) distorsiones del mercado de trabajo formal y de los esquemas de financiamiento de la seguridad social, y iv) generación de "incentivos perversos" para el cumplimiento de las obligaciones previsionales.

Desde el punto de vista teórico, el incumplimiento de los pagos obligatorios en los esquemas contributivos de protección social (el concepto de "evasión contributiva") posee algunas connotaciones particulares que se deben tener en cuenta a la hora de analizar sus determinantes y sus efectos potenciales.

Baumann, Friehe y Jansen (2009) sostienen que, a diferencia de los impuestos tradicionales, el pago de contribuciones a la seguridad social genera para el aportante el derecho a recibir algún tipo de contraprestación en el presente o en el futuro, y que ese factor, junto con la aversión al riesgo, tiene incidencia directa sobre la decisión efectiva de incumplir las obligaciones formales que impone la legislación laboral. Además, el incumplimiento contributivo de un trabajador cotizante puede traducirse en su exclusión del sistema o en la subprovisión de prestaciones. Desde una perspectiva del Estado de bienestar, ello requiere atención, puesto que las personas más jóvenes, por miopía temporal, suelen subestimar las consecuencias de no participar en los esquemas contributivos y postergan el cumplimiento.

Por otra parte, el enfoque actual de la protección social, basado en el reconocimiento de los derechos de la ciudadanía, exige que el Estado no solo se preocupe por los trabajadores registrados formales, sino también por los que se desempeñan en el sector informal de la economía, algo que adquiere especial relevancia en los países de América Latina. Bajo esa perspectiva, el incumplimiento en los esquemas contributivos afecta su sostenibilidad financiera, ya que los individuos no comprendidos en los sistemas de protección social requerirán mayores esfuerzos económicos del Estado (o tasas de imposición más elevadas) para implementar otros esquemas, complementarios y no contributivos, que permitan brindar las prestaciones básicas en materia de pensiones y salud a una porción mayoritaria de la población. Algo similar podría argumentarse sobre las bajas tasas de reemplazo de las cuentas individuales de pensiones, y la mala o volátil inserción laboral en mercados con altos niveles de informalidad, pues así aumenta la cantidad de personas 
que caen bajo esquemas no contributivos con financiamiento fiscal, lo que incrementa las presiones fiscales sobre los gobiernos.

Desde la óptica metodológica el tema es complejo. Las informaciones de las cuentas nacionales sobre empleo y masa salarial, contrastadas con las bases de datos de los organismos de seguridad social podrían brindar resultados preliminares en la cuantificación de las brechas de incumplimiento. Por su parte, las encuestas de hogares también proveen información microeconómica que permitiría inferir la magnitud de dicho incumplimiento en términos de la cantidad de trabajadores que no realizan los debidos aportes. Sin embargo, la especificidad de los esquemas de protección social aplicados y las limitaciones estadísticas particulares obligan a proceder con cautela al utilizar una metodología estándar.

En contraste con el estudio de la evasión del IVA o del impuesto sobre la renta, y ya sea por falta de interés, supeditación a otras urgencias y prioridades, o por las dificultades técnicas asociadas, las investigaciones que tratan de cuantificar específicamente el nivel de incumplimiento en los esquemas contributivos de protección social son mucho menos numerosas y sus resultados son más limitados. En particular, en los países de América Latina no solo son escasas, sino que la heterogeneidad de metodologías es lo que ha predominado durante mucho tiempo. El tema de la evasión contributiva (pensiones y, en menor medida, salud) tuvo cierto auge a principios de los años noventa, cuando varios países de la región comenzaron a considerar (y en algunos casos llegaron a implementar) reformas estructurales de sus esquemas de protección social ante las dificultades registradas en su sostenibilidad financiera (CEPAL, 2006).

Más recientemente, algunas investigaciones empíricas sobre el grado de informalidad laboral en los países de la región brindan una idea aproximada del nivel de incumplimiento en los esquemas contributivos de seguridad social. Estos estudios generalmente sacan provecho de la información contenida en las encuestas de hogares que cada país releva periódicamente y arrojan resultados acerca de la magnitud del problema en términos de la cantidad de trabajadores que, pese a estar obligados a hacerlo, no realizan los aportes correspondientes a las instituciones de seguridad social.

En el cuadro XII.2 se resumen las principales referencias encontradas en esa materia. Entre ellas merecen destacarse dos de las más recientes, referidas a Chile y el Uruguay. En el primer caso, el trabajo de Arenas y otros (2012) muestra que la evasión en materia de pensiones representó el $19,0 \%$ de los asalariados totales en 2011. Dos terceras partes correspondieron a trabajadores sin contrato formal con su empleador y sin protección social y laboral (lo que los autores definen como "evasión laboral"), y el tercio restante se compuso de asalariados con contrato a los que no se les realizaba el pago 
de sus cotizaciones previsionales (definido como "evasión previsional"). Además, los autores comprobaron que un $5 \%$ de los asalariados con contrato y con aportes previsionales correspondientes al año 2009 correspondía a casos en que el empleador, si bien cumplió el deber legal de contratar al trabajador y pagar cotizaciones previsionales, realizaba un pago de cotizaciones por un salario menor que el recibido por el trabajador ("elusión previsional").

\section{Cuadro XII.2}

\section{América Latina (6 países): estimaciones del nivel de incumplimiento en contribuciones de la seguridad social}

\begin{tabular}{|c|c|c|c|c|}
\hline País & Autores y fecha & $\begin{array}{l}\text { Período } \\
\text { analizado }\end{array}$ & Metodología y datos & Principales resultados \\
\hline \multirow[t]{2}{*}{ Argentina } & $\begin{array}{l}\text { Durán } \\
\text { (CEPAL, 1993) }\end{array}$ & $\begin{array}{l}\text { 1980-1987, } \\
1991-1992\end{array}$ & Cuentas nacionales & $\begin{array}{l}\text { La evasión en pensiones osciló } \\
\text { entre el } 41,2 \% \text { y el } 52,8 \% \text { durante } \\
1980-1987 \text { y descendió al } 40,6 \% \\
\text { en } 1991 \text { y al } 34,9 \% \text { en } 1992 .\end{array}$ \\
\hline & $\begin{array}{l}\text { Salim y D'Angela } \\
\text { (AFIP, 2007) }\end{array}$ & $2003-2006$ & $\begin{array}{l}\text { Encuesta Permanente } \\
\text { de Hogares (EPH) }\end{array}$ & $\begin{array}{l}\text { Año } 2006 \text { : la informalidad fue del } \\
35,2 \% \text { en asalariados, del } 50,1 \% \\
\text { en autónomos y del } 81,9 \% \text { en } \\
\text { trabajadores del servicio doméstico. }\end{array}$ \\
\hline Brasil & $\begin{array}{l}\text { Almeida } \\
\text { (CEPAL, 1993) }\end{array}$ & $1985-1990$ & Cuentas nacionales & $\begin{array}{l}\text { Evasión contributiva del } 40,7 \% \text { en } \\
1988 \text { y del } 18,4 \% \text { en } 1990 ; \text { cambio } \\
\text { atribuido a modificaciones legales. }\end{array}$ \\
\hline Chile & $\begin{array}{l}\text { Arenas y otros } \\
\text { (Ministerio } \\
\text { del Trabajo y } \\
\text { Previsión Social, } \\
\text { 2012) }\end{array}$ & $\begin{array}{l}2003 \\
2006, \\
2009,2011\end{array}$ & $\begin{array}{l}\text { Encuesta de } \\
\text { Caracterización } \\
\text { Socioeconómica } \\
\text { Nacional (CASEN) y } \\
\text { Encuesta de Protección } \\
\text { Social (EPS) }\end{array}$ & $\begin{array}{l}\text { Año 2011: evasión en pensiones } \\
\text { del 19,0\% de los asalariados } \\
\text { totales. Subdeclaración } \\
\text { (2009): el } 5 \% \text { de los } \\
\text { asalariados con contrato y con } \\
\text { aportes previsionales. }\end{array}$ \\
\hline \multirow[t]{2}{*}{ Colombia } & $\begin{array}{l}\text { Ministerio de la } \\
\text { Protección Social } \\
\text { de Colombia } \\
(2002)\end{array}$ & 2000 & $\begin{array}{l}\text { Encuesta Nacional } \\
\text { de Hogares (ENH) }\end{array}$ & $\begin{array}{l}\text { Evasión en salud (régimen } \\
\text { contributivo): el } 35,4 \% \text {, (un } 7,5 \% \\
\text { por subdeclaración de ingresos y } \\
\text { el resto por falta de pago). }\end{array}$ \\
\hline & $\begin{array}{l}\text { Unidad de } \\
\text { Gestión } \\
\text { Pensional y } \\
\text { Parafiscales } \\
\text { (UGPP) (2013) }\end{array}$ & 2012 & Auditorías & $\begin{array}{l}\text { Evasión total en aportes } \\
\text { parafiscales: } 14.600 \text { millones } \\
\text { de pesos (en la tasa del } 26,8 \%) \text {, } \\
\text { con } 8.560 \text { millones en pensiones } \\
\text { ( } 35,9 \%) \text { y } 5.320 \text { millones en } \\
\text { salud }(25,6 \%) \text {. }\end{array}$ \\
\hline $\begin{array}{l}\text { Costa } \\
\text { Rica }\end{array}$ & $\begin{array}{l}\text { Brenes } \\
\text { (CEPAL, 1993) }\end{array}$ & $1986-1991$ & Cuentas nacionales & $\begin{array}{l}\text { Evasión del } 16,7 \% \text { en salud y } \\
\text { del } 21,7 \% \text { en pensiones; evasión } \\
\text { contributiva global del } 18,06 \% \text { de } \\
\text { los ingresos potenciales (1991). }\end{array}$ \\
\hline \multirow[t]{2}{*}{ Uruguay } & $\begin{array}{l}\text { Bene (Banco de } \\
\text { Previsión Social } \\
\text { (BPS), 2014) }\end{array}$ & $2004-2013$ & $\begin{array}{l}\text { Encuesta Continua } \\
\text { de Hogares }(\mathrm{ECH})\end{array}$ & $\begin{array}{l}\text { Puestos de trabajo no declarados } \\
\text { al BPS: } 297.967 \text { (2013). Evasión } \\
\text { por no declaración: un } 18,67 \% \text { de la } \\
\text { población económicamente activa } \\
\text { (PEA) ocupada. }\end{array}$ \\
\hline & $\begin{array}{l}\text { Camerosano } \\
\text { y Colombo } \\
\text { (BPS, 2013) }\end{array}$ & 2011 & $\begin{array}{l}\text { Encuesta Continua } \\
\text { de Hogares }(\mathrm{ECH})\end{array}$ & $\begin{array}{l}\text { Evasión contributiva total (2011): } \\
\text { el } 18,9 \% \text { de la recaudación teórica } \\
\text { (un } 6,5 \% \text { por subdeclaración y un } \\
12,4 \% \text { por no declaración). }\end{array}$ \\
\hline
\end{tabular}

Fuente: J.C. Gómez Sabaini, O. Cetrángolo y D. Morán, "La evasión contributiva en la protección social de salud y pensiones. Un análisis para la Argentina, Colombia y el Perú", serie Políticas Sociales, N 208 (LC/L.3882), Santiago, Comisión Económica para América Latina y el Caribe (CEPAL), 2014. 
En el caso del Uruguay, los investigadores de la Asesoría General en Seguridad Social del Banco de Previsión Social (BPS) han venido publicando una serie de trabajos y estimaciones acerca del nivel de evasión en puestos de trabajo durante los últimos años, lo que ha permitido cuantificar los avances logrados en materia de formalización laboral. Por ejemplo, en el cálculo más reciente, Bene (2014) partió de un análisis de los microdatos de la Encuesta Continua de Hogares $(\mathrm{ECH})$ y estimó que la evasión por no declaración de puestos de trabajo fue del $18,6 \%$ en 2013 , con una sostenida disminución desde 2004, cuando dicha tasa era del 39,6\%. Por otra parte, Camerosano y Colombo (2013) tomaron esta metodología y los valores calculados para años anteriores y elaboraron una cuantificación de la evasión monetaria por no declaración y por subdeclaración de ingresos en puestos de trabajo cotizantes al BPS correspondientes a 2011. Los resultados muestran que la evasión total por subdeclaración ascendió en 2011 a casi 140 millones de dólares (un 6,5\% de la recaudación teórica y un $8,1 \%$ de la recaudación efectiva) y a unos 265 millones de dólares en concepto de no declaración (un 12,4\% y un 15,3\%, respectivamente), siendo la evasión monetaria total de 405 millones de dólares aproximadamente (un 18,9\% de la teórica y un 23,4\% de la efectiva).

Recientemente, Gómez Sabaini, Cetrángolo y Morán (2014) realizaron una estimación cuantitativa del nivel de incumplimiento en el pago de contribuciones de la seguridad social, aplicando una metodología estándar a una serie de casos con distintas particularidades (Argentina, Colombia y Perú). A partir de información proveniente de las cuentas nacionales, se buscó determinar la brecha de recaudación (en términos monetarios) que surge de comparar la recaudación teórica estimada y la efectivamente ingresada. No obstante, la metodología se adaptó en cada caso particular en función de la disponibilidad estadística y los parámetros de cada esquema contributivo. Los resultados obtenidos respecto de los trabajadores asalariados, que dependen crucialmente de los supuestos que se tuvieron en cuenta, se presentan en el cuadro XII.3.

En el caso argentino, la tasa de evasión contributiva entre asalariados (pensiones y seguro de salud) alcanzó el 29,0\% de la recaudación teórica del sector privado, aunque representó el 21,5\% si se considera el total de la economía en 2007. Asimismo, el monto evadido en ambos subsistemas representó un 1,48\% del PIB (véase el cuadro XII.3). Por otra parte, la información disponible permitió estimar el nivel de incumplimiento contributivo en el componente de ingreso mixto bruto (autónomos y monotributistas), donde la tasa de evasión de los no asalariados resultó ser del $48,8 \%$ en función de la recaudación potencial, y el 0,15\% del PIB. En suma, la tasa de incumplimiento global (pensiones y salud) se ubicó en torno al 22,7\% de la recaudación teórica total de la economía y representó un 1,64\% del PIB de 2007. Además, el grueso del problema se concentra en las remuneraciones del trabajo de asalariados (un $90,7 \%$ de los recursos resignados). 
Cuadro XII.3

Argentina, Colombia y Perú: estimaciones sobre incumplimiento contributivo de los trabajadores asalariados, 2007 y 2010

\begin{tabular}{lccc}
\hline País y año de estimación & Argentina (2007) & Colombia (2010) & Perú (2007) \\
\hline $\begin{array}{l}\text { Tasa de incumplimiento } \\
\text { (en porcentajes) }\end{array}$ & & & \\
\hline Pensiones & 21,5 & 30,0 & 45,5 \\
\hline Salud & 21,5 & 30,0 & 46,1 \\
\hline Total & 21,5 & 30,0 & 45,8 \\
\hline $\begin{array}{l}\text { Tasa de incumplimiento } \\
\text { (en porcentajes del PIB) }\end{array}$ & & & \\
\hline Pensiones & 0,89 & 1,67 & 1,63 \\
\hline Salud & 0,59 & 1,31 & 1,13 \\
\hline Total & 1,48 & 2,98 & 2,76 \\
\hline
\end{tabular}

Fuente: J.C. Gómez Sabaini, O. Cetrángolo y D. Morán, "La evasión contributiva en la protección social de salud y pensiones. Un análisis para la Argentina, Colombia y el Perú", serie Políticas Sociales, № 208 (LC/L.3882), Santiago, Comisión Económica para América Latina y el Caribe (CEPAL), 2014.

Por otra parte, en el caso de Colombia los resultados reflejan un nivel importante de incumplimiento contributivo entre los asalariados, tanto en materia de pensiones como del seguro de salud. Para el año 2010 se estimó una tasa de evasión del 30,0\% de la recaudación teórica estimada sobre el total de la economía (este indicador asciende hasta un 34,5\% cuando solo se consideran los ingresos generados por el sector privado). Además, el monto evadido alcanza un valor equivalente al 2,98\% del PIB de dicho año, de lo que el 1,67\% corresponde al sistema de pensiones contributivas y el 1,31\% del PIB al sistema contributivo de salud (véase el cuadro XII.3).

En el caso del Perú se calculó el incumplimiento, por un lado, entre los asalariados del sector informal y, por el otro, en el sector formal de la economía. De la sumatoria simple de los valores calculados para cada sector surgió que el nivel de evasión contributiva en pensiones y salud alcanzó en 2007 una tasa global del 45,8\% de la recaudación teórica (levemente superior en el caso del seguro de salud que en el de las pensiones por vejez) y, en relación con el PIB de ese año, el equivalente al 2,76\% en total (un 1,63\% en pensiones y un $1,13 \%$ en salud).

Como ya se indicó, en ninguno de los casos comprendidos en el estudio ha de considerarse la estimación de la evasión contributiva un sinónimo del costo fiscal de la evasión, como sí puede suceder con los tributos tradicionales. Además, en el caso de los sistemas contributivos de pensiones y salud debe considerarse el costo de las prestaciones que el Estado deberá brindar a los trabajadores que no accedieron a los beneficios contributivos, excluidas las contribuciones que pudieran haber realizado esos mismos trabajadores. En el caso de las pensiones en Colombia se devuelven los aportes a quienes no reciben los beneficios y, por tanto, el costo fiscal se acerca al costo de aquel programa. En cambio, en los casos en que esos aportes no se devuelven (por 
ejemplo, en los sistemas de reparto del Perú y la Argentina), pasan a formar parte del financiamiento de las pensiones de quienes sí cumplieron con los requisitos, lo que reduce el costo fiscal de la evasión.

\section{E. Reflexiones finales: obstáculos y desafíos en la materia}

Si bien podrían hacerse muchas consideraciones en torno al fenómeno de la evasión en los países de América Latina, hay una característica que sobresale del resto: a pesar del enorme riesgo de sufrir una pérdida sustancial de recursos tributarios potenciales, aún es escasa e insuficiente la información disponible en cuanto a la magnitud del problema. Se reconocen algunos avances aislados, pero se destaca la limitada disponibilidad de información por parte de varias administraciones tributarias. Por ese motivo no es posible realizar estudios sistemáticos y periódicos que permitan, por un lado, comparar la situación relativa de los países y, por otro, elaborar diagnósticos más precisos tendientes a mejorar aspectos cruciales de la lucha contra la evasión.

La medición de la evasión comenzó a formar parte de las actividades rutinarias de varias administraciones tributarias en los primeros años de la década de 2000, aunque se mantuvo casi circunscrita al caso particular del IVA. Pudo comprobarse un descenso generalizado de las tasas de evasión de ese tributo hasta 2007-2008, cuando los efectos de la crisis financiera comenzaron a revertir esa favorable tendencia en la mayoría de los casos. En años recientes, aunque las estimaciones disponibles son mucho más escasas (ya sea porque se descontinuaron esas mediciones o bien porque no se siguieron difundiendo sus resultados) los países parecen haber tropezado con mayores dificultades para reducir los niveles de incumplimiento del IVA (con la excepción del Uruguay) más allá de los niveles observados antes de la mencionada debacle económica global. Ello puede interpretarse como muestra de la existencia de un "núcleo duro" de evasión en la mayoría de las economías de la región, al que solo será factible acceder mediante reformas aun más profundas, tanto de la estructura como de la administración de ese tributo.

Algo similar puede decirse respecto de la evasión del impuesto sobre la renta. Sin embargo, en este caso el problema es mayor, ya que las mediciones son mucho más escasas, con metodologías no siempre homogéneas, a pesar de los efectos negativos que ello implica para la equidad del sistema. Salvo algunas excepciones, se observa como generalidad una menor tasa de evasión del ISR de personas físicas (respecto del impuesto que recae sobre las sociedades), sobre todo en el caso de los trabajadores asalariados, que generalmente se retienen en la fuente generadora de ingresos. Ocurre lo 
contrario en el caso de los trabajadores independientes, donde la evasión es mucho más elevada.

En el caso de las contribuciones para el financiamiento de la seguridad social, algunas estimaciones recientes dan cuenta de importantes niveles de incumplimiento en los esquemas compulsivos. Dado que en muchos países que tienen sistemas de protección social más consolidados esto representa un caudal muy significativo de ingresos tributarios resignados, la medición de los niveles de evasión contributiva debería introducirse en la agenda tributaria de los países. Esa iniciativa podría implementarse mediante un esfuerzo coordinado entre las agencias de recaudación tributaria y los organismos de seguridad social que cuenten con la información específica que se requiere a tales fines.

En suma, en el ámbito interno las soluciones del problema del cómputo de la evasión se relacionan más directamente con el desempeño de la administración tributaria de cada país. Resulta fundamental que las mediciones del nivel de incumplimiento se entiendan como un insumo de información y diagnóstico para mejorar el funcionamiento del sistema tributario, y no como un mero indicador de la eficacia o la capacidad técnica de dichas instituciones. En lo que respecta a las tareas de fiscalización y control de los contribuyentes, resulta indispensable la incorporación de diversas tecnologías de información que permitan obtener y comparar datos provenientes de distintas fuentes. Es igual de importante priorizar una cultura tributaria en la que se penalice efectivamente a los evasores y, además, se entienda que los ingresos tributarios constituyen la base fundamental de financiamiento de las funciones esenciales de un Estado moderno. Esta idea de "intercambio fiscal" requiere un alto grado de transparencia, no solo por parte de la administración tributaria, sino también de las distintas instituciones y estructuras de donde emanan las decisiones más relevantes de gasto público, con la finalidad de garantizar el vínculo entre las fuentes y los usos de los recursos disponibles, y dar participación a los contribuyentes en el desarrollo económico de un país. 


\section{Bibliografía}

AFIP (Administración Federal de Ingresos Públicos) (2008), "Estimación del incumplimiento en el IVA", Buenos Aires [http://www.afip.gov.ar/estudios/ archivos/incumplimiento_iva_2006.pdf].

Allingham, M. y A. Sandmo (1972), "Income tax evasion: a theoretical analysis", Journal of Public Economics, vol. 1, N³-4, Amsterdam, Elsevier.

Arenas, A. y otros (2012), "Análisis de la evasión y elusión en el pago de las cotizaciones previsionales y medidas de política pública para superar sus causas", Documento de Trabajo, N ${ }^{\mathrm{o}}$ 2, Santiago, Dirección de Estudios Previsionales, Ministerio de Trabajo y Previsión Social.

Ávila Mahecha, J. y A. Cruz Lasso (2015), “Colombia: estimación de la evasión del impuesto de renta de personas jurídicas 2007-2012", Documento Web, ํㅜ 057, Bogotá, Dirección de Impuestos y Aduanas Nacionales (DIAN).

Barbone, L., M. Bonch-Osmolovskiy y G. Poniatowski (2015), Study to Quantify and Analyse the VAT Gap in the EU Member States. 2015 Report (TAXUS/2013/DE/321), La Haya, CPB Netherlands Bureau for Economic Policy Analysis.

Baumann, F., T. Friehe y M. Jansen (2009), "On the economics of contribution evasion", Public Finance Analysis, vol. 65, N².

Bene, N. (2014), "Evasión en puestos de trabajo. Año 2013", Comentarios de Seguridad Social, No 46, Montevideo, Banco de Previsión Social.

Bergman, M. (2009), Tax Evasion and the Rule of Law in Latin America, Pennsylvania, Pennsylvania State University Press.

Camerosano, N. y C. Colombo (2013), “Evasión monetaria por no declaración y por subdeclaración. Año 2011", Comentarios de Seguridad Social, N 41, Montevideo, Banco de Previsión Social.

Carrasco, C.M. (2010), “Instrumentos y técnicas para la medición de la evasión”, serie Temática Tributaria, $\mathrm{N}^{\circ}$ 7, Centro Interamericano de Administraciones Tributarias (CIAT).

CEPAL (Comisión Económica para América latina y el Caribe) (2015), Panorama fiscal de América Latina y el Caribe 2015: dilemas y espacios de políticas (LC/L. 3961), Santiago, marzo. (2006), La protección social de cara al futuro: acceso, financiamiento y solidaridad (LC/G.2294(SES.31/3)), Santiago.

Cetrángolo, O. y J.C. Gómez Sabaini (2009), “La imposición en la Argentina: un análisis de la imposición a la renta, a los patrimonios y otros tributos considerados directos", serie Macroeconomía del Desarrollo, No 84 (LC/L.3046-P), Santiago, Comisión Económica para América Latina y el Caribe (CEPAL).

Contraloría General de la República (2010), “Impuesto sobre las ventas: estimación de la base y la evasión. Actualización”, Informe (DFOE-SAF-IF-10-2010), San José, División de Fiscalización Operativa y Evaluativa. (2009), “Impuesto sobre utilidades. Estudio estadístico de la base y la evasión. Actualización", Informe (DFOE-SAF-IF-16-2009), San José, División de Fiscalización Operativa y Evaluativa.

DGI (Dirección General Impositiva) (2013), “Estimación de la evasión en el impuesto al valor agregado mediante el método del consumo, 2000-2012", Montevideo.

DGII (Dirección General de Impuestos Internos) de El Salvador (2012), Estimación de la evasión del IVA en El Salvador, San Salvador, Unidad de Estudios Tributarios. 
DGII (Dirección General de Impuestos Internos) de la República Dominicana (2008), "Análisis de la recaudación. Enero-diciembre 2007", Estudios económicos y tributarios, Santo Domingo.

Franco, A.O. (2011), "Impuesto sobre la renta: situación actual, gasto tributario, incumplimiento y perspectivas", Guatemala, Superintendencia de Administración Tributaria (SAT).

Fuentes, H.J. (coord.) (2013), Estudio de evasión global de impuestos, Ciudad de México, Instituto Tecnológico y de Estudios Superiores de Monterrey (ITESM).

(2010), Evasión global de impuestos: impuesto sobre la renta, impuesto al valor agregado e impuesto especial sobre producción y servicio no petrolero, Ciudad de México, Instituto Tecnológico y de Estudios Superiores de Monterrey (ITESM).

Gómez Sabaini, J.C., O. Cetrángolo y D. Morán (2014), “La evasión contributiva en la protección social de salud y pensiones. Un análisis para la Argentina, Colombia y el Perú", serie Políticas Sociales, Nº 208 (LC/L.3882), Santiago, Comisión Económica para América Latina y el Caribe (CEPAL).

Gómez Sabaini, J.C. y J.P. Jiménez (2011), “Estructura tributaria y evasión impositiva en América Latina", Documento de Trabajo, N²011/08, Corporación Andina de Fomento (CAF).

Gómez Sabaini, J.C., J.P. Jiménez y D. Rossignolo (2012), “Imposición a la renta personal y equidad en América Latina: nuevos desafíos", serie Macroeconomía del Desarrollo, No 119 (LC/L.3477-P), Santiago, Comisión Económica para América Latina y el Caribe (CEPAL).

Gómez Sabaini, J.C. y D. Morán (2016), “Evasión tributaria en América Latina: nuevos y antiguos desafíos en la cuantificación del fenómeno para los países de la región", serie Macroeconomía del Desarrollo, $\mathrm{N}^{\circ} 172$ (LC/L.4155), Santiago, Comisión Económica para América Latina y el Caribe (CEPAL).

ICEFI (Instituto Centroamericano de Estudios Fiscales) (2015), "Diagnóstico y propuesta alternativa de hoja de ruta para el rescate y reconstrucción de la SAT", Guatemala, inédito.

Jiménez, J.P., J.C. Gómez Sabaini y A. Podestá (comps.) (2010), “Evasión y equidad en América Latina", Documento de Proyectos, N 309 (LC/W.309), Santiago, Comisión Económica para América Latina y el Caribe (CEPAL).

Jorratt, M. (2012), “Estimación de la evasión tributaria en los impuestos selectivos al consumo: el caso de Chile", Revista de Administración Tributaria, № 34, Centro Interamericano de Administraciones Tributarias (CIAT)/Agencia Estatal de Administración Tributaria (AEAT)/Instituto de Estudios Fiscales (IEF).

Jorratt, M. y A. Podestá (2010), “Análisis comparativo de las metodologías empleadas para la estimación de la evasión en el impuesto a la renta", Evasión y equidad en América Latina, Documento de Proyectos, No 309 (LC/W.309), J.P. Jiménez, J.C. Gómez Sabaini y A. Podestá (comps.), Santiago, Comisión Económica para América Latina y el Caribe (CEPAL).

Molina, E. y J.R. Muñoz (2014), "Incumplimiento tributario en impuestos sobre la renta y ventas 2010-2012", San José, Ministerio de Hacienda.

Pecho, M., F. Peláez y J. Sánchez (2012), “Estimación del incumplimiento tributario en América Latina: 2000-2010", Documento de Trabajo, N 03-12, Dirección de Estudios e Investigaciones Tributarias, Centro Interamericano de Administraciones Tributarias (CIAT). 
Salim, J.A. (2011), “Elaboración de la metodología para el cálculo para la evasión del ISR. Informe de consultoría para la Dirección General de Impuestos Internos (DGII), República Dominicana", inédito.

SAT (Superintendencia de Administración Tributaria) (2008), “Medición del incumplimiento del IVA. Años 2001-2007", Guatemala.

SET (Subsecretaría de Estado de Tributación) (2012), “Metodologías para la estimación

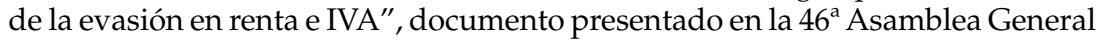
del Centro Interamericano de Administraciones Tributarias (CIAT), Santiago.

SII (Servicio de Impuestos Internos) (2015), Tasa y monto evasión de IVA. Base referencia MIP 2008. Serie 2003-2014, Santiago, Subdirección de Estudios. (2012a), Estimación de la evasión en el impuesto a la renta de las empresas. Serie 2003-2009, Santiago, Subdirección de Estudios. (2012b), "Evasión en el impuesto a la renta en Chile", documento presentado en el Taller Evasión e Impuesto a la Renta en América Latina, Montevideo, Comisión Económica para América Latina y el Caribe (CEPAL).

SUNAT (Superintendencia Nacional de Administración Tributaria y Aduanera) (2010), Memoria anual 2009, Lima.

Torgler, B. (2007), Tax Compliance and Tax Morale: A Theoretical and Empirical Analysis, Edward Elgar Publishing. 
Capítulo XIII

\title{
La evasión internacional y la erosión de las bases tributarias ${ }^{1}$
}

\author{
Juan C. Gómez Sabaini \\ Dalmiro Morán ${ }^{3}$
}

\section{Introducción}

Como bien argumenta Zucman (2015), tres han sido los principios que guiaron el diseño del impuesto sobre la renta (ISR) de las sociedades (o ISR corporativo), primero en los países desarrollados y después en los países en desarrollo: i) el criterio jurisdiccional de la fuente o residencia, ii) el principio de plena competencia (arm's length) y iii) los acuerdos bilaterales de armonización tributaria. Estos principios rectores datan de la década de 1920 y en la actualidad, debido a la creciente globalización económica y financiera, se han visto seriamente diezmados por las estrategias — cada vez más sofisticadas- desplegadas por las empresas multinacionales en su afán por reducir el pago de impuestos a nivel mundial. En particular, y

Este capítulo es un extracto de Gómez Sabaini y Morán (2016).

2 Consultor de la Comisión Económica para América Latina y el Caribe (CEPAL), el Banco Interamericano de Desarrollo (BID), el Fondo Monetario Internacional (FMI) y el Centro Interamericano de Administraciones Tributarias (CIAT) especializado en temas de política tributaria en países de América Latina. Profesor de posgrado en la Universidad Nacional de Buenos Aires. Correo electrónico: gomezsabaini@gmail.com.

3 Consultor de la Comisión Económica para América Latina y el Caribe (CEPAL) y del Centro Interamericano de Administraciones Tributarias (CIAT) especializado en temas de política tributaria en países de América Latina. Correo electrónico: dalomoran@gmail.com. 
en orden a dichos preceptos, el mencionado autor destaca el abuso de los tratados bilaterales para generar ingresos no gravados (lo que se denomina treaty shopping o búsqueda del acuerdo más favorable), la manipulación de los precios de transferencia, el traslado artificial de utilidades y la competencia tributaria para atraer inversiones por la vía de incentivos tributarios.

En un primer momento, fueron los Gobiernos de los países desarrollados los que enfocaron su accionar en garantizar la transparencia para combatir un importante, pero poco conocido, caudal de flujos financieros ilícitos por parte de las multinacionales, que provoca la erosión de las bases tributarias nacionales y el traslado de beneficios entre países (lo que se conoce como la iniciativa BEPS). Más recientemente, los países en desarrollo han mostrado interés en coordinar iniciativas en el mismo sentido, sobre todo debido a que quizás sean los más afectados por este tipo de maniobras al presentar marcos jurídicos e institucionales débiles y sistemas fiscales y de administración tributaria menos desarrollados.

Especialmente en esta dimensión internacional del fenómeno de evasión fiscal se ha percibido un gran desconocimiento cuantitativo y son escasos los cálculos disponibles que permiten conocer la magnitud y la gravedad de dicho fenómeno a nivel sectorial, nacional y regional. Se reconoce que las limitaciones en cuanto a disponibilidad de información representan un gran obstáculo en este sentido (incluso a las respectivas administraciones tributarias se les hace difícil obtener estos datos). Sin embargo, y a pesar de sus limitaciones estadísticas, en algunos trabajos recientes se han brindado cifras que no dejan de ser sorprendentes. Por ejemplo, en OCDE (2015) se estima que la pérdida recaudatoria provocada por los mecanismos de erosión de la base imponible y traslado de beneficios se ubicaría entre 100.000 millones de dólares y 240.000 millones de dólares en 2014, con un mayor impacto relativo en los países en desarrollo por la mayor dependencia fiscal respecto del impuesto sobre la renta de las sociedades.

La envergadura de estos indicios, además de constituir nuevas aproximaciones, justifica la necesidad de revisar y analizar cuáles han sido los principales avances en términos del cálculo de la evasión en el ámbito internacional. Por ello, en la sección A de este capítulo se describe la problemática en torno a la pérdida de recursos fiscales que sufren los países y las herramientas que se ven obligados a utilizar para su control, como consecuencia de una serie de maniobras y prácticas comerciales y financieras que las empresas multinacionales ponen en práctica con el propósito de reducir su carga tributaria ${ }^{4}$. En la sección $B$, a partir de un conjunto de

Aunque escapa a los alcances estipulados para este trabajo, no puede desconocerse que los países también sufren una erosión de las bases tributarias debido a la fuga de capitales, que se materializa a través de la transferencia de activos al extranjero por parte de individuos y empresas, especialmente con destino a países de baja o nula tributación (véase, por ejemplo, Zucman (2015)). 
metodologías alternativas de desarrollo reciente, se presentan algunas evidencias relevantes que han comenzado a brindar una idea aproximada de la magnitud del fenómeno de erosión de las bases tributarias y sus implicancias para los países de América Latina. Por último, en la sección C se resumen las principales conclusiones.

\section{A. La planificación fiscal agresiva y las regulaciones gubernamentales para su control}

En el orden mundial actual, la globalización financiera y la progresiva monopolización corporativa de la economía han permitido que las empresas multinacionales y transnacionales tengan un mayor control de la producción y el comercio, lo que se refleja en un mayor poder económico que les permite adaptarse con más efectividad a los marcos estatales de regulación. Con la intención de maximizar los beneficios y poder extenderse internacionalmente y ampliar sus mercados, estas grandes empresas suelen desplegar sofisticadas estrategias para reducir su carga impositiva global más allá de los países y localizaciones donde operan y generan utilidades. Como contrapartida, esto deteriora la capacidad de los países para retener ingresos fiscales que podrían servir para el financiamiento de sus procesos de desarrollo o el empleo de instrumentos de distribución de la riqueza para lograr equidad social y superar la pobreza.

En este punto vale realizar una aclaración y una interpretación. En sentido estricto, estas prácticas y estrategias de lo que se denomina "planificación fiscal" no implican una evasión impositiva, en tanto no constituyan una maniobra ilícita (violación de leyes o reglas formales), sino que se trate de la búsqueda sistemática de espacios en la legislación tributaria vigente para reducir lícitamente la obligación tributaria. Sin embargo, por estar directamente relacionadas con el tamaño del contribuyente y su poder económico para destinar recursos a tales fines, la planificación fiscal plantea graves distorsiones sobre la equidad del sistema impositivo, que se reflejan en grandes diferencias en las tasas efectivas de imposición societaria para empresas similares de un país. Por ello, en este trabajo se habla de evasión impositiva vinculada a operaciones internacionales aun cuando se trate de estrategias lícitas para sacar provecho de una normativa imperfecta, puesto que se considera que estas oportunidades deterioran los principios básicos de todo sistema tributario (eficiencia, equidad, transparencia y otros) y que, más allá de no constituir maniobras ilícitas, su existencia y permanencia se relaciona con limitaciones y deficiencias propias del sistema vigente, que deben comprenderse de esta manera para realizar diagnósticos precisos y promover acciones tendientes a resolver esta problemática. 
En este contexto se ha destacado la importancia de las prácticas vinculadas a la traslación de utilidades o costos entre filiales de una misma empresa multinacional, desde países o Estados con altos niveles de tributación o con restricciones administrativas al flujo de capitales hacia jurisdicciones con sistemas tributarios débiles, de relativamente baja o nula imposición (los llamados "paraísos fiscales"), a través de la manipulación de los precios de transferencia.

Los precios de transferencia se definen como aquellos pagos resultantes de las transacciones comerciales entre las partes de un mismo grupo empresarial multinacional. Cuando estos son distintos a los que se determinarían según las fuerzas del mercado para operaciones similares entre empresas independientes (principio de plena competencia), existe una alta probabilidad de que esta brecha esconda la intención, no exteriorizada, de disminuir el monto de impuestos a pagar en un determinado país. En la medida en que las autoridades fiscales no puedan detectar y comprobar estas acciones, esto produce un silencioso efecto de erosión de la base tributaria y la consecuente pérdida de recursos fiscales disponibles en el país donde opera la filial que genera los ingresos sujetos a imposición.

Existe consenso respecto de que el factor externo más influyente es el asociado a la imposición societaria. En términos de comercio internacional, las multinacionales suelen tener incentivos para sobredimensionar los gastos deducibles de la renta gravada a fin de reducir el pago de impuestos. De forma análoga, una empresa puede vender a una entidad vinculada mercancías y servicios a precios menores que los de mercado, con lo que reduce su base gravable del ISR. Las empresas multinacionales que utilizan este mecanismo de planificación fiscal realizan múltiples transacciones en diversos países, incluidos paraísos fiscales y jurisdicciones de baja tributación, lo que diluye el tamaño de la base gravable en la que se generan los ingresos (Barrientos Quezada, 2012).

En realidad, existen varias maneras más para transferir las ganancias a subsidiarias en países de baja o nula tributación. Las empresas pueden optar por localizar actividades reales (empleo, activos, producción) en dichas jurisdicciones, pero también pueden responder utilizando varias técnicas legales y contables para girar utilidades con destino a esas jurisdicciones. Uno de estos mecanismos de evasión fiscal vía precios de transferencia es la reestructuración de negocios, que suele implicar transferencias de funciones, activos y riesgos entre subsidiarias localizadas en distintos países. En este caso, la erosión de la base imponible en un determinado país se produce tanto al limitarse el monto de utilidades que se pueden obtener por la actividad principal realizada dentro de un determinado territorio como al reducirse la utilidad del resto de las actividades locales mediante la deducción de pagos a empresas vinculadas del exterior en concepto de servicios entre empresas de un mismo grupo, intereses o regalías. 
Otra estrategia muy utilizada por las empresas multinacionales, especialmente aquellas dedicadas a la producción de manufacturas, consiste en la subfacturación de exportaciones y la sobrefacturación de importaciones. Estas dos maniobras tienen como finalidad reducir el ingreso gravable y también, en algunos casos, el pago por concepto de impuestos al comercio internacional. En ambos casos, además, puede estar involucrado un tercer país (generalmente con baja o nula tributación) que actúa de intermediario entre las empresas vinculadas, lo que da lugar a triangulaciones comerciales que dificultan el control fiscal de dichas operaciones. Incluso la importación de bienes de capital a precios de mercado de una filial a otra puede generar una pérdida para el fisco si permite la amortización de dicha inversión cuando ya hubiera sido amortizada en el país de origen.

Las estrategias de planificación fiscal agresiva que involucran precios de transferencia no se agotan allí y pueden mencionarse otras de creciente relevancia (Grondona, 2014), como la prestación de servicios de comercialización o logística desde el exterior a través de un comisionista, la realización de ventas desde el exterior a través de una empresa comercializadora ubicada en un país de escasa o nula tributación, el registro de la propiedad de activos intangibles en los mismos países a los cuales las filiales de países de mayor tributación realizan pagos periódicos para transferir utilidades, o la prestación de servicios entre empresas de un mismo grupo y servicios empresariales desde las casas matrices o de un tercer país a sus filiales ${ }^{5}$.

En respuesta a la implementación de estas estrategias, según las premisas y directrices establecidas por la Organización de Cooperación y Desarrollo Económicos (OCDE), los países han venido adoptando y perfeccionando una serie de métodos para garantizar la correcta determinación de precios de transferencia entre las partes integrantes de una misma empresa multinacional que se hallen localizadas en países (o jurisdicciones de un mismo país) con distintos regímenes fiscales ${ }^{6}$. Esto apunta a identificar discrepancias que revelen maniobras de planificación fiscal agresiva causantes de la erosión de la base tributaria interna a partir de la transferencia de utilidades hacia el extranjero.

Véase una exposición gráfica de estas y otras estrategias de planificación fiscal agresiva en el anexo 3 de OCDE (2013).

6 El trabajo de la OCDE en este ámbito se remonta a 1979, cuando se confeccionó una serie de directrices (Directrices Aplicables en materia de Precios de Transferencia a Empresas Multinacionales y Administraciones Tributarias), contenidas en el informe titulado Transfer Pricing and Multinational Enterprises, que fueron aprobadas en julio de 1995 por el Consejo de la OCDE con el fin de proporcionar una guía tanto para las administraciones tributarias como para las empresas multinacionales (OCDE, 1979). Estas directrices están constantemente sujetas a revisión y se modifican a medida que los cambios en el derecho tributario internacional lo requieren. La última modificación, que data de julio de 2010, constituye la mayor enmienda a este cuerpo normativo desde su creación e incluye una serie de instrucciones relacionadas a la aplicación de los métodos transaccionales (distribución o reparto de utilidades y margen neto de la transacción), a la determinación de comparables y a la aplicación de precios de transferencia en el caso de la restructuración de negocios (OCDE, 2010). 
En línea con lo observado a nivel internacional, en los últimos años, en los países de América Latina se ha constatado una gradual incorporación de regulaciones específicas para el tratamiento de los precios de transferencia, tendientes a evitar maniobras evasivas. El Brasil, Chile y México fueron los países pioneros a nivel regional al introducir disposiciones de este tipo en el bienio 1996-1997. La Argentina, Colombia y el Perú también incluyeron instrumentos similares en la legislación tributaria a fines de los años noventa e inicios de la década de 2000. El Ecuador, El Salvador, Panamá y el Uruguay siguieron ese camino de 2004 en adelante, con distintos grados de implementación efectiva en la práctica. Aun así, la diversidad de casos y metodologías es la característica saliente a nivel regional en cuanto al tratamiento específico de los precios de transferencia.

En general, los países de América Latina siguen las directivas de la OCDE (2010) en materia de regulaciones específicas dentro de la legislación tributaria para controlar el abuso de los precios de transferencia entre empresas vinculadas. La excepción es el Brasil, que ha adoptado una metodología de márgenes fijos a través de los métodos de costo adicional y precio de reventa. La mayoría de los países, como la Argentina, Colombia, el Ecuador, México, el Perú o el Uruguay, en cambio, utilizan distintos métodos simultáneamente, entre los que se incluyen los dos anteriores más el precio comparable no controlado, la distribución de utilidades o el margen neto de la transacción (Arias Esteban, 2010). A su vez, en la mayoría de los países que establecen otros métodos también se ha incluido el "sexto método" de la normativa argentina. En el Brasil, el Ecuador, Guatemala, Honduras, el Perú y el Uruguay, por ejemplo, se utiliza para operaciones de importación y exportación de bienes primarios.

Si bien exceden el ámbito de los precios de transferencia, también deben mencionarse otras operaciones de tipo financiero entre empresas relacionadas que igualmente atentan contra el tamaño de las bases tributarias nacionales y, por ende, contra los recursos fiscales disponibles. Así, los gastos financieros o pagos por intereses excesivos (pactados a una tasa por encima del nivel de mercado), la prestación de servicios de garantía financiera entre filiales o las operaciones cruzadas o back-to-back (préstamos otorgados a una entidad del exterior que más adelante otorga préstamos a la entidad local) son mecanismos que también se utilizan para transferir ganancias entre empresas vinculadas y hacia aquellas que están sujetas a niveles inferiores de imposición.

Las operaciones financieras señaladas anteriormente responden a otro camino seguido en la tributación internacional, conocido como "capitalización débil o exigua". Dado que la mayoría de los países establecen una distinción fundamental entre el régimen fiscal del financiamiento con deuda o con fondos propios - donde la deuda se considera un recurso que no pertenece 
a la empresa y, en determinadas condiciones, los intereses devengados son deducibles a efectos tributarios-, las normativas vigentes crean un incentivo implícito en favor del financiamiento a través del endeudamiento. Esto lleva a las multinacionales a realizar operaciones financieras en un país de tributación reducida para financiar las actividades de las demás empresas del grupo y, mientras los pagos se deducen de los beneficios imponibles de las filiales sometidas a una considerable carga tributaria, los mismos pagos son objeto de un gravamen favorable, o incluso de una exención, en lo que respecta al perceptor de los intereses, lo que permite una reducción de la carga tributaria total. Es más, este tratamiento diferenciado puede hacer proliferar intentos de caracterizar determinados pagos como intereses deducibles en el país del deudor y, a la vez, como dividendos - que pueden resultar exentos- en el país del beneficiario (OCDE, 2013).

En general, las regulaciones para evitar, reducir y combatir este tipo de prácticas apuntan a establecer un valor máximo para la relación entre la deuda y el capital propio, lo que significa que una empresa no podrá deducir costos por intereses derivados de un préstamo proveniente de una empresa vinculada una vez que supere cierta proporción de su financiamiento accionario. Debe destacarse que, en la mayoría de los países, estas reglas complementan a las que rigen para los precios de transferencia, en tanto estas últimas suelen ser aplicables para la determinación de la tasa de interés (precio) de los préstamos entre empresas relacionadas, de manera de satisfacer el principio de plena competencia.

Varios países de América Latina han introducido este tipo de medidas con el objeto de restringir los incentivos de las empresas multinacionales a utilizar el endeudamiento para transferir beneficios dentro del grupo empresarial. Se observa cierta homogeneidad entre las normas aplicadas en la región, ya que estas se basan en relaciones entre deuda y capital propio, entre deuda y patrimonio o entre deuda y patrimonio neto. En la mayoría de estos países, las reglas para combatir la subcapitalización solo alcanzan al endeudamiento entre empresas relacionadas, aunque en el caso del Brasil también se consideran de manera adicional a los préstamos en general tomados por una empresa brasileña con empresas o personas domiciliadas o constituidas en el exterior y en cualquier país o dependencia con tributación favorecida o régimen fiscal privilegiado.

Los países de la región también regulan las transacciones con paraísos fiscales, puesto que estas operaciones implican efectos similares en términos de erosión de las bases imponibles internas. Los paraísos fiscales y regímenes preferentes son perniciosos porque promueven la elusión fiscal internacional mediante un esquema de promoción de la opacidad que no permite acceder a información de las operaciones de personas físicas o jurídicas allí domiciliadas y en el cual las tasas impositivas suelen ser nulas o muy bajas. Como ya se 
mencionó, los esquemas de planificación que involucran paraísos fiscales por lo general se enfocan en la triangulación de operaciones de exportación e importación y el traslado de gastos que no se pueden comprobar.

En la actualidad, los países que tienen en su legislación tributaria normas anti paraíso fiscal son: Argentina, Brasil, Chile, Colombia, Ecuador, El Salvador, Honduras, México, Perú, República Dominicana, Uruguay y Venezuela (República Bolivariana de). Sin embargo, la definición de paraíso fiscal varía de un país a otro. En algunos casos, se refiere a países o jurisdicciones donde las tasas del ISR son inferiores, en cierto porcentaje, a la tasa vigente en el país en cuestión para tipos de rentas similares (El Salvador y México). Otro criterio considerado es que la tasa resulte inferior a un determinado valor (Brasil y Venezuela (República Bolivariana de)). Otros países adoptan listados definidos por organizaciones internacionales, como la lista negra de la OCDE, o utilizan listas definidas taxativamente a través de normas generales de la administración tributaria, como sucedió en la Argentina y el Ecuador.

Como puede deducirse, el control, la detección y la fiscalización de estas maniobras a través de los instrumentos disponibles resultan tareas por demás complejas. Las administraciones tributarias muchas veces no cuentan con los recursos suficientes para llevarlas a cabo de manera eficaz y, cuando los tienen, los procedimientos legales para su comprobación y resolución suelen prolongarse durante un largo período de tiempo. De acuerdo con un relevamiento presentado por Arias Esteban (2010), en los países de América Latina, las auditorías para controlar los precios de transferencia en operaciones entre empresas vinculadas pueden llevar entre cuatro meses (Costa Rica y Perú) y dos años (Argentina y México).

En ese sentido, una alternativa innovadora desarrollada por la OCDE en 1999 busca promover el cumplimiento voluntario a través de la suscripción de acuerdos previos entre los organismos de recaudación y las grandes multinacionales para reducir la incertidumbre en torno a los precios de transferencia y agilizar los procedimientos de fiscalización. Estos acuerdos han tomado la forma de procedimientos de acuerdo mutuo y de acuerdos de fijación anticipada de precios (AFAP). Los primeros son exclusivos de los convenios para evitar la doble tributación y constituyen un mecanismo de solución de diferencias por tratamientos tributarios específicos, mientras que los segundos buscan prevenir estas disputas al determinar y consensuar de manera anticipada las operaciones controladas, estableciendo criterios apropiados sobre el método, los criterios de comparación, los ajustes que deben ponerse en práctica y otros aspectos relacionados con los precios de transferencia. 
Vale señalar que en función de las ventajas de eficiencia y previsibilidad que ofrecen los acuerdos de fijación anticipada de precios, tanto a las administraciones tributarias como a los contribuyentes, varios países de la región han contemplado estos mecanismos en su legislación específica sobre precios de transferencia, especificando sus características y su plazo máximo de vigencia (entre 18 y 60 meses, según el país). Sin embargo, por las dificultades que implica el proceso previo de negociación y por ser un instrumento relativamente novedoso, su aplicación efectiva aún no se ha difundido a nivel regional, en claro contraste con lo observado en los países desarrollados. La única excepción la constituye México, un país que tiene una larga trayectoria en la negociación de acuerdos de fijación anticipada de precios y que ha suscrito más de 300 de estos acuerdos, sobre todo vinculados a la industria manufacturera. Esto está relacionado con la expansión del comercio de México con el Canadá y los Estados Unidos como resultado del Tratado de Libre Comercio de América del Norte (TLCAN). A excepción del Uruguay, que en diciembre de 2011 suscribió el primer acuerdo de este tipo en América del Sur, en el resto de los países no se han registrado avances concretos en los últimos años.

\section{B. Estudios y metodologías aplicadas para la cuantificación de la evasión internacional}

Una revisión de la literatura empírica a nivel internacional revela la existencia de un variado abanico de estudios específicos que utilizan diferentes metodologías, de manera aislada en el tiempo, generalmente para algunos sectores y países en particular, y, por lo tanto, con escasas posibilidades de comparación entre diferentes casos (véase el cuadro XIII.1). Asimismo, los contados intentos realizados para estimar globalmente las pérdidas fiscales derivadas de estas maniobras por parte de las empresas multinacionales presentan resultados que no están exentos de limitaciones y obligan a interpretarlos con precaución.

La sola dificultad para precisar cuáles son los precios de libre competencia en determinadas transacciones y para probar concretamente un desvío significativo y deliberado respecto de dichos parámetros de referencia torna muy compleja la tarea de control, fiscalización y cuantificación del costo fiscal implícito para los países afectados por estas prácticas. No obstante, a continuación se presentan los estudios más relevantes que pueden identificarse de acuerdo con las diferentes metodologías utilizadas en cada caso. 
Cuadro XIII.1

Metodologías utilizadas para identificar y cuantificar la traslación internacional de ingresos

\begin{tabular}{|c|c|c|c|}
\hline & & \multicolumn{2}{|c|}{ Origen de las estimaciones } \\
\hline & & Administración tributaria & Estudios externos \\
\hline \multirow[t]{4}{*}{ Alcance } & \multirow[t]{2}{*}{ Específico } & Enfoque de auditoría & Enfoque de rentabilidad \\
\hline & & $\begin{array}{l}\text { Aplicación puntual de métodos de } \\
\text { precios de transferencia (principio de } \\
\text { libre competencia) a transacciones } \\
\text { de grandes empresas con } \\
\text { alcance mundial. }\end{array}$ & $\begin{array}{l}\text { Análisis econométricos que } \\
\text { buscan identificar, a partir de datos } \\
\text { específicos a nivel de las empresas, } \\
\text { indicios del traslado de ingresos } \\
\text { entre países con distinto nivel } \\
\text { de impuestos. }\end{array}$ \\
\hline & \multirow[t]{2}{*}{ Amplio } & Enfoque sectorial & Enfoque de manipulación de precios \\
\hline & & $\begin{array}{l}\text { Determinación de las brechas entre } \\
\text { los datos observados y los valores } \\
\text { teóricos de acuerdo con la aplicación } \\
\text { de indicadores de referencia para } \\
\text { cada sector económico. }\end{array}$ & $\begin{array}{l}\text { A partir de la construcción de una } \\
\text { matriz de filtrado de precios, se } \\
\text { detectan aquellos que escapan a un } \\
\text { rango "normal" en operaciones de } \\
\text { comercio internacional. }\end{array}$ \\
\hline
\end{tabular}

Fuente: J.C Gómez Sabaini y D. Morán, “Evasión tributaria en América Latina: nuevos y antiguos desafíos en la cuantificación del fenómeno para los países de la región", serie Macroeconomía del Desarrollo, №172 (LC/L.4155), Santiago, Comisión Económica para América Latina y el Caribe (CEPAL), 2016.

En primer lugar, algunos trabajos empíricos se han concentrado en calcular alícuotas efectivas de las empresas multinacionales para tratar de demostrar la existencia o inexistencia de prácticas de erosión de la base imponible y traslado de beneficios. En la mayoría de los casos, estos estudios utilizan metodologías retrospectivas y datos procedentes de las empresas. Por ejemplo, Avi-Yonah y Lahav (2011) compararon los niveles efectivos de imposición de empresas multinacionales con sede en los Estados Unidos y en la Unión Europea durante el período comprendido entre 2001 y 2010 y pudieron constatar que, a pesar de que la tasa legal del ISR de las sociedades en los Estados Unidos es un 10\% superior a la aplicable en la Unión Europea, las alícuotas efectivas son comparables y las multinacionales con sede en la Unión Europea tienen, por lo general, un tipo impositivo efectivo superior (un promedio aproximado del $34 \%$ ) al que se aplica a las multinacionales con sede en los Estados Unidos (un promedio aproximado del 30\%).

En este mismo argumento pone el acento Zucman (2015) al calcular y comparar, mediante el uso de datos de cuentas nacionales y de la balanza de pagos de los Estados Unidos, la evolución de las alícuotas legales y las alícuotas efectivas del ISR de las sociedades desde 1934 hasta la actualidad. Así, comprueba que las tasas legales y las tasas efectivas (tanto las "pagadas" al Tesoro de los Estados Unidos como a los Estados extranjeros) se ubicaban en un nivel similar cercano al 50\% en los primeros años de la década de 1950 y que, en los años siguientes y a tono con las tendencias internacionales, estas tasas (legal, efectiva interna y efectiva extranjera) mostraron una clara tendencia decreciente en simultáneo hasta los primeros años de la década de 1990. A pesar de que a partir de 1993 la alícuota legal se estableció en un 
$35 \%$, y se mantiene en ese valor hasta la actualidad, las tasas efectivas del impuesto sobre la renta de las sociedades continuaron la trayectoria a la baja y en 2013 se ubicaron en un 16\% para los ingresos gravados en los Estados Unidos y en casi un $20 \%$ para los que se gravan en el extranjero. Esto da una señal del fenómeno de erosión de las bases tributarias en ese país.

Sin embargo, debe reconocerse que este tipo de estudios no brinda pruebas concluyentes de la existencia de comportamientos de erosión de la base imponible y traslado de beneficios, ya que gran parte de las diferencias observadas en las tasas impositivas efectivas podrían responder a otras causas, como la existencia de diversos beneficios e incentivos tributarios. En consecuencia, las investigaciones académicas han avanzado en la búsqueda de estimaciones enfocadas con mayor precisión sobre estos fenómenos. En ese sentido, existe un número creciente de trabajos empíricos que se basan en el enfoque de rentabilidad para cuantificar, a partir de modelos econométricos y datos específicos a nivel de las empresas, el traslado de utilidades hacia el exterior de los países desarrollados.

Entre la literatura empírica que adopta esta metodología se destacan los trabajos pioneros de Grubert y Mutti (1991) y Hines y Rice (1994) y los análisis posteriores realizados por Bartelsman y Beetsma (2003) y Grubert (2003). En todos estos trabajos se encontraron evidencias relacionadas con la transferencia de ingresos por parte de multinacionales estadounidenses y de otros países desarrollados desde jurisdicciones de alta tributación hacia jurisdicciones de baja tributación. Además, en el último de los estudios mencionados se comprobó que las rentas obtenidas por bienes intangibles representan aproximadamente la mitad de los beneficios trasladados entre países y que el mayor volumen de operaciones entre empresas de un mismo grupo se registraba en las filiales localizadas en países con tipos impositivos legales muy elevados o muy reducidos, por lo que tenían una fuerte propensión a trasladar los beneficios o a repatriarlos.

En los últimos años se han multiplicado los estudios académicos de este tipo y se ha adaptado y perfeccionado la metodología de acuerdo con los distintos casos estudiados. Dharmapala (2014) y Riedel (2015) proveen revisiones actualizadas de la literatura empírica en esta materia. También merece destacarse el reciente trabajo de la OCDE sobre medición y seguimiento de los mecanismos de erosión de la base imponible y traslado de beneficios, donde se presenta una extensa revisión de 20 estudios, realizados entre 2007 y 2015, que se basan en el enfoque de rentabilidad y utilizan información individual de las empresas (OCDE, 2015).

En la mayoría de los trabajos empíricos relevados en dicha investigación se busca medir el efecto de la traslación de beneficios originada por las brechas entre tasas impositivas, para lo cual se estima una semielasticidad 
donde el cambio porcentual en las utilidades es una función de un cambio porcentual en las alícuotas aplicadas. Si bien se advierte una amplia variedad de resultados dado que estas regresiones estadísticas difieren en los datos utilizados, las variables escogidas y otros aspectos metodológicos, las estimaciones del traslado de beneficios atribuible a diferencias tributarias muestran claras evidencias acerca de la existencia de este fenómeno.

Un ejemplo interesante se presenta en el trabajo de Heckemeyer y Overesch (2013). Estos autores recopilaron una serie de 25 estudios empíricos con evidencias concretas de una sustancial respuesta de medidas alternativas de la utilidad corporativa ante diferencias internacionales en las tasas impositivas. Basados en estos resultados, predicen una semielasticidad tributaria de los beneficios antes de impuestos cercana a 0,8. Esto implicaría que la utilidad bruta (antes de impuestos) de la subsidiaria o filial se reduciría un $0,8 \%$ si el diferencial de tasas que puede explotarse a través del arbitraje tributario internacional aumenta un $1 \%$, por ejemplo, como resultado de una reducción de alícuotas legales en el país de menor nivel de imposición.

Desafortunadamente, en la mayoría de los estudios académicos no se han extendido las estimaciones (elasticidades) acerca de comportamientos del traslado de beneficios a fin de producir cálculos de sus efectos fiscales en términos de pérdidas o resignación de ingresos tributarios. Las razones de esta limitación se relacionan con las sensibles diferencias que surgen de la normativa tributaria y contable en cada caso, especialmente cuando se refieren al uso de los múltiples beneficios tributarios concedidos, que imponen una brecha clara entre las utilidades declaradas, el ingreso sujeto a imposición y la correspondiente obligación tributaria. Sin embargo, hay ciertas excepciones en este sentido para algunos casos específicos.

Clausing (2009), por ejemplo, comparó las diferencias en los niveles de imposición entre países y las tasas de rentabilidad de las filiales extranjeras y estimó que hacia 2004 se transfirieron desde los Estados Unidos hacia el exterior cerca de 180.000 millones de dólares, lo que implicó un sacrificio del 35\% de los ingresos tributarios en concepto de impuesto sobre la renta corporativa en dicho país. En un trabajo posterior, la misma autora estimó que la pérdida de recursos derivada de la traslación de ingresos por parte de las multinacionales equivalía a entre 57.000 millones de dólares y 90.000 millones de dólares en 2008 (según el indicador y las variables utilizadas), lo que representaba entre un $19 \%$ y un $30 \%$ de los ingresos fiscales efectivos aportados por el impuesto sobre la renta de las sociedades (Clausing, 2011).

El trabajo publicado por Oxfam (2000), con menor rigor técnico, pero mucho más citado, también puede encuadrarse en esta categoría. En este caso, el cálculo parte de multiplicar el volumen de inversión extranjera directa (IED) en los países en desarrollo (1.200 millones de dólares en 1998) por una 
estimación (ajustada) del Banco Mundial para el retorno de la IED del 20\% en dichos países. Suponiendo una tasa impositiva media del 35\%, se determinó un impuesto sobre la renta de las sociedades hipotético de alrededor de 85.000 millones de dólares que, tras sustraerle los ingresos efectivos por aproximadamente 50.000 millones de dólares, desemboca en una brecha fiscal estimada de 35.000 millones de dólares. Oxfam (2000) incrementa esta cifra con los ingresos no percibidos debido a la evasión de ingresos de los activos financieros en el exterior, que se estima en 15.000 millones de dólares, y concluye que las pérdidas estimadas de ingresos fiscales a causa del traslado de utilidades ascendieron a 50.000 millones de dólares hacia 2000. Sin embargo, además de estar desactualizado, debe admitirse que este enfoque plantea una serie de interrogantes; por ejemplo, supone una alícuota media que parece demasiado elevada a nivel mundial - especialmente en los países en desarrollo- $-\mathrm{y}$, aun así, deja de lado la existencia de diversos incentivos fiscales destinados a atraer la radicación de flujos de IED en muchos de estos países.

La otra línea de investigación, que quizás sea la más difundida por el alto impacto que causan sus resultados, es la que adopta el enfoque de manipulación de precios. En este caso, se toman como insumo grandes bases de datos del comercio internacional para comparar los precios informados en operaciones entre dos empresas, vinculadas o independientes, con los precios comparables que surgirían en una situación de libre competencia.

Un aspecto crucial en este tipo de estudios es el que corresponde a la identificación del fenómeno, para lo cual existen distintas estrategias con diferentes implicancias. Por ejemplo, Baker (2005) utilizó encuestas confidenciales realizadas a empleados de distintas empresas para estimar la dimensión de la manipulación de precios en los países en desarrollo. Asumiendo un promedio global mínimo del 5\% del valor conjunto de las exportaciones y las importaciones (aunque para América Latina sería del 10\%, en promedio, para la mitad del comercio internacional de la región, y para países de Asia y África se ubicaría entre el 5\% y el 7\%), este autor calculó que las fugas de capitales debidas al comercio internacional rondaron los 200.000 millones de dólares hacia 2005. Aunque esta metodología para determinar la manipulación de precios presente limitaciones por estar basada en encuestas no replicables, los resultados obtenidos por Baker se citan de manera recurrente como parámetro de referencia por coincidir con los hallazgos de otros estudios en la misma línea de investigación.

Sin embargo, en la mayoría de las estimaciones basadas en el enfoque de manipulación de precios suele utilizarse un análisis de regresión econométrica, donde el precio de un determinado producto importado por una firma $X$ de un país $\mathrm{Y}$ en un momento $\mathrm{Z}$ es la variable dependiente respecto de un 
vector de variables explicativas (características del producto y de la empresa, alícuotas impositivas y aduaneras), una variable aleatoria para determinar la vinculación, o no, entre las empresas involucradas y una serie de variables de control para capturar el efecto de otros posibles factores (Eden, 2012). Como ya se explicó, a partir del establecimiento de rangos intercuartílicos de precios, se identifican aquellos que se ubican por fuera de este (como evidencia de sobrevaluación o subvaluación), y del cómputo global se obtiene una aproximación cuantitativa de la magnitud del problema.

Sobre la base de esta metodología, Pak (2007) estimó que el total de importaciones de los Estados Unidos durante 2005 estuvo subvaluado en aproximadamente 202.000 millones de dólares (un 12,1\% del total importado), mientras que las exportaciones registradas en el mismo año para el mismo país fueron sobrevaluadas en 50.000 millones de dólares (un 5,5\% del total exportado). Anteriormente, Pak, Zanakis y Zdanowicz (2003) usaron la misma metodología para investigar la salida de capitales de Grecia y encontraron que, a través de la manipulación de precios en el comercio internacional, en 1995 se trasladó al exterior del país una suma de ingresos cercana a 5.500 millones de dólares (casi el 4\% del PIB), lo que habría implicado una pérdida de ingresos tributarios de entre 1.400 millones de dólares y 2.000 millones de dólares anuales. De manera análoga, De Boyrie, Nelson y Pak (2007) encontraron que en 2005 se trasladaron unos 4.900 millones de dólares desde un conjunto de 30 países africanos hacia los Estados Unidos, casi en idéntica proporción entre importaciones sobrevaluadas desde ese país y exportaciones subvaluadas desde el continente africano.

La comparación entre los precios de transferencia y el precio de libre competencia en operaciones de comercio internacional también se utilizó como insumo en una serie de estudios académicos más recientes para algunos países puntuales. Entre ellos se destacan el de Vicard (2015) para el caso de Francia, en el período 2000-2010, y el de Cristea y Nguyen (2015) para el caso de multinacionales con casas matrices en Dinamarca, entre 1999 y 2006. Partiendo de un modelo teórico desarrollado por Bernard, Jensen y Schott (2006), en ambos estudios se da cuenta de que las pérdidas, en términos de los ingresos tributarios que dejaron de recaudarse, son significativas en relación con variables macroeconómicas de cada país y han aumentado a lo largo de los años?.

\footnotetext{
Estos autores utilizaron información aduanera para estimar el impacto de los mecanismos de precios de transferencia en los precios de las exportaciones utilizados por las empresas estadounidenses con sus empresas vinculadas del exterior, en comparación con los utilizados con empresas no vinculadas entre 1993 y 2000, y encontraron que los precios de las exportaciones a entidades relacionadas eran significativamente menores que los precios de las exportaciones a entidades no relacionadas y que esta diferencia era mayor en productos más diferenciables.
} 
Si bien los estudios que se refieren a un país en particular suelen sacar provecho de las bases administrativas nacionales que, por lo general, incluyen datos tributarios a nivel de las empresas, la metodología de manipulación de precios ha permitido llevar a cabo estimaciones de carácter mundial para un gran número de países, con el principal objetivo de favorecer la comparación internacional y la difusión de estas cuestiones en distintas latitudes. De hecho, a pesar de las dificultades que esto implica, algunas organizaciones no gubernamentales (ONG) han publicado una serie de resultados basados en datos de comercio bilateral que, a menudo, incluyen estimaciones de las pérdidas fiscales derivadas de supuestas prácticas nocivas por parte de las empresas multinacionales.

En ese sentido, un estudio muy mencionado es el de Christian Aid (2009) donde se intenta cuantificar la transferencia de ingresos a través de mecanismos de manipulación de precios o facturación fraudulenta en el comercio bilateral de la Unión Europea y los Estados Unidos con países extranjeros durante el período 2005-2007, estimándose un total acumulado para los 3 años superior a 1,1 billones de dólares (441.200 millones de dólares hacia el primer grupo de países y 673.600 millones de dólares hacia los Estados Unidos). Además, sobre la base de tasas impositivas legales, esto habría implicado una pérdida fiscal aproximada de 365.400 millones de dólares a nivel mundial en el mismo período, es decir, alrededor de 121.800 millones de dólares por año.

De los valores totales estimados en el trabajo mencionado, que solo comprende el comercio de materias primas y no incluye los servicios ni los activos intangibles, una cifra superior a los 95.000 millones de dólares corresponde a salidas de capitales desde los países de América Latina entre 2005 y 2007 como resultado de la manipulación abusiva de los precios de transferencia. Dada la reducción de ingresos gravables que esto implica, y tomando como referencia las alícuotas legales aplicadas en cada país y en cada año, esto habría significado para América Latina en su conjunto una resignación de ingresos fiscales por un monto superior a los 31.000 millones de dólares como resultado de operaciones mayoritariamente con empresas estadounidenses y el resto (entre un $7 \%$ y un $8 \%$ ) con empresas europeas. Entre los países con mayores pérdidas fiscales acumuladas durante el período 2005-2007 sobresalen México (19.941,69 millones de dólares) y el Brasil (6.448,95 millones de dólares). Ambos países representan el $84,3 \%$ del total regional y van seguidos, muy lejos, por Venezuela (República Bolivariana de) (1.097,91 millones de dólares), Costa Rica (785,21 millones de dólares) y Colombia (756,70 millones de dólares) (véase el cuadro XIII.2). 


\section{Cuadro XIII.2 \\ América Latina (países seleccionados): pérdidas estimadas de ingresos tributarios por manipulación de precios en operaciones comerciales con empresas de los Estados Unidos y la Unión Europea (27 países) ${ }^{a}$}

(En millones de dólares)

\begin{tabular}{lrrrr}
\hline País & 2005 & \multicolumn{1}{c}{2006} & \multicolumn{1}{c}{2007} & \multicolumn{1}{c}{ Total } \\
\hline Argentina & 185,39 & 170,04 & 185,31 & 540,74 \\
\hline Bolivia (Estado Plurinacional de) & 7,94 & 3,68 & 5,49 & 17,11 \\
\hline Brasil & 1112,35 & 1372,16 & 3964,44 & 6448,95 \\
\hline Chile & 134,16 & 121,92 & 163,82 & 419,90 \\
\hline Colombia & 243,22 & 230,66 & 282,82 & 756,70 \\
\hline Costa Rica & 128,84 & 126,26 & 530,11 & 785,21 \\
\hline Ecuador & 64,20 & 38,67 & 47,95 & 150,82 \\
\hline El Salvador & 29,02 & 29,09 & 32,19 & 90,30 \\
\hline Guatemala & 65,47 & 58,06 & 81,58 & 205,11 \\
\hline Honduras & 56,47 & 49,06 & 76,03 & 181,56 \\
\hline México & 560,59 & 6177,97 & 8403,13 & 19941,69 \\
\hline Nicaragua & 15,01 & 19,55 & 70,35 & 104,91 \\
\hline Panamá & 29,38 & 36,98 & 61,05 & 127,41 \\
\hline Paraguay & 3,73 & 11,55 & 2,66 & 17,94 \\
\hline Perú & 146,69 & 72,98 & 135,76 & 355,43 \\
\hline República Dominicana & 173,94 & 96,76 & 85,69 & 356,39 \\
\hline Uruguay & 8,93 & 12,31 & 10,77 & 32,01 \\
\hline Venezuela (República Bolivariana de) & 446,43 & 266,88 & 384,60 & 1097,91 \\
\hline Total & 8211,76 & 8894,58 & 14523,75 & 31630,09 \\
\hline
\end{tabular}

Fuente: Elaboración propia, sobre la base de Christian Aid (2009), False Profits: Robbing the Poor to Keep the Rich Tax-Free. A Christian Aid Report, Londres, 2009.

a Se empleó la matriz de filtrado de precios elaborada por Simon Pak.

En la misma línea, la organización Global Financial Integrity (GFI) realiza una serie de estimaciones para cuantificar los flujos financieros ilícitos que salen de los países en desarrollo. Por ejemplo, Kar y Cartwright-Smith (2008) calcularon que entre 2002 y 2006 se trasladó hacia el exterior de esos países un promedio anual de 370.000 millones de dólares. Sobre la base de estos valores, y a partir de información del Fondo Monetario Internacional (FMI), PricewaterhouseCoopers y la Fundación Heritage, Hollingshead (2010) estimó que las pérdidas tributarias asociadas a dichos flujos de capitales entre 2002 y 2006 promediaron entre 98.000 millones de dólares y 106.000 millones de dólares por año en el agregado de países en desarrollo.

Del valor total calculado, las estimaciones arrojan que América Latina y el Caribe es la segunda región, después de África, donde se registraron mayores pérdidas, con un promedio cercano a los 18.000 millones de dólares por año (un $0,7 \%$ del PIB regional), cuando el total recaudado por el impuesto sobre la renta de las sociedades ronda el 3,1\% del PIB. Además, 3 países de la región (Honduras, Nicaragua y Panamá) aparecen entre los 20 países 
en desarrollo con mayor pérdida fiscal relativa media (como porcentaje de los ingresos totales del gobierno central) para el mismo período 2002-2006 (véase el cuadro XIII.3).

\section{Cuadro XIII.3}

América Latina (países seleccionados): pérdidas estimadas de ingresos tributarios por manipulación de precios en operaciones comerciales, datos anuales, valores medios, 2002-2006

(En millones de dólares y porcentajes de los ingresos públicos ${ }^{b}$ )

\begin{tabular}{lrc}
\hline País & En millones de dólares & $\begin{array}{c}\text { En porcentajes de los } \\
\text { ingresos públicos }\end{array}$ \\
\hline Argentina & 329,47 & 1,5 \\
\hline Bolivia (Estado Plurinacional de) & 27,81 & 1,4 \\
\hline Brasil & 543,47 & n.d. \\
\hline Chile & 206,04 & 0,9 \\
\hline Colombia & 427,57 & 1,9 \\
\hline Costa Rica & 968,80 & 22,2 \\
\hline Ecuador & 137,48 & 0,4 \\
\hline El Salvador & 157,50 & 6,1 \\
\hline Guatemala & 368,11 & 12,1 \\
\hline Honduras & 418,54 & 21,6 \\
\hline México & 11670,52 & 4,5 \\
\hline Nicaragua & 216,97 & 27,7 \\
\hline Panamá & 810,77 & 13,5 \\
\hline Paraguay & 59,75 & 3,4 \\
\hline Perú & 275,66 & 2,2 \\
\hline República Dominicana & 1,31 & 0,0 \\
\hline Uruguay & 63,84 & 1,6 \\
\hline Venezuela (República Bolivariana de) & 307,97 & 1,1 \\
\hline Total & $1699,--$ \\
\hline Punte: & 998 & \\
\hline
\end{tabular}

Fuente: Elaboración propia, sobre la base de A. Hollingshead, The Implied Tax Revenue Loss from Trade Mispricing, Washington, D.C., Global Financial Integrity, 2010.

a Se empleó la metodología de Global Financial Integrity.

b Los ingresos públicos corresponden a la definición del Banco Mundial (Indicadores del Desarrollo Mundial) e incluyen ingresos tributarios y no tributarios del gobierno central, incluidas las transferencias de capital y exceptuadas las donaciones.

A partir de un estudio más actualizado de GFI a nivel mundial, Kar y Spanjers (2014) confirman que las alteraciones o manipulaciones en la facturación del comercio internacional de bienes es la práctica de mayor relevancia en términos de traslado de beneficios hacia el exterior de los países en desarrollo, especialmente por su vinculación con las prácticas de manipulación de precios de transferencia. Al comparar el valor de las exportaciones de un país con el de las importaciones provenientes de dicho país en el lugar de destino, se intenta estimar la subfacturación de exportaciones y la sobrefacturación de importaciones. Los resultados muestran que las 
salidas ilegales de capital en la región (para los 18 países seleccionados) promediaron los 98.351 millones de dólares por año, aunque se advierte que el peso relativo de estos flujos —en términos del PIB — difiere drásticamente de un país de la región a otro (véase el cuadro XIII.4).

\section{Cuadro XIII.4}

América Latina (países seleccionados): flujos financieros ilícitos como producto de la manipulación de precios en operaciones comerciales, datos anuales, valores medios, 2003-2012

(En millones de dólares y porcentajes del PIB)

\begin{tabular}{lrc}
\hline País & En millones de dólares & En porcentajes del PIB \\
\hline Argentina & 512 & 0,1 \\
\hline Bolivia (Estado Plurinacional de) & 42 & 0,1 \\
\hline Brasil & 20549 & 1,4 \\
\hline Chile & 3957 & 2,3 \\
\hline Colombia & 1198 & 0,5 \\
\hline Costa Rica & 9362 & 32,6 \\
\hline Ecuador & 1617 & 2,8 \\
\hline El Salvador & 628 & 3,2 \\
\hline Guatemala & 1040 & 2,9 \\
\hline Honduras & 3154 & 24,1 \\
\hline México & 44327 & 4,5 \\
\hline Nicaragua & 1268 & 16,2 \\
\hline Panamá & 4765 & 20,2 \\
\hline Paraguay & 3586 & 23,6 \\
\hline Perú & 675 & 0,6 \\
\hline República Dominicana & 742 & 1,7 \\
\hline Uruguay & 636 & 2,2 \\
\hline Venezuela (República Bolivariana de) & 293 & 0,1 \\
\hline América Latina (18 países) & 98351 & 2,5 \\
\hline
\end{tabular}

Fuente: Elaboración propia, sobre la base de D. Kar y J. Spanjers, Illicit Financial Flows from Developing Countries: 2003-2012, Washington, D.C., Global Financial Integrity, 2014 y CEPALSTAT (PIB nominal en dólares).

El trabajo recientemente elaborado por la Conferencia de las Naciones Unidas sobre Comercio y Desarrollo (UNCTAD, 2015) merece destacarse especialmente. Además de brindar estimaciones actualizadas, por constituir un importante avance desde el punto de vista metodológico al ubicarse en la intersección de los dos enfoques ya comentados, se basa en el concepto de rentabilidad y explora el papel de los países que actúan como nexos de los flujos de inversión (centros de inversión extraterritoriales) en el traslado de beneficios corporativos y la pérdida implícita de ingresos tributarios para las economías en desarrollo.

Esta novedosa metodología descansa en el supuesto de una relación negativa entre los flujos de inversión provenientes de los países que ofrecen 
un tratamiento legal y financiero relativamente favorable para inversionistas extranjeros, y que suelen utilizarse como jurisdicción de origen con fines impositivos (previamente identificados en el trabajo), y la tasa de retorno del flujo total de IED recibida. Resulta esperable que el ingreso generado por la IED con origen en dichos países esté sujeto, en un mayor grado, a distintas prácticas de traslado de beneficios, con el efecto de reducir artificialmente la tasa de retorno enfrentada.

La estimación para explorar la relación negativa entre los flujos de IED y las tasas de retorno mencionadas se realizó para una muestra de 72 países (27 desarrollados, 34 en desarrollo y 11 en transición) entre 2009 y 2012, y los resultados obtenidos sugieren que la tasa de retorno (estimada) de la IED es de un $1 \%$ a un $1,5 \%$ menor por cada $10 \%$ de participación adicional en los flujos entrantes que provengan de países con ventajas fiscales y baja o nula imposición. Después, el problema de estimar las pérdidas tributarias para los países en desarrollo se redujo a encontrar la brecha de rentabilidad (nivel de IED proveniente de países con ventajas legales o impositivas como una aproximación del desvío de beneficios), para posteriormente traducir esta brecha en montos globales de ingresos tributarios resignados.

Mediante la presentación de cuatro formulaciones alternativas, el estudio concluye que, considerando solo el componente de IED financiado con capital propio y la tasa efectiva media del impuesto sobre la renta de las sociedades $(20 \%)$ - para descontar el efecto de los esquemas de incentivos tributarios-, el valor correspondiente a las pérdidas tributarias estimadas alcanzaría los 90.000 millones de dólares solo en los países en desarrollo y 200.000 millones de dólares a nivel mundial en 2012, lo que representaría aproximadamente un $10 \%$ de los ingresos por la imposición sobre la renta de las sociedades. Vale aclarar que estos resultados provienen solamente de operaciones donde se evidencia una relación de inversión directa, por lo que pueden no incluir otros canales cruciales del fenómeno de erosión de la base imponible y traslado de beneficios, como la manipulación abusiva de precios de transferencia o las operaciones de endeudamiento entre empresas vinculadas.

Por último, merece una mención destacada el trabajo recientemente publicado por la OCDE, denominado Measuring and Monitoring BEPS. ACTION 11: 2015 Final Report (OCDE, 2015), que forma parte de la conclusión de una serie de informes realizados en virtud del plan de acción estipulado para el proyecto de erosión de la base imponible y traslado de beneficios, cuyos orígenes se remontan a 2013. Además de sistematizar la información de la literatura empírica reciente en esta materia, en dicho estudio se efectuó un complejo cálculo global de la magnitud estimada del fenómeno de erosión de la base imponible y traslado de beneficios y su impacto fiscal en términos de ingresos tributarios resignados. 
La estimación de la OCDE se basó tanto en un análisis de traslación de utilidades debido a diferenciales de tasas impositivas (la metodología que predomina en los estudios académicos) como en una evaluación de las diferencias en las alícuotas efectivas entre filiales de grandes empresas multinacionales y compañías nacionales comparables, en un intento por reflejar descalces entre los sistemas tributarios y los tratamientos preferenciales disponibles en cada país. Por una parte, se estimó la semielasticidad de las utilidades declaradas respecto de los diferenciales que surgen entre las alícuotas tributarias legales soportadas por las filiales y la tasa media para toda la empresa multinacional de la que forma parte. A partir del aprovechamiento exhaustivo de la base de datos ORBIS y 1,2 millones de registros entre 2000 y 2010 , este indicador fue aproximado en un valor igual a $-1,0{ }^{8}$. Por otra parte, como resultado de la traslación de beneficios, de los descalces entre sistemas tributarios y del mayor uso relativo de tratamientos preferenciales, se encontró que las tasas efectivas medias para las grandes empresas multinacionales (con más de 250 empleados) son entre 4 y 8,5 puntos porcentuales más bajas que las correspondientes a empresas nacionales comparables.

La estimación de la pérdida de ingresos vinculada a los mecanismos de erosión de la base imponible y traslado de beneficios requiere un número importante de parámetros y supuestos con el fin de poder hacer una extrapolación desde una base de datos hacia un resultado global. Para ello se recurrió no solo a la base ORBIS sino también a información generada por la OCDE (como las proyecciones de ingresos tributarios). No obstante, se identificaron algunos factores que podrían conducir a una subestimación de la pérdida de ingresos, como la falta de representatividad de los datos disponibles y la desigual cobertura en varios países analizados, mientras que otros factores podrían generar una sobreestimación de los resultados.

Reconociendo estas incertidumbres y limitaciones, se estimó que el total de pérdidas de recursos netos actualmente equivaldría a entre un $4 \%$ y un $10 \%$ de los ingresos anuales en concepto de impuesto sobre la renta de las sociedades. A nivel global, esta pérdida recaudatoria por erosión de la base imponible y traslado de beneficios equivale a un monto acumulado de recursos por alrededor de 0,9 billones de dólares a 2,1 billones de dólares durante los últimos 10 años (2005-2014) y de, al menos, entre 100.000 millones de dólares y 240.000 millones de dólares en 2014, dos tercios de los cuales se atribuyen al fenómeno de traslado de beneficios y el resto al aprovechamiento de ventajas particulares para las empresas multinacionales a través de regímenes preferenciales.

ORBIS es una base de datos de información empresaria de alcance mundial, elaborada por una institución privada (Bureau Van Dijk) y basada en un formato estandarizado que la hace comparable para más de 175 millones de empresas en todo el mundo (incluidos bancos y aseguradoras). 
Si bien la estimación es de carácter mundial y agregado, en el trabajo citado se señala que el impacto de la erosión de la base imponible y el traslado de beneficios sobre la recaudación total sería relativamente superior en los países en desarrollo que en los países desarrollados, dada la mayor dependencia de los primeros de los ingresos tributarios aportados por el impuesto sobre la renta de las sociedades (OCDE, 2015) .

Por último, con el fin de promover la generación de datos nuevos, actualizados y continuos en el tiempo, en el trabajo de la OCDE se propusieron los siguientes indicadores que apuntan a detectar indicios y evidencias acerca de la existencia y la magnitud de las prácticas de erosión de la base imponible y traslado de beneficios:

- Concentración de niveles elevados de IED en relación con el PIB (muestra de la desconexión entre las actividades financieras y las actividades de la economía real).

- Diferencial de tasas de rentabilidad comparado con las tasas impositivas efectivas.

- Diferencial de tasas de rentabilidad entre las operaciones globales de las multinacionales y aquellas localizadas en jurisdicciones de baja imposición.

- Tasas impositivas efectivas de grandes filiales de multinacionales respecto de entidades nacionales comparables o con similares características.

- Concentración de niveles elevados de ingresos por regalías en relación con el gasto en investigación y desarrollo (I+D) (traslado de beneficios a través de activos intangibles)

- Ratios entre gastos de intereses e ingresos de filiales de multinacionales en jurisdicciones con nivel elevado de imposición (para detectar maniobras de traslado de beneficios).

Teniendo en cuenta las precauciones señaladas, los cálculos para el Indicador 1 se obtuvieron a partir de datos de 217 países incluidos en la base OECD Foreign Direct Investment Statistics y muestran que los volúmenes de IED, en relación con el PIB, de un grupo de países con ratios elevados (por encima del $50 \%$ en términos netos y del $200 \%$ en términos brutos) han venido creciendo en los últimos años en comparación con el promedio de todos los

Según datos publicados en Gómez Sabaini y Morán (2014), los ingresos tributarios por concepto de impuesto sobre la renta de las sociedades históricamente han representado, en promedio, una mayor proporción de la carga tributaria total para los países de América Latina que para los miembros de la OCDE. En el primer caso, el porcentaje medio regional pasó del 16,2\% en 1990 al $17,4 \%$ en 2012, mientras que para los países desarrollados la participación media de dicho tributo se elevó del 7,3\% en 1990 al 8,9\% en 2012. 
demás países: la IED neta en relación con el PIB de esos países pasó de ser 38 veces más alta que la de otros países en 2005 a ser 99 veces mayor en 2012.

Los Indicadores 2 y 3 muestran una correlación entre bajas tasas efectivas y las tasas de ganancia de las filiales. A partir de información financiera de las 250 multinacionales más importantes, en el primer caso se comprobó que el $45 \%$ del ingreso de estos grupos económicos fue declarado fiscalmente a través de las filiales con tasas efectivas por debajo del promedio y tasas de ganancia por encima de este (este indicador ha exhibido una tendencia creciente en los últimos años). El otro indicador vinculado a la rentabilidad de las empresas muestra que la tasa de utilidad de las filiales radicadas en países de baja tributación es, en promedio, al menos dos veces más alta que la correspondiente a la multinacional de la que forma parte en conjunto.

Mediante el uso de la información financiera no consolidada de las empresas incluidas en la base de datos ORBIS, el Indicador 4 permitió confirmar que entre 2000 y 2010 las tasas efectivas soportadas por las filiales de grandes multinacionales fueron entre 2,7 y 4,5 puntos porcentuales menores que las estimadas para empresas nacionales similares. Con información acerca de la balanza de pagos y de los gastos de I+D proveniente de los Indicadores del Desarrollo Mundial (Banco Mundial), el Indicador 5 muestra que las regalías recibidas en relación con los gastos de I+D en un grupo de países con ratios por encima del $50 \%$ son 6 veces superiores a la media de todos los demás países, cuando en 2009 eran solo 3 veces superiores. Por último, los datos de información financiera recolectados para estimar el Indicador 6 sugieren que las filiales de grandes multinacionales localizadas en países con tasas impositivas relativamente elevadas poseen una relación entre intereses y beneficio bruto casi tres veces mayor que la de otras filiales en jurisdicciones distintas.

En OCDE (2015) se aclara que el uso de estos indicadores para identificar la escala y el impacto económico de la erosión de la base imponible y el traslado de beneficios solo puede proveer indicaciones generales de este fenómeno en los países analizados. Los datos utilizados para estimar estos indicadores están afectados por una serie de limitaciones de las fuentes de información disponibles y, como resultado, deben considerarse ilustrativos y no definitivos ni estrictamente precisos.

Sin embargo, y si bien es muy reciente, se destaca la importancia de esta contribución en tanto se acepte que la combinación de estos indicadores permitiría contar con fuertes indicios acerca de la existencia de conductas ilícitas, así como de la incidencia (aproximada) del fenómeno de traslado de beneficios a nivel mundial y en varios países en particular.

Además, en la medida en que constituyan un primer paso para la obtención de datos comparables entre países, y a lo largo de períodos variables 
de tiempo, estos indicadores tienen un gran potencial para el estudio de estos fenómenos sobre bases estadísticas más firmes que las actuales. Obviamente, al momento de cuantificar la magnitud del problema y las pérdidas fiscales asociadas, deberán complementarse con análisis más rigurosos, como los trabajos académicos señalados en párrafos anteriores, que eventualmente podrán sacar provecho de la nueva información producida.

\section{Conclusiones y perspectivas futuras}

En las últimas dos décadas se ha intensificado un proceso global de deslocalización de las inversiones y de los beneficios obtenidos por las empresas multinacionales mediante la radicación de las bases imponibles de dichas empresas en aquellos países donde la carga tributaria sobre las sociedades resulta ser menor.

Sin embargo, el debate en torno a la erosión de la base imponible y el traslado de beneficios recién cobró mayor importancia en la agenda de los países miembros de la OCDE tras la crisis económica de 2008-2009. Más recientemente, se ha reconocido que la erosión tributaria no es un fenómeno exclusivo del mundo desarrollado, sino que también atañe a las economías en desarrollo. Es por ello que, en un mundo sumamente globalizado, la iniciativa BEPS requiere de un abordaje lo más global posible a los efectos de lograr una mayor eficacia para atacar las prácticas fiscales nocivas, reconociendo las limitaciones que tienen los países para actuar de manera aislada e independiente.

A partir de una vasta recopilación de la literatura disponible, en este trabajo se pudo observar que las estimaciones acerca de la magnitud del fenómeno para casos particulares son más precisas, pues atienden mejor la heterogeneidad entre países y permiten sacar provecho de múltiples bases de datos. Por su parte, algunas estimaciones globales recientes, si bien presentan ciertas debilidades metodológicas y estadísticas, causan mucho más impacto y atraen más la atención del público hacia estas cuestiones, fomentando la obtención y acumulación de datos homogéneos que permitan la comparación entre distintos sistemas tributarios.

Hasta el momento, los resultados obtenidos en la cuantificación del impacto de la erosión de la base imponible y el traslado de beneficios no resultan suficientes y es claro que aún se necesita realizar mucha más investigación en esta área. En tal sentido, los estudios que se realicen en el futuro deberían abordar ciertos aspectos centrales del fenómeno, como: i) la presencia e intensidad de los mecanismos de erosión de la base imponible y traslado de beneficios; ii) la naturaleza de las diferencias en las tasas de rentabilidad entre las grandes empresas multinacionales y las entidades nacionales comparables; iii) los factores que contribuyen a la rentabilidad, 
tanto de las empresas filiales como del grupo económico en su conjunto; iv) los factores tributarios en general, que van más allá de las normas en materia de imposición a la renta, así como los factores no tributarios (incertidumbre, costos de cumplimiento y otros), que inciden en las decisiones de localización de las empresas, y v) los efectos derivados del comportamiento estratégico de los diferentes países respecto del problema.

Las operaciones de las empresas multinacionales trascienden las fronteras geográficas de los países y también las posibilidades de control a través de las administraciones tributarias. Es por ello que en esta área, más que en ninguna otra, la cooperación internacional se erige como un requisito fundamental. $\mathrm{Al}$ respecto, los esfuerzos de la OCDE sobresalen por su alcance, tanto en la elaboración de marcos normativos estándar como en la provisión de espacios de encuentro y discusión entre un gran número de países y en la búsqueda del fomento de una mayor transparencia financiera a nivel internacional. La elaboración de una serie de indicadores generales para identificar y evaluar la presencia de mecanismos de erosión de la base imponible y traslado de beneficios apunta en esa dirección, al igual que las iniciativas de coordinación de importantes acuerdos para facilitar el intercambio automático de información financiera y tributaria entre los organismos de recaudación.

\section{Bibliografía}

Arias Esteban, I.G. (2010), "Estudio comparado sobre la situación actual de las legislaciones sobre precios de transferencia en Latinoamérica", Documento de Trabajo, $\mathrm{N}^{\circ}$ 01-2010, Centro Interamericano de Administraciones Tributarias (CIAT).

Avi-Yonah, R. y Y. Lahav (2011), "The effective tax rate of the largest US and EU multinationals", Law \& Economics Working Paper, N ${ }^{\circ} 41$, Michigan, University of Michigan Law School.

Baker, R.W. (2005), Capitalism's Achilles Heel: Dirty Money and How to Renew the FreeMarket System, Hoboken, John Wiley \& Sons.

Barrientos Quezada, J.R. (2012), “Hacia el combate de la evasión tributaria vía manipulación de precios de transferencia. El caso de Guatemala", Boletín de Estudios Fiscales, $\mathrm{N}^{\circ} 15$, Ciudad de Guatemala, Instituto Centroamericano de Estudios Fiscales.

Bartelsman, E.J., y R.M. Beetsma (2003), “Why pay more? Corporate tax avoidance through transfer pricing in OECD countries", Journal of Public Economics, vol. 87, $\mathrm{N}^{\circ}$ 9-10, Amsterdam, Elsevier.

Bernard, A.B., J.B. Jensen y P.K. Schott (2006), “Transfer pricing by U.S.-based multinational firms", NBER Working Papers, $\mathrm{N}^{\circ}$ 12493, Cambridge, Massachusetts, National Bureau of Economic Research.

Christian Aid (2009), False Profits: Robbing the Poor to Keep the Rich Tax-Free. A Christian Aid Report, Londres.

Clausing, K.A. (2011), "The revenue effects of multinational firm income shifting", Tax Notes, 28 de marzo. 
(2009), "Multinational firm tax avoidance and tax policy", National Tax Journal, vol. 62, $\mathrm{N}^{\circ}$ 4, National Tax Association.

Cristea, A.D. y D.X. Nguyen (2013), “Transfer pricing by multinational firms: new evidence from foreign firm ownerships", inédito.

De Boyrie, M.E., J.A. Nelson y S.J. Pak (2007), “Capital movement through trade misinvoicing: the case of Africa", Journal of Financial Crime, vol. 14, N 4, Emerald Group Publishing Limited.

Dharmapala, D. (2014), "What do we know about base erosion and profit shifting? A review of the empirical literature", CESifo Working Paper series, $\mathrm{N}^{\circ} 4612$, Munich, CESifo Group Munich.

Eden, L. (2012), "Transfer price manipulation", Draining Development? Controlling Flows of Illicit Funds from Developing Countries, P. Reuter (ed.), Washington, D.C., Banco Mundial.

Gómez Sabaini, J.C y D. Morán (2016), "Evasión tributaria en América Latina: nuevos y antiguos desafíos en la cuantificación del fenómeno para los países de la región", serie Macroeconomía del Desarrollo, N 172 (LC/L.4155), Santiago, Comisión Económica para América Latina y el Caribe (CEPAL).

(2014), "Política tributaria en América Latina: agenda para una segunda generación de reformas", serie Macroeconomía del Desarrollo, Nº 133 (LC/L.3632), Santiago, Comisión Económica para América Latina y el Caribe (CEPAL).

Grondona, V. (2014), “Fuga de capitales IV. Argentina, 2014. La manipulación de los precios de transferencia", Documento de Trabajo, N ${ }^{\circ}$ 58, Buenos Aires, Centro de Economía y Finanzas para el Desarrollo de la Argentina (CEFID-AR).

Grubert, H. (2003), "Intangible income, intercompany transactions, income shifting and the choice of location", National Tax Journal, vol. 56, N 1, National Tax Association.

Grubert, H. y J. Mutti (1991), "Taxes, tariffs and transfer pricing in multinational corporate decision making", Review of Economics and Statistics, vol. 73, N², Cambridge, Massachusetts, The MIT Press.

Heckemeyer, J. y M. Overesch (2013), “Multinationals' profit response to tax differentials: effect size and shifting channels", ZEW Discussion Papers, $\mathrm{N}^{\circ} 13-045$, Center for European Economic Research (ZEW).

Hines, J.R y E.M. Rice (1994), "Fiscal paradise: foreign tax havens and American business", The Quarterly Journal of Economics, vol. 109, $\mathrm{N}^{\circ} 1$, Cambridge, Massachusetts, The MIT Press.

Hollingshead, A. (2010), The Implied Tax Revenue Loss from Trade Mispricing, Washington, D.C., Global Financial Integrity.

Kar, D. y D. Cartwright-Smith (2008), Illicit Financial Flows from Developing Countries, 2002-2006, Washington, D.C., Global Financial Integrity.

Kar, D. y J. Spanjers (2014), Illicit Financial Flows from Developing Countries: 2003-2012, Washington, D.C., Global Financial Integrity.

Molina Bolaños, E. y J.R. Muñoz Núñez (2014), “Incumplimiento tributario en impuestos sobre la renta y ventas 2010-2012", San José, Ministerio de Hacienda.

OCDE (Organización de Cooperación y Desarrollo Económicos) (2015), Measuring and Monitoring BEPS. ACTION 11: 2015 Final Report, París, OECD Publishing. (2013), Lucha contra la erosión de la base imponible y el traslado de beneficios, París. (2010), Directrices de la OCDE aplicables en materia de precios de transferencia a empresas multinacionales y administraciones tributarias, París, OECD Publishing. (1979), Transfer Pricing and Multinational Enterprises, París, OECD Publishing. 
Oxfam (2000), "Tax havens: releasing the hidden billions for poverty eradication", Oxfam Briefing Paper, Londres, Oxfam International.

Pak, S.J. (2007), "Capital flight and tax avoidance through abnormal pricing in international trade: the issue and the solution", Closing the Floodgates: Collecting Tax to Pay for Development, Londres, Tax Justice Network.

Pak, S.J., S. Zanakis y J.S. Zdanowicz (2003), "Detecting abnormal pricing in international trade: the Greece-USA case", Interfaces, vol. 33, N².

Riedel, N. (2015), "Quantifying international tax avoidance: a review of academic literature", European Tax Policy Forum, Policy Papers, $N^{\circ} 2$ [en línea] www.etpf. org/papers/PP002QuantAvoid.pdf.

UNCTAD (Conferencia de las Naciones Unidas sobre Comercio y Desarrollo) (2015), "An FDI-driven approach to measuring the scale and economic impact of BEPS", World Investment Report 2015: Reforming International Investment Governance, Ginebra, Naciones Unidas.

Vicard, V. (2015), "Profit shifting through transfer pricing: evidence from French firm level trade data", Banque de France Working Paper, $N^{\circ} 555$, Banco de Francia.

Zucman, G. (2015), The Hidden Wealth of Nations. The Scourge of Tax Havens, Chicago, University of Chicago Press. 
Parte 5

Nuevos desafíos en materia tributaria 



\title{
El impacto fiscal de los recursos naturales no renovables ${ }^{1}$
}

\author{
Juan C. Gómez Sabaini² \\ Juan Pablo Jiménez ${ }^{3}$ \\ Dalmiro Morán ${ }^{4}$
}

\section{Introducción}

El crecimiento económico que registró la región entre 2003 y 2008, así como el aumento del consumo, el descenso de la pobreza y la reducción de la desigualdad, ha estado vinculado, entre otros factores, a los elevados precios de los recursos naturales durante ese período. Este ciclo favorable ha sido fundamental en la mejora de los resultados macroeconómicos y de la posición fiscal de los países exportadores de América Latina y el Caribe.

Este capítulo constituye una versión resumida y actualizada de Gómez Sabaini, Jiménez y Morán (2015).

2 Consultor de la Comisión Económica para América Latina y el Caribe (CEPAL), el Banco Interamericano de Desarrollo (BID), el Fondo Monetario Internacional (FMI) y el Centro Interamericano de Administraciones Tributarias (CIAT) especializado en temas de política tributaria en países de América Latina. Profesor de posgrado en la Universidad Nacional de Buenos Aires. Correo electrónico: gomezsabaini@gmail.com.

3 Oficial de Asuntos Económicos de la División de Desarrollo Económico de la Comisión Económica para América Latina y el Caribe (CEPAL). Correo electrónico: juanpablo.jimenez@cepal.org.

4 Consultor de la Comisión Económica para América Latina y el Caribe (CEPAL) y del Centro Interamericano de Administraciones Tributarias (CIAT) especializado en temas de política tributaria en países de América Latina. Correo electrónico: dalomoran@gmail.com. 
El papel preponderante de los recursos naturales no renovables en estas economías no es una característica novedosa si se tiene en cuenta que estos históricamente han constituido una de las principales fuentes de ingreso de divisas internacionales. Sin embargo, el mencionado período de bonanza internacional para los productos primarios no solo ha confirmado la gran importancia relativa que adquieren estos recursos en varios países de la región, sino que ha motivado la implementación de distintos mecanismos fiscales por parte de los respectivos Gobiernos con el objeto de lograr una adecuada apropiación estatal de las rentas derivadas de las industrias extractivas.

El contexto internacional actual es muy diferente al observado hace solo una década atrás, ya que el precio de los productos básicos ha descendido drásticamente (véase el gráfico XIV.1). Sin embargo, estos cambios no invalidan las consideraciones que pueden realizarse respecto de la importancia fiscal de los recursos naturales agotables en las economías de América Latina y el Caribe. En todo caso, un nuevo contexto de precios estables, o incluso decrecientes, de los hidrocarburos y los minerales exportables podría amenguar o exacerbar las implicancias a ellos asociadas, tales como la diversificación productiva de los países, el grado de dependencia fiscal respecto de dichos recursos y la necesidad de buscar fuentes alternativas para el financiamiento del Estado en los países productores de la región.

\section{Gráfico XIV.1}

Índice de precios de productos primarios no renovables, 2000 a mayo de 2016 (Índice medio base año 2005=100)

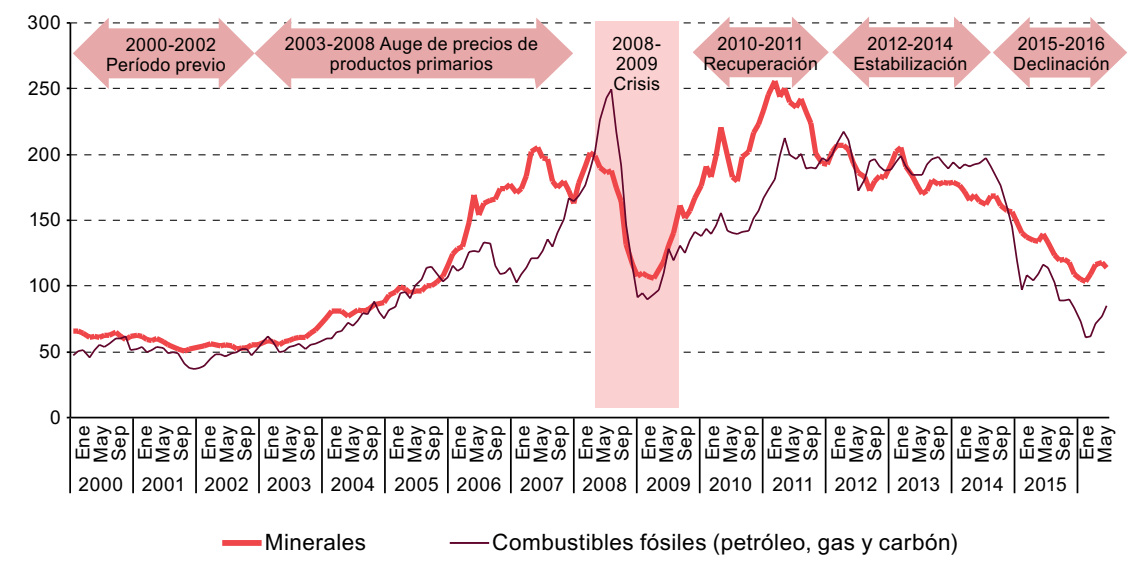

Fuente: Elaboración propia, sobre la base de índices de precios elaborados por el Fondo Monetario Internacional.

Tras esta introducción, en la sección A se describen los diferentes mecanismos fiscales de captación de rentas provenientes de recursos naturales no renovables, tanto desde una perspectiva teórica como a partir de las experiencias recientes a nivel internacional. En la sección B se pone especial 
énfasis en las distintas políticas seguidas por los Gobiernos de la región en lo que respecta a la imposición de estos recursos, así como en la evolución reciente y la importancia económica de los ingresos fiscales que derivan de su explotación económica, distinguiendo los casos de hidrocarburos y minerales. Por último, en la sección $C$ se recogen las principales conclusiones del trabajo y las perspectivas en esta temática.

\section{A. Instrumentos fiscales en las industrias extractivas: principales alternativas}

En las últimas décadas se ha observado una diversificación en la gama de instrumentos fiscales, tanto de carácter tributario como no tributario, que pueden aplicarse y adaptarse específicamente a las industrias extractivas presentes en cada país 5 .

Una clasificación moderna de estos instrumentos fiscales distingue entre aquellos basados en utilidades (o alguna definición de ingresos netos de costos vinculados) y los que se determinan sobre la base de la producción, ya sea que recaigan sobre las reservas o sobre los insumos y servicios utilizados en la explotación. Además, existen diversos mecanismos a través de los cuales el Estado puede participar, de manera activa o pasiva, en la producción o en las ganancias de las empresas privadas. En el cuadro XIV.1 se expone un relevamiento realizado por el Fondo Monetario Internacional (FMI, 2012), donde se describen los principales instrumentos fiscales que suelen encontrarse en las industrias extractivas y se muestra el grado de frecuencia con que estos se utilizan en una amplia muestra de 25 países mineros y 67 productores de hidrocarburos.

En las industrias extractivas, dado que posibilitan la obtención de rentas a partir de recursos naturales agotables que son originariamente propiedad del Estado, es común que los Gobiernos establezcan algunos instrumentos fiscales relativamente fijos en las etapas más tempranas de los proyectos con el objeto de fijar ciertas pautas iniciales en su regulación. Entre ellos se destacan las subastas por el derecho de exploración y explotación como mecanismo competitivo para seleccionar al operador más eficiente que permita capturar el valor esperado de la renta económica potencial. Otro elemento recurrente (sobre todo en el sector de hidrocarburos) está constituido por los bonos de signatura (al momento de firmar los contratos), de descubrimiento (al momento de confirmar la viabilidad del yacimiento) y de producción (al momento de iniciar la producción efectiva). Todos estos bonos representan un monto fijo cuyo pago se "dispara" ante la ocurrencia de un evento y que guarda cierta relación con el tipo de explotación económica.

Véase un análisis detallado del diseño específico de estos instrumentos en Tordo (2007) y Boadway y Keen (2010). 


\section{Cuadro XIV.1}

Instrumentos usualmente aplicados en regímenes fiscales de industrias extractivas

\begin{tabular}{|c|c|c|c|}
\hline \multirow{3}{*}{ Instrumentos } & \multirow{3}{*}{ Descripción } & \multirow{2}{*}{\multicolumn{2}{|c|}{$\begin{array}{c}\text { Prevalencia } \\
\text { Número de países }\end{array}$}} \\
\hline & & & \\
\hline & & Minería & Hidrocarburos \\
\hline $\begin{array}{l}\text { Bono de } \\
\text { signatura }\end{array}$ & $\begin{array}{l}\text { Pago por adelantado para la adquisición de derechos } \\
\text { de exploración (comúnmente usados como parámetros } \\
\text { de subasta) }\end{array}$ & 1 & 16 \\
\hline $\begin{array}{l}\text { Bono de } \\
\text { producción }\end{array}$ & $\begin{array}{l}\text { Pago fijo al alcanzar cierto nivel de producción acumulada } \\
\text { o una tasa de producción determinada }\end{array}$ & Ninguno & 10 \\
\hline \multirow[t]{6}{*}{ Regalías } & Especificas (cantidad por unidad de volumen producido) & 2 & 1 \\
\hline & Ad valorem (porcentaje del valor de la producción) & 17 & 31 \\
\hline & Ad valorem progresiva con los precios & 1 & 9 \\
\hline & Ad valorem progresiva con la producción & Ninguno & 8 \\
\hline & $\begin{array}{l}\text { Ad valorem progresiva con el coeficiente de } \\
\text { explotación beneficios }\end{array}$ & 3 & 1 \\
\hline & Ad valorem aplicada sobre el margen operativo (utilidad neta) & 2 & Ninguno \\
\hline $\begin{array}{l}\text { Impuesto sobre } \\
\text { la renta de } \\
\text { sociedades } \\
\text { (nivel federal) }\end{array}$ & $\begin{array}{l}\text { Impuesto tradicional con tasa proporcional sobre los ingresos } \\
\text { netos de los costos y gastos deducibles (se suelen considerar } \\
\text { beneficios específicos de estos sectores) }\end{array}$ & 22 & 67 \\
\hline $\begin{array}{l}\text { Impuesto sobre } \\
\text { la renta de } \\
\text { sociedades (nivel } \\
\text { subnacional) }\end{array}$ & $\begin{array}{l}\text { Tasa de impuesto sobre la renta corporativo a nivel estatal, } \\
\text { provincial o local en adición al impuesto a nivel federal }\end{array}$ & 2 & 4 \\
\hline $\begin{array}{l}\text { Impuesto variable } \\
\text { sobre la renta } \\
\text { de sociedades }\end{array}$ & $\begin{array}{l}\text { Impuesto sobre la renta de sociedades con tasas crecientes } \\
\text { en función de tramos del nivel de ingreso }\end{array}$ & 3 & Ninguno \\
\hline \multirow[t]{4}{*}{$\begin{array}{l}\text { Impuestos sobre } \\
\text { la renta pura } \\
\text { del recurso }\end{array}$} & $\begin{array}{l}\text { Flujo de caja (ingresos menos costos y gastos en general, } \\
\text { con deducibilidad total de las pérdidas incrementadas para } \\
\text { mantener su valor presente) }\end{array}$ & 5 & 5 \\
\hline & $\begin{array}{l}\text { Flujo de caja con límites en el incremento en el valor } \\
\text { de las pérdidas acumuladas }\end{array}$ & Ninguno & 2 \\
\hline & Deducción por el capital ajeno invertido & Ninguno & 1 \\
\hline & $\begin{array}{l}\text { Deducción por patrimonio o capital propio, con } \\
\text { una tasa hipotética de retorno además del pago } \\
\text { de intereses financieros }\end{array}$ & Ninguno & 1 \\
\hline $\begin{array}{l}\text { Impuestos } \\
\text { adicionales sobre } \\
\text { las utilidades }\end{array}$ & $\begin{array}{l}\text { Otros mecanismos de tributación sobre los beneficios } \\
\text { distintos a los anteriores (por ejemplo, impuestos sobre las } \\
\text { utilidades extraordinarias en función de precios de referencia) }\end{array}$ & 1 & 3 \\
\hline \multirow{4}{*}{$\begin{array}{l}\text { Contratos de } \\
\text { producción } \\
\text { compartida }\end{array}$} & Cuota fija en la producción & Ninguno & 5 \\
\hline & $\begin{array}{l}\text { Factor R (proporción de los ingresos acumulados } \\
\text { sobre los costos acumulados) }\end{array}$ & Ninguno & 13 \\
\hline & Tasa de retorno, antes o después de impuestos & Ninguno & 3 \\
\hline & Nivel de producción & Ninguno & 13 \\
\hline \multirow[t]{3}{*}{$\begin{array}{l}\text { Participación } \\
\text { del Estado }\end{array}$} & $\begin{array}{l}\text { Participación libre (el Gobierno recibe un porcentaje de } \\
\text { los dividendos sin participar en el pago de los costos) }\end{array}$ & 2 & Ninguno \\
\hline & $\begin{array}{l}\text { Participación diferida (las contribuciones del Gobierno se } \\
\text { recuperan a través del cobro de dividendos más intereses } \\
\text { por el capital invertido) }\end{array}$ & 3 & 8 \\
\hline & $\begin{array}{l}\text { Participación pagada (el Gobierno paga su parte } \\
\text { de los costos y recibe dividendos en esa proporción) }\end{array}$ & Ninguno & 19 \\
\hline $\begin{array}{l}\text { Requerimientos } \\
\text { de inversiones } \\
\text { sociales o } \\
\text { infraestructura }\end{array}$ & $\begin{array}{l}\text { Empresas operadoras proveen infraestructura o hacen } \\
\text { otras inversiones sociales (escuelas, hospitales y demás) }\end{array}$ & 1 & 6 \\
\hline
\end{tabular}

Fuente: Fondo Monetario Internacional (FMI), "Fiscal Regimes for Extractive Industries: Design and Implementation" Fiscal Affairs Department, agosto de 2012 [en línea] https://www.imf.org/external/ np/pp/eng/2012/081512.pdf. 
En varios países también se exige el pago de cargos (fijos o variables) a las empresas concesionarias en concepto de arrendamiento y uso del terreno delimitado de cada proyecto. Estos cargos en general son aplicados por los gobiernos subnacionales y en ocasiones tienen cierta finalidad de protección ambiental. Como ejemplos pueden citarse los impuestos de extracción (severance taxes) aplicados en la gran mayoría de los estados estadounidenses y canadienses, donde la propiedad de los recursos — o del territorio del que se extraen- está en manos de privados, lo que transforma a estos instrumentos en sustitutos de las regalías que se utilizan en los países donde el Estado es el propietario legal de los recursos naturales no renovables.

En algunos casos, se ha optado por complementar el impuesto sobre la renta (ISR) que pagan las empresas con alícuotas adicionales, ya sea a nivel federal o subnacional. Ejemplos de la primera alternativa son Noruega, que aplica un tasa del 50\% sobre la producción de petróleo en adición a la alícuota general del $28 \%$, y el Reino Unido, donde se aplica una tasa del $30 \%$ a la producción sobre la plataforma continental (en lugar de la tasa estándar del 28\%). Para ilustrar la segunda variante pueden citarse los casos del Canadá, los Estados Unidos, la Federación de Rusia e Italia, con sobretasas a nivel estadual o local. Además, al contrario de la práctica convencional, algunos países, como Botswana, Sudáfrica (en la minería aurífera) y Zambia, han llegado a establecer un impuesto sobre los ingresos corporativos con alícuotas progresivas (FMI, 2012).

Por otra parte, la participación directa del Estado, principalmente en los sistemas contractuales aplicados en el sector petrolero, admite una serie de variantes que merecen identificarse. Una opción consiste en la compra, por parte del Estado, de una participación en la propiedad de las empresas mineras (este sistema se utiliza tanto en países desarrollados como en países en desarrollo). La participación puede contemplar un pago por el costo total de la inversión y el Estado recibe una cuota equivalente del flujo de utilidades más el rendimiento de la inversión como contraparte.

Otra alternativa disponible para los Estados, en su afán por participar en la explotación económica de los recursos naturales no renovables y así lograr un mejor control de la actividad de las empresas que operan en estos sectores, se refiere a los contratos de producción compartida, donde las compañías adquieren derechos de propiedad sobre la fracción del flujo de recursos producidos que queda después de entregar al Estado una parte de la producción (medida en términos físicos o monetarios) y de pagar las regalías. En general, si bien existen diferentes variantes, el contratista debe pagar todos los costos y riesgos asociados a la exploración y el Estado (generalmente a través de la empresa estatal) se reserva el derecho de asociarse en la etapa de desarrollo y producción del yacimiento. A su vez, es usual que el contratista deba cubrir los costos de capacitación del personal local, 
de operación y, en algunos casos, de exploración y desarrollo, aunque estos pueden recuperarse previo a la división de la producción entre la empresa y el Estado (Medinaceli, 2010).

Con el paso del tiempo, se han ido introduciendo impuestos con los que se busca gravar los beneficios que no son alcanzados por los instrumentos tradicionales (por ejemplo, los impuestos de retención sobre dividendos distribuidos por las empresas privadas). En esta línea, la literatura especializada en la materia ha puesto especial interés en los denominados "impuestos sobre la renta económica pura de los recursos".

En general, estos tributos están basados en los flujos de efectivo donde la totalidad de los gastos incurridos en la exploración, el desarrollo y la explotación de los yacimientos se deducen de manera total e inmediata de los ingresos, razón por la cual no suelen contemplar ningún mecanismo de depreciación contable ni tampoco prevén deducciones por intereses u otros costos financieros. Idealmente, cuando el flujo de efectivo neto es negativo, las pérdidas se trasladan a ejercicios futuros a una tasa de interés adecuada, de manera tal que el impuesto solo considere las transacciones reales en una base "caja o efectivo". En la literatura, este impuesto se denomina Brown tax y se considera un punto de referencia al evaluar otros instrumentos fiscales alternativos, ya que no solo establece una carga fiscal que se ajusta a la rentabilidad del inversionista, sino que asegura que este obtenga beneficios solamente hasta alcanzar una tasa de retorno "normal" (en función de los flujos de efectivo potenciales y de los riesgos asociados al proyecto) (CEPAL, 2015).

En la práctica, los países han adoptado distintas formas de implementación de este tipo de impuestos. El impuesto sobre la renta del recurso (resource rent tax), por ejemplo, replica las características del Brown tax a través de una deducción anual de las pérdidas acumuladas sobre las utilidades hasta que estas sean recuperadas sin la necesidad de devoluciones en efectivo (Garnaut y Clunies Ross, 1983). Australia utiliza este esquema en las industrias de hidrocarburos y minerales. Otra posibilidad consiste en ajustar las utilidades agregando la depreciación y los intereses y deduciendo por completo todos los gastos de capital para obtener una base imponible de flujo neto de efectivo, sobre la cual se aplica una sobretasa. En esta metodología, aplicada en el Reino Unido, la deducción por la inversión realizada no se prorroga, sino que se agrega a los costos de capital al inicio del proyecto (CEPAL, 2015).

Existen otros mecanismos que modifican el impuesto societario tradicional y que - en esencia - también replican los efectos de un impuesto de este tipo sobre la renta económica pura. En un esquema con deducción por el capital ajeno invertido (allowance for corporate capital), en lugar del 
reconocimiento fiscal de los intereses sobre la deuda, a las empresas se les permite deducir una tasa de retorno imputado sobre la base íntegra de activos, eliminando cualquier distinción entre las formas de financiamiento (deuda o capital propio). El impuesto especial sobre el petróleo que aplica Noruega se aproxima a este esquema, donde se combinan una deducción sobre la inversión total, una limitación en la deducción de intereses y un reembolso por las pérdidas originadas en la etapa de exploración. De manera alternativa, puede implementarse una deducción por capital propio (allowance for corporate equity), que también modifica el cálculo del ISR para la empresa, ya que, además de la deducción estándar para los intereses de la deuda, a las empresas se les permite deducir una tasa de retorno nocional sobre el patrimonio neto contable. Este mecanismo lo aplican actualmente Bélgica y el Brasil, y en el pasado también fue utilizado en Croacia e Italia. A pesar de sus diferencias, en estas dos variantes, el pago de impuestos a lo largo de la vida de un proyecto es generalmente anterior (cuando el ingreso anual cubre el costo anual de financiamiento del capital) al que se observaría en un esquema con un impuesto del estilo brown tax, que solo genera una obligación fiscal efectiva recién cuando todos los costos asociados al proyecto se recuperan por completo (FMI, 2012).

Independientemente de la forma específica que adopten estos tributos, debe tenerse en cuenta que la justificación económica que subyace tras su uso se relaciona con el concepto de progresividad fiscal dado por la capacidad de lograr una mayor apropiación por parte del Estado de las rentas económicas generadas en las industrias extractivas a medida que dichas rentas se incrementan con la evolución de los proyectos ${ }^{6}$.

En años más recientes, se han añadido al menú las regalías contingentes (sliding-scale royalties), las regalías sobre utilidades o sobre algún concepto de ingresos netos, y los impuestos sobre ganancias extraordinarias o inesperadas (windfall taxes). Estos instrumentos tienen una racionalidad económica en común: dada la elevada volatilidad de los precios internacionales de los productos primarios (hidrocarburos y minerales especialmente), se busca contar con algún mecanismo que permita a los Estados disponer de cierto grado de reacción fiscal ante cambios contextuales. Sobre todo durante ciclos de crecimiento acelerado de los precios de referencia, que podrían dar origen a rentas extraordinarias en las empresas, este tipo de instrumentos suele contar con algún umbral mínimo a partir del cual su impacto fiscal se hace efectivo y, en la mayoría de los casos, contemplan una serie de alícuotas escalonadas que varía en función de un precio internacional de referencia (CEPAL, 2015).

Véase una exposición analítica de las distintas variantes existentes en Boadway y Keen (2010). 


\section{B. Experiencias y reformas recientes en la región}

En los países de América Latina y el Caribe que poseen importantes dotaciones de recursos naturales no renovables, la forma más directa en que los Gobiernos se apropian de los ingresos por la exportación de productos básicos y los transforman en recursos fiscales ha sido, históricamente, mediante su participación en la explotación, ya sea a través de empresas públicas o mediante una participación accionaria (Jiménez y Tromben, 2006). Dichas empresas suelen estar sometidas a un régimen tributario especial que puede consistir en pagos de alquileres o cánones, en impuestos adicionales para las empresas públicas o en impuestos especiales sobre la producción de petróleo.

Sin embargo, ante la magnitud y la persistencia del ciclo alcista de precios que se inició en 2003, los países productores/exportadores de la región encontraron argumentos suficientes para introducir reformas significativas en los regímenes fiscales aplicados a la producción de hidrocarburos y minerales, con el principal objetivo de incrementar y garantizar una apropiada captación de ingresos por parte del Estado.

Como se destaca en CEPAL (2013), entre 2005 y 2012 las reformas legales más importantes dirigidas a asegurar el control público de los recursos naturales no renovables se enfocaron en el sector de hidrocarburos. Estas medidas incluyeron la nacionalización de dicho sector a través de empresas mixtas en Venezuela (República Bolivariana de) (entre 2005 y 2007), la nacionalización de hidrocarburos y la reestatización de la mina de estaño Huanuni en Bolivia (Estado Plurinacional de) (2006), la renegociación de contratos petroleros en el Ecuador (2010) —donde se cambiaron contratos de producción compartida por contratos de servicios donde el Estado es propietario de todo el petróleo crudo extraído con la estipulación de que el Gobierno capturaría el 100\% de los eventuales incrementos del precio del petróleo-, la expropiación del 51\% de las acciones de YPF en la Argentina (2012) y la nacionalización de la mina de Colquirí, en Oruro, Bolivia (Estado Plurinacional de) (2012).

Además, los Gobiernos han reforzado otros mecanismos de apropiación estatal, como las regalías, habitualmente basadas en la producción, y los impuestos específicos. Esto ha sido especialmente importante en el sector de la minería, donde la captación de recursos por la vía de la participación estatal en empresas ha sido de menor importancia relativa. Las regalías y los impuestos han permitido asegurar un pago mínimo por los recursos a los Gobiernos, tanto nacionales como subnacionales, como ocurre en un número creciente de países donde se han introducido reformas en los sistemas de regalías, incluidos Bolivia (Estado Plurinacional de) (2005), el Ecuador (2010), Colombia (2011) y el Perú (2011). En el Ecuador, además, la reforma a la Ley de Hidrocarburos estableció el denominado "margen de soberanía", destinado a garantizar un ingreso mínimo al Estado ante posibles disminuciones de precios por un monto del $25 \%$ del valor bruto de producción. 
En algunos de los casos mencionados, no solo se han modificado los niveles de imposición, sino que se establecieron escalas de alícuotas variables en función de criterios de fácil verificación, como el nivel de producción, la ubicación y profundidad de los pozos, el tipo de recurso extraído u otra variable relacionada con la estructura de costos. En el Perú, por ejemplo, a partir de la modificación de la Ley de Regalías Mineras en septiembre de 2011, este instrumento ya no tiene como base las ventas (vigente desde 2004) sino la utilidad operativa, sobre la cual se aplica una escala de alícuotas marginales progresivas - que van del $1 \%$ al 7,14\% (con una tasa efectiva máxima del $12 \%$ - en función del margen operativo de la empresa.

En la mayoría de los casos también se ha aplicado el tradicional ISR con tasas diferenciales junto con otros gravámenes especiales, a menudo con tasas progresivas, sobre las empresas públicas o privadas dedicadas a la explotación de recursos no renovables. Esto se ha reforzado en el período 2005-2012 mediante la introducción de nuevos instrumentos de recaudación.

Entre los casos más salientes se destaca el del Estado Plurinacional de Bolivia, donde en 2005 se introdujo el impuesto directo a los hidrocarburos (IDH), el cual, sumado a las regalías y participaciones al Tesoro General del Estado (TGE), llevó al 50\% la participación directa del Estado sobre las rentas extractivas. En Chile, a partir de 2006 se introdujo el impuesto específico a la actividad minera (IEAM) con el objetivo de fortalecer la tributación sobre la minería (complementando al impuesto societario y al adicional sobre remesas de utilidades al exterior) y no desalentar la inversión privada, para lo cual se aplicó sobre una forma de renta neta que contemplaba los costos por depreciación financiera del equipo de capital y los intereses. En la República Bolivariana de Venezuela se aumentaron las tasas del ISR del petróleo (50\%) a partir de 2006 y se crearon tres nuevos impuestos: el impuesto a la extracción de crudo, el impuesto al registro de exportación y la contribución especial sobre precios extraordinarios y exorbitantes del mercado internacional. En el Perú se introdujeron dos nuevos instrumentos a finales de 2011: el impuesto especial a la minería (IEM) y el gravamen especial a la minería (GEM), cuyo pago es deducible como gasto a los efectos del cálculo del ISR y con tasas aplicables de acuerdo con una escala progresiva en función del margen operativo (ingresos por ventas después de deducir el costo de ventas y los gastos operativos, incluidos los gastos de venta y administrativos) ${ }^{7}$.

La diferencia fundamental entre ambos instrumentos fiscales es que el IEM se aplica de forma exclusiva sobre empresas mineras que no gozan de convenios de estabilidad tributaria, mientras que el GEM grava específicamente la actividad minera suscrita a través de convenios con el Estado en proyectos con contratos de garantías y medidas de fomento de la inversión de conformidad con la Ley General de Minería. La diferencia en las tasas aplicables (mayores en el GEM que en el IEM) tiene por objeto hacer que la carga tributaria sea relativamente equivalente para todas las empresas mineras. 
Por otra parte, dada la elevada volatilidad de los precios internacionales de los recursos no renovables, varios países también han considerado la aplicación de impuestos, derechos, participaciones o contribuciones vinculadas a precios o utilidades extraordinarias, como ha sucedido en Bolivia (Estado Plurinacional de), el Brasil, Colombia, el Ecuador, Trinidad y Tabago y Venezuela (República Bolivariana de) ${ }^{8}$. Aunque la heterogeneidad es muy amplia en esta materia, todos los países que introdujeron este tipo de instrumentos fiscales - principalmente en el sector de hidrocarburos- lo han hecho en el período de auge de precios (2003-2008), en clara respuesta al formidable incremento en la renta económica asociada a los sectores de hidrocarburos y minerales en los países de la región?.

Como señalan Acquatella y otros (2013), los avances en materia de progresividad del régimen fiscal han sido más claros y concretos en el sector petrolero que en el sector minero de los países de América Latina y el Caribe. En la explotación de hidrocarburos, por ejemplo, es común el contrato de riesgo o producción compartida que incorpora una escala creciente de participación del Estado en las utilidades a medida que el proyecto alcanza tasas de retorno cada vez mayores. La incorporación de este tipo de concepto en el tratamiento fiscal del sector minero es todavía muy incipiente en los países de la región. Quizás la única excepción sea el contrato del proyecto Pueblo Viejo, firmado entre el Gobierno de la República Dominicana y Barrick Gold Corporation, en el cual se incorpora la condición de que, una vez que el proyecto haya alcanzado la tasa interna de retorno del $10 \%$, el Estado entra a participar con un $28,75 \%$ en la utilidad neta. En combinación con la regalía del 3,2\% y el ISR del 25\%, este instrumento aproximaría la participación de la República Dominicana a un 50\% de los flujos netos del proyecto en los años de operación.

En relación con lo expuesto, las medidas más recientes — anunciadas o promulgadas- revelan, además de la necesidad de mantener o aumentar la contribución fiscal de los recursos naturales no renovables, una creciente preocupación por fortalecer los mecanismos que garanticen la participación de la inversión privada en la producción.

En términos generales, tal como se detalla en la publicación de OCDE/ CEPAL/CIAT/BID (2016) sobre estadísticas tributarias en América Latina y el Caribe, los ingresos públicos provenientes de recursos naturales no renovables

El impuesto adicional del 25\% sobre las utilidades extraordinarias del Estado Plurinacional de Bolivia fue derogado con la Ley de Hidrocarburos núm. 3058 (2005) y sustituido por la participación de YPFB en los nuevos contratos de operación.

9 De acuerdo con CEPAL (2014), la renta económica del sector minero se triplicó en América Latina y el Caribe como porcentaje del PIB durante el período de aumento de precios de 2004 a 2009 con relación al período 2000-2003 (pasó del 0,6\% al 1,98\% del PIB regional), mientras que en el sector de hidrocarburos también se registró un incremento en la mayor parte de la región gracias a los altos precios internacionales, aunque este fue más moderado en algunos países (Argentina, México, Venezuela (República Bolivariana de)) debido al descenso de la producción en los principales campos petrolíferos. 
registraron una pronunciada caída en 2015 (medida como proporción del PIB), como resultado de la continua debilidad de los precios internacionales de los productos básicos. Así, según el trabajo citado, se estima que los ingresos provenientes de los hidrocarburos en América Latina y el Caribe han regresado en 2015 a los niveles que registraban previo al auge de precios de la década de 2000, con un descenso de 2,1 puntos porcentuales del PIB, en promedio, hasta ubicarse en un $4,5 \%$ del PIB (véase el gráfico XIV.2). Por su parte, los ingresos derivados de la minería han registrado un leve descenso en 2015, aunque continúa una tendencia declinante iniciada alrededor de 2011 para la mayoría de los productores de la región.

\section{Gráfico XIV.2 \\ América Latina y el Caribe (10 países): ingresos provenientes de recursos naturales no renovables, 2000-2015 \\ (En porcentajes del PIB)}

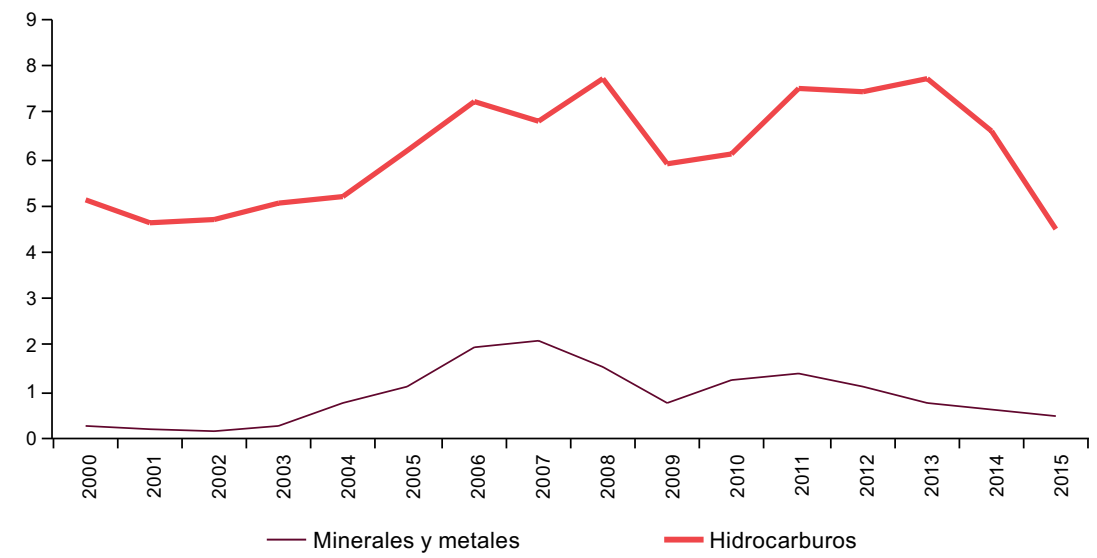

Fuente: Organización de Cooperación y Desarrollo Económicos (OCDE)/Comisión Económica para América Latina y el Caribe (CEPAL)/Centro Interamericano de Administraciones Tributarias (CIAT)/Banco Interamericano de Desarrollo (BID), Estadísticas tributarias en América Latina y el Caribe 1990-2014, París, OECD Publishing, 2016.

\section{Hidrocarburos}

El monto de ingresos fiscales provenientes del sector de hidrocarburos puede analizarse a partir de distintos indicadores que surgen de ponderar el monto total de estos recursos (tanto los de carácter tributario como no tributario) en función de algunas variables de referencia ${ }^{10}$. En particular, aquí se considerarán los siguientes indicadores:

10 No se desconoce, no obstante, el hecho de que en algunos países de la región pueden ser importantes los impuestos sobre la comercialización de los combustibles y demás derivados de los hidrocarburos. No solo el impuesto específico sobre el consumo de estos productos, sino también el IVA y el derecho de importación que recaen sobre estos sectores pueden generar, en algunos casos, montos considerables de recursos tributarios. 
- La presión fiscal sobre el sector (en porcentajes del PIB) como una medida estándar de la magnitud y relevancia de los recursos fiscales involucrados.

- El grado de dependencia fiscal (en porcentajes del total de ingresos fiscales) como una medida de la vulnerabilidad del financiamiento del Estado.

Si se considera el primer indicador señalado, puede afirmarse que el ciclo alcista del precio internacional de los hidrocarburos (particularmente el petróleo crudo), iniciado en los primeros años de la década de 2000, ha propiciado un aumento de los ingresos fiscales derivados de la explotación de estos recursos naturales en varios países de la región. Sin embargo, su relevancia económica es diferente y ha variado según el país considerado.

En la primera columna del cuadro XIV.2 se presentan los valores medios (datos acumulados calculados sobre la base de moneda nacional corriente) de la carga fiscal representada por este tipo de recursos en tres períodos distintos: 2000-2003 (antes del inicio del ciclo alcista de precios), 2005-2008 (años de notable crecimiento en el precio internacional de los productos primarios) y 2010-2014 (después de la crisis financiera internacional de 2008-2009)11.

Mientras que en la Argentina, el Brasil y el Perú los recursos fiscales derivados de la explotación de hidrocarburos no alcanzan una magnitud demasiado significativa (al menos en relación con otros sectores de la economía), en el resto de los países se observa lo contrario, especialmente en Bolivia (Estado Plurinacional de), el Ecuador, Trinidad y Tabago y Venezuela (República Bolivariana de), en donde se alcanzaron niveles cercanos e incluso superiores al 10\% del PIB. Estas contribuciones también son importantes, aunque en menor medida, en Colombia, México y Suriname, donde superan el 3\% del PIB (véase el cuadro XIV.2).

Además, varios de estos países muestran una evolución desigual de la carga fiscal del sector de hidrocarburos. Por ejemplo, gracias a las reformas estructurales realizadas en el período de auge de precios (cambio de régimen fiscal con la creación del IDH y la readecuación de las regalías), el Estado Plurinacional de Bolivia llevó el monto medio de ingresos fiscales de valores comprendidos entre 2 y 3 puntos porcentuales del PIB para el período 2000-2003 a un rango de entre el $8 \%$ y el 12\% del PIB a partir de $2006^{12}$. Esta singular tendencia también se registró, con ciertas variaciones, en Colombia, el Ecuador, México y Suriname. En Trinidad y Tabago y Venezuela

\footnotetext{
11 Si bien se buscó abarcar la mayor cantidad de años posible, se decidió suprimir el año 2009 de los períodos seleccionados para evitar las distorsiones derivadas de los drásticos efectos de la crisis económica del bienio 2008-2009.

12 Sería errado, sin embargo, no reconocer también en esta evolución la influencia de los precios más elevados y los mayores volúmenes contractuales de exportación de gas natural con destino a la Argentina y el Brasil.
} 
(República Bolivariana de), en cambio, se observó una disminución reciente de los ingresos fiscales por hidrocarburos respecto de los valores máximos alcanzados en los años previos a la crisis.

\section{Cuadro XIV.2}

\section{América Latina y el Caribe (10 países): indicadores relativos de los ingresos fiscales} generados por la producción de hidrocarburos, 2000-2014 (En porcentajes)

\begin{tabular}{|c|c|c|c|c|c|c|}
\hline \multirow[t]{2}{*}{ Países } & \multicolumn{3}{|c|}{ En proporción al PIB total del país } & \multicolumn{3}{|c|}{$\begin{array}{l}\text { En proporción a los ingresos } \\
\text { fiscales totales }\end{array}$} \\
\hline & $2000-2003$ & $2005-2008$ & $2010-2014$ & $2000-2003$ & $2005-2008$ & 2010-2014 \\
\hline Argentina & 0,8 & 1,6 & 1,0 & 4,5 & 7,3 & 3,4 \\
\hline $\begin{array}{l}\text { Bolivia (Estado } \\
\text { Plurinacional de) }\end{array}$ & 2,7 & 9,1 & 10,6 & 11,0 & 28,2 & 30,2 \\
\hline Brasil & 0,8 & 1,2 & 0,8 & 2,8 & 3,9 & 3,0 \\
\hline Colombia & 1,6 & 2,4 & 3,4 & 5,6 & 8,2 & 12,0 \\
\hline Ecuador & 5,7 & 8,7 & 12,8 & 29,3 & 35,3 & 38,2 \\
\hline México $^{\circ}$ & 3,0 & 5,9 & 5,3 & 21,1 & 38,3 & 32,7 \\
\hline Perú & 0,5 & 1,1 & 1,4 & 3,2 & 5,9 & 6,9 \\
\hline Suriname & 3,6 & 5,2 & 5,8 & $\ldots$ & 20,7 & 24,8 \\
\hline $\begin{array}{l}\text { Trinidad y } \\
\text { Tabago }\end{array}$ & 7,6 & 16,2 & 12,4 & 31,3 & 51,8 & 40,2 \\
\hline $\begin{array}{l}\text { Venezuela } \\
\text { (República } \\
\text { Bolivariana de) }\end{array}$ & 10,5 & 13,8 & 9,9 & 48,2 & 50,6 & 39,3 \\
\hline
\end{tabular}

Fuente: Comisión Económica para América Latina y el Caribe (CEPAL), sobre la base de cifras oficiales.

a Los ingresos fiscales incluyen recursos tributarios y no tributarios vinculados a la producción de hidrocarburos. El detalle de los instrumentos considerados en cada caso puede encontrarse en Gómez Sabaini, Jiménez y Morán (2015).

b Se consideran los ingresos fiscales totales del Gobierno general netos de las contribuciones de la seguridad social. No obstante, en la Argentina, Colombia y el Ecuador se toma en cuenta la información a nivel del sector público no financiero (SPNF) en términos netos, salvo en el caso de Colombia.

c No incluye los ingresos propios de la empresa petrolera estatal PEMEX.

Otro indicador relevante tiene que ver con la importancia relativa de los ingresos fiscales provenientes de la explotación de hidrocarburos en el financiamiento del Estado. En este sentido, durante la última década se ha observado una mayor vulnerabilidad de las economías respecto del sector por la evidente dependencia de los ingresos del Gobierno general en relación con la recaudación fiscal tributaria (especialmente del ISR) y no tributaria (por medio de regalías y otros) aplicada al uso y explotación de los recursos petroleros y gasíferos. Es así como en el último período, comprendido entre 2010 y 2013, el sector aportó un 30\% o más de los ingresos totales necesarios para financiar el gasto público en países como Bolivia (Estado Plurinacional de), el Ecuador, México, Trinidad y Tabago y Venezuela (República Bolivariana de). A excepción de este último caso (donde la participación se aproxima al $39 \%$ y se observa una considerable merma de aproximadamente 9 puntos porcentuales, aunque desde valores muy elevados), esto también pone en 
evidencia un claro y notable crecimiento del peso específico de estos recursos fiscales respecto de los valores calculados para el período 2000-2003 (véase el cuadro XIV.2).

Desde el punto de vista del financiamiento del Estado, esto impone como desafío la búsqueda de una mayor diversificación de fuentes de ingreso con el fin de evitar la denominada "pereza fiscal". Esta hipótesis bastante peculiar sostiene que la disponibilidad de ingresos fiscales provenientes de los recursos naturales disminuye los incentivos para recaudar impuestos generales en el resto de la economía y los Gobiernos con estas características tienden a ser menos transparentes, responsables y eficientes. Además, la dependencia fiscal de los sectores de recursos no renovables aumenta los riesgos fiscales, dado que estos ingresos son volátiles y, lo que también es importante, están sujetos a un proceso de agotamiento. Por lo tanto, los encargados de formular políticas públicas tienen que planificar con una mirada prospectiva, a fin de reemplazar esos recursos con otras fuentes a medida que decaigan.

Por otra parte, un análisis más detallado de los datos disponibles permite comprobar los cambios - en algunos casos, muy notorios-que se han registrado en términos de la estructura de los regímenes fiscales aplicados por los países de la región, cada uno con diferentes criterios en cuanto a la propiedad de los recursos, a la participación del Estado en la producción (con la intervención de grandes empresas de bandera nacional) y a la aplicación de instrumentos de recaudación como el ISR de las sociedades, las regalías y otros ${ }^{13}$. También aquí puede verse la marcada heterogeneidad que caracteriza a estos regímenes fiscales para el sector de hidrocarburos, así como las distintas estrategias económicas y filosofías políticas que los países muestran en el afán de lograr una adecuada extracción fiscal de parte de las rentas generadas en estas actividades.

En el cuadro XIV.3 se presenta la estructura de participación relativa de los ingresos fiscales provenientes de la producción de hidrocarburos en los diez países de la región considerados y en los mismos tres períodos establecidos anteriormente. En gran parte como resultado de las reformas implementadas en el período de auge de precios, algunos países, como la Argentina, Bolivia (Estado Plurinacional de), el Brasil o Colombia, exhiben regímenes fiscales con cierta diversificación en su estructura, con participaciones variables del ISR corporativa, las regalías (generalmente fijas) y otros instrumentos más específicos del sector de hidrocarburos. Sin embargo, en Trinidad y Tabago, el ISR de las sociedades aporta la mayor parte de la recaudación, con una

13 Si bien las regalías percibidas por el derecho a extraer petróleo o gas (así como a explotar otros recursos minerales) suelen considerarse como ingresos no tributarios, en algunos casos, la aplicación de criterios para distinguir un impuesto puede resultar particularmente problemática. El caso más emblemático es el de los derechos sobre la producción de hidrocarburos en México, donde no existe consenso general acerca de su clasificación como tributo. 
participación media superior al 80\% entre 2010 y 2014. Esto contrasta mucho con el caso del Perú, donde la mayoría de los ingresos fiscales derivados de la explotación de hidrocarburos proviene de las regalías.

\section{Cuadro XIV.3}

\section{América Latina y el Caribe (10 países): estructura de los ingresos fiscales} provenientes del sector de hidrocarburos, 2000-2014

(En porcentajes del total)

\begin{tabular}{|c|c|c|c|c|}
\hline Países & Instrumento & $2000-2003$ & $2005-2008$ & 2010-2014 \\
\hline \multirow[t]{3}{*}{ Argentina } & Impuesto sobre la renta & 29,7 & 34,3 & 24,6 \\
\hline & Regalías $^{a}$ & 59,6 & 33,0 & 42,0 \\
\hline & Otros & 10,7 & 32,7 & 33,4 \\
\hline \multirow{3}{*}{$\begin{array}{l}\text { Bolivia (Estado } \\
\text { Plurinacional de) }\end{array}$} & Impuesto sobre la renta & 5,2 & 6,9 & 6,1 \\
\hline & Regalías & 94,8 & 35,8 & 34,1 \\
\hline & Otros & 0,0 & 57,3 & 59,8 \\
\hline \multirow[t]{3}{*}{ Brasil } & Impuesto sobre la renta & 39,0 & 35,2 & 12,6 \\
\hline & Regalías & 26,3 & 26,3 & 36,5 \\
\hline & Otros & 34,7 & 38,5 & 50,9 \\
\hline \multirow[t]{3}{*}{ Colombia } & Impuesto sobre la renta & 22,9 & 30,9 & 31,1 \\
\hline & Regalías & 51,2 & 41,3 & 33,9 \\
\hline & Otros & 25,9 & 27,8 & 35,0 \\
\hline \multirow[t]{3}{*}{ Ecuador } & Impuesto sobre la renta & 0,0 & 0,0 & 0,0 \\
\hline & Regalías & 0,0 & 0,0 & 0,0 \\
\hline & Otros & 100,0 & 100,0 & 100,0 \\
\hline \multirow[t]{3}{*}{ México } & Impuesto sobre la rentab & 0,0 & 0,5 & 0,3 \\
\hline & Regalias & 0,0 & 0,0 & 0,0 \\
\hline & Otros & 100,0 & 99,5 & 99,7 \\
\hline \multirow[t]{3}{*}{ Perú } & Impuesto sobre la renta & 15,4 & 24,1 & 27,2 \\
\hline & Regalías & 84,6 & 75,9 & 72,8 \\
\hline & Otros & 0,0 & 0,0 & 0,0 \\
\hline \multirow[t]{3}{*}{ Suriname } & Impuesto sobre la renta & 60,3 & 49,9 & 47,4 \\
\hline & Regalías & 0,0 & 0,0 & 0,0 \\
\hline & Otros & 39,7 & 50,1 & 52,6 \\
\hline \multirow[t]{3}{*}{ Trinidad y Tabago } & Impuesto sobre la renta & 64,1 & 85,1 & 80,2 \\
\hline & Regalías & 16,5 & 7,5 & 11,4 \\
\hline & Otros & 19,3 & 7,4 & 8,4 \\
\hline \multirow{3}{*}{$\begin{array}{l}\text { Venezuela (República } \\
\text { Bolivariana de) }\end{array}$} & Impuesto sobre la renta & 19,8 & 25,1 & 14,5 \\
\hline & Regalías & 53,2 & 68,8 & 33,6 \\
\hline & Otros & 27,0 & 6,0 & 51,9 \\
\hline
\end{tabular}

Fuente: Elaboración propia, sobre la base de información oficial de los países y la Comisión Económica para América Latina y el Caribe (CEPAL).

a En la Argentina, las regalías incluyen el valor residual por minería.

b Corresponde al impuesto a los rendimientos petroleros (PEMEX está exenta del ISR convencional).

El Ecuador y México constituyen dos casos singulares en este sentido, ya que el peso de la tributación sobre la renta y de las regalías es nulo en términos de recaudación y los ingresos fiscales del sector se vinculan más directamente con mecanismos de control y administración operativa de las respectivas 
empresas nacionales. Los datos para el Ecuador suelen presentarse como ingresos petroleros del Gobierno Central (por ventas internas y exportaciones) sin discriminar por instrumento fiscal, mientras que en el caso de México prácticamente la totalidad de los ingresos considerados corresponden a los derechos sobre hidrocarburos y un resto marginal proviene del impuesto a los rendimientos petroleros.

En definitiva, a partir de la observación de todos los datos presentados, en el sector de hidrocarburos no parece observarse un patrón definido que relacione el tipo de instrumento utilizado y el desempeño fiscal en términos de recursos obtenidos. De hecho, los cuatro países con mayor carga fiscal y mayor dependencia fiscal respecto de estos recursos (Bolivia (Estado Plurinacional de), Ecuador, Trinidad y Tabago y Venezuela (República Bolivariana de)) poseen regímenes fiscales muy diferentes entre sí, aunque en todos ellos la empresa estatal tiene un papel preponderante en la producción de hidrocarburos.

\section{Minerales}

De forma análoga al sector de hidrocarburos, el funcionamiento de los regímenes fiscales aplicados al sector minero puede analizarse de manera descriptiva considerando la cuantía y representatividad de los ingresos fiscales obtenidos por los países productores de América Latina y el Caribe ${ }^{14}$. Además, a los efectos de este trabajo, resulta útil e ilustrativo proceder en términos comparativos, procurando identificar las principales semejanzas o diferencias respecto de lo observado en el sector de hidrocarburos de los países de la región, para lo cual se tomarán como referencia los mismos períodos analizados en la sección B.1.

En primer lugar, a partir de los cálculos del Banco Mundial (World Development Indicators), se ha podido comprobar que la renta económica potencial del sector minero se incrementó mucho a partir de 2003, especialmente en los países de mayor tradición minera y con una importante participación de este sector en la economía. Esto fue evidente por ejemplo en Chile, donde la renta económica llegó a superar el 20\% del PIB en el bienio 2006-2007, cuando apenas promediaba el 6,6\% en el período 2000-2003. El Perú es otro caso a destacar: la renta minera estimada pasó de un promedio del 0,4\% del PIB en el período 2000-2003 a un valor máximo del 11,9\% del PIB en 2007, y se mantuvo en torno al 10\% entre 2010 y 2014.

Este notable incremento de la renta económica en la actividad minera hacia mediados de la década pasada tuvo como correlato un significativo

14 Respecto de la actividad minera, los países analizados son: Argentina, Bolivia (Estado Plurinacional de), Brasil, Chile, Colombia, Jamaica, México y Perú. La selección de estos países responde a la relevancia económica actual del sector minero en cada uno de ellos (como proporción de las exportaciones y su aporte al PIB o al financiamiento del Estado). 
aumento, en términos absolutos, de los ingresos fiscales provenientes del sector minero. Precisamente, en países como Bolivia (Estado Plurinacional de), Chile y el Perú (donde el aumento de la renta minera fue comparativamente mayor), este tipo de recursos experimentó un crecimiento superlativo. Con un alza algo menor, les sigue Colombia, único caso en el que, por su relevancia, se incluyen los ingresos fiscales provenientes de la explotación de carbón mineral. En el cuadro XIV.4 se presentan los valores medios acumulados de la carga fiscal que aporta el sector de minerales en un conjunto de ocho países de la región.

\section{Cuadro XIV.4}

América Latina y el Caribe (8 países): indicadores relativos de los ingresos fiscales generados por la producción de minerales, 2000-2014a

(En porcentajes)

\begin{tabular}{|c|c|c|c|c|c|c|}
\hline \multirow{2}{*}{ Países } & \multicolumn{3}{|c|}{ En proporción al PIB total del país } & \multicolumn{3}{|c|}{$\begin{array}{l}\text { En proporción a los ingresos } \\
\text { fiscales totales }\end{array}$} \\
\hline & $2000-2003$ & $2005-2008$ & $2010-2014$ & $2000-2003$ & $2005-2008$ & $2010-2014$ \\
\hline Argentina & 0,0 & 0,1 & 0,1 & 0,0 & 0,4 & 0,4 \\
\hline $\begin{array}{l}\text { Bolivia (Estado } \\
\text { Plurinacional de) }\end{array}$ & 0,1 & 0,7 & 1,0 & 0,4 & 2,0 & 2,8 \\
\hline Brasil & 0,0 & 0,2 & 0,2 & 0,1 & 0,5 & 0,8 \\
\hline Chile & 0,8 & 6,9 & 3,0 & 4,0 & 28,1 & 13,8 \\
\hline CODELCO & 0,6 & 4,3 & 1,6 & 3,2 & 17,5 & 7,4 \\
\hline $\begin{array}{l}\text { Minería Privada } \\
(\text { GMP-10) }\end{array}$ & 0,2 & 2,6 & 1,4 & 0,8 & 10,6 & 6,4 \\
\hline Colombia & 0,2 & 0,5 & 0,4 & 0,5 & 1,5 & 1,3 \\
\hline Jamaica & 0,5 & 0,6 & 0,1 & 2,1 & 2,1 & 0,4 \\
\hline México & 0,0 & 0,1 & 0,2 & 0,3 & 0,8 & 1,0 \\
\hline Perú & 0,2 & 2,1 & 1,3 & 1,0 & 10,6 & 6,4 \\
\hline
\end{tabular}

Fuente: Comisión Económica para América Latina y el Caribe (CEPAL), sobre la base de cifras oficiales.

a Los ingresos fiscales incluyen recursos tributarios y no tributarios vinculados a la producción de minerales. El detalle de los instrumentos considerados en cada caso puede encontrarse en Gómez Sabaini, Jiménez y Morán (2015).

b Aquí se consideran los ingresos fiscales totales del Gobierno general netos de las contribuciones de la seguridad social. No obstante, en la Argentina y Colombia se toma en cuenta la información a nivel del sector público no financiero (SPNF) en términos netos, salvo en el caso de Colombia.

Al igual que ocurrió en el sector de hidrocarburos, con posterioridad a la crisis financiera internacional, los países mostraron una recuperación importante en el indicador señalado durante 2010 y 2011. Sin embargo, los ingresos fiscales aportados por el sector minero sufrieron un estancamiento y una progresiva caída en la mayoría de los países de la región durante los años posteriores (2012, 2013 y 2014). Se destaca la gran reducción experimentada por Chile, donde los ingresos fiscales mineros bajaron hasta un monto equivalente al 3,9\% del PIB en 2014 (tras alcanzar un 8,2\% del PIB en 2007) ${ }^{15}$.

15 Vale agregar que el Gobierno de Chile estima un descenso adicional de 0,5 puntos del PIB para 2015 (OCDE/CEPAL/CIAT/BID, 2016). 
En el cuadro XIV.4 también puede comprobarse que en el período más reciente (2010-2014), algunos países han logrado recuperar parcialmente y estabilizar la cuantía del aporte fiscal minero como porcentaje de los ingresos fiscales totales respecto de los valores alcanzados en los años previos a la crisis financiera mundial. Tal es el caso del Perú, donde dicho indicador alcanzó el 10,6\%, como promedio, entre 2005 y 2008 (tras partir de un $1,0 \%$ en $2000-2003)$ y se ubicó levemente por debajo $(6,4 \%)$ en el período más reciente. Chile, por su parte, presenta una tendencia más acentuada: el monto de ingresos fiscales provenientes del sector minero alcanzaba un magro promedio del $4,0 \%$ de los ingresos fiscales totales del Gobierno en el período $2000-2003$, ascendió a un notable $28,1 \%$ en pleno auge de precios internacionales $\mathrm{y}$, a pesar de la fuerte caída de estos recursos en términos absolutos, mantuvo ese grado de dependencia fiscal respecto de la actividad minera en un valor medio del 13,8\% en el período 2010-2014. El resto de los países analizados muestra un comportamiento dispar, aunque en ningún caso los ingresos fiscales provenientes del sector minero constituyen una fuente significativa de financiamiento del Estado.

Respecto de la composición de los regímenes fiscales aplicados sobre la actividad minera en América Latina y el Caribe, y en claro contraste con lo que ocurre en el sector de hidrocarburos, la diversidad de los instrumentos que los componen es mucho más acotada, y el ISR de las empresas es el principal instrumento mediante el cual el Estado se apropia de una parte en las rentas generadas por la explotación minera (véase el cuadro XIV.5). Se destacan, asimismo, los cambios observados en Chile, a partir de la introducción del impuesto específico a la actividad minera (asimilable a una regalía escalonada), y en el Perú, con la incorporación de dos nuevos instrumentos (el IEM y el GEM), que ampliaron la diversidad de sus respectivos regímenes fiscales sobre la actividad minera.

Además, los regímenes fiscales diseñados específicamente para captar una proporción de la renta minera se han complementado, en la mayoría de los países de la región y al igual que en el sector de hidrocarburos, con la aplicación de distintos sistemas de regalías habitualmente basadas en la producción. Algunos países - en particular Chile y el Perú- reaccionaron al auge de precios iniciado en 2003 con la introducción del pago de regalías, cuya determinación está vinculada a los márgenes operativos de las empresas mineras, con lo que se busca asegurar una participación progresiva del Estado en períodos de utilidades extraordinarias.

La práctica observada a nivel regional, sobre todo en el sector minero, hace que la regalía termine siendo un mecanismo para aumentar marginalmente la tasa efectiva del impuesto a la utilidad corporativa que pagan las empresas mineras. En cierta forma, los países han optado por 
introducir estas regalías como una forma de lograr que el sector minero realice un aporte fiscal relativamente mayor que el de las empresas de otros sectores económicos, lo que suele justificarse por el hecho de tratarse de la extracción de un recurso natural no renovable que es propiedad del Estado. En ese sentido, las regalías fijas brindan la posibilidad de asegurar un ingreso mínimo para el financiamiento público, con la ventaja de una mayor simplicidad en términos administrativos. En su versión más moderna, cuando se establece un pago mínimo fijo, pero su determinación efectiva queda sujeta a la rentabilidad o la utilidad operativa de las empresas privadas, se mantienen dichas ventajas y se dota a estas regalías de una mayor flexibilidad ante cambios en la ecuación financiera de los proyectos.

\section{Cuadro XIV.5}

América Latina y el Caribe (8 países): estructura de los ingresos fiscales provenientes del sector de minerales, 2000-2014

(En porcentajes del total)

\begin{tabular}{|c|c|c|c|c|}
\hline Países & Instrumento & $2000-2003$ & $2005-2008$ & $2010-2014$ \\
\hline \multirow[t]{3}{*}{ Argentina } & Impuesto sobre la renta & 80,3 & 85,6 & 62,3 \\
\hline & Regalías & 0,0 & 0,0 & 0,0 \\
\hline & Otros & 19,7 & 14,4 & 37,7 \\
\hline \multirow{3}{*}{$\begin{array}{l}\text { Bolivia } \\
\text { (Estado Plurinacional de) }\end{array}$} & Impuesto sobre la renta & 11,8 & 32,2 & 42,8 \\
\hline & Regalías & 88,2 & 67,8 & 57,2 \\
\hline & Otros & 0,0 & 0,0 & 0,0 \\
\hline \multirow[t]{3}{*}{ Brasil } & Impuesto sobre la renta & 28,5 & 85,1 & 81,7 \\
\hline & Regalías & 68,3 & 13,5 & 16,5 \\
\hline & Otros & 3,2 & 1,4 & 1,8 \\
\hline \multirow[t]{3}{*}{ Chile } & Impuesto sobre la renta & 43,3 & 72,0 & 86,5 \\
\hline & Regalías & 0,0 & 0,0 & 0,0 \\
\hline & Otros & 56,7 & 28,0 & 13,5 \\
\hline \multirow[t]{3}{*}{ Colombia } & Impuesto sobre la renta & 37,2 & 51,2 & 35,8 \\
\hline & Regalías & 62,8 & 48,8 & 64,2 \\
\hline & Otros & 0,0 & 0,0 & 0,0 \\
\hline \multirow[t]{3}{*}{ Jamaica } & Impuesto sobre la renta & 7,7 & 15,3 & 13,4 \\
\hline & Regalías & 92,3 & 84,7 & 86,6 \\
\hline & Otros & 0,0 & 0,0 & 0,0 \\
\hline \multirow[t]{3}{*}{ México } & Impuesto sobre la renta & 95,7 & 94,7 & 89,3 \\
\hline & Regalías & 4,3 & 5,3 & 10,7 \\
\hline & Otros & 0,0 & 0,0 & 0,0 \\
\hline \multirow[t]{3}{*}{ Perú } & Impuesto sobre la renta & 100,0 & 93,4 & 78,7 \\
\hline & Regalías & 0,0 & 6,6 & 10,0 \\
\hline & Otros & 0,0 & 0,0 & 11,3 \\
\hline
\end{tabular}

Fuente: Elaboración propia, sobre la base de información oficial de los países y la Comisión Económica para América Latina y el Caribe (CEPAL). 


\section{Conclusiones}

La última década ha representado una etapa única y trascendental en la historia económica de los países de América Latina y el Caribe. Entre otros logros, los procesos sostenidos de gran crecimiento económico, la destacada estabilidad del orden político y los grandes avances en materia de indicadores sociales (descenso de la pobreza y de la desigualdad) han sido posibles gracias a las acertadas medidas adoptadas por los gobernantes de turno para sacar provecho de un contexto externo muy favorable, con elevados precios internacionales de las materias primas. Además, los mayores ingresos fiscales provenientes de la explotación de los recursos naturales disponibles han contribuido a fortalecer la posición fiscal de los países exportadores de la región, permitiéndoles enfrentar con mayor holgura la crisis económica de 2008-2009 mediante la aplicación de políticas anticíclicas.

En las industrias extractivas existe una amplia gama de instrumentos fiscales disponibles para lograr una adecuada apropiación estatal de las rentas provenientes de estas actividades. Si bien en la literatura especializada se ha insistido en recomendar la introducción de instrumentos basados en la rentabilidad de los proyectos (impuestos sobre la renta pura del recurso), el actual contexto internacional de precios declinantes parece obligar a los encargados de formular las políticas a priorizar aquellos que aseguren la obtención de un monto mínimo de ingresos fiscales, especialmente en los países con un elevado grado de dependencia fiscal respecto de estos recursos. Si bien la combinación de instrumentos aplicada a los sectores de hidrocarburos y minerales varía visiblemente de un país de la región a otro, la mayoría sigue manteniendo sistemas tradicionales de regalías y de impuestos sobre la renta corporativa. Solo en el caso de los hidrocarburos, algunos países han avanzado con la introducción de instrumentos más sofisticados (impuestos o regalías escalonadas y variantes de participación estatal en la producción o las utilidades) con la finalidad de incrementar, de la manera más eficiente posible, el margen de apropiación de las rentas generadas en estos sectores por parte del Estado.

Las estadísticas disponibles permiten comprobar que son varios los países de la región donde la explotación de recursos no renovables adquiere una relevancia económica destacada. Ante el ciclo alcista de precios internacionales que se experimentó entre 2003 y 2008, muchos de ellos introdujeron una serie de reformas fiscales con la clara finalidad de aumentar el margen de apropiación estatal de rentas generadas en los sectores extractivos. En particular, se avanzó en asegurar el control estatal de los recursos disponibles (Argentina, Bolivia (Estado Plurinacional de), Ecuador y Venezuela (República Bolivariana de)) y se introdujeron nuevos tributos (Argentina, Bolivia (Estado Plurinacional de), Chile, Perú y Venezuela 
(República Bolivariana de)), al tiempo que se fortalecieron los esquemas de regalías (Bolivia (Estado Plurinacional de), Brasil, Colombia y Perú) y se establecieron impuestos sobre los ingresos extraordinarios (Bolivia (Estado Plurinacional de), Brasil, Colombia, Ecuador, Trinidad y Tabago y Venezuela (República Bolivariana de)).

El cambio de contexto internacional y la mayor incertidumbre acerca del retorno a un nivel de precios elevados en el mediano plazo imponen desafíos adicionales, especialmente en los países que muestran un elevado grado de dependencia fiscal respecto de la explotación de los recursos naturales no renovables. Dada la necesidad que presentan todos los países de la región en materia de inversiones privadas para alcanzar un mayor desarrollo de las industrias extractivas, un período de precios internacionales bajos se traduciría en una reducción del poder de negociación del Estado para establecer regímenes fiscales que protejan sus propios intereses más allá de la rentabilidad económica de los proyectos. Todo esto sin contar las usuales implicancias sociales, económicas y ambientales que se vinculan a las industrias extractivas y que hacen que su economía política sea singularmente compleja.

\section{Bibliografía}

Acquatella, J. y otros (2013), “Rentas de recursos naturales no renovables en América Latina y el Caribe: evolución 1990-2010", serie Seminarios y Conferencias, $\mathrm{N}^{\circ} 72$ (LC/L.3645), Santiago, Comisión Económica para América Latina y el Caribe (CEPAL), junio.

Boadway, R. y M. Keen (2010), "Theoretical perspectives on resource tax design", The Taxation of Petroleum and Minerals: Principles, Problems and Practice, P. Daniel, M. Keen y C. McPherson (eds.), Nueva York, Routledge.

CEPAL (Comisión Económica para América Latina y el Caribe) (2013), Panorama Fiscal de América Latina y el Caribe, 2013. Reformas tributarias y renovación del pacto fiscal, (LC/L.3580), Santiago, febrero.

(2014), Pactos para la igualdad: hacia un futuro sostenible (LC/G.2586(SES.35/3)), Santiago, abril.

(2015), Panorama Fiscal de América Latina y el Caribe 2015. Dilemas y espacios de politicas (LC/L.3961), Santiago.

FMI (Fondo Monetario Internacional) (2012), “Fiscal Regimes for Extractive Industries: Design and Implementation", Fiscal Affairs Department, agosto [en línea] https:/ / www.imf.org/external/np/pp/eng/2012/081512.pdf.

Garnaut, R. y A. Clunies Ross (1983), Taxation of Mineral Rents, Oxford, Clarendon Press. Gómez Sabaini, J.C., J.P. Jiménez y D. Morán (2015), “El impacto fiscal de los recursos naturales no renovables en los países de América Latina", Documentos de Proyecto (LC/W.658), Santiago, Comisión Económica para América Latina y el Caribe (CEPAL) [en línea] http:/ / repositorio.cepal.org/bitstream/handle/11362/38235/ S1500128_es.pdf?sequence $=1$. 
Jiménez, J.P. y V. Tromben (2006), "Política fiscal en países especializados en productos no renovables en América Latina", serie Macroeconomía del Desarrollo, № 46 (LC/L.2521-P), Santiago, Comisión Económica para América Latina y el Caribe (CEPAL).

Medinaceli, M. (2010), Contratos de exploración y explotación de hidrocarburos: América Latina 2010, Organización Latinoamericana de Energía (OLADE).

OCDE/CEPAL/CIAT/BID (Organización de Cooperación y Desarrollo Económicos/ Comisión Económica para América Latina y el Caribe/Centro Interamericano de Administraciones Tributarias/Banco Interamericano de Desarrollo) (2016), Estadísticas tributarias en América Latina y el Caribe 1990-2014, París, OECD Publishing. Tordo, S. (2007), "Fiscal systems for hydrocarbons. Design issues", Working Paper, $N^{\circ} 123$, Washington, D.C., Banco Mundial. 


\title{
Capítulo XV \\ Reformas fiscales ambientales: el rol de los tributos ${ }^{1}$
}

\author{
José María Fanelli² \\ Juan Pablo Jiménez $z^{3}$ \\ Isabel López Azcúnaga ${ }^{4}$
}

\section{Introducción}

El objetivo principal de este trabajo es analizar las reformas fiscales ambientales desde la perspectiva de América Latina. Para estudiar esas reformas se parte de un enfoque pionero desarrollado en Europa, centrado en las externalidades asociadas con el cambio climático, en las medidas tributarias necesarias para solucionarlas y en la búsqueda de un doble dividendo que permitiría no solo disminuir el daño ambiental, sino utilizar la recaudación adicional con objetivos como la reducción de la carga tributaria. Sin embargo, existen diferencias visibles entre los países de la región y las economías desarrolladas que fueron pioneras en aplicar las reformas fiscales ambientales y que aportaron la mayor cantidad de evidencia sobre el tema. Por ese motivo, se

Este capítulo es una versión resumida de Fanelli, Jiménez y López Azcúnaga (2015).

2 Profesor investigador de la Universidad de San Andrés y del Consejo Nacional de Investigaciones Científicas y Técnicas (CONICET) de la Argentina. Correo electrónico: josefanelli@gmail.com.

3 Oficial de Asuntos Económicos de la División de Desarrollo Económico de la Comisión Económica para América Latina y el Caribe (CEPAL). Correo electrónico: juanpablo.jimenez@cepal.org.

4 Consultora de la Comisión Económica para América Latina y el Caribe (CEPAL) en temas de política fiscal. Correo electrónico: ilopezazcunaga@gmail.com. 
advierte que algunos aspectos de las reformas de ese tipo que son centrales para una economía en desarrollo no han sido suficientemente investigados, y el presente trabajo se ha hecho con la intención de abundar en ese punto.

En las páginas siguientes se discute qué se entiende por reforma fiscal ambiental y cómo esta y los instrumentos que suelen componerla, han ido evolucionando a lo largo del tiempo, tanto desde el punto de vista analítico como aplicado. Luego, se revisa la experiencia en materia de reformas fiscales ambientales tanto en los países desarrollados como en los países de América Latina donde, a pesar de la escasez de casos, se hace un esfuerzo por interpretar las iniciativas detectadas a nivel regional en términos de los conceptos relacionados con ese tema planteados en la primera sección. Por último, se presenta una serie de lecciones sobre el diseño de esas reformas en la región.

\section{A. Reformas fiscales ambientales: enfoque conceptual}

En esta sección se repasa la literatura pertinente en busca de los instrumentos tributarios y de otro tipo que se asocian con una reforma fiscal ambiental, con el fin de evaluar cómo evolucionaron en el tiempo. Luego se intentará mostrar cómo ese tipo de reformas se vincula con el marco institucional y la provisión de bienes públicos y, por último, se estudiará el vínculo entre reformas fiscales ambientales, economía verde y desarrollo sostenible desde la perspectiva de un enfoque sistémico. En función de los objetivos del trabajo, la revisión conceptual pone el énfasis en los aspectos de mayor relevancia para América Latina.

\section{El concepto de reforma fiscal ambiental y su evolución}

El concepto de reforma fiscal ambiental surgió hacia fines de los años ochenta y se consolidó en la década de 1990 en el marco de reformas llevadas a cabo sobre todo en Europa. La idea básica que impulsó las reformas fue la de utilizar el mecanismo de precios - con su capacidad de brindar información e influir sobre los incentivos- para corregir las distorsiones que deterioran el medio ambiente e impiden un uso racional del capital natural. Siguiendo el principio de "quien contamina paga", las reformas buscaban que los precios incorporaran el costo social de las externalidades negativas, y el instrumento que se propuso para lograrlo fue el de los impuestos "pigouvianos" (Pigou, 1920).

Según ese enfoque inspirado en Pigou y los desarrollos posteriores sobre teoría del bienestar de raíces utilitaristas, la actividad que genera efectos sobre el medio ambiente debe pagar un impuesto equivalente a la externalidad que produce sobre el entorno. Según la Organización de 
Cooperación y Desarrollo Económicos (OCDE, 2010), los impuestos ambientales son aquellos cuya base imponible consiste en una unidad física (o similar) de algún material que tiene un impacto negativo comprobado y específico sobre el medio ambiente. Por ejemplo, los impuestos sobre las emisiones que contaminan el aire, sobre los afluentes o sobre la emisión de $\mathrm{CO}_{2} ;$ la adaptación de gravámenes existentes de acuerdo a criterios ambientales (eficiencia de motores, grado de emisiones de cada combustible), y la introducción de nuevos impuestos ambientales puros sobre emisiones o sobre productos contaminantes (desechos, envases, entre otros).

Como el instrumento privilegiado en este ámbito fue el de los impuestos energético-ambientales, ello implicó agregar un motivo a los dos tradicionalmente utilizados para justificar la imposición sobre la energía fósil, consistentes en que la demanda de energía es inelástica y que los recursos naturales generan una renta que puede ser apropiada por el Estado. En algunos países de América Latina, esos dos motivos tradicionales juegan un papel que es típicamente mayor que en los países pioneros de las reformas fiscales ambientales ${ }^{5}$. Por esa razón, las iniciativas relacionadas con el ambiente necesitan ser calibradas en función de sus efectos, tanto sobre el espacio fiscal como sobre el ingreso disponible. Incluso es frecuente la coexistencia de subsidios e impuestos sobre productos energéticos como, por ejemplo, los subsidios al transporte público que utiliza combustible diésel y los impuestos a la gasolina que consumen los automóviles (Clements y otros, 2013; Di Bella y otros, 2015).

Por supuesto, también es un objetivo de esas reformas fiscales eliminar subsidios que incentiven actividades nocivas para el medio ambiente. Esta faceta no se enfatiza demasiado en el diseño de las reformas, pero es sumamente importante en el caso de América Latina, donde los subsidios y la intervención para fijar precios por debajo de los precios de mercado son prácticas muy extendidas. Más allá de que la justificación política canónica se basa en que esas medidas favorecen a los sectores de menores recursos, lo cierto es que, en los países ricos en hidrocarburos y otros recursos naturales, los subsidios y las distorsiones de los precios relativos suelen ser la forma en que amplios sectores de la población (incluidos los últimos deciles de la distribución) se apropian de la renta de recursos naturales valiéndose del poder del Estado (Parry y otros, 2014; Di Bella y otros, 2015).

Un segundo principio, independiente del anterior, que se asoció con las reformas fiscales ambientales pioneras fue el de la neutralidad en cuanto a los efectos. Las reformas ambientales no deberían aumentar la carga tributaria y, para cumplir tal propósito, lo recaudado debería destinarse a

Se hace referencia a un conjunto de países europeos, especialmente los escandinavos, que diseñaron e implementaron satisfactoriamente distintas modalidades de reforma fiscal ambiental en la primera mitad de los años noventa. 
financiar una reducción en esa carga. Es más, si el principio de neutralidad se ejecutara en la forma adecuada, las reformas fiscales ambientales deberían generar un "doble dividendo": no solo se corregiría la externalidad, sino que se podrían reducir impuestos distorsivos. Según el enfoque de la OCDE (2010), la recaudación de los impuestos debería utilizarse para introducir recortes en la imposición directa con el fin de suavizar sus efectos sobre los incentivos y atenuar la carga fiscal sobre el empleo mediante reducciones de los aportes a la seguridad social ${ }^{6}$.

A partir de la experiencia con la implementación de reformas desde los años noventa, se fue acumulando conocimiento tanto en el plano técnico como en el de la interacción de las reformas fiscales ambientales con la economía política (OCDE, 2005; OCDE, 2010; Banco Mundial, 2005). Como consecuencia, la visión de esas reformas que se tenía en los años noventa fue evolucionando y es posible clasificarlas en diferentes "generaciones", que se distinguen tanto por la articulación con otros objetivos de política como por los instrumentos considerados (Gago y Labandeira, 2012).

La crisis europea también influyó sobre la visión de las reformas fiscales ambientales porque puso en primer lugar la necesidad de consolidación fiscal y de preservar la competitividad en el contexto de una unión monetaria bajo la que el tipo de cambio no puede utilizarse como instrumento de política. Esto llevó a que se introdujera en las reformas la posibilidad de utilizar los recursos para la consolidación fiscal y un mayor cuidado en la evaluación de los efectos sobre la competitividad externa de las economías. La preocupación por la competitividad se intensificó por el hecho de que volvieron a ganar consideración en la agenda pública las políticas industriales, actualmente conocidas como políticas de desarrollo productivo. Esa preocupación tiene también incidencia sobre los bienes públicos globales (por las guerras de monedas y los efectos de derrame financieros) e interactúa, por ende, con las iniciativas para el ambiente (ONUDI, 2008).

La preocupación por los problemas distributivos a la hora de diseñar una reforma fiscal ambiental surgió, sobre todo, en el contexto de las propuestas para los países menos avanzados, donde la pobreza siempre tiende a aparecer en un lugar destacado, y ello se reflejó en los temas incluidos dentro de la reforma (Banco Mundial, 2005; Gillingham y Keen, 2012; de Mooij, Parry y Keen, 2012; Somanathan y Sterner, 2003; Milne, 2014). Este hecho está bien ejemplificado en un documento reciente del Programa de las Naciones Unidas para el Medio Ambiente (PNUMA, 2011). El PNUMA considera que una economía verde debe mejorar el bienestar del ser humano y la equidad social, y a la vez reducir significativamente los riesgos ambientales

Vale aclarar que el recorte de la imposición directa no parece un objetivo deseable en América Latina, teniendo en cuenta la debilidad estructural de ese grupo de impuestos en la región, sobre todo del impuesto a la renta personal (Jiménez, 2015). 
y las escaseces ecológicas. En su forma más básica, sería una economía que tiene bajas emisiones de carbono, utiliza los recursos de forma eficiente y es socialmente incluyente (Smulders, Toman y Withagen, 2014).

\section{La reforma fiscal y sus instrumentos: incentivos, mercados y regulación}

Las externalidades ambientales tienen un papel protagónico en la justificación de las reformas fiscales ambientales, que se fundamentan en que existen fallas de mercado que hacen que los efectos de las decisiones privadas no se manifiesten plenamente a través del sistema de precios, lo que acarrea daños para el medio ambiente y mal manejo de los recursos naturales (Acquatella, 2005; Gago y Labandeira, 2010; Heine, Norregaard y Parry, 2012). Más allá de que la literatura tiende a privilegiar los impuestos de tipo pigouviano como solución, lo cierto es que también pueden utilizarse otros instrumentos para el mismo fin. Se puede recurrir a esquemas de tasas y contribuciones (Somanathan y Sterner, 2003; Milne, 2014), entre los que se destacan los cargos por uso de agua, por uso de recursos naturales (flora y fauna) y por afluentes contaminantes (Acquatella, 2005). Las reformas fiscales ambientales también pueden beneficiarse con mecanismos de mercado que permitan atacar la externalidad mediante la organización de un mercado de permisos transferibles. Una tercera alternativa es recurrir a la modificación de los derechos de propiedad y la negociación, como ha propuesto Coase (1960). Ese curso de acción, más allá de las virtudes prácticas que puede tener bajo ciertas circunstancias, tiene la ventaja de que impone la necesidad de concebir esas reformas en un mundo con costos de transacción que están lejos de ser nulos. Un último tipo de instrumento es la regulación directa (mecanismos administrativos de "comando y control").

Según Prust (2005), en los países en desarrollo las combinaciones ideales de políticas generalmente comprenderán elementos fiscales y de otra naturaleza, por ejemplo, cargos por uso de recursos naturales y permisos negociables de emisiones. Cuando existen restricciones que impiden actuar directamente sobre la externalidad, suelen utilizarse impuestos que cumplen su rol solo de manera parcial. Según Gillingham y Keen (2012), dados los problemas de administración y de cumplimiento tributario, los países en desarrollo deben basar sus estrategias en la imposición a productos energéticos, incluida la eliminación de "impuestos negativos" mediante subsidios al consumo de combustibles fósiles.

Una de las ventajas más mencionadas de los impuestos pigouvianos es que, al actuar a través del mercado, tienen mayor flexibilidad que la regulación directa y brindan incentivos para la innovación en materia de tecnologías limpias o que utilicen los recursos de forma más eficiente, además de que actúa sobre el lado de la demanda al encarecer los productos. No obstante, 
esas ventajas se opacan cuando se evalúa la información que se requiere para implementar las reformas fiscales ambientales.

Para aplicar el principio de "quien contamina paga" es necesario conocer el valor de la externalidad a fin de calcular la alícuota óptima del impuesto. Ello implica conocer con exactitud el daño marginal: es decir, cuánto y a quién perjudica la emisión (Heine, Norregaard y Parry, 2012). Además, típicamente se producen cambios en la producción y la tecnología a los que puede ser difícil adaptar el impuesto, al quedar obsoleta la información anterior. Esas dificultades son mucho mayores en los países de nivel de desarrollo medio de la región, debido a las menores capacidades de gestión ambiental que muestra el Estado y que se reflejan en una oferta subóptima de información. Bajo esas condiciones es muy difícil calcular un precio sombra que refleje los costos de oportunidad correctos para la sociedad, una tarea que de por sí es compleja y está rodeada de ambigüedades en lo que respecta al plano valorativo y los supuestos sobre el funcionamiento de los mecanismos de asignación de la economía (Dasgupta, 2009).

Saber quién paga el impuesto es altamente relevante en el caso de América Latina, por los efectos distributivos y sobre la competitividad. Como se ha indicado, esos efectos también han ganado atención en Europa. En el caso de los combustibles, en América Latina se puede acotar la regresividad y existe la posibilidad de aplicar medidas compensatorias, como la diferenciación de alícuotas según el tipo de combustible, pero puede haber conflicto con el objetivo ambiental. Es posible otorgar subsidios, pero ello tiene costo fiscal, afecta la asignación de recursos y suele beneficiar de manera desproporcionada a los más ricos (Acquatella y Bárcena, 2005). Además, es necesario calcular la forma en que determinada combinación de subsidios e impuestos afectaría la competitividad en una región especializada en recursos naturales. Sin embargo, también puede haber sinergias: una mayor tributación sobre la energía fósil en el nivel del consumo interno podría liberar productos que pueden exportarse, lo que aliviaría la restricción externa. Tanto la distribución como la competitividad suelen dar lugar a la movilización de grupos de interés y ello pone la economía política en primer plano.

Además de esas dificultades, la práctica internacional ha mostrado que la externalidad ambiental es una entre otras distorsiones, como lo son las fallas de mercado que inciden sobre la competitividad y requieren políticas de desarrollo productivo. No tomar en cuenta las interacciones entre las distorsiones puede dañar la efectividad de la reforma e, incluso, generar resultados contrarios a lo esperado, o erosionar el apoyo político a las reformas fiscales ambientales. En tal caso, es difícil alcanzar el primer mejor escenario y se pasa a operar en un mundo de la segunda mejor alternativa, con impuestos y subsidios ambientales imperfectos del tipo antes señalado. 
En suma, el medio ambiente es un bien público y, en la mayoría de los casos, no recibe protección debido a una falla de acción colectiva. La elaboración de un instrumento para atacar la externalidad no es otra cosa que el problema de cómo definir una estructura de gobernanza para actividades y transacciones que dañan el medio ambiente, de forma que el agente internalice el costo de la emisión al tomar decisiones. Para generar esa estructura se requiere un marco institucional apropiado. Si la gobernanza es adecuada, los agentes de la transacción tendrán incentivos para evitar la falla o, lo que es lo mismo, "proveer" el bien público consistente en preservar el medio. Justamente por ese motivo, los instrumentos para atacar la externalidad no deberían analizarse como si los costos de transacción fueran cero y los "servicios de gobernanza" que proveen las instituciones fueran gratuitos. Como lo afirman Milgrom y Roberts (1993), los costos de transacción son los gastos necesarios para hacer funcionar el sistema económico. Los servicios de gobernanza (en este caso, estructurar los incentivos correctamente mediante impuestos pigouvianos $u$ otros instrumentos) son también un bien público que contribuye a hacer funcionar el sistema (Stiglitz, 1988; Ostrom, 2007).

Vale resaltar la importancia de los bienes públicos: para inducir a los agentes a proveer el bien público denominado "preservación del ambiente", se necesitan como insumos otros dos bienes públicos: información y gobernanza. Un gobierno con poca capacidad para generar bienes públicos tendrá necesariamente poca capacidad para implementar una reforma fiscal ambiental. Tal vez en un país desarrollado sea razonable, en principio, suponer que el marco institucional y el Estado estarán en condiciones de proveer los bienes públicos pertinentes. No obstante, ese supuesto no sería correcto en el caso de América Latina. Por esa razón, las reformas fiscales ambientales deberían concebirse en términos sistémicos, de forma que se considere tanto la estructura productiva como las instituciones.

El marco institucional necesario para proveer los bienes públicos lo establece el sistema político. Por lo tanto, cuando se observa la cuestión desde esta perspectiva, aparecen de forma natural en el análisis de las reformas fiscales ambientales las consideraciones de economía política. Se trata de un aspecto central, pues cualquiera que sea el instrumento utilizado para corregir la externalidad, es muy difícil que los efectos sean neutros desde el punto de vista distributivo (Stiglitz, 2009).

Hoy, en suma, sería muy difícil entender la estructura y la orientación de las reformas fiscales ambientales tanto en los países avanzados como en los países pobres y de ingreso medio sin tomar en cuenta que esas reformas se están redefiniendo en un mundo que se concibe sobre la base del segundo mejor escenario. Este mundo es bastante más complejo que el de los impuestos pigouvianos orientados a conseguir resultados óptimos, y donde los problemas distributivos, del empleo y de la consolidación fiscal están en 
primera fila. Asimismo, en un contexto en que se desea inducir un cambio estructural hacia el crecimiento verde, las reformas fiscales ambientales tienen vínculos cada vez más estrechos con las políticas económicas relacionadas con el cambio climático, los recursos renovables y la eficiencia energética, y la economía circular. A su vez, esos factores se complementan con metas distributivas, de innovación y de preservación de la competitividad (Gago y Labandeira, 2012).

\section{B. La experiencia internacional y regional}

En esta sección se analiza la experiencia acumulada en Europa y en América Latina. Luego se presenta un conjunto de hechos estilizados que deben considerarse en el caso de una reforma fiscal ambiental para la región.

\section{Europa}

Las primeras reformas fiscales ambientales se llevaron a cabo en Europa. Los países pioneros fueron Finlandia (1990), Suecia (1991), Noruega (1992), Dinamarca (1994), Países Bajos (1995), Finlandia (1997), Italia (1999) y Alemania (1999). Más recientemente, Estonia introdujo una reforma fiscal ambiental del mismo tipo de las pioneras. Francia intentó una reforma que incluía un cheque verde para mitigar los efectos distributivos, pero esa iniciativa fracasó. Desde un punto de vista de economía política, estas reformas ganaron terreno en la agenda de los años noventa porque estaban en línea con dos preocupaciones de la época: los problemas ambientales y la voluntad de reducir la ineficiencia de la imposición sobre el trabajo y el esfuerzo de ahorro. En cuanto a las externalidades consideradas, se priorizaron las relacionadas con la emisión de gases de efecto invernadero y la contaminación atmosférica.

Gago y Labandeira (2012) distinguen dos generaciones de reformas a partir de las experiencias de los países pioneros. La primera, aplicada en los años noventa, se caracteriza por la utilización de impuestos ambientales potentes y generalmente relacionados con el sector energético. Los ingresos derivados de esos nuevos impuestos se destinaban a reducir los impuestos sobre la renta, siendo además frecuentes las exenciones a los sectores industriales para evitar pérdidas de competitividad, con lo que la carga fiscal recaía principalmente sobre los consumidores finales.

La segunda generación, aplicada por países como Alemania y el Reino Unido una década después, se basaba en la aplicación de impuestos similares a los de la primera generación. La principal diferencia radicaba en el reciclaje de los ingresos, esta vez dirigidos a reducir las cotizaciones sociales. En esa generación, se aplicaban normalmente medidas distributivas compensatorias para los grupos o sectores más afectados por el cambio fiscal. 
Una tercera generación englobaría las reformas más heterogéneas y caracterizadas por atribuir mayor relevancia a la existencia de otras distorsiones en un mundo basado en el segundo mejor escenario. Se toman como ejemplos las experiencias irlandesa y australiana (Gago y Labandeira, 2012). También hay intentos crecientes de coordinar las acciones comunitarias para evitar distorsiones en la competitividad, no solo en lo relativo a costos sino, también, como incentivo a la deslocalización de inversiones. Para el reciclaje de la recaudación se agrega la consolidación fiscal. Por otra parte, las eventuales consecuencias distributivas y sobre el empleo ganaron relevancia por el incremento del desempleo luego de la crisis. Como consecuencia de esos factores, apareció una visión más heterodoxa de las reformas fiscales ambientales.

En las reformas fiscales ambientales de Italia se dispone que un tercio de la mayor tributación de los productos derivados del petróleo se destine a medidas distributivas y orientadas a mejorar la eficiencia energética. Las reformas de Suiza (2008) también incluyen elementos como la devolución de recaudación a ciudadanos, y firmas y planes de eficiencia energética. La reforma australiana abarca aspectos distributivos, la financiación de exenciones (competitividad) y medidas de apoyo a las empresas y el empleo, además de diversos programas de eficiencia energética.

El esfuerzo europeo por avanzar en cuestiones medioambientales no ha dejado de crecer en los dos últimos decenios. Lo que comenzó como un ejercicio entre una pequeña vanguardia de los países europeos se ha ido ampliando progresivamente para abarcar una serie de países y regiones de todo el mundo. Hay planes e iniciativas en marcha en varios países para introducir nuevos impuestos, cargas y gravámenes ambientales o modificar los sistemas existentes, ya sea como parte de un paquete más amplio de reforma fiscal o como propuestas individuales que reflejan diferentes intereses y circunstancias.

En el ámbito de la Unión Europea (UE), los impuestos ambientales representaron 310.300 millones de euros en 2012, lo que equivale a un 6,05\% del total de los impuestos y contribuciones sociales en 27 países de la Unión Europea (UE-27), contribución que representó en promedio un 2,4\% del PIB. La mayor parte de los ingresos ambientales proceden de los impuestos sobre la energía, que representaron el 4,5\% en 2012 (véanse los gráficos XV.1 y XV.2).

La experiencia internacional también aporta ejemplos de imposición de tributos con objetivos ambientales que no necesariamente están centrados en las emisiones de origen energético. En ese sentido, pueden mencionarse el sistema de impuestos y cuotas individuales transferibles (CIT) aplicado sobre los recursos pesqueros en Islandia; el paquete de impuestos sobre la extracción de recursos naturales (cal, cemento, piedra, tierra, arena, grava, entre otros), la eliminación de residuos (por ejemplo, domésticos, peligrosos, 
industriales, de construcción y demolición) y productos contaminantes del agua (aceites, baterías) y del aire $\left(\mathrm{CO}_{2}, \mathrm{SO}_{2}, \mathrm{NOx}\right.$, entre otros); así como el impuesto sobre pesticidas en Noruega.

\section{Gráfico XV.1}

Unión Europea (27 países): total de impuestos ambientales

(En miles de millones de euros)

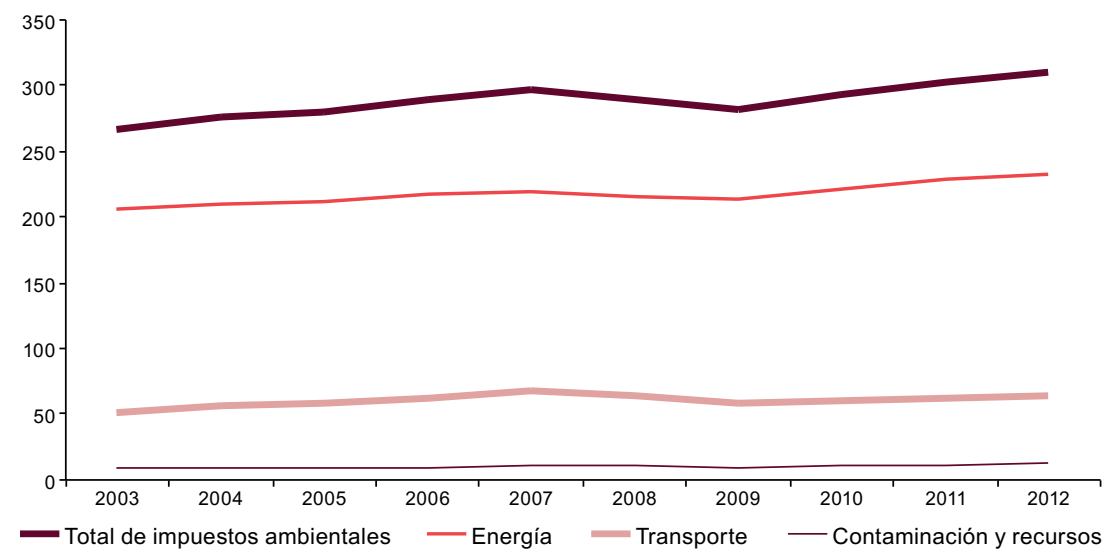

Fuente: Elaboración propia, sobre la base de datos de Eurostat.

\section{Gráfico XV.2}

Unión Europea: composición de los impuestos ambientales por tipo de impuesto, 2012

(En porcentajes)

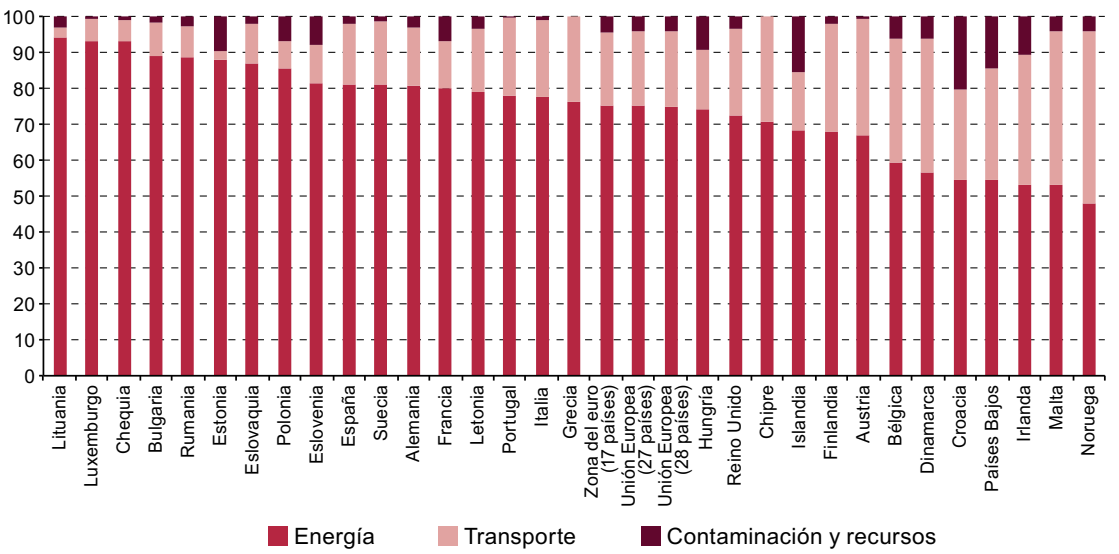

Fuente: Elaboración propia, sobre la base de datos de Eurostat.

La experiencia con las reformas fiscales ambientales ha permitido extraer ciertas lecciones. Si el objetivo primordial es incentivar comportamientos favorables al medio ambiente, se recomienda que la actividad objeto del 
gravamen sea muy cercana al problema ambiental que se desea solucionar. Además, el objeto del impuesto debe ser lo más amplio posible para cubrir el mayor número de casos posibles y evitar situaciones de ambigüedad en la legislación. Por último, se deberían minimizar los costos administrativos para no perjudicar la viabilidad de la instrumentación del impuesto, derecho o cargo.

En cuanto a la eficacia, el consenso de la literatura es que los efectos de las reformas sobre el consumo energético y las emisiones de carbono son significativos, pero que su impacto sobre producción, empleo y competitividad es limitado (Gago y Labandeira, 2012). Por su parte, Miller y Vela (2013), con datos de alrededor de 50 países entre 1995 y 2009, encuentran que los países con altos impuestos relacionados con el ambiente como porcentaje del PIB registran mayores reducciones en los niveles de contaminación y un aumento en el uso de recursos renovables.

\section{Los países de la región}

En América Latina no existen experiencias de reformas fiscales ambientales en sentido estricto. Sin embargo, en las últimas reformas fiscales llevadas a cabo en la región se observa una utilización más frecuente de instrumentos fiscales de carácter ambiental. En el cuadro XV.1 se detallan reformas fiscales realizadas en los últimos años que son relevantes para este estudio.

Debido a su carácter pionero en la región, merece la pena analizar con mayor detalle la reciente imposición al carbono implantada en México y en Chile. Como ya se mencionó, los impuestos al carbono se consideran impuestos pigouvianos porque procuran corregir las externalidades sociales del funcionamiento del mercado y han sido promovidos en el contexto de control de emisiones de dióxido de carbono, y por su impacto sobre el cambio climático. Algunos economistas sugieren que pueden ser uno de los métodos más eficientes para reducir emisiones y estiman que deben ser elevados y de alcance global.

En el contexto de la reciente reforma tributaria aprobada en 2014, Chile dispuso la creación del primer impuesto al carbono en América Latina, mediante el que se gravarán las emisiones producidas por establecimientos "cuyas fuentes fijas, conformadas por calderas o turbinas, individualmente o en su conjunto, sumen una potencia térmica mayor o igual a $50 \mathrm{MWt}$ ". Los compuestos contaminantes afectados son: material particulado, óxidos de nitrógeno y dióxido de azufre (que componen la categoría "daño local para la salud") y dióxido de carbono como factor de "daño global por cambio climático". Ese tributo ha de entrar en vigor en 2017 y su recaudación comenzará en 2018. Sin embargo, ya está previsto que, en el caso de los contaminantes asociados a la contaminación local (los tres primeros), el impuesto se determinará a partir de una fórmula establecida en la legislación mientras que, en el caso del dióxido de carbono $\left(\mathrm{CO}_{2}\right)$, será de 5 dólares por cada tonelada métrica emitida. 


\section{Cuadro XV.1}

\section{América Latina: elementos ambientales de las reformas tributarias recientes}

\begin{tabular}{llll}
\hline País & Tipo de impuestos & $\begin{array}{l}\text { Utilización de } \\
\text { los recursos }\end{array}$ & $\begin{array}{l}\text { Otras características } \\
\text { de la reforma }\end{array}$ \\
\hline $\begin{array}{lll}\text { Argentina } \\
2013\end{array}$ & $\begin{array}{l}\text { Impuesto a automóviles } \\
\text { y motocicletas de alta gama, } \\
\text { embarcaciones y aeronaves } \\
\text { deportivas: del 10\% a un rango entre }\end{array}$ & $\begin{array}{l}\text { IR: Cambios en el impuesto } \\
\text { sobre la renta personal } \\
\text { (IRP) (aumento del mínimo }\end{array}$ \\
& el $30 \%$ y el $50 \%$. & no imponible). \\
& & Cambios en la tributación \\
& & al capital (eliminación de \\
& & exención de compraventa \\
& & en acciones y títulos \\
\end{tabular}

\begin{tabular}{ll}
\hline Bolivia & Impuesto sobre la renta de las \\
(Estado & empresas (IRE): alícuota adicional \\
Plurinacional & para la minería del 12,5\%. Regalía \\
de) 2007 & $\begin{array}{l}\text { minera acreditable al impuesto sobre } \\
\text { las utilidades de las empresas (IUE) } \\
\end{array}$ \\
& (si los precios son bajos).
\end{tabular}

Brasil 2013 Impuesto sobre los productos Sin reciclaje expreso.

industrializados (IPI): extensión de Consolidación fiscal. la reducción para vehículos y tasa cero para ciertos azúcares de caña. Reducción de impuestos y tarifas a la energía eléctrica.

\begin{tabular}{|c|c|c|c|}
\hline Chile 2014 & Impuesto sobre el carbono. & Consolidación fiscal. & \\
\hline $\begin{array}{l}\text { Costa Rica } \\
2009-2013\end{array}$ & $\begin{array}{l}\text { Impuesto de } 25 \text { dólares sobre } \\
\text { cada exportación de mercancías } \\
\text { que salen por un puesto } \\
\text { fronterizo terrestre. }\end{array}$ & $\begin{array}{l}\text { Sin reciclaje expreso. } \\
\text { Consolidación fiscal. }\end{array}$ & \\
\hline $\begin{array}{l}\text { Ecuador } \\
2007-2010- \\
2013\end{array}$ & $\begin{array}{l}\text { Exclusión de los vehículos híbridos } \\
\text { y eléctricos del IVA (tasa cero). } \\
\text { Nueva tarifa progresiva del impuesto } \\
\text { a los consumos especiales (ICE) } \\
\text { para vehículos híbridos y eléctricos. }\end{array}$ & $\begin{array}{l}\text { Sin reciclaje expreso. } \\
\text { Consolidación fiscal. }\end{array}$ & $\begin{array}{l}\text { IRP: del } 25 \% \text { al } 35 \% \text { (tasa } \\
\text { máxima y nuevos tramos). } \\
\text { IRE: del } 25 \% \text { al } 22 \% \\
\text { (en } 2013) .\end{array}$ \\
\hline
\end{tabular}
para vehículos híbridos y eléctricos. Impuesto ambiental a la contaminación vehicular (IACV). Impuesto a las botellas de plástico no retornables: 0,02 dólares por unidad.

Sin reciclaje expreso.

Consolidación fiscal.

\begin{tabular}{lll}
\hline El Salvador & Nuevo impuesto ad valorem al primer Sin reciclaje expreso. \\
2009-2011- & registro de vehículos: automotores: Consolidación fiscal.
\end{tabular}

2013 del $1 \%$ al $8 \%$; navales: del $2 \%$ al $10 \%$; aéreos: del $2 \%$ y el $5 \%$.

Consolidación fiscal.

IRP: del $25 \%$ al $30 \%$ (tasa efectiva, último tramo).

Nuevo impuesto ad valorem a la IRE: del $25 \%$ al $30 \%$ (tasa máxima). venta de combustible con base en el precio internacional del petróleo.

\begin{tabular}{|c|c|c|c|}
\hline $\begin{array}{l}\text { Guatemala } \\
2009-2012\end{array}$ & $\begin{array}{l}\text { Impuesto sobre la circulación de } \\
\text { vehículos terrestres, marítimos y } \\
\text { aéreos (ISCV): aumentan las tasas } \\
\text { y valores mínimos según el tipo } \\
\text { de vehículo. } \\
\text { Reducción del } 50 \% \text { del } \\
\text { impuesto sobre la circulación } \\
\text { de vehículos (2013). } \\
\text { Se establece un impuesto específico } \\
\text { a la primera matrícula de vehículos } \\
\text { automotores terrestres. }\end{array}$ & Sin reciclaje expreso. & $\begin{array}{l}\text { IRE: del } 31 \% \text { al } 25 \% \text {. } \\
\text { IRP: entre el } 15 \% \text { y el } \\
31 \% \text { (con cuatro tramos) a } \\
\text { tasas del } 5 \% \text { y el } 7 \% \text { (con } \\
\text { dos tramos). } \\
\text { IRP: aumento del mínimo } \\
\text { exento asalariado. }\end{array}$ \\
\hline $\begin{array}{l}\text { Honduras } \\
2010-2011- \\
2012\end{array}$ & $\begin{array}{l}\text { Sobretasa (ecotasa) para la } \\
\text { importación de vehículos usados: } \\
\text { entre } 5.000 \text { y } 10.000 \text { lempiras. }\end{array}$ & & $\begin{array}{l}\text { IR: Aportación solidaria } \\
\text { temporal: del } 5 \% \text { al } 10 \% \\
\text { (hasta 2015). } \\
\text { Ciertos rubros: del } 10 \% \\
\text { al } 25 \% \text { (bienes muebles } \\
\text { o inmuebles, minería } \\
\text { y regalías). } \\
\text { IRP: aumento del } \\
\text { mínimo exento. }\end{array}$ \\
\hline
\end{tabular}


Cuadro XV.1 (conclusión)

\begin{tabular}{|c|c|c|c|}
\hline País & Tipo de impuestos & $\begin{array}{l}\text { Utilización de } \\
\text { los recursos }\end{array}$ & $\begin{array}{l}\text { Otras características } \\
\text { de la reforma }\end{array}$ \\
\hline México 2014 & Impuesto al carbono. & $\begin{array}{l}\text { Financiamiento de } \\
\text { proyectos de mitigación } \\
\text { especíicos que deben } \\
\text { demostrar beneficios } \\
\text { ambientales tangibles. }\end{array}$ & $\begin{array}{l}\text { Sistema de compraventa } \\
\text { de bonos de carbono como } \\
\text { mecanismo sustitutivo. }\end{array}$ \\
\hline $\begin{array}{l}\text { Nicaragua } \\
2009-2012\end{array}$ & Aumentos de tasa para vehículos. & Sin reciclaje específico. & $\begin{array}{l}\text { Dividendos e intereses: } 10 \% \text {. } \\
\text { IRP: aumento del mínimo } \\
\text { exento para rentas } \\
\text { del trabajo. }\end{array}$ \\
\hline $\begin{array}{l}\text { Perú } \\
2007-2012\end{array}$ & $\begin{array}{l}\text { Modificación de las tasas del } \\
\text { impuesto selectivo al consumo (ISC) } \\
\text { de combustibles, proporcional a la } \\
\text { nocividad del combustible. } \\
\text { Eliminación de la tasa del ISC del } \\
10 \% \text { a la importación de automóviles } \\
\text { nuevos que utilicen gas natural o } \\
\text { gasolinas como combustible. }\end{array}$ & Sin reciclaje específico. & $\begin{array}{l}\text { IVA: Del } 19 \% \text { al } 18 \% \text {. } \\
\text { IR: Eliminación de } \\
\text { exoneraciones a intereses } \\
\text { y ganancias de capital. } \\
\text { Ampliación del gravamen } \\
\text { a dividendos. }\end{array}$ \\
\hline $\begin{array}{l}\text { República } \\
\text { Dominicana } \\
\text { 2012-2013 }\end{array}$ & $\begin{array}{l}\text { Aumento de los impuestos } \\
\text { especiales (hidrocarburos entre } \\
\text { otros) con la introducción de un } \\
\text { ad valorem. }\end{array}$ & Sin reciclaje expreso. & $\begin{array}{l}\text { IRE: del } 29 \% \text { al } 27 \% \\
\text { (2013-2015). } \\
\text { Gravamen sobre } \\
\text { dividendos (incluidas } \\
\text { zonas francas) e intereses } \\
\text { de residentes: } 10 \% \text {. }\end{array}$ \\
\hline $\begin{array}{l}\text { Uruguay } \\
2007-2012- \\
2013\end{array}$ & $\begin{array}{l}\text { Incremento de las tasas máximas del } \\
\text { impuesto específico interno (IMESI) } \\
\text { para vehículos automotores. }\end{array}$ & & $\begin{array}{l}\text { IRP: del } 25 \% \text { al } 30 \% \\
\text { (tasa máxima). }\end{array}$ \\
\hline
\end{tabular}

Fuente: Elaboración propia, sobre la base de Comisión Económica para América Latina y el Caribe (CEPAL), Panorama Fiscal de América Latina y el Caribe, 2014 (LC/L.3766), Santiago, 2014; y de la legislación de cada país.

En el caso de México y en el marco de la reforma fiscal de 2014, el Gobierno Federal estableció un nuevo impuesto a la enajenación e importación de combustibles fósiles de acuerdo a su contenido de carbono, con el doble objetivo de inducir a la adopción de tecnologías más limpias en la producción de bienes y servicios y desincentivar las emisiones de gases de efecto invernadero que ocasionan el cambio climático. Los combustibles fósiles afectados por ese impuesto son: propano, butano, gasolinas y gas-avión, turbosina y otros kerosenos, diésel, combustóleo, coque de petróleo y de carbón, carbón mineral y otros de menor relevancia. En este caso se añade un mecanismo innovador mediante el que es posible comprar bonos de carbono, o certificados de reducción de emisiones, en el mercado de carbono. Con ellos, los fabricantes, productores e importadores registrados como contribuyentes pueden sustituir el pago de la obligación tributaria.

Más allá de esos casos, en América Latina priman los impuestos con fines recaudatorios. No es inusual que más del 90\% de la recaudación de carácter ambiental provenga de impuestos sobre vehículos automotores $\mathrm{y}$, especialmente, sobre sus combustibles (gasolinas y diésel), que aportan entre un $0,5 \%$ y un 3,5\% del PIB en ingresos tributarios según el país. A nivel recaudatorio, los ingresos fiscales procedentes de instrumentos de carácter 
ambiental en la región, representan, en promedio, un $6 \%$ del total de los ingresos tributarios, con diferencias muy significativas entre los países (véase el cuadro XV.2).

\section{Cuadro XV.2}

América Latina: impuestos ambientales, 1990-2012 (En porcentajes del total de ingresos tributarios)

\begin{tabular}{|c|c|c|c|c|c|c|c|c|c|}
\hline & 1990 & 2000 & 2004 & 2007 & 2008 & 2009 & 2010 & 2011 & 2012 \\
\hline Argentina & 12 & 7 & 6 & 4 & 4 & 4 & 4 & 4 & 4 \\
\hline $\begin{array}{l}\text { Bolivia (Estado } \\
\text { Plurinacional de) }\end{array}$ & 0 & 18 & 10 & 35 & 35 & 26 & 29 & 27 & 26 \\
\hline Brasil & 0 & 1 & 2 & 10 & 10 & 10 & 9 & 9 & 9 \\
\hline Chile & 0 & 7 & 0 & 9 & 7 & 8 & 7 & 7 & 8 \\
\hline Colombia & 0 & 6 & 0 & 6 & 6 & 6 & 5 & 5 & 1 \\
\hline Costa Rica & 2 & 2 & 13 & 11 & 10 & 11 & 11 & 11 & 10 \\
\hline $\begin{array}{l}\text { República } \\
\text { Dominicana }\end{array}$ & 5 & 9 & 10 & 18 & 18 & 17 & 18 & 18 & 17 \\
\hline Ecuador & 0 & 1 & 1 & 1 & 1 & 1 & 1 & 1 & 1 \\
\hline El Salvador & 0 & 0 & 0 & 0 & 0 & 0 & 0 & 0 & 0 \\
\hline Guatemala & 5 & 10 & 8 & 7 & 6 & 7 & 7 & 6 & 6 \\
\hline Honduras & 2 & 16 & 17 & 13 & 11 & 13 & 12 & 11 & 11 \\
\hline México & 0 & 8 & 0 & -1 & -7 & 2 & -1 & -4 & -6 \\
\hline Nicaragua & 0 & 16 & 0 & 9 & 8 & 8 & 8 & 7 & 6 \\
\hline Panamá & 0 & 6 & 5 & 3 & 3 & 3 & 2 & 2 & 3 \\
\hline Paraguay & 12 & 9 & 13 & 11 & 9 & 9 & 8 & 9 & 11 \\
\hline Perú & 24 & 9 & 0 & 4 & 2 & 4 & 3 & 3 & 3 \\
\hline Uruguay & 14 & 13 & 10 & 8 & 7 & 6 & 7 & 6 & 5 \\
\hline $\begin{array}{l}\text { Venezuela } \\
\text { (República } \\
\text { Bolivariana de) }\end{array}$ & 1 & 4 & 1 & 1 & 1 & 1 & 1 & 0 & 0 \\
\hline $\begin{array}{l}\text { Promedio de } \\
\text { América Latina }\end{array}$ & 5 & 8 & 5 & 8 & 7 & 8 & 7 & 7 & 6 \\
\hline
\end{tabular}

Fuente: Elaboración propia, sobre la base de Organización de Cooperación y Desarrollo Económicos (OCDE)/Comisión Económica para América Latina y el Caribe (CEPAL)/Banco Interamericano de Desarrollo (BID)/Centro Interamericano de Administraciones Tributarias (CIAT), Estadísticas Tributarias en América Latina y el Caribe 1990-2013, París, OECD Publishing, 2015.

a Incluye impuestos a la extracción de recursos naturales en los países que corresponde.

La variación interanual en algunos de los países es significativa (véase el cuadro XV.2), lo que se debe principalmente a la introducción de nuevos impuestos o tasas. Tal es el caso del impuesto directo a los hidrocarburos (IDH), introducido en el Estado Plurinacional de Bolivia en 2005, con una alícuota del $32 \%$ en boca de pozo, de carácter no deducible, y que permitió elevar la participación del Estado en la renta petrolera de un $18 \%$ a un $50 \%$. En el caso del Brasil, la reforma de 2007 sobre el impuesto a la circulación de mercaderías y servicios (ICMS), incrementó la recaudación de ese impuesto sobre los vehículos, la electricidad y el combustible. Costa Rica simplificó su 
impuesto a los combustibles en 2001, y la República Dominicana y Honduras establecieron en el año 2000 un impuesto sobre el consumo de combustibles fósiles y derivados del petróleo.

Cabe mencionar que la relación negativa de los impuestos ambientales en México obedece al subsidio que venía otorgando el Gobierno Federal a los ingresos asociados a los impuestos ambientales, como lo es el impuesto sobre producción y servicios (IEPS) aplicable a las gasolinas y el diésel. El impuesto al consumo de esos combustibles se convirtió en subsidio cuando los precios internacionales del petróleo eran altos y el Gobierno Federal debió compensar a la empresa paraestatal Petróleos Mexicanos (PEMEX) por la diferencia entre los precios internacionales y los precios internos de venta de gasolina y diésel, que habían sido fijados por el Gobierno a un menor costo. En 2015, y como parte de la reforma energética que se implementó, la Secretaría de Hacienda eliminó esos subsidios. Una década después, México volverá a recaudar impuestos a las gasolinas y dejará así de ser el único miembro de la OCDE con saldo negativo en la recaudación de impuestos ambientales (véase el gráfico XV.3).

Gráfico XV.3

América Latina: composición de la tributación ambiental, 2012

(En porcentajes del PIB)

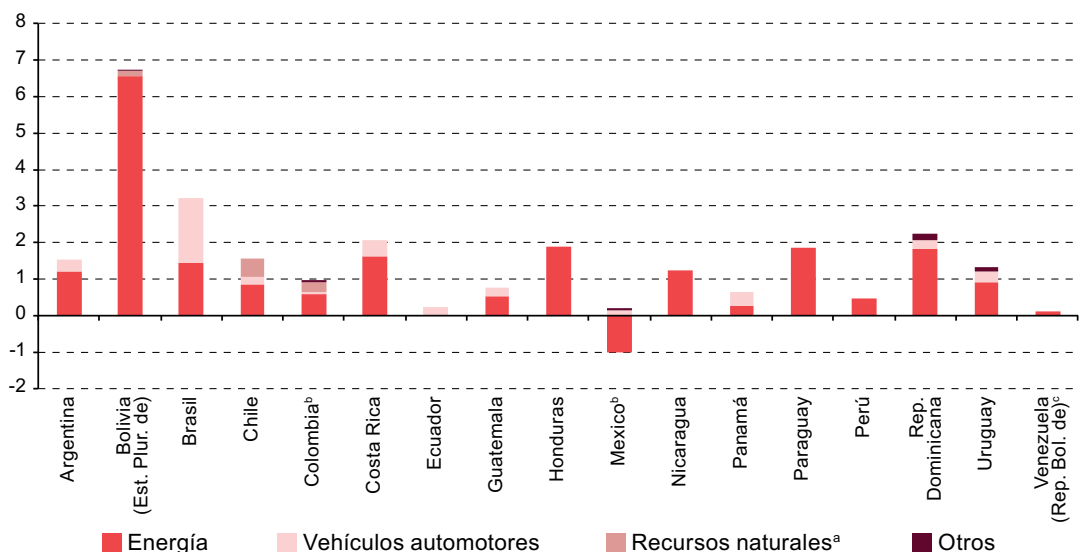

Fuente: Elaboración propia sobre la base de Organización de Cooperación y Desarrollo Económicos (OCDE)/Comisión Económica para América Latina y el Caribe (CEPAL)/Banco Interamericano de Desarrollo (BID)/Centro Interamericano de Administraciones Tributarias (CIAT), Estadísticas Tributarias en América Latina y el Caribe 1990-2013, París, OECD Publishing, 2015.

Dentro de esta categoría se excluyen los impuestos sobre el petróleo.

Datos correspondientes a 2011.

c Datos correspondientes a 2010.

Como se observa en el gráfico XV.3, la mayor parte de los impuestos están relacionados con la energía, sobre todo los impuestos a los combustibles, y a los vehículos automotores, que por lo general son de carácter municipal. 
Dadas las características de la región, se ha considerado relevante incluir también los impuestos de carácter ambiental relacionados con la explotación de los recursos naturales. Esos impuestos, aunque no estén definidos explícitamente como ambientales (siguiendo el criterio de la Comisión Europea), pueden clasificarse como tales dada su característica intrínseca de desincentivar la explotación de esos recursos al ser tasados ${ }^{7}$.

Vale señalar que, en el campo de la tributación ambiental, otra tendencia reciente en los países desarrollados parece haber ido en pos de afianzar el vínculo de la tributación vehicular con las políticas ambientales. En los últimos años, los Gobiernos de esos países han venido adaptando esos impuestos para tener en cuenta a la hora de su diseño, por ejemplo, aspectos tales como la eficiencia en el consumo de combustibles de los motores, las emisiones de gases contaminantes, el planeamiento urbano y las políticas de transporte ${ }^{8}$.

En esa materia, hay a nivel regional algunos ejemplos recientes que merecen ser destacados (Gómez Sabaini y Morán, 2013). El primero se refiere a la República Dominicana, donde se introdujo un gravamen adicional a los vehículos, ya sean nuevos o usados, con tasas progresivas del 1\% al 3\%, determinadas conforme a las emisiones de $\mathrm{CO}_{2}$ por kilómetro. Ese gravamen se aplica además de la tarifa del $17 \%$ ya establecida en 2005 para la expedición de la primera placa o primera registración de los vehículos automotores en dicho país. El segundo ejemplo es el del impuesto ambiental a la contaminación vehicular (IACV) en el Ecuador, introducido en noviembre de 2011, que recae sobre los propietarios de vehículos y se determina mediante una fórmula que toma en cuenta la cilindrada del motor (medida en centímetros cúbicos) y los años de antigüedad contados a partir de su fecha de fabricación?.

El último y más reciente ejemplo está dado por el caso de Chile donde, en el marco de la mencionada reforma tributaria integral, se introdujo el impuesto adicional por emisiones contaminantes de vehículos nuevos

\footnotetext{
Como señala Brosio (2013), si bien la finalidad predominante de los impuestos aplicados a las industrias proveedoras de materias primas es la recaudación de ingresos fiscales a partir de la captación de rentas económicas, algunos de ellos tienen un impacto ambiental potencial, aunque limitado (y, en la mayoría de los casos, no intencional) mediante un aumento ex ante de los costos percibidos por el productor y una esperable reducción de la producción. Ese es claramente el caso de las regalías y los impuestos a la extracción de recursos naturales.

8 Según la OCDE (2013), durante 2012 más de la mitad (24 de 34) de los países miembros de la OCDE aplicaron tasas diferenciadas o reducciones impositivas con criterios ambientales, tanto en gravámenes de registración (por única vez) como en aquellos recurrentes con periodicidad anual. Entre ellos, 19 utilizan directamente el nivel de emisiones contaminantes como criterio para determinar la tasa de impuesto aplicable $u$ ofrecer descuentos específicos, mientras que 16 de ellos ofrecen reducciones o exenciones para los vehículos de propulsión eléctrica (entre ellos, México).

9 Después de más de cinco años desde su introducción en el sistema tributario ecuatoriano, los datos recopilados y difundidos por el Servicio de Rentas Internas (SRI) dan cuenta de alentadores resultados en función a los objetivos establecidos, con un gradual descenso en la cilindrada promedio de los automóviles en circulación y una incorporación creciente de unidades más modernas y menos contaminantes.
} 
(también llamado "impuesto verde a fuentes móviles"). Se aplica, como pago único, sobre la compra de vehículos motorizados nuevos (livianos y medianos) y cuya cuantía se determina a partir de una fórmula que contempla el rendimiento urbano y la emisión de óxido de nitrógeno del vehículo y el precio final de venta o importación, es decir, incluyendo el IVA y los impuestos aduaneros. Así, como en los casos anteriores, este nuevo tributo tiene como objetivo incentivar el ingreso de vehículos menos contaminantes al parque automotor en circulación.

Por otra parte, un elemento esencial a tener en cuenta es el de los subsidios a la energía, que están presentes en la mayoría de los países en desarrollo, sobre todo en los productores de hidrocarburos, y América Latina no es una excepción. En el gráfico XV.4 se muestran los subsidios medios a la energía antes de impuestos, correspondientes al período 2011-2013. Los subsidios a los combustibles, en promedio, representaron un 1,4\% del PIB por año, mientras que los subsidios a la electricidad representaron un promedio anual del $0,8 \%$ del PIB.

\section{Gráfico XV.4}

América Latina (19 países): subsidios a la energía antes de impuestos, 2011-2013 (En porcentajes del PIB)

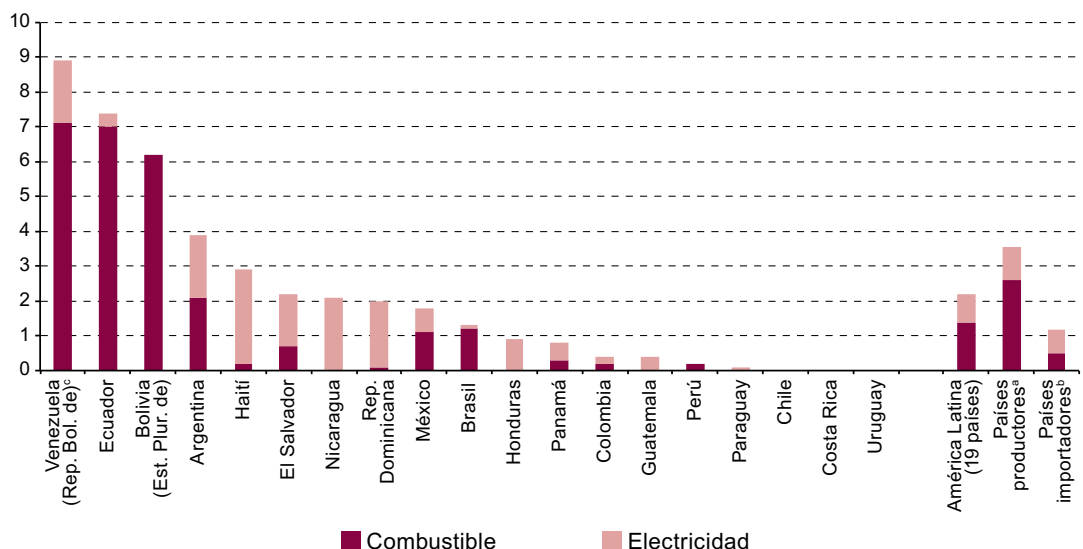

Fuente: Elaboración propia sobre la base de G. Di Bella y otros, "Energy subsidies in Latin America and the Caribbean: stocktaking and policy challenges", IMF Working Paper, N ${ }^{\circ} 15 / 30$, Washington, D.C., Fondo Monetario Internacional (FMI), 2015.

a Promedio simple correspondiente a la Argentina, Bolivia (Estado Plurinacional de), el Brasil, Colombia, el Ecuador, México, el Perú y Venezuela (República Bolivariana de).

b Promedio simple que corresponde a Chile, El Salvador, Haití, Nicaragua, la República Dominicana, Honduras, Panamá, Guatemala, el Paraguay, Costa Rica y el Uruguay.

Los países ricos en recursos no renovables tienden a subsidiar más los combustibles, lo que se percibe como una forma de participar en las rentas de los recursos naturales. En cambio, los países más pobres en esa dimensión son 
más propensos a subsidiar la electricidad, sobre todo en Centroamérica. Los que más subsidian la energía y la electricidad en la región son la República Bolivariana de Venezuela (8,9\% del PIB), el Ecuador (7,5\% del PIB), el Estado Plurinacional de Bolivia (6,2\% del PIB) y la Argentina (3,9\% del PIB). Esos casos contrastan fuertemente con los del Uruguay, Costa Rica y Chile, que no subsidian ni la energía ni la electricidad. Las cifras mencionadas indican que en varios países el monto de los subsidios incluso supera el valor del déficit fiscal o el gasto en educación. Así, los subsidios a la energía absorben buena parte del espacio fiscal disponible. En promedio, representan el $7 \%$ de los ingresos del gobierno y el $11 \%$ de la recaudación tributaria. Por supuesto, el guarismo varía mucho de país a país. En la República Bolivariana de Venezuela representaban el 85\% de la recaudación; en el Ecuador, el 55\%; en el Estado Plurinacional de Bolivia, el 20\%, y en la Argentina, el 14\% entre 2011 y 2013.

Los subsidios a la electricidad, por otra parte, tienen una distribución menos concentrada, siendo los países con menores ingresos (como Haití, Nicaragua y, en menor medida, Honduras), los que mayor porcentaje del PIB destinan. Ese tipo de subsidios suele surgir como parte de la política social o industrial de un país, con el objetivo de dar un acceso más barato a la energía a grupos específicos (consumidores de bajos ingresos o productores de sectores estratégicos). Sin embargo, muchas veces esos subsidios se implementan sin basarse en reglas y cálculos diseñados para alcanzar de manera eficiente a las poblaciones objetivo. Ello torna sumamente difícil, desde el punto de vista político, la decisión de desactivarlos o reducir su cuantía económica.

\section{Lecciones para el diseño de la reforma fiscal ambiental en la región}

Los argumentos a favor de las reformas fiscales ambientales tienen fundamentos en la teoría del bienestar y existe consenso sobre la necesidad de colocar los temas ambientales en la agenda fiscal. Sin embargo, los problemas de implementación asociados con ese tipo de reformas plantean una serie de desafíos, sobre todo cuando se toman en cuenta el grado de desarrollo y la estructura económica de cada país. A modo de conclusión se señalan, a continuación, las principales lecciones que surgen del análisis para el diseño de una reforma fiscal ambiental eficaz y sostenible en América Latina.

En primer lugar, debe señalarse que en América Latina priman los impuestos con fines recaudatorios, entre los que se destacan los impuestos ambientales sobre la energía (combustibles). Además, los impuestos sobre la explotación de recursos naturales, clasificados o no dentro de ese grupo, no se han concebido con una finalidad ambiental explícita, sino principalmente como formas de apropiación de rentas. Las experiencias recientes de México y Chile pueden ser un primer paso hacia una imposición ambiental 
dirigida puntualmente a la emisión, pero son incipientes. Asimismo, la reformulación de los impuestos sobre vehículos automotores tendiente a incorporar variables ambientales (una práctica bastante generalizada entre los países desarrollados) se ha visto materializada en pocos casos, como los de Chile, el Ecuador y la República Dominicana. Todos esos ejemplos apuntan a favorecer un proceso de modernización del parque automotor en circulación (mediante el aumento de la eficiencia energética) y la reducción del consumo de combustibles fósiles.

La información sobre impuestos ambientales compilados en la base de datos de la OCDE no solo indica la tasa y el producto o servicio que se grava. También se muestra su eficiencia ambiental en función de los costos administrativos y su incidencia en el comportamiento. Los países de la región deberían emular esa línea de trabajo de la OCDE e ir generando capacidades que les permitan contar con ese tipo de información. Así estarían en mejores condiciones de diseñar los impuestos ambientales y orientarse a minimizar las distorsiones adicionales asociadas con el uso de impuestos imperfectos para combatir la contaminación y el agotamiento del capital natural.

Por otra parte, la introducción de instrumentos tributarios de carácter ambiental en la región no ha conllevado la reducción de otro tipo de impuestos, como ocurrió con las reformas introducidas en los países europeos. Esto se explica por la necesidad de aumentar la carga fiscal para ensanchar el espacio fiscal. Los subsidios a la energía absorben una buena parte de ese espacio, por lo que parece razonable argumentar que el diseño de las reformas fiscales ambientales no debería pasarlos por alto. Los subsidios que operan a través de los bajos precios de la energía son importantes, sobre todo en países ricos en recursos energéticos, y son un mecanismo de apropiación de la renta de los recursos naturales por parte del sector privado, que favorece a todos los sectores sin discriminar a favor de los más pobres. En los países que no poseen recursos y subsidian la electricidad más que el combustible, los efectos sobre la pobreza pueden ser sustanciales. Además, se incentiva el uso de energía contaminante y de recursos agotables ya que, para apropiarse de parte de la renta, hay que consumir esa energía.

La baja prioridad de las reformas fiscales ambientales en la agenda de políticas de América Latina tal vez se explique en parte por ciertas características específicas de la región. Un país latinoamericano tiene cuatro diferencias económicas con un país desarrollado típico que son especialmente relevantes: i) el crecimiento sigue siendo un objetivo privilegiado; ii) la incidencia de la pobreza es significativa y, además, se trata de una región con grandes disparidades en la distribución de la riqueza y el ingreso; iii) los recursos naturales tienen mayor peso relativo en la región y ello ha influido y seguirá influyendo en los instrumentos fiscales utilizados y en las características del espacio fiscal, y iv) el marco institucional suele ser más 
débil, los mercados exhiben una variedad de fallas y el Estado muestra una capacidad reducida de proveer bienes públicos. Además, se deben resaltar dos hechos estilizados: i) la composición y la importancia de las fuentes de emisión de $\mathrm{CO}_{2}$ son menores y distintas a las de los países de la OCDE, y ii) la presencia de subsidios a la energía es significativa. Esas diferencias contextuales determinan que las prioridades de política de cada país de la región sean diferentes a las de un país típico de la OCDE y a las de economías con ingreso similar, pero menos dotadas de recursos naturales.

De lo anterior se puede concluir que las reformas fiscales ambientales en la región deberán diseñarse considerando el sesgo favorable al crecimiento y a la población pobre que debe mostrar la trayectoria de la economía, así como el estadio de la transición demográfica en que se encuentra cada país. En relación con esto último, vale señalar que las economías de mayor tamaño (Argentina, Brasil, Chile o México) están cursando el bono demográfico y las más pobres aún no lo han alcanzado, lo que significa que la estructura tributaria no debería ignorar la necesidad de generar empleo. Además, en los países de América Latina que subsidian el consumo de energía, una reforma fiscal ambiental que incluya una racionalización de los subsidios a la energía contribuiría sin lugar a dudas a reducir las emisiones y a utilizar racionalmente el capital natural y controlar otras externalidades negativas, como la contaminación ambiental.

Una reforma fiscal ambiental adaptada a la región tal vez debería dar mayor peso a las externalidades asociadas con los cambios en el uso de la tierra, las explotaciones agropecuarias y las industrias extractivas. No obstante, ello traería rápidamente al centro de la escena el dilema entre medio ambiente y competitividad: buena parte de las exportaciones se explican por esos rubros, ya que la región es exportadora de minerales, energía y alimentos. Por otro lado, la actividad agropecuaria, si bien es contaminante (debido a la emisión de metano por el ganado y de otros factores relacionados con los fertilizantes), tampoco ha estado en el foco de las reformas fiscales ambientales pioneras debido a cuestiones de economía política relacionadas con la política agrícola común europea (Usubiaga y otros, 2011). Hay que considerar, sin embargo, que la contribución que América Latina podría hacer al esfuerzo global en relación con el cambio climático depende en gran medida del aporte de pocos países, ya que las emisiones están muy concentradas, sobre todo en lo que se refiere a cambios en el uso del suelo.

Una reforma fiscal ambiental diseñada para lograr el desacople en las emisiones (que logre reducir la ratio de emisiones por unidad de producto a medida que crece el PIB) tendría que poner especial consideración en dos factores: los subsidios a la energía y las políticas de deforestación. Los subsidios y el cambio en el uso de la tierra son importantes para explicar las emisiones en América Latina, pero no necesariamente han tenido protagonismo en las 
reformas fiscales ambientales implementadas en los países europeos. Por supuesto, ello no implica dejar de lado instrumentos como la imposición al componente de carbono o los impuestos al uso de automóviles, con miras a reducir la congestión. No obstante, las prioridades hoy parecen claras: hay que comenzar con los dos factores antes mencionados y utilizar los ahorros obtenidos mediante la eliminación de los subsidios para financiar la construcción de infraestructura y políticas productivas que sean funcionales para fortalecer capacidades de los segmentos sociales menos favorecidos y cambiar el perfil competitivo de forma favorable a los recursos naturales y conducente a la generación de empleo.

En el caso de América Latina, hay que poner especial atención a los efectos sobre la pobreza y la distribución. Por ese motivo, los subsidios no podrían desactivarse sin mejorar los programas focalizados o universales de protección social. Para atender este punto, habría que incluir en un lugar protagónico para ser tratados con instrumentos fiscales los factores de daño ambiental que más inciden sobre la pobreza, como la contaminación del aire y del agua, y los efectos sobre la salud y el uso del espacio urbano y su infraestructura.

Para evitar dilemas y reforzar el apoyo a las reformas fiscales ambientales en el plano político es fundamental establecer las posibles sinergias entre las políticas favorables al medio ambiente, las conducentes a la disminución de la pobreza, las demográficas y las de crecimiento. Un enfoque sistémico parece particularmente útil en ese sentido. Una conclusión central del trabajo es que las reformas deben ser un instrumento para impulsar un "doble cambio estructural", hacia una economía desarrollada y desde una economía "café" a una "verde". En definitiva, se trata de impulsar un proceso de "convergencia limpia". 


\section{Bibliografía}

Acquatella, J. (2005), “El papel conjunto de las autoridades fiscales y ambientales en la gestión ambiental de los países de América Latina y el Caribe", Política fiscal y medio ambiente: bases para una agenda común, Libros de la CEPAL, No 85 (LC/G.2274-P), J. Acquatella y A. Bárcena (eds.), Santiago, Comisión Económica para América Latina y el Caribe (CEPAL).

Acquatella, J. y A. Bárcena (eds.) (2005), Política fiscal y medio ambiente: bases para una agenda común, Libros de la CEPAL, No 85 (LC/G.2274-P), Santiago, Comisión Económica para América Latina y el Caribe (CEPAL).

Banco Mundial (2005), Environmental Fiscal Reform. What Should Be Done and How to Achieve it, Washington, D.C.

Brosio, G. (2013), “Interacciones intergubernamentales entre los impuestos sobre el petróleo y el gas y la protección ambiental", serie Macroeconomía del Desarrollo, No 128 (LC/L.3583), Santiago, Comisión Económica para América Latina y el Caribe (CEPAL).

CEPAL (Comisión Económica para América Latina y el Caribe) (2014), Panorama Fiscal de América Latina y el Caribe, 2014: hacia una mayor calidad de las finanzas públicas (LC/L.3726), Santiago.

Clements, B. y otros (eds.) (2013), Energy Subsidy Reform: Lessons and Implications, Washington, D.C., Fondo Monetario Internacional (FMI).

Coase, R. (1960), "The problem of social cost", Journal of Law and Economics, vol. 3, No 1.

Dasgupta, P. (2009), "The place of nature in economic development", Handbook of Development Economics, vol. 5, D. Rodrik y M. Rosenzweig (eds.), Amsterdam, North Holland.

De Mooij, R, I. W.H. Parry y M. Keen (eds.) (2012), Fiscal Policy to Mitigate Climate Change. A Guide for Policymakers, Washington, D.C., Fondo Monetario Internacional (FMI).

Di Bella, G. y otros (2015), "Energy subsidies in Latin America and the Caribbean: stocktaking and policy challenges", IMF Working Paper, $\mathrm{N}^{\mathrm{o}} 15 / 30$, Washington, D.C., Fondo Monetario Internacional (FMI).

Fanelli, J. M., J.P. Jiménez e I. López Azcúnaga (2015), “La reforma fiscal ambiental en América Latina", Documentos de Proyecto (LC/W.658), Santiago, Comisión Económica para América Latina y el Caribe (CEPAL) [en línea] http: / / repositorio. cepal.org/bitstream/handle/11362/39782/S1501147_es.pdf?sequence=1.

Gago Rodríguez, A. y X. Labandeira (2010), "Impuestos ambientales y reformas fiscales verdes en perspectiva", Economics for Energy (WP 09/2010) [en línea] www.eforenergy.org.

(2012), "Un nuevo modelo de reforma fiscal verde", Economics of Energy (WP 03/2012) [en línea] www.eforenergy.org.

Gillingham, R. y M. Keen (2012), "Mitigation and fuel pricing in developing economies", Fiscal Policy to Mitigate Climate Change. A Guide for Policymakers, R. de Mooij, I.W.H. Parry y M. Keen (eds.),Washington, D.C., Fondo Monetario Internacional (FMI).

Gómez Sabaini, J.C. y D. Morán (2013), "Política tributaria y protección del medio ambiente: Imposición sobre vehículos en América Latina", serie Macroeconomía del Desarrollo, N 141 (LC/L.3732), Santiago, Comisión Económica para América Latina y el Caribe (CEPAL).

Heine, D., J. Norregaard e I. Parry (2012), “Environmental tax reform: principles from theory and practice to date", IMF Working Paper, N 12/180, Washington, D.C., Fondo Monetario Internacional (FMI). 
Jiménez, J. P. (ed.) (2015), Desigualdad, concentración del ingreso y tributación sobre las altas rentas en América Latina, Libros de la CEPAL, No 134 (LC/G.2638-P), Santiago, Comisión Económica para América Latina y el Caribe (CEPAL).

Milgrom, P. y J. Roberts (1993), Economía, organización y gestión de la empresa, Barcelona, Ariel Economía.

Miller, S. y M. A. Vela (2013), "Are environmentally related taxes effective?", IDB Working Paper, N ${ }^{o}$ IDB-WP-467, Washington, D.C., Banco Interamericano de Desarrollo (BID).

Milne, J. E. (2014), "Environmental taxes and fees: wrestling with theory", Environmental Taxation and Green Fiscal Reform: Theory and impact, L. Kreiser y otros (eds.), Cheltenham, Elgar Publishing.

OCDE (Organización de Cooperación y Desarrollo Económicos) (2005), Environmental Fiscal Policy for Poverty Reduction, París, OECD Publishing. (2010), Taxation, Innovation and the Environment, París, OECD Publishing. (2013), The OECD database on instruments used for environmental policy and natural resources management. Disponible en: www.oecd.org/env/policies/database (Consultado en abril de 2015).

OCDE/CEPAL/BID/CIAT (Organización de Cooperación y Desarrollo Económicos / Comisión Económica para América Latina y el Caribe/Banco Interamericano de Desarrollo/Centro Interamericano de Administraciones Tributarias) (2015), Estadísticas Tributarias en América Latina y el Caribe 1990-2013, París, OECD Publishing. ONUDI (Organización de las Naciones Unidas para el Desarrollo Industrial) (2008), Public Goods for Economic Development (ID/437), Viena.

Ostrom, E. (2007), "Institutional rational choice: An assessment of the institutional analysis and development framework", Theories of the Policy Process, P. A. Sabatier (ed.), Cambridge, Westview Press.

Parry, I. y otros (2014), Getting Energy Prices Right From Principle to Practice, Washington, D.C., Fondo Monetario Internacional (FMI).

Pigou, A. C. (1920), The Economics of Welfare, Londres, Macmillan.

PNUMA (Programa de las Naciones Unidas para el Medio Ambiente) (2011), Towards a Green Economy. Pathways to Sustainable Development and Poverty Eradication. A Synthesis for Policy Makers [en línea] www.unep.org/greeneconomy/.

Prust, J. (2005), "Impuestos ambientales en los países en desarrollo", Política fiscal y medio ambiente: bases para una agenda común, Libros de la CEPAL, Nº 85 (LC/G.2274-P), J. Acquatella y A. Bárcena (eds.), Santiago, Comisión Económica para América Latina y el Caribe (CEPAL).

Smulders, S., M. Toman y C. Withagen (2014), "Growth theory and green growth", OxCarre Research Paper, $\mathrm{N}^{\circ}$ 135, Oxford Centre for the Analysis of Resource Rich Economies.

Somanathan J.E. y F. Sterner (2003), "Environmental policy instruments and institutions in developing countries", Initiative for Policy Dialogue Working Paper Series, Columbia University Academic Commons [en línea] http://hdl.handle. net/10022/AC:P:8971.

Stiglitz, J. (1988), La economía del sector público, Barcelona: Antoni Bosch Editor. (2009), "Regulation and failure", Government and Markets. Toward a New Theory of Regulation, E. Balleisen y D. Moss, Cambridge, The Tobin Project.

Usubiaga, A. y otros (2011), EU Subsidies for polluting and unsustainable practices, Bruselas, Parlamento Europeo. 



\section{Reseña biográfica de los autores}

\section{Claudio Agostini}

Profesor titular de la Escuela de Gobierno de la Universidad Adolfo Ibáñez de Chile. Correo electrónico: claudio.agostini@uai.cl.

\section{Isabel López Azcúnaga}

Consultora de la Comisión Económica para América Latina y el Caribe (CEPAL) en temas de política fiscal. Correo electrónico: ilopezazcunaga@gmail.com.

\section{Maynor Cabrera}

Director Asociado del Instituto Commitment to Equity (CEQ) de la Universidad de Tulane de los Estados Unidos. Correo electrónico: maynor.cabrera@ceqinstitute.org.

\section{Oscar Cetrángolo}

Consultor de la Comisión Económica para América Latina y el Caribe (CEPAL) y de la Organización Internacional del Trabajo (OIT) especializado en política fiscal. Profesor de grado y posgrado en la Universidad Nacional de Buenos Aires y la Universidad Nacional de Tres de Febrero (Argentina). Correo electrónico: ocetrangolo@gmail.com.

\section{José María Fanelli}

Profesor investigador de la Universidad de San Andrés y del Consejo Nacional de Investigaciones Científicas y Técnicas (CONICET) de la Argentina. Correo electrónico: josefanelli@gmail.com.

\section{Juan Carlos Gómez Sabaini (editor)}

Consultor de la Comisión Económica para América Latina y el Caribe (CEPAL), el Banco Interamericano de Desarrollo (BID), el Fondo Monetario Internacional (FMI) y el Centro Interamericano de Administraciones Tributarias (CIAT) 
especializado en temas de política tributaria en países de América Latina. Profesor de posgrado en la Universidad Nacional de Buenos Aires. Correo electrónico: gomezsabaini@gmail.com.

\section{Ivonne González}

Asistente de Investigación de la División de Desarrollo Económico de la Comisión Económica para América Latina y el Caribe (CEPAL). Correo electrónico: ivonne.gonzalez@cepal.org.

\section{Michael Hanni}

Oficial de Asuntos Económicos de la División de Desarrollo Económico de la Comisión Económica para América Latina y el Caribe (CEPAL). Correo electrónico: michael.hanni@cepal.org.

\section{Juan Pablo Jiménez (editor)}

Oficial de Asuntos Económicos de la División de Desarrollo Económico de la Comisión Económica para América Latina y el Caribe (CEPAL). Correo electrónico: juanpablo.jimenez@cepal.org.

\section{Michel Jorratt}

Consultor especializado en política y administración tributaria y profesor del Departamento de Ingeniería Industrial de la Universidad de Chile. Correo electrónico: michel.jorrat@gmail.com.

\section{Ricardo Martner (editor)}

Jefe de la Unidad de Asuntos Fiscales de la División de Desarrollo Económico de la Comisión Económica para América Latina y el Caribe (CEPAL). Correo electrónico: ricardo.martner@cepal.org.

\section{Dalmiro Morán}

Consultor de la Comisión Económica para América Latina y el Caribe (CEPAL) y del Centro Interamericano de Administraciones Tributarias (CIAT) especializado en temas de política tributaria en países de América Latina. Correo electrónico: dalomoran@gmail.com.

\section{Andrea Podestá}

Consultora de la Comisión Económica para América Latina y el Caribe (CEPAL). Correo electrónico: andrea.podesta@cepal.org.

\section{Darío Rossignolo}

Investigador y consultor de organismos internacionales. Especialista en el análisis de los efectos económicos de las políticas tributarias y fiscales. Profesor de grado y posgrado de la Universidad de Buenos Aires. Correo electrónico: darossignolo@yahoo.com. 


\section{Publicaciones recientes de la CEPAL ECLAC recent publications}

\section{www.cepal.org/publicaciones}

\section{Informes periódicos / Annual reports}

También disponibles para años anteriores / Issues for previous years also available

- Estudio Económico de América Latina y el Caribe 2016, 236 p. Economic Survey of Latin America and the Caribbean 2016, 232 p.

- La Inversión Extranjera Directa en América Latina y el Caribe 2016, 170 p. Foreign Direct Investment in Latin America and the Caribbean 2016, 164 p.

- Anuario Estadístico de América Latina y el Caribe 2016 / Statistical Yearbook for Latin America and the Caribbean 2016, $132 \mathrm{p}$.

- Balance Preliminar de las Economías de América Latina y el Caribe 2016, 132 p. Preliminary Overview of the Economies of Latin America and the Caribbean 2016, $124 \mathrm{p}$.

- Panorama Social de América Latina 2015, 226 p. Social Panorama of Latin America 2015, 222 p.

- Panorama de la Inserción Internacional de América Latina y el Caribe 2016, 174 p. Latin America and the Caribbean in the World Economy 2015, 170 p.

\section{Libros y documentos institucionales / Institutional books and documents}

- ECLAC Thinking. Selected Texts (1948-1998), 2016, 520 p.

- La matriz de la desigualdad en América Latina, 2016, 96 p. The social inequality matrix in Latin America, 2016, 94 p.

- Autonomía de las mujeres e igualdad en la agenda de desarrollo sostenible, 2016, 184 p. Equality and women's autonomy in the sustainable development agenda, 2016, 168 p. Autonomia das mulheres e igualdade na agenda de desenvolvimento sustentável. Síntese, 2016, $106 p$

- La Unión Europea y América Latina y el Caribe ante la Agenda 2030 para el Desarrollo Sostenible: el gran impulso ambiental, 2016, $112 p$.

The European Union and Latin America and the Caribbean vis-à-vis the 2030 Agenda for Sustainable Development: The environmental big push, 2016, 112 p.

- Horizontes 2030: la igualdad en el centro del desarrollo sostenible, 2016, $176 \mathrm{p}$. Horizons 2030: Equality at the centre of sustainable development, 2016, $174 \mathrm{p}$. Horizontes 2030: a igualdade no centro do desenvolvimento sustentável, 2016, 176 p.

- 40 años de agenda regional de género, 2016, $130 \mathrm{p}$. 40 years of the regional gender agenda, 2016,128 p.

- La nueva revolución digital: de la Internet del consumo a la Internet de la producción, 2016, 100 p. The new digital revolution: From the consumer Internet to the industrial Internet, 2016, $100 \mathrm{p}$.

- Panorama fiscal de América Latina y el Caribe 2016: las finanzas públicas ante el desafío de conciliar austeridad con crecimiento e igualdad, 2016, 90 p.

Fiscal Panorama of Latin America and the Caribbean 2016: Public finances and the challenge of reconciling austerity with growth and equality, 2016, 86 p. 
- Reflexiones sobre el desarrollo en América Latina y el Caribe: conferencias magistrales 2015, 2016, $74 \mathrm{p}$.

- La nueva revolución digital: de la Internet del consumo a la Internet de la producción, 2015, 98 p. The new digital revolution: From the consumer Internet to the industrial Internet, 2015, 98 p.

- Pactos para la igualdad: hacia un futuro sostenible, 2014, 340 p. Covenants for Equality: Towards a sustainable future, 2014, 330 p.

\section{Libros de la CEPAL / ECLAC books}

141 Brechas y transformaciones: la evolución del empleo agropecuario en América Latina, Jürgen Weller (ed.), 2016, $274 \mathrm{p}$.

140 Protección y formación: instituciones para mejorar la inserción laboral en América Latina y Asia, Alberto Isgut, Jürgen Weller (eds.), 2016, 428 p.

Protection and training: Institutions for improving workforce integration in Latin America and Asia, Alberto Isgut, Jürgen Weller (eds.), 2016, 428 p.

139 Hacia una nueva gobernanza de los recursos naturales en América Latina y el Caribe, Hugo Altomonte, Ricardo J. Sánchez, 2016, 256 p.

138 Estructura productiva y política macroeconómica: enfoques heterodoxos desde América Latina, Alicia Bárcena, Antonio Prado, Martín Abeles (eds.), 2015, 282 p.

137 Juventud: realidades y retos para un desarrollo con igualdad, Daniela Trucco, Heidi Ullmann (eds.), $2015,282 \mathrm{p}$.

136 Instrumentos de protección social: caminos latinoamericanos hacia la universalización, Simone Cecchini, Fernando Filgueira, Rodrigo Martínez, Cecilia Rossel (eds.), 2015, 510 p.

\section{Páginas Selectas de la CEPAL / ECLAC Select Pages}

- Planificación y prospectiva para la construcción de futuro en América Latina y el Caribe. Textos seleccionados 2013-2016, Jorge Máttar y Mauricio Cuervo (comps.), 2016, 222 p.

- Desarrollo inclusivo en América Latina. Textos seleccionados 2009-2016, Ricardo Infante (comp.), 2016, 294 p.

- Globalización, integración y comercio inclusivo en América Latina. Textos seleccionados 2010-2014, Osvaldo Rosales (comp.), 2015, 326 p.

- El desafío de la sostenibilidad ambiental en América Latina y el Caribe. Textos seleccionados 2012-2014, Carlos de Miguel, Marcia Tavares (comps.), 2015, 148 p.

\section{Copublicaciones / Co-publications}

- El imperativo de la igualdad, Alicia Bárcena, Antonio Prado, CEPAL/Siglo Veintiuno, Argentina, 2016, $244 \mathrm{p}$.

- Gobernanza global y desarrollo: nuevos desafíos y prioridades de la cooperación internacional, José Antonio Ocampo (ed.), CEPAL/Siglo Veintiuno, Argentina, 2015, 286 p.

- Decentralization and Reform in Latin America: Improving Intergovernmental Relations, Giorgio Brosio and Juan Pablo Jiménez (eds.), ECLAC/Edward Elgar Publishing, United Kingdom, 2012, 450 p.

- Sentido de pertenencia en sociedades fragmentadas: América Latina desde una perspectiva global, Martín Hopenhayn y Ana Sojo (comps.), CEPAL/Siglo Veintiuno, Argentina, 2011, 350 p. 


\section{Coediciones / Co-editions}

- Perspectivas económicas de América Latina 2017: Juventud, Competencias y Emprendimiento, 2016, 338 p. Latin American Economic Outlook 2017: Youth, Skills and Entrepreneurship, 2016, 314 p.

- Desarrollo e integración en América Latina, 2016, 314 p.

- Hacia un desarrollo inclusivo: el caso del Uruguay, 2016, 174 p.

- Perspectivas de la agricultura y del desarrollo rural en las Américas: una mirada hacia América Latina y el Caribe 2015-2016, CEPAL/FAO/IICA, 2015, 212 p.

\section{Documentos de proyecto / Project documents}

- El cambio tecnológico y el nuevo contexto del empleo: tendencias generales y en América Latina, Sebastian Krull, 2016, 48 p.

- Cambio climático, políticas públicas y demanda de energía y gasolinas en América Latina: un meta-análisis, Luis Miguel Galindo, Joseluis Samaniego, Jimy Ferrer, José Eduardo Alatorre, Orlando Reyes, 2016, 68 p.

- Estado de la banda ancha en América Latina y el Caribe 2016, 2016, 46 p.

\section{Cuadernos estadísticos de la CEPAL}

44 Las cuentas de los hogares y el bienestar en América Latina. Más allá del PIB, 2016.

43 Estadísticas económicas de América Latina y el Caribe: Aspectos metodológicos y resultados del cambio de año base de 2005 a 2010

\section{Series de la CEPAL / ECLAC Series}

Asuntos de Género / Comercio Internacional / Desarrollo Productivo / Desarrollo Territorial / Estudios Estadísticos / Estudios y Perspectivas (Bogotá, Brasilia, Buenos Aires, México, Montevideo) / Studies and Perspectives (The Caribbean, Washington) / Financiamiento del Desarrollo / Gestión Pública / Informes y Estudios Especiales / Macroeconomía del Desarrollo / Medio Ambiente y Desarrollo / Población y Desarrollo / Política Fiscal / Políticas Sociales / Recursos Naturales e Infraestructura / Seminarios y Conferencias.

\section{Manuales de la CEPAL}

4 Territorio e igualdad: planificación del desarrollo con perspectiva de género, 2016, 84 p.

3 Manual de formación regional para la implementación de la resolución 1325 (2000) del Consejo de Seguridad de las Naciones Unidas relativa a las mujeres, la paz y la seguridad, María Cristina Benavente R., Marcela Donadio, Pamela Villalobos, 2016, 126 p.

2 Guía general para la gestión de residuos sólidos domiciliarios, Estefani Rondón Toro, Marcel Szantó Narea, Juan Francisco Pacheco, Eduardo Contreras, Alejandro Gálvez, 2016, 212 p.

\section{Revista CEPAL / CEPAL Review}

La Revista se inició en 1976, con el propósito de contribuir al examen de los problemas del desarrollo socioeconómico de la región. La Revista CEPAL se publica en español e inglés tres veces por año.

CEPAL Review first appeared in 1976, its aim being to make a contribution to the study of the economic and social development problems of the region. CEPAL Review is published in Spanish and English versions three times a year. 


\title{
Observatorio demográfico / Demographic Observatory
}

Edición bilingüe (español e inglés) que proporciona información estadística actualizada, referente a estimaciones y proyecciones de población de los países de América Latina y el Caribe. Desde 2013 el Observatorio aparece una vez al año.

Bilingual publication (Spanish and English) proving up-to-date estimates and projections of the populations of the Latin American and Caribbean countries. Since 2013, the Observatory appears once a year.

\section{Notas de población}

Revista especializada que publica artículos e informes acerca de las investigaciones más recientes sobre la dinámica demográfica en la región. También incluye información sobre actividades científicas y profesionales en el campo de población. La revista se publica desde 1973 y aparece dos veces al año, en junio y diciembre.

Specialized journal which publishes articles and reports on recent studies of demographic dynamics in the region. Also includes information on scientific and professional activities in the field of population. Published since 1973, the journal appears twice a year in June and December.

\section{Las publicaciones de la CEPAL están disponibles en:} ECLAC publications are available at: www.cepal.org/publicaciones

También se pueden adquirir a través de: They can also be ordered through: www.un.org/publications

\author{
United Nations Publications \\ PO Box 960 \\ Herndon, VA 20172 \\ USA
}

Tel. (1-888)254-4286

Fax (1-800)338-4550

Contacto / Contact. publications@un.org

Pedidos / Orders: order@un.org 


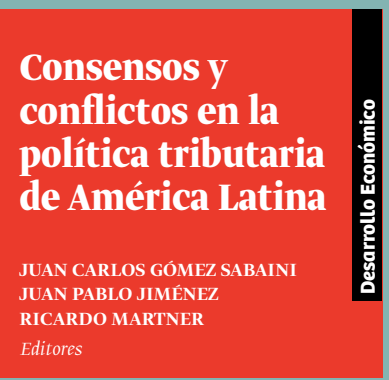

En este libro se destaca la importancia de la política tributaria como instrumento de desarrollo en los países de América Latina. A lo largo de esta publicación pueden identificarse una serie de consensos y conflictos que conviven en torno al diseño y la implementación de los diferentes tributos en cada país. Si bien los consensos - como la necesidad de asegurar pactos que garanticen un nivel estable de ingresos tributarios que produzcan distorsiones mínimas en la asignación de recursos- pueden parecer logros afianzados y generalizados, mucho es lo que falta para conciliar la política tributaria con otros objetivos no menos importantes, como asegurar la capacidad redistributiva de los sistemas tributarios, la equidad horizontal y vertical que debería prevalecer en los mismos, definir el rol del impuesto sobre la renta personal y de los incentivos impositivos o la asignación de los gravámenes entre niveles de gobierno.

Se propone en este libro un debate sobre cada uno de estos temas, además de una serie de lineamientos para futuras reformas tributarias en la región. Se destaca la utilización de la tributación con otros objetivos, como la gobernanza de los recursos naturales o como herramienta preponderante de las políticas ambientales. Asimismo, se plantea un análisis de la evasión tributaria y la informalidad, los dos obstáculos principales que enfrenta la tributación en todos los países de la región y que son transversales a los demás temas que se examinan en este libro.

\section{LIBROS}

C E P \& L L 